\begin{tabular}{l|l|l}
\hline $\begin{array}{l}\text { 2. To: (Receiving Organization) } \\
\text { Fluor Hanford Spent Nuclear Fuels }\end{array}$ & $\begin{array}{l}\text { 3. From: (Originating Organization) } \\
\text { WMTS EM\&I }\end{array}$ \\
\hline $\begin{array}{l}\text { 5. Proj./Prog./Dept./Div.: HMF } 500 / 3 \\
772032 / 203\end{array} \quad \begin{array}{l}\text { 6. Design Authority/Design Agent/Cog. Engr.: } \\
\text { R. M. Mitchell }\end{array}$ \\
\hline $\begin{array}{l}\text { 8. Originator Remarks: } \\
\text { This document represents the data review and analyses for the } \\
\text { preoperational environmental survey of the Spent Nuclear Fuel } \\
\text { Project Facilities. }\end{array}$
\end{tabular}

11. Receiver Remarks:

11A. Design Baseline Document? $\square$ Yes $\bigotimes$ No

\begin{tabular}{|c|c|c|c|c|c|c|c|c|c|c|}
\hline \multicolumn{4}{|c|}{ 2. To: (Receiving Organization) } & \multirow{2}{*}{\multicolumn{3}{|c|}{$\begin{array}{l}\text { 3. From: (Originating Organization) } \\
\text { WMTS EM\&I }\end{array}$}} & \multirow{2}{*}{\multicolumn{4}{|c|}{$\begin{array}{l}\text { 4. Related EDT No.: } \\
\text { NA }\end{array}$}} \\
\hline \multicolumn{4}{|c|}{ Fluor Hanford Spent Nuclear Fuels } & & & & & & & \\
\hline \multirow{2}{*}{\multicolumn{2}{|c|}{$\begin{array}{l}\text { 5. Proj./Prog./Dept./Div.: } \\
772032 / 203\end{array}$}} & \multirow{2}{*}{\multicolumn{2}{|c|}{$\begin{array}{l}\text { HMFS0013 } \\
112755 / C A 30\end{array}$}} & \multirow{2}{*}{\multicolumn{3}{|c|}{$\begin{array}{l}\text { 6. Design Authority/Design Agent/Cog. Engr.: } \\
\text { R. M. Mitchell }\end{array}$}} & \multicolumn{4}{|c|}{$\begin{array}{l}\text { 7. Purchase Order No: } \\
\text { NA }\end{array}$} \\
\hline \multirow{4}{*}{\multicolumn{7}{|c|}{$\begin{array}{l}\text { 8. Originator Remarks: } \\
\text { This document represents the data review and analyses for the } \\
\text { preoperational environmental survey of the spent Nuclear Fuel } \\
\text { Project Facilities. }\end{array}$}} & \multirow{2}{*}{\multicolumn{4}{|c|}{$\begin{array}{l}\text { 9. Equip./Component No.: } \\
\text { NA }\end{array}$}} \\
\hline & & & & & & & & & & \\
\hline & & & & & & & \multicolumn{4}{|c|}{$\begin{array}{l}\text { 10. System/Bidg./Facillty: } \\
\text { NA } \\
\end{array}$} \\
\hline & & & & & & & \multicolumn{4}{|c|}{ 12. Major Assm. Dwg. No.: } \\
\hline \multirow{3}{*}{\multicolumn{3}{|c|}{ 11. Receiver Remarks: }} & \multirow{3}{*}{\multicolumn{4}{|c|}{ 1A. Design Baseline Document? $\square$ Yes $\square$ No }} & \multirow{2}{*}{\multicolumn{4}{|c|}{$\begin{array}{l}\text { NA } \\
\text { 13. Permit/Permit Application No.: } \\
\text { NA }\end{array}$}} \\
\hline & & & & & & & & & & \\
\hline & & & & & & & \multicolumn{4}{|c|}{$\begin{array}{l}\text { 14. Required Response Date: } \\
\text { NA }\end{array}$} \\
\hline \multicolumn{3}{|l|}{15.} & \multicolumn{4}{|c|}{ DATA TRANSMITTED } & (F) & (G) & (H) & (l) \\
\hline $\begin{array}{c}\text { (A) } \\
\text { lfem } \\
\text { No. }\end{array}$ & \multicolumn{2}{|c|}{ (B) Document/Drawing No. } & $\begin{array}{l}\text { (C) Sheet } \\
\text { No. }\end{array}$ & (D) Rev. & \multicolumn{2}{|c|}{ (E) Title or Description of Data Transmitted } & $\begin{array}{l}\text { Agproval } \\
\text { nator } \\
\text { nator }\end{array}$ & $\begin{array}{c}\text { Reason } \\
\text { for Trans } \\
\text { mittal }\end{array}$ & $\begin{array}{c}\text { Origi- } \\
\text { nator } \\
\text { Dispo- } \\
\text { stion }\end{array}$ & $\begin{array}{l}\text { Receiv- } \\
\text { er } \\
\text { Dispo- } \\
\text { sition }\end{array}$ \\
\hline \multirow[t]{4}{*}{1} & \multicolumn{2}{|l|}{$\mathrm{HNF}-6150$} & NA & 0 & \multicolumn{2}{|c|}{ Preoperational Environ- } & $E$ & 2 & 1 & \\
\hline & & & & & \multicolumn{2}{|c|}{ mental Survey for the } & & & & \\
\hline & & & & & \multicolumn{2}{|c|}{ Spent Nuclear Fuel Project } & & & & \\
\hline & & & & & \multicolumn{2}{|c|}{ Facilities } & & & & \\
\hline & & & & & & & & & & \\
\hline & & & & & & & & & & \\
\hline & & & & & & & & & & \\
\hline \multicolumn{11}{|c|}{ KEY } \\
\hline \multicolumn{2}{|c|}{ Approval Designator $(F)$} & \multicolumn{4}{|c|}{ Reason for Transmittal (G) } & \multicolumn{5}{|c|}{ Disposition (H) \& (I) } \\
\hline \multicolumn{2}{|c|}{$\begin{array}{l}\text { E, S, Q, D OR N/A } \\
\text { (See WHC-CM-3-5, } \\
\text { Sec. 12.7) }\end{array}$} & $\begin{array}{l}\text { 1. Approval } \\
\text { 2. Release } \\
\text { 3. Information }\end{array}$ & \multicolumn{3}{|c|}{$\begin{array}{l}\text { 4. Review } \\
\text { 5. Post-Review } \\
\text { 6. Dist. (Receipt Acknow. Required) }\end{array}$} & $\begin{array}{l}\text { 1. Approved } \\
\text { 2. Approved w/comme } \\
\text { 3. Disapproved w/com }\end{array}$ & int & $\begin{array}{l}\text { 4. Review } \\
\text { 5. Review } \\
\text { 6. Recolip }\end{array}$ & $\begin{array}{l}\text { od no/co } \\
\text { od w/cor } \\
\text { acknow }\end{array}$ & $\begin{array}{l}\text { nment } \\
\text { ment } \\
\text { ddged }\end{array}$ \\
\hline
\end{tabular}

16.

\begin{tabular}{|c|l|}
\hline Approval Designator (F) & \\
\hline E, S, Q D OR N/A & 1. Approval \\
(See WHC.CM-3-5, & 2. Release \\
Sec. 12.7) & 3. Information \\
\hline
\end{tabular}

17.

Reason for Transmittal (G)
4. Review
5. Post-Review (Receipt Acknow. Required)

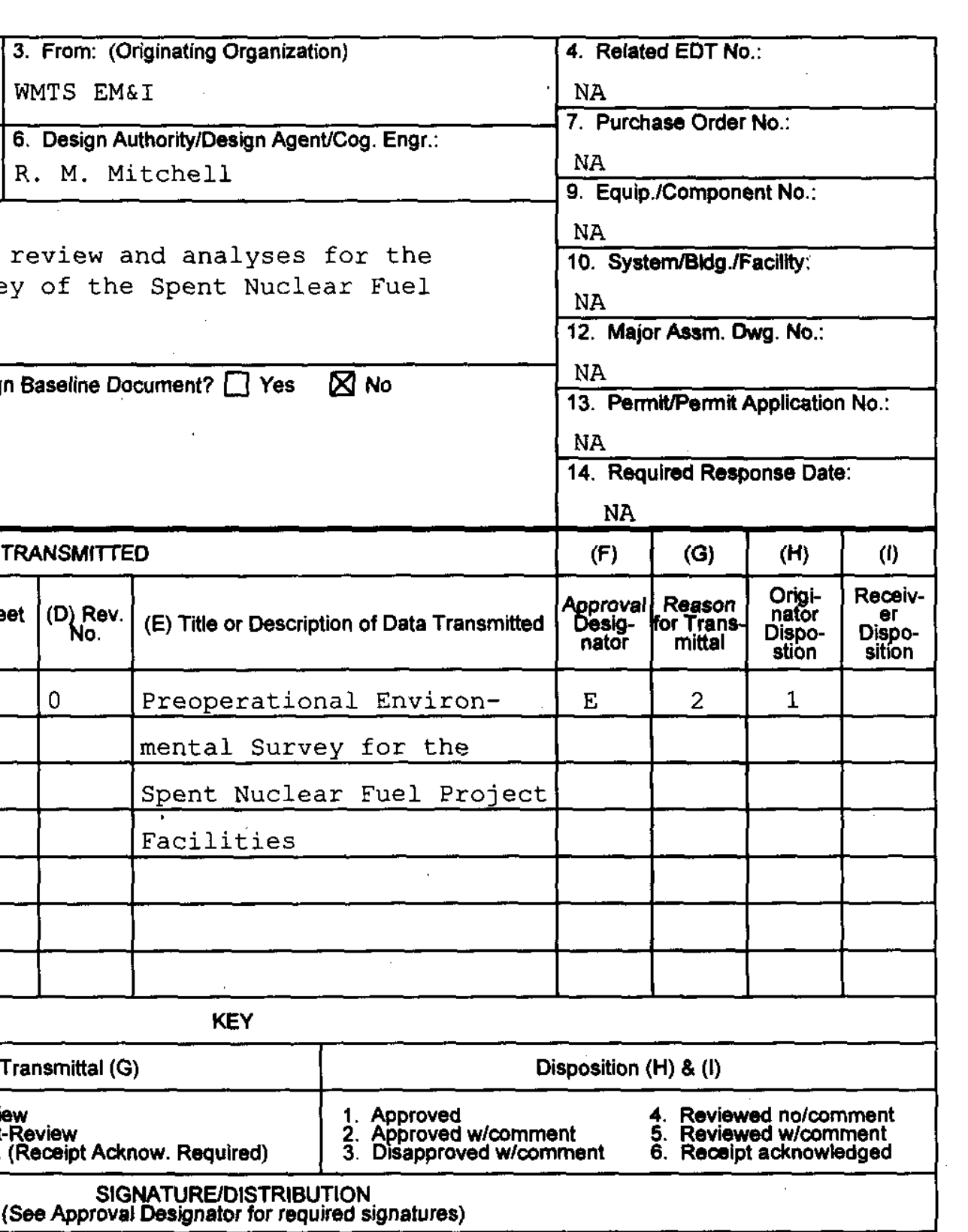

13. Permit/Permit Application No.: NA 14. Required Response Date:

NA

KEY

\section{Disposition (H) \& (I)}

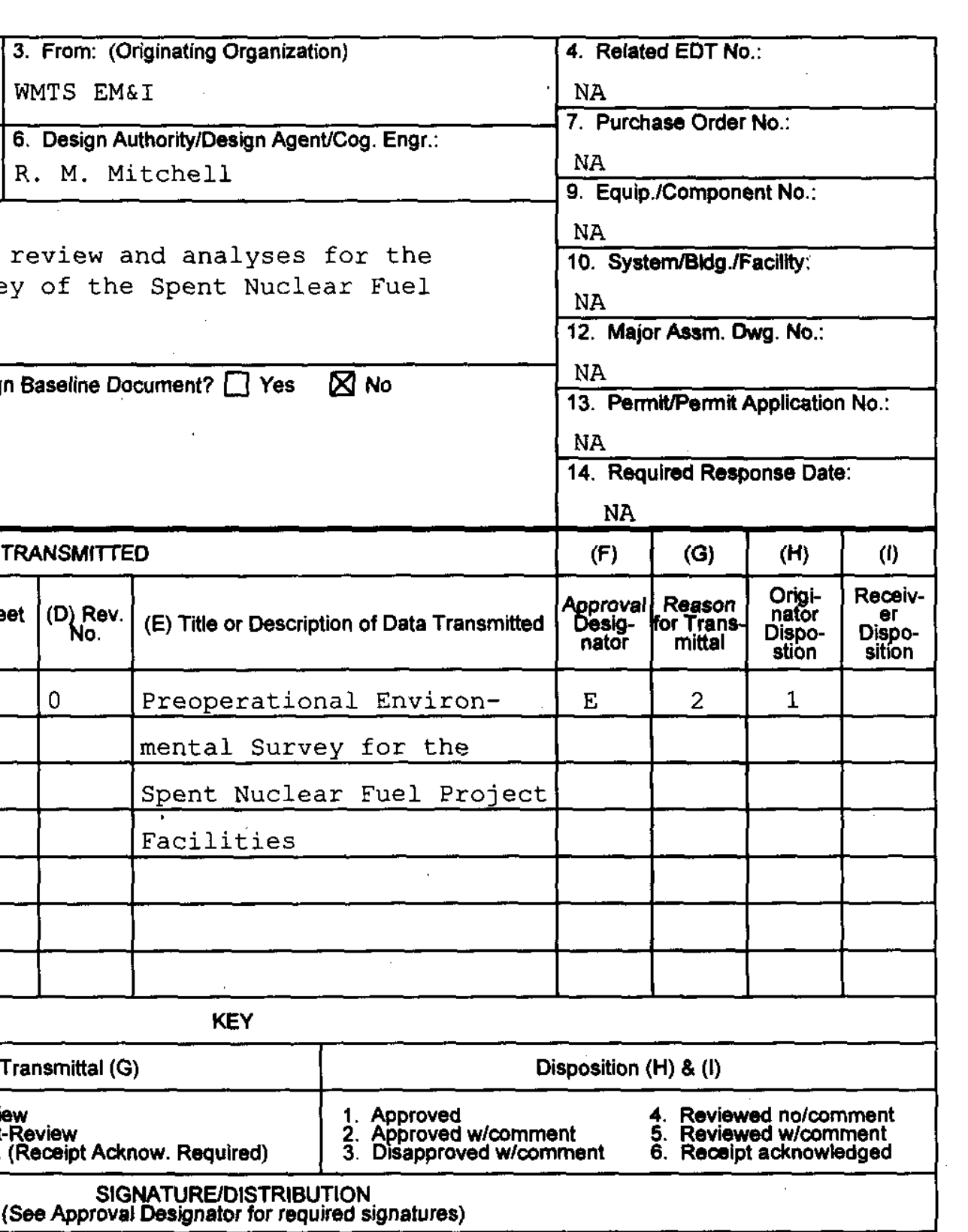

SIGNATURE/DISTRIBUTION

(See Approval Designator for required signatures)

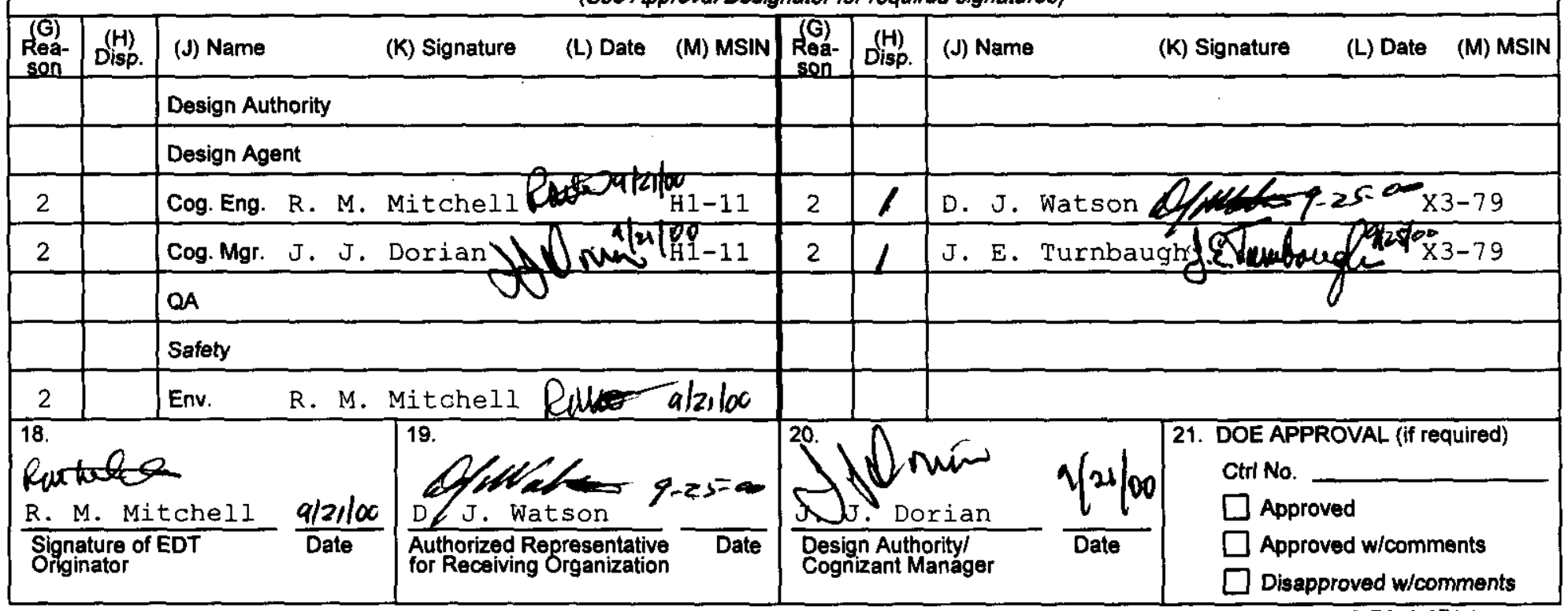




\section{DISTRIBUTION SHEET}

To

Distribution

\section{Project Title/Work Order}

Preoperational Environmental Survey of the Spent Nuclear Fuel

Project Facilities (HNF-6150, Rev. 0)

Name

G. D. Bazinet

P. K. Brockman

L. P. Diediker

R. L. Dirkes

J. J. Dorian

J. B. Hall

A. R. Johnson

B. M. Markes

S. M. McKinney

R. M. Mitchell (10)

D. J. Moak

C. J. Perkins

C. C. Pitkoff

J. E. Turnbaugh (2)

D. J. Watson (4)

Central Files

RL Reading Room

Records Management (SA Myers)

Washington State Department of Health

Division of Radiation Protection

Airdustrial Center, Bldg. 5

PO Box 47827

Olympia WA 98504-0095

R. A. Danielson

MS -7827
Page 1 of 1

Date September 26, 2000

EDT No. 628175

ECN No.

\begin{tabular}{|c|c|c|c|c|c|}
\hline & MSIN & $\begin{array}{c}\text { Text } \\
\text { With All } \\
\text { Attach. }\end{array}$ & Text Only & $\begin{array}{c}\text { Attach.I } \\
\text { Appendix } \\
\text { Only }\end{array}$ & $\begin{array}{c}\text { EDT/ECN } \\
\text { Only }\end{array}$ \\
\hline & $58-06$ & $x$ & & & \\
\hline & H $1-11$ & $x$ & & & \\
\hline & H6-36 & $\mathrm{x}$ & & & \\
\hline & $\mathrm{K} 6-75$ & $x$ & & & \\
\hline & H1-11 & $x$ & & & \\
\hline & A2-15 & $\mathrm{x}$ & & & \\
\hline & H $1-11$ & $x$ & & & \\
\hline & H $1-11$ & $\mathrm{x}$ & & & \\
\hline & H1-11 & $x$ & & & \\
\hline & H1 -11 & $\mathrm{x}$ & & & \\
\hline & H1-11 & $\mathrm{x}$ & & & \\
\hline & $\mathrm{H} 1-11$ & $\mathrm{x}$ & & & \\
\hline & R3-86 & $x$ & & & \\
\hline & $\times 3-79$ & $\mathrm{x}$ & & & \\
\hline & $\times 3-79$ & $x$ & & & \\
\hline & B1-07 & $x$ & & & \\
\hline & $\mathrm{H} 2-53$ & $x$ & & & \\
\hline & $\mathrm{H} 1-11$ & $\mathrm{x}$ & & & \\
\hline \multicolumn{6}{|l|}{ ealth } \\
\hline & & & & & \\
\hline & & & & & \\
\hline & & & & & \\
\hline & & & & & \\
\hline MS -7827 & & $x$ & & & \\
\hline & & & & & \\
\hline & & & & & \\
\hline & & & & & \\
\hline & & & & & \\
\hline & & & & & \\
\hline & & & & & \\
\hline
\end{tabular}

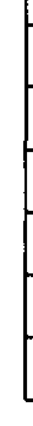


HNF-6150

Revision 0

\section{Preoperational Environmental Survey for the Spent Nuclear Fuel Project Facilities}

Prepared for the U.S. Department of Energy

Assistant Secretary for Environmental Management

Project Hanford Management Contractor for the

U.S. Department of Energy under Contract DE-AC06-86RL 13200

Fluor Hanford

P.O. Box 1000

Richland, Washington 


\title{
Preoperational Environmental Survey for the Spent Nuclear Fuel Project Facilities
}

\author{
Document Type: TR Division: SNF
}

R.M. Mitchell

Waste Management Technical Services

L.M. HAY

A.R. JOHNSON

B.M. MARKES

C.J. PERKINS

Waste Management Technical Services

Date Published

September 2000

Prepared for the U.S. Department of Energy

Assistant Secretary for Environmental Management

Project Hanford Management Contractor for the

U.S. Department of Energy under Contract DE-AC06-96RL13200

Fuor Hanford

P.O. Box 1000

Richland, Washington
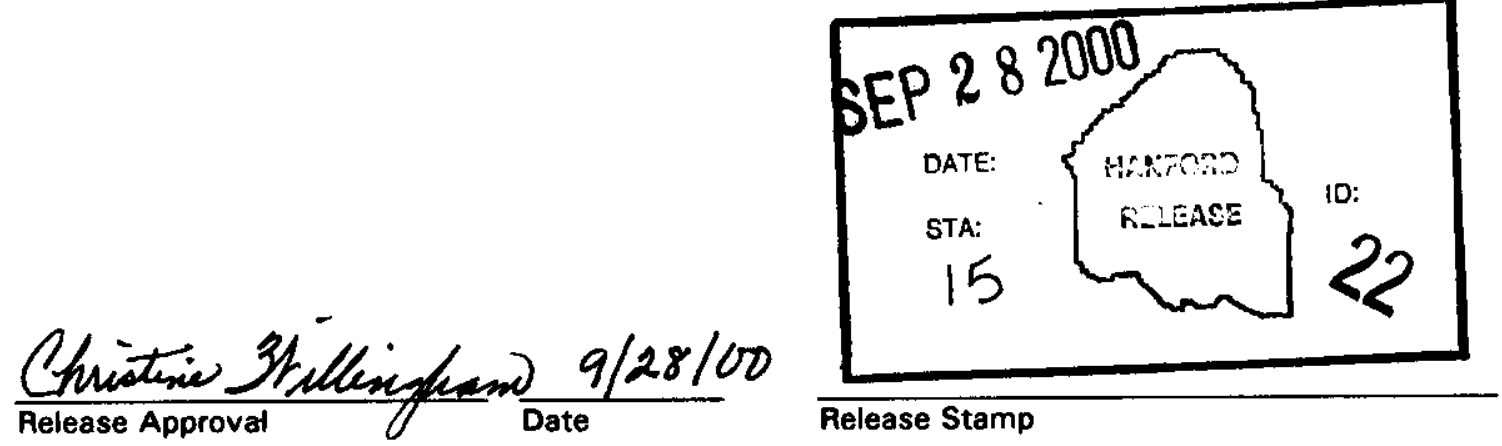


\section{TRADEMARK DISCLAMER}

Reference herein to any specific commercial product, process,

or service by trade name, trademark, manufacturer, or

otherwise, does not necesserlly conatitute or imply its

endorsement, recommendation, or favoring by the United

States Government or any agency thereof or its contractors or subcontractore.

This report has been reproduced from the beat aveilable copy.

Printed in the Unitad States of America

Total Pages: $\quad 72$ 
HNF-6150

Revision 0

Key Words: site characterization, preoperational survey, environmental baseline, radiological, Canister Storage Building, Cold Vacuum Drying Facility

\begin{abstract}
This document represents the report for environmental sampling of soil, vegetation, litter, cryptogams, and small mammals at the Spent Nuclear Fuel Project facilities located in $100 \mathrm{~K}$ and 200 East Areas in support of the preoperational environmental survey.
\end{abstract}




\section{PREOPERATIONAL ENVIRONMENTAL SURVEY FOR THE SPENT NUCLEAR FUEL PROJECT FACILITIES}

R. M. Mitchell

B. M. Markes

C. J. Perkins

L. M. Hay

A. R. Johnson 


\section{EXECUTIVE SUMMARY}

As noted in U.S. Department of Energy (DOE) Order 5400.1, ${ }^{1}$ a preoperational environmental survey is required for new facilities with potential for environmental impact to surrounding areas. The survey is to provide a baseline for appropriate environmental parameters and is to be conducted over a period of months to allow for determination of seasonal variation. Such a survey was conducted from September 1999 through August 2000 in support of the Spent Nuclear Fuel Project facilities. This report summarizes the results of the environmental characterization and reviews the potential for environmental impact from this project based on the findings of analytical results reported in this final document.

Environmental components addressed in this report included area history, topography, physiography, ecology, cultural resources, radiological status, external radiation, and potential chemical hazards. Sample site selections were based on a review of available historical documents, and site "walk-downs." The primary emphasis for the new facilities was at locations south and east of the Canister Storage Building (CSB) in 200 East Area and west, south and east of the $100 \mathrm{~K}$ Area. The western and southern sample locations were near the cold vacuum drying facility (CVDF) and the eastern locations near the $100 \mathrm{KE}$ basins. Samples from these locations included surface soil and vegetation. Parameters analyzed included radionuclides (e.g., gamma energy analysis, ${ }^{90} \mathrm{Sr}$, isotopic plutonium and uranium), metals and selected chemicals (e.g., cyanide, anions, polychlorinated biphenyls [PCBs] and pesticides).

Radionuclide analyses at all sample points were either below detection limits or, although measurable, within acceptable ranges for all measured constituents. The highest radionuclide values for ${ }^{137} \mathrm{Cs},{ }^{90} \mathrm{Sr}$, and ${ }^{239 / 240} \mathrm{Pu}$ occurred in surface soil, vegetation and cryptogam samples collected in and around the $100 \mathrm{~K}$ Area. Alternatively, the highest values for these same radionuclides in plant litter were collected near the CSB in the 200 East Area. These values were not generally above expectations for these locations. The values reported for hazardous chemicals analyses at the sample points were either below detection limits or, although measurable, within expected ranges for the measured conditions.

\footnotetext{
${ }^{1}$ DOE, 1988, General Environmental Protection Program, DOE Order 5400.1, U.S. Department of Energy, Washington, D.C.
} 
HNF-6150 Rev. 0

\section{LIST OF TERMS}

\begin{tabular}{ll} 
AHA & Activity Hazard Analysis \\
CERCLA & Comprehensive Environmental Response, Compensation and Liability Act of 1980 \\
CFR & Code of Federal Regulations \\
cm & centimeter \\
COC & Chain of Custody \\
CSB & Canister Storage Building \\
CVDF & Cold Vacuum Drying Facility \\
DOE & U.S. Department of Energy \\
DQOs & Data Quality Objectives \\
EIS & Environmental Impact Statement \\
EMP & Environmental Monitoring Program \\
EPA & U.S. Environmental Protection Agency \\
ERDF & Environmental Restoration Disposal Facility \\
FH & Fluor Hanford \\
ft & foot \\
GIS & Geographic Information System \\
GSSI & Geophysical Survey Systems Inc. \\
HLW & high-level waste \\
HPT & health physics technician \\
in. & inch \\
ISA & 200 East Interim Storage Area \\
KE & K East Area/Basin \\
km & kilometer \\
KW & K West Area/Basin \\
LLW & low-level waste \\
MCOs & multicanister overpacks \\
m & meter \\
mi & mile \\
min & minute \\
mm & millimeter \\
NAD & North American Datum \\
NEPA & National Environmental Policy Act of 1969 \\
OVM & organic-vapor monitor \\
PCB & polychlorinated biphenyls \\
PAM & portable alpha meter \\
PNNL & Pacific Northwest National Laboratory \\
ppm & parts per million \\
PUREX & Plutonium-Uranium Extraction (Plant) \\
QA & quality assurance \\
QA/QC & quality assurance/quality control \\
QC & quality control \\
RCRA & Resource Conservation and Recovery Act of 1976 \\
RHO & Rockwell Hanford Operations \\
& \\
\hline
\end{tabular}




\section{HNF-6150 Rev. 0}

$\begin{array}{ll}\text { ROD } & \text { Record of Decision } \\ \text { SAS } & \text { special analytical studies } \\ \text { SCF } & \text { Sludge Conditioning Facility } \\ \text { SAP } & \text { sampling and analysis plan } \\ \text { SNF } & \text { Spent Nuclear Fuel } \\ \text { SP } & \text { standard practice } \\ \text { SWOC } & \text { Solid Waste Operations Complex } \\ \text { TLD } & \text { thermoluminescent dosimeter } \\ \text { TWRS } & \text { Tank Waste Remediation System } \\ \text { WDOH } & \text { Washington State Department of Health } \\ \text { WHC } & \text { Westinghouse Hanford Company } \\ \text { WMTS } & \text { Waste Management Technical Services } \\ \text { WSCF } & \text { Waste Sampling and Characterization Facility } \\ \text { yd } & \text { yard }\end{array}$




\section{CONTENTS}

1.0 INTRODUCTION

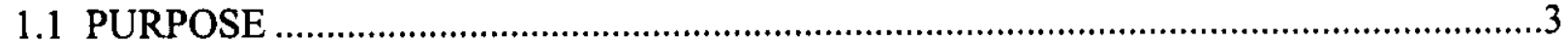

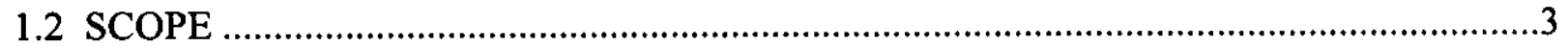

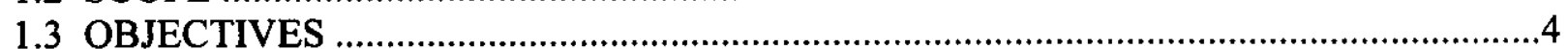

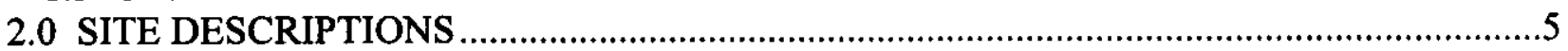

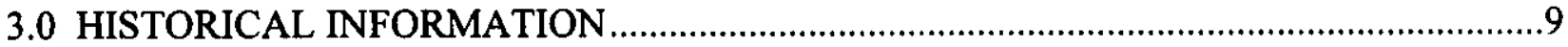

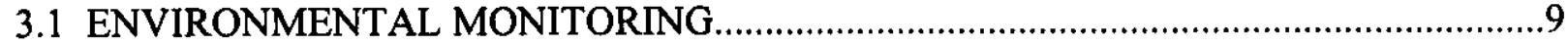

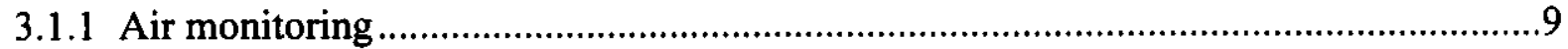

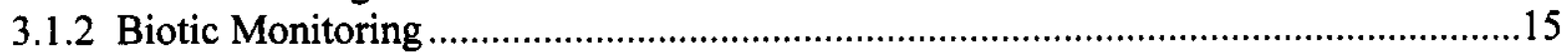

3.1.3 Thermoluminescent Dosimeter Monitoring …….....................................................22

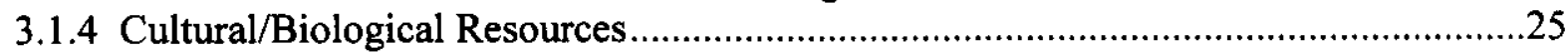

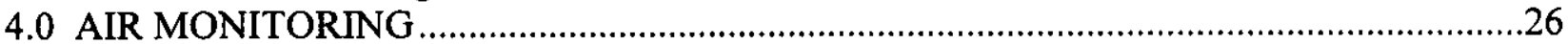

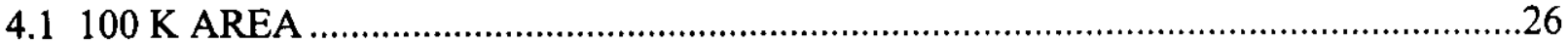

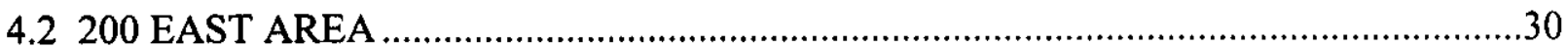

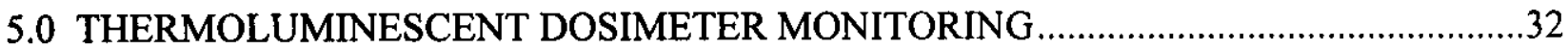

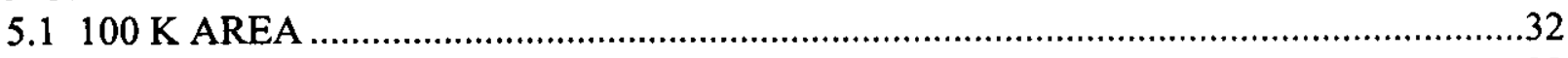

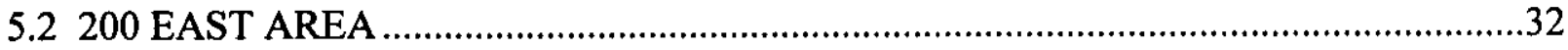

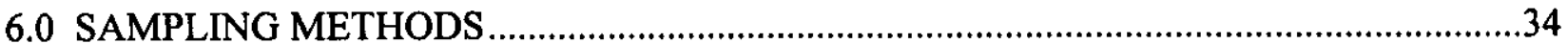

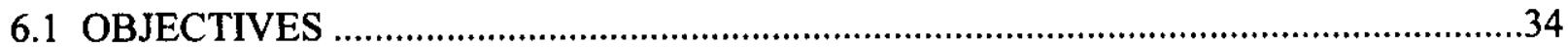

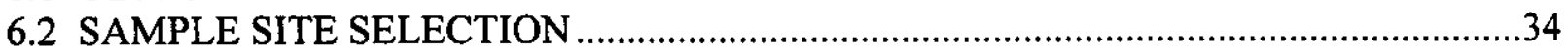

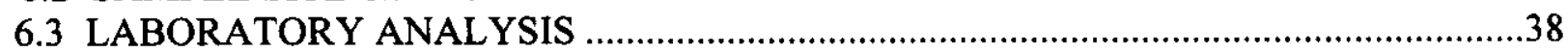

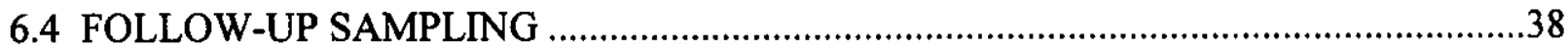

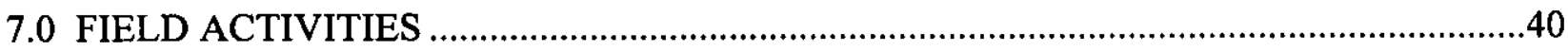

7.1 PRELIMINARY FIELD ACTIVITIES …………......................................................

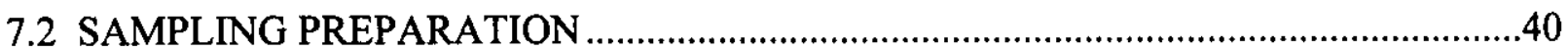

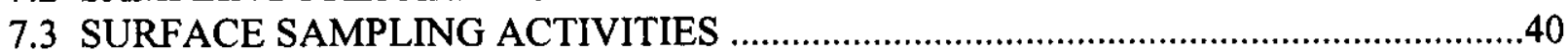

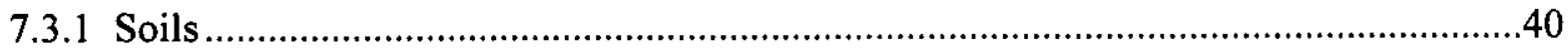

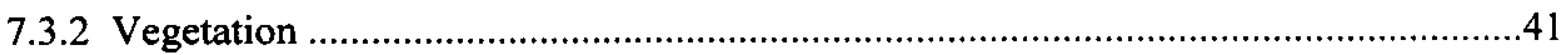

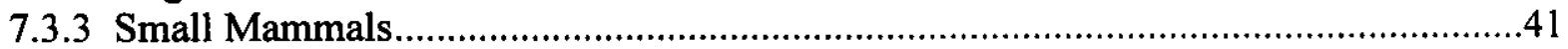

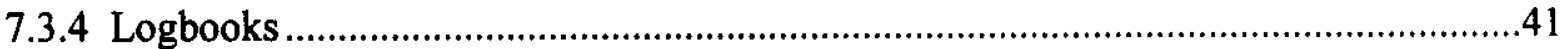

7.4 QUALITY ASSURANCE/QUALITY CONTROL SAMPLES ........................................41

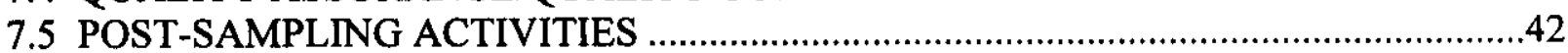

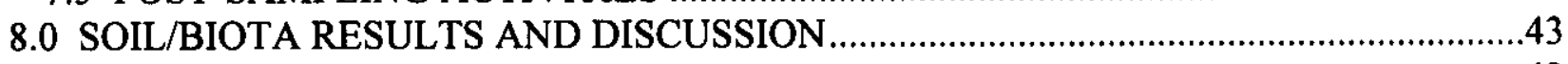

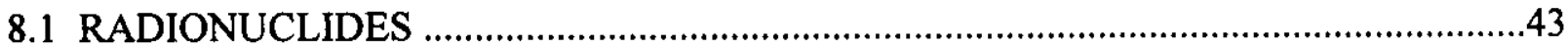

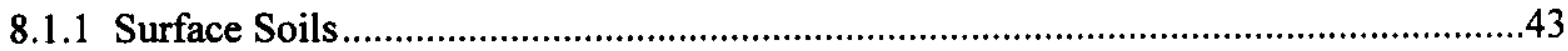

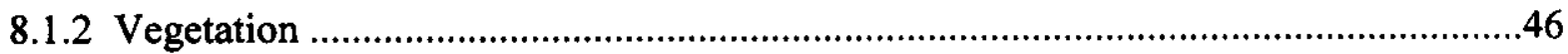

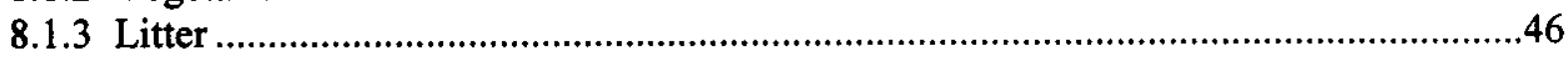

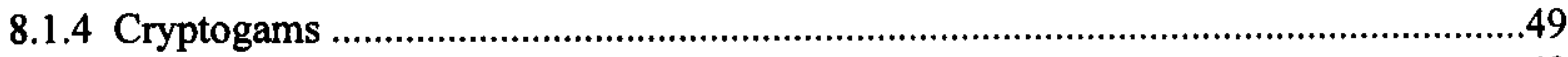

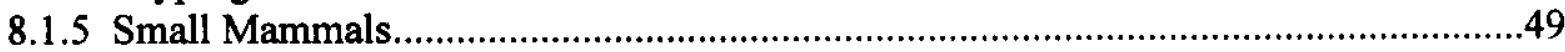

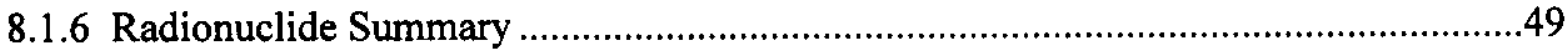

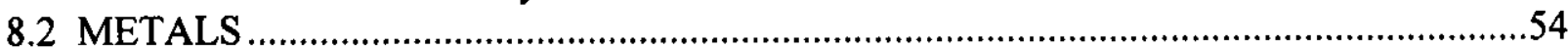

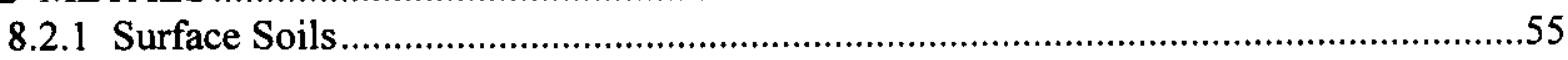

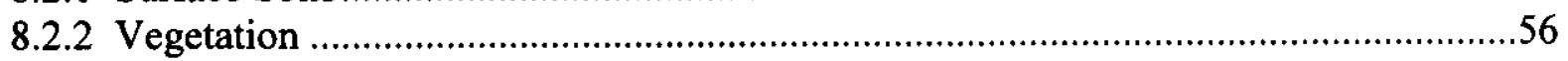




\section{HNF-6150 Rev. 0}

\section{CONTENTS (continued)}

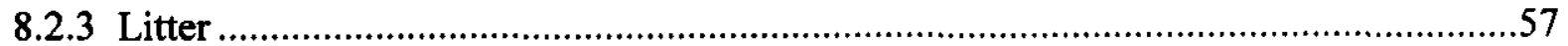

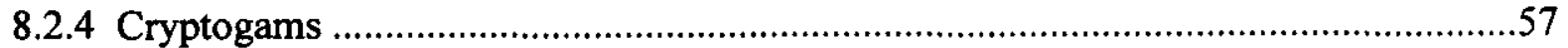

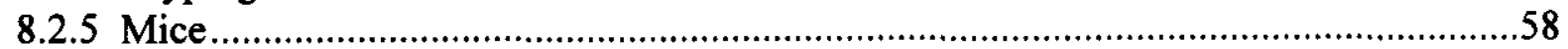

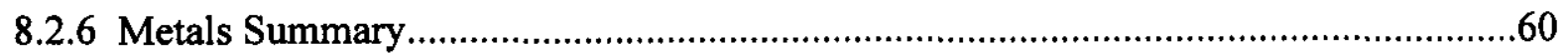

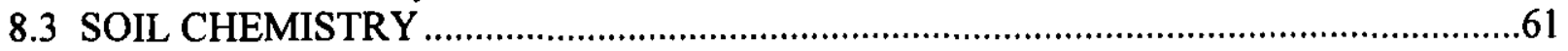

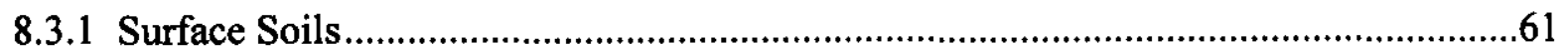

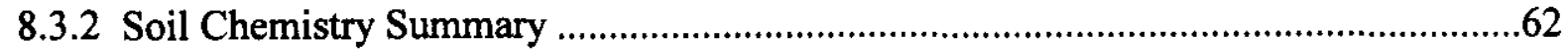

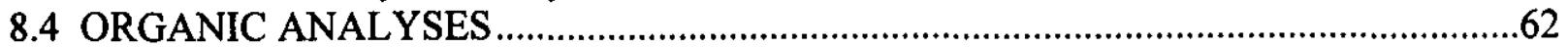

8.5 QUALITY ASSURANCE/QUALITY CONTROL DATA SUMMARY …………….......63

8.6 WASHINGTON STATE DEPARTMENT OF HEALTH SAMPLING DATA .................65

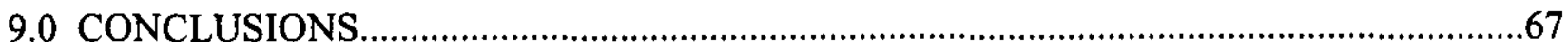

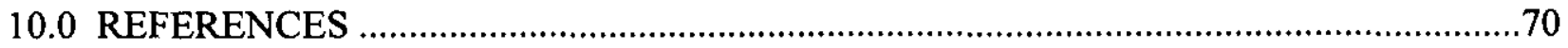

\section{APPENDICES}

A BIOLOGICAL/CULTURAL RESOURCES REVIEWS .............................................. A-i

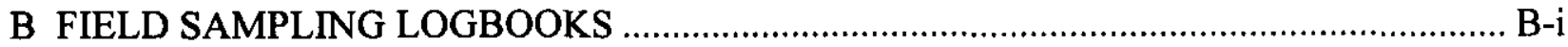

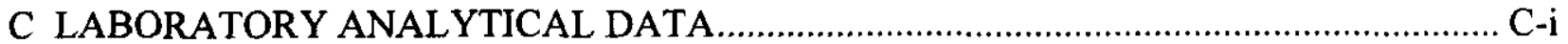




\section{HNF-6150 Rev. 0}

\section{TABLES}

Table 3-1. $100 \mathrm{~K}$ Ambient Air Monitoring Results-Five Year Averages ( $\left.\mathrm{pCi} / \mathrm{m}^{3}\right)$............... 12 Table 3-2. 200 East Ambient Air Monitoring Results-Five Year Averages $\left(\mathrm{pCi} / \mathrm{m}^{3}\right) \ldots \ldots \ldots \ldots 14$ Table 3-3. Average Radionuclide Concentrations (pCi/g) Detected in $100 \mathrm{~K}$ Area

Surface Soil Samples from 1981 to 1993.

Table 3-4. Average Radionuclide Concentrations (pCi/g) Detected in $100 \mathrm{~K}$ Area Vegetation

Samples from 1981 to 1993.

Table 3-5. Summary of Routine Monitoring Samples Collected in the

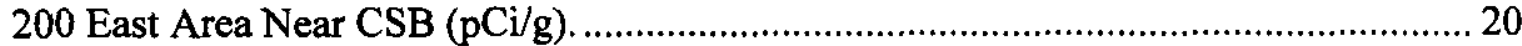

Table 3-6. Cross-site Transfer Line Study Radionuclides (pCi/g) ..................................... 21

Table 3-7. Cross-site Transfer Line Study Metals (ppm). ..................................................... 21

Table 3-8. Summary of Selected Constituents (ppm) Analyzed by Wasmiller (1993).............. 21

Table 4-1. Average 100 K Area Radionuclide Concentrations from 1994 through 1999

$\left(\mathrm{pCi} / \mathrm{m}^{3} \pm 2 \mathrm{SEM}\right)$.

Table 4-2. Average $100 \mathrm{~K}$ Area Radionuclide Concentrations from February 1999 through

December $1999\left(\mathrm{pCi} / \mathrm{m}^{3} \pm 2 \mathrm{SEM}\right)$.

Table 4-3. Average 200 East Radionuclide Concentrations from 1994 through 1999

$\left(\mathrm{pCi} / \mathrm{m}^{3} \pm 2 \mathrm{SEM}\right)$.

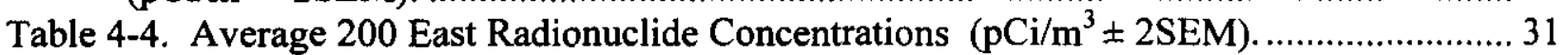

Table 5-1. $100 \mathrm{~K}$ Area Quarterly TLD Dose Rates Near the CVDF...................................... 33

Table 5-2. 200 East Area vs. CSB Quarterly TLD Dose Rates.............................................. 33

Table 6-1. Sample Site Coordinates for the SNF Project Facilities Sampling Locations............ 35

Table 6-2. Sample Analyses Summary ........................................................................... 39

Table 8-1, Part A. Radionuclide Data from $100 \mathrm{~K}$ Area Surface Soils (pCi/g)....................... 44

Table 8-1, Part B. Radionuclide Data from $100 \mathrm{~K}$ Area Surface Soils (pCi/g)........................ 44

Table 8-2, Part A. Radionuclide Data for 200 East Area Surface Soils (pCi/g) ...................... 45

Table 8-2, Part B. Radionuclide Data for 200 East Area Surface Soils (pCi/g)...................... 45

Table 8-3, Part A. Radionuclide Data for $100 \mathrm{~K}$ Area Vegetation (pCi/g). ............................. 47

Table 8-3, Part B. Radionuclide Data for $100 \mathrm{~K}$ Area Vegetation (pCi/g).............................. 47

Table 8-4, Part A. Radionuclide Data for 200 East Area Vegetation (pCi/g). ........................ 47

Table 8-4, Part B. Radionuclide Data for 200 East Area Vegetation (pCi/g)........................ 47

Table 8-5, Part A. Radionuclide Data for $100 \mathrm{~K}$ Area Litter Samples (pCi/g) ....................... 48

Table 8-5, Part B. Radionuclide Data for $100 \mathrm{~K}$ Area Litter Samples (pCi/g)........................ 48

Table 8-6, Part A. Radionuclide Data for 200 East Area Litter Samples (pCi/g).................... 48

Table 8-6, Part B. Radionuclide Data for 200 East Area Litter Samples (pCi/g)..................... 48

Table 8-7, Part A. Radionuclide Data for Cryptogam Collected at $100 \mathrm{~K}$ Area (pCi/g)........... 50

Table 8-7, Part B. Radionuclide Data for Cryptogam Collected at $100 \mathrm{~K}$ Area (pCi/g)........... 50

Table 8-8, Part A. Radionuclide Data for Cryptogam Samples Collected at 200 East Area

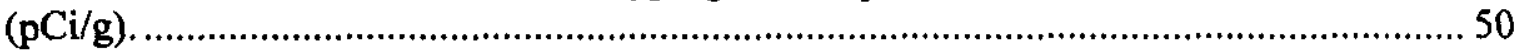

Table 8-8, Part B. Radionuclide Data for Cryptogam Samples Collected at 200 East Area

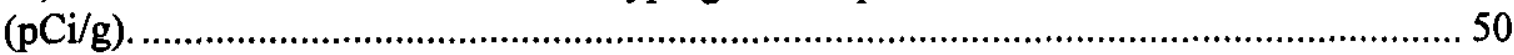

Table 8-9, Part A. Radionuclide Summary for Mice Captured at $100 \mathrm{~K} \mathrm{Area} \mathrm{(pCi/g).............} 51$

Table 8-9, Part B. Radionuclide Summary for Mice Captured at $100 \mathrm{~K}$ Area (pCi/g). ............. 51

Table 8-10, Part A. Radionuclide Summary for Mice Captured in 200 East Area (pCi/g)........ 51 
Table 8-10, Part B. Radionuclide Summary for Mice Captured in 200 East Area (pCi/g)........ 51

Table 8-11. Summary of Average and Maximum Values for Selected

Constituents in Sample Media (pCi/g) ................................................................... 52

Table 8-12. Summary of Maximum Radionuclide Values Analyzed in Mice

From This and Previous Studies (pCi/g) ................................................................... 53

Table 8-13. Summary ${ }^{(a)}$ of Reported Maximum Metals Concentrations for

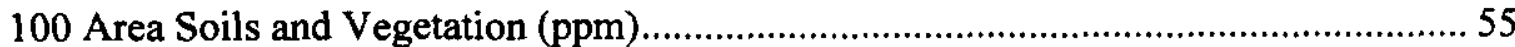

Table 8-14. Summary of Maximum Metals Values Reported for 200 Area Soils and

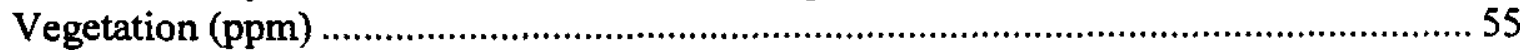

Table 8-15. Metals Data for $100 \mathrm{~K}$ Area Surface Soils (ppm) .............................................. 56

Table 8-16. Metals Data for 200 East Area Surface Soils (ppm). .......................................... 56

Table 8-17. Metals Data for $100 \mathrm{~K}$ Area Vegetation (ppm)................................................. 57

Table 8-18. Metals Data for 200 East Area Vegetation (ppm) .............................................. 57

Table 8-19. Metals Data for $100 \mathrm{~K}$ Area Litter (ppm) ......................................................... 58

Table 8-20. Metals Data for 200 East Area Litter (ppm)...................................................... 58

Table 8-21. Metals Data for $100 \mathrm{~K}$ Area Cryptogams (ppm) ..............................................58

Table 8-22. Metals Data for 200 East Area Cryptogams (ppm) .......................................... 58

Table 8-23. Summary of Values for Selected Metals in Mice Collected in $100 \mathrm{~K}$ Area (ppm).. 59

Table 8-24. Summary of Metals Data (Maximum Values) for Mice in

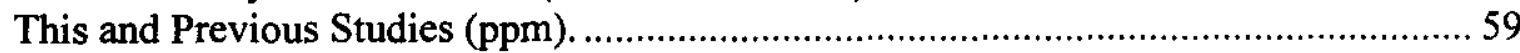

Table 8-25. Summary of Values for Selected Metals in Mice Collected at

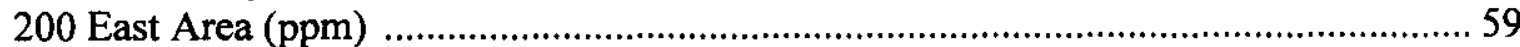

Table 8-26. Summary of the Maximum Metals Values Reported for SNF Project Samples

Comparisons are Provided to Hanford Site and Washington ........................................6 60

Table 8-27. Chemical Data for $100 \mathrm{~K}$ Area Surface Soils (ppm) .......................................... 61

Table 8-28. Chemical Data for 200 East Area Surface Soils (ppm) ...................................... 62

Table 8-29. Summary of Reported Soil Chemistry Maximum Soil Values (ppm) for the

SNF Study, Other 200 Area Studies and the Hanford Site Soil Background................... 62

Table 8-30, Part A. Radionuclide Concentrations in Soil Samples (pCi/g)............................ 63

Table 8-30, Part B. Radionuclide Concentrations in Soil Samples (pCi/g) ............................63

Table 8-31, Part A. Radionuclide Concentrations Reported for Vegetation (pCi/g)................ 63

Table 8-31, Part B. Radionuclide Concentrations Reported for Vegetation (pCi/g) ................ 64

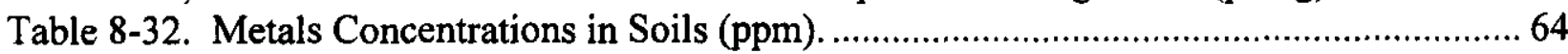

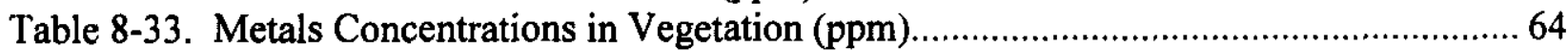

Table 8-34. Chemical Concentrations in Soils (ppm) ........................................................ 64

Table 8-35, Part A. WDOH Radionuclide Data for Collocated Soil Samples ..........................66

Table 8-35, Part B. WDOH Radionuclide Data for Collocated Soil Samples............................ 66

Table 8-36. WDOH Radionuclide Data for Collocated Vegetation Samples............................ 66 


\section{HNF-6150 Rev. 0}

\section{FIGURES}

Figure 1-1. Map of the Hanford Site and the $100 \mathrm{~K}$ Area and 200 East Area............................. 2

Figure 2-1. Location of the cold vacuum drying facility in the $100 \mathrm{~K}$ Area of the

Hanford Site. ............................................................................................................. 6

Figure 2-2. Location of the Canister Storage Building Site in 200 East Area.............................. 7

Figure 3-1. $100 \mathrm{~K}$ Area Showing the Location of Existing and New

Air Monitoring Stations ................................................................................................ 11

Figure 3-2. 200 Air Sampling Locations for Near-Facility Monitoring.

New locations in gray 13

Figure 3-3. Historical (1981-1993) Soil and Vegetation Sampling Locations at $100 \mathrm{~K}$ Area..... 16

Figure 3-4. 200 East Soil Sampling Locations for Near-Facility Monitoring .............................. 19

Figure 3-5. Map of $100 \mathrm{~K}$ Area Showing TLD Monitoring Locations. ...................................... 23

Figure 3-6 TLD Monitoring Locations in 200 East Area. The two new sites are in gray.......... 24

Figure 4-1. Strontium-90 Concentrations for the $100 \mathrm{~K}$ Area .................................................. 28

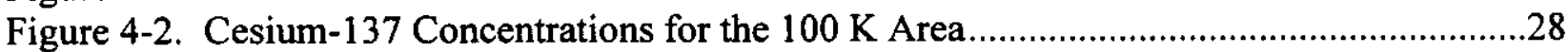

Figure 4-3. Plutonium-239/240 Concentrations for the $100 \mathrm{~K}$ Area..........................................29

Figure 4-4. Americium-241 Concentrations for the $100 \mathrm{~K}$ Area.................................................29

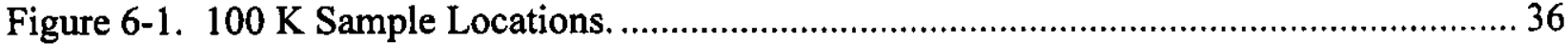

Figure 6-2. Canister Storage Building (CSB) Sample Locations. ............................................. 37 
HNF-6150 Rev. 0

\section{PREOPERATIONAL ENVIRONMENTAL SURVEY FOR THE SPENT NUCLEAR FUEL PROJECT FACILTIES}

\subsection{INTRODUCTION}

This survey report supports the preoperational environmental monitoring for construction, development, and operation of the Spent Nuclear Fuel (SNF) Project facilities, which have been designed for the conditioning and storage of spent nuclear fuels; particularly the fuel elements associated with the operation of N-Reactor. The SNF consists principally of irradiated metallic uranium, and therefore includes plutonium and mixed fission products. The primary effort will consist of removing the SNF from the storage basins in K East and K West Areas (Figure 1-1), placing it in multicanister overpacks, vacuum drying, conditioning, and subsequent dry vault storage in the 200 East Area.

The primary purpose and need for this action is to reduce the risks to public health and safety and to the environment. Specifically, these efforts include prevention of the release of radioactive materials into the air or to the soil surrounding the $K$ Basins, prevention of the potential migration of radionuclides through the soil column to the nearby Columbia River, reduction of occupational radiation exposure, and elimination of the risks to the public and to workers from the deterioration of SNF in the K Basins (U.S. Department of Energy [DOE] 1995, 1996).

Preoperational monitoring efforts were conducted to determine existing environmental conditions, assess the potential for contaminants, and evaluate potential risks and hazards prior to construction and operation of new facilities in accordance with DOE Order 5484.1, Environmental Protection, Safety and Health Protection Information Reporting Requirements (DOE 1981).

DOE Order 5400.1, General Environmental Protection Program (DOE 1988a), requires an environmental study before the startup of new facilities and processes. This DOE order is expected to become part of 10 CFR 834, Radiological Protection of the Public and the Environment, in the future. 


\section{HNF-6150 Rev. 0}

Figure 1-1. Map of the Hanford Site and the $100 \mathrm{~K}$ Area and 200 East Area. 
HNF-6150 Rev. 0

\subsection{PURPOSE}

The sampling and monitoring efforts described herein were conducted in support of an environmental baseline to establish the preoperational conditions at the SNF Project facilities sites in accordance with the requirements set forth in DOE Order 5400.1, Chapter IV (DOE 1988a). The data obtained from the baseline sampling activities is being used to meet the following objectives:

- Identify baseline levels of contaminants in surface soils, vegetation, and the smallmammal community

- Allow for future determination of potential impacts to the environment from SNF Project facilities construction and operation activities

- Provide guidance for development of monitoring and surveillance requirements within, and surrounding, the SNF Project facilities.

\subsection{SCOPE}

With the selection of the preferred alternative (DOE 1996) to remove the SNF from the storage basins in $\mathrm{K}$ East and $\mathrm{K}$ West, vacuum dry, condition, and provide dry vault storage, new facilities will be required. This proposed effort will require the construction of a new "cold vacuum" drying facility (CVDF) located in the western portion of the $\mathrm{K}$ West Area (Figure 2-1). A second facility, the Canister Storage Building (CSB), along with the establishment of the Interim Storage Area (ISA), which has been constructed in the west-central portion of the 200 East Area (Figure 2-2), will be utilized for dry vault storage. The debris and water which will be removed from the $\mathrm{K}$ East $/ \mathrm{K}$ West storage basins will be disposed of in existing facilities. The sludge, which will be removed from the $100 \mathrm{~K}$ East and $100 \mathrm{~K}$ West storage basins, will be removed and stored elsewhere at Hanford.

Prior to the startup of new facilities or modification of existing facilities, DOE requires the development of environmental baseline surveys for the protection of workers, the public, and the surrounding environment. This regulatory guidance is provided as part of DOE Order 5400.1 (DOE 1988a); DOE Order 5484.1 (DOE 1981); and Radiation Protection of the Public and the Environment, DOE 5400.5 (DOE 1990a). Additionally, since the product will be accepted by DOE and disposed of on the Hanford Site, it will be subject to DOE Order 435.1, Radioactive Waste Management (DOE 1999).

The technical guidance for implementation of baseline environmental surveys is provided in DOE/EH-0173T, Environmental Regulatory Guide for Radiological Effluent Monitoring and Environmental Surveillance (DOE 1991) and in the handbook entitled, Environmental Monitoring for Low Level Waste Disposal Sites (DOE 1990b).

The focus of this survey was to determine the environmental conditions in and around the proposed CVDF in K West and the CSB in 200 East. To direct this effort, a Sampling and 
HNF-6150 Rev. 0

Analysis Plan (SAP) was prepared that delineated the type and number of samples to be collected, their locations, analyses required etc. (Mitchell et al. 1999).

\subsection{OBJECTIVES}

The primary objective of this preoperational survey was to establish an environmental baseline for the SNF Project facilities as prescribed and defined by the regulatory requirements. This was done to determine the environmental conditions and establish background levels for contamination that may exist proximate to the proposed facility location. This effort provided documentation of the current levels of radioactive and selected chemical contaminants in the air, soils, vegetation, and small-mammal community at the two locations. External radiation levels were also measured utilizing TLDs.

Specific considerations were given to the proximity of cribs, transfer lines, trenches, and other waste sites located near the proposed facilities. Other potential concerns included prevailing winds which could transport contaminated dust particles from waste sites located upwind, as well as contaminated vegetation which could blow onto the site and scatter contaminated particles.

Therefore, elevated levels of radionuclides or chemical constituents found during this preoperational survey could be attributable to past practices and/or ongoing operations in the vicinity proximal to the location of the SNF Project facilities. This information will provide guidance for the determination of potential contaminant transport pathways. The data obtained will also assist in the development of the operational monitoring and surveillance system for early detection of potential impacts from other facility operations, or from SNF Project facilities operations to the surrounding environment. 


\subsection{SITE DESCRIPTIONS}

The $100 \mathrm{~K}$ Area is located along the Columbia River approximately $3 \mathrm{~km}(1.9 \mathrm{mi})$ upstream of the $100 \mathrm{~N}$ Area (Figure 2-1). It consisted of two reactors, $\mathrm{K}$ East and $\mathrm{K}$ West whose cooling basins currently contain the Spent Nuclear Fuel (Figure 2-1).

The 200 East Area lies on a plateau in the central portion of the Hanford Site (Figure 2-2) approximately $11 \mathrm{~km}(6.8 \mathrm{mi})$ south of the Columbia River. These two sites are the location of various radionuclide and hazardous waste process facilities and waste disposal facilities (e.g., liquid waste cribs and solid waste burial grounds).

The ecology of the 100 and 200 Areas was originally mature shrub-steppe desert characterized by such vegetation as big sagebrush (Artemisia tridentata) and Sandberg's bluegrass (Poa sandbergii). Large tracts of these habitat types exist outside these areas. However, the sagebrush habitat within the areas has generally been disturbed. These disturbed areas support a variety of plants such as introduced bunchgrasses (Agropyron spp.), and invaders such as Russian thistle (Salsola kali), cheatgrass (Bromus tectorum), and rabbitbrush (Chrysothamnus spp.).

Animal species of the Hanford Site, while still similar to those found before human use of the area (except certain invaders which have taken advantage of the changed habitats), are generally at reduced numbers where there is a reduction in vegetative cover and species. Native species include the long-billed curlew (Numenius americanus), the horned lark (Eremiphila alpestris), the burrowing owl (Athene cunicularia), the great horned owl (Bubo virginianus), the sage sparrow (Amphispiza belli), the loggerhead shrike (Lanius ludovicianus), the Great Basin pocket mouse (Perognathus parvus), the deer mouse (Peromyscus maniculatus), the Western harvest mouse (Reithrodontomys megalotis), the pocket gopher (Thomomys talpoides), the blacktailed jackrabbit (Lepus californicus), the badger (Taxidea taxis), the coyote (Canis latrans), and the mule deer (Odocoileus hemionus).

Non-native species taking advantage of the altered habitats include the domestic pigeon (Columba livia) and the house mouse (Mus musculus). Additional information on existing habitat and associated species can be found in Neitzel (1999).

Twelve plant species considered to be endangered, threatened, or sensitive by the Washington Natural Heritage Program (1994) are known to survive on or near the Hanford Site, seven of which are upland species (Sackschewsky et al. 1992). The upland species are northern wormwood (Artemisia campestris spp. Borealis var. wormskiodii), Hoover's desert parsley (Lomatium tuberosum), Piper's daisy (Erigeron piperianus), gray cryptantha (Cryptantha leucophea), Palouse milkvetch (Astragalus arrectus), and coyote tobacco (Nicotiana attenuata). Currently, none of the plant species are listed as federal threatened or endangered species. However, three local upland species are candidates for federal protection: (1) northern wormwood, (2) Hoover's desert parsley, and (3) Columbia milkvetch. 


\section{HNF-6150 Rev. 0}

Figure 2-1. Location of the Cold Vacuum Drying Facility in the $100 \mathrm{~K}$ Area of the Hanford Site. 


\section{HNF-6150 Rev. 0}

Figure 2-2. Location of the Canister Storage Building Site in 200 East Area. 


\section{HNF-6150 Rev. 0}

The bald eagle and peregrine falcon are the only federally listed threatened or endangered wildlife species occurring near the 200 Areas. Federal candidate species occurring near the 200 Areas include the ferrunginous hawk and loggerhead shrike. The pygmy rabbit, a shrubsteppe species listed as a federal candidate species and state threatened species, has not been observed on the Hanford Site since 1984 (Fitzner et al. 1992). The sage grouse, another federal candidate shrub-steppe species, has not been observed at the Hanford Site since the mid-1980's and probably no longer resides at the Site (Landeen et al. 1992). State listed threatened or endangered wildlife includes the peregrine falcon and ferruginous hawk. State candidate species observed near the 200 Areas include the golden eagle, burrowing owl, sage thrasher, Swainson's hawk, striped whipsnake, Merriam's shrew, and sage sparrow (Stegen 1992).

The specific areas comprising the proposed facilities are generally devoid of native vegetation, which over the years has been disturbed by various waste management activities, as well as construction of roads, buildings, storage basins, and other facilities. Therefore, the human activities and ongoing construction efforts have greatly reduced the likelihood that any protected species occur in the near vicinity. During the sampling activities, biologists did not observe any protected species. 
HNF-6150 Rev. 0

\subsection{HISTORICAL INFORMATION}

Environmental monitoring efforts to determine radionuclide levels in the $100 \mathrm{~K}$ and 200 East Areas have been conducted by Rockwell Hanford Operations and Westinghouse Hanford Company in association with the burial grounds, liquid waste disposal facilities, and waste management activities conducted within and around these sites (Panesko et al. 1977; Panesko et al. 1978; Houston and Blumer 1978, 1979a, 1979b; Schmidt et al. 1990, 1991, 1992a, 1992b, 1993, 1994, 1995, 1996; Perkins 1988, 1990, 1991, 1992). Since October 1997 this monitoring has been conducted by Waste Management Technical Services (WMTS) for Fluor Hanford (FH) (Perkins et al. 1997, 1998).

Since the $100 \mathrm{~K}$ and 200 East proposed facility sites comprise largely disturbed areas located proximal to a number of waste sites and active facilities, the utilization of the previously developed historical data allowed for collection of a minimal number of additional samples in the appropriately selected media. This determination was in concert with the recommendations in DOE Order 5400.1 (DOE 1988a) to utilize existing data. A summary of the historical information that was researched and used for this study follows.

\subsection{ENVIRONMENTAL MONITORING}

\subsubsection{Air monitoring}

Ambient air monitoring is conducted to determine baseline concentrations of radionuclides in the operations areas, to assess the impact of operations on the local environment, and to monitor diffuse emissions from sources located within the operations area. These measurements also provide an indication of facility and/or project performance and are used to demonstrate compliance with environmental protection criteria.

The placement of air monitoring stations takes into consideration potential source terms, prevailing wind direction, as well as proximity to obstructions and activities that could result in unusual, localized effects on the air samplers. Meteorological conditions are monitored continuously by Pacific Northwest National Laboratory (PNNL) meteorology stations, which are strategically positioned in and around the Hanford Site. Field evaluations are conducted in concert with Washington State Department of Health (WDOH) personnel to determine optimum air sampler locations.

Hanford Site air samplers operate at a flow rate of $0.056 \mathrm{~m}^{3} / \mathrm{min}\left(2 \mathrm{ft}^{3} / \mathrm{min}\right)$, drawing a sample through a $47 \mathrm{~mm}$ (2-in.), open-faced filter about $2 \mathrm{~m}(6 \mathrm{ft})$ aboveground. Typically, sample filters are exchanged biweekly, held one week (to allow for decay of the short-lived natural radioactivity), and then sent to the analytical laboratory for initial analysis of total alpha and total beta activity. These initial analyses serve as an indicator of potential environmental problems. 
The filters are stored until the end of the 6-month sampling period, then segregated and composited by sample location (or as deemed appropriate) for specific radionuclide analysis. Segregating and compositing air filters by site provides a larger sample size and, thus, a more sensitive and accurate measurement of the concentration of airborne radionuclides.

3.1.1.1 100 K Area. Figure 3-1 shows the locations of the existing ambient air samplers in the $100 \mathrm{~K}$ Area. Stations N-401, N-402, N-403 and N-404 in the $100 \mathrm{~K}$ East Area have been in operation since March 1993. These samplers provide environmental monitoring data required by the Washington Department of Health for operation of the $105 \mathrm{~K}$ East Fuel Storage Basin. Stations N-476, N-477, N-478 and N-479 located in the $100 \mathrm{~K}$ West Area were established as part of this study and became operational in February 1999.

Table 3-1 provides five-year summaries (1993 through 1997) of the radioanalytical data collected from the four (4) existing samplers at $100 \mathrm{~K}$ East and from the distant communities' sampling stations (1993 through 1996), as well as the corresponding derived concentration guides for each radionuclide. The analytical results for ${ }^{60} \mathrm{Co},{ }^{235} \mathrm{U}$ and ${ }^{238} \mathrm{Pu}$ for all locations frequently exhibit statistical uncertainties above $100 \%$ and/or average concentrations approaching zero, indicating that these radionuclides are below analytical detection levels. Only ${ }^{241}$ Am was consistently detected at each sampling location. All other radionuclides shown in Table 3-1 are infrequently detected. Sampler N-401 often exhibits the highest concentrations for the radionuclides ${ }^{137} \mathrm{Cs},{ }^{234} \mathrm{U},{ }^{239 / 240} \mathrm{Pu},{ }^{241} \mathrm{Pu}$ and ${ }^{241} \mathrm{Am}$.

3.1.1.2 200 East Area. Figure 3-2 shows the locations of the four, preexisting sampling stations, situated in the general vicinity of the CSB (N-967, N-973, N-019 and N-968). Two new ambient air samplers (N-480 and N-481) were established for this study near the CSB.

Table 3-2 provides five-year summaries (1993 through 1997) of radioanalytical data collected from these four (4) existing samplers and from the distant communities' sampling stations (1993 through 1996), as well as the corresponding derived concentration guides for each radionuclide. The average analytical results for ${ }^{90} \mathrm{Sr},{ }^{235} \mathrm{U},{ }^{238} \mathrm{Pu}$ and ${ }^{239 / 240} \mathrm{Pu}$ for all locations frequently exhibited statistical uncertainties above $100 \%$ and/or average concentrations approaching zero during the time period, indicating that these radionuclides are below analytical detection levels. Uranium- 234 and ${ }^{238} U$ are frequently detected at most locations. Cobalt-60 and ${ }^{137} \mathrm{Cs}$ are not consistently detected at any of the locations. 
HNF-6150 Rev. 0

Figure 3-1. $100 \mathrm{~K}$ Area Showing the Location of Existing and New Air Monitoring Stations 


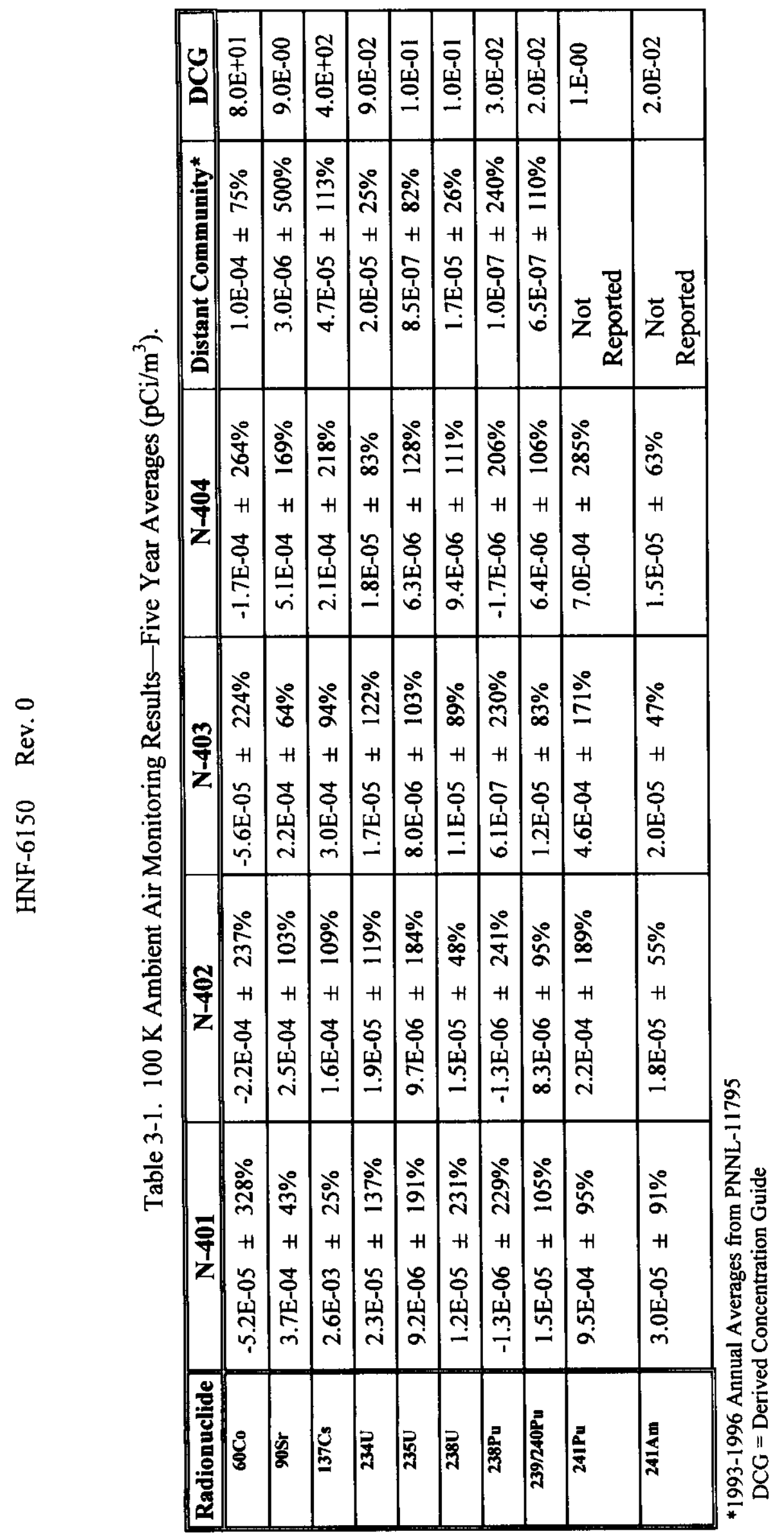


Figure 3-2. 200 Air Sampling Locations for Near-Facility Monitoring. New locations in gray.

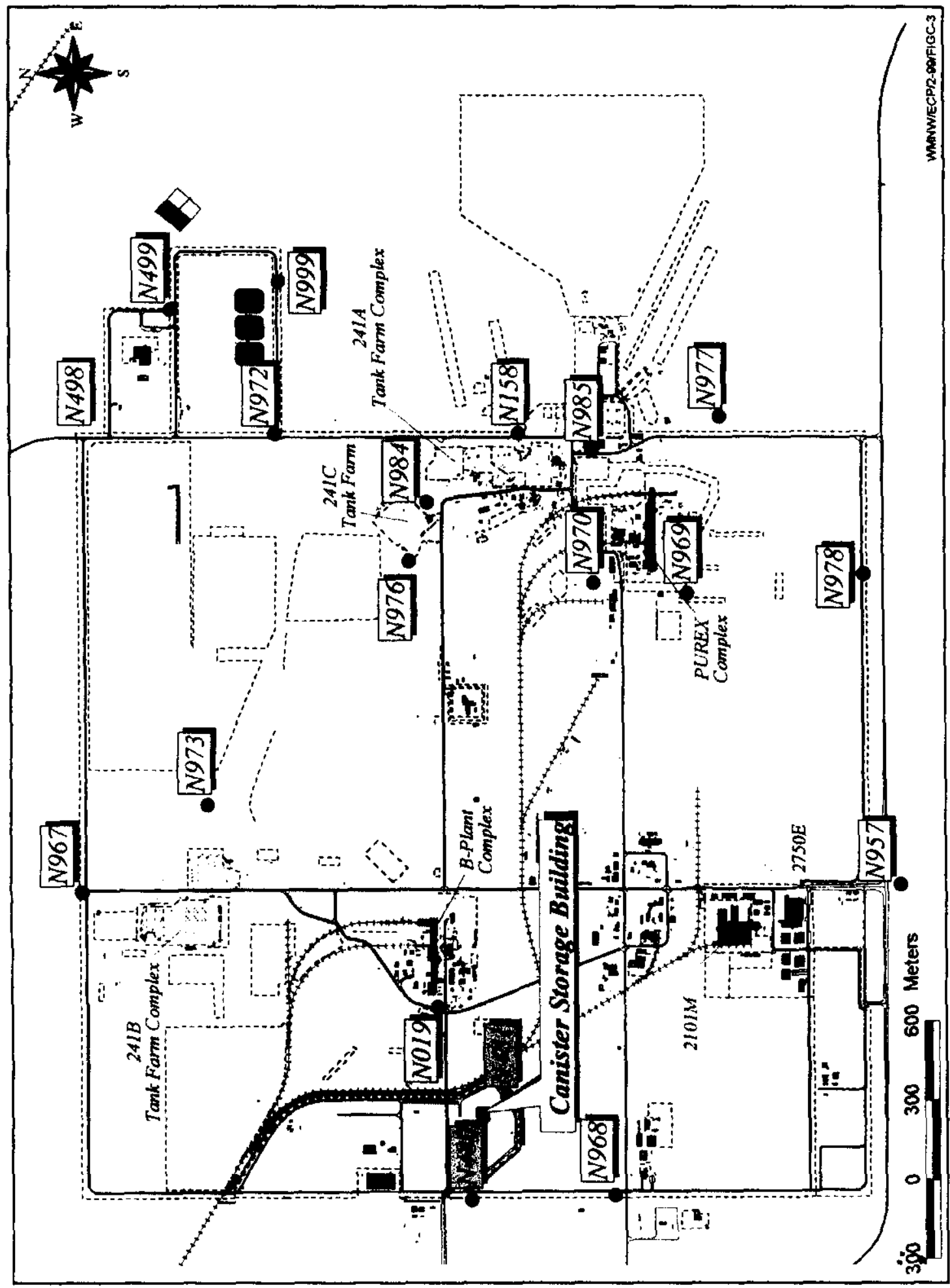




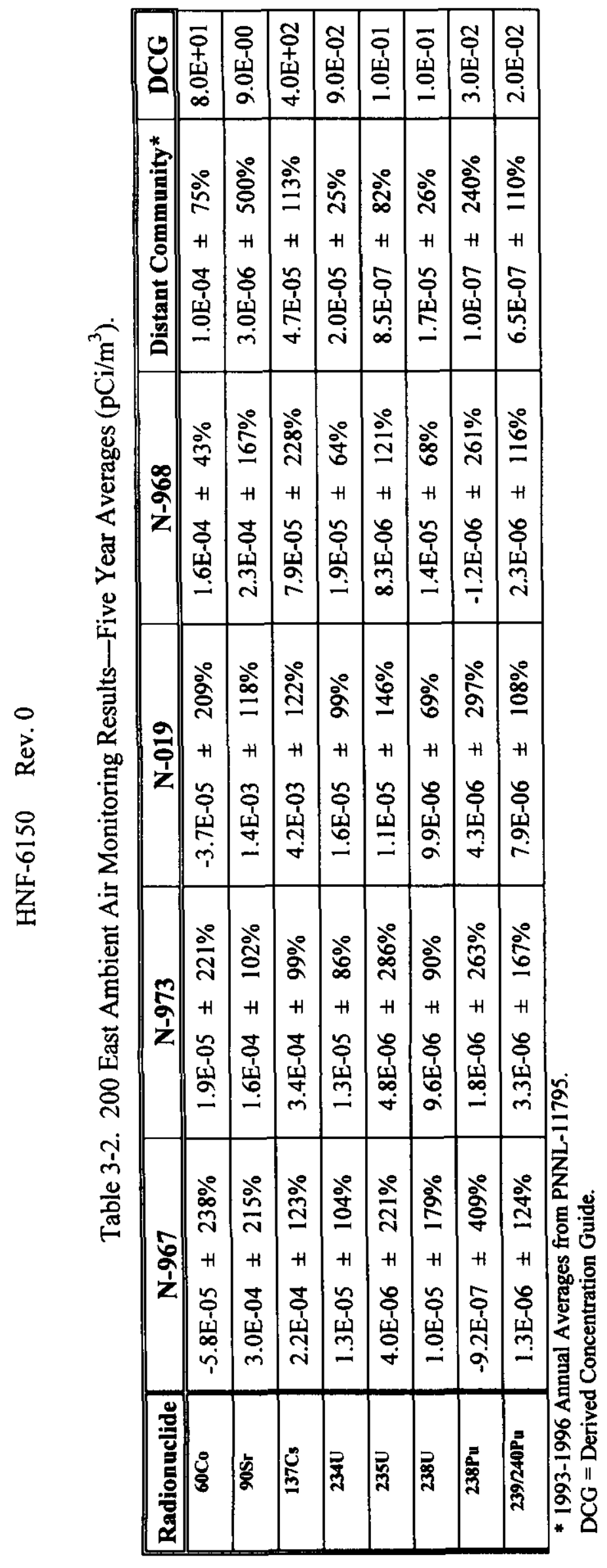




\subsubsection{Biotic Monitoring}

3.1.2.1 100 K Area. Soil and vegetation sampling was conducted on a routine basis beginning in 1981 at five locations near burial grounds and liquid effluent disposal facilities associated with past reactor operations located in the northeast perimeter of the $100 \mathrm{~K}$ Area (Figure 3-3). Routine sampling at these sites was discontinued in 1993. Trend analysis of the data collected since 1980 indicated that migration of the contaminants was not occurring and therefore routine annual sample collection and analysis was no longer cost-effective (Schmidt et al. 1995). Table 3-3 provides a summary of the average radionuclide values detected in $100 \mathrm{~K}$ surface soil samples near the burial grounds from 1981 through 1993 (Schmidt et al. 1994). It should be noted that levels of radioactive isotopes present in environmental samples are often so low that the error bar may appear exaggerated, however, it is a common and accepted occurrence.

Table 3-4 is a summary of the average radionuclide values found in vegetation samples collected from the $100 \mathrm{~K}$ Area from 1981 to 1993 (Schmidt et al. 1994). With the exception of

${ }^{90} \mathrm{Sr}$ in soils and plants, there has been a trend toward decreasing values for the other radionuclide values listed. Although these samples are from a location somewhat distant from the proposed CVDF location (Figure 3-3), they provide a useful baseline for comparative purposes with the data developed during this study.

3.1.2.2 200 East Area. Soil and vegetation sampling has been conducted on a routine basis in the 200 Areas and surrounding environs for a number of years. A sample site (D080) located southeast of the CSB near the Cross-Site Transfer Line (Figure 3-4) has been sampled biannually for the last six years. Sample values collected during the preoperational survey for the Cross-Site Transfer Line was utilized for providing a comparative baseline (Johnson and Mitchell 1996). Information from another sample site (D062), which is sampled less frequently and located near the B-55 and B-12 Cribs, was also utilized (Figure 3-4). These sites are located east and southeast, respectively, of the CSB in association with waste facilities. Although the prevailing winds are out of the west, easterly winds blowing off these sites toward the CSB do occur annually between 18 to 22 percent of the time. Table 3-5 includes a summary of the most recent samples of soil and vegetation collected at these two sites.

During a preoperational environmental survey conducted along the proposed replacement route for the Area Site Transfer line, soil and vegetation samples were collected near the now southern boundary of the CSB (Johnson \& Mitchell 1996). Figure 2-2 provides an approximate location for the line. Table 3-6 provides a summary of the radionuclide values for soil and vegetation samples collected at this site, while Table 3-7 provides a survey of metals values. Values were also reported for chloride $(0.4 \mathrm{ppm})$, flouride $(<0.1 \mathrm{ppm})$, nitrate $(8.1 \mathrm{ppm})$, nitrite $(0.1 \mathrm{ppm})$, phosphate (6.2 ppm) and sulfate (1.6 ppm) (Johnson and Mitchell 1996).

Additionally, information available in the "Hanford Waste Vitrification Project (HWVP) Baseline Summary Report" (Wasmiller 1993) was utilized, where possible, to aid in the development of the environmental baseline for the CSB.

Site survey work was conducted in 1991 and 1992 in support of the HWVP. The southern portion of that proposed site included the current location for the CSB (Wasmiller 1993). Based on a radiological survey using the Ultra-Sonic Ranging and Data System (USRADS), a 
Figure 3-3. Historical (1981-1993) Soil and Vegetation Sampling Locations at $100 \mathrm{~K}$ Area.

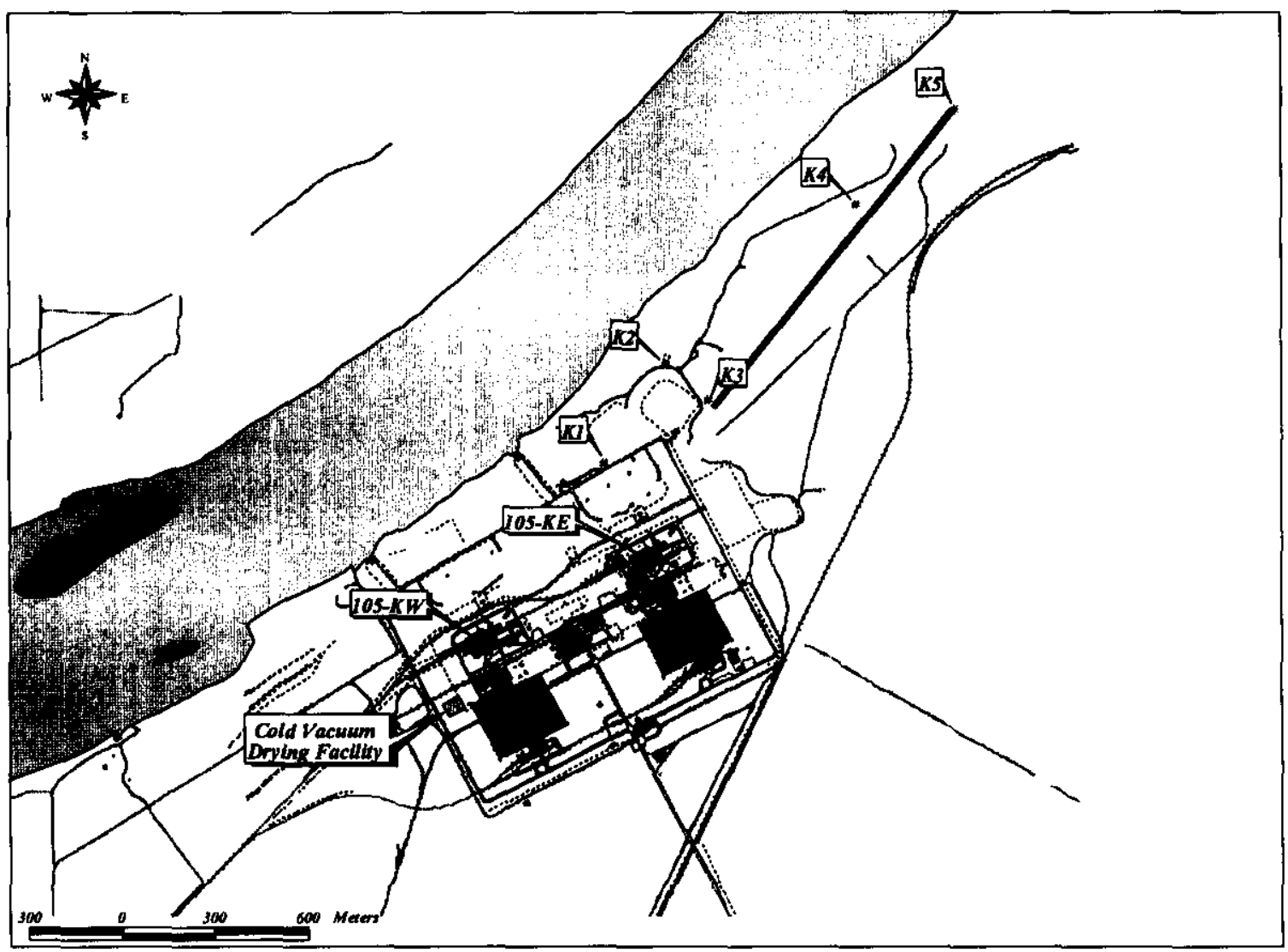


Table 3-3. Average Radionuclide Concentrations (pCi/g) Detected in $100 \mathrm{~K}$ Area Surface Soil Samples from 1981 to 1993.

\begin{tabular}{|c|c|c|c|c|c|}
\hline Year & ${ }^{60} \mathrm{Co}$ & ${ }^{90} \mathrm{Sr}$ & ${ }^{137} \mathrm{Cs}$ & ${ }^{238} \mathrm{Pu}$ & ${ }^{239,240} \mathrm{Pu}$ \\
\hline 1981 & $8.3 \mathrm{E}-01$ & $\mathrm{NR}{ }^{(\mathrm{a})}$ & $4.4 \mathrm{E}+00$ & $\mathrm{NR}$ & $\mathrm{NR}$ \\
\hline 1982 & $2.6 \mathrm{E}+01$ & $\mathrm{NR}$ & $8.8 \mathrm{E}-01$ & $\mathrm{NR}$ & $\mathrm{NR}$ \\
\hline 1983 & $5.5 \mathrm{E}+01$ & $\mathrm{NR}$ & $5.3 \mathrm{E}+01$ & $\mathrm{NR}$ & $\mathrm{NR}$ \\
\hline 1984 & $3.3 \mathrm{E}+00$ & $8.4 \mathrm{E}-01$ & $1.2 \mathrm{E}+01$ & $9.6 \mathrm{E}-04$ & $2.9 \mathrm{E}-02$ \\
\hline 1985 & $7.4 \mathrm{E}-01$ & $2.9 \mathrm{E}-01$ & $1.1 \mathrm{E}+00$ & $1.4 \mathrm{E}-03$ & $3.2 \mathrm{E}-02$ \\
\hline 1986 & $1.0 \mathrm{E}+00$ & $1.8 \mathrm{E}-01$ & $1.1 \mathrm{E}+00$ & $9.1 \mathrm{E}-04$ & $2.3 \mathrm{E}-02$ \\
\hline 1987 & $1.2 \mathrm{E}+00$ & $4.3 \mathrm{E}-01$ & $1.3 \mathrm{E}+00$ & $2.7 \mathrm{E}-03$ & $5.5 \mathrm{E}-02$ \\
\hline 1988 & $3.9 \mathrm{E}-01$ & $2.3 \mathrm{E}-01$ & $7.3 \mathrm{E}-01$ & $7.1 \mathrm{E}-04$ & $2.0 \mathrm{E}-02$ \\
\hline 1989 & $7.7 \mathrm{E}-01$ & $6.3 \mathrm{E}-01$ & $7.5 \mathrm{E}+00$ & $2.8 \mathrm{E}-03$ & $7.8 \mathrm{E}-02$ \\
\hline 1990 & $2.3 \mathrm{E}-01$ & $2.3 \mathrm{E}-01$ & $9.7 \mathrm{E}-01$ & $6.8 \mathrm{E}-04$ & $1.4 \mathrm{E}-02$ \\
\hline 1991 & $2.7 \mathrm{E}-01$ & $1.7 \mathrm{E}-01$ & $1.2 \mathrm{E}+00$ & $8.6 \mathrm{E}-04$ & $2.0 \mathrm{E}-02$ \\
\hline 1992 & $1.3 \mathrm{E}-01$ & $2.5 \mathrm{E}-01$ & $5.3 \mathrm{E}-01$ & $5.7 \mathrm{E}-04$ & $1.3 \mathrm{E}-02$ \\
\hline 1993 & $7.5 \mathrm{E}-02$ & $2.0 \mathrm{E}-01$ & $5.0 \mathrm{E}-01$ & $2.4 \mathrm{E}-04$ & $7.0 \mathrm{E}-03$ \\
\hline
\end{tabular}

${ }^{\text {(a) }} \mathrm{NR}=$ not reported. 
Table 3-4. Average Radionuclide Concentrations (pCi/g) Detected in $100 \mathrm{~K}$ Area Vegetation Samples from 1981 to 1993.

\begin{tabular}{|c|c|c|c|c|c|}
\hline Year & ${ }^{60} \mathrm{Co}$ & ${ }^{90} \mathrm{Sr}$ & ${ }^{137} \mathrm{Cs}$ & ${ }^{238} \mathrm{Pu}$ & ${ }^{239,240} \mathrm{Pu}$ \\
\hline 1981 & $1.2 \mathrm{E}+00$ & $\mathrm{NR}^{(\mathrm{a})}$ & $1.0 \mathrm{E}-01$ & $\mathrm{NR}$ & $\mathrm{NR}$ \\
\hline 1982 & $2.4 \mathrm{E}-01$ & $\mathrm{NR}$ & $9.7 \mathrm{E}-01$ & $\mathrm{NR}$ & $\mathrm{NR}$ \\
\hline 1983 & $1.5 \mathrm{E}-01$ & $\mathrm{NR}$ & $2.5 \mathrm{E}-01$ & $\mathrm{NR}$ & $\mathrm{NR}$ \\
\hline 1984 & $1.8 \mathrm{E}-01$ & $1.3 \mathrm{E}+00$ & $1.3 \mathrm{E}-01$ & $2.9 \mathrm{E}-04$ & $6.9 \mathrm{E}-04$ \\
\hline 1985 & $4.6 \mathrm{E}-01$ & $3.9 \mathrm{E}-01$ & $1.3 \mathrm{E}-01$ & $1.9 \mathrm{E}-04$ & $7.1 \mathrm{E}-04$ \\
\hline 1986 & $2.8 \mathrm{E}-01$ & $4.0 \mathrm{E}-01$ & $1.5 \mathrm{E}+00$ & $2.5 \mathrm{E}-04$ & $7.9 \mathrm{E}-04$ \\
\hline 1987 & $2.3 \mathrm{E}-01$ & $1.3 \mathrm{E}+00$ & $1.1 \mathrm{E}-01$ & $1.9 \mathrm{E}-04$ & $2.2 \mathrm{E}-04$ \\
\hline 1988 & $4.9 \mathrm{E}-01$ & $1.2 \mathrm{E}+00$ & $1.8 \mathrm{E}-01$ & $5.2 \mathrm{E}-05$ & $3.8 \mathrm{E}-04$ \\
\hline 1989 & $3.1 \mathrm{E}-01$ & $1.3 \mathrm{E}+00$ & $1.6 \mathrm{E}-01$ & $1.1 \mathrm{E}-04$ & $1.5 \mathrm{E}-04$ \\
\hline 1990 & $4.5 \mathrm{E}-02$ & $8.0 \mathrm{E}+00$ & $4.1 \mathrm{E}-02$ & $-1.7 \mathrm{E}-04^{(\mathrm{b})}$ & $2.5 \mathrm{E}-04$ \\
\hline 1991 & $6.3 \mathrm{E}-02$ & $4.1 \mathrm{E}-01$ & $7.6 \mathrm{E}-02$ & $5.2 \mathrm{E}-05$ & $5.9 \mathrm{E}-04$ \\
\hline 1992 & $-4.2 \mathrm{E}-02$ & $5.3 \mathrm{E}-01$ & $3.8 \mathrm{E}-02$ & $-6.5 \mathrm{E}-05$ & $9.8 \mathrm{E}-05$ \\
\hline 1993 & $-1.3 \mathrm{E}-02$ & $4.5 \mathrm{E}-01$ & $-3.0 \mathrm{E}-02$ & $-9.1 \mathrm{E}-05$ & $-1.4 \mathrm{E}-04$ \\
\hline
\end{tabular}

${ }^{(a)} \mathrm{NR}=$ not reported.

(b) Negative value indicates results at or below background levels of radioactivity. 


\section{HNF-6150 Rev. 0}

Figure 3-4. 200 East Soil Sampling Locations for Near-Facility Monitoring 
Table 3-5. Summary of Routine Monitoring Samples Collected in the 200 East Area Near CSB (pCi/g).

\begin{tabular}{|c|c|c|c|c|c|c|c|c|c|}
\hline \multirow{2}{*}{$\begin{array}{c}\text { Sample } \\
\text { Site }\end{array}$} & \multirow[t]{2}{*}{ Date } & \multicolumn{2}{|c|}{ Cobalt -60} & \multicolumn{2}{|c|}{ Strontium-90 } & \multicolumn{2}{|c|}{ Cesium-137 } & \multicolumn{2}{|c|}{$\begin{array}{l}\text { Plutonium- } \\
239 / 240\end{array}$} \\
\hline & & Result & Error & Result & Error & Result & Error & Result & Error \\
\hline \multicolumn{10}{|c|}{ Soils } \\
\hline D062 & 1994 & -0.003 & $343 \%$ & 0.2 & $19 \%$ & 4.5 & $10 \%$ & 0.006 & $19 \%$ \\
\hline D062 & 1996 & -0.02 & $91 \%$ & 0.3 & $19 \%$ & 0.7 & $11 \%$ & 0.01 & $18 \%$ \\
\hline D062 & 1998 & 0.005 & $150 \%$ & 0.1 & $80 \%$ & 1.0 & $16 \%$ & 0.007 & $86 \%$ \\
\hline \multicolumn{10}{|c|}{ Vequtation } \\
\hline D062 & 1994 & - & - & 0.2 & $23 \%$ & 0.7 & $11 \%$ & 0.03 & $13 \%$ \\
\hline D062 & 1996 & -0.05 & $300 \%$ & 0.2 & $20 \%$ & 1.0 & $11 \%$ & 0.03 & $14 \%$ \\
\hline D062 & 1998 & 0.01 & $330 \%$ & 0.006 & $>999 \%$ & 0.02 & $35 \%$ & 0.007 & $100 \%$ \\
\hline \multicolumn{10}{|c|}{ Soils } \\
\hline D080 & 1994 & -0.007 & $145 \%$ & 0.2 & $23 \%$ & 0.7 & $11 \%$ & 0.03 & $13 \%$ \\
\hline D080 & 1996 & -0.007 & $167 \%$ & 0.2 & $20 \%$ & 1.0 & $11 \%$ & 0.03 & $14 \%$ \\
\hline D080 & 1998 & 0.004 & $120 \%$ & 0.006 & $>999 \%$ & 0.02 & $35 \%$ & 0.007 & $100 \%$ \\
\hline \multicolumn{10}{|c|}{ Vegetation } \\
\hline D080 & 1994 & -0.02 & $488 \%$ & 0.3 & $20 \%$ & 0.002 & $110 \%$ & 0.002 & $54 \%$ \\
\hline D080 & 1996 & -0.02 & $310 \%$ & $1-3$ & $23 \%$ & -0.01 & $575 \%$ & 0.0009 & $92 \%$ \\
\hline D080 & 1998 & $\mathrm{NC}^{*}$ & $\mathrm{NC}$ & NC & NC & $\mathrm{NC}$ & $\mathrm{NC}$ & $\mathrm{NC}$ & $\mathrm{NC}$ \\
\hline
\end{tabular}

$* \mathrm{NC}=$ not collected. 
Table 3-6. Cross-site Transfer Line Study Radionuclides (pCi/g).

\begin{tabular}{|c|c|c|c|c|c|c|c|c|c|c|}
\hline \multirow{2}{*}{$\begin{array}{l}\text { Sample } \\
\text { Number }\end{array}$} & \multirow{2}{*}{$\begin{array}{c}\text { Date } \\
\#\end{array}$} & \multirow{2}{*}{$\begin{array}{r}\text { Sample } \\
\text { Medium }\end{array}$} & \multicolumn{2}{|c|}{${ }^{60} \mathrm{Co}$} & \multicolumn{2}{|c|}{${ }^{90} \mathrm{Sr}$} & \multicolumn{2}{|c|}{${ }^{137} \mathrm{Cs}$} & \multicolumn{2}{|c|}{${ }^{239 / 240} \mathrm{Pu}$} \\
\hline & & & Result & Error & Result & Error & Result & Error & Result & Error \\
\hline BODMP2 & 1995 & Veg & -0.014 & \pm 0.021 & 0.39 & \pm 0.20 & 0.021 & \pm 0.048 & 0.046 & \pm 0.052 \\
\hline BODMQ4 & 1995 & Soil & -0.004 & \pm 0.011 & 0.26 & \pm 0.16 & 1.30 & \pm 0.15 & 0.39 & \pm 0.019 \\
\hline
\end{tabular}

Table 3-7. Cross-site Transfer Line Study Metals (ppm).

\begin{tabular}{|c|c|c|c|c|c|c|c|c|c|c|c|}
\hline $\begin{array}{l}\text { Sample } \\
\text { Number }\end{array}$ & Date & $\begin{array}{l}\text { Sample } \\
\text { Medium }\end{array}$ & 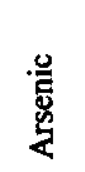 & 总 & 菲 & $\underset{\Xi}{\Xi}$ & 惡 & 鸹 & $\begin{array}{l}\frac{\mathbf{g}}{2} \\
\text { o }\end{array}$ & $\frac{\grave{D}}{\bar{s}}$ & $\stackrel{\mathscr{E}}{\mathrm{N}}$ \\
\hline BODMQ4 & 1995 & Soil & 2.6 & 87.3 & 0.69 & 6.3 & 0.12 & 8.5 & 12.8 & 0.92 & 40.4 \\
\hline BODMP2 & 1995 & Veg & 0.55 & 17.2 & 0.82 & 1.1 & 0.14 & 1.8 & 10.3 & 1.1 & 16.5 \\
\hline
\end{tabular}

Table 3-8. Summary of Selected Constituents (ppm) Analyzed by Wasmiller (1993).

\begin{tabular}{|l|c|c|c|}
\hline \multicolumn{1}{|c|}{ Constituent } & Average & Minimum & Maximum \\
\hline Arsenic & 2.5 & 1.6 & 3.2 \\
\hline Barium & 84.5 & 75 & 95.5 \\
\hline Cadmium & 0.31 & 0.2 & 0.46 \\
\hline Chromium & 7.8 & 6.1 & 9 \\
\hline Copper & 11.2 & 8.8 & 14.2 \\
\hline Lead & 6.7 & 4.6 & 9 \\
\hline Mercury & 0.21 & 0.09 & 0.48 \\
\hline Silver & 0.90 & 0.4 & 1.1 \\
\hline Zinc & 41.5 & 32.4 & 51.9 \\
\hline Fluoride & 2.0 & $<1.0$ & 6.9 \\
\hline Chloride & 12.8 & 8.3 & 17.6 \\
\hline Sulfate & 30.8 & $<1.0$ & 59 \\
\hline Ammonia & 13.6 & 0.8 & 66 \\
\hline
\end{tabular}


determination was made not to collect surface soil samples for radiological analyses. Of the 6 soil survey locations located in the general area of the CSB, none exhibited the $\geq 100 \mathrm{ppm}$ level requiring lab analyses for volatile organic compounds. Values that were obtained for selected metals and chemical constituents of surface soils are summarized in Table 3-8.

\subsubsection{Thermoluminescent Dosimeter Monitoring}

A network of TLDs is positioned in and around the 100 and 200 Areas to monitor dose rates from external radiation sources (primarily gamma rays). The environmental TLDs measure dose rates from all types of external radiation sources. These include cosmic radiation, naturally occurring radiation in air and soil, and fallout from nuclear weapons testing, as well as any contribution from the Hanford Site activities. These outside radiation sources cause an estimated $\pm 20 \%$ deviation in TLD analyses. The results are reported in units of millirems per year (mrem/yr).

The TLD measurements are taken to determine dose rates in the operations area environment. From these data, the contribution of the Hanford Site activities to the dose rates in these areas can be discerned.

The Hanford Site uses the Harshaw TLD system, which includes the Harshaw 8807 dosimeter and the Harshaw 8800 TLD reader. The TLD packaging, which uses an "O ring" seal, protects the TLDs from light, heat, moisture, and dirt. The TLDs are placed $1 \mathrm{~m}$ (approximately $3 \mathrm{ft}$ ) aboveground at each location. The TLDs are placed near active and inactive surface-water disposal sites and near facilities (e.g., tank farms, cribs, and the facility fence line). Changing conditions in the vicinity of the TLD sample locations, such as remediation activities, removal or storage of radioactive material, tank farm and other operations may also cause fluctuations in TLD analyses over time. The TLDs are exchanged each calendar quarter (January, April, July, October).

3.1.3.1 100 K Area. Figure 3-5 indicates the locations of the existing TLD monitoring stations in the $100 \mathrm{~K}$ Area. Four new TLD stations were established around the CVDF site in the spring of 1999. In 1997, the maximum reported TLD value reported for $100 \mathrm{~K}$ Area was $2250 \mathrm{mrem} / \mathrm{yr}$, with an average of $1300 \mathrm{mrem} / \mathrm{yr}$. By 1998, with the removal of radioactive waste stored in the proximity of three of the TLD locations, the levels had dropped to $720 \mathrm{mrem} / \mathrm{yr}$ and $180 \mathrm{mrem} / \mathrm{yr}$, respectively (Perkins et al. 1999).

3.1.3.2 200 East Area. The current locations of the 200 East Area TLD monitoring stations are shown in Figure 3-6. Two additional TLD monitoring stations were established in the spring of 1999 proximal to the CSB site and are also indicated. For the TLD stations monitoring the 200 Areas in 1997, the maximum reported dose was $350 \mathrm{mrem} / \mathrm{yr}$ and average was $100 \mathrm{mrem} / \mathrm{yr}$. For 1998, that decreased about $10 \%$ to an average of $90 \mathrm{mrem} / \mathrm{yr}$ (Perkins et al. 1999). 
Figure 3-5. Map of $100 \mathrm{~K}$ Area Showing TLD Monitoring Locations.

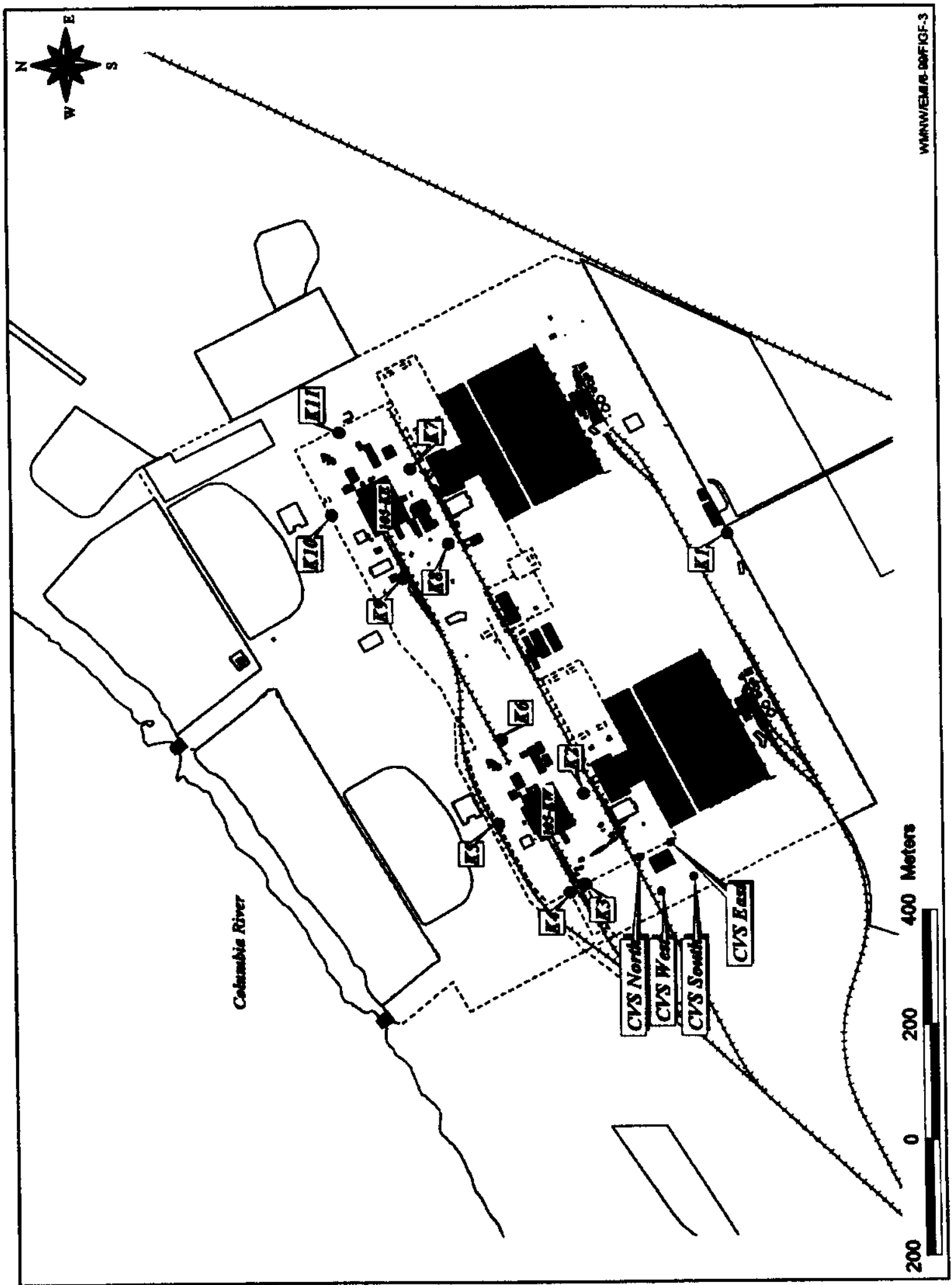




\section{HNF-6150 Rev. 0}

Figure 3-6 TLD Monitoring Locations in 200 East Area. The two new sites are in gray.

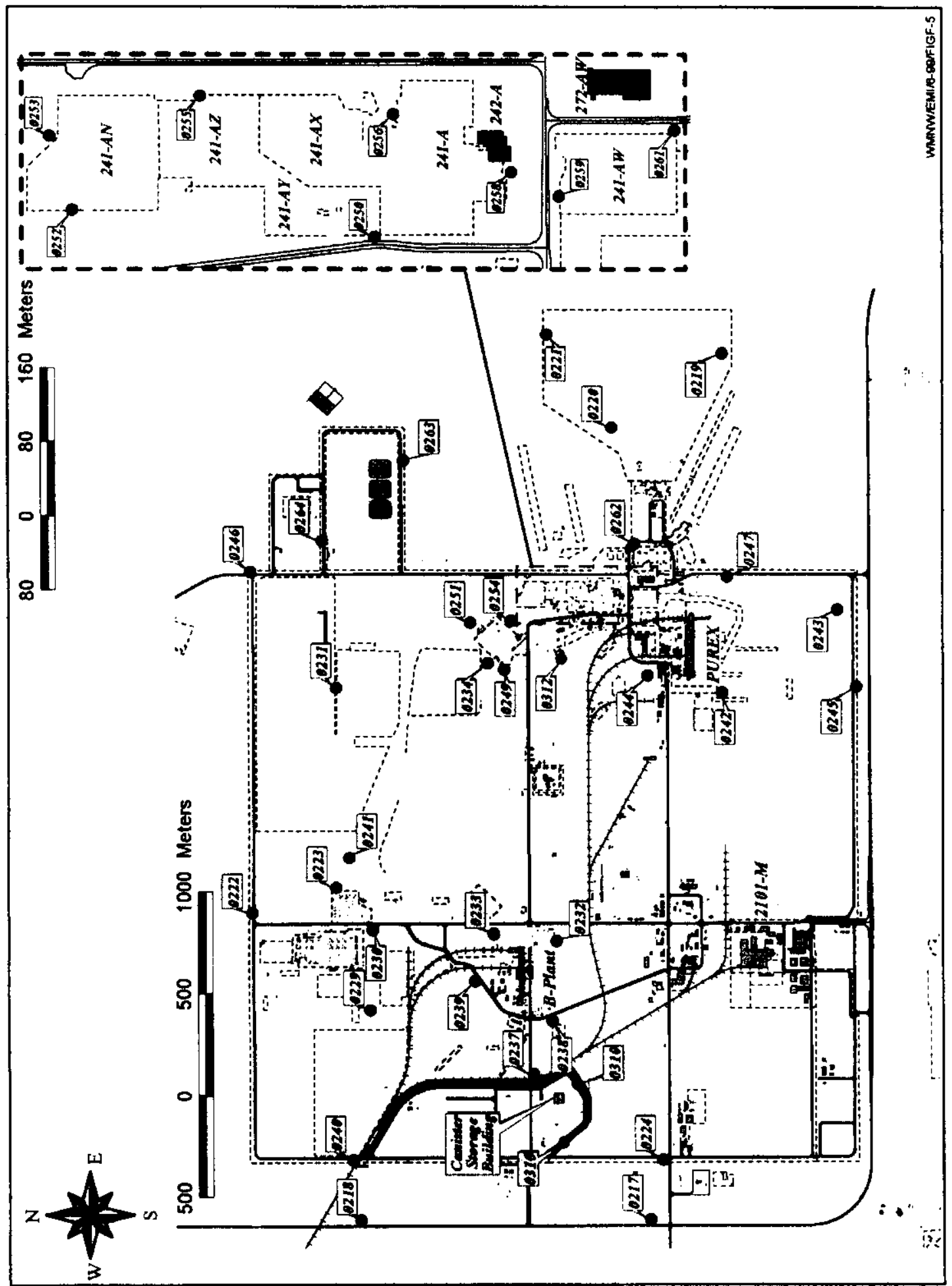




\section{HNF-6150 Rev. 0}

\subsubsection{Cultural/Biological Resources}

The potential impacts of removing SNF from the $\mathrm{K}$ Basins, processing it, and storing it on a long-term basis have previously been reviewed (DOE 1995, 1996). The $100 \mathrm{~K}$ facility and 200 East facility are both located inside the fenced portions of the site, which have received extensive review (Chatters and Cadoret 1990). Previously, cultural resource reviews and biological assessments have been conducted for the SNF Project facilities and these documents are included in Appendix A.

No known archaeological or historical sites are located within the proposed project sites. However, sampling personnel were informed to be on the lookout for any cultural resources and to notify the responsible personnel. However, none were observed. 


\subsection{AIR MONITORING}

Ambient air monitoring is conducted for a number of reasons: to determine baseline concentrations of radionuclides in the operations areas; to assess the impact of operations on the local environment; and to monitor diffuse emissions from sources located within the operations area. These measurements also provide an indication of facility and/or project performance and are used to demonstrate compliance with environmental protection criteria.

The placement of air monitoring stations takes into consideration potential source terms as well as prevailing wind direction and proximity to obstructions and activities that might bias the air samplers.

To help assess the impact of Site operations, monitoring results are compared to DOE derived concentration guides, to the results obtained from the distant communities of Yakima and Sunnyside (reported by the PNNL Environmental Surveillance Program) and to data acquired from distant station N-981 located at the Wye Barricade.

\subsection{K AREA}

Figure 3-1 shows the locations of the ambient air samplers in the $100 \mathrm{~K}$ Area. Stations N-401, N-402, N-403 and N-404 in the 100 K East Area have been in operation since March 1993.

Stations N-476, N-477, N-478 and N-479, located in the $100 \mathrm{~K}$ West Area, were established as part of this study and became operational in February 1999. For somewhat more than a year, these samplers have been collecting preoperational monitoring data as required by WDOH.

Table 4-1 provides an updated summary of the reported values for the four existing air monitoring stations in the $100 \mathrm{~K}$ Area through December 1999 . The analytical results for ${ }^{60} \mathrm{Co}$, ${ }^{235} \mathrm{U}$ and ${ }^{238} \mathrm{Pu}$ for all locations frequently exhibit statistical uncertainties above $100 \%$ and/or average concentrations less than zero, indicating that these radionuclides are below analytical detection levels. Only ${ }^{241} \mathrm{Am}$ was consistently detected at each sampling location. All other radionuclides shown in Table 4-1 are infrequently detected. Sampler N-401 often exhibits the highest concentrations for the radionuclides ${ }^{137} \mathrm{Cs},{ }^{234} \mathrm{U},{ }^{239 / 240} \mathrm{Pu},{ }^{241} \mathrm{Pu}$ and ${ }^{241} \mathrm{Am}$.

Table 4-2 represents a summary of the 1999 radionuclide concentrations for the four new air samplers established for this study (Figure 3-1). Figures 4-1 through 4-4 provide graphic representations of the $100 \mathrm{~K}$ Area, annual average radionuclide concentrations for ${ }^{90} \mathrm{Sr},{ }^{137} \mathrm{Cs}$, ${ }^{239 / 240} \mathrm{Pu}$ and ${ }^{241} \mathrm{Am}$. The information provided for 1999 includes the data obtained by the four new samplers established for this preoperational survey. 

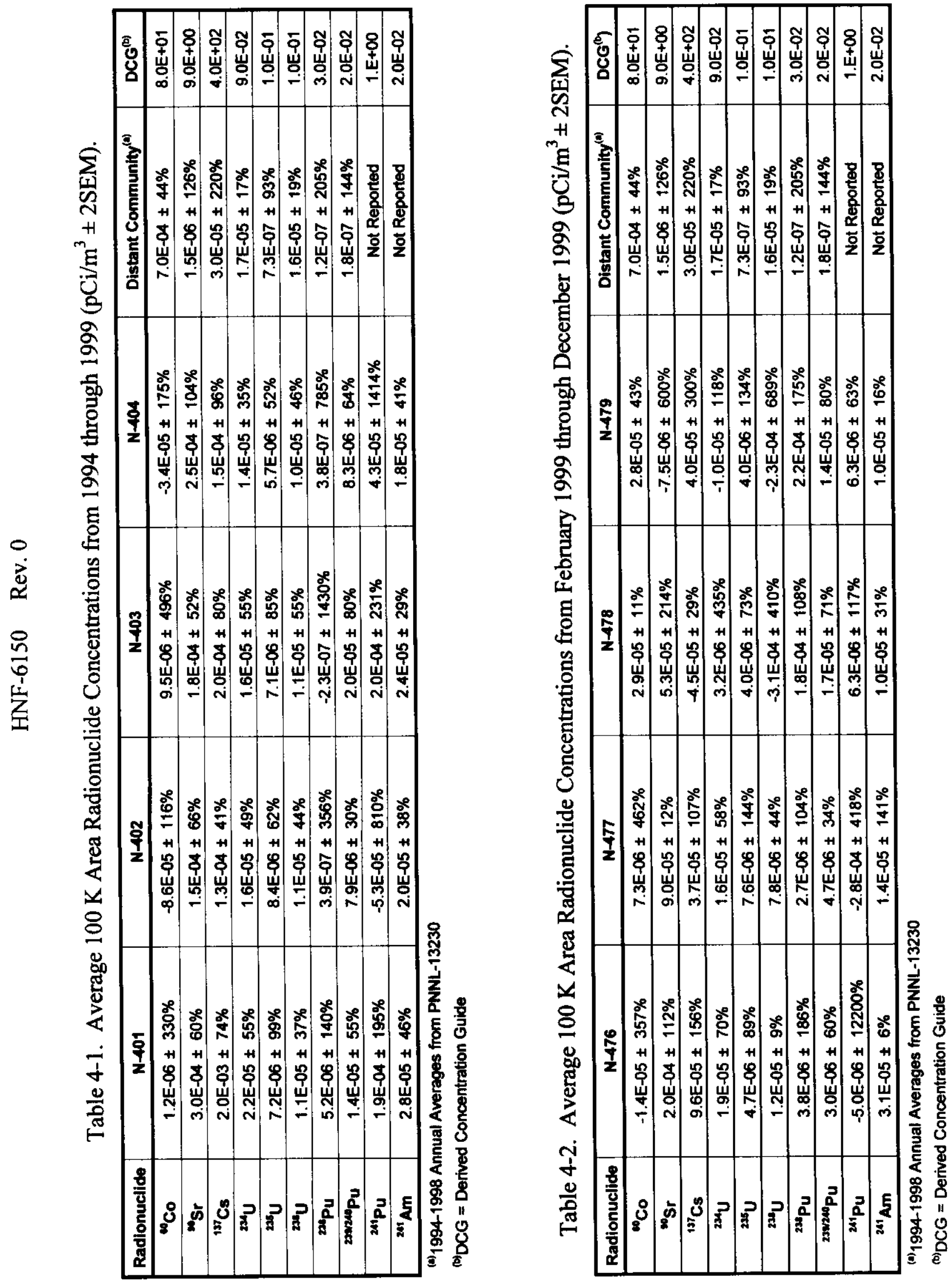
HNF-6150 Rev. 0

Figure 4-1. Strontium-90 Concentrations for the $100 \mathrm{~K}$ Area.

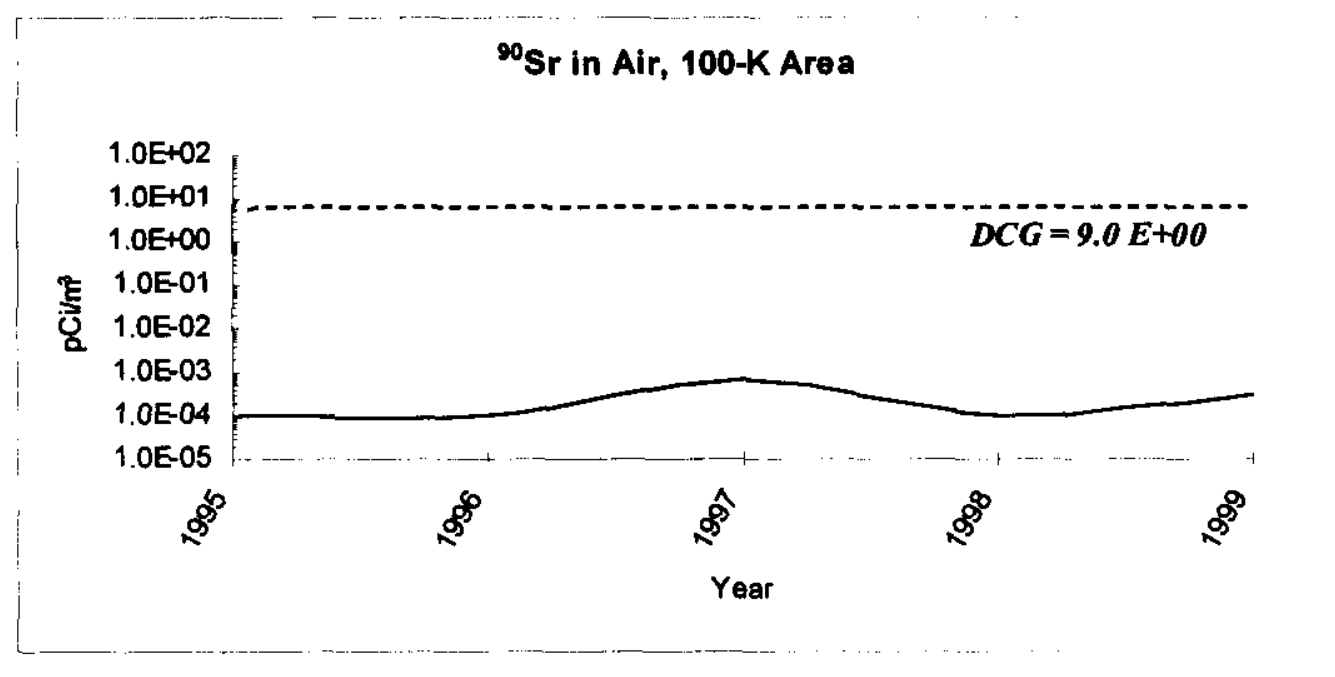

Figure 4-2. Cesium-137 Concentrations for the $100 \mathrm{~K}$ Area.

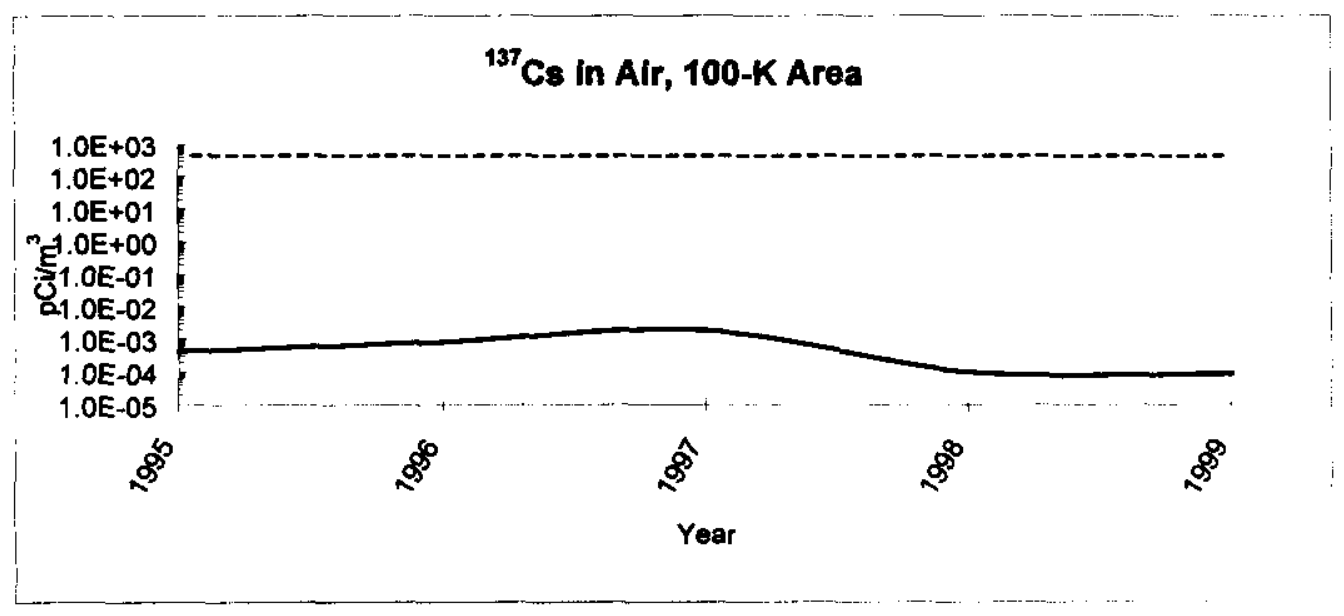


HNF-6150 Rev. 0

Figure 4-3. Plutonium-239/240 Concentrations for the $100 \mathrm{~K}$ Area.

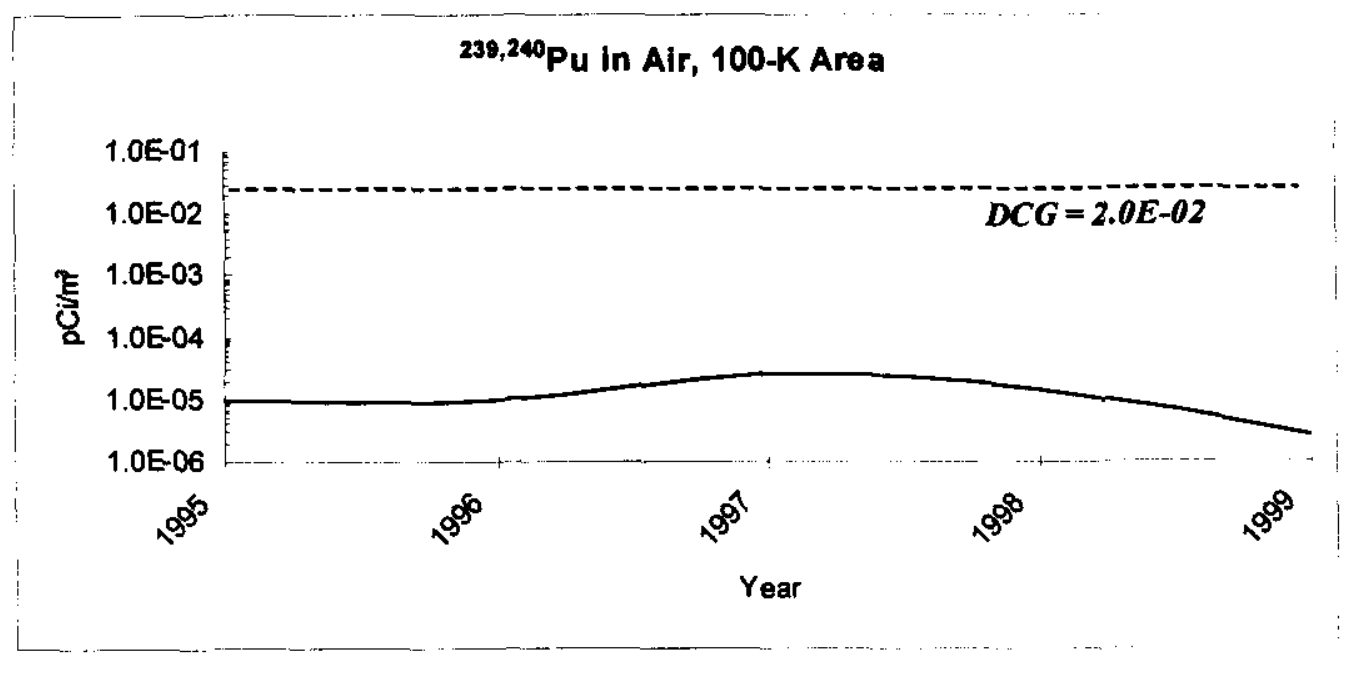

Figure 4-4. Americium-241 Concentrations for the $100 \mathrm{~K}$ Area.

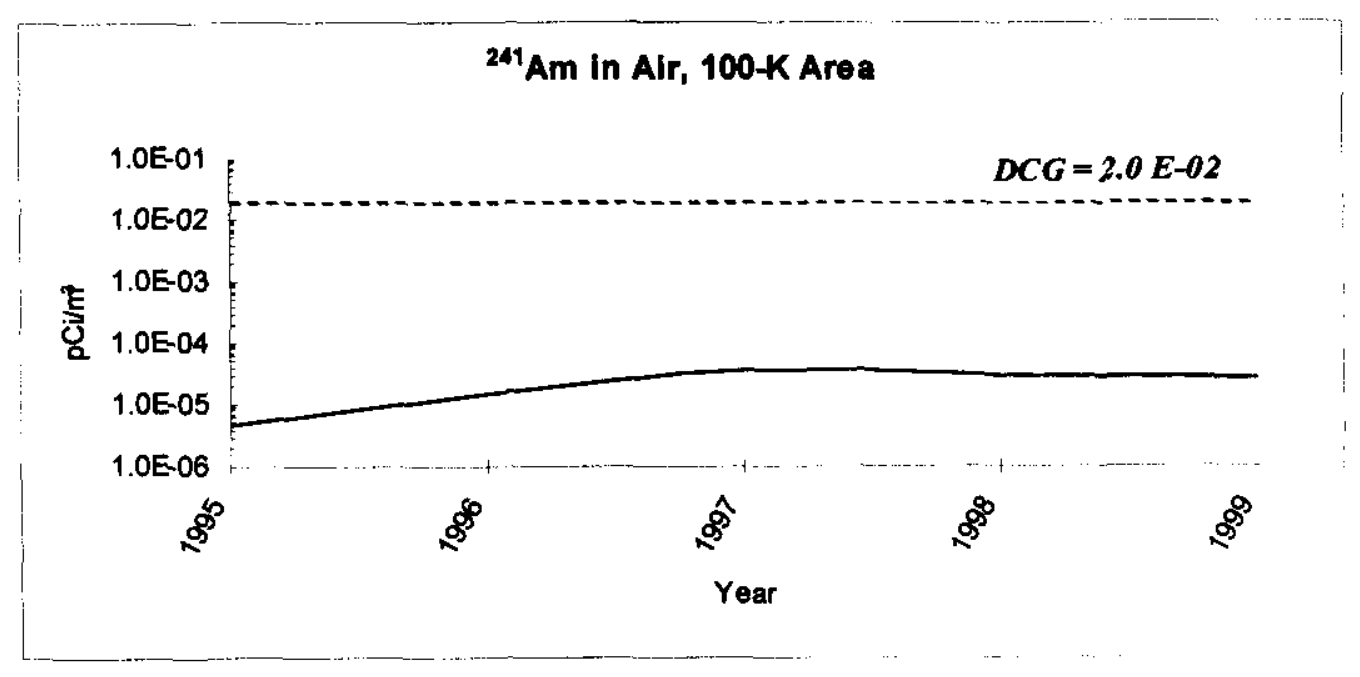




\subsection{EAST AREA}

Figure 3-2 shows the locations of the two new ambient air samplers (N-480 and N-481) established in November 1998 for this study near the CSB, as well as the existing stations in the 200 East Area. Four, pre-existing sampling stations, situated in the general vicinity of the CSB, are used to provide comparative data (N-967, N-973, N-019 and N-968).

Table 4-3 provides an updated summary of radionuclide concentrations for the four existing air samplers located near the CSB. The average analytical results for ${ }^{90} \mathrm{Sr},{ }^{235} \mathrm{U},{ }^{238} \mathrm{Pu}$ and ${ }^{239 / 240} \mathrm{Pu}$ for all locations frequently exhibited statistical uncertainties above $100 \%$ and/or average concentrations less than zero during the time period, indicating that these radionuclides are usually below analytical detection levels. Uranium-234 and ${ }^{238} \mathrm{U}$ are frequently detected at most locations. Cobalt-60 and ${ }^{137} \mathrm{Cs}$ are not consistently detected at any of the locations.

Table 4-4 provides summaries of the radiological data collected from the two (2) new samplers at the CSB and from the distant communities' sampling stations, as well as the corresponding derived concentration guides for each radionuclide. The analytical results for ${ }^{60} \mathrm{Co}$, ${ }^{137} \mathrm{Cs},{ }^{238} \mathrm{Pu}$ and ${ }^{241} \mathrm{Pu}$ at both locations consistently exhibit statistical uncertainties above $100 \%$ and/or concentrations less than zero, indicating that these radionuclides are below analytical detection limits. Americium- 241 and ${ }^{234,235,238} \mathrm{U}$ were detected in approximately $70 \%$ of the samples at both locations. Strontium-90 and ${ }^{239 / 240} \mathrm{Pu}$ were detected in approximately half of the samples. 

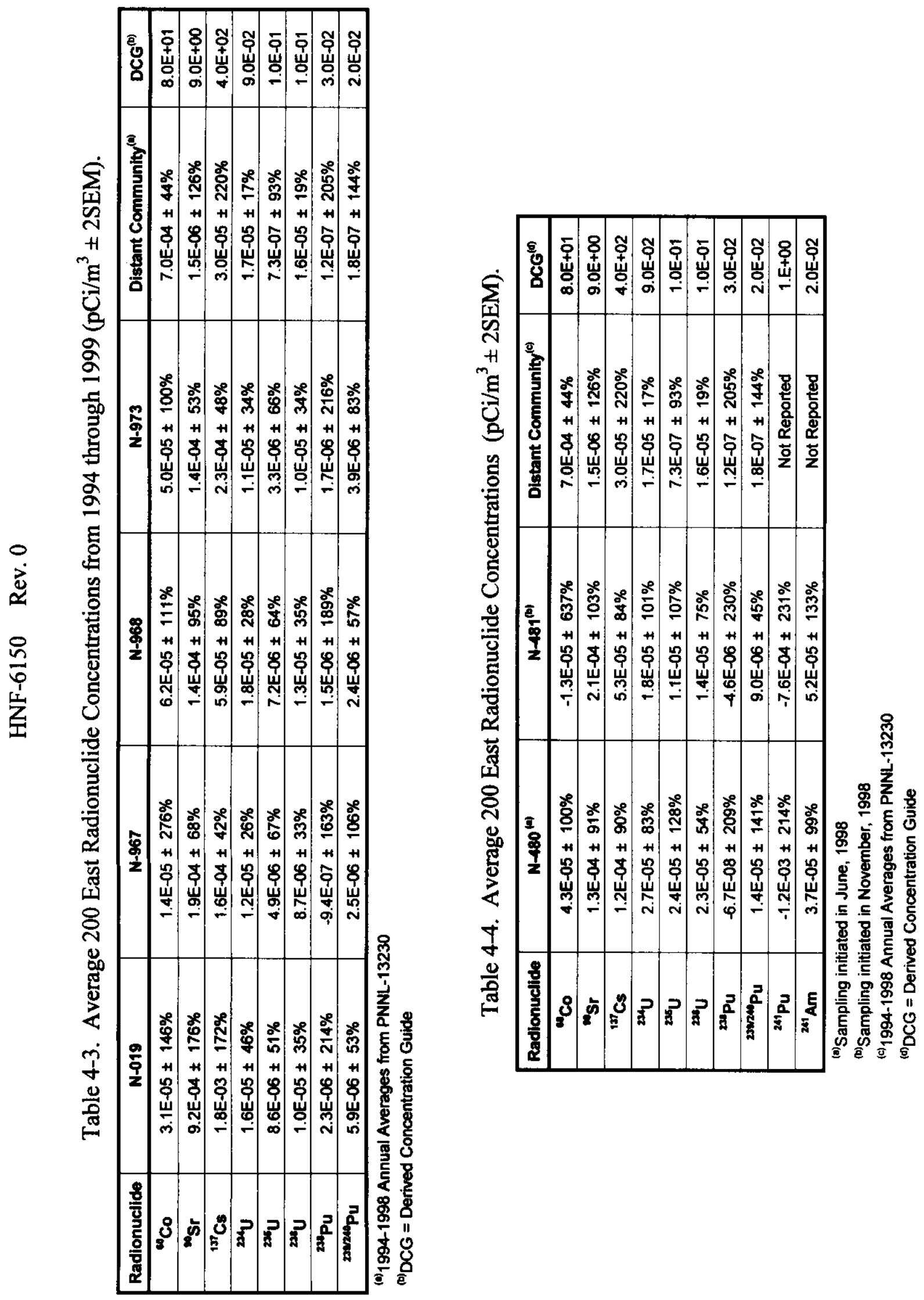


\subsection{THERMOLUMINESCENT DOSIMETER MONITORING}

A network of TLDs is positioned in and around the 100 and 200 Areas to monitor dose rates from external radiation sources (primarily gamma rays). The environmental TLDs measure dose rates from all types of external radiation sources. These include the following: cosmic radiation; naturally occurring radiation in air and soil; and fallout from nuclear weapons testing, as well as any contribution from Hanford Site activities. These outside radiation sources can cause an estimated $\pm 20 \%$ deviation in TLD analyses.

The TLD measurements are taken to determine dose rates in the operations area environment. The results are reported in units of millirems per year $(\mathrm{mrem} / \mathrm{yr})$. From these data, the contribution of the Hanford Site activities to the dose rates in these areas can be discerned.

\section{$5.1100 \mathrm{~K}$ AREA}

Figure 3-5 indicates the locations of the existing TLD monitoring stations in the $100 \mathrm{~K}$ Area. Four new TLD stations (CVS North, CVS East, CVS South and CVS West) were established around the CVDF site in June 1999. Table 5-1 provides a summary of the available quarterly results for the TLD stations near the CVDF established for this preoperational survey. These data are complete as of August 3, 2000.

\subsection{EAST AREA}

The current locations of the 200 East Area TLD monitoring stations are shown in Figure 3-6. Two additional TLD monitoring stations (310 and 311) were established in June 1999 proximal to the CSB site and are also indicated in gray tones. Table 5-2 provides a summary of the three quarters of data that were collected for the two CSB locations. These data are complete as of August 3, 2000. 
Table 5-1. $100 \mathrm{~K}$ Area Quarterly TLD Dose Rates Near the CVDF.

\begin{tabular}{|l|c|c|c|c|}
\hline TLD No. & $\begin{array}{c}4^{\text {th }} \text { Quarter } \\
(1999)\end{array}$ & $\begin{array}{c}1^{\text {st }} \text { Quarter } \\
(2000)\end{array}$ & $\begin{array}{c}2^{\text {nd }} \text { Quarter } \\
(2000)\end{array}$ & $\begin{array}{c}\text { mrem/yr } \\
\text { (extrapolated) }\end{array}$ \\
\hline CSV North (12) & 17 & 19 & 16 & 69 \\
\hline CSV East (13) & 27 & 24 & 19 & 93 \\
\hline CSV South (14) & 16 & 18 & 17 & 68 \\
\hline CSV West (15) & 16 & 19 & 17 & 69 \\
\hline
\end{tabular}

Table 5-2. CSB Quarterly TLD Dose Rates.

\begin{tabular}{|l|c|c|c|c|}
\hline TLD No. & $\begin{array}{c}4^{\text {th }} \text { Quarter } \\
(1999)\end{array}$ & $\begin{array}{c}1^{\text {st }} \text { Quarter } \\
(2000)\end{array}$ & $\begin{array}{c}2^{\text {nd }} \text { Quarter } \\
(2000)\end{array}$ & $\begin{array}{c}\text { mrem/yr } \\
\text { (extrapolated) }\end{array}$ \\
\hline $310(\mathrm{CSB})$ & 25 & 25 & 16 & 88 \\
\hline $311(\mathrm{CSB})$ & 37 & 39 & 20 & 128 \\
\hline
\end{tabular}




\subsection{SAMPLING METHODS}

Sampling efforts for the SNF Project facilities focused on the collection of environmental data and media, which include soil, vegetation, discussed herein, as well as small mammals. Historical information was reviewed and evaluated to determine the types of samples needed, the analyses required for potential contaminants of concern, and prospective sample site selection.

\subsection{OBJECTIVES}

The primary objectives of the preoperational survey included the following: (1) determining current levels of radionuclides in environmental media attributable to previous and on-going operations of other waste management facilities in the area; (2) providing data that will demonstrate the level of potential environmental impacts during SNF Project facilities construction and operations and, possibly, when corrective actions may be necessary; (3) characterizing existing levels of radionuclides in the selected media and other environmental pollutants for comparison of past and future trends for the enhancement of routine operational monitoring; and (4) identifying potential pathways for human exposure and environmental impacts.

Environmental sampling consisting of soil and vegetation had not been conducted as part of the routine monitoring program in the $100 \mathrm{~K}$ Area since 1993. However, the 200 East Area and the environs around the CSB were part of the Near-Field Monitoring program which collects soil and vegetation samples on an annual basis. Therefore, for this study, greater emphasis was placed on collecting a greater number of samples in the $100 \mathrm{~K}$ Area to compensate for this difference.

\subsection{SAMPLE SITE SELECTION}

Before the initiation of sampling activities, detailed maps of the SNF Project facilities were obtained that showed the location of existing and proposed buildings, facilities, and other structures. The location of nearby waste sites, such as burial grounds, cribs, ditches, and ponds, were also noted. Using the map, $100 \mathrm{~K}$ and 200 East Areas were reconnoitered to determine the prime areas for the location of sampling points. Each potential sample site was marked with a surveyor's stake and noted on a map.

A Global Positioning System (GPS) operator then collected geographic data pertaining to these sites using a survey quality GPS capable of $2 \mathrm{~cm}(0.8 \mathrm{in}$.) accuracy in real time. These data were transferred to a personal computer with software designed to process and assess the quality of the GPS data. This software was also used to convert the raw GPS data into the Washington State Plane, North American Datum 83-91 coordinate system. This is the system recognized by state and federal authorities. Once the data had been processed and approved, they were exported 


\section{HNF-6150 Rev. 0}

to an ASCII comma delimited file for use in conventional software programs (i.e., Microsoft ${ }^{2}$ Excel and Word) for reporting and to use in Geographic Information System software to prepare maps of the sample locations. Table 6-1 provides a summary for each of the sample sites. Maps showing locations for each sample site are included in Figures 6-1 and 6-2.

Table 6-1. Sample Site Coordinates for the SNF Project Facilities Sampling Locations.

\begin{tabular}{|c|c|c|}
\hline $\begin{array}{c}\text { Sample } \\
\text { Point }\end{array}$ & Easting & Northing \\
\hline 1 & 573002.5457 & 136467.6962 \\
\hline 2 & 573014.5974 & 136078.4049 \\
\hline 3 & 572933.3377 & 136041.0546 \\
\hline 4 & 572695.5347 & 136146.4576 \\
\hline 5 & 568397.467 & 146278.384 \\
\hline 6 & 568248.166 & 146197.437 \\
\hline 7 & 569469.9969 & 147055.8244 \\
\hline 8 & 569352.8416 & 146203.4707 \\
\hline 9 & 568806.6031 & 145916.4584 \\
\hline 10 & 568640.1985 & 145849.5992 \\
\hline 11 & 569650.901 & 146748.229 \\
\hline
\end{tabular}

${ }^{2}$ Microsoft is a trademark of Microsoft Corporation, Redmond, Washington. 
HNF-6150 Rev. 0

Figure 6-1. $100 \mathrm{~K}$ Sample Locations. 
HNF-6150 Rev. 0

Figure 6-2. Canister Storage Building (CSB) Sample Locations. 


\subsection{LABORATORY ANALYSIS}

Data Quality Objectives (DQOs) for determining the analytes of concern for the SNF Project were agreed upon in concert with concerned parties. A series of meetings were held during the summer of 1997 with personnel representing SNF, DOE, WDOH and WMTS. Utilizing lists (DOE 1995, WHC 1995) developed for radionuclide inventories, exposure scenarios, emission potentials and relative hazard indices from the $\mathrm{K}$ Basins, a consensus was reached to analyze for those detected contaminants summarized in Table 6-2. Analytes determined to be of particular interest were Americium-241, Plutonium-241, pesticides and PCBs.

ES-SSPM-001, Sampling Services Procedures Manual, SP 2-1, "Bottle Preservation," provided general guidance for containers and preservation requirements. Sample containers were purchased precleaned from a supplier providing certification of internal laboratory procedures, or from the contract laboratory.

Samples collected for radionuclide analyses were transported to the contract laboratory for processing. These samples were analyzed by gamma spectroscopy. Additional analyses included ${ }^{90} \mathrm{Sr}$ and ${ }^{241} \mathrm{Am}$, as well as isotopic plutonium and metals, anions, and other analytes as requested (see Table 6-3).

\subsection{FOLLOW-UP SAMPLING}

Follow-up sampling was conducted on two occasions, November 4, 1999, and February 24,2000 . This was done to meet the requirement to conduct subsequent sampling to account for "seasonal changes" (DOE 1988a), or fluctuations in the ecological community and changes in environmental conditions, as well as for QA/QC purposes. These efforts consisted of the collection of soil, vegetation, litter and cryptogams at selected sample locations. Not all media were collected at each sample point; in order to achieve cost savings. 


\section{HNF-6150 Rev. 0}

Table 6-2. Sample Analyses Summary.

\begin{tabular}{|l|}
\hline \multicolumn{1}{|c|}{ Parameter/Analysis } \\
\hline ICP metals \\
\hline Arsenic \\
\hline Lead \\
\hline Isotopic uranium \\
\hline Mercury \\
\hline Cyanide \\
\hline Anions-- \\
\hline $\mathrm{SO}_{4}, \mathrm{~F}, \mathrm{Cl}$ \\
\hline $\mathrm{NO}_{2}, \mathrm{NO}_{3}, \mathrm{PO}_{4}$ \\
\hline Gamma scan \\
\hline${ }^{90} \mathrm{Sr}$ \\
\hline${ }^{241} \mathrm{Am}$ \\
\hline${ }^{238,239 / 240 / 241} \mathrm{Pu}$ \\
\hline $\mathrm{PCBs}_{\mathrm{Pesticides}}$ \\
\hline
\end{tabular}




\subsection{FIELD ACTIVITIES}

\subsection{PRELIMINARY FIELD ACTIVITIES}

Field inspections were completed prior to onsite sampling activities. Prior to initiating fieldwork, entry approvals, cultural and biological resource reviews (Appendix A), etc. were obtained. These field inspections provided information supporting preliminary documentation and planning. An Activity Hazard Analysis (AHA) was developed for the FY 1999 and FY 2000 sampling sessions and is included in Appendix B.

\subsection{SAMPLING PREPARATION}

In support of the SNF Project facilities, sampling containers meeting U.S. Environmental Protection Agency Level 1 cleanliness guidelines were selected. Each container had been bar coded with a lot and serial number (provided by the manufacturer). Certificates of analysis verifying the cleanliness of the containers by lot are maintained by sampling services of Waste Management Technical Services (WMTS) in accordance with ES-SSPM-001, Sampling Services Procedures Manual, SP 1-3, "Control of Certificates of Analysis." Types of containers and lot numbers are listed in the field logbook and are contained in this document (Appendix B).

The Sampling and Analysis Plan (Mitchell et al. 1999) for the SNF preoperational survey specified that stainless steel sampling equipment be cleaned in accordance with ES-SSPM-001, SP 2-5, "Laboratory Cleaning of Sampling Equipment." All stainless steel bowls and spoons were cleaned to this procedure prior to deployment to the field.

\subsection{SURFACE SAMPLING ACTIVITIES}

Surface sampling activities were conducted at the sites indicated in Figures 6-1 and 6-2 on May 18, 19 and November 4, 1999, and February 24, 2000. The environmental samples collected included surface soils and sagebrush leaves, sagebrush, litter and cryptogams (mosses and lichens).

\subsubsection{Soils}

The surface samples were obtained by marking off a $0.3 \mathrm{~m}(1 \mathrm{ft})$ square area of the least disturbed soil. The top $5 \mathrm{~cm}(2 \mathrm{in}$.) of soil were removed with a cleaned stainless steel spade into a cleaned stainless steel bowl. The soil was mixed and placed into vender certified clean bottles with a cleaned stainless steel spoon. 


\subsubsection{Vegetation}

At the sites selected, vegetation consisting of sagebrush leaves, sagebrush litter, and/or cryptogams was collected and placed into one-gallon sealable plastic bags. All of the samples were collected within approximately a $50 \mathrm{~m}(54.7 \mathrm{yd})$ radius of the sample stake.

\subsubsection{Small Mammals}

Sampling for small mammals was initiated on May 19, 1999. Samples were collected with "Sherman" live-traps set out and baited with rolled oats. The traps were then checked in the morning. Only one species of mouse, the deer mouse (Peromyscus maniculatus) was collected. Each animal was given a unique sample number, and submitted to the 222-S Lab for analyses. Due to constraints on the laboratory capabilities, the mice were only analyzed for gammaemitting radionuclides, ${ }^{241} \mathrm{Am}$, isotopic uranium and plutonium (222-S labs cannot analyze for ${ }^{241} \mathrm{Pu}$ ) and heavy metals. The mice were frozen until being shipped to the laboratory. A total of five mice were submitted for analyses. Other animals captured, but not required for sampling, were released unharmed. Sampling for small mammals was completed on May 20, 1999.

\subsubsection{Logbooks}

Photographs of sample locations were collected for the field logbook and are included in Appendix B or stored on computer disk. Samples were then shipped to the Waste Sampling and Characterization Facility (WSCF) by government vehicle in a sealed ice chest, packed on wet ice and accompanied by a Chain of Custody form.

\subsection{QUALITY ASSURANCE/QUALITY CONTROL SAMPLES}

A duplicate soil and vegetation sample was collected from sample locations No. 7 and No. 5, respectively. Both sample sets were delivered to the WSCF laboratory. This was conducted as a check on the replicability of the analysis performed by the laboratory, as well as the representativeness of the samples collected in the field.

An equipment blank was collected to ensure the effectiveness of the equipment cleaning process. Clean, certified silica sand was poured into a clean bowl and thoroughly mixed with a clean spoon. The sand was then spooned into sample containers and labeled. An equipment blank was collected at sample site No. 11.

Split samples of soil and vegetation were collected at sample locations No. 2, No. 4 and No. 5 on May 18, 1999. A split soil sample was collected at site No. 1 and a vegetation split at site 11 on November 4,1999 . A volume of material was collected at the sample location that would fill two sample sets. Once the material was collected in the bowl, it was homogenized and run through a sample splitter provided by WDOH Radiation Protection personnel. The two sets were assigned separate sample identification numbers. 


\section{HNF-6150 Rev. 0}

The primary sample was sent to the WSCF and special analytical studies laboratories. The split sample was sent to the WDOH Public Health Laboratory in Seattle, Washington. Split samples were collected to aid in the verification of the results produced by the WSCF laboratory.

\subsection{POST-SAMPLING ACTIVITIES}

Chain of custody was used to maintain custody of all samples and conducted in accordance with ES-SSPM-001, SP 1-1, "Chain of Custody/Sample Analysis Request." The chain of custody was maintained from the sample collection site through delivery of the samples to the laboratory. Samples were delivered to the laboratory on the final day of collection. Samples from the previous day were stored overnight in a refrigerated custody-locked storage area (6269 Building) maintained by WMTS.

The field logbook were used in accordance with ES-SSPM-001, SP 1-5, "Field Logbooks" to document all sampling activities and are included in Appendix B. 
HNF-6150 Rev. 0

\subsection{SOIL/BIOTA RESULTS AND DISCUSSION}

This section provides a summary of the laboratory analytical data reported for the contaminants of concern, which included radionuclides $\left({ }^{137} \mathrm{Cs},{ }^{90} \mathrm{Sr},{ }^{60} \mathrm{Co}\right.$, isotopic uranium, ${ }^{239 / 240 / 241} \mathrm{Pu}$, and ${ }^{241} \mathrm{Am}$ ), metals (arsenic, barium, cadmium, lead, mercury, chromium, copper, silver, and zinc), soil chemistry data for constituents such as chloride, fluoride, nitrate, nitrite, phosphate, sulfate, and cyanide, pesticides and PCBs. The complete laboratory data packages for all analyses and all constituents are contained in Appendix C.

The methods and protocols for obtaining preoperational environmental monitoring data were described in the Sampling and Analysis Plan (Mitchell et al. 1999) developed for sampling the proposed SNF Project facilities. This plan provided detailed information for the collection of media (surface soils, vegetation, litter and cryptogams) and inclusion of analyses for radionuclides, metals, anions, etc. The designated samples were collected from 11 locations located in and around the $100 \mathrm{~K}$ Area and 200 East Area. Some of the sites sampled had been previously disturbed by waste management activities of one kind or another (e.g., fences, roads, excavations, etc.). The results will be summarized based on area collected, chemical constituents and media type (see Figures 6-1 and 6-2).

\subsection{RADIONUCLIDES}

\subsubsection{Surface Soils}

As part of the sampling for radionuclides, each of the soil samples were analyzed for gamma-emitting radionuclides such as ${ }^{137} \mathrm{Cs},{ }^{60} \mathrm{Co}$, and ${ }^{241} \mathrm{Am}$, as well as ${ }^{90} \mathrm{Sr}$, isotopic uranium, and isotopic plutonium. These were the constituents considered to be of primary concern with regard to the basin cleanup and which could result in potential site contamination (see Section 5.3, Laboratory Analysis).

8.1.1.1 $100 \mathrm{~K}$ Area. The average values reported for this study (Table 8-1) for ${ }^{90} \mathrm{Sr}$ and ${ }^{239 / 240} \mathrm{Pu}$ were generally higher than those reported for the routine data collected previously (Table 3-3). Cesium-137 values were about the same. Cobalt-60 values, although low, were higher at $100 \mathrm{~K}$ than 200 East as expected.

8.1.1.2 200 East Area. The average values reported for this study (Table 8-2) for ${ }^{137} \mathrm{CS}$ $(0.2 \rho \mathrm{Ci} / \mathrm{g})$ and ${ }^{90} \mathrm{Sr}(1.0 \rho \mathrm{Ci} / \mathrm{g})$ were somewhat different than the average values reported in the 200 Areas for the 1998 routine monitoring program by Perkins et al. (1999) of $1.5 \rho \mathrm{\rho i} / \mathrm{g}$ and $0.5 \mathrm{pCi} / \mathrm{g}$, respectively. Sample locations 1,2 and 3 near the CSB (Figure 6-2) had somewhat elevated strontium levels compared with surrounding routine collection sites at 1.4, 1.0 and 1.2 $\mathrm{pCi} / \mathrm{g}$, respectively. All other values were at, or below, detection limits. However, ${ }^{241} \mathrm{Pu}$ averages in soil were an order of magnitude higher in 200 East than at $100 \mathrm{~K}(1.4 \mathrm{vs} 0.4 \mathrm{pCi} / \mathrm{g}$, respectively). 
Table 8-1, Part A. Radionuclide Data from $100 \mathrm{~K}$ Area Surface Soils (pCi/g).

\begin{tabular}{|c|c|c|c|c|c|c|c|c|c|c|c|c|c|c|c|c|c|}
\hline \multirow{2}{*}{$\begin{array}{c}\text { Sample } \\
\text { Site }\end{array}$} & \multirow[b]{2}{*}{ Date } & \multirow{2}{*}{$\begin{array}{c}\text { Sample } \\
\text { No. }\end{array}$} & \multirow{2}{*}{$\begin{array}{l}\text { Sample } \\
\text { Medium }\end{array}$} & \multicolumn{2}{|c|}{$\mathrm{C} 0-60$} & \multicolumn{3}{|c|}{ Sr-90 } & \multicolumn{3}{|c|}{ Cs-137 } & \multicolumn{3}{|c|}{ Pu-239/240 } & \multicolumn{3}{|c|}{ Pu-241 } \\
\hline & & & & Result & Error & Result & & ror & Result & & tor & Result & & Error & Result & & Error \\
\hline 5 & $05 / 18 / 1999$ & 59015-11 & Soil & 5.2E-04 & $\pm 1000 \%$ & $6.8 E-01$ & \pm & $45 \%$ & 1.6E-01 & \pm & $22 \%$ & $3.9 E-03$ & 12 & $500 \%$ & $2.0 \mathrm{E}-01$ & \pm & $45 \%$ \\
\hline 6 & $05 / 18 / 1999$ & $9015-15$ & Soil & $-1.4 \mathrm{E}-03$ & $447 \%$ & 7.3E-01 & \pm & $41 \%$ & 1.7E-01 & \pm & $16 \%$ & $-3.9 E-03$ & \pm & $200 \%$ & 7.0E-01 & $I$ & $40 \%$ \\
\hline 7 & $05 / 18$ & $9015-19$ & Soil & 8.2E-03 & $52 \%$ & $1.5 \mathrm{E}+00$ & \pm & $26 \%$ & 1.4E-01 & \pm & $18 \%$ & 1.1E-02 & \pm & $120 \%$ & 4.0E-01 & \pm & $40 \%$ \\
\hline 8 & $05 / 19 / 1999$ & $59015-23$ & Soil & $9.0 \mathrm{E}-04$ & $539 \%$ & $1.1 \mathrm{E}+00$ & \pm & $32 \%$ & 9.1E-02 & \pm & $18 \%$ & -02 & \pm & $180 \%$ & $1.0 \mathrm{E}+00$ & \pm & $40 \%$ \\
\hline 9 & $05 / 19 / 1999$ & $59015-24$ & Soil & 1.5E-03 & $292 \%$ & $1.1 \mathrm{E}+00$ & \pm & $30 \%$ & $1.1 \mathrm{E}+00$ & \pm & $13 \%$ & 6.2E-02 & \pm & $59 \%$ & 6.0E-01 & \pm & $41 \%$ \\
\hline 10 & $05 / 19 / 1999$ & $59015-25$ & Soil & 1.7E-03 & $300 \%$ & 8.2E-01 & \pm & $40 \%$ & 7.9E-02 & \pm & $20 \%$ & $3.1 \mathrm{E}-02$ & \pm & $99 \%$ & 4.0E-01 & \pm & $55 \%$ \\
\hline 9 & $11 / 04 / 1999$ & S0007-04 & Soil & $3.0 \mathrm{E}-03$ & $192 \%$ & 9.4E-01 & \pm & $30 \%$ & $1.3 E+00$ & \pm & $13 \%$ & $5.9 E-02$ & {$[ \pm$} & $57 \%$ & $-8.0 \mathrm{E}-01$ & \pm & $100 \%$ \\
\hline 11 & $11 / 04 / 1999$ & s0007-03 & Soil & 9.2E-03 & $71 \%$ & 7.2E-01 & \pm & $32 \%$ & 2.6E-01 & \pm & $17 \%$ & $1.4 E-02$ & $1 \pm$ & $180 \%$ & $3.0 \mathrm{E}-01$ & \pm & $30 \%$ \\
\hline & Average & \pm 2 SEM & & $3.0 \mathrm{E}-03$ & $\pm 2.7 \mathrm{E}-03$ & 9.5E-01 & \pm & $\mathrm{E}-01$ & 4.1E-01 & \pm & 5E-01 & $2.4 E-02$ & \pm & $1.8 \mathrm{E}-02$ & 3.5E-01 & \pm & $7 E-01$ \\
\hline
\end{tabular}

Table 8-1, Part B. Radionuclide Data from $100 \mathrm{~K}$ Area Surface Soils (pCi/g).

\begin{tabular}{|c|c|c|c|c|c|c|c|c|c|c|c|}
\hline \multirow{2}{*}{$\begin{array}{c}\text { Sample } \\
\text { Site }\end{array}$} & \multirow[b]{2}{*}{ Date } & \multirow{2}{*}{$\begin{array}{c}\text { Sample } \\
\text { No. }\end{array}$} & \multirow{2}{*}{$\begin{array}{c}\text { Sample } \\
\text { Medium }\end{array}$} & \multicolumn{2}{|c|}{ U-234 } & \multicolumn{2}{|c|}{$\mathrm{U}-235$} & \multicolumn{2}{|c|}{ U-238 } & \multicolumn{2}{|c|}{ Am-241 } \\
\hline & & & & Result & Error & Result & Error & Result & Error & Result & Error \\
\hline 5 & $05 / 18 / 1999$ & 59015-11 & Soil & 1.7E-01 & $38 \%$ & $1.5 E-02$ & $87 \%$ & 1.7E-01 & $38 \%$ & 8.3E-02 & $57 \%$ \\
\hline 6 & $05 / 18 / 1999$ & $59015-15$ & Soil & 1.5E-01 & $38 \%$ & 1.6E-02 & $77 \%$ & 1.6E-01 & $38 \%$ & 7.1E-02 & $88 \%$ \\
\hline 7 & 05/19/1999 & 59015-19 & Soil & $1.4 \mathrm{E}-01$ & $38 \%$ & $2.5 \mathrm{E}-02$ & $63 \%$ & 1.3E-01 & $38 \%$ & $4.5 \mathrm{E}-02$ & $120 \%$ \\
\hline 8 & $05 / 19 / 1999$ & 59015-23 & Soil & 1.5E-01 & $38 \%$ & 1.7E-02 & $73 \%$ & 1.7E-01 & $37 \%$ & $1.4 E-01$ & $55 \%$ \\
\hline 9 & $05 / 19 / 1999$ & 59015-24 & Soil & 1.3E-01 & $40 \%$ & $2.8 \mathrm{E}-02$ & $70 \%$ & 1.3E-01 & $40 \%$ & $8.0 E-02$ & $69 \%$ \\
\hline 10 & $05 / 19 / 1999$ & 59015-25 & Soil & 1.4E-01 & $39 \%$ & $9.9 E-02$ & $95 \%$ & $1.5 \mathrm{E}-01$ & $38 \%$ & 4.3E-02 & $94 \%$ \\
\hline 9 & $11 / 04 / 1999$ & S0007-04 & Soil & 1.1E-01 & $41 \%$ & $5.2 \mathrm{E}-03$ & $220 \%$ & $1.2 \mathrm{E}-01$ & $38 \%$ & $8.6 \mathrm{E}-02$ & $54 \%$ \\
\hline 11 & $11 / 04 / 1999$ & S0007-03 & Soil & $1.6 \mathrm{E}-01$ & $36 \%$ & 2.3E-02 & $65 \%$ & 1.5E-01 & $37 \%$ & $8.9 E-02$ & $52 \%$ \\
\hline \multicolumn{4}{|c|}{ Average \pm 2 SEM } & 1.4E-01 & $\pm 1.3 E-02$ & $2.9 \mathrm{E}-02$ & $\pm 2.1 E-02$ & $1.5 \mathrm{E}-01$ & $\pm 1.3 \mathrm{E}-02$ & $8.0 E-02$ & $\pm 2.1 \mathrm{E}-02$ \\
\hline
\end{tabular}


Table 8-2, Part A. Radionuclide Data for 200 East Area Surface Soils (pCi/g).

\begin{tabular}{|c|c|c|c|c|c|c|c|c|c|c|c|c|c|c|}
\hline \multirow{2}{*}{$\begin{array}{c}\text { Sample } \\
\text { Site }\end{array}$} & \multirow[b]{2}{*}{ Date } & \multirow{2}{*}{$\begin{array}{c}\text { Sample } \\
\text { No. }\end{array}$} & \multirow{2}{*}{$\begin{array}{l}\text { Sample } \\
\text { Medium }\end{array}$} & \multicolumn{2}{|c|}{$\mathrm{Co}-60$} & \multicolumn{2}{|c|}{ Sr-90 } & \multicolumn{2}{|c|}{ Cs-137 } & \multicolumn{2}{|c|}{$\mathrm{Pu}-239 / 240$} & \multicolumn{3}{|c|}{ Pu-241 } \\
\hline & & & & Result & Error & Result & Error & Result & Error & Result & Error & Result & & Error \\
\hline 1 & 05/18/1999 & 59015-01 & Soil & 2.1E-03 & $455 \%$ & $1.4 E+00$ & $25 \%$ & 1.3E-01 & $21 \%$ & $1.8 E-02$ & $95 \%$ & $-8.0 \mathrm{E}-01$ & \pm & $1000 \%$ \\
\hline 2 & $05 / 18 / 1999$ & 59015-04 & Soil & $-2.5 E-03$ & $405 \%$ & 8.4E-01 & $40 \%$ & 2.5E-01 & $19 \%$ & 1.7E-02 & $150 \%$ & $3.0 \mathrm{E}-01$ & \pm & $45 \%$ \\
\hline 3 & $05 / 18 / 1999$ & 59015-07 & Soil & $1.9 E-03$ & $460 \%$ & $1.2 \mathrm{E}+00$ & $31 \%$ & $1.5 \mathrm{E}-01$ & $21 \%$ & $4.9 \mathrm{E}-02$ & $95 \%$ & $6.1 E+\infty$ & \pm & $40 \%$ \\
\hline 4 & $05 / 18 / 1999$ & 59015-08 & Soil & $3.0 \mathrm{E}-03$ & $154 \%$ & $7.6 \mathrm{E}-01$ & $40 \%$ & $2.4 \mathrm{E}-01$ & $14 \%$ & $-3.7 \mathrm{E}-03$ & $350 \%$ & $5.0 \mathrm{E}-01$ & \pm & $40 \%$ \\
\hline 1 & $11 / 04 / 1999$ & $50007-01$ & Soil & $-2.4 E-03$ & $185 \%$ & 9.6E-01 & $30 \%$ & 3.1E-01 & $14 \%$ & $6.0 \mathrm{E}-02$ & $60 \%$ & $1.2 \mathrm{E}+00$ & \pm & $30 \%$ \\
\hline 2 & $11 / 04 / 1999$ & $50007-02$ & Soil & $-6.7 \mathrm{E}-03$ & $100 \%$ & $1.0 \mathrm{E}+00$ & $30 \%$ & $1,8 \mathrm{E}-01$ & $16 \%$ & $2.8 \mathrm{E}-02$ & $87 \%$ & $8.0 \mathrm{E}-01$ & \pm & $30 \%$ \\
\hline \multicolumn{4}{|c|}{ Average \pm 2 SEM } & $-7.7 E-04$ & $\pm 3.1 E-03$ & $1.0 \mathrm{E}+00$ & $\pm 1.9 \mathrm{E}-01$ & 2.1E-01 & $\pm 5.6 \mathrm{E}-02$ & $2.8 \mathrm{E}-02$ & $\pm 1.9 \mathrm{E}-02$ & $1.4 \mathrm{E}+00$ & 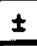 & $.0 \mathrm{E}+00$ \\
\hline
\end{tabular}

Table 8-2, Part B. Radionuclide Data for 200 East Area Surface Soils (pCi/g).

\begin{tabular}{|c|c|c|c|c|c|c|c|c|c|c|c|c|c|c|c|}
\hline \multirow{2}{*}{$\begin{array}{c}\text { Sample } \\
\text { Site }\end{array}$} & \multirow[b]{2}{*}{ Date } & \multirow{2}{*}{$\begin{array}{c}\text { Sample } \\
\text { No. }\end{array}$} & \multirow{2}{*}{$\begin{array}{l}\text { Sample } \\
\text { Medium }\end{array}$} & \multicolumn{3}{|c|}{ U-234 } & \multicolumn{3}{|c|}{ U-235 } & \multicolumn{3}{|c|}{ U-238 } & \multicolumn{3}{|c|}{$\mathrm{Am}-241$} \\
\hline & & & & Result & & & Result & & ror & Result & & Error & Result & & rror \\
\hline 1 & 05/18/1999 & 59015-01 & Soil & 1.7E-01 & \pm & $37 \%$ & 2.1E-02 & \pm & $68 \%$ & 2.3E-01 & \pm & $35 \%$ & 3.7E-02 & \pm & $63 \%$ \\
\hline 2 & $05 / 18 / 1999$ & $59015-04$ & Soil & $2.1 E-01$ & \pm & $36 \%$ & $3.3 E-02$ & \pm & $57 \%$ & 2.3E-01 & \pm & $35 \%$ & $6.4 E-02$ & \pm & $76 \%$ \\
\hline 3 & 05/18/1999 & 59015-07 & Soil & $1.5 E-01$ & \pm & $37 \%$ & $1.5 \mathrm{E}-02$ & \pm & $73 \%$ & $1.6 \mathrm{E}-01$ & \pm & $36 \%$ & $5.9 E-02$ & \pm & $73 \%$ \\
\hline 4 & $05 / 18 / 1999$ & $59015-08$ & Soil & 1.5E-01 & \pm & $39 \%$ & 2.1E-02 & \pm & $76 \%$ & $1.4 \mathrm{E}-01$ & \pm & $39 \%$ & $7.9 \mathrm{E}-02$ & \pm & $57 \%$ \\
\hline 1 & $11 / 04 / 1999$ & 50007.01 & Soil & $1.6 \mathrm{E}-01$ & \pm & $37 \%$ & $1.2 E-02$ & \pm & $82 \%$ & 1.5E-01 & \pm & $37 \%$ & $5.5 E-02$ & \pm & $56 \%$ \\
\hline 2 & $11 / 04 / 1999$ & $50007-02$ & Soil & $1.5 E-01$ & \pm & $37 \%$ & $2.0 \mathrm{E}-02$ & \pm & $68 \%$ & 1.9E-01 & \pm & $36 \%$ & $5.0 \mathrm{E}-02$ & \pm & $67 \%$ \\
\hline \multicolumn{4}{|c|}{ Average \pm 2 SEM } & 1.7E-01 & \pm & E-02 & $2.0 \mathrm{E}-02$ & \pm & 9E-03 & $1.8 E-01$ & \pm & $3.3 E-02$ & 5.7E-02 & \pm & 1E-02 \\
\hline
\end{tabular}




\subsubsection{Vegetation}

The vegetation samples collected for this study consisted of the tips and shoots of sagebrush. These actively-growing, meristematic tissues of the sagebrush have been shown (Whicker and Schultz 1982) to concentrate radionuclides at higher levels than the woody tissues of the plants. The vegetation was analyzed for the same radionuclides as in the soil. All of the analytical data are provided for review in the data packages in Appendix $\mathrm{C}$.

8.1.2.1 100 K Area. The range of values and reported averages for radionuclides in vegetation at $100 \mathrm{~K}$ Area (Table 8-3) were within expected norms.

8.1.2.2 200 East Area. The averages reported (Table 8-4) were comparable for all radionuclides except ${ }^{90} \mathrm{Sr},{ }^{137} \mathrm{Cs}$ and ${ }^{239 / 240} \mathrm{Pu}$. The values reported for this study were an order of magnitude higher for ${ }^{90} \mathrm{Sr}$ and ${ }^{137} \mathrm{Cs}$ and 2 orders of magnitude higher for ${ }^{239 / 240} \mathrm{Pu}$ than those averages reported for the 1998 routine monitoring program by Perkins et al. (1999).

\subsubsection{Litter}

In addition to the sagebrush samples, litter samples were collected from the dead plant material that accumulates underneath the sagebrush canopy and serves as an indicator of uptake trends for plant transfer pathways (Whicker and Schultz 1982). Litter samples were analyzed for the same radiological constituents as the surface soil and vegetation samples. A complete set of the analytical data packages is contained in Appendix C.

8.1.3.1 100 K Area. The range of values and reported averages (Table 8-5) for $100 \mathrm{~K}$ Area litter sampling were generally within expected levels. However, sample location 7 (Figure 6-1) exhibited a somewhat elevated ${ }^{90} \mathrm{Sr}$ value of $1.0 \mathrm{pCi} / \mathrm{g}$ compared to past results.

8.1.3.2 200 East Area. Sample values for litter collected at 200 East Area were somewhat anomalous. Elevated sample values (Table 8-6) for ${ }^{90} \mathrm{Sr}$ and ${ }^{137} \mathrm{Cs}$ were recorded at locations 1, 2 and 4 (Figure 6-2). And like the data reported for the soils, the ${ }^{241} \mathrm{Pu}$ values in litter at 200 East Area were an order of magnitude higher than those analyzed from $100 \mathrm{~K}$ Area (Table 8-5). 
HNF-6150 Rev. 0

Table 8-3, Part A. Radionuclide Data for $100 \mathrm{~K}$ Area Vegetation (pCi/g).

\begin{tabular}{|c|c|c|c|c|c|c|c|c|c|c|c|c|c|c|c|c|c|}
\hline \multirow{2}{*}{$\begin{array}{c}\text { Sample } \\
\text { Site }\end{array}$} & \multirow[b]{2}{*}{ Dato } & \multirow{2}{*}{$\begin{array}{c}\text { Sample } \\
\text { No. }\end{array}$} & \multirow{2}{*}{$\begin{array}{l}\text { Sample } \\
\text { Medium }\end{array}$} & \multicolumn{3}{|c|}{ Co-60 } & \multicolumn{3}{|c|}{ Sr-90 } & \multicolumn{3}{|c|}{ Cs-137 } & \multicolumn{3}{|c|}{ Pu-239/240 } & \multicolumn{2}{|c|}{ Pu-241 } \\
\hline & & & & Result & & Error & Result & & ror & Result & & Error & Result & & Error & Result & Error \\
\hline 5 & $05 / 18 / 1999$ & 59015-13 & Vegetation & $-2.1 E-03$ & \pm & $1000 \%$ & 4.9E-01 & \pm & $35 \%$ & $-9.6 \mathrm{E}-03$ & \pm & $221 \%$ & 6.6E-03 & \pm & $200 \%$ & 5.0E-01 & $51 \%$ \\
\hline 6 & $05 / 18 / 1999$ & S9015-17 & Vegetation & $-3.2 E-02$ & \pm & $100 \%$ & 6.9E-01 & \pm & $45 \%$ & $-1.6 \mathrm{E}-02$ & \pm & $165 \%$ & $3.8 \mathrm{E}-03$ & \pm & $100 \%$ & $-1.8 E-02$ & $1000 \%$ \\
\hline 7 & $05 / 19 / 1999$ & 59015-21 & Vegetation & 1.7E-02 & \pm & $133 \%$ & 8.8E-01 & \pm & $40 \%$ & $3.0 \mathrm{E}-03$ & \pm & $665 \%$ & 4.7E-03 & \pm & $450 \%$ & 2.4E-02 & $50 \%$ \\
\hline 9 & $11 / 04 / 1999$ & $50007-10$ & Vegetation & $3.3 E-02$ & \pm & $120 \%$ & 4.9E-01 & \pm & $30 \%$ & 2.3E-02 & \pm & $177 \%$ & 1.9E-02 & \pm & $81 \%$ & $-1.6 \mathrm{E}+00$ & $100 \%$ \\
\hline 11 & $11 / 04 / 1999$ & $50007-09$ & Vegetation & $-6.0 \mathrm{E}-03$ & \pm & $368 \%$ & $3.6 \mathrm{E}-01$ & \pm & $40 \%$ & $-9.9 E-03$ & \pm & $234 \%$ & 7.3E-03 & \pm & $130 \%$ & $-9.0 E-01$ & $100 \%$ \\
\hline & Average & \pm 2 SEM & & 2.0E-03 & \pm & $2.2 \mathrm{E}-02$ & 5.8E-01 & \pm & $8 E-01$ & $-1.9 E-03$ & \pm & $1.4 \mathrm{E}-02$ & 8.3E-03 & \pm & 5.5E-03 & $-4.0 \mathrm{E}-01$ & $\pm 7.5 \mathrm{E}-01$ \\
\hline
\end{tabular}

Table 8-3, Part B. Radionuclide Data for $100 \mathrm{~K}$ Area Vegetation (pCi/g).

\begin{tabular}{|c|c|c|c|c|c|c|c|c|c|c|c|c|c|c|c|}
\hline \multirow{2}{*}{$\begin{array}{c}\text { Sample } \\
\text { Site }\end{array}$} & \multirow[b]{2}{*}{ Date } & \multirow{2}{*}{$\begin{array}{c}\text { Sample } \\
\text { No. }\end{array}$} & \multirow{2}{*}{$\begin{array}{l}\text { Sample } \\
\text { Medium }\end{array}$} & \multicolumn{3}{|c|}{ U-234 } & \multicolumn{3}{|c|}{ U-235 } & \multicolumn{3}{|c|}{ U.238 } & \multicolumn{3}{|c|}{ Am-241 } \\
\hline & & & & Result & & ror & Result & & Error & Result & & Error & Result & & fror \\
\hline 5 & $05 / 18 / 1999$ & $59015-13$ & Vegetation & 1.4E-01 & \pm & $36 \%$ & 1.0E-01 & \pm & $38 \%$ & 5.7E-02 & \pm & $42 \%$ & 3.7E-02 & $\mathbf{t}$ & $62 \%$ \\
\hline 6 & $05 / 18 / 1999$ & 59015-17 & Vegetation & 2.2E-02 & \pm & $70 \%$ & $1.4 \mathrm{E}-02$ & \pm & $99 \%$ & $1.3 E-02$ & \pm & $99 \%$ & $5.0 E-02$ & \pm & $96 \%$ \\
\hline 7 & $05 / 19 / 1999$ & 59015-21 & Vegetation & $4.2 E-02$ & \pm & $51 \%$ & 5.3E-03 & \pm & $150 \%$ & 2.6E-02 & \pm & $59 \%$ & 8.6E-02 & \pm & $51 \%$ \\
\hline 9 & $11 / 04 / 1999$ & $50007-10$ & Vegetation & $1.6 \mathrm{E}-01$ & \pm & $34 \%$ & $8.9 E-03$ & \pm & $81 \%$ & $1.6 \mathrm{E}-01$ & \pm & $34 \%$ & $1.6 E-02$ & \pm & $780 \%$ \\
\hline 11 & $11 / 04 / 1999$ & $50007-09$ & Vegetation & 1.2E-02 & \pm & $67 \%$ & $2.0 \mathrm{E}-03$ & \pm & $150 \%$ & $1.8 \mathrm{E}-03$ & \pm & $250 \%$ & 4.1E-02 & \pm & $49 \%$ \\
\hline & Averag & $\theta \pm 2$ SEM & & 7.5E-02 & \pm & E-02 & 2.6E-02 & \pm & 3.7E-02 & 5.2E-02 & \pm & 5.7E-02 & 4.6E-02 & \pm & 3E-02 \\
\hline
\end{tabular}

Table 8-4, Part A. Radionuclide Data for 200 East Area Vegetation (pCi/g).

\begin{tabular}{|c|c|c|c|c|c|c|c|c|c|c|c|c|c|c|}
\hline \multirow{2}{*}{$\begin{array}{c}\text { Sample } \\
\text { Site }\end{array}$} & \multirow[b]{2}{*}{ Date } & \multirow{2}{*}{$\begin{array}{c}\text { Sample } \\
\text { No. }\end{array}$} & \multirow{2}{*}{$\begin{array}{l}\text { Sample } \\
\text { Medium }\end{array}$} & \multicolumn{2}{|c|}{$\mathrm{C} 060$} & \multicolumn{3}{|c|}{ Sr-90 } & \multicolumn{2}{|c|}{ Cs-137 } & \multicolumn{2}{|c|}{ Pu-239/240 } & \multicolumn{2}{|c|}{ Pu-241 } \\
\hline & & & & Result & Error & Result & & Error & Result & Enror & Result & Error & Result & Error \\
\hline 1 & $05 / 18 / 1999$ & $59015-03$ & Vegetation & $-3.1 E-02$ & $100 \%$ & 6.7E-01 & \pm & $40 \%$ & $2.0 \mathrm{E}-02$ & $96 \%$ & 2.7E-03 & $\pm \quad 1000 \%$ & $1.4 \mathrm{E}+00$ & $35 \%$ \\
\hline 2 & $05 / 18 / 1999$ & 59015-06 & Vegetation & $2.9 \mathrm{E}-04$ & $\pm \quad 1000 \%$ & $4.0 \mathrm{E}-01$ & \pm & $55 \%$ & $4.4 \mathrm{E}-03$ & $500 \%$ & 3.7E-02 & $77 \%$ & $1.5 E+00$ & $40 \%$ \\
\hline 4 & $05 / 18 / 1999$ & 59015-10 & Vegetation & $-2.3 \mathrm{E}-03$ & $722 \%$ & 3.3E-01 & \pm & $50 \%$ & 7.7E-03 & $254 \%$ & $-3.2 E-03$ & $200 \%$ & $-1.5 \mathrm{E}-02$ & $\pm \quad 1000 \%$ \\
\hline & Average & \pm 2 SEM & & $-1.1 E-02$ & $\pm 2.0 \mathrm{E}-02$ & 4.7E-01 & \pm & $2.1 E-01$ & $1.1 E-02$ & $\pm 9.5 E-03$ & $1.2 E-02$ & $\pm 2.5 \mathrm{E}-02$ & $9.6 E-01$ & $\pm 9.8 E-01$ \\
\hline
\end{tabular}

Table 8-4, Part B. Radionuclide Data for 200 East Area Vegetation (pCi/g).

\begin{tabular}{|c|c|c|c|c|c|c|c|c|c|c|c|c|c|}
\hline \multirow{2}{*}{$\begin{array}{c}\text { Sample } \\
\text { Site }\end{array}$} & \multirow[b]{2}{*}{ Date } & \multirow{2}{*}{$\begin{array}{c}\text { Sample } \\
\text { No. }\end{array}$} & \multirow{2}{*}{$\begin{array}{l}\text { Sample } \\
\text { Medium }\end{array}$} & \multicolumn{2}{|c|}{$U-234$} & \multicolumn{3}{|c|}{ U-235 } & \multicolumn{3}{|c|}{ U-238 } & \multicolumn{2}{|c|}{ Am-241 } \\
\hline & & & & Result & Error & Result & & & Result & & Error & Result & Error \\
\hline 1 & $05 / 18 / 1999$ & $59015-03$ & Vegetation & $1.6 \mathrm{E}-01$ & $35 \%$ & 8.2E-02 & \pm & $40 \%$ & 6.9E-02 & \pm & $41 \%$ & 3.3E-02 & $80 \%$ \\
\hline 2 & $05 / 18 / 1999$ & 59015-06 & Vegetation & $9.0 \mathrm{E}-02$ & $38 \%$ & 4.4E-02 & \pm & $46 \%$ & $4.5 E-02$ & \pm & $44 \%$ & $4.2 E-02$ & $66 \%$ \\
\hline 4 & $05 / 18 / 1999$ & $59015-10$ & Vegetation & 2.0E-01 & $35 \%$ & 9.9E-02 & \pm & $39 \%$ & 6.8E-02 & \pm & $41 \%$ & 4.7E-02 & $56 \%$ \\
\hline \multicolumn{3}{|c|}{ Average \pm 2 SEM } & & 1.5E-01 & $\pm 6.4 E-02$ & 7.5E-02 & \pm & 3E-02 & 6.1E-02 & \pm & $1.6 \mathrm{E}-02$ & 4.1E-02 & $\pm 8.2 E-03$ \\
\hline
\end{tabular}


Table 8-5, Part A. Radionuclide Data for $100 \mathrm{~K}$ Area Litter Samples (pCi/g).

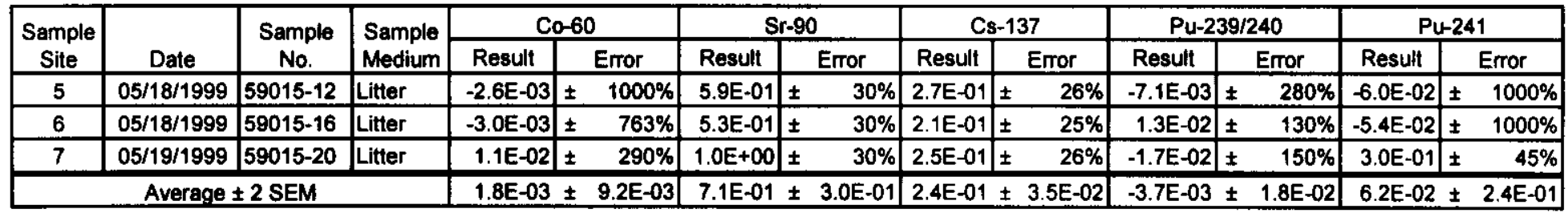

Table 8-5, Part B. Radionuclide Data for $100 \mathrm{~K}$ Area Litter Samples (pCi/g).

\begin{tabular}{|c|c|c|c|c|c|c|c|c|c|c|c|}
\hline \multirow{2}{*}{$\begin{array}{c}\text { Sample } \\
\text { Site }\end{array}$} & \multirow[b]{2}{*}{ Date } & \multirow{2}{*}{$\begin{array}{c}\text { Sample } \\
\text { No. }\end{array}$} & \multirow{2}{*}{$\begin{array}{l}\text { Sample } \\
\text { Medium }\end{array}$} & \multicolumn{2}{|c|}{ U-234 } & \multicolumn{2}{|c|}{ U-235 } & \multicolumn{2}{|c|}{ U-238 } & \multicolumn{2}{|c|}{$A m-241$} \\
\hline & & & & Result & Error & Result & Error & Result & Error & Result & Error \\
\hline 5 & $05 / 18 / 1999$ & 59015-12 & Litter & 2.1E-01 & $35 \%$ & $1.2 E-01$ & $38 \%$ & 1.4E-01 & $36 \%$ & 4.1E-02 & $57 \%$ \\
\hline 6 & $05 / 18 / 1999$ & 59015-16 & Litter & 1.2E-01 & $37 \%$ & 5.5E-02 & $43 \%$ & 1.4E-01 & $36 \%$ & \begin{tabular}{|l|}
$3.8 \mathrm{E}-02$ \\
\end{tabular} & $57 \%$ \\
\hline 7 & $05 / 19 / 1999$ & 59015-20 & Litter & 8.3E-02 & $45 \%$ & 1.7E-02 & $82 \%$ & $8.5 \mathrm{E}-02$ & $45 \%$ & 7.1E-02 & $69 \%$ \\
\hline & Average & 2 SEM & & 1.4E-01 & $\pm 7.5 \mathrm{E}-01$ & 6.4E-02 & $\pm 6.0 \mathrm{E}-02$ & 1.2E-01 & $\pm \quad 3.7 E-02$ & 5.0E-02 & $\pm 2.1 E-02$ \\
\hline
\end{tabular}

Table 8-6, Part A. Radionuclide Data for 200 East Area Litter Samples (pCi $/ \mathrm{g})$.

\begin{tabular}{|c|c|c|c|c|c|c|c|c|c|c|c|c|c|}
\hline \multirow{2}{*}{$\begin{array}{l}\text { Sample } \\
\text { Site }\end{array}$} & \multirow[b]{2}{*}{ Date } & \multirow{2}{*}{$\begin{array}{c}\text { Sample } \\
\text { No. }\end{array}$} & \multirow{2}{*}{$\begin{array}{l}\text { Sample } \\
\text { Medium }\end{array}$} & \multicolumn{2}{|c|}{$\mathrm{C} 0-60$} & \multicolumn{2}{|c|}{ Sr-90 } & \multicolumn{2}{|c|}{ Cs-137 } & \multicolumn{2}{|c|}{$\mathrm{Pu}-239 / 240$} & \multicolumn{2}{|c|}{ Pu-241 } \\
\hline & & & & Result & Error & Result & Error & Result & Error & Result & Error & Result & Error \\
\hline 1 & $05 / 18 / 1999$ & 59015-02 & Litter & 1.7E-03 & $894 \%$ & 1.1E+o0: & $30 \%$ & 7.5E-01 & $15 \%$ & 4.1E-02 & $60 \%$ & 4.0E-01: & $50 \%$ \\
\hline 2 & $05 / 18 / 1999$ & 59015-05 & Litter & $-1.3 \mathrm{E}-02$ & $104 \%$ & 6.2E-01: & $40 \%$ & $1.8 E+00$ & $15 \%$ & $3.5 \mathrm{E}-02$ & $65 \%$ & 8.0E-01 & $40 \%$ \\
\hline 4 & $05 / 18 / 1999$ & 59015-09 & Litter & $1.2 \mathrm{E}-02$ & $162 \%$ & $1.0 \mathrm{E}+00$ & $40 \%$ & $2.0 E+00$ & $13 \%$ & $4.0 \mathrm{E}-02$ & $68 \%$ & $-1.3 E-02$ & $\pm \quad 1000 \%$ \\
\hline & Average: & \pm 2 SEM & & 2.3E-04 & $\pm 1.5 E-02$ & 9.1E-01 & $\pm 2.9 \mathrm{E}-01$ & $1.5 \mathrm{E}+00$ & $\pm 7.8 \mathrm{E}-01$ & 3.9E-02 & $\pm 3.7 \mathrm{E}-03$ & 4.0E-01 & $\pm 4.7 E-01$ \\
\hline
\end{tabular}

Table 8-6, Part B. Radionuclide Data for 200 East Area Litter Samples (pCi/g).

\begin{tabular}{|c|c|c|c|c|c|c|c|c|c|c|c|c|c|}
\hline \multirow{2}{*}{$\begin{array}{c}\text { Sample } \\
\text { Site }\end{array}$} & \multirow[b]{2}{*}{ Date } & \multirow{2}{*}{$\begin{array}{c}\text { Sample } \\
\text { No. }\end{array}$} & \multirow{2}{*}{$\begin{array}{l}\text { Sample } \\
\text { Medium }\end{array}$} & \multicolumn{2}{|c|}{ U-234 } & \multicolumn{3}{|c|}{ U-235 } & \multicolumn{3}{|c|}{ U-238 } & \multicolumn{2}{|c|}{ Am-241 } \\
\hline & & & & Result & Error & Result & & Error & Result & & ror & Result & Error \\
\hline 1 & $05 / 18 / 1999$ & 59015-02 & Litter & 2.1E-01 & $34 \%$ & $9.8 \mathrm{E}-02$ & \pm & $38 \%$ & 1.7E-01 & \pm & $34 \%$ & $3.8 \mathrm{E}-02$ & $54 \%$ \\
\hline 2 & $05 / 18 / 1999$ & 59015-05 & Litter & 3.7E-01 & $33 \%$ & 1.7E-01 & \pm & $36 \%$ & 2.2E-01 & \pm & $34 \%$ & $6.9 \mathrm{E}-02$ & $45 \%$ \\
\hline 4 & $05 / 18 / 1999$ & $59015-09$ & Litter & $3.5 E-01$ & $33 \%$ & $1.4 \mathrm{E}-01$ & \pm & $37 \%$ & 2.5E-01 & \pm & $34 \%$ & 4.2E-02 & $62 \%$ \\
\hline & Average : & \pm 2 SEM & & 3.1E-01 & $\pm 1.0 \mathrm{E}-01$ & $1.4 \mathrm{E}-01$ & \pm & $4.2 E-02$ & 2.1E-01 & \pm & $7 E-02$ & $5.0 \mathrm{E}-02$ & $\pm 1.9 \mathrm{E}-02$ \\
\hline
\end{tabular}


HNF-6150 Rev. 0

\subsubsection{Cryptogams}

Cryptogam (mosses/lichens) samples were collected from the area near the associated soil and plant samples. Cryptogam samples are often more sensitive indicators of environmental quality in areas affected by airborne pollutants (Landeen et al. 1994, Richardson 1992).

The cryptogams were analyzed for the same potential radionuclides as in the soil, vegetation and litter. All of the analytical data packages are provided in Appendix C.

8.1.4.1 100 K Area. Cryptogam samples collected in the $100 \mathrm{~K}$ Area (Table 8-7) exhibited somewhat elevated levels of ${ }^{60} \mathrm{Co},{ }^{90} \mathrm{Sr},{ }^{137} \mathrm{Cs},{ }^{239 / 241} \mathrm{Pu}$, especially at sample location 7 (Figure 6-1) which had the maximum values reported for all these radionuclides. Sites 9 and 11 also had slightly elevated levels of ${ }^{137} \mathrm{Cs}$ and ${ }^{241} \mathrm{Pu}$.

8.1.4.2 200 East Area. The 200 East Area cryptogam samples all demonstrated lower averages (Table 8-8) than those reported for the $100 \mathrm{~K}$ Area. Cesium-137 and ${ }^{241} \mathrm{Pu}$ average values were an order of magnitude lower.

\subsubsection{Small Mammals}

Mice were collected as part of the preoperational survey to represent a higher organism within the food chain and to evaluate the potential transfer pathways from soil to vegetation to herbivore (vegetation consumer). In this case, the ubiquitous deer mouse was the most common small mammal found in the environs sampled and has been implicated in the biotic transfer of radionuclides on the Hanford Site on numerous occasions (Johnson et al. 1994). Mice could only be analyzed for selected radionuclides, based on laboratory capabilities.

8.1.5.1 100 K Area. Three deer mice were captured in the vicinity of the CVDF and the results are summarized in Table 8-9.

8.1.5.2 200 East Area. Two deer mice were captured in the vicinity of the CSB and the results summarized in Table 8-10. The values reported here are very comparable to those from the $100 \mathrm{~K}$ Area. However, average ${ }^{90} \mathrm{Sr}$ values were an order of magnitude higher in mice from the $100 \mathrm{~K}$ Area than from the 200 Areas (6.4 vs. $0.62 \mathrm{pCi} / \mathrm{g}$, respectively).

\subsubsection{Radionuclide Summary}

Table 8-11 provides a summary of the radionuclide values reported for soil and vegetation media sampled with reported averages for each area. The maximum values reported for each radionuclide in each media and the sample location where collected is also included. It can be observed that ${ }^{90} \mathrm{Sr}$ and ${ }^{239 / 240} \mathrm{Pu}$ values for both areas are essentially the same. However, ${ }^{137} \mathrm{Cs}$ values are generally higher in the 200 East Area samples, with the exception of $100 \mathrm{~K}$ cryptogams. Interestingly, ${ }^{241} \mathrm{Pu}$, which is not a normal constituent in routine monitoring, was an order of magnitude higher in 200 East soils, vegetation and litter, but not in cryptogams. 
Table 8-7, Part A. Radionuclide Data for Cryptogam Collected at $100 \mathrm{~K}$ Area (pCi/g).

\begin{tabular}{|c|c|c|c|c|c|c|c|c|c|c|c|c|c|c|c|c|c|}
\hline \multirow{2}{*}{$\begin{array}{c}\text { Sample } \\
\text { Site }\end{array}$} & \multirow[b]{2}{*}{ Date } & \multirow{2}{*}{$\begin{array}{c}\text { Sample } \\
\text { No. }\end{array}$} & \multirow{2}{*}{$\begin{array}{l}\text { Sample } \\
\text { Medium }\end{array}$} & \multicolumn{3}{|c|}{$\mathrm{C} 0-60$} & \multicolumn{3}{|c|}{ Sr-90 } & \multicolumn{3}{|c|}{ Cs-137 } & \multicolumn{2}{|c|}{ Pu-239/240 } & \multicolumn{3}{|c|}{ Pu-241 } \\
\hline & & & & Result & & Error & Result & & Error & Result & & Error & Result & Error & Result & & Error \\
\hline 5 & $05 / 18 / 1999$ & 59015-14 & Cryptogams & $1.5 \mathrm{E}-03$ & \pm & $978 \%$ & 5.5E-01 & \pm & $30 \%$ & 7.0E-01 & \pm & $14 \%$ & $6.8 \mathrm{E}-03 \pm$ & $150 \%$ & $-1.0 \mathrm{E}-01$ & \pm & $1000 \%$ \\
\hline 6 & $05 / 18 / 1999$ & $59015-18$ & Cryptogams & $-6.4 \mathrm{E}-03$ & \pm & $226 \%$ & $1.2 \mathrm{E}+00$ & \pm & $30 \%$ & 2.2E-01 & \pm & $21 \%$ & 2.3E-02 \pm & $95 \%$ & 2.0E-01: & \pm & $41 \%$ \\
\hline 7 & $05 / 19 / 1999$ & 59015-22 & Cryptogams & $1.8 \mathrm{E}+00$ & \pm & $8 \%$ & $1.2 \mathrm{E}+00$ & \pm & $30 \%$ & $2.6 E+01$ & \pm & $13 \%$ & $1.1 \mathrm{E}+00 \pm$ & $33 \%$ & $6.4 E+00$ & \pm & $30 \%$ \\
\hline 9 & $11 / 04 / 1999$ & $50007-08$ & Cryptogams & $5.6 \mathrm{E}-03$ & \pm & $238 \%$ & $5.8 E-01$ & \pm & $40 \%$ & $1.5 E+\infty$ & \pm & $15 \%$ & $7.8 E-02 \pm$ & $56 \%$ & 1.3E+o0: & \pm & $25 \%$ \\
\hline 11 & $11 / 04 / 1999$ & $50007-07$ & Cryptogams & $3.2 E-02$ & \pm & $46 \%$ & 8.6E-01 & \pm & $30 \%$ & $2.6 \mathrm{E}+00$ & \pm & $15 \%$ & $1.0 \mathrm{E}-01]$ & $49 \%$ & 1.2E+00: & \pm & $30 \%$ \\
\hline \multicolumn{3}{|c|}{ Average \pm 2 SEM } & & \multicolumn{3}{|c|}{$3.7 E-01 \pm 7.2 E-01$} & \multicolumn{3}{|c|}{$9.0 \mathrm{E}-01 \pm 2.9 \mathrm{E}-01$} & \multicolumn{3}{|c|}{$6.2 E+00 \pm 9.9 E+00$} & \multicolumn{2}{|c|}{$2.6 E-01 \pm 4.2 E-01$} & \multicolumn{3}{|c|}{$1.8 E+00 \pm 2.4 E+00$} \\
\hline
\end{tabular}

Table 8-7, Part B. Radionuclide Data for Cryptogam Collected at $100 \mathrm{~K}$ Area (pCi/g).

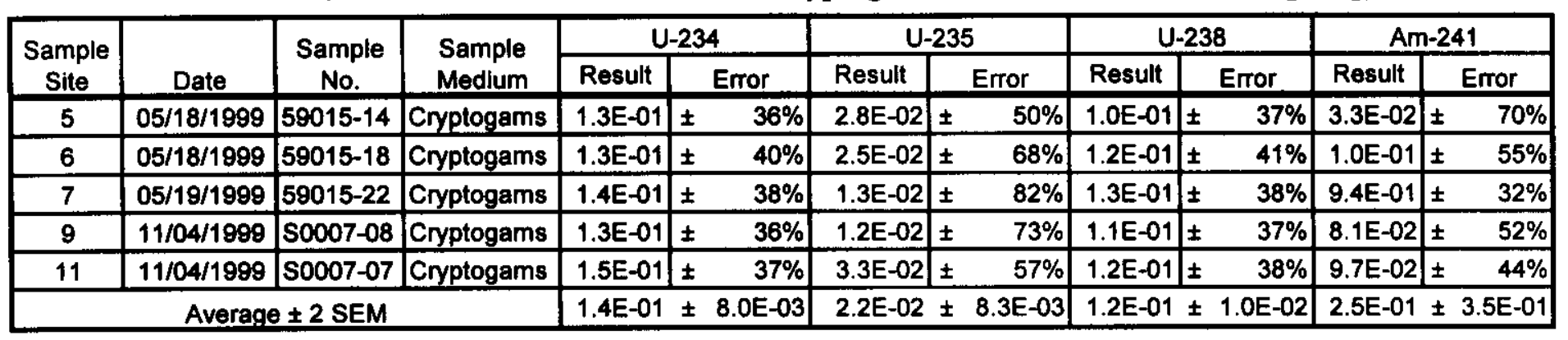

Table 8-8, Part A. Radionuclide Data for Cryptogam Samples Collected at 200 East Area (pCi/g).

\begin{tabular}{|c|c|c|c|c|c|c|c|c|c|c|c|c|c|}
\hline \multirow{2}{*}{$\begin{array}{c}\text { Sample } \\
\text { Site }\end{array}$} & \multirow[b]{2}{*}{ Date } & \multirow{2}{*}{$\begin{array}{c}\text { Sample } \\
\text { No. }\end{array}$} & \multirow{2}{*}{$\begin{array}{l}\text { Sample } \\
\text { Medium }\end{array}$} & \multicolumn{2}{|c|}{ Co-60 } & \multicolumn{2}{|c|}{ Sr-90 } & \multicolumn{2}{|c|}{ Cs-137 } & \multicolumn{2}{|c|}{$\mathrm{Pu}-239 / 240$} & \multicolumn{2}{|c|}{ Pu-241 } \\
\hline & & & & Result & Error & Result & Error & Result & Enror & Result & Error & Result & Error \\
\hline 1 & $11 / 04 / 1999$ & $50007-05$ & Cryptogams & $-3.8 E-03$ & $304 \%$ & 4.6E-01 & $32 \%$ & $1.2 \mathrm{E}+00$ & $13 \%$ & 2.4E-02 & $68 \%$ & $-1.4 E+00$ & $100 \%$ \\
\hline 2 & $11 / 04 / 1999$ & S0007-06 & Cryptogams & $2.5 \mathrm{E}-03$ & $689 \%$ & $4.8 \mathrm{E}-01$ & $31 \%$ & $7.8 \mathrm{E}-01$ & $16 \%$ & 1.1E-02 & $99 \%$ & $-1.8 E+00$ & $100 \%$ \\
\hline & Avereg & $\theta \pm 2$ SEM & & $-6.5 E-04$ & $\pm 6.3 E-03$ & 4.7E-01 & $\pm 2.0 \mathrm{E}-02$ & 9.9E-01 & $\pm 4.2 E-01$ & $1.8 \mathrm{E}-02$ & $\pm \quad 1.3 \mathrm{E}-02$ & $-1.6 \mathrm{E}+\infty$ & $\pm 4.0 \mathrm{E}-01$ \\
\hline
\end{tabular}

Table 8-8, Part B. Radionuclide Data for Cryptogam Samples Collected at 200 East Area (pCi/g).

\begin{tabular}{|c|c|c|c|c|c|c|c|c|c|c|c|c|c|c|}
\hline \multirow{2}{*}{$\begin{array}{l}\text { Sample } \\
\text { Site }\end{array}$} & \multirow[b]{2}{*}{ Date } & \multirow{2}{*}{$\begin{array}{c}\text { Sample } \\
\text { No. }\end{array}$} & \multirow{2}{*}{$\begin{array}{l}\text { Sample } \\
\text { Medium }\end{array}$} & \multicolumn{2}{|c|}{ U-234 } & \multicolumn{3}{|c|}{ U-235 } & \multicolumn{3}{|c|}{ U-238 } & \multicolumn{3}{|c|}{ Am-241 } \\
\hline & & & & Result & Error & Result & & Error & Result & & Error & Result & & Error \\
\hline 1 & $11 / 04 / 1999$ & S0007-05 & Cryptogams & 1.5E-01 & $34 \%$ & 1.9E-02 & \pm & $57 \%$ & 1.4E-01 & \pm & $35 \%$ & 4.7E-02 & \pm & $46 \%$ \\
\hline 2 & $11 / 04 / 1999$ & $50007-06$ & Cryptogams & $1.5 \mathrm{E}-02$ & $64 \%$ & 5.0E-03 & \pm & $95 \%$ & 1.1E-02 & \pm & $70 \%$ & $4.5 E-02$ & \pm & $48 \%$ \\
\hline \multicolumn{3}{|c|}{ Average \pm 2 SEM } & & 8.3E-02 & $\pm \quad 1.4 \mathrm{E}-01$ & 1.2E-02 & \pm & $1.4 \mathrm{E}-02$ & $7.6 \mathrm{E}-02$ & \pm & 1.3E-01 & $4.6 \mathrm{E}-02$ & \pm & 2.0E-03 \\
\hline
\end{tabular}


Table 8-9, Part A. Radionuclide Summary for Mice Captured at $100 \mathrm{~K}$ Area (pCi/g).

\begin{tabular}{|c|c|c|c|c|c|c|c|c|c|c|c|c|c|}
\hline \multirow[b]{2}{*}{ Sample Site } & \multirow[b]{2}{*}{ Date } & \multirow{2}{*}{$\begin{array}{c}\text { Sample } \\
\text { No. }\end{array}$} & \multirow{2}{*}{$\begin{array}{l}\text { Sample } \\
\text { Medium }\end{array}$} & \multicolumn{2}{|c|}{$\mathrm{C} 0-60$} & \multicolumn{2}{|c|}{ Sr-90 } & \multicolumn{2}{|c|}{ Cs-137 } & \multicolumn{2}{|c|}{ Pu-238. } & \multicolumn{2}{|c|}{$\mathrm{Pu}-239 / 240$} \\
\hline & & & & Result & Error & Result & Error & Result & Error & Result & Enror & esult & Error \\
\hline CVDF $/ 100 \mathrm{~K}$ & $5 / 19 / 1999$ & 6865 & mice & $<6.4 E-01$ & NA & $7.7 \mathrm{E}+00$ & $\pm 7.5 \mathrm{E}+00$ & $<9.5 \mathrm{E}-01$ & NA & $<1.9 \mathrm{E}-01$ & $\pm 1.0 E+02$ & $<1.9 E-01$ & $\pm 1.0 \mathrm{E}+02$ \\
\hline OK & $05 /$ & 36 & $c e$ & -01 & NA & $5.4 E+00$ & $\pm 9.6 \mathrm{E}+00$ & $<1.0 \mathrm{E}+00$ & $\mathrm{NA}$ & $<2.1 \mathrm{E}-01$ & +02 & $<2.1 \mathrm{E}-01$ & \pm 1 \\
\hline & $05 / 20 / 1999$ & 6867 & & $<5.5 \mathrm{E}-01$ & \pm & $6.0 E+00$ & $\pm 8.2 \mathrm{E}+00$ & $<9.4 E-01$ & NA & $<2.0 \mathrm{E}-01$ & $\pm 1.0 \mathrm{E}+02$ & $<2.0 \mathrm{E}-01$ & $\pm 1.0 \mathrm{E}+02$ \\
\hline & Average \pm 2 & $M$ & & 6.0E-01 & $\pm 5.5 \mathrm{E}-0$ & $6.4 E+00$ & $\pm 1.4 \mathrm{E}+00$ & 9.6E-01 & $\pm 3.7 \mathrm{E}-01$ & 2.0E-01 & $\pm 1.2 \mathrm{E}-02$ & $2.0 \mathrm{E}-01$ & $\pm 1.2 \mathrm{E}-02$ \\
\hline
\end{tabular}

Table 8-9, Part B. Radionuclide Summary for Mice Captured at $100 \mathrm{~K}$ Area (pCi/g).

\begin{tabular}{|c|c|c|c|c|c|c|c|c|c|c|c|c|c|c|}
\hline \multirow[b]{2}{*}{ Sample Site } & \multirow[b]{2}{*}{ Date } & \multirow{2}{*}{$\begin{array}{c}\text { Sample } \\
\text { No. }\end{array}$} & \multirow{2}{*}{$\begin{array}{l}\text { Sample } \\
\text { Medium }\end{array}$} & \multicolumn{3}{|c|}{$\mathrm{U}-234$} & \multicolumn{3}{|c|}{ U-235 } & \multicolumn{3}{|c|}{$\mathrm{U}-238$} & \multicolumn{2}{|c|}{ Am-241 } \\
\hline & & & & Result & & Error & Result & & Error & Result & & Error & Result & Error \\
\hline CVDF/100K & $05 / 19 / 1999$ & 6865 & mice & $<2.0 \mathrm{E}-02$ & \pm & NA & $<2.0 \mathrm{E}-02$ & 1 & NA & $<2.0 \mathrm{E}-02$ & \pm & NA & $<4.9 E+00$ & NA \\
\hline CVDF/100K & $05 / 20 / 4999$ & 6866 & mice & $<2.1 \mathrm{E}-02$ & \pm & NA & $<2.1 E-02$ & \pm & NA & $<2.1 E-02$ & \pm & NA & $<5.5 E+\infty 0$ & NA \\
\hline NE/100K & $05 / 20 / 1999$ & 6867 & mice & 1.9E-02 & 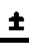 & NA & 1.9E-02 & \pm & NA & $1.9 E-02$ & \pm & NA & $<5.1 E+\infty 0$ & NA \\
\hline \multicolumn{4}{|c|}{ Average \pm 2 SEM } & 2.0E-02 & \pm & $1.2 \mathrm{E}-03$ & $2.0 \mathrm{E}-02$ & \pm & $1.2 \mathrm{E}-03$ & 2.0E-02 & \pm & $1.2 \mathrm{E}-03$ & $5.2 E+\infty$ & $\pm 3.5 \mathrm{E}-01$ \\
\hline
\end{tabular}

Table 8-10, Part A. Radionuclide Summary for Mice Captured in 200 East Area (pCi/g).

\begin{tabular}{|c|c|c|c|c|c|c|c|c|c|c|c|c|c|}
\hline \multirow{2}{*}{$\begin{array}{c}\text { Sample } \\
\text { Site }\end{array}$} & \multirow[b]{2}{*}{ Date } & \multirow{2}{*}{$\begin{array}{c}\text { Sample } \\
\text { No. }\end{array}$} & \multirow{2}{*}{$\begin{array}{l}\text { Sample } \\
\text { Medium }\end{array}$} & \multicolumn{2}{|c|}{$\mathrm{Co}-6 \mathrm{O}$} & \multicolumn{2}{|c|}{ Sr-90 } & \multicolumn{2}{|c|}{ Cs-137 } & \multicolumn{2}{|c|}{ Pu-238 } & \multicolumn{2}{|c|}{ Pu-239/240 } \\
\hline & & & & Result & Error & Result & Error & Result & Error & Result & Error & Result & Error \\
\hline $\mathrm{CSB} / 200 \mathrm{E}$ & $05 / 19 / 1999$ & 6863 & mice & $<6.2 \mathrm{E}-01$ & NA & $<6.4 E-01$ & $\pm 1.2 E+02$ & $<9.4 \mathrm{E}-01$ & NA & $<2.0 \mathrm{E}-01$ & $\pm 1.0 E+02$ & $<2.0 \mathrm{E}-01$ & $\pm 1.0 E+00$ \\
\hline $\mathrm{CSB} / 200 \mathrm{E}$ & $05 / 19 / 1999$ & 6864 & mice & $<6.8 \mathrm{E}-01$ & NA & $<5.9 E-01$ & $\pm 2.8 E+02$ & $<1.0 \mathrm{E}+00$ & NA & $<2.1 E-01$ & $\pm 1.0 \mathrm{E}+02$ & $<2,1 \mathrm{E}-01$ & $\pm 1.0 \mathrm{E}+02$ \\
\hline & Averege \pm 2 & $E M$ & & 6.5E-01 & $\pm 6.0 \mathrm{E}-02$ & 6.2E-01 & $\pm 5.0 \mathrm{E}-02$ & 9.7E-01 & $\pm 6.0 \mathrm{E}-02$ & 2.1E-01 & $\pm 1.0 \mathrm{E}-02$ & 2.1E-01 & $\pm 1.0 \mathrm{E}-02$ \\
\hline
\end{tabular}

Table 8-10, Part B. Radionuclide Summary for Mice Captured in 200 East Area (pCi/g).

\begin{tabular}{|c|c|c|c|c|c|c|c|c|c|c|c|c|c|c|c|}
\hline \multirow{2}{*}{$\begin{array}{c}\text { Sample } \\
\text { Site }\end{array}$} & \multirow[b]{2}{*}{ Date } & \multirow{2}{*}{$\begin{array}{c}\text { Sample } \\
\text { No. }\end{array}$} & \multirow{2}{*}{$\begin{array}{l}\text { Sample } \\
\text { Medium }\end{array}$} & \multicolumn{3}{|c|}{ U-234 } & \multicolumn{3}{|c|}{ U-235 } & \multicolumn{3}{|c|}{ U-238 } & \multicolumn{3}{|c|}{ Am-241 } \\
\hline & & & & Result & & Error & Result & & Error & Result & & Error & Result & & Error \\
\hline CSB/200E & $05 / 19 / 1999$ & 6863 & mice & $<1.9 E-02$ & \pm & NA & $<1.9 \mathrm{E}-02$ & & NA & $<1.9 E-02$ & \pm & NA & $<4.7 E+00$ & 1 & NA \\
\hline $\mathrm{CSB} / 200 \mathrm{E}$ & $05 / 19 / 1999$ & 6864 & mice & $<2.3 E-02$ & \pm & NA & $<2.3 E-02$ & \pm & NA & $<2.3 E-02$ & \pm & NA & $<5.7 \mathrm{E}+\infty$ & 1 & NA \\
\hline \multicolumn{4}{|c|}{ Average \pm 2 SEM } & 2.1E-02 & \pm & 4.0E-03 & 2.1E-02 & & 4.0E-03 & 2.1E-02 & \pm & 4.0E-03 & $5.2 E+00$ & & $1.0 \mathrm{E}+00$ \\
\hline
\end{tabular}


Table 8-11. Summary of Average and Maximum Values for Selected Constituents in Sample Media (pCi/g).

\begin{tabular}{|c|c|c|c|c|}
\hline Analyte & $\begin{array}{l}100 \mathrm{~K} \text { Area } \\
\text { Average }\end{array}$ & $\begin{array}{c}200 \text { East Area } \\
\text { Average }\end{array}$ & $\begin{array}{c}\text { Maximum } \\
\text { Reported Value }\end{array}$ & Sample Location \\
\hline \multicolumn{5}{|c|}{ Sodits } \\
\hline${ }^{137} \mathrm{Cs}$ & 0.4 & 0.2 & 1.3 & $100 \mathrm{~K}$-\#9 \\
\hline${ }^{90} \mathrm{Sr}$ & 1.0 & 1.0 & 1.5 & $100 \mathrm{~K}$ \\
\hline${ }^{239 / 240} \mathrm{Pu}$ & 0.02 & 0.03 & 0.06 & $100 \mathrm{~K}$ \\
\hline${ }^{241} \mathrm{Pu}$ & 0.4 & 1.4 & 6.1 & $200 \mathrm{E}-\# 3$ \\
\hline \multicolumn{5}{|c|}{ Vephnon } \\
\hline${ }^{137} \mathrm{Cs}$ & -0.002 & 0.01 & 0.02 & $100 \mathrm{~K}$-\#9 \\
\hline${ }^{90} \mathrm{Sr}$ & 0.6 & 0.5 & 0.9 & $100 \mathrm{~K}$ \\
\hline${ }^{239 / 240} \mathrm{Pu}$ & 0.008 & 0.01 & 0.04 & $200 \mathrm{E}-\# 2$ \\
\hline${ }^{241} \mathrm{Pu}$ & -0.4 & 1.0 & 1.5 & $200 \mathrm{E}-\# 2$ \\
\hline \multicolumn{5}{|c|}{ Litter } \\
\hline${ }^{137} \mathrm{Cs}$ & 0.2 & 1.5 & 2.0 & $200 \mathrm{E}-\# 4$ \\
\hline${ }^{90} \mathrm{Sr}$ & 0.7 & 0.9 & 1.1 & $200 \mathrm{E}-\# 1$ \\
\hline${ }^{239 / 240} \mathrm{Pu}$ & -0.004 & 0.04 & 0.04 & $200 \mathrm{E}-\# 1$ \\
\hline${ }^{241} \mathrm{Pu}$ & 0.06 & 0.4 & 0.8 & $200 \mathrm{E}-\# 2$ \\
\hline \multicolumn{5}{|c|}{ Crypogatios } \\
\hline${ }^{137} \mathrm{CS}$ & 6.2 & 1.0 & 26.0 & $100 \mathrm{~K}-\# 7$ \\
\hline${ }^{90} \mathrm{Sr}$ & 0.9 & 0.5 & 1.2 & $100 \mathrm{~K}-\# 6 / 7$ \\
\hline${ }^{239 / 240} \mathrm{Pu}$ & 0.3 & 0.02 & 1.1 & $100 \mathrm{~K}$ \\
\hline${ }^{241} \mathrm{Pu}$ & 1.8 & -1.6 & 6.4 & $100 \mathrm{~K}-\# 7$ \\
\hline
\end{tabular}

In a comparison of the locations where maximum values occurred, Site $7(100 \mathrm{~K})$ had 6 of the 12 highest values, Site $9(100 \mathrm{~K})$ had 3 and Site 2 (200 East) had 3. No other sampling location had more than 1 maximum value.

With regard to the values collected for small mammals (mice), Table 8-12 provides a comparison of this study with similar studies in the general locations around the 200 Area. The variability in the values reported probably reflects to some degree the variability between laboratories and the difficulties in analyzing whole organisms. However, ${ }^{137} \mathrm{Cs}$ and ${ }^{90} \mathrm{Sr}$ are consistently identified and the values for mice reported from $100 \mathrm{~K}$ Area are among the highest for all the studies conducted (see Table 8-12). 
HNF-6150 Rev. 0

Table 8-12. Summary of Maximum Radionuclide Values Analyzed in Mice From This and Previous Studies (pCi/g).

\begin{tabular}{|l|c|c|c|c|c|}
\hline Analytes & This Study & $\begin{array}{c}\text { Waste Site } \\
\text { Ecology }^{(\mathrm{a})}\end{array}$ & $\begin{array}{c}\text { PUREX } \\
\text { Study }^{(\mathrm{b})}\end{array}$ & $\begin{array}{c}\text { ERDF } \\
\text { Study }\end{array}$ & $\begin{array}{c}\text { SWOC } \\
\text { Study }\end{array}$ \\
\hline Cesium-137 & $\begin{array}{c}<1.0 \\
\text { (both areas) }\end{array}$ & 10.0 & 0.7 & $\mathrm{NR}^{(\mathrm{c})}$ & 0.004 \\
\hline Strontium-90 & $7.7(100 \mathrm{~K})$ & 1.6 & 0.1 & 0.5 & 0.003 \\
\hline Cobalt-60 & $\begin{array}{c}<0.7 \\
\text { (both areas) }\end{array}$ & 0.09 & $\mathrm{NR}$ & $\mathrm{NR}$ & $\mathrm{NR}$ \\
\hline $\begin{array}{l}\text { Total } \\
\text { Uranium }\end{array}$ & $\mathrm{NR}$ & 0.3 & $\mathrm{NR}$ & $\mathrm{NR}$ & $\mathrm{NR}$ \\
\hline $\begin{array}{l}\text { Plutonium- } \\
239 / 240\end{array}$ & $\begin{array}{c}<0.2 \\
\text { (both areas) }\end{array}$ & $\mathrm{NR}$ & $\mathrm{NR}$ & $\mathrm{NR}$ & 0.007 \\
\hline
\end{tabular}

(a) Mitchell and Weiss 1994.

(b) Landeen et al. 1994.

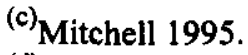

(d) Mitchell and Johnson 1996.

(c) not reported. 


\subsection{METALS}

There is a general paucity of information relative to the environmental concentrations of metals in Hanford Site soils, plants, and mammals. Some data collected in the 300 Area (Brandt and Rickard 1992) for plants and animals indicated the occurrence of metals at very low levels. The most extensive information for the Hanford Site is the study (Landeen et al. 1993) conducted in the 100 Areas along the Columbia River. Data are summarized for metals in soils, various types of plants, as well as raptor pellets (hawks), owls, and coyote scat. However, the values obtained must be viewed with some caution since mining and refining activities in upper Columbia River drainages (Johnson 1991, Maxfield 1974, Silker 1964), no doubt, contribute to elevated background levels for metals in soils and sediments and for uptake by plants and animals (Adriano 1986).

More recent studies have been conducted in the 200 Areas (Mitchell and Johnson 1996, Mitchell 1999) on metals in soil and vegetation, and in the 100 Areas on metals in fruit trees, reed canary grass and the aquatic plant, milfoil (Poston 1998). For comparative purposes, a summary of the maximum concentration for metals in soils and various types of vegetation from the 100 Areas (Landeen et al. 1993) is included in Table 8-13. Table 8-14 provides a summary of the maximum values observed in soils, vegetation and borehole soils from the 200 Areas (Mitchell and Johnson 1996) compared to the Hanford Site soil background values (DOE 1995).

The State of Washington conducted an extensive study of natural background concentration of metals in soils. A total of 490 soil samples from 166 locations throughout Washington were collected and reported on. Values for the general Hanford Site regions were reported for the area designated as the Yakima Basin (San Juan 1994). 
Table 8-13. Summary ${ }^{(a)}$ of Reported Maximum Metals Concentrations for 100 Area Soils and Vegetation (ppm).

\begin{tabular}{|l|c|c|c|c|c|}
\hline \multicolumn{1}{|c|}{ Analytes } & Soils & Asparagus & Reed canary grass & Milfoil & Tree leaves \\
\hline Chromium & 13.2 & 6.0 & 8.7 & 16.2 & 6.0 \\
\hline Copper & 39.2 & 14.2 & 25.0 & 61.1 & 92.5 \\
\hline Zinc & 496.0 & 97.4 & 305.0 & 319.0 & 468.0 \\
\hline Arsenic & 4.8 & 7.5 & 4.2 & 6.3 & 393 \\
\hline Lead & 24.3 & 1.9 & 11.1 & 28.3 & 7.1 \\
\hline Mercury & 0.09 & 1.5 & 0.4 & 0.5 & 2.7 \\
\hline Silver & 1.3 & 3.6 & 1.2 & 2.9 & 4.0 \\
\hline
\end{tabular}

(a) Landeen et al. 1993.

Table 8-14. Summary of Maximum Metals Values Reported for 200 Area Soils and Vegetation (ppm).

\begin{tabular}{|c|c|c|c|c|c|}
\hline Analytes & $\begin{array}{c}\text { Maximum } \\
\text { surface soils }\end{array}$ & $\begin{array}{l}\text { Maximum } \\
\text { plants }^{(a)}\end{array}$ & $\begin{array}{c}\text { Maximum } \\
\text { surface soils }\end{array}$ & $\begin{array}{l}\text { Maximum } \\
\text { plants }^{(b)}\end{array}$ & $\begin{array}{c}\text { Background }^{\text {(c) }} \\
\text { value (soil) }\end{array}$ \\
\hline Chromium & 11.1 & 10.4 & 8.9 & 1.7 & 23.0 \\
\hline Copper & 12.5 & 20.1 & 13.0 & 4.9 & 25.2 \\
\hline Zinc & 45.8 & 47.1 & 157.0 & 26.2 & 71.6 \\
\hline Arsenic & 2.6 & 2.4 & 12.6 & 6.4 & 7.7 \\
\hline Lead & 4.7 & 5.2 & $\overline{5.5}$ & 1.8 & 12.3 \\
\hline Mercury & 0.02 & 0.07 & $<0.2$ & $<0.2$ & 0.7 \\
\hline Silver & 0.53 & 0.5 & $<1.4$ & $<0.7$ & 1.5 \\
\hline
\end{tabular}

(a) Mitchell and Johnson 1996 (values reported for 200 West Area).

${ }^{(b)}$ Mitchell 1999 (values reported for 200 East Area).

${ }^{(c)}$ DOE 1995.

\subsubsection{Surface Soils}

8.2.1.1 100 K Area. Surface soils sampled in the $100 \mathrm{~K}$ Area had moderately elevated levels of lead and chromium. Site 9 was sampled on two occasions (Table 8-15) and showed levels of 28.9 ppm and $20.0 \mathrm{ppm}$, respectively, for lead. Chromium samples from sites 5 and 9 exhibited levels of $39.0 \mathrm{ppm}$ and $40.0 \mathrm{ppm}$, respectively. The lead and chromium values are higher than values previously reported for soils sampled in the 100 Areas (Table 8-13).

There was a somewhat high value reported for zinc at site $9(73.0 \mathrm{ppm})$ during the second sampling episode. However, the value is between the Hanford Site and Washington State soil background values, and below that previously reported in the 100 Areas (Table 8-14). The initial sample showed a value of $50 \mathrm{ppm}$ (Table 8-15). 
Table 8-15. Metals Data for $100 \mathrm{~K}$ Area Surface Soils (ppm).

\begin{tabular}{|c|c|c|c|c|c|c|c|c|c|c|c|c|}
\hline \multirow{2}{*}{$\begin{array}{c}\text { Sample } \\
\text { Site }\end{array}$} & Date & $\begin{array}{c}\text { Sample } \\
\text { No. }\end{array}$ & $\begin{array}{c}\text { Sample } \\
\text { Medium }\end{array}$ & \multicolumn{1}{|c|}{ Mrsenic } & Barium & Cadmium & Lead & Mercury & Chromium & Copper & Silver & Zinc \\
\hline 5 & $05 / 18 / 1999$ & $59015-11$ & Soil & 1.4 & 71.0 & 0.3 & 5.7 & $<0.2$ & 39.0 & 12.0 & $<0.2$ & 33.0 \\
\hline 6 & $05 / 18 / 1999$ & $59015-15$ & Soil & 3.1 & 68.0 & 0.4 & 7.8 & $<0.3$ & 11.0 & 15.0 & $<0.3$ & 38.0 \\
\hline 7 & $05 / 19 / 1999$ & $59015-19$ & Soil & 2.2 & 33.0 & $<0.3$ & 4.5 & $<0.3$ & 5.9 & 14.0 & 0.4 & 25.0 \\
\hline 8 & $05 / 19 / 1999$ & $59015-23$ & Soil & 1.8 & 52.0 & 0.3 & 5.9 & $<0.2$ & 7.3 & 10.0 & $<0.2$ & 31.0 \\
\hline 9 & $05 / 19 / 1999$ & $59015-24$ & Soil & 1.6 & 56.0 & 0.5 & 28.9 & $<0.2$ & 40.0 & 17.0 & $<0.2$ & 50.0 \\
\hline 10 & $05 / 19 / 1999$ & $59015-25$ & Soil & 1.6 & 47.0 & 0.3 & 5.6 & $<0.2$ & 6.0 & 15.0 & $<0.2$ & 31.0 \\
\hline 9 & $11 / 04 / 1999$ & $50007-04$ & Soil & 1.8 & 63.0 & 0.3 & 20.0 & 0.1 & 8.5 & 17.0 & $<0.1$ & 73.0 \\
\hline 11 & $11 / 04 / 1999$ & S0007-03 & Soil & 1.8 & 67.0 & 0.2 & 7.6 & $<0.1$ & 9.8 & 11.0 & $<0.1$ & 37.0 \\
\hline
\end{tabular}

8.2.1.2 200 East Area. The metals concentrations in soil samples from the 200 East Area (Table 8-16) are all below values for Hanford Site and Washington State soil background values. The values are also below those of soils previously sampled in the 200 East Area shown in Table 8-14. An interesting comparison here is that while lead, chromium and zinc values were all relatively constant in the 100 East Area samples (Table 8-16), these same constituents were highly variable in the $100 \mathrm{~K}$ soils (Table 8-15).

\subsubsection{Vegetation}

8.2.2.1 100 K Area. The vegetation samples (Table 8-17) taken from growing sagebrush stems in the $100 \mathrm{~K}$ Area demonstrate metals values below those previously reported in other types of plants in Table 8-13.

8.2.2.2 200 East Area. The metals values for vegetation samples in the 200 East Area (Table 8-18) show most values below those reported for other 200 Area projects (Table 8-14). A copper value from Site 1 was a little higher at $6.2 \mathrm{ppm}$ than the previously reported maximum of $4.9 \mathrm{ppm}$ (Table 8-14).

Table 8-16. Metals Data for 200 East Area Surface Soils (ppm).

\begin{tabular}{|c|c|c|c|c|c|c|c|c|c|c|c|c|}
\hline \multirow{2}{*}{$\begin{array}{c}\text { Sample } \\
\text { Site }\end{array}$} & Date & $\begin{array}{c}\text { Sample } \\
\text { No. }\end{array}$ & $\begin{array}{c}\text { Sample } \\
\text { Medium }\end{array}$ & \multicolumn{10}{|c|}{ Arsenic } & Barium & Cadmium & Lead & Mercury & Chromium & Copper & Silver & Zinc \\
\hline 1 & $05 / 18 / 1999$ & $59015-01$ & Soil & 2.1 & 78.1 & 0.3 & 5.9 & $<0.2$ & 5.5 & 9.3 & $<0.2$ & 31.1 \\
\hline 2 & $05 / 18 / 1999$ & $59015-04$ & Soil & 2 & 75.0 & 0.3 & 5.9 & $<0.2$ & 5.7 & 8.5 & $<0.2$ & 28.0 \\
\hline 3 & $05 / 18 / 1999$ & $59015-07$ & Soil & 1.8 & 79.0 & 0.3 & 5.7 & $<0.2$ & 6.3 & 8.8 & $<0.2$ & 30.0 \\
\hline 4 & $05 / 18 / 1999$ & $59015-08$ & Soil & 1.7 & 68.0 & 0.3 & 5.6 & $<0.2$ & 5.8 & 8.2 & $<0.2$ & 30.0 \\
\hline 1 & $11 / 04 / 1999$ & $50007-01$ & Soil & 2.2 & 73.0 & 0.2 & 5.3 & $<0.1$ & 7.1 & 8.5 & $<0.1$ & 37.0 \\
\hline 2 & $11 / 04 / 1999$ & $50007-02$ & Soil & 2.0 & 78.0 & 0.2 & 5.0 & $<0.0$ & 6.5 & 8.7 & $<0.1$ & 36.0 \\
\hline
\end{tabular}


Table 8-17. Metals Data for $100 \mathrm{~K}$ Area Vegetation (ppm).

\begin{tabular}{|c|c|c|c|c|c|c|c|c|c|c|c|c|}
\hline \multirow{2}{*}{$\begin{array}{c}\text { Sample } \\
\text { Site }\end{array}$} & \multirow[b]{2}{*}{ Date } & \multirow{2}{*}{$\begin{array}{c}\text { Sample } \\
\text { No. }\end{array}$} & \multirow{2}{*}{$\begin{array}{l}\text { Sample } \\
\text { Medium }\end{array}$} & \multicolumn{9}{|c|}{ Analyte (ppm) } \\
\hline & & & & Arsenic & Barium & Cadmium & Lead & Mercury & Chromium & Copper & Silver & Zinc \\
\hline 5 & 05/18/1999 & 59015-13 & Vegetation & $<0.4$ & 1.4 & $<0.2$ & 0.6 & $<0.1$ & 1.4 & 2.4 & $<0.2$ & 5.7 \\
\hline 6 & $05 / 18 / 1999$ & 59015-17 & Vegetation & $<0.4$ & 1.9 & $<0.2$ & 0.9 & $<0.1$ & $<0.6$ & 4.0 & $<0.2$ & 11.4 \\
\hline 7 & $05 / 19 / 1999$ & 59015-21 & Vegetation & $<0.4$ & 0.9 & $<0.2$ & 0.8 & $<0.1$ & $<0.5$ & 2.0 & $<0.2$ & 4.3 \\
\hline 9 & $11 / 04 / 1999$ & $50007-10$ & Vegetation & $<0.1$ & 2.4 & $<0.1$ & $<0.6$ & $<0.0$ & 1.5 & 3.2 & $<0.1$ & 24.0 \\
\hline 11 & $11 / 04 / 1999$ & $50007-09$ & Vegetation & $<0.1$ & 3.3 & $<0.1$ & $<0.6$ & $<0.0$ & 1.5 & 4.7 & $<0.1$ & 8.2 \\
\hline
\end{tabular}

Table 8-18. Metals Data for 200 East Area Vegetation (ppm).

\begin{tabular}{|c|c|c|c|c|c|c|c|c|c|c|c|c|}
\hline \multirow{2}{*}{$\begin{array}{c}\text { Sample } \\
\text { Site }\end{array}$} & \multirow[b]{2}{*}{ Date } & \multirow{2}{*}{$\begin{array}{c}\text { Sample } \\
\text { No. }\end{array}$} & \multirow{2}{*}{$\begin{array}{l}\text { Sample } \\
\text { Medium }\end{array}$} & \multicolumn{9}{|c|}{ Analyte (ppm) } \\
\hline & & & & Arsenic & Barium & Cadmium & Lead & Mercury & Chromium & Copper & Silver & Zinc \\
\hline 1 & $05 / 18 / 1999$ & $59015-03$ & Vegetation & 1.1 & 5 & $<0.2$ & 1.3 & 0.1 & 1.8 & 6.2 & 0.3 & 8 \\
\hline 2 & $05 / 18 / 1999$ & $59015-06$ & Vegetation & $<0.4$ & 2.5 & $<0.2$ & 0.5 & 0.1 & 1.6 & 4.7 & $<0.2$ & 8.5 \\
\hline 4 & $05 / 18 / 1999$ & $59015-10$ & Vegetation & 0.4 & 2.2 & $<0.2$ & 0.3 & $<0.1$ & 1.6 & 3.5 & $<0.2$ & 7.8 \\
\hline
\end{tabular}

\subsubsection{Litter}

8.2.3.1 100 K Area. Litter samples from the $100 \mathrm{~K}$ Area (Table 8-19) show values that are generally low compared with those previously reported for vegetation in Table 8-13.

8.2.3.2 200 East Area. Values for metals in litter in the 200 East Area (Table 8-20) are generally higher than those reported for the $100 \mathrm{~K}$ Area. However, the values are low as compared to those previously reported for the 200 Areas.

\subsubsection{Cryptogams}

8.2.4.1 100 K Area. The values for cryptogam samples collected at site 7 (Table 8-21) showed elevated concentrations of lead $(1030 \mathrm{ppm})$ and chromium $(180 \mathrm{ppm})$. The cryptogams collected at Site 9 exhibited elevated concentrations of zinc $(1800 \mathrm{ppm})$. These values are higher than those previously reported for any type of vegetation in Table 8-13.

8.2.4.2 200 East Area. The concentration for metals in cryptogams from the 200 East Area (Table 8-22) are lower than those reported for the $100 \mathrm{~K}$ Area (Table 8-21) and in comparison to those previously reported for other 200 Areas Sites (Table 8-14). 
Table 8-19. Metals Data for $100 \mathrm{~K}$ Area Litter (ppm).

\begin{tabular}{|c|c|c|c|c|c|c|c|c|c|c|c|c|}
\hline $\begin{array}{c}\text { Sample } \\
\text { Site }\end{array}$ & Date & $\begin{array}{c}\text { Sample } \\
\text { No. }\end{array}$ & $\begin{array}{c}\text { Sample } \\
\text { Medium }\end{array}$ & \multicolumn{10}{|c|}{ Analyte (ppm) } & Barium & Cadmium & Lead & Mercury & Chromium & Copper & Silver & Zinc \\
\hline 5 & $05 / 18 / 1999$ & $59015-12$ & Litter & 0.8 & 33.0 & 0.3 & 2.3 & 0.1 & 3.5 & 8.1 & $<0.2$ & 26.0 \\
\hline 6 & $05 / 18 / 1999$ & $59015-16$ & Litter & 1.2 & 38.0 & 0.3 & 3.7 & 0.1 & 4.6 & 12.0 & $<0.2$ & 33.0 \\
\hline 7 & $05 / 19 / 1999$ & $59015-20$ & Litter & 0.8 & 28.0 & 0.3 & 3.7 & 0.1 & 1.2 & 10.0 & $<0.2$ & 28.0 \\
\hline
\end{tabular}

Table 8-20. Metals Data for 200 East Area Litter (ppm).

\begin{tabular}{|c|c|c|c|c|c|c|c|c|c|c|c|c|}
\hline $\begin{array}{c}\text { Sample } \\
\text { Site }\end{array}$ & Date & $\begin{array}{c}\text { Sample } \\
\text { No. }\end{array}$ & $\begin{array}{c}\text { Sample } \\
\text { Medium }\end{array}$ & \multicolumn{10}{|c|}{ Analyte (ppm) } \\
\hline 1 & $05 / 18 / 1999$ & $59015-02$ & Litter & 2.2 & 67.0 & 0.4 & 6.5 & 0.1 & 5.4 & 15.0 & $<0.2$ & 33.0 \\
\hline 2 & $05 / 18 / 1999$ & $59015-05$ & Litter & 2.6 & 79.0 & 0.5 & 8.8 & 0.4 & 6.5 & 18.0 & $<0.2$ & 33.0 \\
\hline 4 & $05 / 18 / 1999$ & $59015-09$ & Litter & 2.2 & 71.0 & 0.4 & 7.4 & 0.2 & 6.1 & 19.0 & $<0.2$ & 38.0 \\
\hline
\end{tabular}

Table 8-21. Metals Data for $100 \mathrm{~K}$ Area Cryptogams (ppm).

\begin{tabular}{|c|c|c|c|c|c|c|c|c|c|c|c|c|}
\hline \multirow{2}{*}{$\begin{array}{c}\text { Sample } \\
\text { Site }\end{array}$} & \multirow[b]{2}{*}{ Date } & \multirow{2}{*}{$\begin{array}{c}\text { Sample } \\
\text { No. }\end{array}$} & \multirow{2}{*}{$\begin{array}{l}\text { Sample } \\
\text { Medium }\end{array}$} & \multicolumn{9}{|c|}{ Analyte (ppm) } \\
\hline & & & & Arsenic & Barium & Cadmium & Lead & Mercury & Chromium & Copper & Silver & Zinc \\
\hline 5 & $05 / 18 / 1999$ & $59015-14$ & Cryptogams & 1 & 45.0 & 0.3 & 14.8 & $<0.1$ & 6.2 & 10.0 & $<0.2$ & 30.0 \\
\hline 6 & $05 / 18 / 1999$ & $59015-18$ & Cryptogams & 1.4 & 44.0 & 0.3 & 5.2 & $<0.1$ & 5.4 & 9.9 & $<0.2$ & 26.0 \\
\hline 7 & $05 / 19 / 1999$ & $59015-22$ & Cryptonams & 1.3 & 33.0 & 0.2 & 1030 & $<0.1$ & 180.0 & 16.0 & $<0.2$ & 28.0 \\
\hline 9 & $11 / 04 / 1999$ & $50007-08$ & Cryptogams & 1.4 & 33.0 & 0.7 & 13.0 & $<0.0$ & 5.4 & 19.0 & $<0.1$ & 1800.0 \\
\hline 11 & $11 / 04 / 1999$ & S0007-07 & Cryptogams & 3.1 & 64.0 & 0.2 & 18.0 & 0.2 & 11.0 & 15.0 & $<0.1$ & 44.0 \\
\hline
\end{tabular}

Table 8-22. Metals Data for 200 East Area Cryptogams (ppm).

\begin{tabular}{|c|c|c|c|c|c|c|c|c|c|c|c|c|}
\hline \multirow{2}{*}{$\begin{array}{l}\text { Sample } \\
\text { Site }\end{array}$} & \multirow[b]{2}{*}{ Date } & \multirow{2}{*}{$\begin{array}{c}\text { Sample } \\
\text { No. }\end{array}$} & \multirow{2}{*}{$\begin{array}{l}\text { Sample } \\
\text { Medium }\end{array}$} & \multicolumn{9}{|c|}{ Analyte (ppm) } \\
\hline & & & & Arsenic & Barium & Cadmium & Lead & Mercury & Chromium & Copper & Silver & Zinc \\
\hline 1 & $11 / 04 / 1999$ & S0007-05 & Cryptogams & 1.6 & 49.0 & 0.1 & 3.2 & $<0.0$ & 5.4 & 8.4 & $<0.1$ & 30.0 \\
\hline 2 & $11 / 04 / 1999$ & S0007-06 & Cryptogams & 1.6 & 55.0 & 0.1 & 3.8 & $<0.0$ & 5.7 & 7.8 & $<0.1$ & 26.0 \\
\hline
\end{tabular}

\subsubsection{Mice}

8.2.5.1 100 K Area. The values reported by the $222 \mathrm{~S}$ laboratory for the $100 \mathrm{~K}$ Area (Table 8-23) mouse samples are generally consistent with values reported from other studies (Table 8-24). However, the "less than" values reported for arsenic $(<13 \mathrm{ppm})$ and lead $(<13 \mathrm{ppm})$ are lab artifacts for detection levels and are, in reality, probably much lower than the values reported.

8.2.5.2 200 East Area. The metals concentrations in mice reported for the 200 East Area (Table 8-25) are generally comparable to those of the $100 \mathrm{~K}$ Area and the previous comments relative to arsenic and lead also apply here. 
HNF-6150 Rev. 0

Table 8-23. Summary of Values for Selected Metals in Mice Collected in $100 \mathrm{~K}$ Area (ppm).

\begin{tabular}{|c|c|c|c|c|c|c|c|c|c|c|c|c|}
\hline \multirow[b]{2}{*}{ Sample Site } & \multirow[b]{2}{*}{ Date } & \multirow[b]{2}{*}{$\begin{array}{c}\text { Sample } \\
\text { No. }\end{array}$} & \multirow[b]{2}{*}{$\begin{array}{l}\text { Sample } \\
\text { Medium }\end{array}$} & \multicolumn{9}{|c|}{ Analyte } \\
\hline & & & & Arsenic & Barium & Cadmium & Lead & Mercury & Chromium & Copper & Silver & Zinc \\
\hline CVDF/100K & $05 / 19 / 1999$ & 6865 & mice & $<11.0$ & 7.5 & $<0.6$ & $<1.0$ & $<0.53$ & $<1.1$ & 3.8 & $<1.1$ & 36.0 \\
\hline CVDF/100K & $05 / 20 / 1999$ & 6866 & mice & $<12.0$ & 7.0 & $<0.6$ & $<12.0$ & $<0.57$ & $<1.2$ & 2.9 & $<1.2$ & 37.0 \\
\hline NE/100K & $05 / 20 / 1999$ & 6867 & mice & $<11.0$ & 8.4 & $<0.6$ & $<11.0$ & $<0.51$ & $<1.1$ & 2.8 & $<1.1$ & 32.0 \\
\hline
\end{tabular}

Table 8-24. Summary of Metals Data (Maximum Values) for Mice in This and Previous Studies (ppm).

\begin{tabular}{|l|c|c|c|c|}
\hline Analyte & This Study & $\begin{array}{l}\text { Waste Site } \\
\text { Ecology }^{(\mathrm{a})}\end{array}$ & ERDF Study $^{(\mathrm{b})}$ & SWOC Study $^{(\mathrm{c})}$ \\
\hline Arsenic & $<13.0$ & 0.2 & 1.5 & 0.1 \\
\hline Barium & 9.6 & $\mathrm{NR}^{(\mathrm{d})}$ & $\mathrm{NR}$ & 0.5 \\
\hline Cadmium & $<0.7$ & 1.0 & 0.9 & 0.3 \\
\hline Lead & $<13.0$ & 1.3 & 10.1 & 0.09 \\
\hline Mercury & $<0.6$ & 0.6 & 0.2 & 0.06 \\
\hline Chromium & $<1.3$ & 1.8 & 5.8 & 0.3 \\
\hline Copper & 3.8 & 43.0 & 10.2 & 2.2 \\
\hline Silver & $<1.3$ & 0.6 & 2.5 & 0.2 \\
\hline Zinc & 78 & 33.7 & 69.1 & 2.3 \\
\hline
\end{tabular}

(a)Mitchell and Weiss 1994.

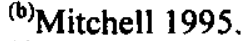

(c) Mitchell and Johnson 1996.

(d) not reported.

Table 8-25. Summary of Values for Selected Metals in Mice Collected at 200 East Area (ppm).

\begin{tabular}{|c|c|c|c|c|c|c|c|c|c|c|c|c|}
\hline \multirow[b]{2}{*}{ Sample Site } & \multirow[b]{2}{*}{ Date } & \multirow[b]{2}{*}{$\begin{array}{c}\text { Sample } \\
\text { No. }\end{array}$} & \multirow[b]{2}{*}{$\begin{array}{l}\text { Sample } \\
\text { Medium }\end{array}$} & \multicolumn{9}{|c|}{ Analyte } \\
\hline & & & & Arsenic & Barium & Cadmium & Lead & Mercury & Chromium & Copper & Silver & Zinc \\
\hline CSB/200E & $05 / 19 / 1999$ & 6863 & mice & $<11.0$ & 8.7 & $<0.6$ & $<11.0$ & $<0.51$ & $<1.1$ & 2.9 & $<1.1$ & 78.0 \\
\hline $\mathrm{CSB} / 200 \mathrm{E}$ & $05 / 19 / 1999$ & 6864 & mice & $<13.0$ & 9.6 & $<0.7$ & $<13.0$ & $<0.59$ & $<1.3$ & 3.3 & $<1.3$ & 43.0 \\
\hline
\end{tabular}




\subsubsection{Metals Summary}

Table 8-26 provides a summary of the maximum concentrations reported in the soil and vegetation-type samples collected at $100 \mathrm{~K}$ Area and 200 East Area for this study. Soil values for the Hanford Site background (DOE 1995) and Washington State (San Juan 1994) are also provided for comparison.

An interesting aspect that developed from the data analyses indicated that all of the maximum vegetation-type concentrations in $100 \mathrm{~K}$ Area were in cryptogams. However, for 200 East Area vegetation-types, the maximum values all occurred in litter. Silver concentrations were the lone exception for each location. As indicated previously, the lead (1030 ppm), chromium $(180 \mathrm{ppm})$ and zinc $(1800 \mathrm{ppm})$ values are some of the highest reported for Hanford vegetation. As is indicated in the radionuclide summary (Section 8.1.6), the sites that were implicated were again No. 7 and No. 9.

Clean-up standards are based on soil concentrations in the State of Washington (Table 826) and most of the soil values reported were well below the Hanford and State background standards. However, lead $(28.9 \mathrm{ppm})$ and chromium $(40 \mathrm{ppm})$ concentrations collected in soils from site No. 9 again were somewhat elevated with regard to the background standards (Table 826) and may warrant further attention. Values for lead, chromium and zinc were highly variable depending on location in the $100 \mathrm{~K}$ Area. In contrast, these same constituents were very stable between 200 East Area locations.

Table 8-26. Summary of the Maximum Metals Values Reported for SNF Project Samples Comparisons are Provided to Hanford Site and Washington

State Background Values (ppm).

\begin{tabular}{|l|c|c|c|c|c|c|}
\hline Analytes & $\begin{array}{c}\text { Maximum } \\
100 \mathrm{~K} \\
\text { Cyyptogams }\end{array}$ & $\begin{array}{c}\text { Maximum } \\
200 \text { East } \\
\text { Litter }\end{array}$ & $\begin{array}{c}\text { Maximum } \\
100 \mathrm{~K} \\
\text { Soils }^{(\mathbf{a})}\end{array}$ & $\begin{array}{c}\text { Maximum } \\
200 \text { East } \\
\text { Soils }\end{array}$ & $\begin{array}{c}\text { Hanford Site } \\
\text { Soil } \\
\text { Background }^{(\mathrm{b})}\end{array}$ & $\begin{array}{c}\text { Washington } \\
\text { State Soil } \\
\text { Background }^{(\mathrm{c})}\end{array}$ \\
\hline Arsenic & 3.1 & 2.6 & 3.1 & 2.2 & 7.7 & 9.3 \\
\hline Barium & 64.0 & 79.0 & 71.0 & 79.0 & 149.3 & $\ldots$ \\
\hline Cadmium & 0.7 & 0.5 & 0.5 & 0.3 & 23.0 & 0.7 \\
\hline Lead & 1030 & 8.8 & 28.9 & 5.9 & 12.3 & 11.0 \\
\hline Mercury & 0.2 & 0.4 & $<0.3$ & $<0.2$ & 0.7 & 0.05 \\
\hline Chromium & 180.0 & 6.5 & 40.0 & 7.1 & 23.0 & 17.8 \\
\hline Copper & 19.0 & 19.0 & 17.0 & 9.3 & 25.2 & 21.6 \\
\hline Silver & $<0.2$ & 0.3 & 0.4 & $<0.2$ & 1.5 & $\ldots$ \\
\hline Zinc & 1800.0 & 38.0 & 73.0 & 37.0 & 71.6 & 78.7 \\
\hline
\end{tabular}

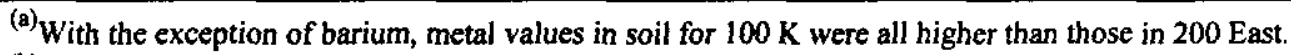

(b) DOE 1995.

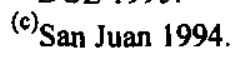




\subsection{SOIL CHEMISTRY}

In preoperational environmental surveys, soil chemistry data are useful for comparative purposes to note contrasts between disturbed and undisturbed sites, and as a screening method to note elevated values or other possible anomalies which could provide for the identification of loss of contaminant control.

It is generally recognized that among the factors affecting the mobility of the chemical constituents in soil that ion exchange and sorption/desorption are of prime importance (Bohn et al. 1979). Numerous authors (Rhoades and Bernstein 1971, Black 1965, Bower and Wilcox 1995) have demonstrated that the tremendous sorptive area of soils, coupled with high ion exchange capacities influence the fate of radionuclides, metals, pesticides, nutrient elements, and other inorganic solutes. Anion and cyanide analyses were requested for this study.

\subsubsection{Surface Soils}

8.3.1.1 100 K Area. Essentially no information is available for chemical constituents associated with anions in $100 \mathrm{~K}$ surface soils. The report developed by Landeen et al. (1993) concentrated on metals and did not include anion analyses. Table 8-27 provides a summary of the soil chemical data collected at $100 \mathrm{~K}$ Area. Site No. 9 had 5 of the 7 highest values reported.

Table 8-27. Chemical Data for $100 \mathrm{~K}$ Area Surface Soils (ppm).

\begin{tabular}{|c|c|c|c|c|c|c|c|c|c|c|}
\hline \multirow{2}{*}{$\begin{array}{c}\text { Sample } \\
\text { Site }\end{array}$} & Date & Sample No. & Medium & \multicolumn{6}{|c|}{ Analyte (ppm) } \\
\hline & & Chloride & Fluoride & Nitrate & Nitrite & Phosphate & Sulfate & Cyanide \\
\hline 5 & $05 / 18 / 1999$ & $59015-11$ & Soil & 0.9 & 0.7 & 4.6 & $<0.4$ & 3.6 & $<1.0$ & 0.0 \\
\hline 6 & $05 / 18 / 1999$ & $59015-15$ & Soll & 0.8 & 0.9 & 3.0 & 0.7 & 4.3 & 4.0 & 0.0 \\
\hline 7 & $05 / 19 / 1999$ & $59015-19$ & Soil & 0.9 & 1.0 & 1.7 & 0.6 & 4.1 & $<1.0$ & 0.0 \\
\hline 8 & $05 / 19 / 1999$ & $59015-23$ & Soil & 0.9 & 0.8 & 1.3 & $<0.4$ & 3.1 & $<1.0$ & 0.0 \\
\hline 9 & $05 / 19 / 1999$ & $59015-24$ & Soll & 0.9 & 0.8 & 1.8 & 0.7 & 3.7 & $<1.0$ & 0.0 \\
\hline 10 & $05 / 19 / 1999$ & $59015-25$ & Soll & 0.9 & 0.9 & 0.9 & 0.6 & 2.9 & $<1.0$ & 0.0 \\
\hline 8 & $11 / 04 / 1999$ & S0007-04 & Soil & 1.0 & 1.0 & 1.9 & 0.5 & 4.7 & 6.0 & $<0.3$ \\
\hline 11 & $11 / 04 / 1999$ & S0007-03 & Soll & 0.8 & 0.9 & 0.9 & 0.3 & 3.5 & 3.0 & $<0.3$ \\
\hline
\end{tabular}

8.3.1.2 200 East Area. Table 8-28 contains the summary of chemical data for the samples collected near the CSB. Site 1 again had a rather high number (4) of the maximum values reported for the four sampling locations. 
HNF-6150 Rev. 0

Table 8-28. Chemical Data for 200 East Area Surface Soils (ppm).

\begin{tabular}{|c|c|c|c|c|c|c|c|c|c|c|}
\hline \multirow{2}{*}{$\begin{array}{c}\text { Sample } \\
\text { Site }\end{array}$} & \multirow[b]{2}{*}{ Date } & \multirow[b]{2}{*}{ Sample No. } & \multirow[b]{2}{*}{ Medium } & \multicolumn{7}{|c|}{ Analyte (ppm) } \\
\hline & & & & Chloride & Fluoride & Nitrate & Nitrite & Phosphate & Sulfate & Cyanide \\
\hline 1 & $05 / 18 / 1999$ & 59015-01 & Soil & 0.8 & 0.8 & 3.1 & $<0.4$ & $<0.6$ & 4.0 & 0.0 \\
\hline 2 & $05 / 18 / 1999$ & 59015-04 & Soil & 0.7 & 0.7 & 3.4 & $<0.4$ & $<0.6$ & $<1.0$ & 0.0 \\
\hline 3 & $05 / 18 / 1999$ & $59015-07$ & Soil & 0.7 & $<0.1$ & 3.4 & $<0.4$ & $<0.5$ & $<1.0$ & 0.0 \\
\hline 4 & $05 / 18 / 1999$ & 59015-08 & Soil & 1 & 0.7 & 2.6 & $<0.4$ & 3.0 & $<1.0$ & 0.0 \\
\hline 1 & $11 / 04 / 1999$ & S0007-01 & Soll & 0.8 & 1.0 & 2.4 & 0.4 & 3.0 & 4.0 & 0.3 \\
\hline 2 & $11 / 04 / 1999$ & $50007-02$ & Soil & 0.5 & 0.1 & 2.0 & 0.4 & 2.9 & 3.0 & $<0.3$ \\
\hline
\end{tabular}

\subsubsection{Soil Chemistry Summary}

A comparison of the results of this study with those reported in previous studies conducted in the 200 Areas and the Hanford Site Soil Background (DOE 1995) levels is provided in Table 8-29. Cyanide values are not included, since they are generally zero and are not included in the Hanford Site soil background database.

It can be seen that, with the exception of nitrite, the results reported for this study are equal to or well below the values reported in other Hanford Site studies and the Hanford Site soil background.

Table 8-29. Summary of Reported Soil Chemistry Maximum Soil Values (ppm) for the SNF Study, Other 200 Area Studies and the Hanford Site Soil Background.

\begin{tabular}{|l|c|c|c|c|c|}
\hline Analytes & $\begin{array}{c}\text { SNF } \\
100 \mathrm{~K}\end{array}$ & $\begin{array}{c}\text { SNF } \\
200 \text { East }\end{array}$ & $\begin{array}{c}200 \mathrm{Area} \\
\text { SWOC }^{(\mathrm{a})(\mathrm{b})}\end{array}$ & $\begin{array}{c}200 \text { Area } \\
\text { W-314 }^{(\mathrm{c})}\end{array}$ & $\begin{array}{c}\text { Hanford Site } \\
\text { Soil } \\
\text { Background }^{(\mathrm{d})}\end{array}$ \\
\hline Chloride & 1.0 & 1.0 & 9.5 & 20.0 & 259.0 \\
\hline Flouride & 1.0 & 1.0 & 1.8 & 1.0 & 4.0 \\
\hline Nitrate & 4.6 & 3.4 & 7.7 & 31.5 & 115.9 \\
\hline Nitrite & 0.7 & 0.4 & 0.2 & 0.1 & (.. $^{(\mathrm{e})}$ \\
\hline Phosphate & 4.7 & 3.0 & 12.0 & 10.5 & 4.3 \\
\hline Sulfate & 6.0 & 4.0 & 13.4 & 28.6 & 585.0 \\
\hline
\end{tabular}

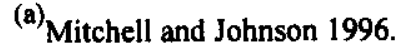

(b) SWOC = Solid Waste Operations Complex.

(c) Mitchell 1999.

(d) DOE 1995.

(e) Not reported.

\subsection{ORGANIC ANALYSES}

It was determined during the DQO process that the surface soil samples would be analyzed for pesticides and PCBs. This was due to reports that PCBs could potentially be a small 
HNF-6150 Rev. 0

component of some of the waste materials within the K basins (WHC 1995). None of the surface soil samples collected contained any detectable levels of pesticides, or PCBs. The complete analytical data packages for organic pesticides and PCBs are contained in Appendix C.

\subsection{QUALITY ASSURANCE/QUALITY CONTROL DATA SUMMARY}

As mentioned in Sections 5.4 and 6.4, follow-up sampling was conducted to provide for QA/QC comparisons, as well as to determine seasonal environmental variability in analytical results. Tables 8-30 through 8-34 provide a summary of the duplicate samples collected of soil and vegetation, as well as the sample blank, in the $100 \mathrm{~K}$ Area. Radionuclide, metal and chemical analyses were run on each sample collected. There were no anomalies reported in these data compared with the initial sample results. Site 7 continued to demonstrate elevated radionuclide values for ${ }^{90} \mathrm{Sr}$ and ${ }^{241} \mathrm{Pu}$.

Laboratory $\mathrm{QA} / \mathrm{QC}$ records are maintained by the analytical laboratory conducting the analyses. The WSCF laboratory has the records for all samples, with the exception of the mice, which were analyzed by the $222-S$ laboratory.

Table 8-30, Part A. Radionuclide Concentrations in Soil Samples (pCi/g).

\begin{tabular}{|c|c|c|c|c|c|c|c|c|c|c|c|c|c|}
\hline \multirow{2}{*}{$\begin{array}{c}\text { Sample } \\
\text { Site }\end{array}$} & \multirow[b]{2}{*}{ Date } & \multirow{2}{*}{$\begin{array}{c}\text { Sample } \\
\text { No. }\end{array}$} & \multirow{2}{*}{$\begin{array}{l}\text { Sample } \\
\text { Medium }\end{array}$} & \multicolumn{2}{|c|}{ Co-60 } & \multicolumn{2}{|c|}{ Sr-90 } & \multicolumn{2}{|c|}{ Cs-137 } & \multicolumn{2}{|c|}{ Pu-239/240 } & \multicolumn{2}{|c|}{$P_{U-241}$} \\
\hline & & & & Result & Error & Result & Error & Result & Error & Result & Error & Result & Error \\
\hline 7 & $02 / 24 / 2000$ & KON4V7 & Soil & 6.5E-03 & $\pm 100 \%$ & $1.1 E+00$ & $30 \%$ & $4.4 \mathrm{E}-02$ & $\pm 32 \%$ & $7.1 \mathrm{E}-03$ & $\pm 250 \%$ & $1.5 \mathrm{E}+00$ & $\pm 30 \%$ \\
\hline 7 (dup) & $02 / 24 / 2000$ & KON4V8 & Soil & $-2.8 E-03$ & $\pm 206 \%$ & $6.9 \mathrm{E}-01$ & $\pm 40 \%$ & $5.9 \mathrm{E}-02$ & $\pm 25 \%$ & $7.3 \mathrm{E}-03$ & $\pm 280 \%$ & $5.0 \mathrm{E}-01$ & $\pm 30 \%$ \\
\hline 11 (blank) & $02 / 24 / 2000$ & KON4V9 & Soil & $-5.2 E-04$ & $\pm 519 \%$ & $7.5 E-01$ & $\pm \quad 45 \%$ & $4.0 \mathrm{E}-03$ & $\pm 95 \%$ & $1.9 \mathrm{E}-02$ & $\pm 110 \%$ & $6.0 \mathrm{E}-01$ & $\pm 30 \%$ \\
\hline
\end{tabular}

Table 8-30, Part B. Radionuclide Concentrations in Soil Samples (pCi/g).

\begin{tabular}{|c|c|c|c|c|c|c|c|c|c|c|c|}
\hline \multirow{2}{*}{$\begin{array}{c}\text { Sample } \\
\text { Site }\end{array}$} & \multirow[b]{2}{*}{ Date } & \multirow{2}{*}{$\begin{array}{c}\text { Sample } \\
\text { No. }\end{array}$} & \multirow{2}{*}{$\begin{array}{l}\text { Sample } \\
\text { Medium }\end{array}$} & \multicolumn{2}{|c|}{ U-234 } & \multicolumn{2}{|c|}{ U-235 } & \multicolumn{2}{|c|}{$U-238$} & \multicolumn{2}{|c|}{$A m-241$} \\
\hline & & & & Result & Error & Result & Error & Result & Error & lesult & Error \\
\hline 7 & $/ 24 / 2000$ & KON4V7 & Soil & -01 & $\pm 36 \%$ & 2.7E-02 & $63 \%$ & 2.2E-01 & $36 \%$ & $\mathrm{E}-02$ & \\
\hline & & & & & $\pm 36 \%$ & & $\pm \quad 130 \%$ & -01 & $36 \%$ & $7.1 \mathrm{E}-02$ & \\
\hline ank & $02 / 24 / 2000$ & $4 \sqrt{9}$ & Soil & $3.8 \mathrm{E}-02$ & $\pm 56 \%$ & $6.8 E-03$ & $\pm 150 \%$ & 1.5E-02 & $\pm 110 \%$ & $6.5 \mathrm{E}-02$ & \pm 56 \\
\hline
\end{tabular}

Table 8-31, Part A. Radionuclide Concentrations Reported for Vegetation (pCi/g).

\begin{tabular}{|c|c|c|c|c|c|c|c|c|c|c|c|c|c|}
\hline \multirow{2}{*}{$\begin{array}{c}\text { Sample } \\
\text { Site }\end{array}$} & \multirow[b]{2}{*}{ Date } & \multirow{2}{*}{$\begin{array}{c}\text { Sample } \\
\text { No. }\end{array}$} & \multirow{2}{*}{$\begin{array}{l}\text { Sample } \\
\text { Medium }\end{array}$} & \multicolumn{2}{|c|}{$\mathrm{C} 0-60$} & \multicolumn{2}{|c|}{ Sr-90 } & \multicolumn{2}{|c|}{$C_{s-137}$} & \multicolumn{2}{|c|}{$P_{u-239 / 240}$} & \multicolumn{2}{|c|}{ Pu-241 } \\
\hline & & & & Result & Error & Result & Error & Result & Error & Result & Error & Result & Error \\
\hline 5 & $02 / 24 / 2000$ & KON4V5 & vegetation & $-1.9 E-03$ & $\pm 818 \%$ & 4.1E-01 & $\pm \quad 35 \%$ & $1.3 E-02$ & $\pm 145 \%$ & $1.8 \mathrm{E}-03$ & $\pm 100 \%$ & $3.0 E-01$ & $\pm 30 \%$ \\
\hline 5(dup) & $02 / 24 / 2000$ & KON4V6 & vegetation & $1.3 E-02$ & $\pm 215 \%$ & 2.0E-01 & $\pm 65 \%$ & $6.3 \mathrm{E}-03$ & $\pm 417 \%$ & $1.9 \mathrm{E}-03$ & $\pm 350 \%$ & $8.5 \mathrm{E}-02$ & $\pm 30 \%$ \\
\hline
\end{tabular}


Table 8-31, Part B. Radionuclide Concentrations Reported for Vegetation (pCi/g).

\begin{tabular}{|c|c|c|c|c|c|c|c|c|c|c|c|}
\hline \multirow{2}{*}{$\begin{array}{c}\text { Sample } \\
\text { Site }\end{array}$} & \multirow[b]{2}{*}{ Date } & \multirow{2}{*}{$\begin{array}{c}\text { Sample } \\
\text { No. }\end{array}$} & \multirow{2}{*}{$\begin{array}{l}\text { Sample } \\
\text { Medium }\end{array}$} & \multicolumn{2}{|c|}{$\mathrm{U}-234$} & \multicolumn{2}{|c|}{ U-235 } & \multicolumn{2}{|c|}{$U-238$} & \multicolumn{2}{|c|}{ Am-241 } \\
\hline & & & & Result & Error & Result & Error & Result & Error & Result & Error \\
\hline 5 & $02 / 24 / 2000$ & KON4V5 & vegetation & $1.9 \mathrm{E}-02$ & $\pm 55 \%$ & $5.9 \mathrm{E}-03$ & $87 \%$ & $1.2 \mathrm{E}-02$ & $\pm 63 \%$ & $4.4 \mathrm{E}-02$ & $\pm \quad 52 \%$ \\
\hline 5(dup) & $02 / 24 / 2000$ & KON4V6 & vegetation & $1.4 \mathrm{E}-02$ & $\pm 60 \%$ & $3.0 \mathrm{E}-03$ & $\pm 120 \%$ & $1.4 \mathrm{E}-02$ & $\pm 60 \%$ & $1.5 \mathrm{E}-02$ & $\pm 120 \%$ \\
\hline
\end{tabular}

Table 8-32. Metals Concentrations in Soils (ppm).

\begin{tabular}{|c|c|c|c|c|c|c|c|c|c|c|c|c|}
\hline \multirow{2}{*}{\begin{tabular}{|c|} 
Sample \\
Site
\end{tabular}} & \multirow[b]{2}{*}{ Date } & \multirow{2}{*}{$\begin{array}{c}\text { Sample } \\
\text { No. }\end{array}$} & \multirow{2}{*}{$\begin{array}{l}\text { Sample } \\
\text { Medium }\end{array}$} & \multicolumn{9}{|c|}{ Analyte (ppm) } \\
\hline & & & & Arsenic & Barium & Cadmium & Lead & Mercury & Chromium & Copper & Silver & Zinc \\
\hline 7 & $02 / 24 / 2000$ & KON4V7 & Soil & 1.5 & 57.0 & 0.1 & 4.0 & $<0.0$ & 10.0 & 9.8 & $<0.1$ & 30.0 \\
\hline 7(dup) & $02 / 24 / 2000$ & KON4V8 & Soil & 1.6 & 61.0 & 0.1 & 3.7 & $<0.0$ & 7.7 & 9.3 & $<0.1$ & 29.0 \\
\hline 11(blank) & $02 / 24 / 2000$ & KON4V9 & Soil & $<0.1$ & 0.1 & $<0.1$ & $<0.6$ & $<0.1$ & $<0.6$ & $<0.4$ & $<0.1$ & $<0.7$ \\
\hline
\end{tabular}

Table 8-33. Metals Concentrations in Vegetation (ppm).

\begin{tabular}{|c|c|c|c|c|c|c|c|c|c|c|c|c|}
\hline \multirow{2}{*}{$\begin{array}{c}\text { Sample } \\
\text { Site }\end{array}$} & \multirow[b]{2}{*}{ Date } & \multirow{2}{*}{$\begin{array}{c}\text { Sample } \\
\text { No. }\end{array}$} & \multirow{2}{*}{$\begin{array}{l}\text { Sample } \\
\text { Medium }\end{array}$} & \multicolumn{9}{|c|}{ Analyte (ppm) } \\
\hline & & & & Arsenic & Barium & Cadmium & Lead & Mercury & Chromium & Copper & Silver & Zinc \\
\hline 5 & $02 / 24 / 2000$ & KON4V5 & vegetation & 0.1 & 3.6 & $<0.1$ & $<0.6$ & $<0.0$ & 1.5 & 4.1 & $<0.1$ & 18.0 \\
\hline 5 (dup) & $02 / 24 / 2000$ & KON4V6 & vegetation & $<0.1$ & 3.0 & $<0.1$ & $<0.6$ & $<0.1$ & 1.5 & 5.1 & $<0.1$ & 23.0 \\
\hline
\end{tabular}

Table 8-34. Chemical Concentrations in Soils (ppm).

\begin{tabular}{|c|c|c|c|c|c|c|c|c|c|c|}
\hline $\begin{array}{c}\text { Sample } \\
\text { Site }\end{array}$ & Date & $\begin{array}{c}\text { Sample } \\
\text { No. }\end{array}$ & Medium & Chloride & Fluoride & Nitrate & Nitrite & Phosphate & Sulfate & Cyanide \\
\hline 7 & $02 / 24 / 2000$ & KON4V7 & Soil & 0.3 & 0.1 & 1.0 & 0.2 & 1.0 & 3.0 & $<0.3$ \\
\hline 7 (dup) & $02 / 24 / 2000$ & KON4V8 & Soil & 0.3 & 0.1 & 0.9 & 0.2 & 1.0 & 3.0 & $<0.3$ \\
\hline 11 (blank) & $02 / 24 / 2000$ & KON4V9 & Soil & 2.3 & 0.1 & 0.4 & 0.2 & 0.6 & 4.0 & $<0.3$ \\
\hline
\end{tabular}




\subsection{WASHINGTON STATE DEPARTMENT OF HEALTH SAMPLING DATA}

During the sampling episodes, personnel from the WDOH collected split soil and vegetation (sagebrush) samples from Sites 2, 4, 5 and 6 on May 18, 1999. During the follow-up sampling conducted on November 4, 1999, they collected a soil sample from Site 1 and a vegetation sample from Site 9. These samples satisfied the WDOH requirement for collecting independent samples for verification of the preoperational study results. The results were also utilized in this study as the "split" samples for inter-laboratory comparisons. The WDOH samples were analyzed for radionuclides and the results for the soils are summarized in Table 8-35 and the vegetation results in Table 8-36.

For a comparison of the WDOH soil data with the soil data provided by this study see Tables 8-1 and 8-2. The results provided by both laboratories are comparable for ${ }^{60} \mathrm{Co},{ }^{137} \mathrm{Cs}$, ${ }^{239 / 240} \mathrm{Pu}$ and the uranium isotopes $\left({ }^{234} \mathrm{U},{ }^{238} \mathrm{U}\right)$. The WSCF laboratories reported consistently higher results for ${ }^{90} \mathrm{Sr}$ and ${ }^{241} \mathrm{Am}$; approximately an order of magnitude. This is a favorable finding, since this study has consistently reported the maximum concentrations observed.

With regard to the vegetation samples (See Tables 8-3 and 8-4) the results are again comparable for ${ }^{60} \mathrm{Co}$ and the uranium isotopes reported. The WDOH laboratory did report two slightly higher values for ${ }^{137} \mathrm{Cs}$ for samples collected at Sites 4 and 5 . However, since both results were reported at concentrations of $0.02 \mathrm{pCi} / \mathrm{g}$, the slight differences probably represent expected laboratory variation. The overall set of results represents acceptable levels of correlation between the radionuclide results provided by the separate laboratories. 
HNF-6150 Rev. 0

Table 8-35, Part A. WDOH Radionuclide Data for Collocated Soil Samples.

\begin{tabular}{|c|c|c|c|c|c|c|c|c|c|c|}
\hline \multirow{2}{*}{$\begin{array}{l}\text { Sample } \\
\text { Site }\end{array}$} & \multirow{2}{*}{ Date } & \multirow{2}{*}{$\begin{array}{l}\text { Sample } \\
\text { Medium }\end{array}$} & \multicolumn{2}{|c|}{$\mathrm{Co}-60$} & \multicolumn{2}{|c|}{ Sr-90 } & \multicolumn{2}{|c|}{ Cs-137 } & \multicolumn{2}{|c|}{ Pu-239/240 } \\
\hline & & & Result & Error & Result & Error & Result & Error & Result & Error \\
\hline 2 & $05 / 18 / 1999$ & Soil & $5.0 \mathrm{E}-03$ & $\pm 6.0 \mathrm{E}-03$ & $7.3 \mathrm{E}-02$ & $\pm 8.0 \mathrm{E}-03$ & $3.3 \mathrm{E}-01$ & $\pm 3.0 \mathrm{E}-02$ & 0 & $\pm 4.0 \mathrm{E}-03$ \\
\hline 4 & $05 / 18 / 1999$ & Soil & $6.0 \mathrm{E}-03$ & $\pm 6.0 \mathrm{E}-03$ & $4.0 \mathrm{E}-02$ & $\pm 6.0 \mathrm{E}-03$ & $3.5 \mathrm{E}-01$ & $\pm 3.0 \mathrm{E}-02$ & $6.2 \mathrm{E}-03$ & $\pm 3.5 \mathrm{E}-03$ \\
\hline 5 & $05 / 18 / 1999$ & Soil & $-5.0 \mathrm{E}-03$ & $\pm 8.0 \mathrm{E}-03$ & $3.4 \mathrm{E}-02$ & $\pm 6.0 \mathrm{E}-03$ & $1.9 \mathrm{E}-01$ & $\pm 2.0 \mathrm{E}-02$ & $2.0 \mathrm{E}-03$ & $\pm 3.0 \mathrm{E}-03$ \\
\hline 6 & $05 / 18 / 1999$ & Soil & 0 & $\pm 5.0 \mathrm{E}-03$ & $1.9 \mathrm{E}-02$ & $\pm 5.0 \mathrm{E}-03$ & $2.0 \mathrm{E}-01$ & $\pm 1.0 \mathrm{E}-02$ & $3.0 \mathrm{E}-03$ & $\pm 3.0 \mathrm{E}-03$ \\
\hline 1 & $11 / 04 / 1999$ & Soil & $3.3 \mathrm{E}-03$ & $\pm 7.6 \mathrm{E}-03$ & $\mathrm{NA}^{*}$ & -- & $4.4 \mathrm{E}-01$ & $\pm 3.0 \mathrm{E}-02$ & $1.5 \mathrm{E}-02$ & $\pm 4.0 \mathrm{E}-03$ \\
\hline
\end{tabular}

NA = not analyzed

Table 8-35, Part B. WDOH Radionuclide Data for Collocated Soil Samples.

\begin{tabular}{|c|l|l|l|l|c|c|c|c|}
\hline \multirow{2}{*}{$\begin{array}{l}\text { Sample } \\
\text { Site }\end{array}$} & \multirow{2}{*}{ Date } & \multirow{2}{*}{$\begin{array}{l}\text { Sample } \\
\text { Medium }\end{array}$} & & \multicolumn{2}{|c|}{ U-234 } & \multicolumn{2}{c|}{ U-238 } & \multicolumn{2}{c|}{ Am-241 } \\
\cline { 4 - 9 } & & Result & Error & Result & Error & Result & Error \\
\hline 2 & $05 / 18 / 1999$ & Soil & $6.5 \mathrm{E}-01$ & $\pm 1.2 \mathrm{E}-01$ & $6.0 \mathrm{E}-01$ & $\pm 1.0 \mathrm{E}-01$ & $1.0 \mathrm{E}-03$ & $\pm 2.0 \mathrm{E}-03$ \\
\hline 4 & $05 / 18 / 1999$ & Soil & $7.2 \mathrm{E}-01$ & $\pm 9.0 \mathrm{E}-02$ & $5.0 \mathrm{E}-01$ & $\pm 8.0 \mathrm{E}-02$ & $1.0 \mathrm{E}-03$ & $\pm 2.0 \mathrm{E}-03$ \\
\hline 5 & $05 / 18 / 1999$ & Soil & $5.6 \mathrm{E}-01$ & $\pm 1.2 \mathrm{E}-01$ & $5.7 \mathrm{E}-01$ & $\pm 1.1 \mathrm{E}-01$ & $2.0 \mathrm{E}-03$ & $\pm 3.0 \mathrm{E}-03$ \\
\hline 6 & $05 / 18 / 1999$ & Soil & $6.4 \mathrm{E}-01$ & $\pm 8.0 \mathrm{E}-02$ & $4.7 \mathrm{E}-01$ & $\pm 7.0 \mathrm{E}-02$ & $1.0 \mathrm{E}-03$ & $\pm 2.0 \mathrm{E}-03$ \\
\hline 1 & $11 / 04 / 1999$ & Soil & $6.3 \mathrm{E}-01$ & $\pm 1.3 \mathrm{E}-01$ & $8.0 \mathrm{E}-01$ & $\pm 1.3 \mathrm{E}-01$ & $3.5 \mathrm{E}-03$ & $\pm 4.8 \mathrm{E}-03$ \\
\hline
\end{tabular}

Table 8-36. WDOH Radionuclide Data for Collocated Vegetation Samples.

\begin{tabular}{|c|c|c|c|c|c|c|c|c|c|c|c|c|}
\hline \multirow{2}{*}{$\begin{array}{l}\text { Sample } \\
\text { Site }\end{array}$} & \multirow{2}{*}{ Date } & \multirow{2}{*}{$\begin{array}{l}\text { Sample } \\
\text { Medium }\end{array}$} & \multicolumn{2}{|c|}{$\mathrm{C} 0-60$} & \multicolumn{2}{|c|}{ Cs- 137} & \multicolumn{2}{|c|}{$\mathrm{Pu}-239 / 240$} & \multicolumn{2}{|c|}{ U-234 } & \multicolumn{2}{|c|}{ U-238 } \\
\hline & & & Result & Error & Result & Error & Result & Етог & Result & Error & Result & Error \\
\hline 2 & $05 / 18 / 1999$ & Vegetation & $2.0 \mathrm{E}-03$ & $\pm 1.3 \mathrm{E}-02$ & $3.0 \mathrm{E}-04$ & $\pm 1.4 \mathrm{E}-02$ & $\mathrm{NA}^{*}$ & - & $5.0 \mathrm{E}-03$ & $\pm 5.0 \mathrm{E}-03$ & $7.0 \mathrm{E}-03$ & $\pm 5.0 \mathrm{E}-03$ \\
\hline 4 & $05 / 18 / 1999$ & Vegetation & $-1.2 \mathrm{E}-02$ & $\pm 9.0 \mathrm{E}-03$ & $2.0 \mathrm{E}-02$ & $\pm 1.0 \mathrm{E}-02$ & NA & -- & $-6.0 \mathrm{E}-03$ & $\pm 4.0 \mathrm{E}-03$ & $7.0 \mathrm{E}-03$ & $\pm 4.0 \mathrm{E}-03$ \\
\hline 5 & $05 / 18 / 1999$ & Vegetation & $-8.0 \mathrm{E}-03$ & $\pm 1.3 \mathrm{E}-02$ & $1.9 \mathrm{E}-02$ & $\pm 1.4 \mathrm{E}-02$ & NA & - & $-9.0 \mathrm{E}-04$ & $\pm 3.3 \mathrm{E}-04$ & $1.0 \mathrm{E}-03$ & $\pm 4.3 \mathrm{E}-03$ \\
\hline 6 & $05 / 18 / 1999$ & Vegetation & $7.0 \mathrm{E}-03$ & $\pm 1.3 \mathrm{E}-02$ & $9.0 \mathrm{E}-04$ & $\pm 1.3 \mathrm{E}-02$ & $\mathrm{NA}$ & $\ldots$ & $-0.7 \mathrm{E}-04$ & $\pm 4.2 \mathrm{E}-03$ & $1.5 \mathrm{E}-03$ & $\pm 2.4 \mathrm{E}-03$ \\
\hline 9 & $11 / 04 / 1999$ & Vegetation & $-1.1 \mathrm{E}-02$ & $\pm 1.8 \mathrm{E}-02$ & $1.5 \mathrm{E}-02$ & $\pm 1.6 \mathrm{E}-02$ & $9.0 \mathrm{E}-04$ & $\pm 1.9 \mathrm{E}-03$ & NA & - & NA & 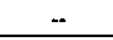 \\
\hline
\end{tabular}

NA $=$ not aralyzed. 


\subsection{CONCLUSIONS}

The sampling data and corresponding information that have been developed from this preoperational environmental survey have been evaluated. The values reported for radionuclides in $100 \mathrm{~K}$ and 200 East Areas have been below the accessible soil concentration limits developed for use at the Hanford Site (Perkins et al. 1998). Radionuclide soil concentration limits were established to ensure that effective dose equivalent to the public does not exceed the established limits for any reasonable scenario (such as direct exposure, inadvertent ingestion, inhalation, and ingestion of food crops, including animal products). The concentration limits apply to the Hanford Site with respect to onsite disposal operations, stabilization and cleanup, decontamination and decommissioning operations (Perkins et al. 1998). Therefore, although the samples collected were not exhaustive, they do provide a reasonable representation of the general environmental quality in, and around, the CVDF at $100 \mathrm{~K}$ Area and the CSB in 200 East Area.

All of the air sampling data reported to date indicates that all radionuclides are consistently below the DCGs. In $100 \mathrm{~K}$ Area, with the exception of ${ }^{241} \mathrm{Am}$, all of the radionuclides analyzed are below analytical detection levels or only infrequently detected. While in the 200 East Area, only ${ }^{241} \mathrm{Am}$ and the Uranium isotopes are consistently detected with ${ }^{90} \mathrm{Sr}$ and ${ }^{239 / 240} \mathrm{Pu}$ detected about $70 \%$ of the time. Again, all values reported were well below the DCGs.

The TLDs located at both the CVDF in $100 \mathrm{~K}$ Area and CSB in the 200 East Area indicate levels of external radiation concomitant with surrounding dosimeter locations.

In addition to radionuclide concentrations, the values reported for chemical constituents such as organics (PCBs and pesticides), anions and metals in soils have been generally at, or below, laboratory detection limits (PCBs and pesticides). When these levels have been detectable in metals and ions in soils, they have been within Hanford Site (DOE1995) or Washington State (San Juan 1994) soil background threshold values.

Based on the data analyses, some trends became apparent. With the exception of cryptogams, average values reported for ${ }^{241} \mathrm{Pu}$ were an order of magnitude higher in soils, vegetation and litter sampled from 200 East. The vegetation samples exhibited higher average values for ${ }^{90} \mathrm{Sr}$ (order of magnitude) and ${ }^{239 / 240} \mathrm{Pu}$ (two orders of magnitude) in 200 East Area. Sample Sites 7 and 9 located in the $100 \mathrm{~K}$ Area had 9 of the 12 highest radionuclide values reported for all media (Table 8-11). Six of the high values occurred at Site 7 and three at Site 9.

The trends seen in the metals data were less distinctive. The metals concentrations reported for all media from the 200 East Area were all below the background thresholds and very similar within each medium. However, while metals values reported for $100 \mathrm{~K}$ Area vegetation, litter and mice were all below threshold values, the concentrations of lead, chromium and zinc observed in $100 \mathrm{~K}$ Area soils and cryptogams were extremely variable. Lead and chromium concentrations in soils at Site 9 and chromium at Site 5 were above the Hanford Site and Washington State threshold levels. Cryptogam samples collected at Site 7 exhibited elevated lead and chromium concentrations and Site 9 had elevated zinc levels. These are some of the highest levels reported for vegetation at the Hanford Site. While these locations may warrant further 
HNF-6150 Rev. 0

attention in the future, none of the concentrations reported exceeded any of the state clean-up standards.

Based on the results of the field characterization efforts and analytical data, some general conclusions can be made regarding the SNF Project facilities. The data collected represent a good "snapshot" of conditions where the probability of contamination might be expected. However, sampling methods by their very design do not provide detailed information on every aspect of the proposed projects. Unanticipated field conditions during operations can occur and should probably be expected within the 100 and 200 Areas, where 50 years of waste operations activities, changing environmental conditions, and current cleanup operations affect these sites on a regular basis. The conclusions which can be made from this preoperational survey include the following:

- While there were no definitive trends from the radionuclide concentrations in the various media and between the areas, there were two $100 \mathrm{~K}$ sample locations ( 7 and 9) that demonstrated a high number at the maximum values reported.

- Metals concentrations were generally higher and more variable in the $100 \mathrm{~K}$ Area than the 200 East Area. Sites 7 and 9 again demonstrated a number of the highest levels reported.

- The above observations can possibly be explained by past and on-going cleanup activities that are impacting the site and a "laminated impact" effect which could result in long-term buildup of contaminants in environmental "sinks," e.g., soils and cryptogams.

- Data from a single sample, which indicates a lack of contamination at, or near, a facility, should not be construed to mean that the site is entirely free of contamination.

- The sample location represents only a single reference point around/near any particular facility and may not represent all the environmental conditions which are extant. This should be kept in mind during operations and eventual cleanup.

- Comprehensive health and safety guidelines should be delineated for workers involved in operational activities.

- Any of the above conclusions can be obviated by anomalous conditions not encountered during the characterization study, by ongoing or new construction or operational activities which may impact the proposed locations, and by constantly changing environmental conditions which could affect the movement of contaminants away from the waste sites during the period from finalization of this characterization effort to project completion.

Based on the findings of this preoperational environmental survey, and in conjunction with the existing Near-Facility Monitoring network, sufficient data have been obtained to establish an adequate environmental baseline, to determine the extent of potential impacts from 


\section{HNF-6150 Rev. 0}

this facility and neighboring facilities and operations, and for making decisions pertaining to future cleanup of these facilities. 


\subsection{REFERENCES}

CFR 834, 1998, "Radiological Protection of the Public and the Environment," Code of Federal Regulations, as amended.

10 CFR 834, 1998, "Radiological Protection of the Public and the Environment," Code of Federal Regulations, as amended.

Adriano, D. C., 1986, Trace Elements in the Terrestrial Environment, Springer-Verlag, New York, New York.

Black, C. A. (ed), 1965, Methods of Soil Analyses, Agronomy No. 9, American Society of Agronomy, Madison, Wisconsin.

Bohn, H. L., B. L. McNeal, and G. A. O'Conner, 1979, Soil Chemistry, Wiley Interscience, New York, New York.

Bower, C. A., and L. V. Wilcox, 1965, "Soluble Salts," Methods of Soil Analyses, C. A. Black (ed), Agronomy No. 9, 933-951, American Society of Agronomy, Madison, Wisconsin.

Brandt, C. A., and W. H. Rickard, 1992, Metals Concentration in Vegetation of the 300-FF-I Operable Unit and Vicinity, WHC-SD-EN-TI-026, Rev. 0, Westinghouse Hanford Company, Richland, Washington.

Chatters, J. C. and N. A. Cadoret, 1990, Archaeological Survey of the 200-East Area 200-West Area, Hanford Site, Washington, PNL-7264, Pacific Northwest Laboratory, Richland, Washington.

Connelly, M. P., B. H. Ford, J. W. Lindberg, S. J. Trent, C. D. Delaney, and J. V. Borghese, 1992, Hydrogeologic Model for the 200 East Groundwater Aggregate Area, WHC-SD-EN-TI019, Westinghouse Hanford Company, Richland, Washington.

DOE, 1981, Environmental Protection, Safety, and Health Protection Information Reporting Requirements, DOE Order 5484.1, U.S. Department of Energy, Washington, D.C.

DOE, 1988a, General Environmental Protection Program, DOE Order 5400.1, U.S. Department of Energy, Washington, D.C.

DOE, 1988b, Radioactive Waste Management, DOE Order 5820.2A, U.S. Department of Energy, Washington, D.C.

DOE, 1990a, Radiation Protection of the Public and the Environment, DOE Order 5400.5, U.S. Department of Energy, Washington, D.C. 
DOE, 1990b, Low Level Waste Management Handbook Series: Environmental Monitoring for Low Level Waste Disposal Sites, DOE-LLW-13Tg, Rev. 2, Washington, D.C.

DOE, 1991, Environmental Regulatory Guide for Radiological Effluent Monitoring and Environmental Surveillance, DOE/EH-0173T, U.S. Department of Energy, Washington, D.C.

DOE, 1995, Hanford Site Background: Part 1, Soil Background for Nonradioactive Analytes, DOE/RL-92-24, Rev. 3, U.S. Department of Energy Richland Field Office, Richland, Washington.

DOE, 1996, Hanford Site Background: Part 2, Soil Background for Radionuclides, DOE/RL-96-12, Rev. 0, U.S. Department of Energy Richland Field Office, Richland, Washington.

EPA, 1986, Test Methods for Evaluating Solid Waste, SW-846, $3^{\text {rd }}$ Edition, EPA/Office of Solid Waste and Emergency Response, U.S. Environmental Protection Agency, Washington, D.C.

ES-SSPM-001, Sampling Services Procedures Manual, SP 2-1, "Bottle Preservation," Waste Management Technical Services, Richland, Washington.

Fitzner, R. E., S. G. Weiss, and J. A. Stegen, 1992, Biological Assessment for Threatened and Endangered Wildlife Species, Related to CERCLA Characterization Activities, WHC-EP-0513, Westinghouse Hanford Company, Richland, Washington.

HNF-EP-0538-5, Near-Facility Environmental Monitoring Quality Assurance Project Plan, Waste Management Technical Services, Richland, Washington.

Houston, J. R. and P. J. Blumer, 1979a, Environmental Surveillance at Hanford for Calendar Year 1978, PNL-2932, Battelle, Pacific Northwest Laboratory, Richland, Washington.

Houston, J. R. and P. J. Blumer, 1979b, Environmental Status of the Hanford Site for Calendar Year 1978, PNL-2933, Battelle, Pacific Northwest Laboratory, Richland, Washington.

Houston, J. R. and P. J. Blumer, 1978, Environmental Status of the Hanford Site for Calendar Year 1977, PNL-2677, Battelle, Pacific Northwest Laboratory, Richland, Washington.

Johnson, A. R. and R. M. Mitchell, 1996, Preoperational Environmental Survey Report: 200 Areas Cross-Site Transfer Line Replacement (W-058), WHC-SD-W058-RPT-001, Westinghouse Hanford Company, Richland, Washington.

Johnson, A. R., B. M. Markes, J. W. Schmidt, A. N. Shah. S. G. Weiss, and K. J. Wilson, 1994, Historical Record of Radioactive Contamination in Biota at the 200 Area of the Hanford Site, WHC-MR-0418, Westinghouse Hanford Company, Richland, Washington. 
Johnson, V. G., 1991, Contaminant Storage and Mixing in Bed Sediment of the Lower Columbia River and Estuary, Supplement to EOS, Transactions, American Geophysical Union, Vol. 72, No. 44.

Landeen, D. S., A. R. Johnson, and R. M. Mitchell, 1992, Status of Birds at the Hanford Site in Southeastern Washington, WHC-EP-0402, Rev. 1, Westinghouse Hanford Company, Richland, Washington.

Landeen, D. S., A. R. Johnson, and R. M. Mitchell, 1994, Comparison of Radionuclide Levels in Soil, Sagebrush, Plant Litter, Cryptogams, and Small Mammals, WHC-EP-0771, Westinghouse Hanford Company, Richland, Washington.

Landeen, D. S., M. R. Sackschewsky, S. G. Weiss, 1993, 100 Areas CERCLA Ecological Investigations, WHC-EP-0620, Westinghouse Hanford Company, Richland, Washington.

Maclean, A. J., 1974, "Efforts of Soil Properties and Amendments of Availability of Zinc in Soils," Canadian Journal of Soil Science, 54:364-378.

McKinney, S. M., 1999, Near-Facility Environmental Monitoring Quality Assurance Project Plan, HNF-EP-0538-4, Fluor Daniel Hanford, Inc., Richland, Washington.

Miller, M. L., J. J. Fix and P. E. Bramson, 1977, Radiochemical Analysis of Soil and Vegetation Samples Taken from the Hanford Environs, 1971-1976, BNWL-2249, Battelle Northwest Laboratories, Richland, Washington.

Mitchell, R. M., 1995, Preoperational Environmental Baseline Survey Conducted at the Environmental Restoration Disposal Facility (ERDF), BHI-00172, Rev. 00, Bechtel Hanford, Inc., Richland, Washington.

Mitchell, R. M., 1999, Preoperational Environmental Survey of the Project W-314 Pipeline, HNF-4401, Fluor Daniel Hanford, Inc., Richland, Washington.

Mitchell, R. M., and A. R. Johnson, 1996, Preoperational/Operational Environmental Survey Report: Solid Waste Operations Complex, WHC-SD-WM-TI-778, Westinghouse Hanford Company, Richland, Washington.

Mitchell, R. M., B. M. Markes, and C. J. Perkins, 1999, Sampling and Analysis Plan for the Preoperational Environmental Survey of the Spent Nuclear Fuels Project Facilities, HNFSD-SF-AP-003, Rev. 0, Fluor Daniel Hanford, Inc., Richland, Washington.

Mitchell, R. M., and S. G. Weiss, 1994, Ecological Sampling at Four Waste Sites in the 200 Areas, BHI-00032, Rev 00, Bechtel Hanford, Inc., Richland, Washington.

Neitzel, D. A., 1999, Hanford Site National Environmental Policy Act (NEPA) Characterization, PNL-6415, Rev 11, Pacific Northwest National Laboratory, Richland, Washington. 
Panesko, J. V., G. H. Carbough, D. J. Carrell, R. L. Dirkes, R. L. Laughman, H. L. Maxfield, and R. E. Wheeler, 1977, Environmental Protection Annual Report Calendar Year 1976, ARH-LD-154, Atlantic Richfield Hanford Company, Richland, Washington.

Panesko, J. V., R. L. Dirkes, K. Kover, and R. E. Wheeler, 1978, Environmental Protection Annual Report Calendar Year 1977, RHO-LD-78-75, Rockwell Hanford Operations, Richland, Washington.

Perkins, C. J., 1992, Westinghouse Hanford Company Environmental Surveillance Annual Report - 100 Areas CY 1990, WHC-EP-0258-2, Westinghouse Hanford Company, Richland, Washington.

Perkins, C. J., 1991, Westinghouse Hanford Company Environmental Surveillance Annual Report-100 Areas CY 1989, WHC-EP-0258-1, Westinghouse Hanford Company, Richland, Washington.

Perkins, C. J., 1990, Westinghouse Hanford Company Environmental Surveillance Annual Report-100 Areas CY 1988, WHC-EP-0258, Westinghouse Hanford Company, Richland, Washington.

Perkins, C. J., 1988, Westinghouse Hanford Company Environmental Surveillance Annual Report-100 Areas, Calendar Year 1987, WHC-EP-0161, Westinghouse Hanford Company, Richland, Washington.

Perkins, C. J., A. R. Johnson, B. M. Markes, S. M. McKinney, R. M. Mitchell and R. C. Roos, 1999, Hanford Site Near-Facility Environmental Monitoring Data Report, Calendar Year 1998, PNNL-12088, Appendix 2, Waste Management Technical Services for Fluor Daniel Hanford, Inc., Richland, Washington.

Perkins, C. J., A. R. Johnson, B. M. Markes, S. M. McKinney, and R. M. Mitchell, 1998, Hanford Site Near-Facility Environmental Monitoring Annual Report, Calendar Year 1997, HNF-EP-0573-6, Waste Management Federal Services, Inc., Northwest Operations for Fluor Daniel Hanford, Inc., Richland, Washington.

Perkins, C. J., A. R. Johnson, B. M. Markes, S. M. McKinney, and R. M. Mitchell, 1997, Hanford Site Near-Facility Environmental Monitoring Annual Report, Calendar Year 1996, HNF-EP-0573-5, Waste Management Federal Services, Inc., Northwest Operations for Fluor Daniel Hanford, Inc., Richland, Washington.

Poston, T. W., 1998, "Soil and Vegetation Surveillance," Hanford Site Environmental Report for Calendar Year 1997, (PNNL-11795), R. L. Dirkes and R. W. Hanf, Pacific Northwest National Laboratory, Richland, Washington.

Poston, T. W., R. W. Hanf and R. L. Dirkes, 2000, Hanford Site Environmental Report for Calendar Year 1999, (PNNL-13230), Pacific Northwest National Laboratory, Richland, Washington. 
Rhoades, J. D., and L. Bernstein, 1971, "Chemical, Physical, and Biological Characteristics of Irrigation and Soil Water," Water and Water Pollution Handbook, Vol. 1, L. L. Ciaccio (ed), 141-22, Marcel Dekker, Inc., New York, New York.

Richardson, D. H. S., 1992, Pollution Monitoring with Lichens, Richmond Publishing Co., Ltd., Slough, England.

Sackschewsky, M. R., D. S. Landeen, G. I. Baird, W. H. Richard, and J. L. Downs, 1992, Vascular Plants of the Hanford Site, WHC-EP-0554, Westinghouse Hanford Company, Richland, Washington.

San Juan, C., 1994, Natural Background Soil Metals Concentrations in Washington State, 94-115, Toxic Cleanup Program, Olympia, Washington.

Schmidt, J. W., A. R. Johnson, B. M. Markes, S. M. McKinney, and C. J. Perkins, 1994, Westinghouse Hanford Company Operational Environmental Monitoring Annual Report, Calendar Year 1993, WHC-EP-0573-2, Westinghouse Hanford Company, Richland, Washington.

Schmidt, J. W., A. R. Johnson, S. M. McKinney, and C. J. Perkins, 1993, Westinghouse Hanford Company Operational Environmental Monitoring Annual Report, CY 1992, WHC-EP-0573-1, Westinghouse Hanford Company, Richland, Washington.

Schmidt, J. W., A. R. Johnson, S. M. McKinney, and C. R. Webb, 1992a, Westinghouse Hanford Company Environmental Surveillance Annual Report - 200/600 Areas, Calendar Year 1990, WHC-EP-0145-4, Westinghouse Hanford Company, Richland, Washington.

Schmidt, J. W., A. R. Johnson, S. M. McKinney, C. J. Perkins, and C. R. Webb, 1992b, Westinghouse Hanford Company Environmental Surveillance Annual Report - 200/600 Areas, Calendar Year 1991, WHC-EP-0573, Westinghouse Hanford Company, Richland, Washington.

Schmidt, J. W., C. R. Huckfeldt, A. R. Johnson, and S. M. McKinney, 1990, Westinghouse Hanford Company Environmental Surveillance Annual Report - 200/600 Areas, Calendar Year 1989, WHC-EP-0145-2, Westinghouse Hanford Company, Richland, Washington.

Schmidt, J. W., J. W. Fassett, A. R. Johnson, V. G. Johnson, B. M. Markes, S. M. McKinney, K. J. Moss, C. J. Perkins, and L. R. Richterich, 1995, Westinghouse Hanford Company Operational Environmental Monitoring Annual Report, CY 1994, WHC-EP-0573-3, Westinghouse Hanford Company, Richland, Washington.

Schmidt, J. W., J. W. Fassett, V. G. Johnson, R. M. Mitchell, B. M. Markes, S. M. McKinney, K. J. Moss, C. J. Perkins, 1996, Westinghouse Hanford Company Operational Environmental Monitoring Annual Report, CY 1995, WHC-EP-0573-4, Westinghouse Hanford Company, Richland, Washington. 
Shord, A. L., 1986, Hanford Waste Vitrification Plant Site Evaluation Report, SD-HWV-SE-001, Rev. 0, Rockwell Hanford Operations, Richland, Washington.

Sittig, M., 1985, "Handbook of Toxic and Hazardous Chemicals and Carcinogens," Noyes Publications, Park Ridge, New Jersey.

Stegen, J. A., 1992, Biological Assessment for State Candidate and Monitor Wildlife Species Related to CERCLA, WHC-SD-EN-EE-009, Westinghouse Hanford Company, Richland, Washington.

Tyler, G., 1972, "Heavy Metals May Pollute Nature, May Reduce Productivity," Ambio, 1:52-59.

Washington Natural Heritage Program, 1994, Endangered, Threatened and Sensitive Vascular Plants of Washington, Washington State Department of Natural Resources, Olympia, Washington.

Wasmiller, M. A., 1993, Hanford Waste Vitrification Plant Soil Baseline Summary Report, WHC-SD-HWV-TI-033, Westinghouse Hanford Company, Richland, Washington.

WHC, 1995, K Basins Environmental Impact Statement Technical Input Document-Spent Nuclear Fuel Project, WHC-SD-SNF-TI-013, Westinghouse Hanford Company, Richland, Washington.

WHC, 1994, Hanford Spent Fuel Inventory Baseline, WHC-SD-SNF-TI-001, Rev. 0, Westinghouse Hanford Company, Richland, Washington.

Wheeler, R. E. and A. G. Law, 1980, Rockwell Hanford Operations Environmental Surveillance for Calendar Year 1979, RHO-LD-132, Rockwell Hanford Operations, Richland, Washington.

Whicker, F. Ward and V. Schultz, 1982, Radioecology: Nuclear Energy and the Environment, CRC Press, Boca Raton, Florida.

WMTS-OEM-001, Operational Environmental Monitoring, Waste Management Technical Services, Richland, Washington.

WMTS-SERM-001, Safety and Environmental Reference Manual, Waste Management Technical Services, Richland, Washington. 


\section{HNF-6150 Rev. 0}

This page intentionally left blank. 
HNF-6150 Rev. 0

APPENDIX A

BIOLOGICAL/CULTURAL RESOURCES REVIEWS 
HNF-6150 Rev. 0

This page intentionally left blank. 
HNF-6150 Rev. 0

January 12, 1996

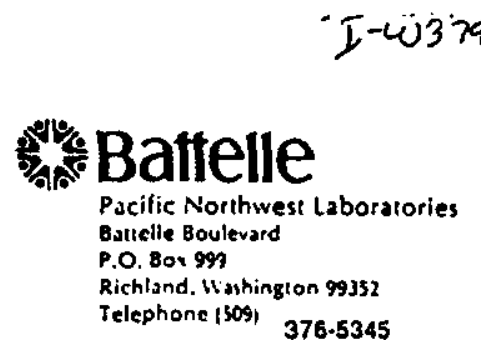

Mr. Vernon J. Chamberlain

ICF Kaiser Hantord Company

P. O. Box 888, MSIN S8.07

Richiand, WA 99352

Dear Mr. Chamberlain:

BIOLOGICAL REVIEW OF THE EXCAVATE FOR CSB CONSTRUCTION SITE PROJECT. 200 East Area, $\# 96-200-018$

Project Description:

- Excavation ol approximately 300 leet by 4 feet by 4 feet deep (92 $\mathrm{m}$ by $1.2 \mathrm{~m}$ by $1.2 \mathrm{~m}$ ) for temporary consinuction power and lighing. contractor trailer anchors, all traller utilities, water, sewer, electrical, and telecommunications.

Survey Objectlves:

- To determine the occurrence in the project area of plant and animal species protecled under the Endangered Species ACl (ESA), candidates for such protection, and species isted as threatened. endangered, candidate, sensilve, or monitor by the state of Washington, and species protected under the Migratory Bird Treaty Act.

- To evaluate the potential impacts of disturbance on priority habitats and protected piant and animal species identitied in the survey.

Survey Methods:

- Pedestrian and ocular reconnaissance of the proposed site was conducted by G. Fortner, J. A. Stegen, and R. Zutell on June 1, 1995. The Braun-Blanquet cover-abundance scale (Bonham 1989) was used to determine percent cover of dominant vegetation,

- Priority habllals and species of concern are documented as such in the following: Washington Department of Fish and Wildite (1993, 1994), U. S. Fish and Wildlife Service (1985,1994a \& b) and Washington State Depariment of Natural Resources (1994).

Survey Results:

- No native lora were observed in the vicinity,

- No migratory bltd species were observed nesting in the vicinity of the proposed site.

\section{Considerations and Recommendations:}

- No plant and animal specles protected under the ESA, candidales for such protection, or species listed by the Washington state government were observed in the vicinity of the proposed site. 
HNF-6150 Rev, 0

Mr. V. J. Chamberlain

$96.200-018$

Page 2 of 3

- No adverse impacts to species or habitats of concern are expected to occur from the proposed action.

Sincerely,

ORsumal

CA Brandt, Ph.D.

Project Manager

Ecological Compliance Assessment

CAB:glf 


\section{HNF-6150 Rev. 0}

Mr. V. J. Chambertain

$96-200 \cdot 018$

Page 3 of 3

REFERENCES

Bonham, Charles D. 1989. Measuremenls for Terrestrial Vegelation, published by John Wiley \& Sons, Inc. pp. 127.128.

U. S. Fish and Wildile Service. 1985. Revised List ol Mlgratory Birds; Final Rule. 50 FR 13708 (April 5 , 1985).

U. S. Department of Interior, U. S. Fish and Wildite Service. 1992a. Endangered and Threatened Wildite and Plants. 50 CFR 17.11 and 17.12. (August 29, 1992).

U. S. Fish and Wildife Service. 1994b. Endangered and Threatened Wildife and Plants, Animal Candidate Review for Listing as Endangered or Threatened Species, Proposed Rule, 50 CFR 17. (November 15, 1994).

Washington Department of Fish and Wildlife. 1993. Priority Habitats and Species. pp. 22.

Washington Department of Fish and Wildlife. 1994. Specles of Special Concern in Washington. (April 1994).

Washington Department of Natural Resources. 1994. Endangered, Threalened \& Sensitive Vascular Plants of Washington. (January 1994). 
HNF-6150 Rev. 0

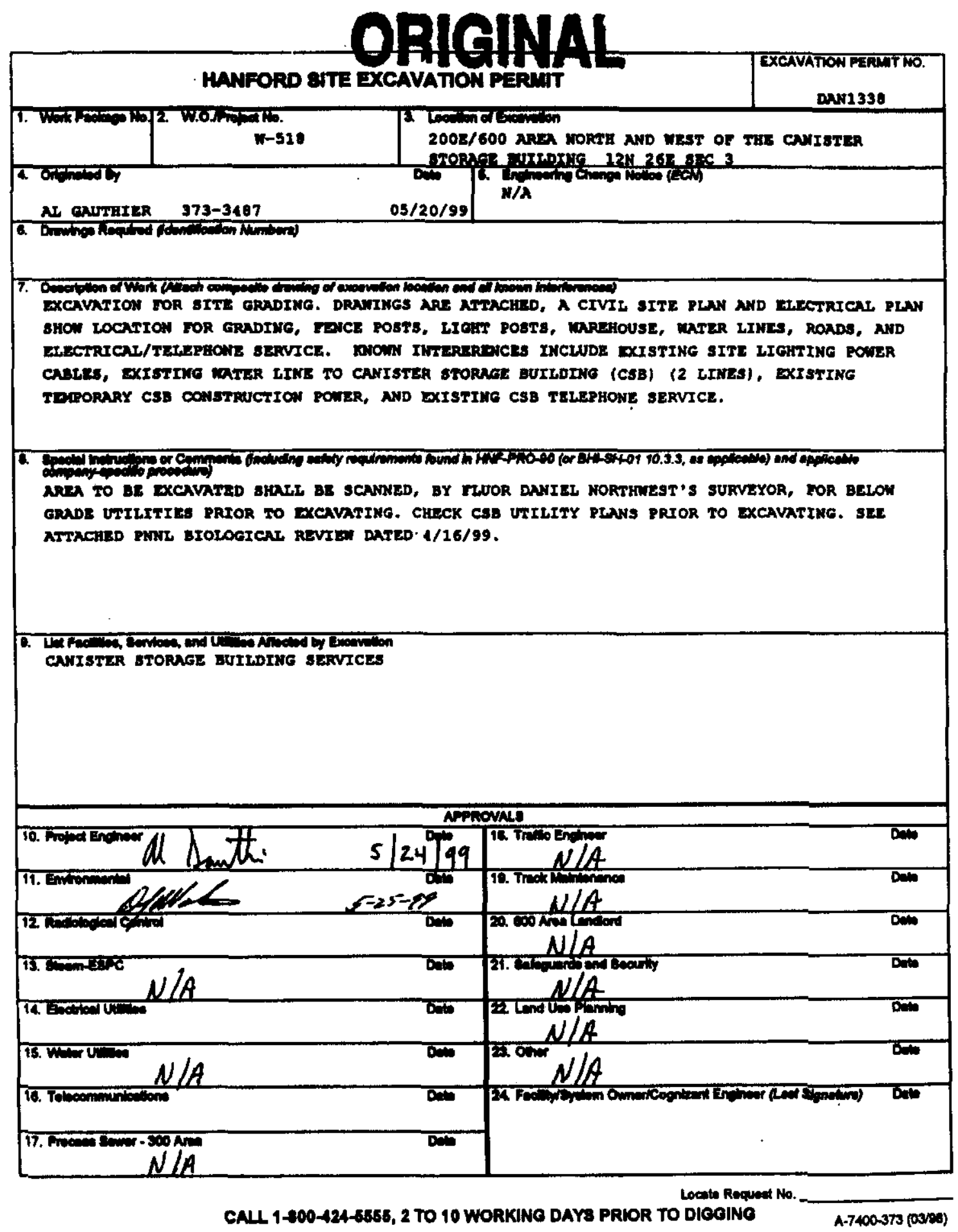


HNF-6150 Rev. 0

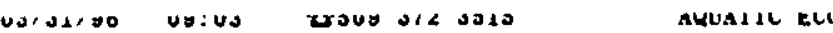

Pacific Northwest National Laboratory

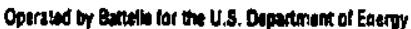

May 31, 1996

No Known Historic Properties

Mr. G. S. Hunacek

Westinghouse Hantord Company

P. O. Box $1970 \times 3.79$

Richland, WA 99352

Dear Mr. Hunacek.

CULTURAL. RESOURCES REVIEW OF THE COLD VACUUM DAYING FACILITY,

MODIFICATIONS TO ORIGINAL REVIEWS. HCRC 196-100-016 AND HCRC $* 96-100-031$

In response to your requeet recelved May 27, 1996, etaff of the Hantord Cultural Resources Laboratory (HCRL) conducted a cultural resources rewiew of the modifications of the subject project, located in the $100 \mathrm{~K}$ Area of the Hanford Slte. According to the information that you 8upplied, excavations for the Colo Vacuum Drying Facilty will be up to 25 feet, deeper than the 3 foet stated In the original review (96-100-016). Test bore holes for the foundations will be up to 100 feel deep as opposed to the 8 feet as stated in the orlalnel review (98-100-031). Additionally, a fence wit be construcled around the construction site which will necessitate the excavation of holes to 4 feet deep for the fence posts. Tha fence will be constructed within the area originally reviewed for the projeci (Area F).

Our literature and records review shows that the project area is localed within the industrial part of the $100 \mathrm{~K}$ Area over $400 \mathrm{~m}$ from the Columbia. Examination of historic aerial photographs and maps shows that the project area has been disturbed by previous construction actlvities. Surface sediments in the project area are eandy gravel and are devoid of vegetation. Sediments expoeed in the banks along the sides of the roads are also sandy gravel and much of the area appears to have been filed and leveled. Examination of weil logs from the $100 \mathrm{~K}$ area shows that the sandy gravels of the Hanford Formation continue to depth. It is, therefore, highly unlikely that any intact archaeologlcal materials will be affected by the proposed project. Survey and monitoring of the project by an archaeologist are not necessary.

It is the finding of the HCRL staff that there are no known cultural resources or histork properties within the proposed project area. The workers, however, must be directed to watch for cultural materials (e.g., bones, shells, artfacts) during all work activities. If any are encountered, work in the vicinity of the discovery must atop unth an HCAL archaeologist has been nottifed, assessed the slonificance of the tind, and, If neceasery, arrenged for mitipation of the impacts to the flind. The HCAL must be notified if any changes to project location or scope are anticlpated. This is a Class III case, delined as a project which involves new construction in a disturted, low-sensitivity area.

Copies of thls letter have been sent to Dee Loyd, DOE, Richland Operations Office, as official documentation. H you have any questions, please call me at 376-8107. Please use the HCRC. above for any future correspondence concerning this project.

Very truly yours,

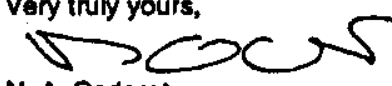

N. A. Cadoret

Technical Specialist

Cultural Resources Project

Concurrence:

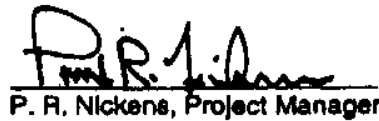

P. P. Nlckens, Project Manage
Cultural Resources Project

c: D. Lloyd, RL (2)

D. A. Kane

Flens

Poottl" brand tax transmittal memo 7871 cot pepae "

Battelie Boulevard = P.O. B

\begin{tabular}{|c|c|}
\hline Jerm Huse & 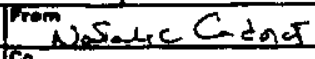 \\
\hline का. & thenen \\
\hline $\ln 373-33$ & +ax \\
\hline
\end{tabular}


June 3, 1996

C.A. Brandt
K6-84 K6.84

Mr. G.S. Hunacek

Westinghouse Hantord Company

P. O. Box 1970 , MSIN X3.79

Richland, WA 99352

Dear Mr. Hunacek:

BIOLOGICAL REVIEW OF THE COLD VACUUM DRYING PROJECT, $100 \mathrm{~K}$ ATEa, \#96-100-016 amendment $b$

\section{Project Descriptlon:}

- Construction of a temporary Cold Vacuum Drying facility south west of $105 \mathrm{KW}$. The excavation will be approximately 141 feet long by 48 feet wide by 3 feet deep ( $43 \mathrm{~m}$ long by $14.6 \mathrm{~m}$ wide by $0.9 \mathrm{~m}$ deep). Excavation depth will be to 25 leet and will include tencing at the perimeter and 5 exploratory boreholes to support design of the foundation.

\section{Survey Objectives:}

- To determine the occurrence in the project area of plant and animal specles protected under the Endangered Species Act (ESA), candidates for such protection, and species listed as threatened, endangered, candidate, sensitive, or monttor by the state of Washington, and species protected under the Migratory Bird Treaty Act,

- To evaluate the potential impacts of disturbance on priority habitats and protected plant and animal species iofentified in the survey.

\section{Survey Methods:}

- Pedestrian and ocular reconnalssance of the $100 \mathrm{~K}$ Area was conducted by M. Sackschewsky, T. Hanrahan, and J. Becker on Aprll 25, 1996, and by C. Brandt. J. Becker, and T. Hanrahan on May, 2, 1996.

- Priority habitats and species of concern are documented as such in the following: Washington Department of Fish and Wildlife $(1993,1994)$, U. S. Fish and Wildife Service $(1985,1994$ a \& b) and Washington State Department of Natural Resources (1994).

\section{Survey Results:}

- The area for the proposed work consists largely of pavement and packed gravel with no significant flora of any kind.

- An active starling nest was observed on the south side of the $105 \mathrm{KW}$ building, and numerous pigeons utilize the area. Nether of these species is protected under either federal or state laws and regulations. 


\section{HNF-6150 Rev. 0}

Mr. G.S. Hunacok

96-100-016 amendment $b$

Page 2 of 3

\section{Considerations and Recommendations:}

- This biological survey is effective until the issuance of a new blanket letter for the $100 \mathrm{~K}$ area in May of 1997. At that time, a new ecological baseline survey will be done and this letter will be updated as necessary.

- No protected species were observed within the proposed site. Bald eagles roost in trees at the northwest corner of the $100 \mathrm{~K}$ area. This species is listed under the Endangered Species Act as Threatened with extinction.

- The proposed CVD project is the subject of ongoing informal consultation with the US Fish and Wildilife Service. Pending the outcome of that consultation, construction work on the CVD should be restricted to those periods of the year when bald eagles are not present, l.e. November 1 to May 1. Consultation is expected to provide modifications to these work restrictions during the perlod of eagle residence. The restrictions/guidance provided by the US Fish and Wildilife Service should be included with this review lefter as defining the ecological compliance review information and guidance for the CVD project at $100 \mathrm{~K}$.

- Provided the restrictions presented in this letter, as superseded by consultation with US Fish and Widilfe Service, are complied with, no adverse impacts to species or habitats of concern are expected to occur from the proposed action.

Sincerely,

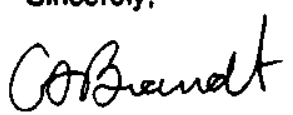

CA Brandt, Ph.D.

Manager

Ecological Compliance Assessment Project 


\section{HNF-6150 Rev. 0}

Mr. G.S. Hunacek

96-100-016 amendment $b$

Page 3 of 3

\section{REFERENCES}

Bonham, Charles D. 1989. Measurements for Terrestrlal Veaetation, published by John Wiley \& Sons, Inc. pp. 127-128.

U. S. Fish and Wildlife Service. 1985. Revised List of Migratory Birds; Final Rule. 50 FR 13708 (April 5 , 1985).

U.S. Department of Interior, U. S. Fish and Wildifie Service. 1992a. Endangered and Threatened Wildife and Plants. 50 CFR 17.11 and 17.12. (August 29, 1992).

U.S. Fish and Wildlife Service. 1994b. Endangered and Threatened Wildife and Plants, Animal Candidate Review for Llsting as Endangered or Threatened Specles, Proposed Rule, 50 CFR 17. (November 15. 1994).

Washington Depantment of Fish and Wildlife. 1993. Priority Habltats and Species. pp. 22.

Washington Department of Fish and Wildlife. 1994. Species of Special Concern in Washington. (April 1994).

Washington Department of Natural Resources. 1994. Endangered, Threatened \& Sensitive Vascular Plants of Washington. (January 1994). 
HNF-6150 Rev. 0

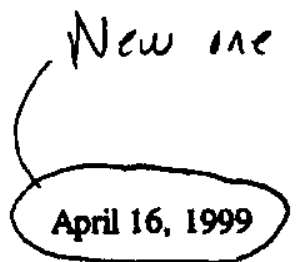

\section{Pacific Northwest National Laboratory \\ Operated by Battalle for the \\ U.S. Department of Energy}

Mr. Chip Consulman

ARES

CIO Flour Daniel Hanford Co.

P. O. Box 1000, MSDN R3-11

Richland, WA 99352

Dear Mr. Consulman:

BIOLOGICAL REVIEW OF THE INTERIM STORAGE AREA PROJECT, 200E Area, ECR \$99-200-045.

\section{Project Description:}

- Create assorted small excavations for footings and utilities at and near the location of the 200 E Interim Storage Area, just northwest of the Canister Storage Building.

\section{Survey Objectives:}

- To determine the occurrence in the project area of plant and animal species protected under the Endangered Species Act (ESA), candidates for such protection, and species listed as threatened, endangered, candidate, sensitive, or monitor by the state of Washington, and species protected under the Migratory Bird Treaty Act,

- To evaluate and quantify the potential impacts of disturbance on priority habitats and protected plant and animal species identified in the survey.

Survey Methods:

- Pedestrian and ocular reconnaissance of the proposed project site were performed by $\mathbf{M}$. $\mathbf{R}$. Sackschewsky on 16 April 1999. The Braun-Blanquet cover-abundance scale (Bonham 1989) was used to determine percent cover of dominant vegetation,

- Priority habitats and species of concern are documented as such in the following: Washington Department of Fish and Wildlife (1994, 1996), Washington State Department of Natural Resources (1997), and for migratory birds, U.S. Fish and Wildlife Service (1985). Lists of animal and plant species considered Endangered, Threatened, Proposed, or Candidate by the USFWS are maintained at SO CFR 17.11 and 50 CFR 17.12.

\section{Survey Results:}

- The project site has been previously denuded. No living vegetation was observed.

- No migratory bird species were observed nesting in the vicinity of the proposed site.

902 Battelle Boulevard • P.O. Bax 999 • Richland, W'A 99352 
Mr. C. Consulman

99-200-045

Page 2 of 2

\section{Considerations and Recommendations:}

- No plant or animal species protected under the ESA, candidates for such protection, or species listed by the Washington state government as threatened or endangered were observed in the vicinity of the proposed site.

- No adverse impacts to species, habitats, or other biological resources are expected to result from the proposed actions.

- This Ecological Compliance Review is valid until 15 April 2000.

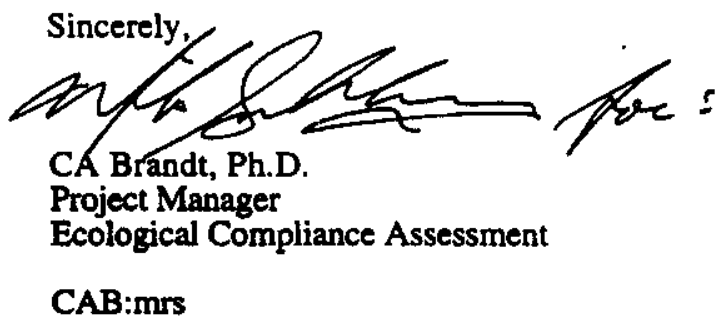

\section{REFERENCES}

Bonham, Charles D. 1989. Measurements for Terrestrial Vegetation, John Wiley \& Sons, Inc. pp. 127-128.

U. S. Fish and Wildlife Service. 1985. Revised List of Migratory Birds; Final Rule. 50 FR 13708 (April 5, 1985).

Washington Department of Fish and Wildlife. 1994. Species of Special Concern in Washington. (April 1994).

Washington Department of Fish and Wildlife. 1996. Priority Habitats and Species List. (January 1996).

Washington Department of Natural Resources. 1997. Endangered, Threatened \& Sensitive Vascular Plants of Washington (August 1997). 
HNF-6150 Rev. 0

APPENDIX B

FIELD SAMPLING LOGBOOKS

B-i 
HNF-6150 Rev. 0

This page intentionally left blank.

B-ii 
HNF-6150 Rev. 0

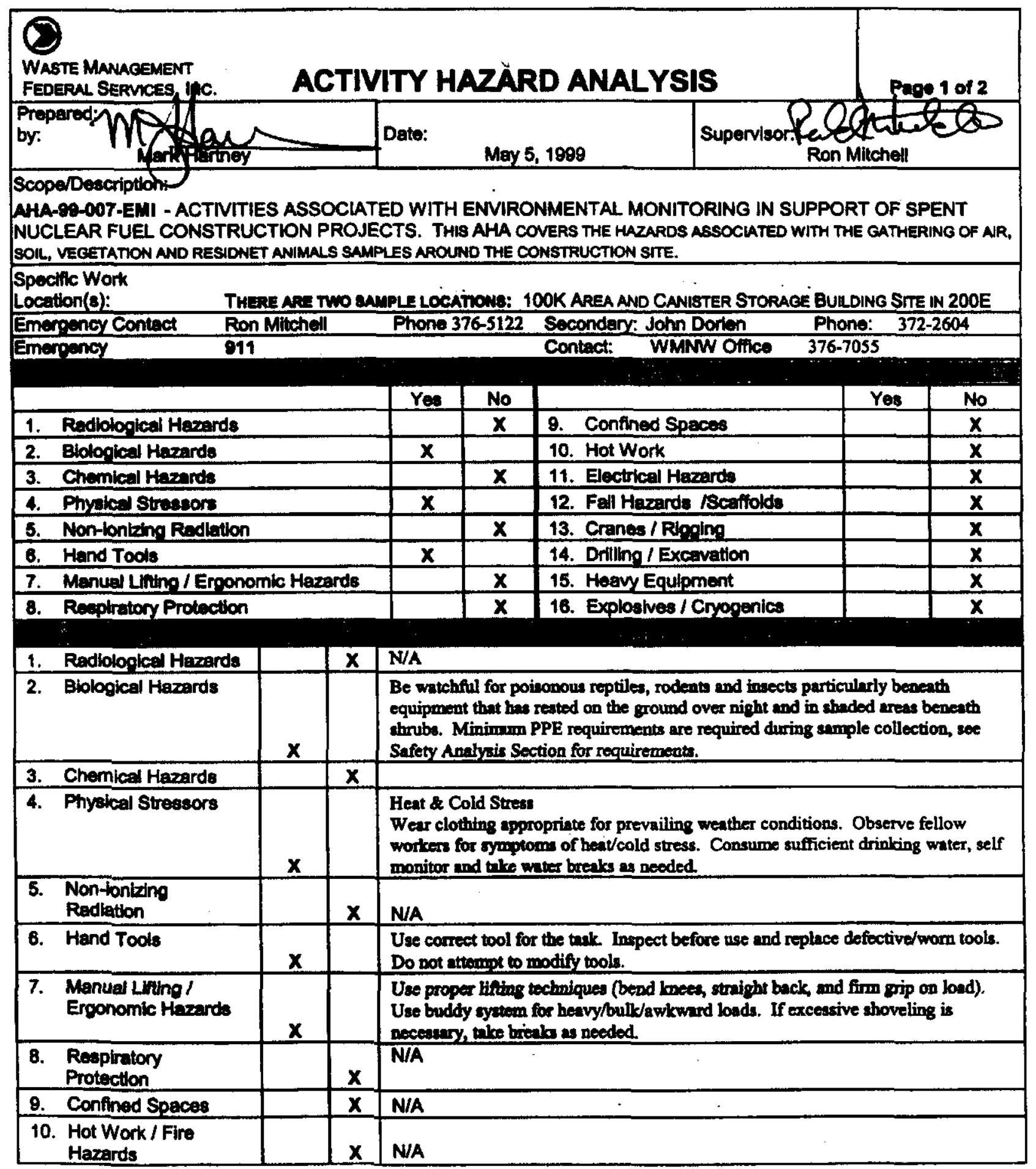


HNF-6150 Rev. 0

\begin{tabular}{|c|c|c|}
\hline 11. Electrical Hazards & $x$ & NIA \\
\hline $\begin{array}{l}\text { 12. Fall Hazards } \\
\text { /Scaffolds }\end{array}$ & $\mathbf{x}$ & $N / A$ \\
\hline 13. Cranes / Rigging & $x$ & N/A \\
\hline 14. Drilling / Excavation & $x$ & N/A \\
\hline 15. Heavy Equipment & $x$ & N/A \\
\hline $\begin{array}{l}\text { 16. Explosives / } \\
\text { Cryogenics }\end{array}$ & $\underline{x}$ & N/A \\
\hline \multicolumn{3}{|c|}{$\begin{array}{l}\text { Notes and spedal Instructions: } \\
\text { EVERY WORKER MUST UNDERSTAND THE HAZARDS ASSOCIATED WITH THIS WORK AND THE } \\
\text { CORRECTIVE MEASURES. IF YOU DO NOT UNDERSTAND ANY PORTION OF THIS AHA OR HAVE } \\
\text { ENCOUNTERED CONDITIONS THAT HAVE NOT BEEN ADEQUATELY IDENTIFIED STOP AND DO NOT } \\
\text { PROCEED UNTIL YOU HAVE CONTACTED YOUR SUPERVISION! }\end{array}$} \\
\hline
\end{tabular}

\section{EXPOSURE ASSESSMENT}

\section{Description of Work Conditions}

- This task is being performed in an area that has no process knowledge of chemical or radiological hazards. The scope of this AHA does not inciude these types of hazards. Should they be encountered, additional assessment will be necessary. Al of the samples will be gathered outdoors around the perimeters of the $100 \mathrm{~K}$ Area and the Canister Storage Building Site in 200E. As such all types of environmental conditions will be encountered. Jobs and Tasks

- Air, soil, vegetation, and resident animals will be collected for subsequent analysis. These samples will be taken by hand with common hand tools.

Hazard Characterization

- The work conducted under this scope is relatively hazard free. As such it presents a low hazard potential. Of primary concern are the hezards from over exertion in inclement weather, animal/insect bite/sting and encountering areas that have not been previously identified.

- Other identified hazards include a potential for fire should vehicles be taken off road.

Monitorino/Medical Surveillance (none identified for this scope)

\section{SAFETY ANALYSIS SECTION}

Minlmum Personal. Protective Equipment (PPE)

- Sleeved shirt at least 4 inches below the shoulder.

- Long pants.

- Substantial footwear - footwear that is constructed to provide adequate protection for the work environment. Shoes generally should be closed toe, firm material with a rigid sole.

- Leather gloves or equivalent while sampling.

Off road vehicle use

- Should vehicies need to be taken off road, they shail be equipped with a fire extinguisher and a shovel. Park them in areas where vegetation will not come in contact with the underside. Awways notify 911 if there is any indication of a fire and do not attempt to fight the fire unless you can do so without endangering yourself or others.

\section{Emeraency Preparedness}

- The sample crew shall have at least one member certified first aid/CPR. A first aid kit will be available at the job location. Communications will be by cellular phone, radio or other equivalent methods. Each member of the team will know how to activate the 911 system.

Page 2 of 2 
HNF-6150 Rev. 0

\section{WMNW ACTIVITY HAZARD ANALYSIS ACKNOWLEDGMENT AHA-99-007-EMI}

I have read, understand, and agree to abide by the provisions detailed in this Activity Hazard Analysis. I understand that failure to comply with these provisions may lead to disciplinary action and my removal from this job activity.

PRINTED NAME $\quad$ SIGNATURI

EMPLOYEE NO.

OR

DATE SOCIAL SECURTYY NO.

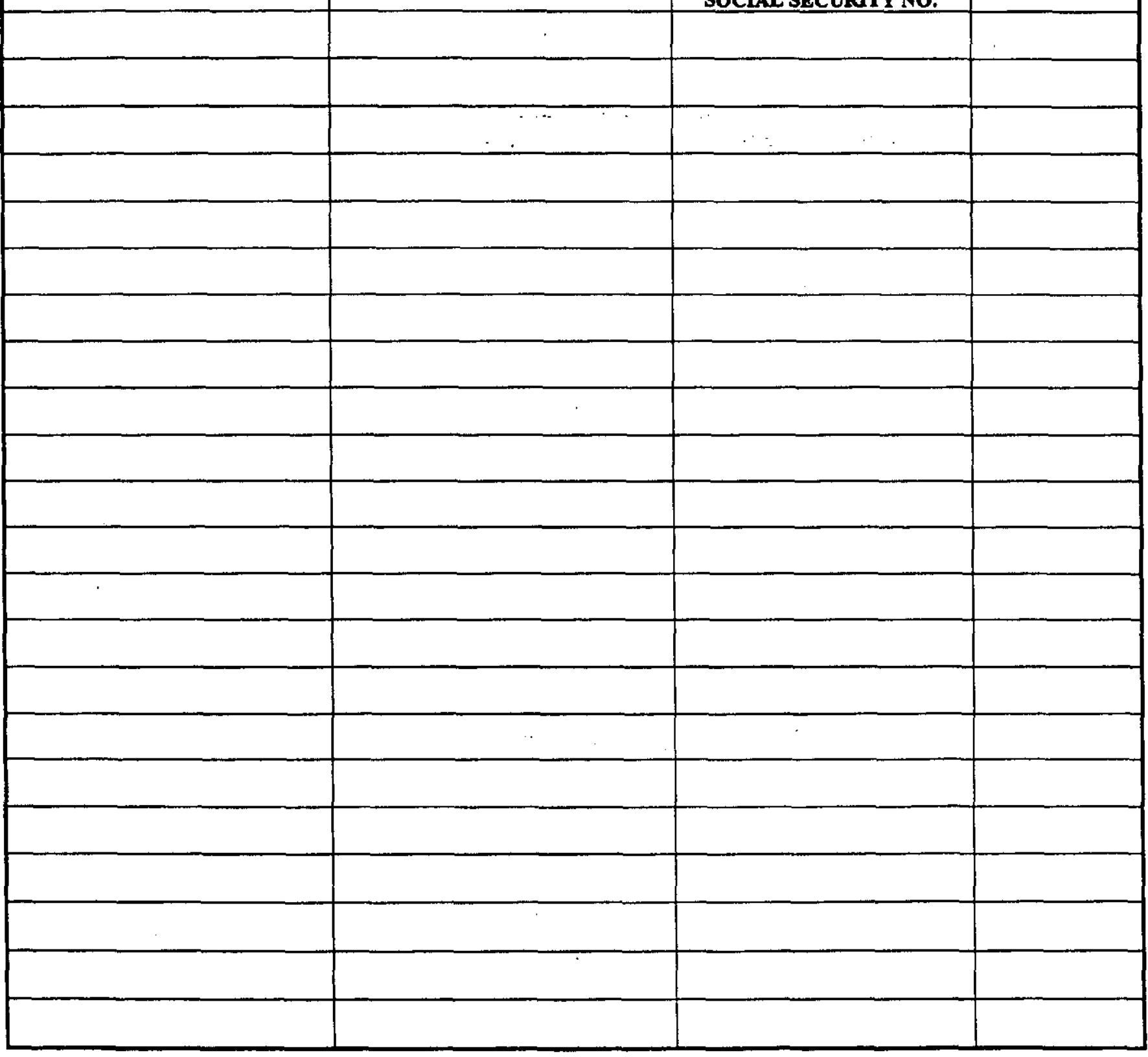


HNF-6150 Rev. 0

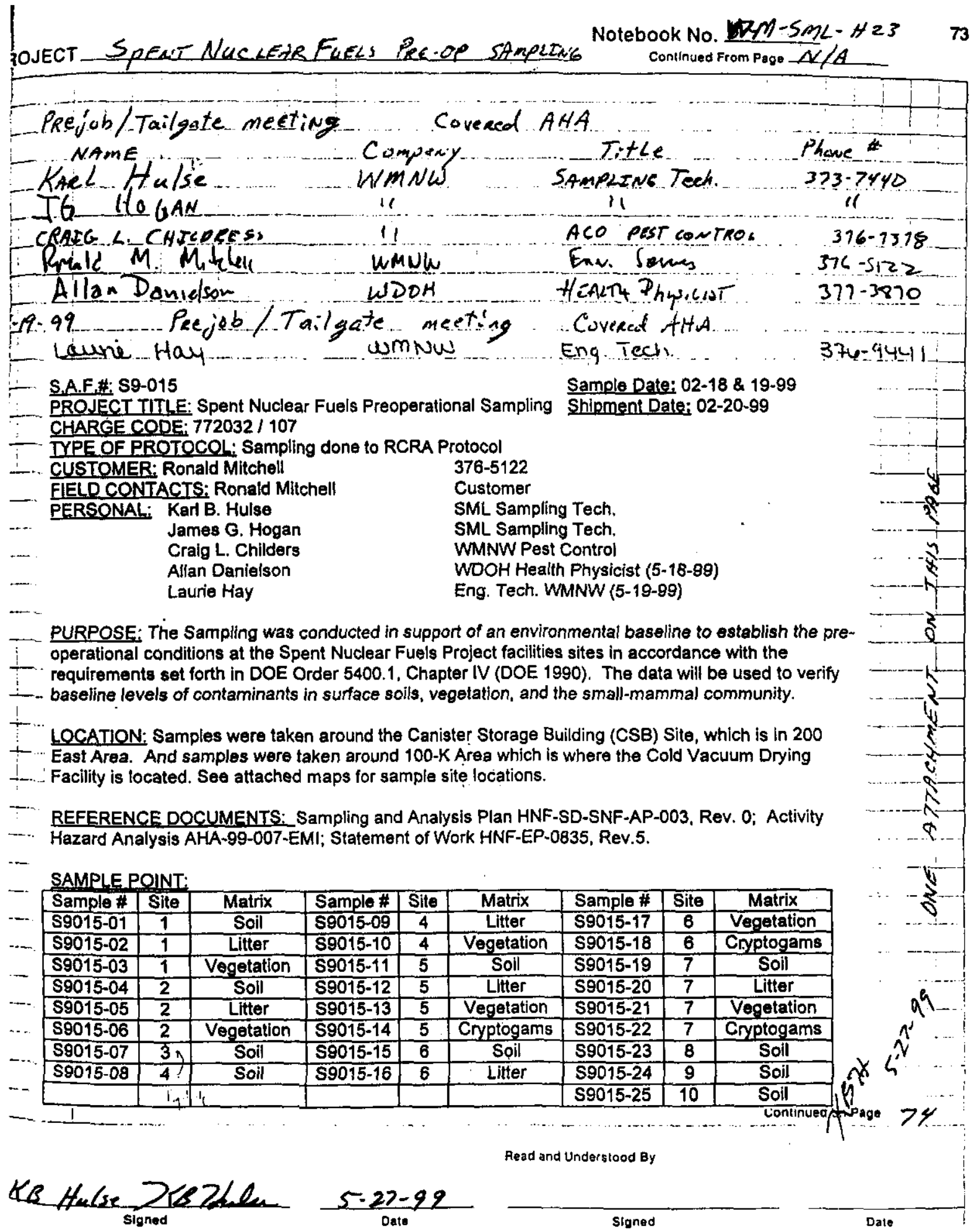


74 PROJect_Spent Natlesk_Fuels Pre-Op SAmpling

Notebook No. Wm-sml- 123 Continued From Page -23

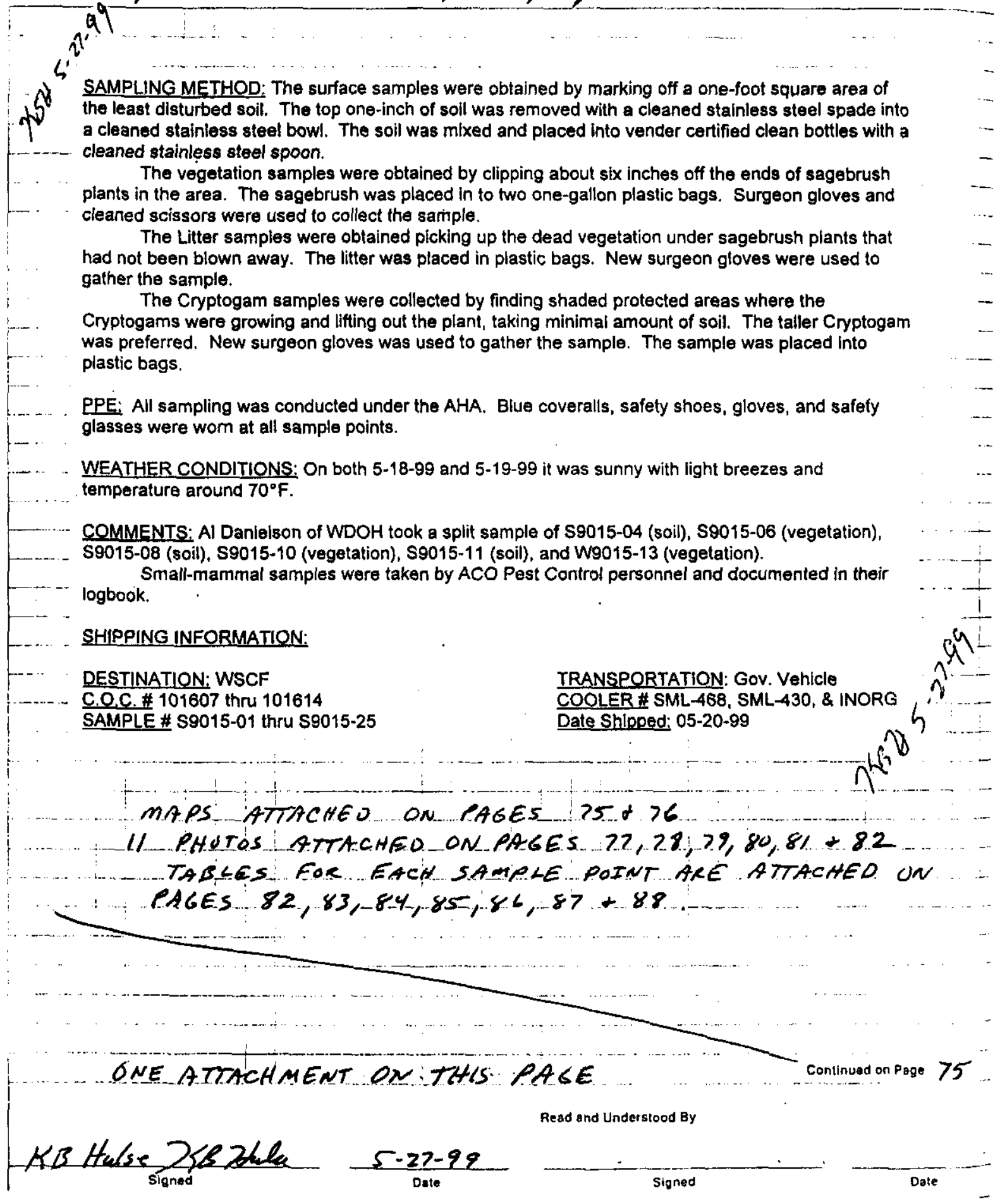




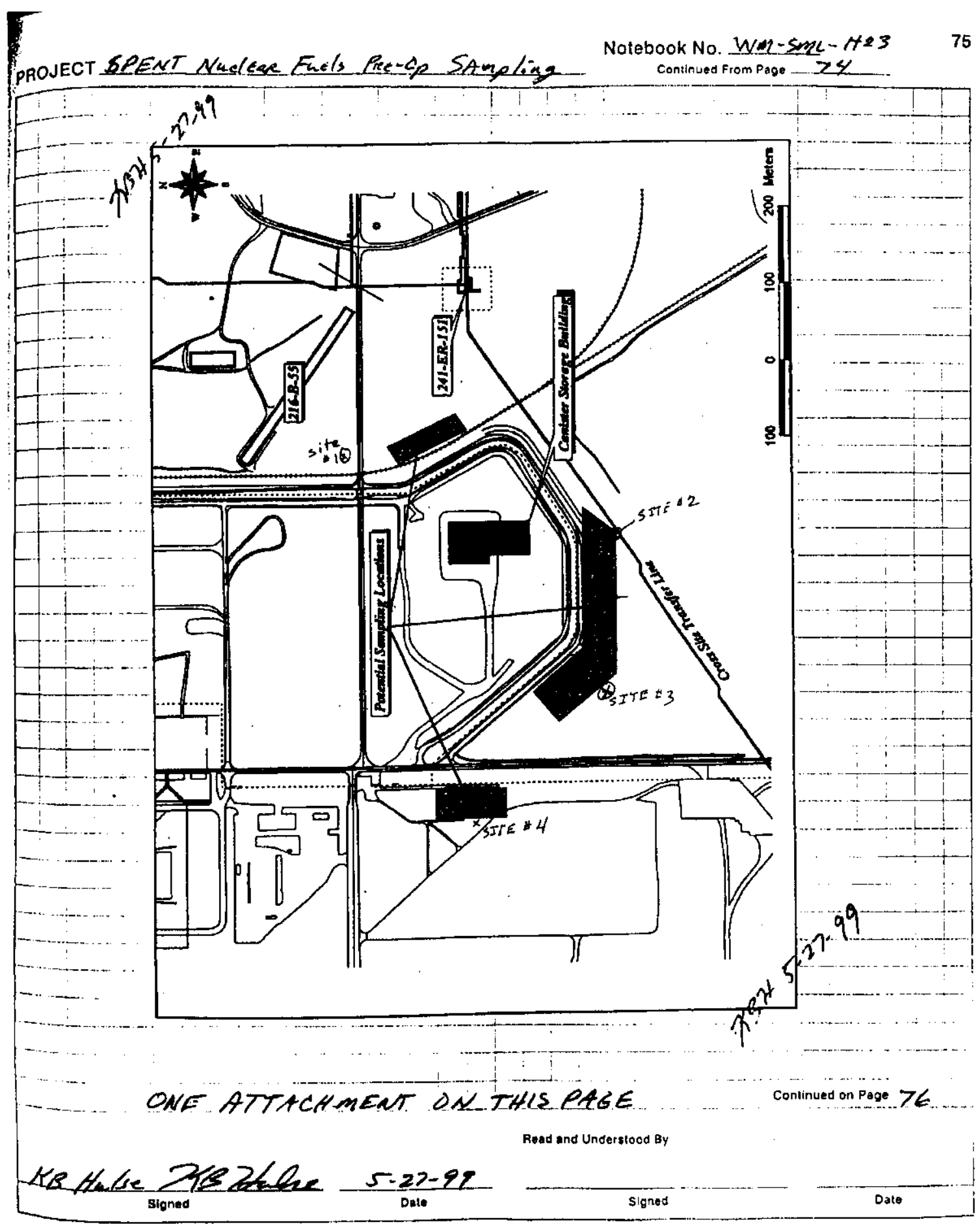


HNF-6150 Rev. 0

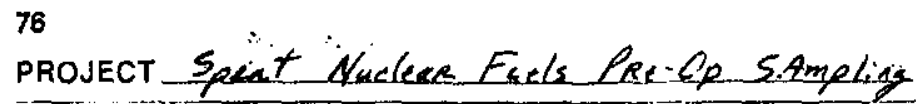
Notebook No, $K x h L-\operatorname{Sen}-N_{23}$

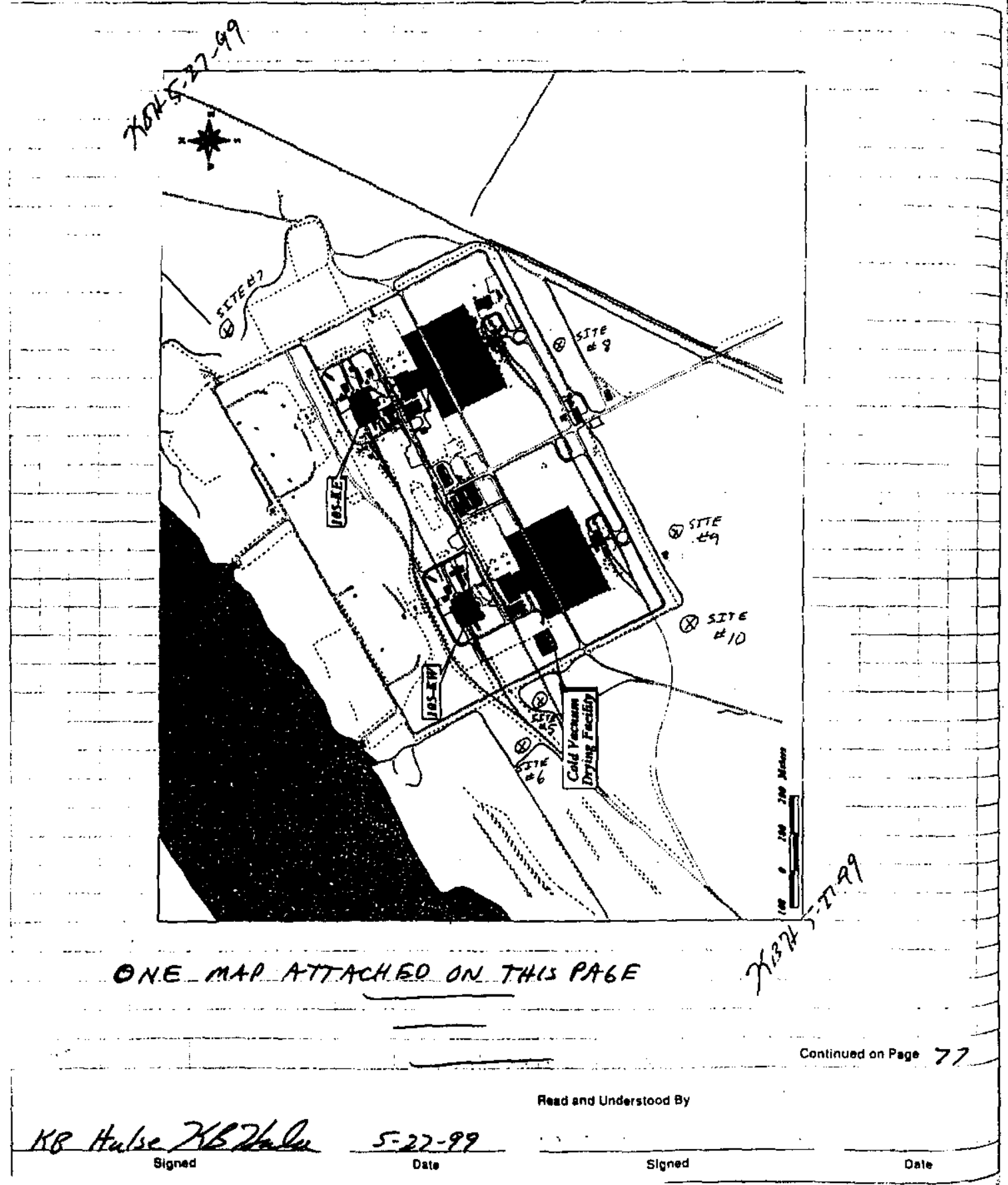




\section{HNF-6150 Rev. 0}

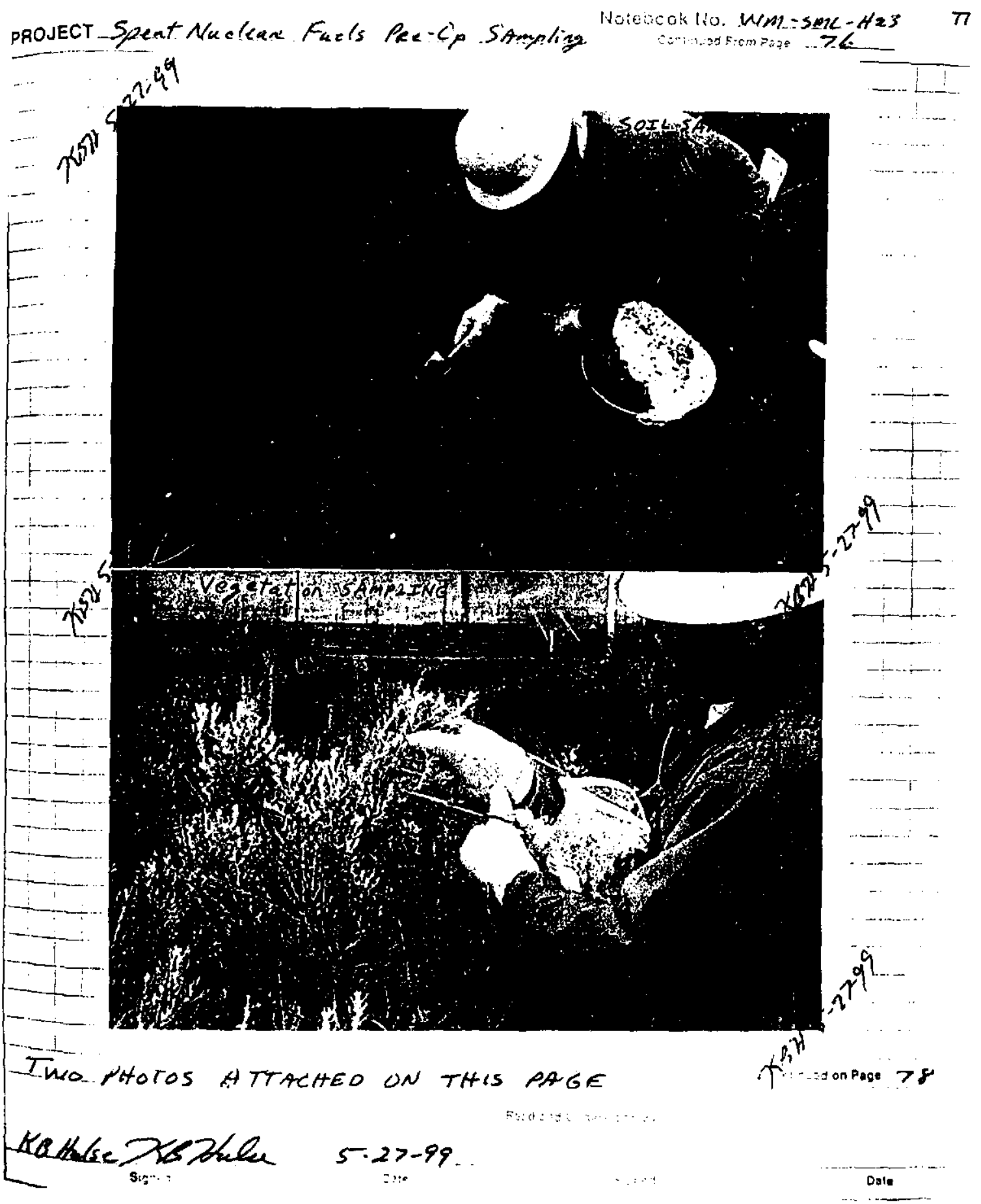


78

PROJECT - Spent it-r'eare Fuels Prer=Qp SAmpling

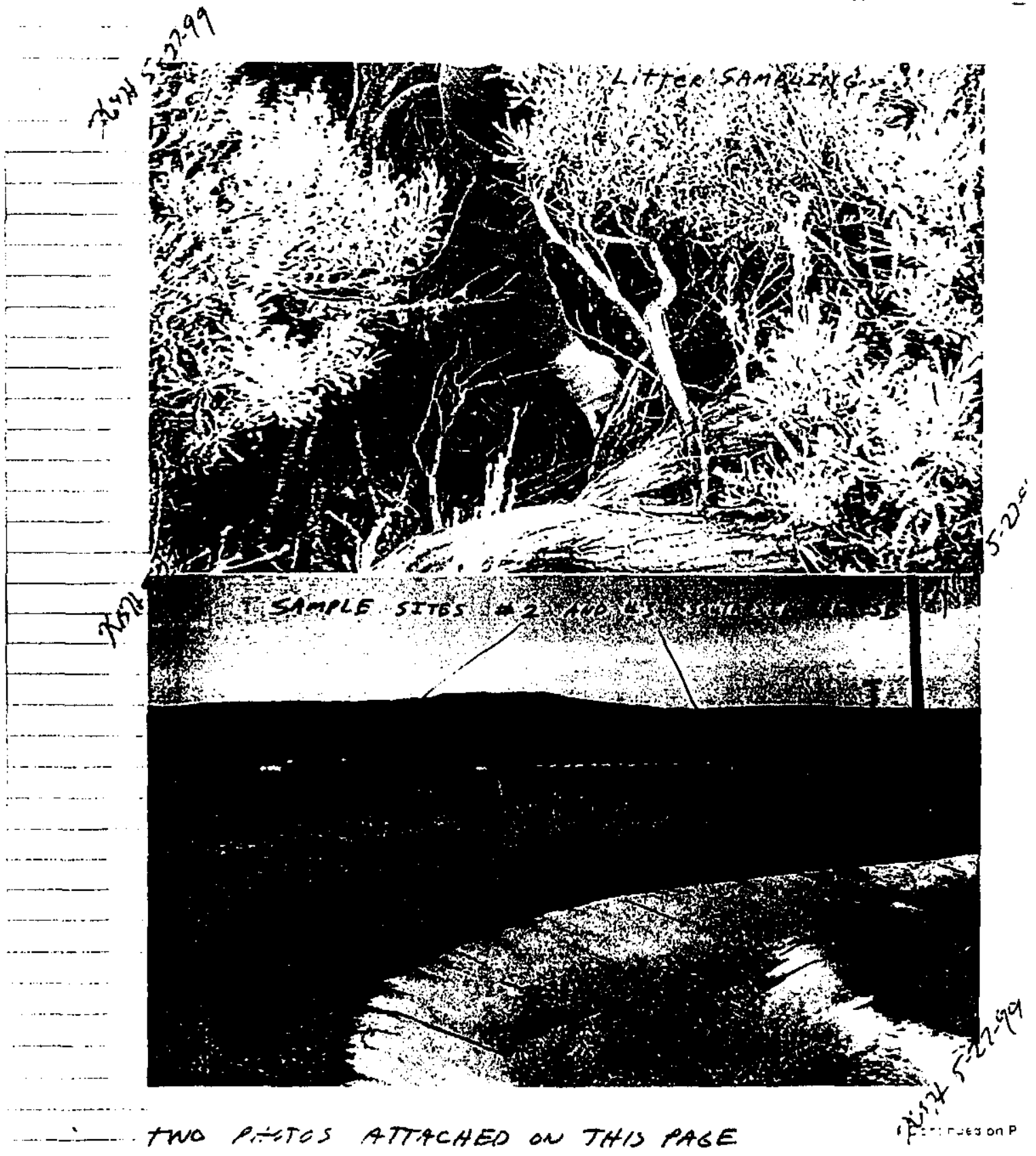

TWO PUETOS ATTACHED ON THIS PAGE

Peadand deislood By
Notetook No. W $v e 1-\operatorname{sen} L-1+2$ Coritined $=:-=1 ; \ldots \ldots Z Z$. 
HNF-6150 Rev. 0

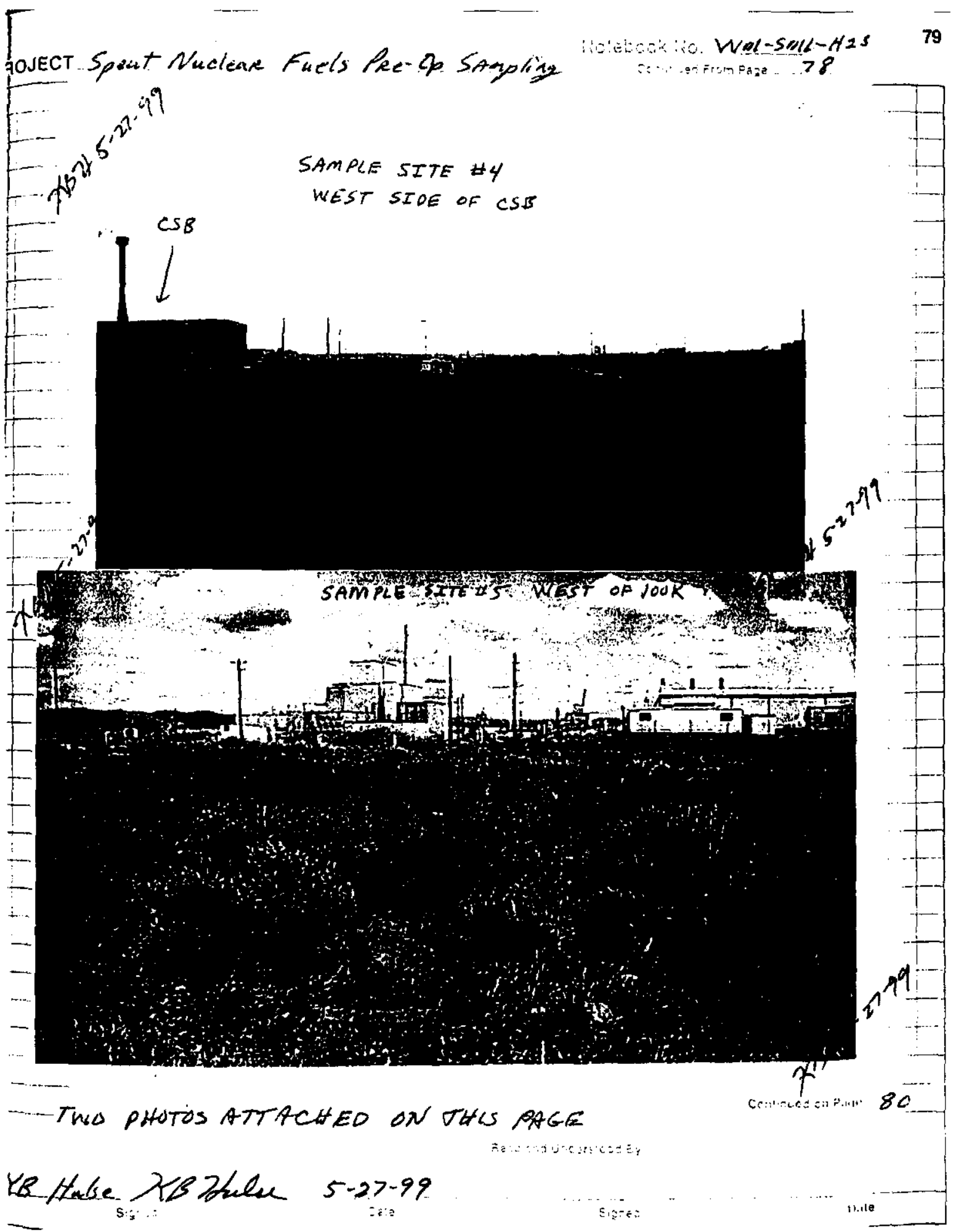


PROJECT Spent Nucleare Frels Pre-Cp SAmpling th SAMPLE SITE \# 6 Nouth West of look Notebock No. WII-Silll-H23

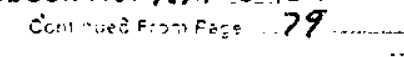

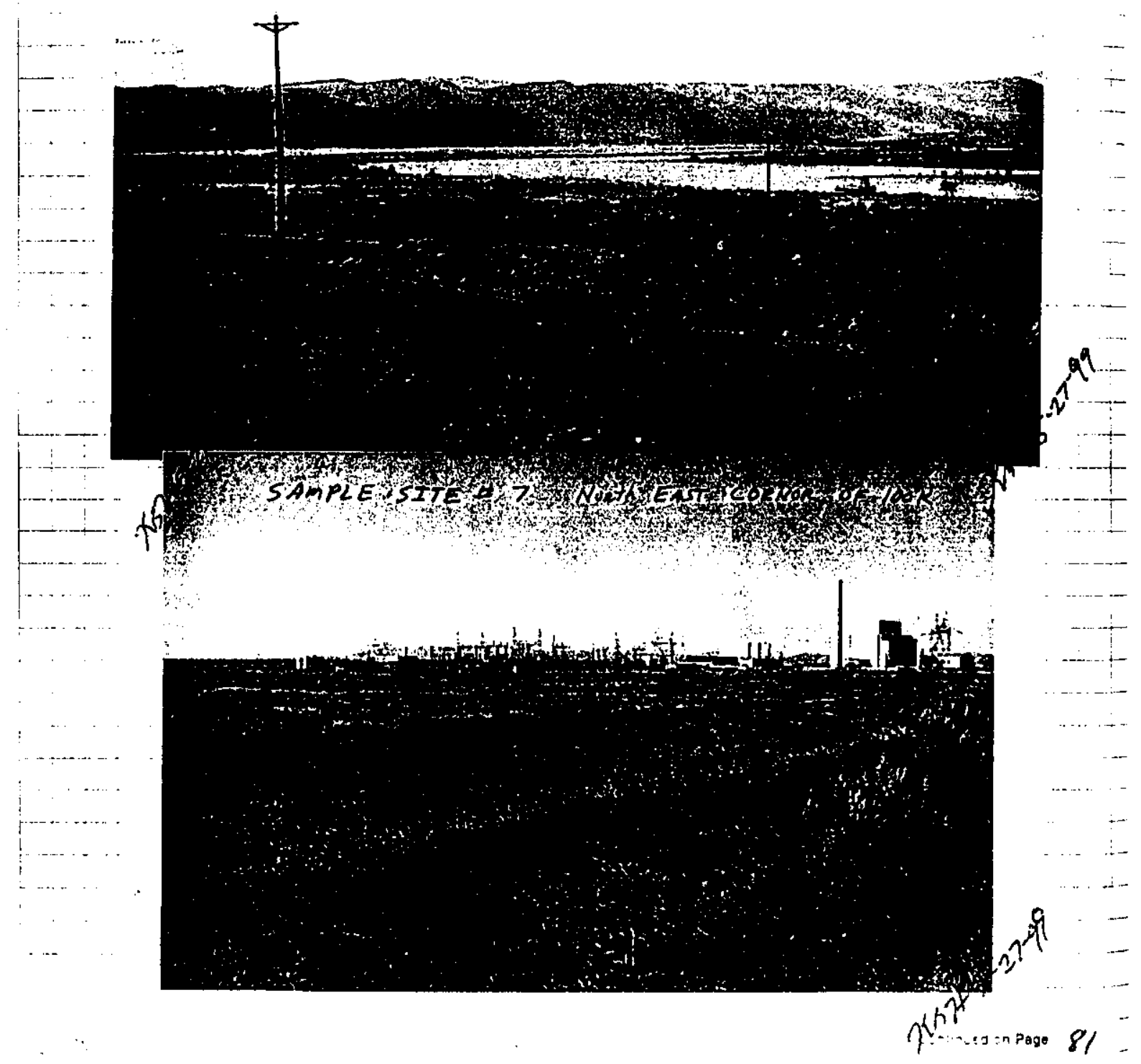

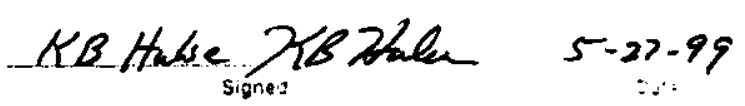


HNF-6150 Rev. 0

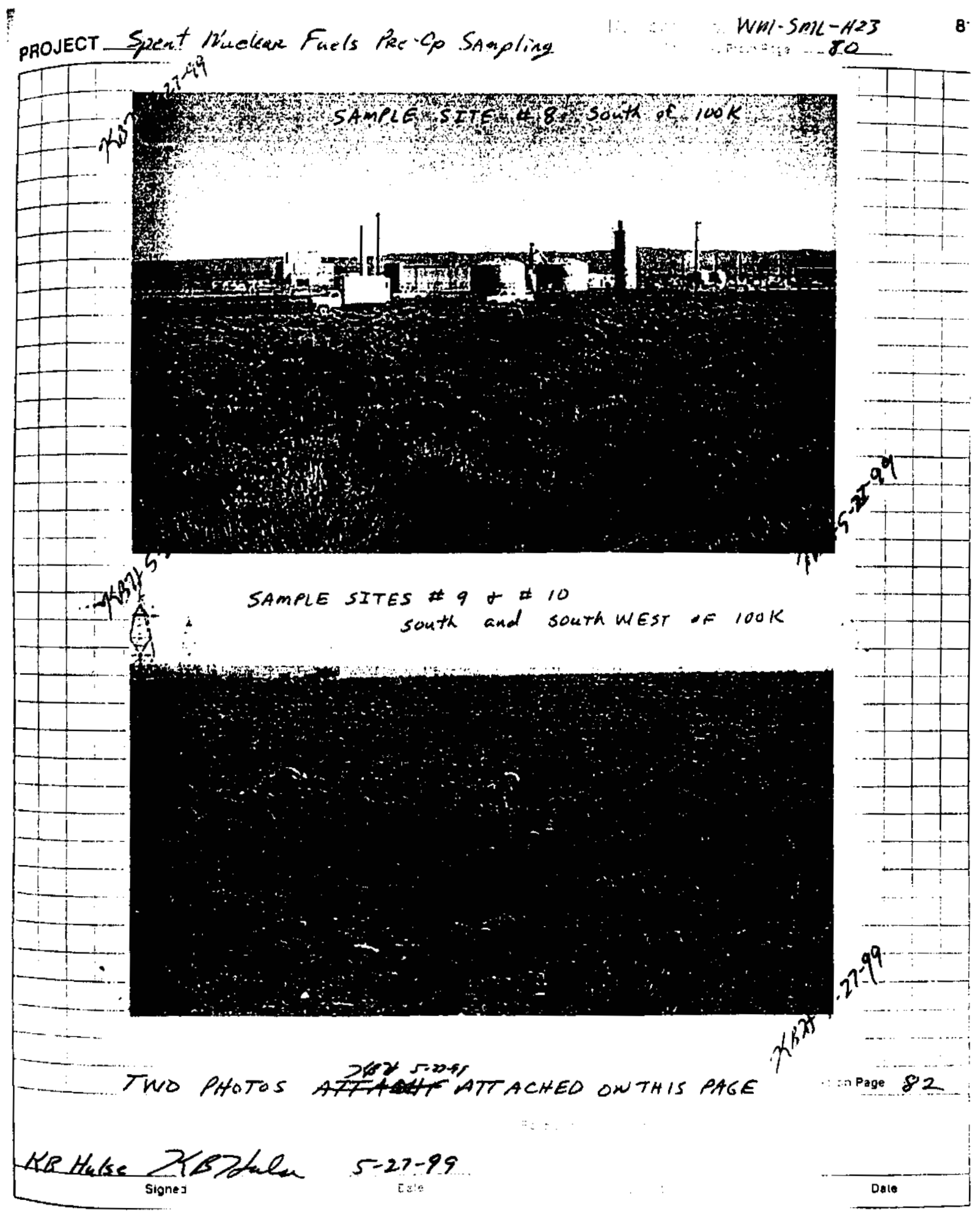


82

ProJect Spent Nuclear Fuels Pre-Op SAmpling
Notebook No. WM- $\sin L-1+2.3$ Continued From Page -81

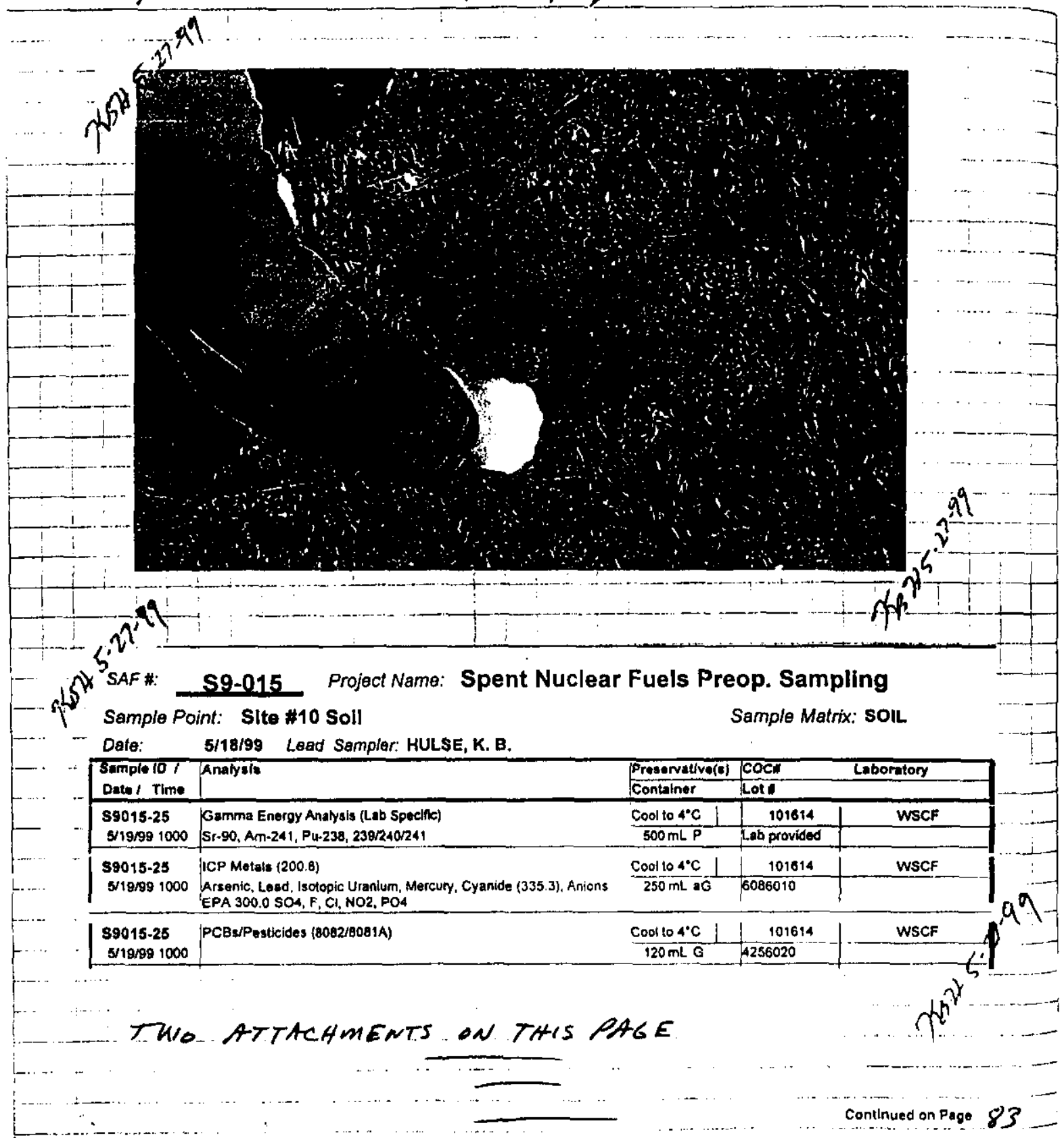

Read and Understood $8 y$

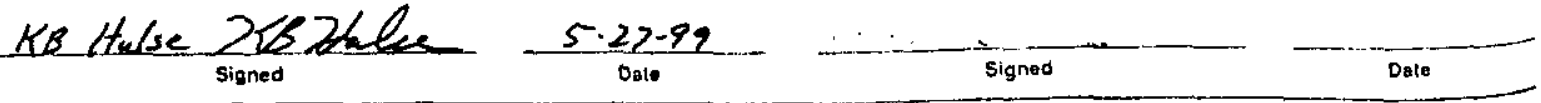




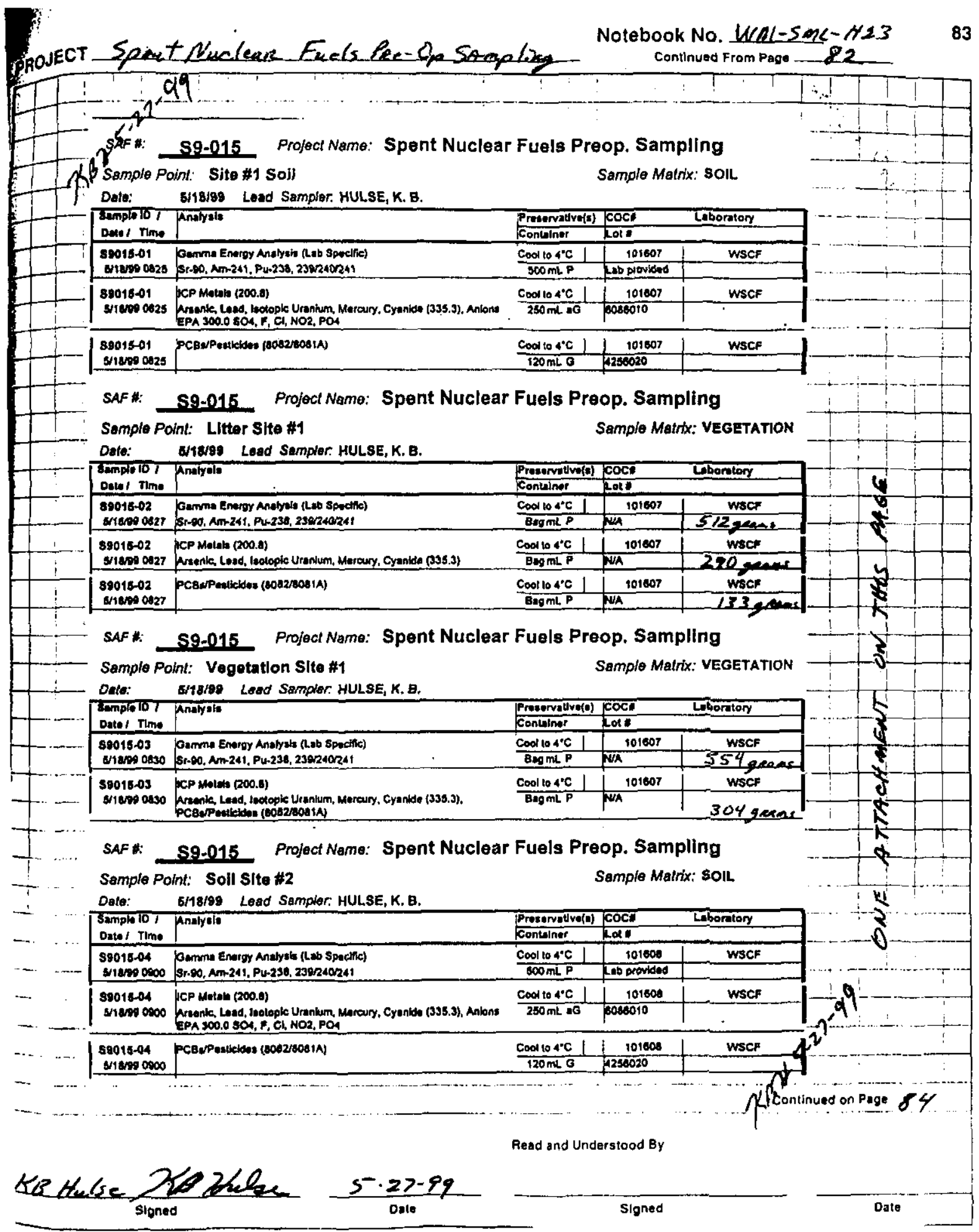


84

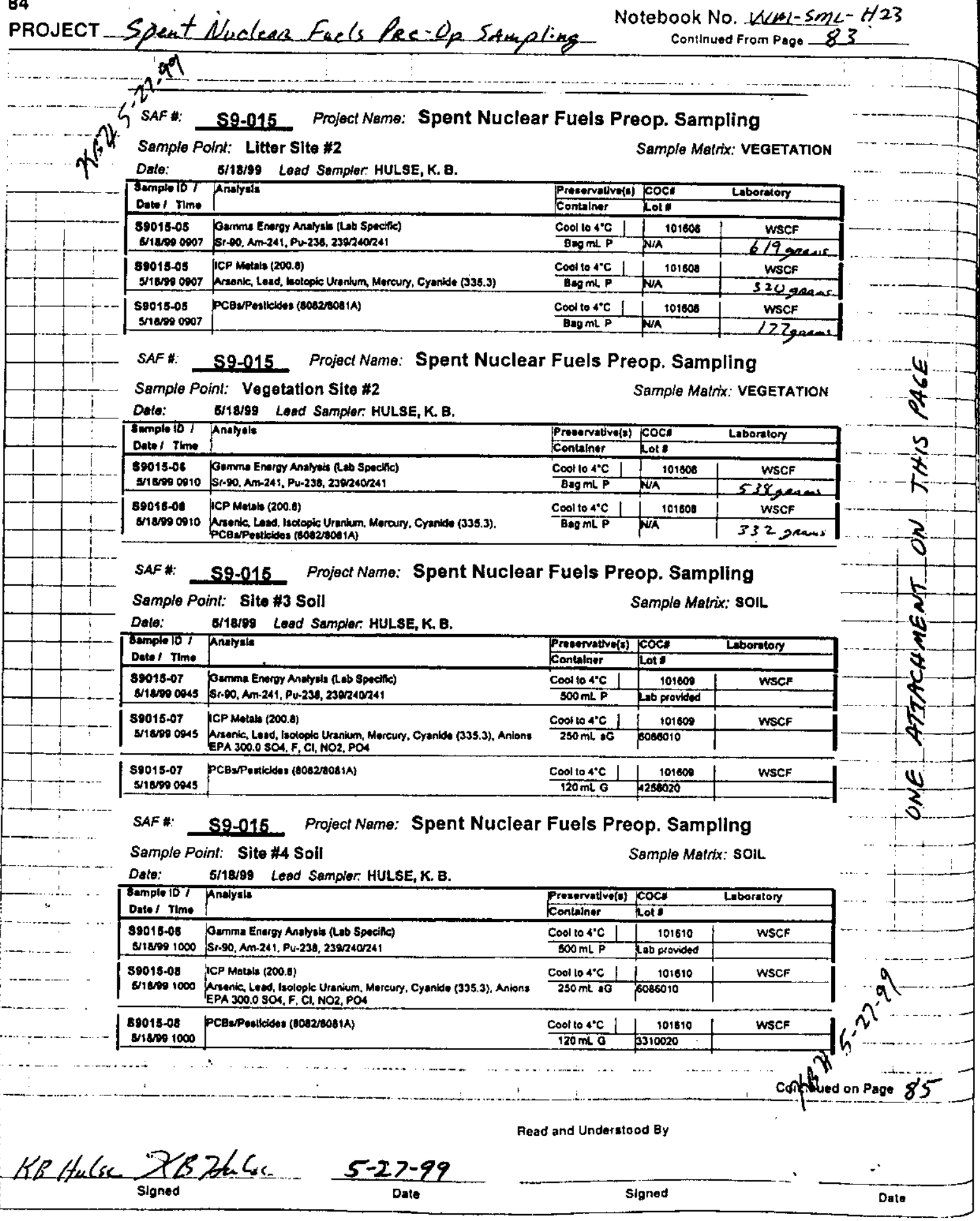




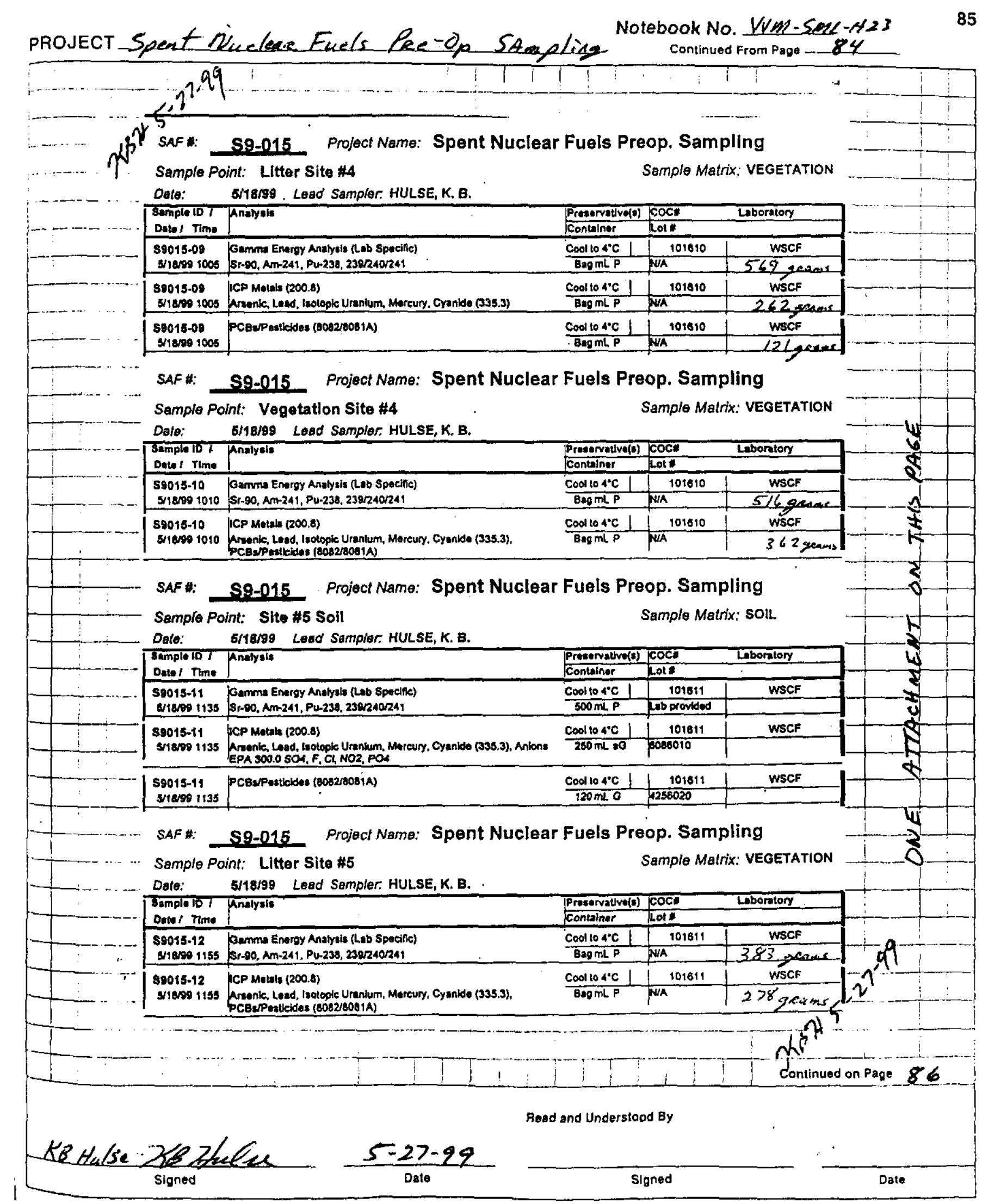

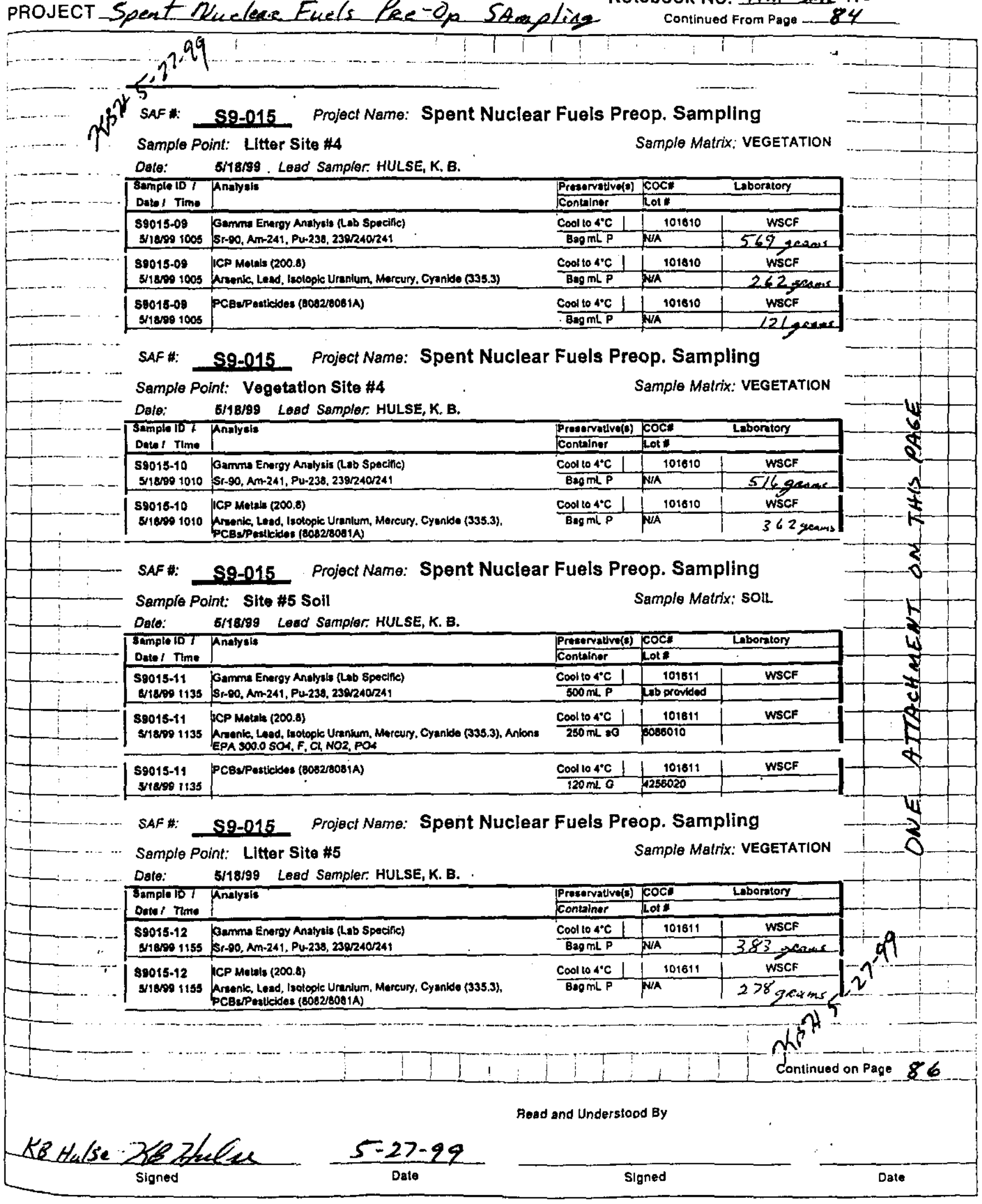


86

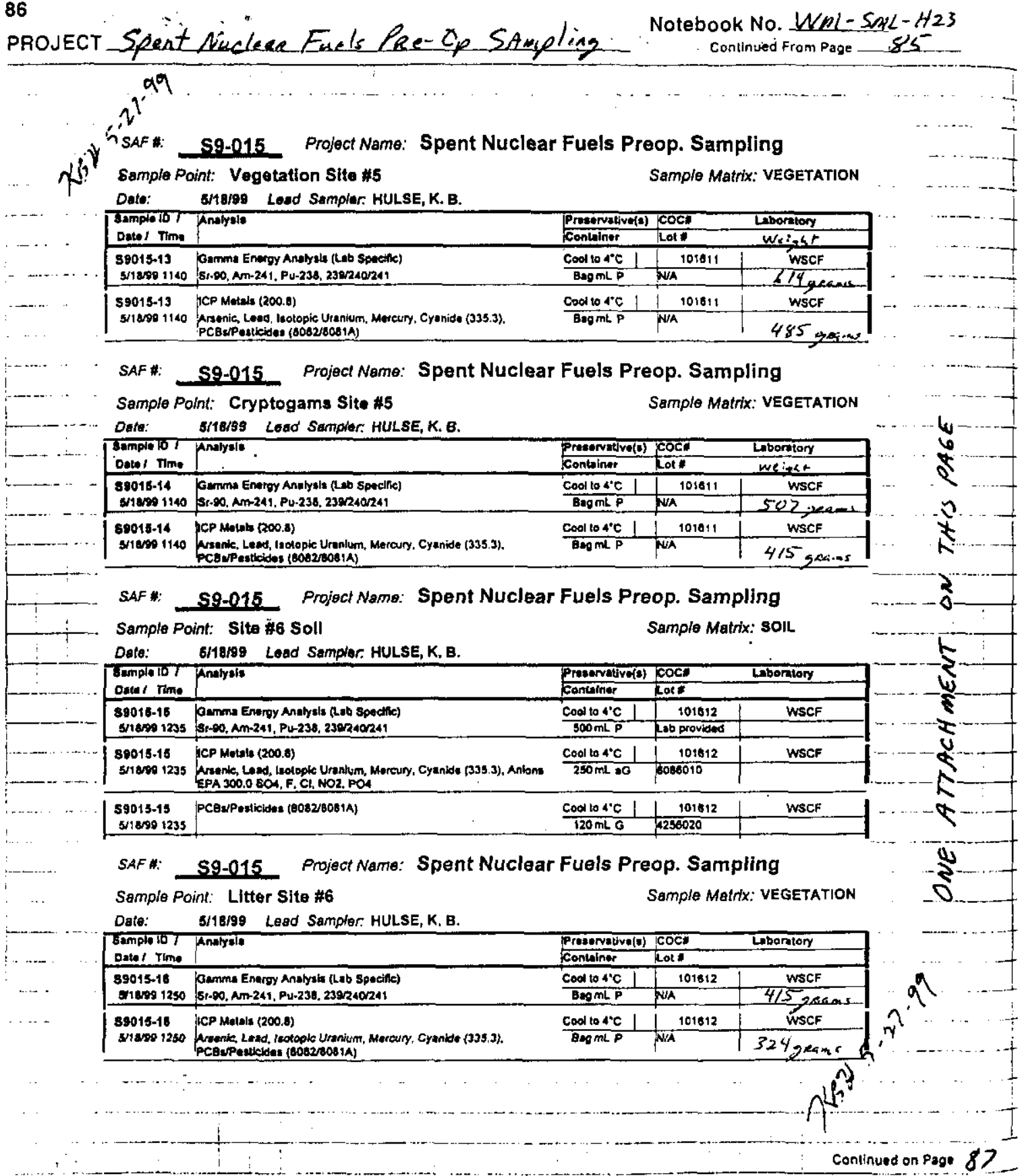

Read and Understood By

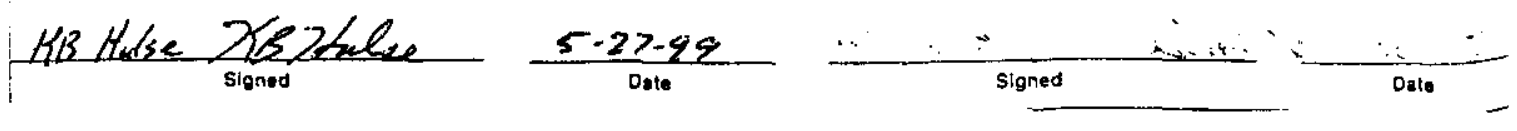




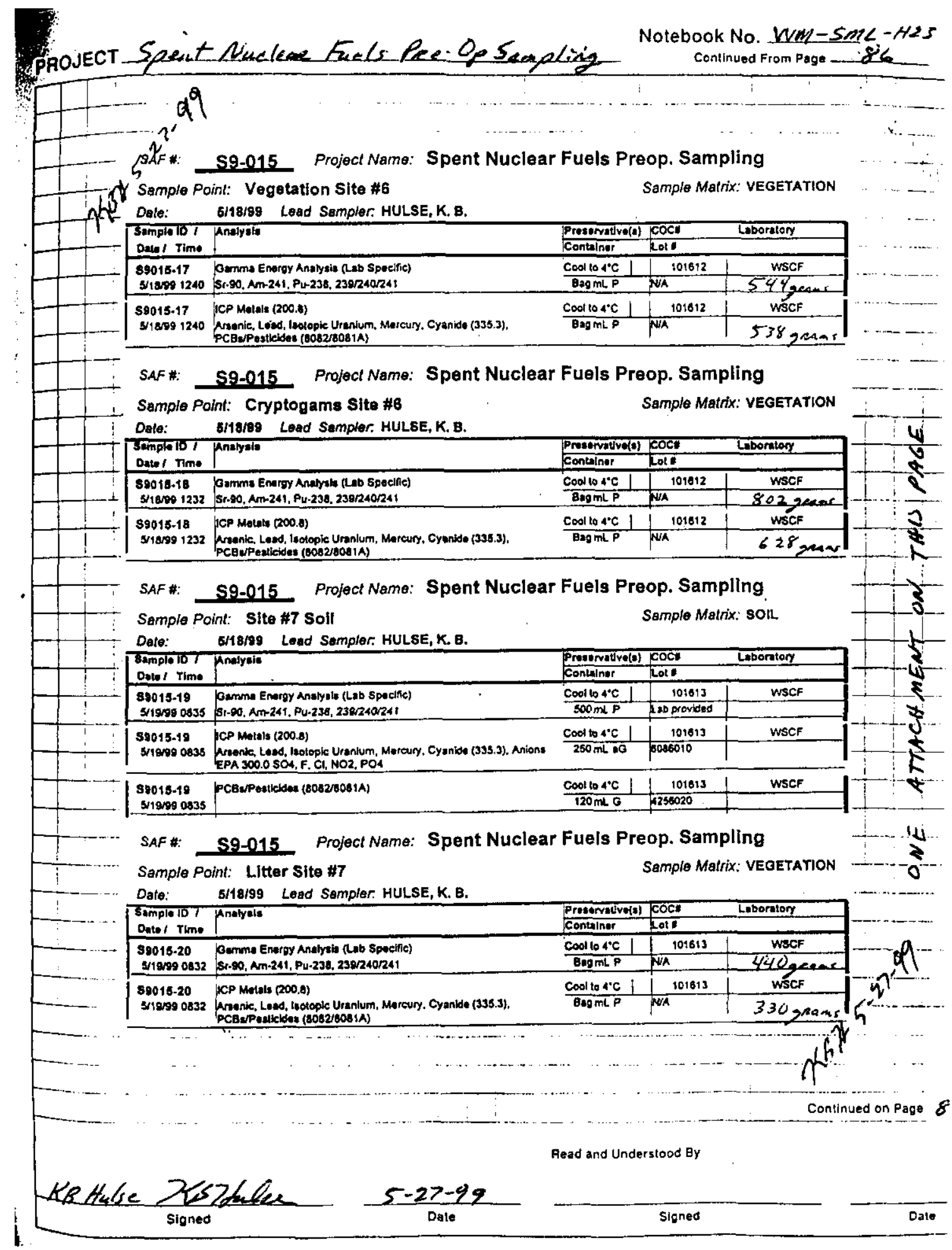




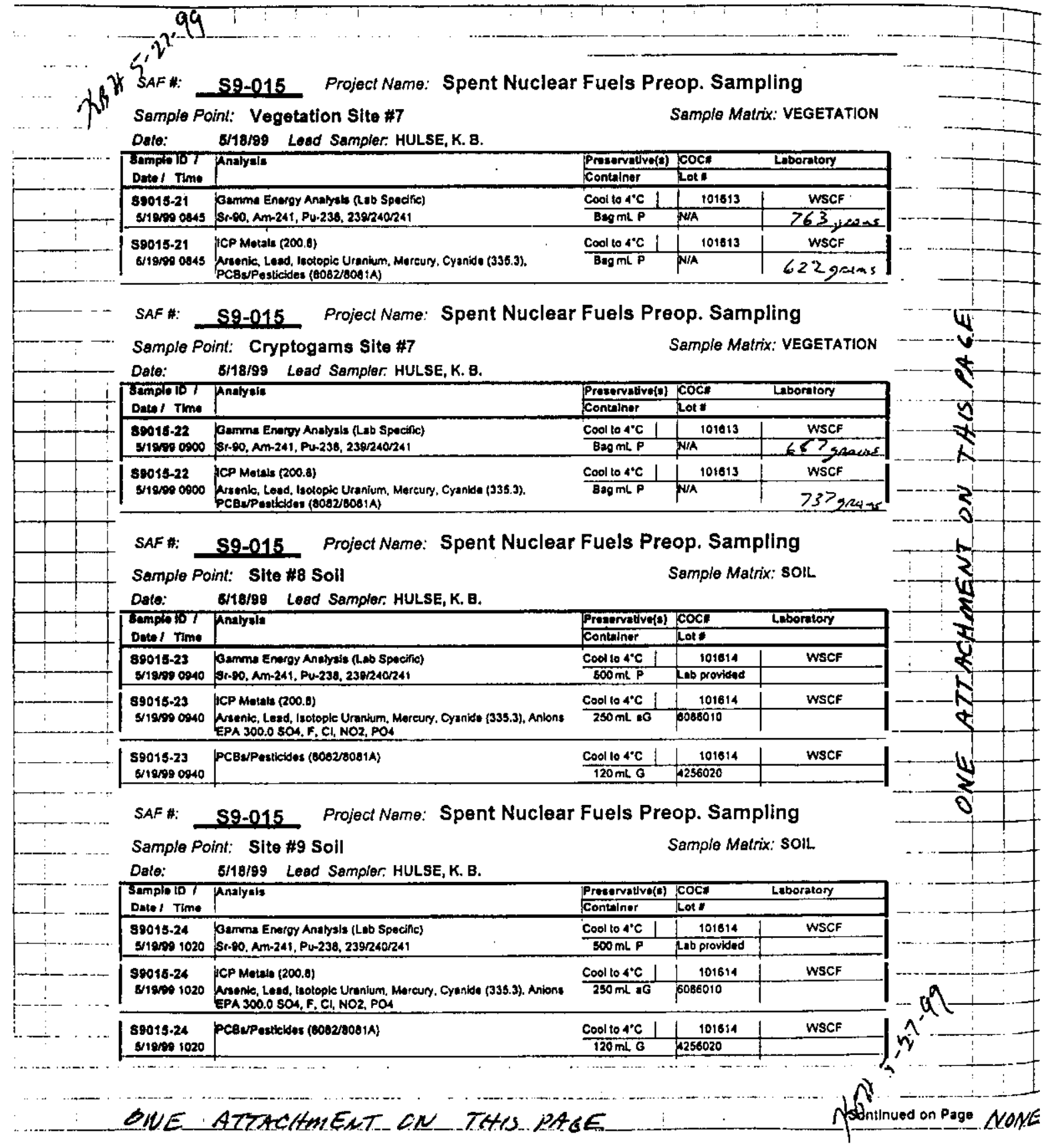

Read and Understood By

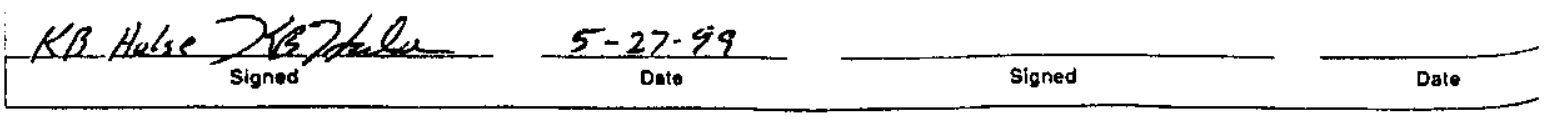



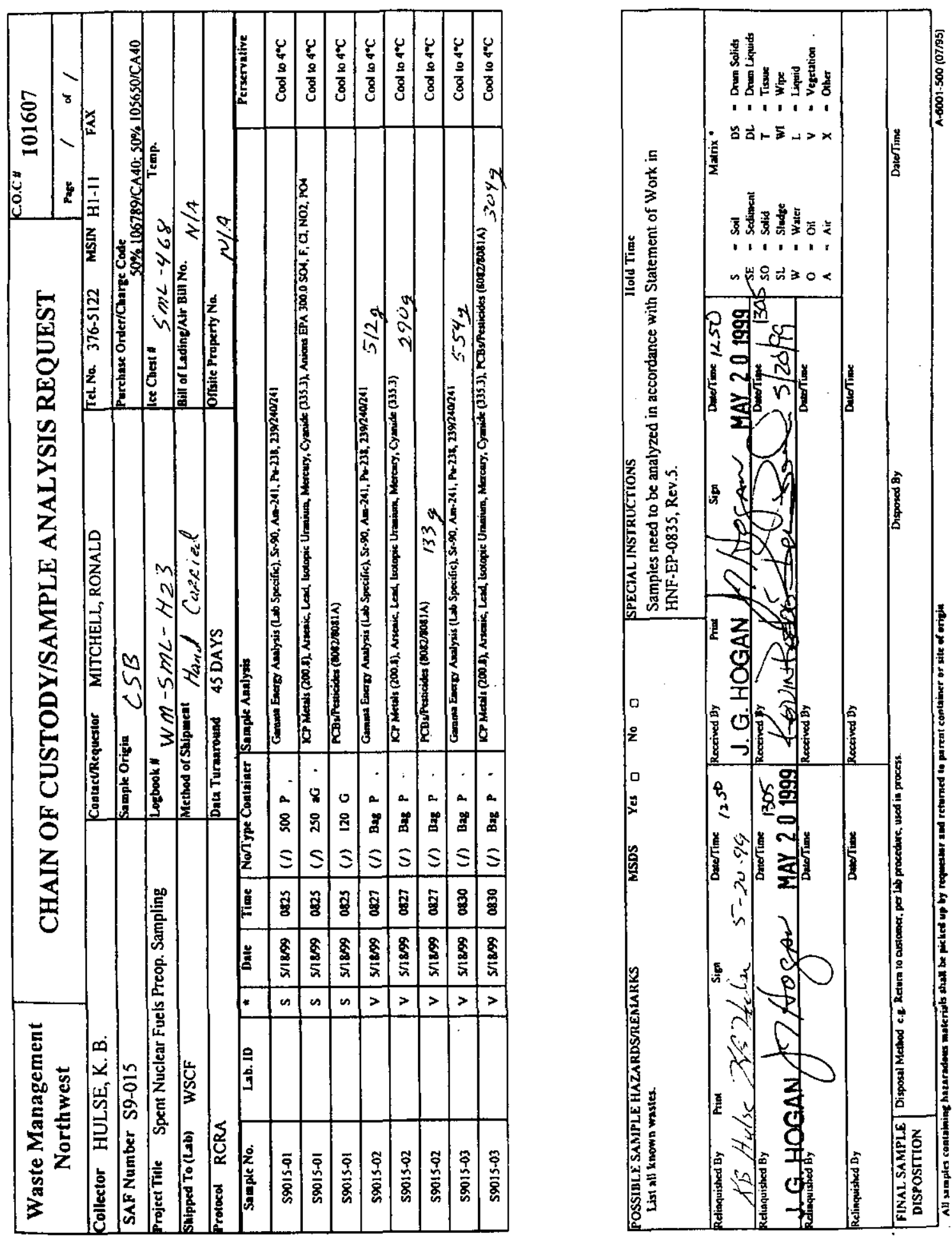
HNF-6150 Rev 0
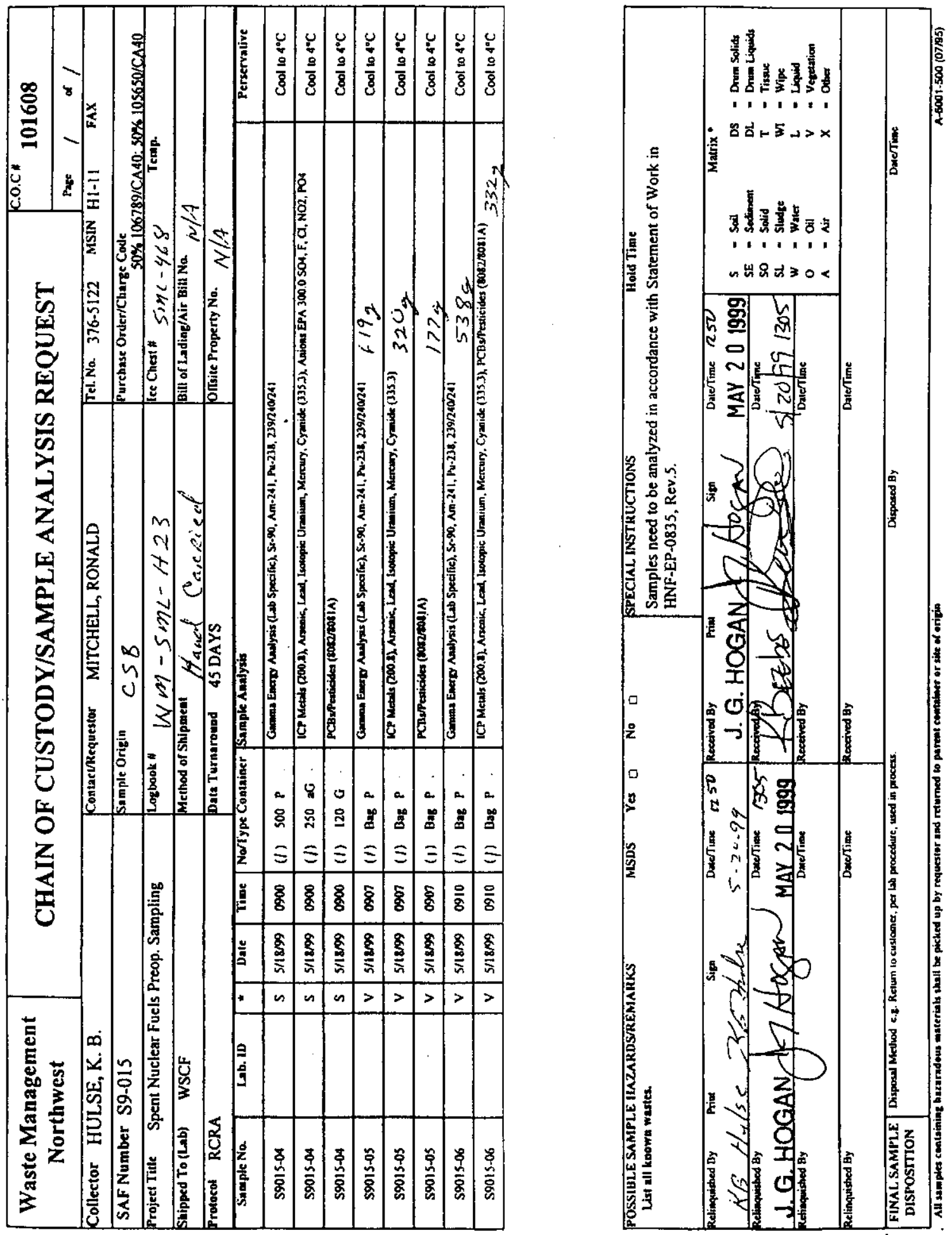

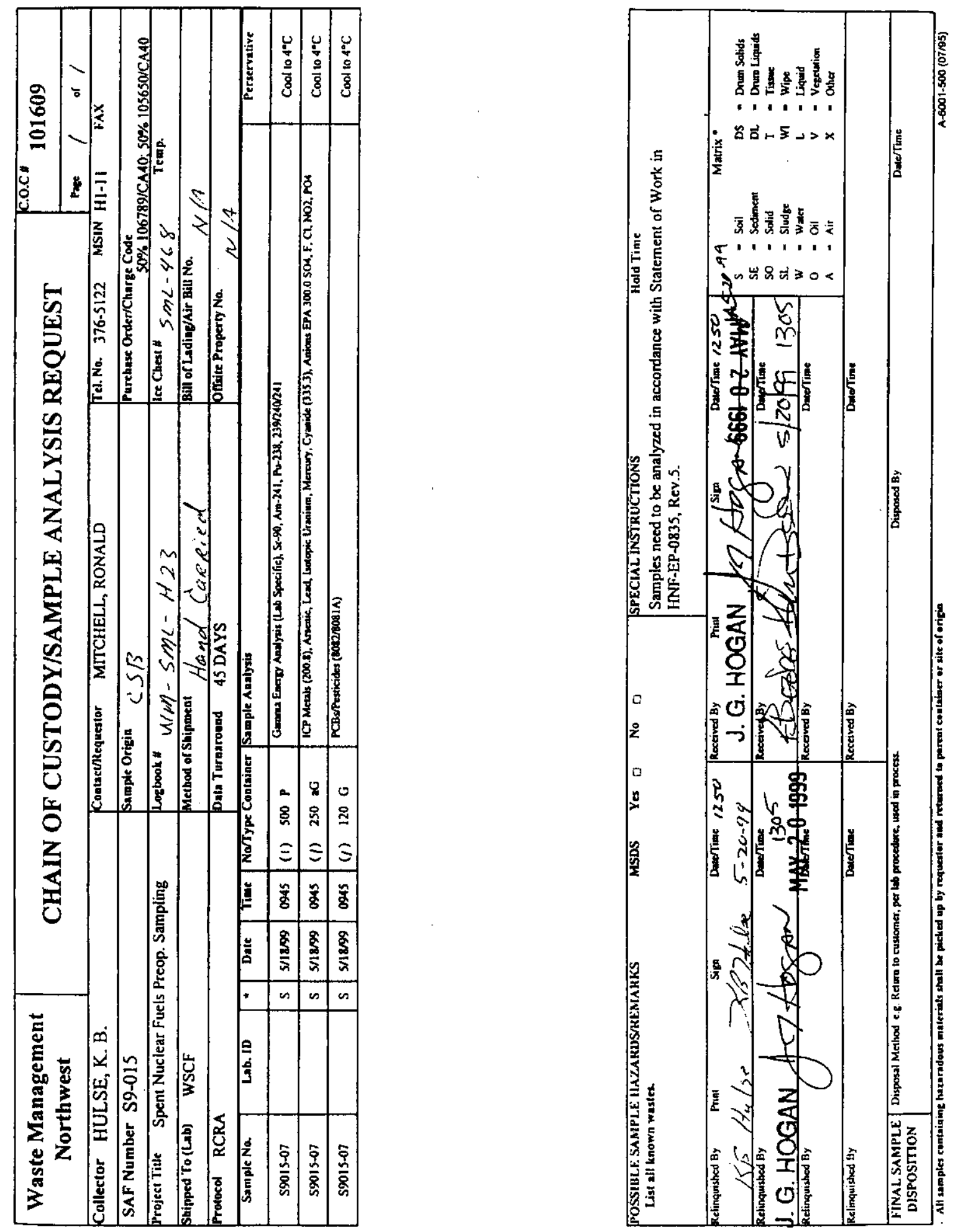

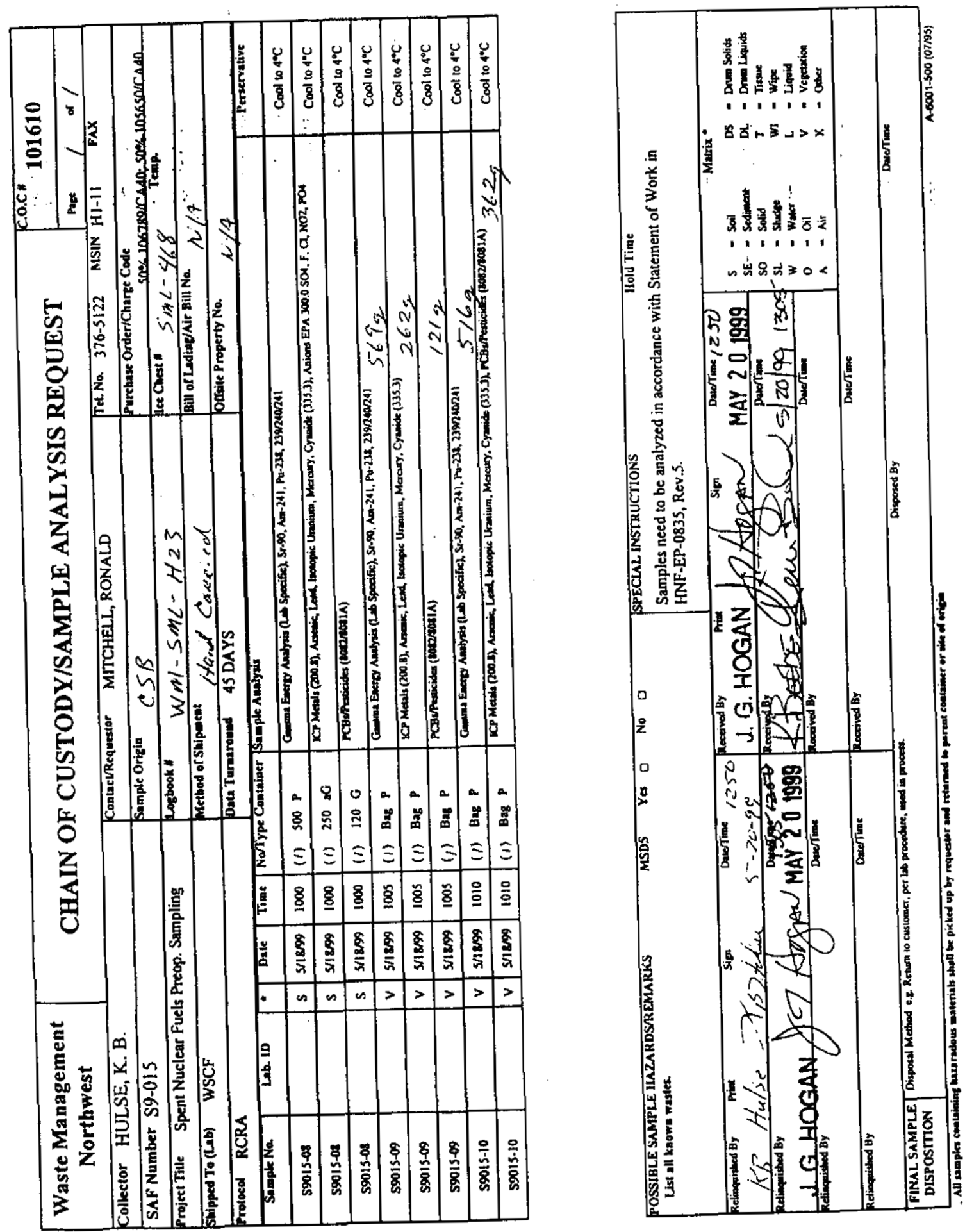
HNF-6150 Rev 0
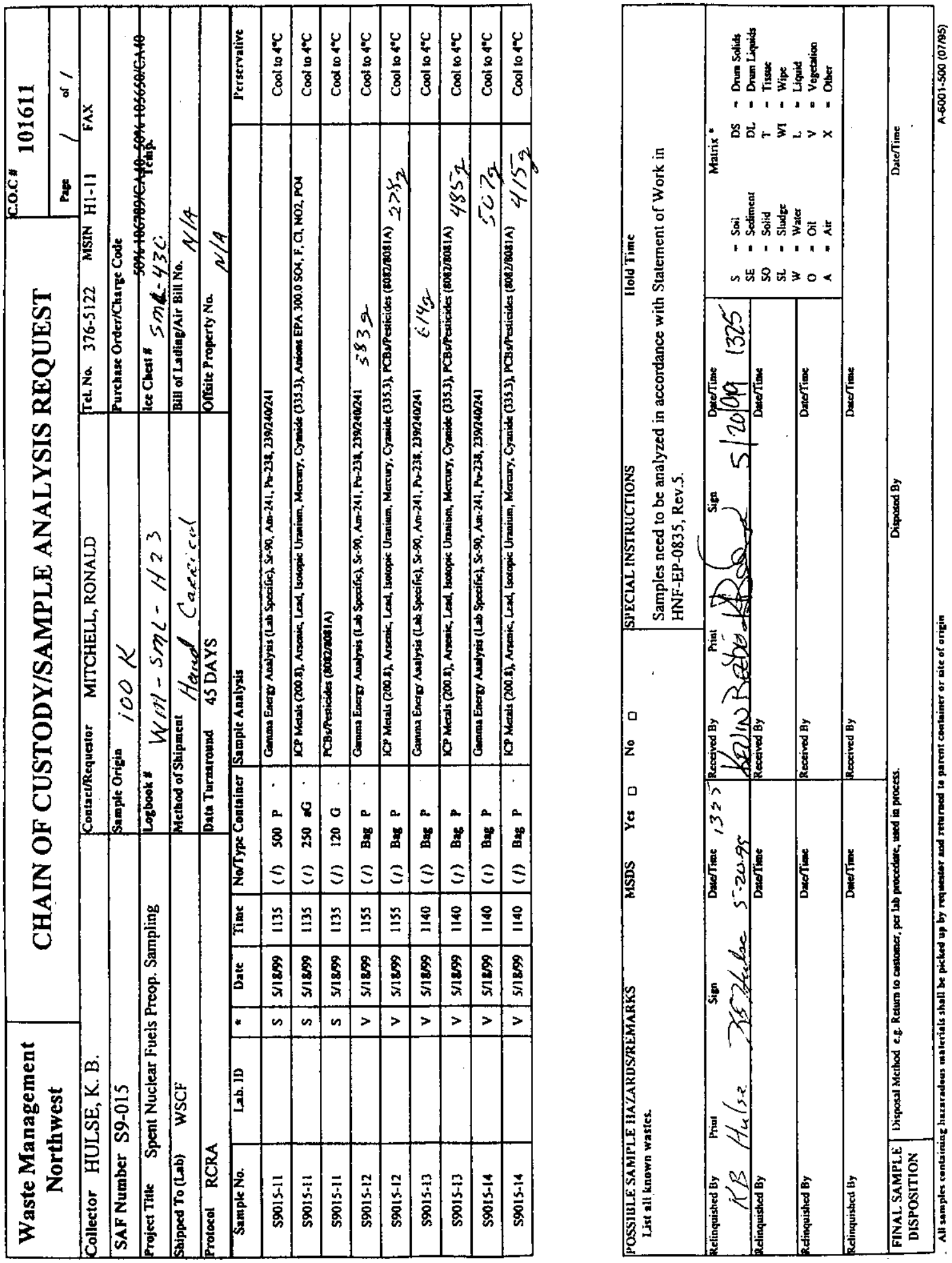

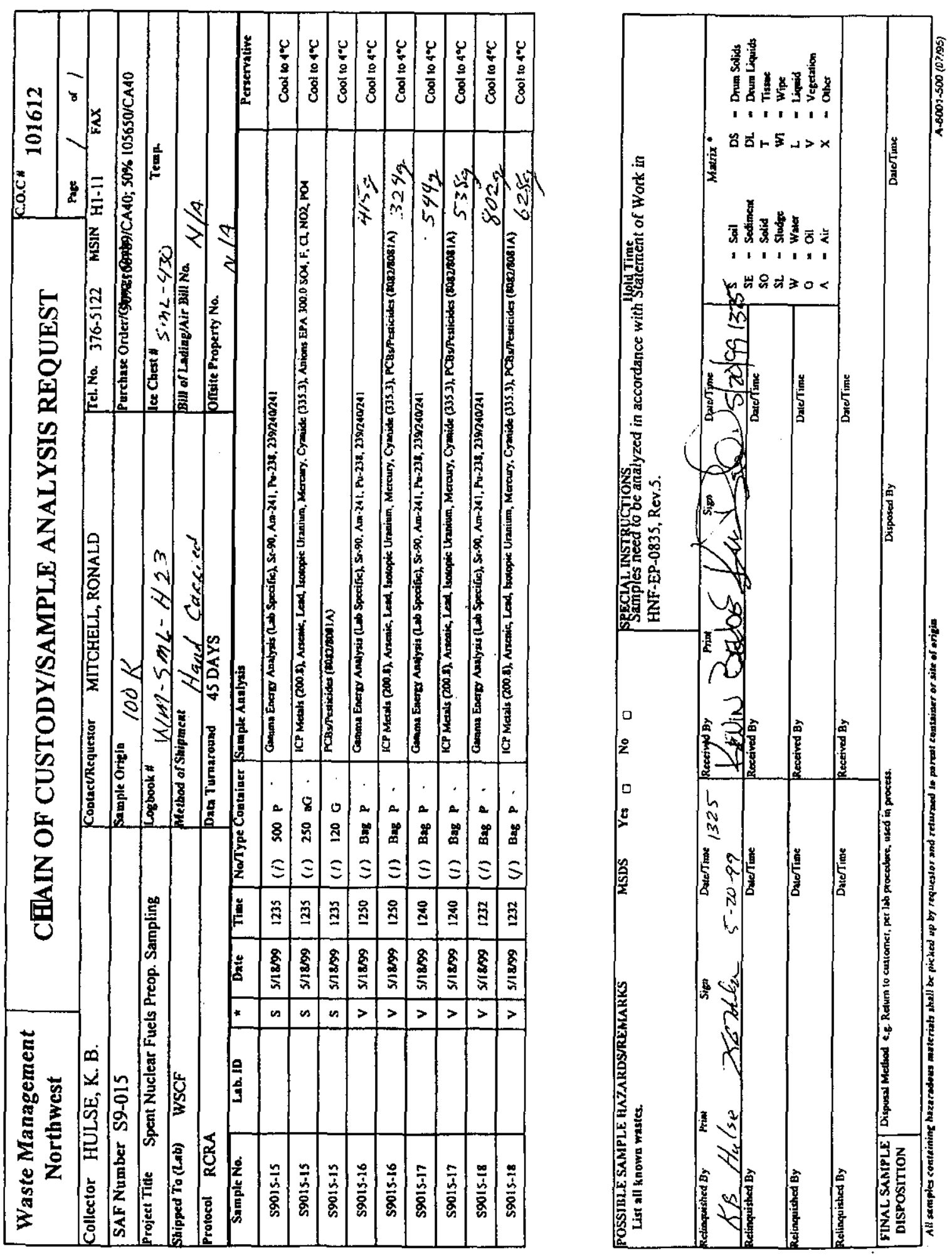

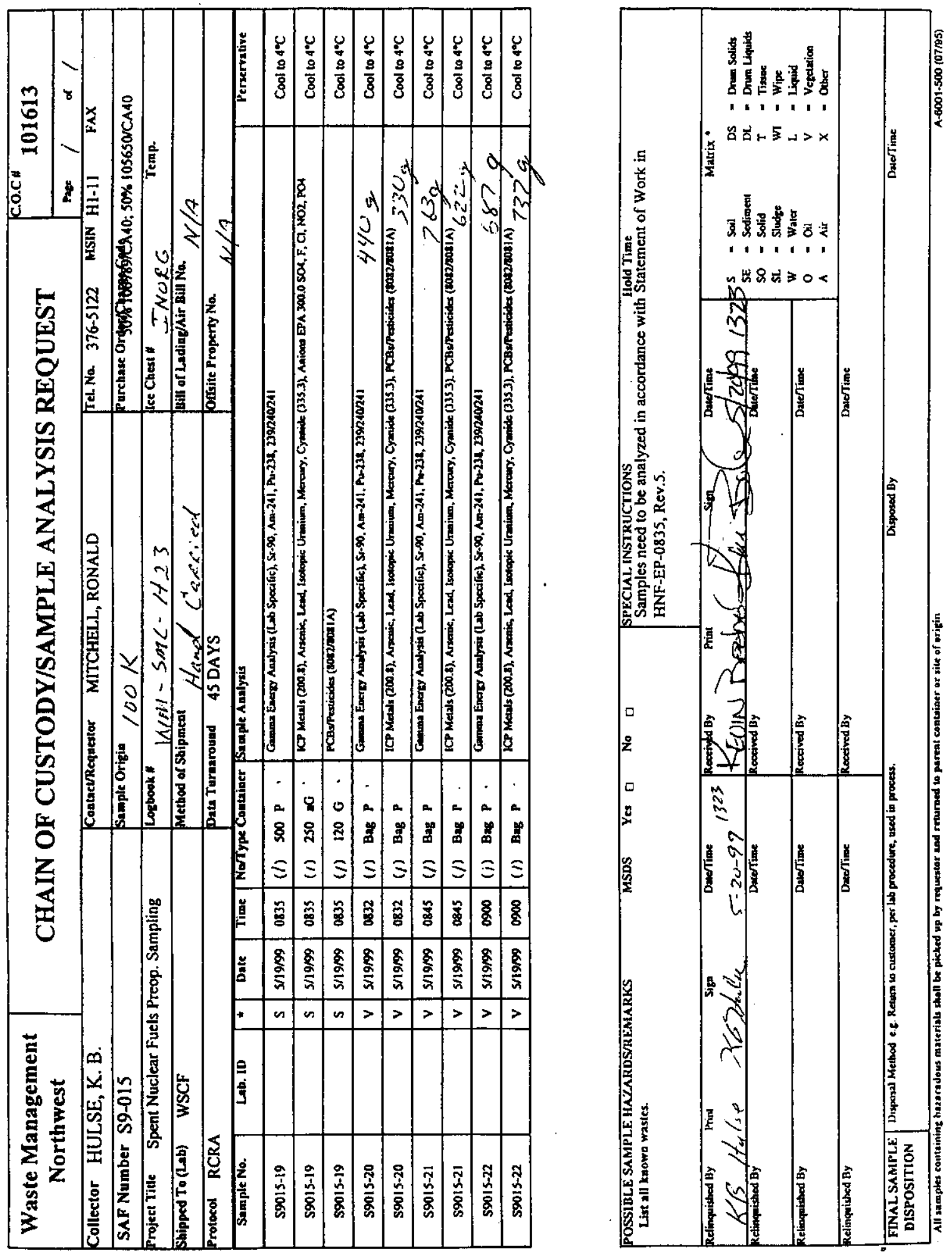

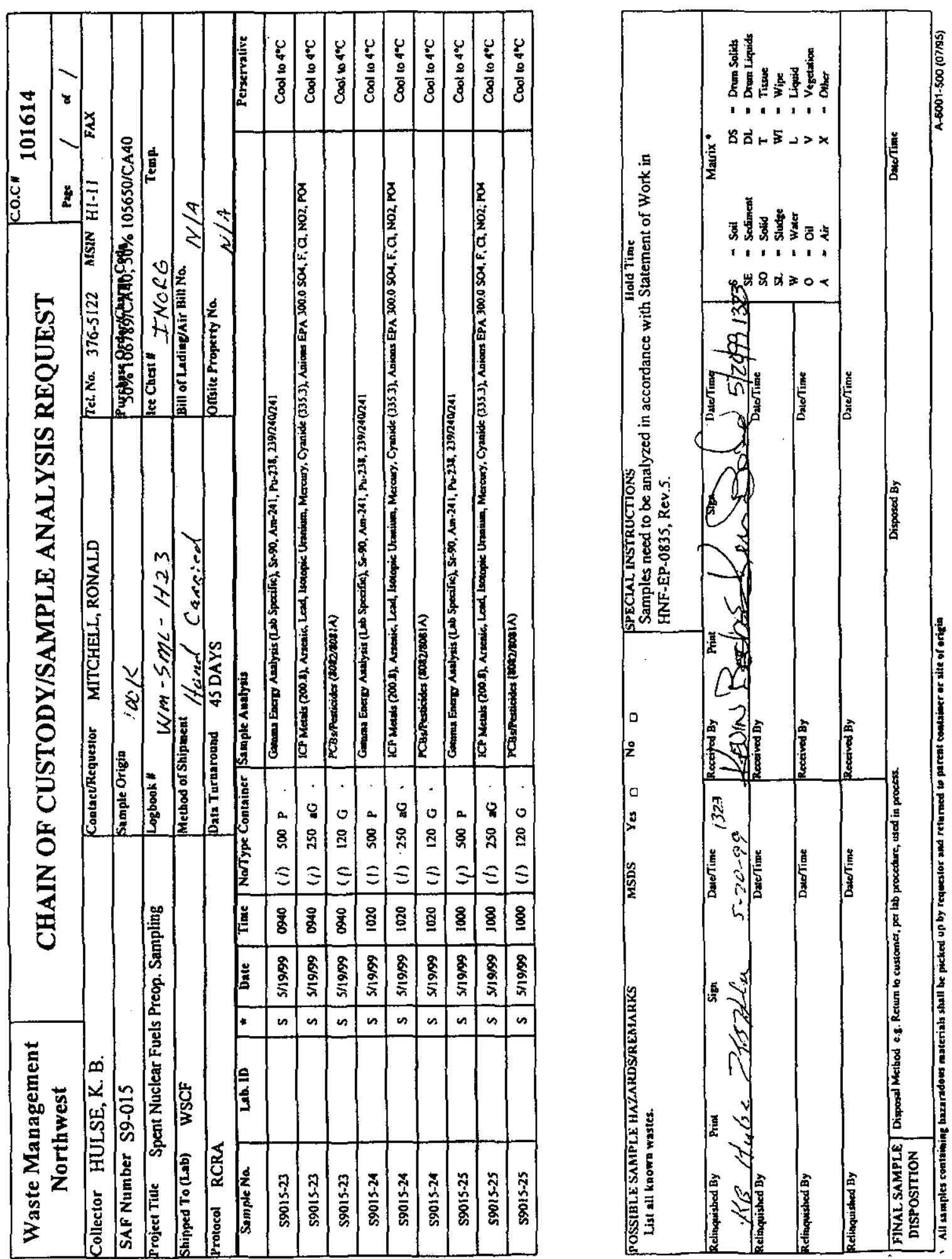


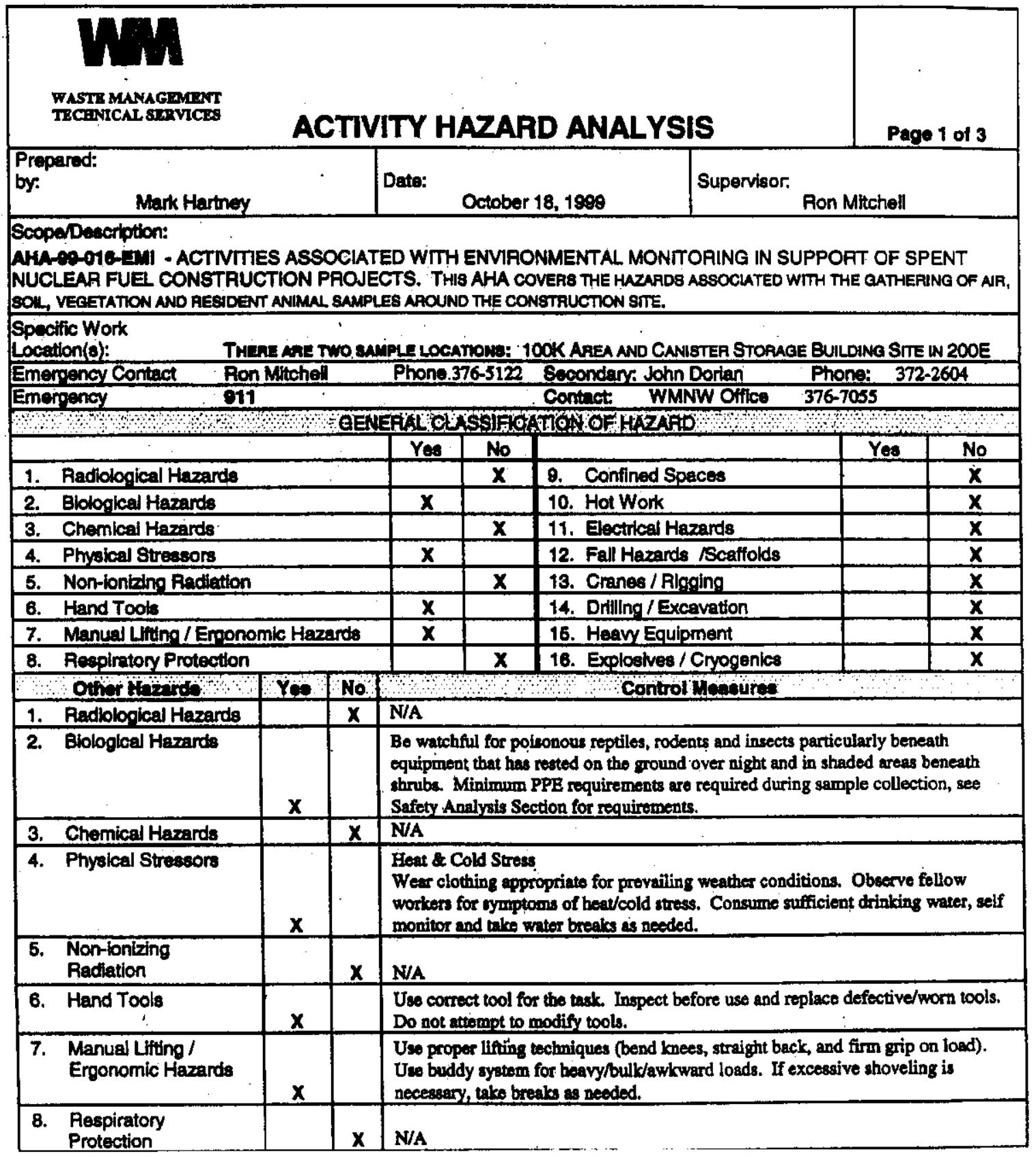




\section{HNF-6150 Rev 0}

\begin{tabular}{|c|c|c|}
\hline 9. Confined Spaces & $x$ & N/A \\
\hline $\begin{array}{l}\text { 10. Hot Work / Fire } \\
\text { Hazards }\end{array}$ & $x$ & N/A \\
\hline 11. Electrical Hazards & $x$ & N/A \\
\hline $\begin{array}{l}\text { 12. Fall Hazarde } \\
\text { Scaftolds }\end{array}$ & $x$ & N/A \\
\hline 13. Cranes / Rloring & $x$ & N/A \\
\hline 14. Drilling / Excavation & $x$ & N/A \\
\hline 15. Heav Equiloment & $x$ & N/A \\
\hline $\begin{array}{l}\text { 16. Exploeives / } \\
\text { Cryogenics }\end{array}$ & $\underline{x}$ & $\mathbf{N} / \mathbf{A}$ \\
\hline \multicolumn{3}{|c|}{ 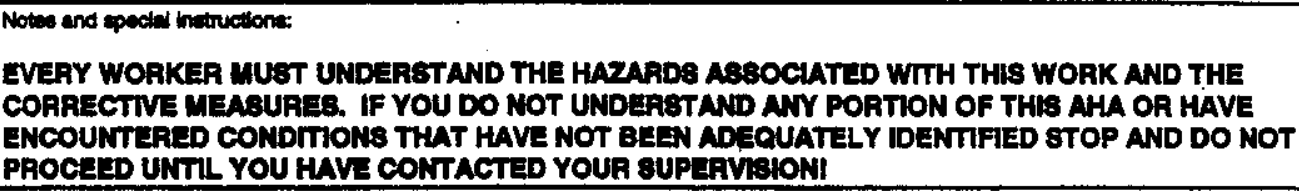 } \\
\hline
\end{tabular}

\section{EXPOSURE ASBESCHINT}

Deicetpotion of Work.condition:

- This task is being performed in an area that has no process knowledge of chemical or radiological hazards. The ecope of this AHA don mot Include these types of hazarda. Should thoy be encountered, additlonal acescament will be nicescary. All of the samples will be gathered outdoors around the perimeters of the 100K Area and the Canister Storage Bullding Site in 200E. As such all types of environmental conditions will be encountered.

Jobas and Tasks

- Ar, eoll, vegetation, and resident anlmals will be collected for subsequent analysis. These samples will be taken by hand with common hand tooks.

Hezand Chancterization

- The work conducted under thls scope is relattvely hazard free. As such it presents a low hazard potential. Of primary concem are the hazards from over exertion in inclement weather, animalinsect bita/sting and encountering areas that have not been previouely identified.

- Other identffled hazards include a potential for fire shoutd vehicles be taken off roed.

Monitorinomadical Surveillance

None identified for this scope)

\section{SAFETY AWLYSS BECTION}

Minimum Personal Protective Equlpment. (PPE)

- Sleeved shirt at least 4 inchee below the shoulder.

- Long pants.

- Substantial footwear - footwear that is constructed to provide adequate protection for the work environment. Shoes generally should be closed toe, firm materlal with a rigid sole.

- Leather gloves or equivalent while sampling.

Offroad vehicle use

- Should vehicles need to be taken off roed, they shall be equipped with a fire extinguisher and a shovel. Park them in areas where vegetation will not come in contact with the underide. Awways notify 911 if there is any indication of a fire and do not attempt to flght the fire unless you can do 80 wthout endangering yourself or others.

Page 2 of 3 


\section{Emeroency Preparadness}

- The sample crew shall have at least one member certfied first ald/CPR. A first aid klt will be avallable at the job location. Communications will be by cellular phone, radio or other equivalent methods. Each member of the team will know how to activate the 911 system.

All emergencies such as injury, fire, explosion, spill shall be reported using the listed identified emergency numbers. After emergency eervices have been contacted and the ste is stable, contact WMNW management on the phone matrix below. Continue to call until you reach one of these points of contact.

\section{EMEAOENCY NUMBERS}

Hantord Site Emergency Services

(for Hanford land line only)

Feld Team Leader (Ron Mitchell)

Manager (John Dorian)

Safety Representattve (Mark Hartney)

EMEACENCY MEDICAL SERVICES

\section{$373-3800$}

\section{1}

Office

$372-2604$

$372-3288$

Cellular $\begin{aligned} & \text { Pager } \\ & 85-2347 \\ & 85-3348\end{aligned}$

$\begin{array}{llr}200 \text { East } & 2719 \text { EA } & 373-2314 \\ 200 \text { West } & \text { Cloced } & \\ 300 \text { Area } & 3919 A & 370-3315 \\ \text { HEHF } & 3080 \text { G. Washington Wy. } 376-6881 \\ \text { Kadlec Medical Center } & 898 \text { Swift Ehd } & 046-4611\end{array}$

Kadlec Medical Center 888 Switt Elvd $846-4611$ 


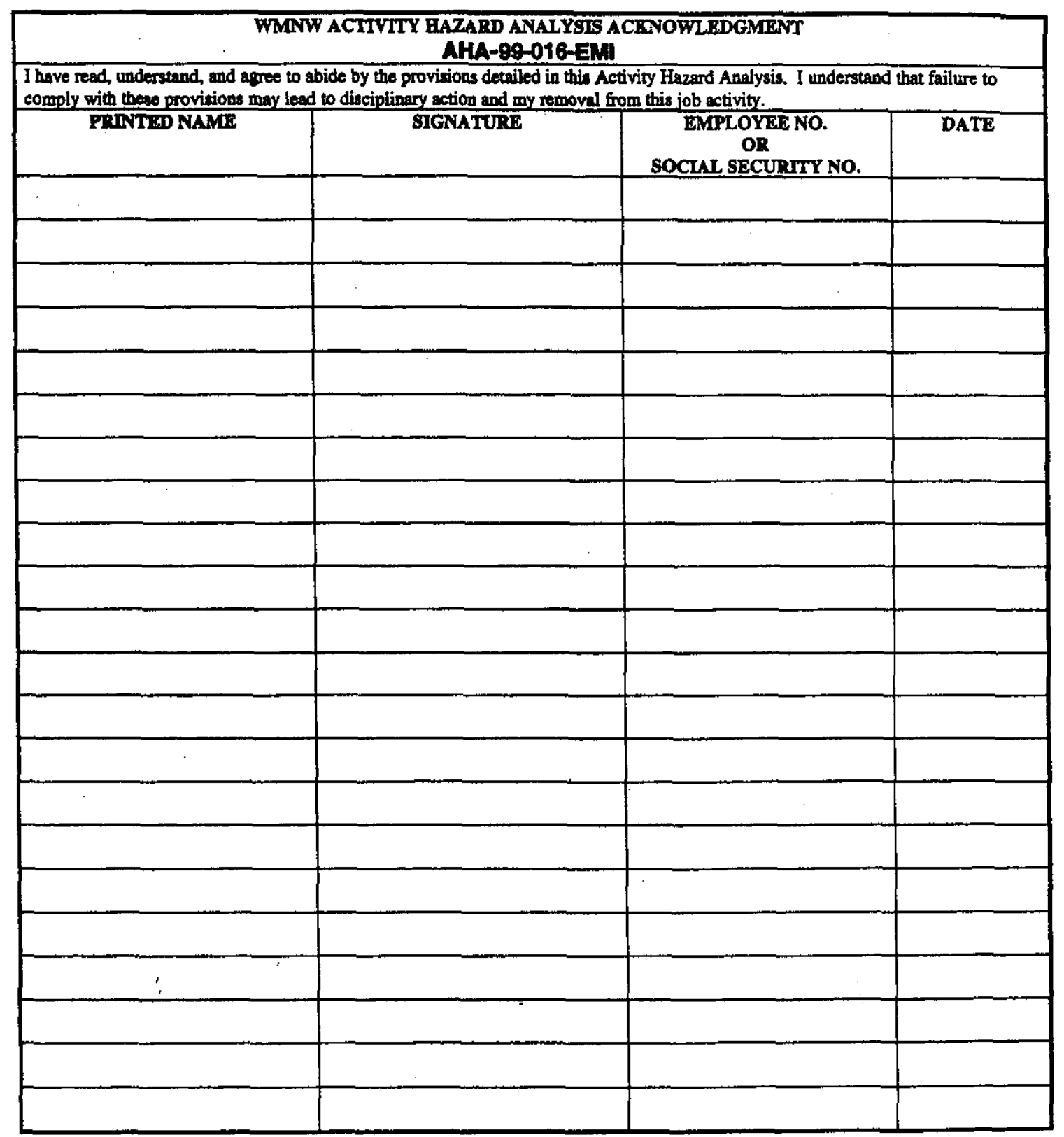


PROJECT SPENT NULLEAR FLIEL /RE-SAMPLE

Notebook No. LIIIT-SML-HL 7

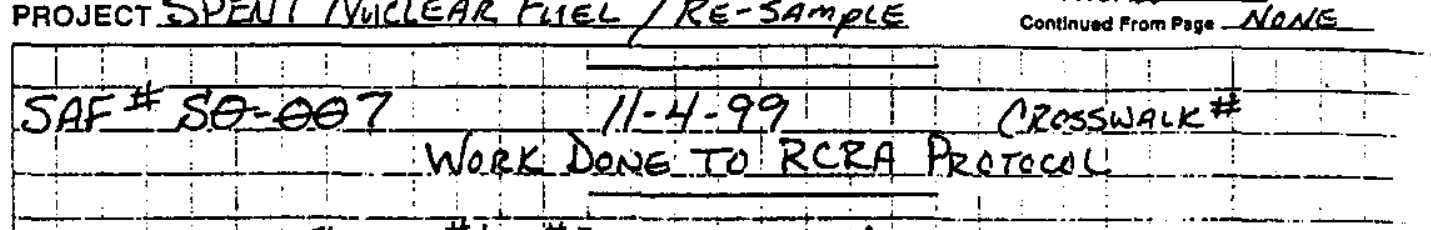

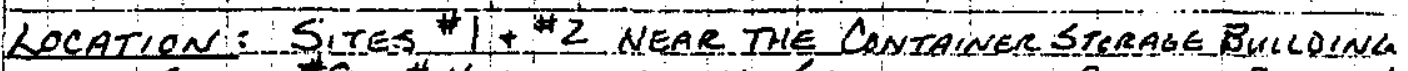

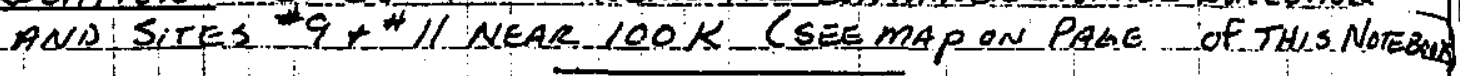

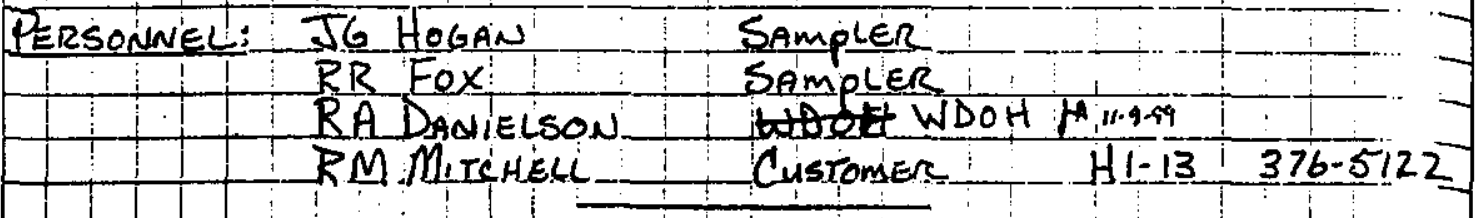

Purpose: Baseline Investigation SAP HNF-SD-SNF-AP COS PPE: BLUES, Hard Hat SAFETYGLASSES SURgeons gloves

SAmoLE EVENT:SAMPLES WERE CAUECTED TO SUPPORT THE

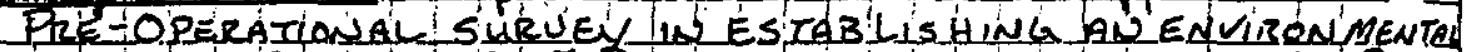

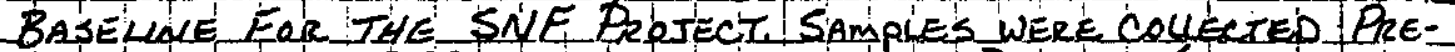

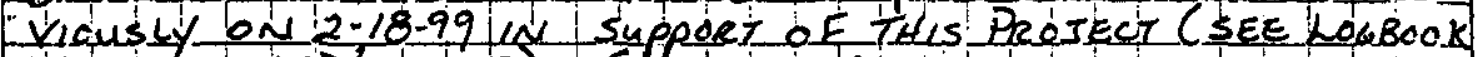
WM-SML-H23/PAGE 73). SOLLAND CRYPTOLAMS WIERE COLLECTES EROM THE TWO SITES BJ THE CSB. SOL ICRYPTOGAMS AND VEGE IATION WERE COLLECIED FRCM THE SITES NEARITHE VOO-KIARER

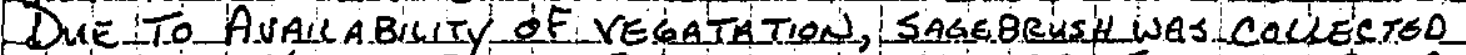

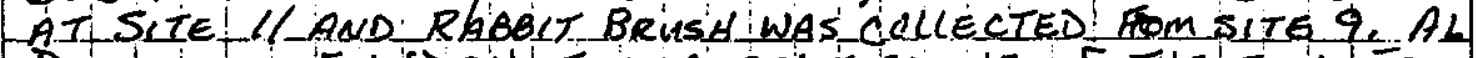
DANiESON OF WDQHLTSOK A SPLIT SAMPLE OF THE SOLLIFROM SITE 1 AND R SPLT SAMPLE OF THE VEGATATION FROM SITE $11_{1}$ SAMPLE VETHOD SOIL SAMPLES WERE COLLECTED WITH THE USE

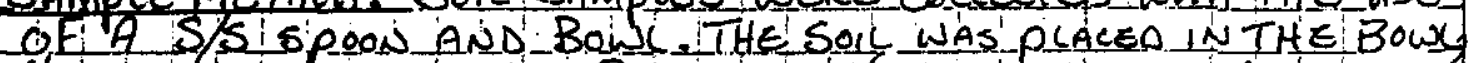

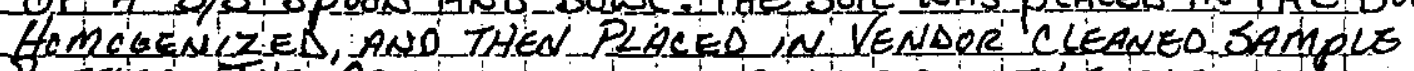
BOTTLES, THE CRYPTOGAMS_WERE CULCTEO WITH SURGEONS LUOUES

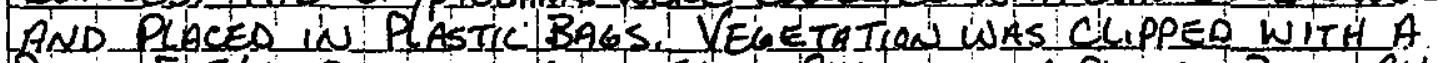
PAIR OF S/S SCISSORS AND THEN PLACED IN A AASTIC BAG ALL

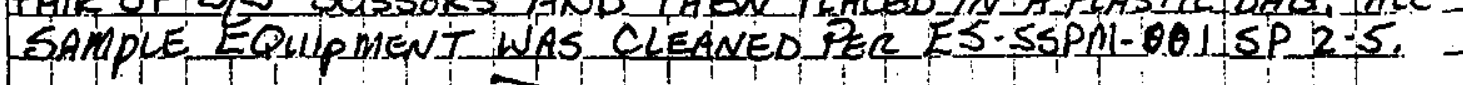

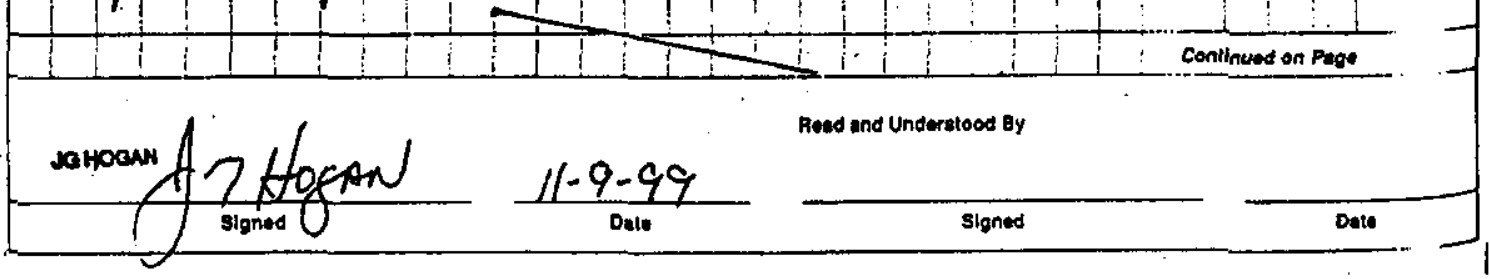




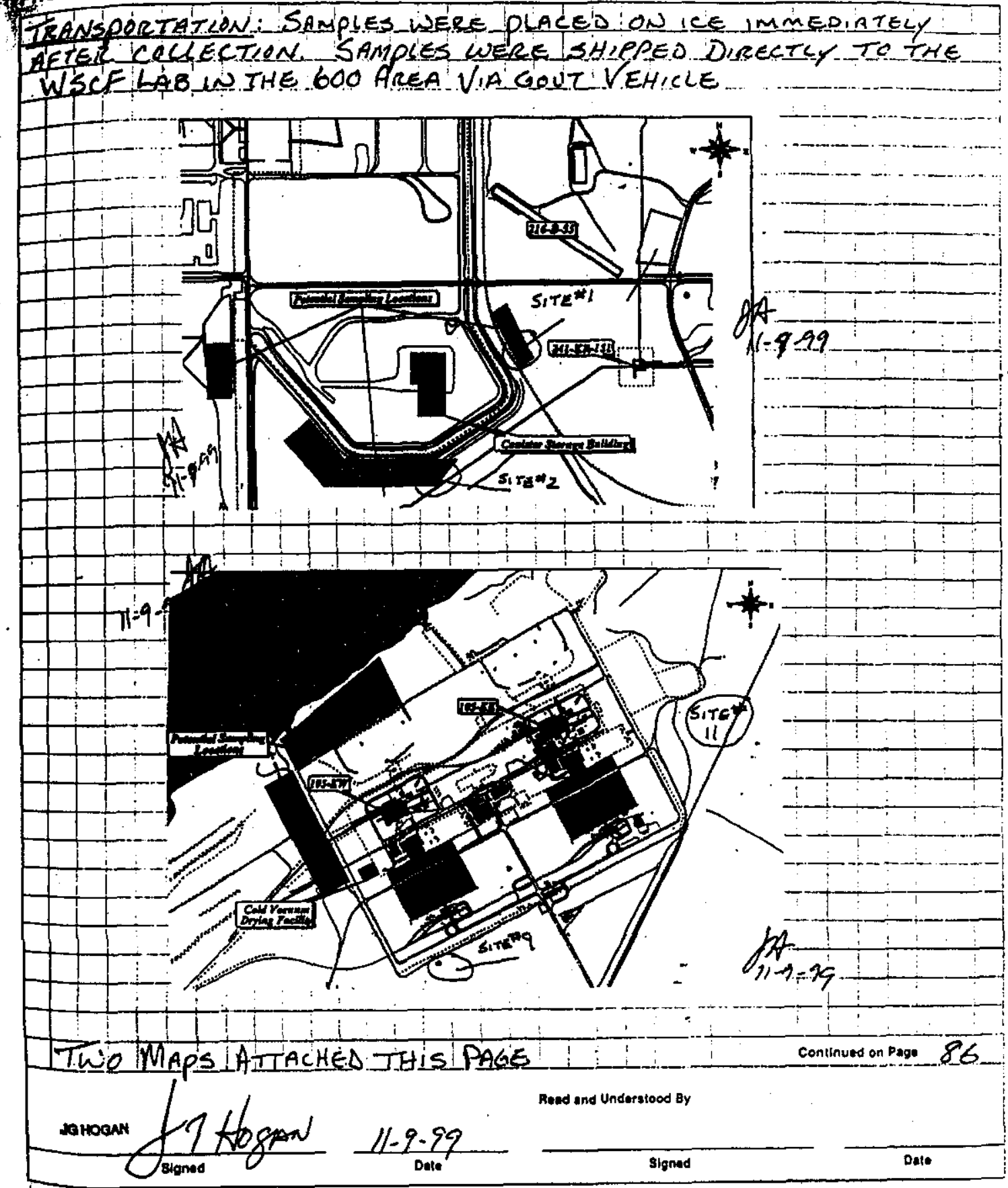




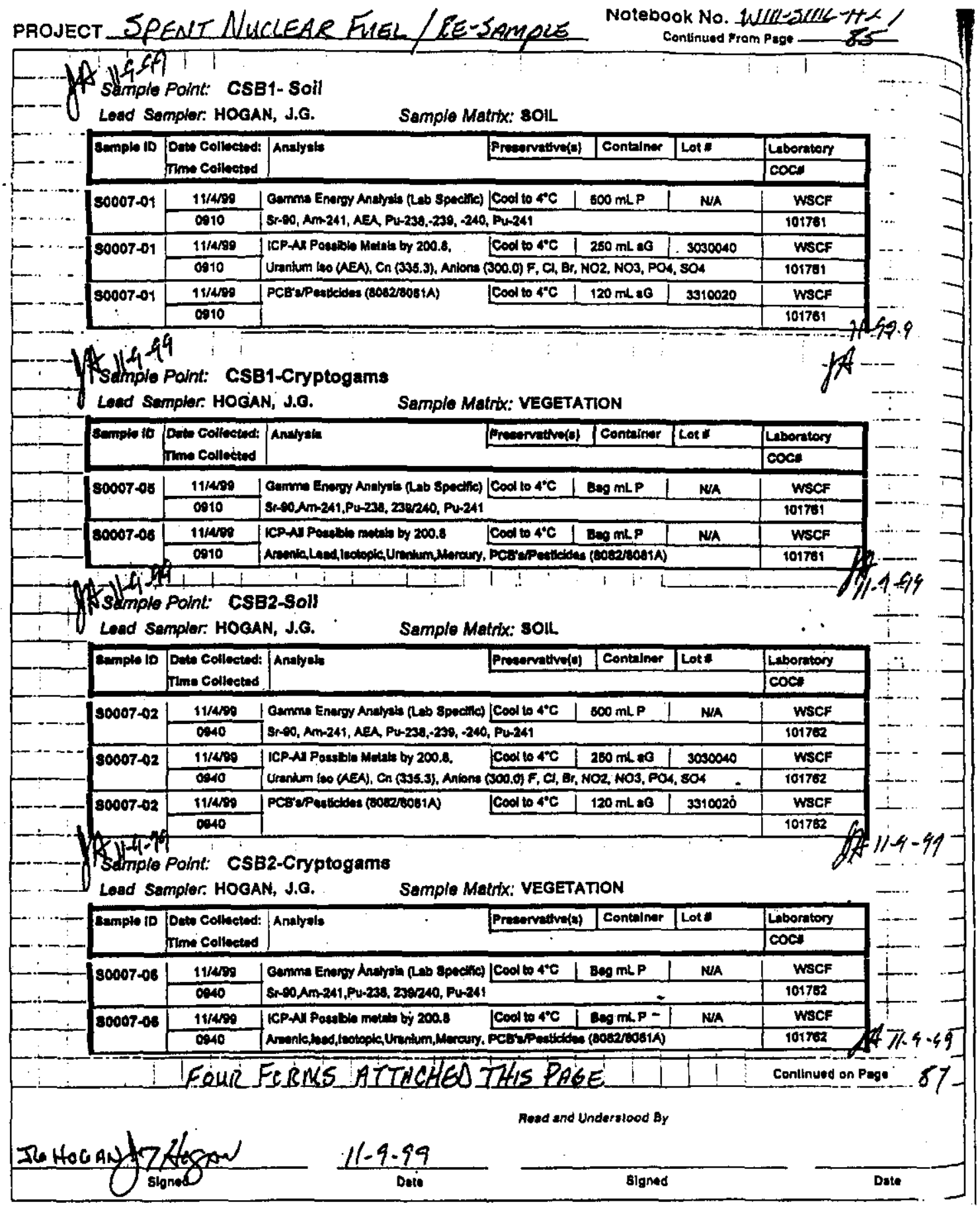




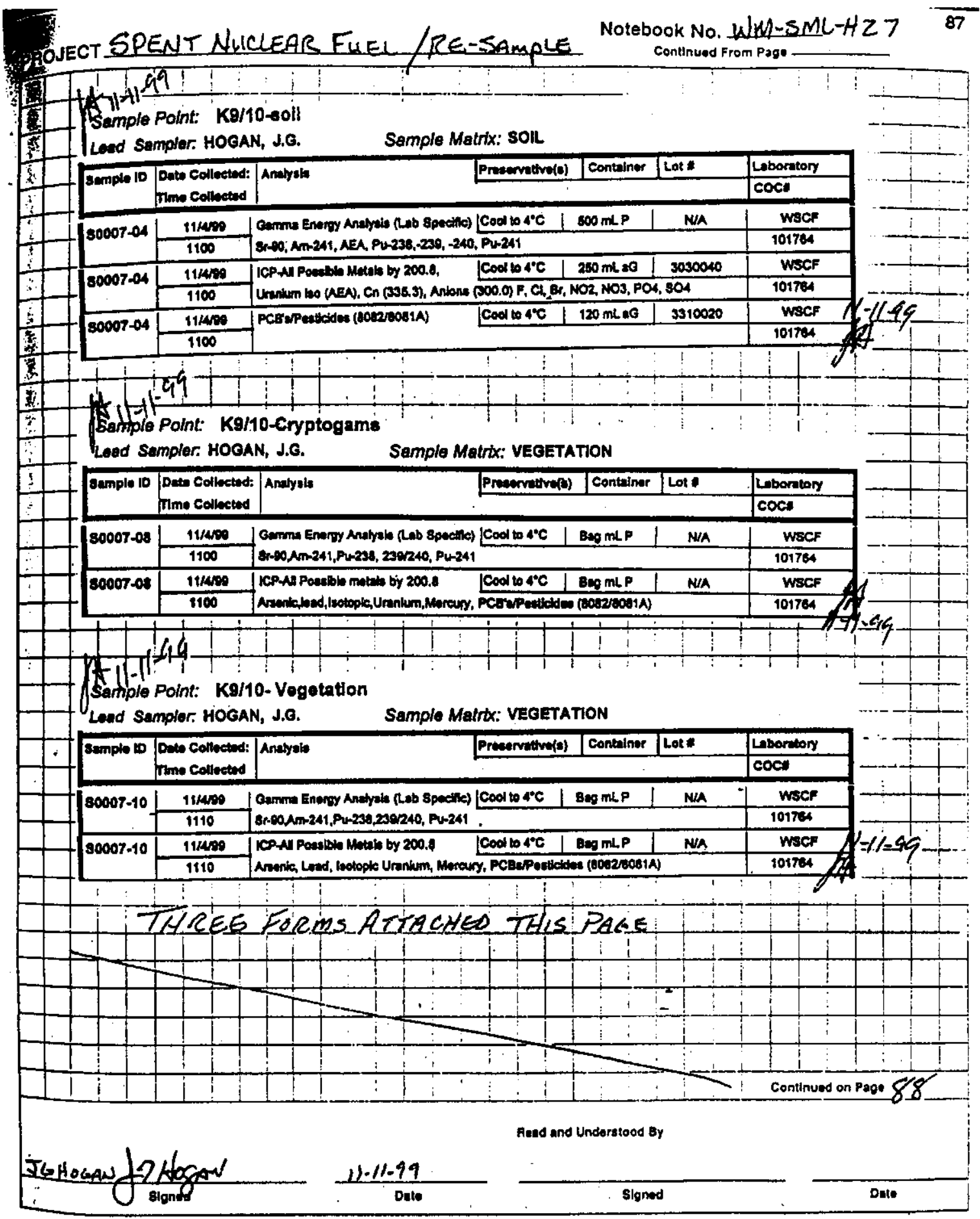


${ }^{88}$ PROJECT SPENT NUCLEAR FIEL/RE-SAMPLE

Notebook No. $14 M-S M L-427$

Contumed From page 8 ?

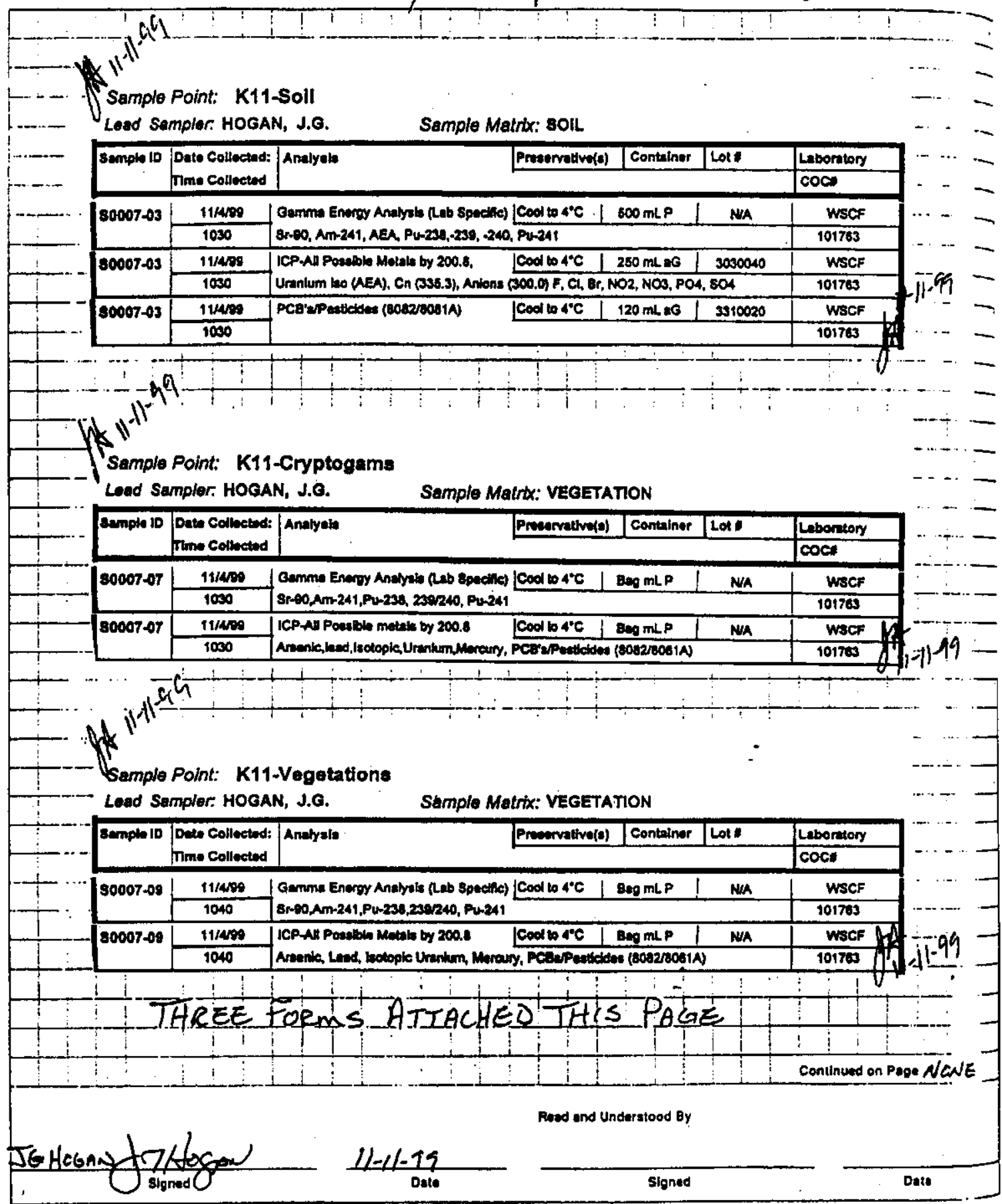




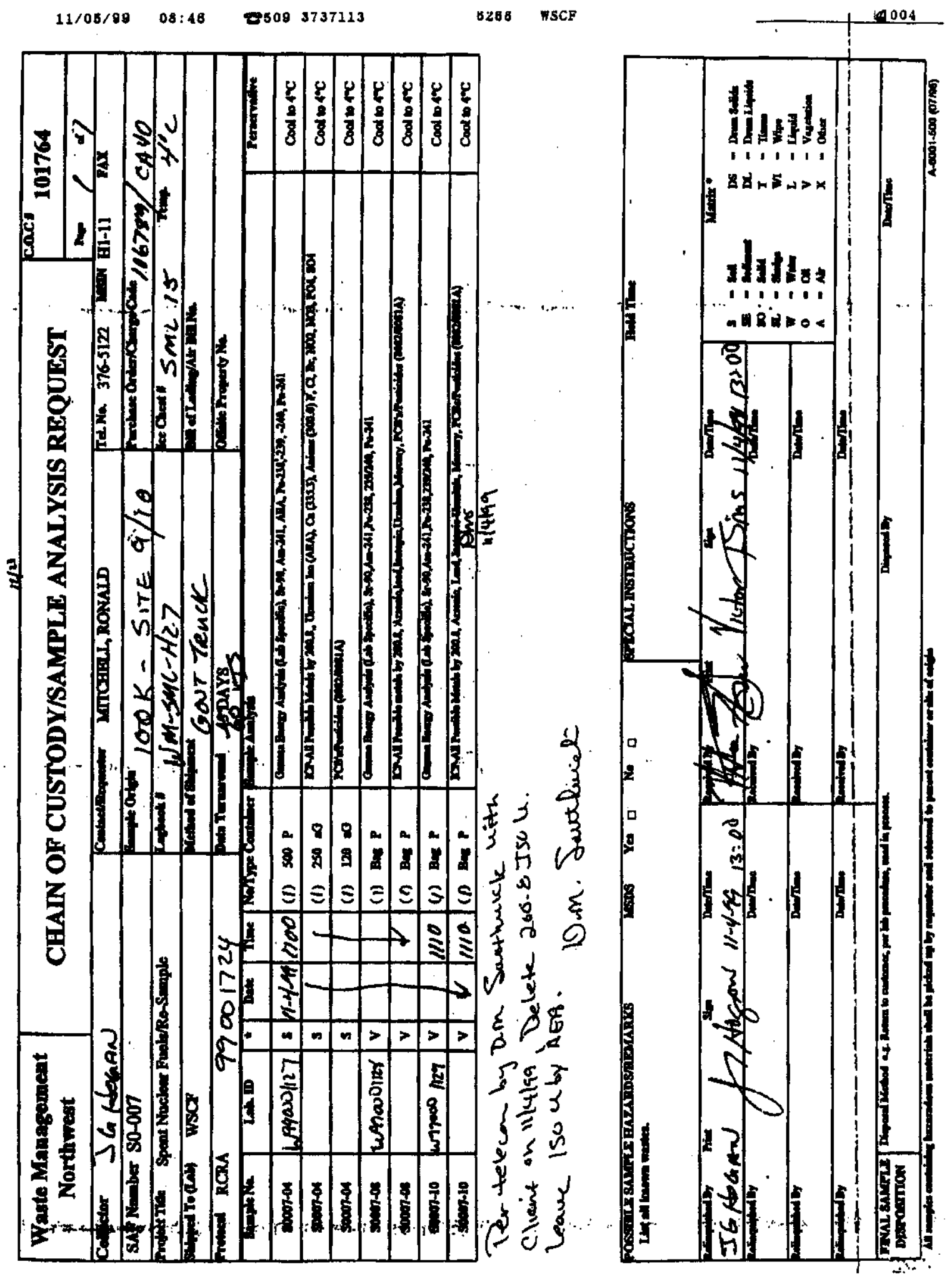


HNF-6150 Rev 0

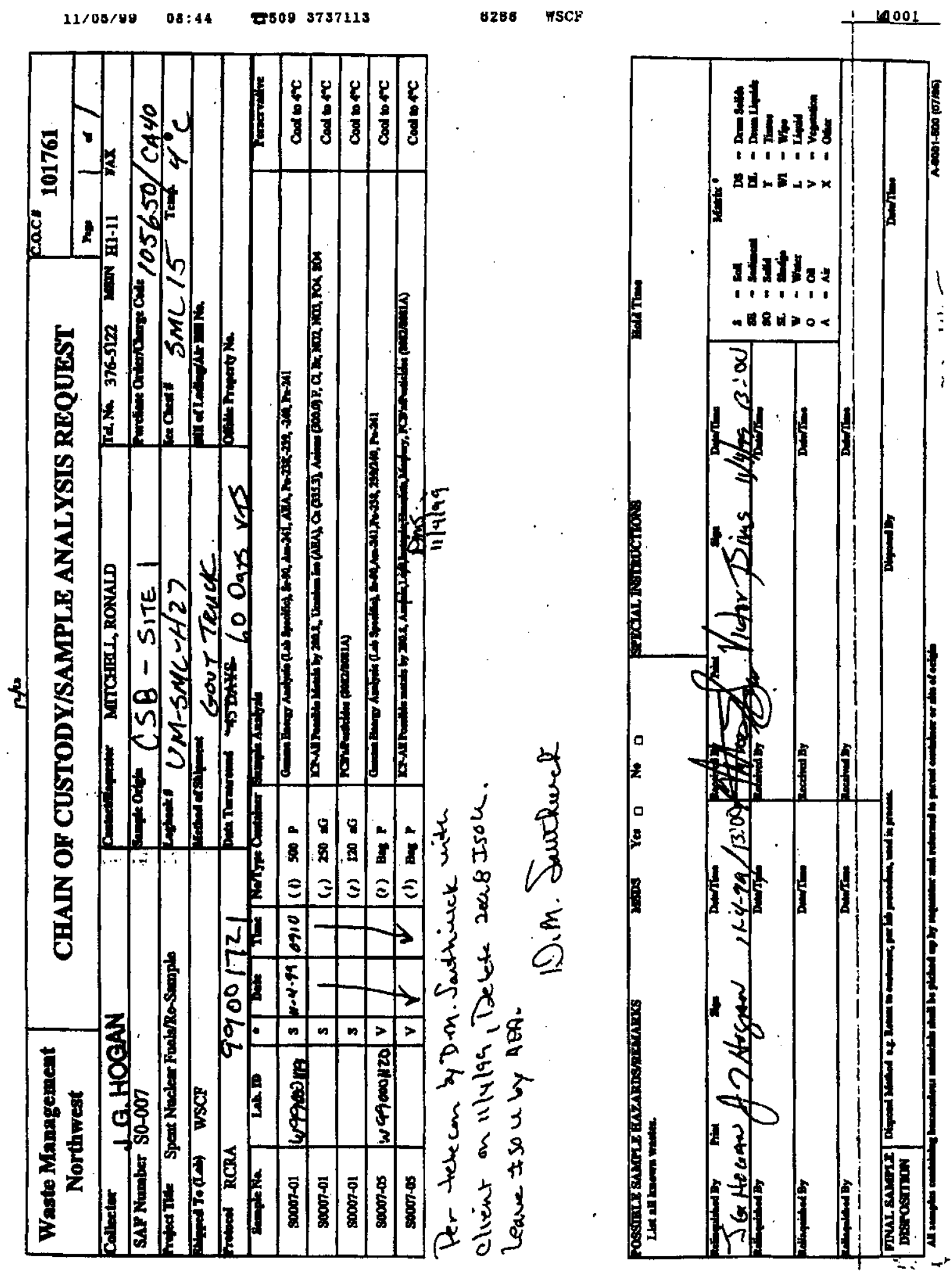




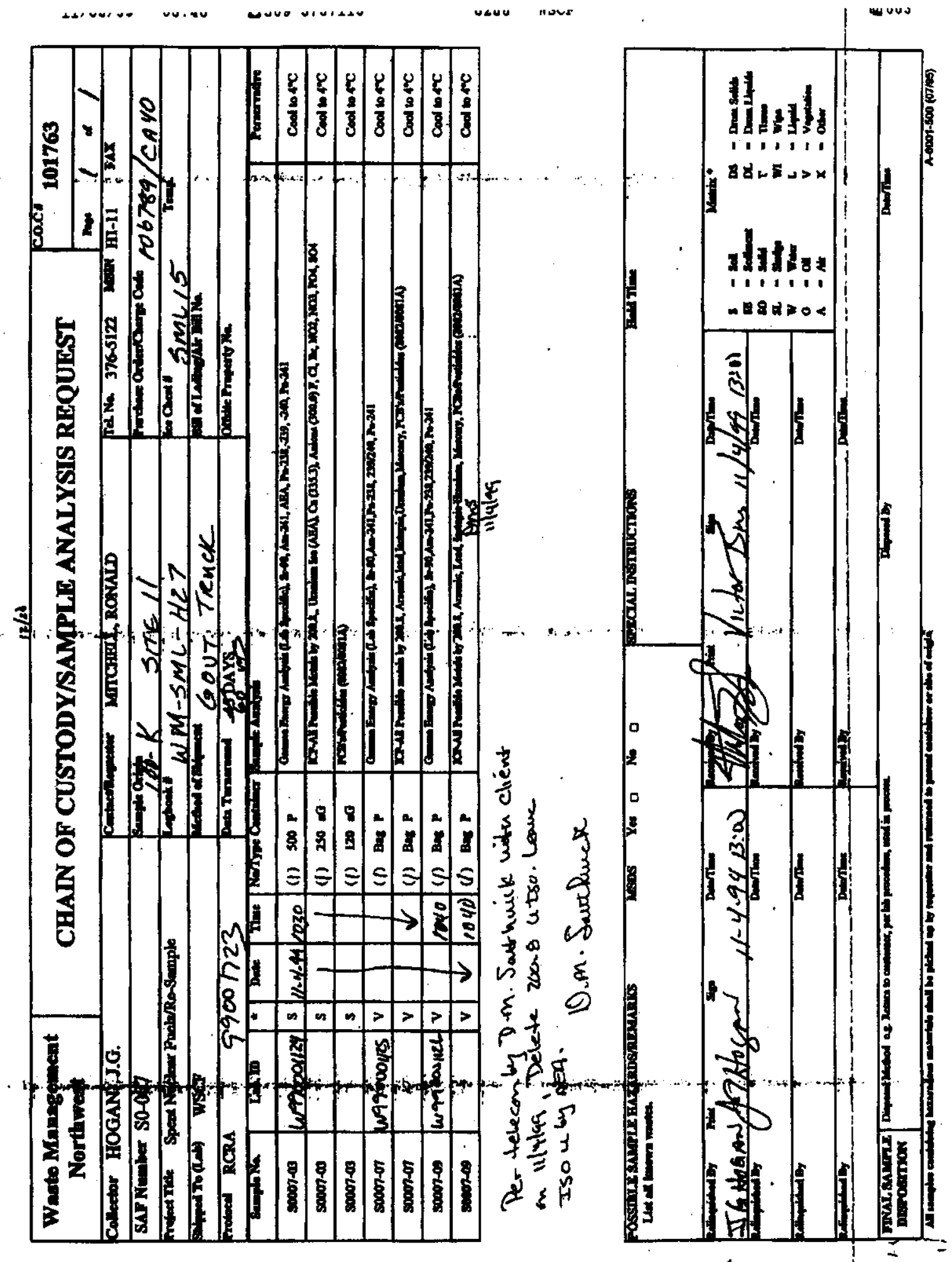



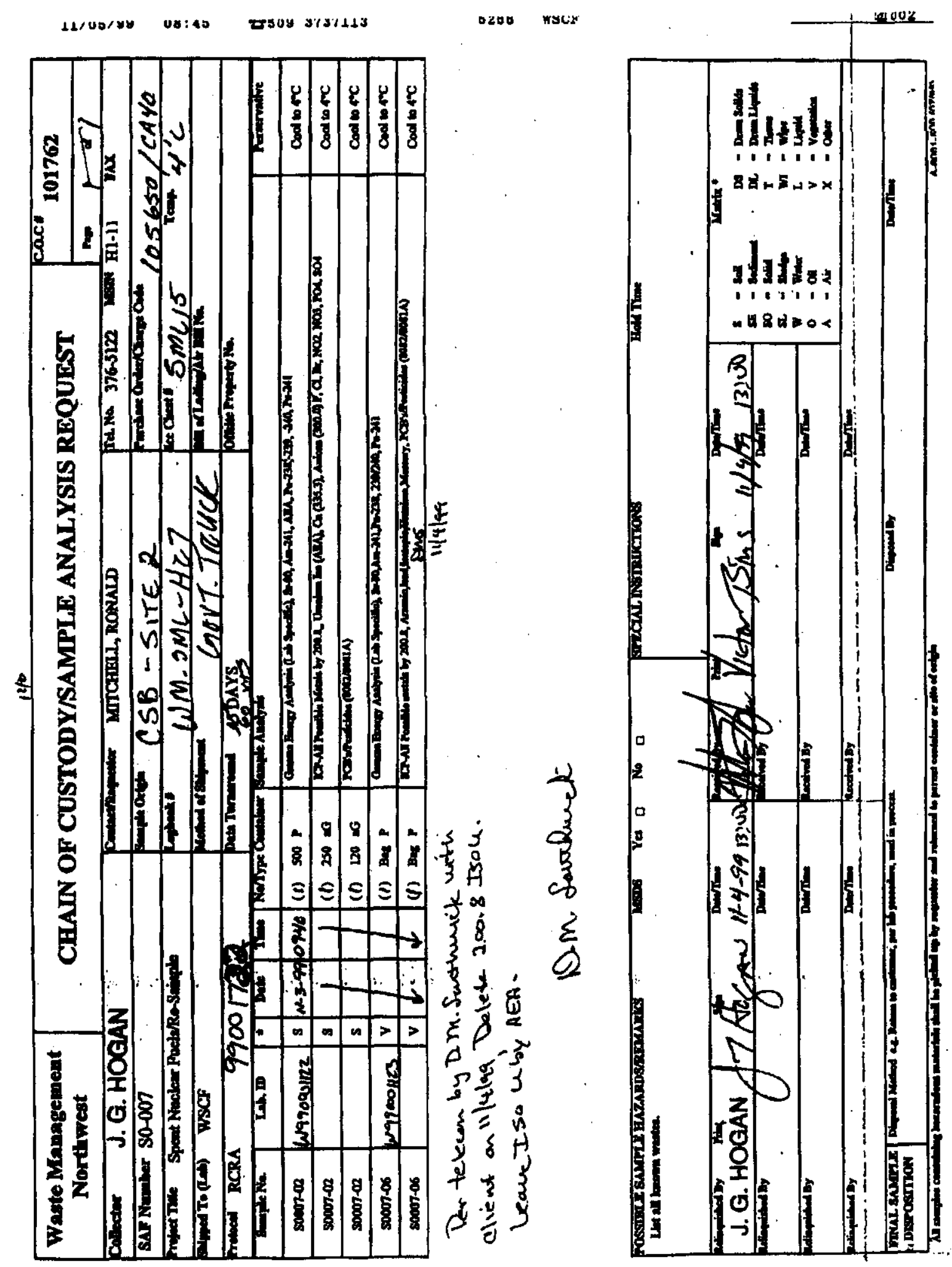
74

PROJECT SOLL AMAGSISFOR EM+I
Notebook No. WM-SAWS-H32 continued From Page NONE

SAF \# R100-028

$2-24-00$

CHARGE CODE: 106789

Work Dowe to RCRA Protocol

LOCATION: $100 \mathrm{~K}$ AREA

PERSONNEL: IG HOGAN

RM MITCHELL

SAmpler

Customer 376-5/22 ...HI-11

Purpese: To set a Pre-operational environmental baseline for THE COLD VACUUM STORAGE FACILITY BEING BUILT AT 100K.

PPE: BLUES, SAFETY Glasses, SURGEONS Gloves, Haro HAT

WEATHER: CLEAR, CALM $15^{\circ}$

SAMPLE EVENT: DUE TO SOME ANOMALIES IN THE ANALYSIS OF THE SAMPLES COCLECTED ON 11/4/99 (SEE LOGBOOK WM-SML-H27), WEN SAMPLES WERE COLLECTED FIROM. THE EASTERN SIDE OF THE $100-\mathrm{K}$ AREA. A DUPLICATE SOIL SAMPLE AND AN EQUIPMENT BLAUK OF CLEAN SILICA SAND WAS collected. THE EQUIPMENT BLANK WAS COUESTED NEAR SITE \#"I WHILE THE SOIL SAMPLES. WAS COLLECTED AT SITE 7 (SEE MAP ON PAGE 78 OF. THIS LOGDOOK.)

SAMple METHOD: THE EQUipment BLAUK WRS COllected BY POURING CLEAN SILICA. SAND OUER THE SAMPLE EQUIPMENT. WHICH WAS GOING TO BE USED TO COllect THE SOIL SAMPLES. THE SAND was THAN

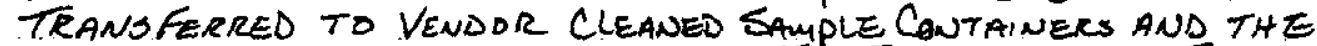
SAmple EQuipment was Re-WRAPPES For FURTHER USE. THE SOIL SAMPLE WAS COLLECTED BY USING A STAINLESS STEE SPOON TO SCOOP THE TOP ONE INCA OF SOIL FROM THE SELECTED AREA THE SOIL WAS MIXED IN A LARGE S/S BOWL TO ENSURE HOM OGENEITY and then transferrreo to Vendor Cleaned sample Contaneser. TWO SETS OF TDENTEAL SAMPLES WERE COULCTEO FOR THE EVALUATION OF THE LABORATORY'S PERFORMANUE BY BENG aBLE To compare THE ANALYTICAL RESULTS. All SAMPLE EQUIPMENT NAS CLEANED PER ES-SSPM-6OI SP 2-5

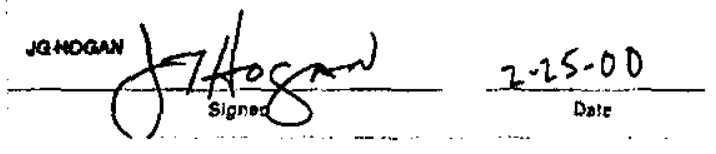

Road and Undersiood $\theta \mathrm{y}$ 
PROJECT SOIL AWALYSIS FOR EMH I

Notebook No. WM-SANS $-432-75$ Continued From Page —7Y

TraUsportation: SAMPLES wERE EVIDENCE TAPED, PACKEO ON WET ILE IN A POLYCOOLER ANDSHIPPED TO THE WSCF LAS IN THE 600 AREA.

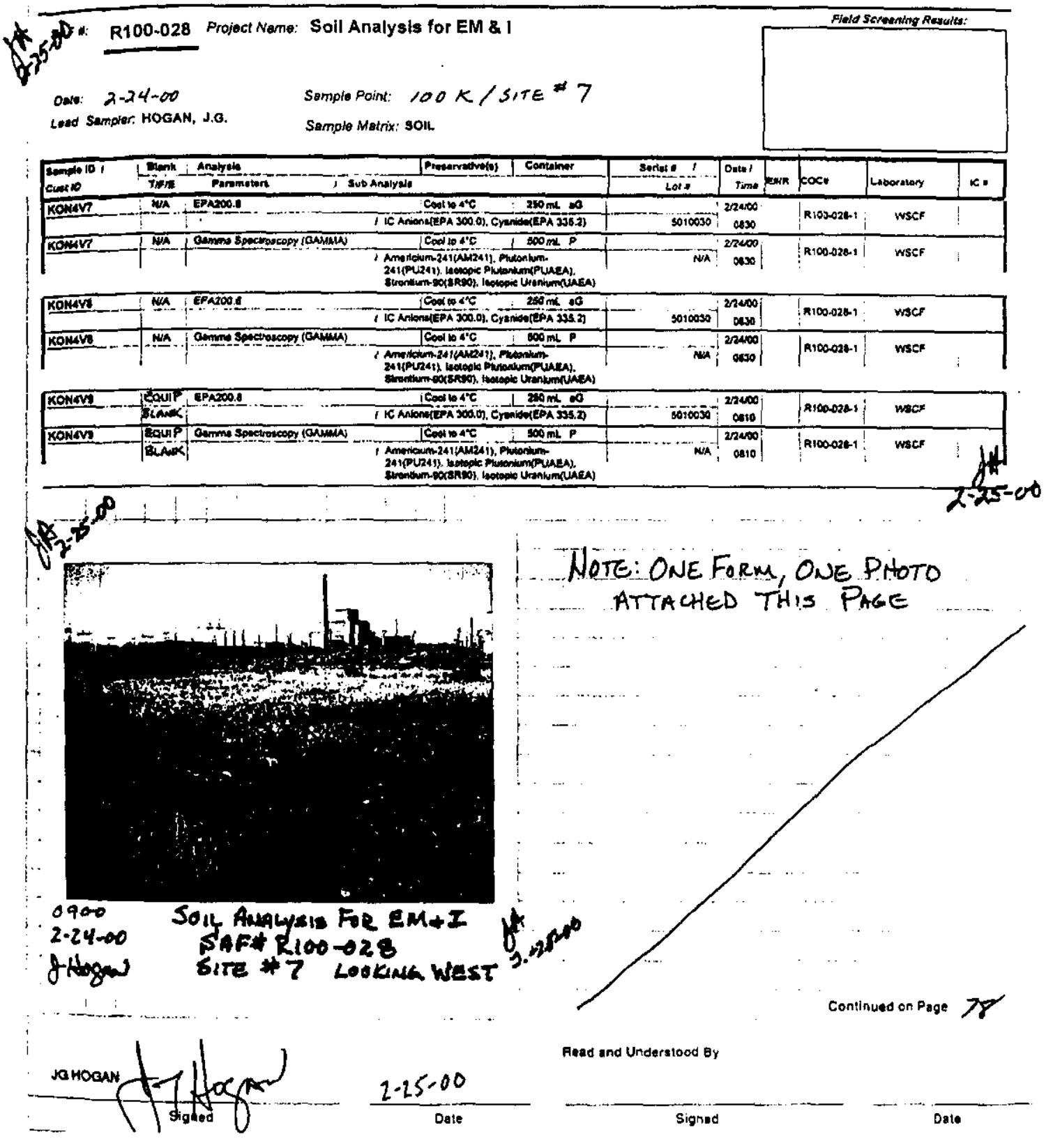


HNF-6150 Rev 0

76

PROJECT VEGETATION AWALYSIS Fer EM+I

Notebook No. Wh-SAWS-H32 Continued From Page - NEONE.

SAF R100-029 2.24-00 CHARGE CODE: 105650 Work Done to RCRA Protocol

LOCATION: $100-K$ AREA

Personnel: IG hogan sampler

RM MitCHELL CUstomer 376-5122 H/-1I

Purpose: To set a pre-operational environmental baseline for THE Cold VacuUm storage Facility BeInG BuLlt at 100-K

PPE: Blues, SAfety glasses, SUrgeons gloves, hard Hat

WEATHER: CLEAR, CACM $48^{\circ}$

SAMPLE EVENT: DUE TO SOME ANOMALIES IN THE ANAWSIS OF THE SAMPLES COLLECTED ON $11 / 4199$ (SEE LOGBOOK WM-SML-HZ7) NEW VELETATIN SAMPLES WERE COLLCTED FROM THE WESTERN SIDE OF THE 100-K

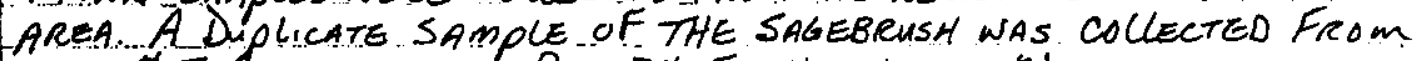
SITE HS (SEE maP ON PAGE $780 \mathrm{~F}$. THIS LOGBOOK).

Sample Method: SAmples were collectes By SUIPPINA Pieces of THE SAGEBRUSH WITH CLEAN STAINLESS STEEL SCISSORS AND compositing THEM IN A LARGg CleAN PLAOTIC BaG. AFTER SUFF. CIENT. VOLUME WAS COllected, THE SAGEBRUSH WAS HOMOGENIZE and THEN TWO IDENTICaL SAMPLE SETS WERE COLlected IN Clean. FreEzer Bags for the EVALUATION OF THE LABORATORY'S PERFormance By Beinle able to compare the anayytcal Results. AUL SAMPLE EQUIPMENT WAS ClEANED RER ES'-SISPM-00I SP 2-5. iransportafion: Samples were EVIDENCE Taped, PLACED ON NET ICE. IN A POLY COOCER AND SHIPPEO TO WSCF LAO IN THE GOO AREA.

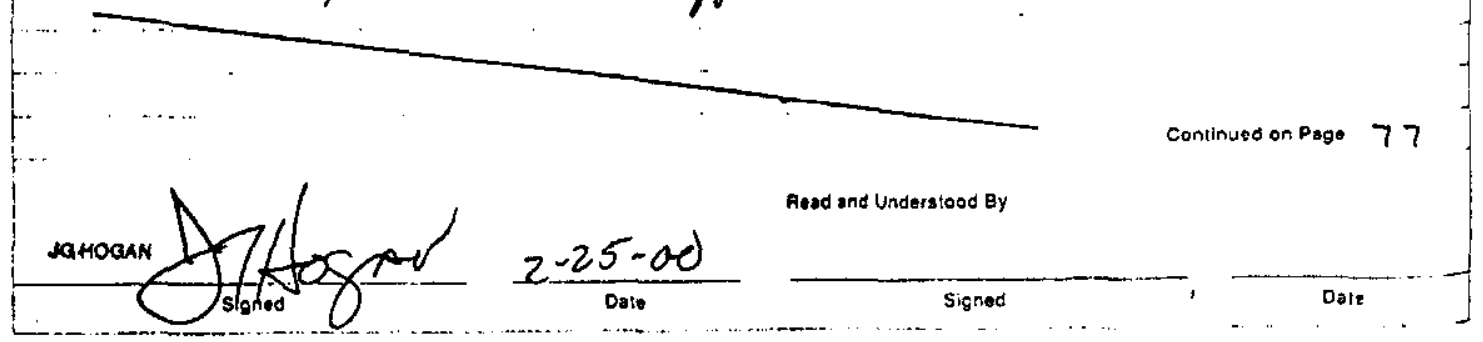




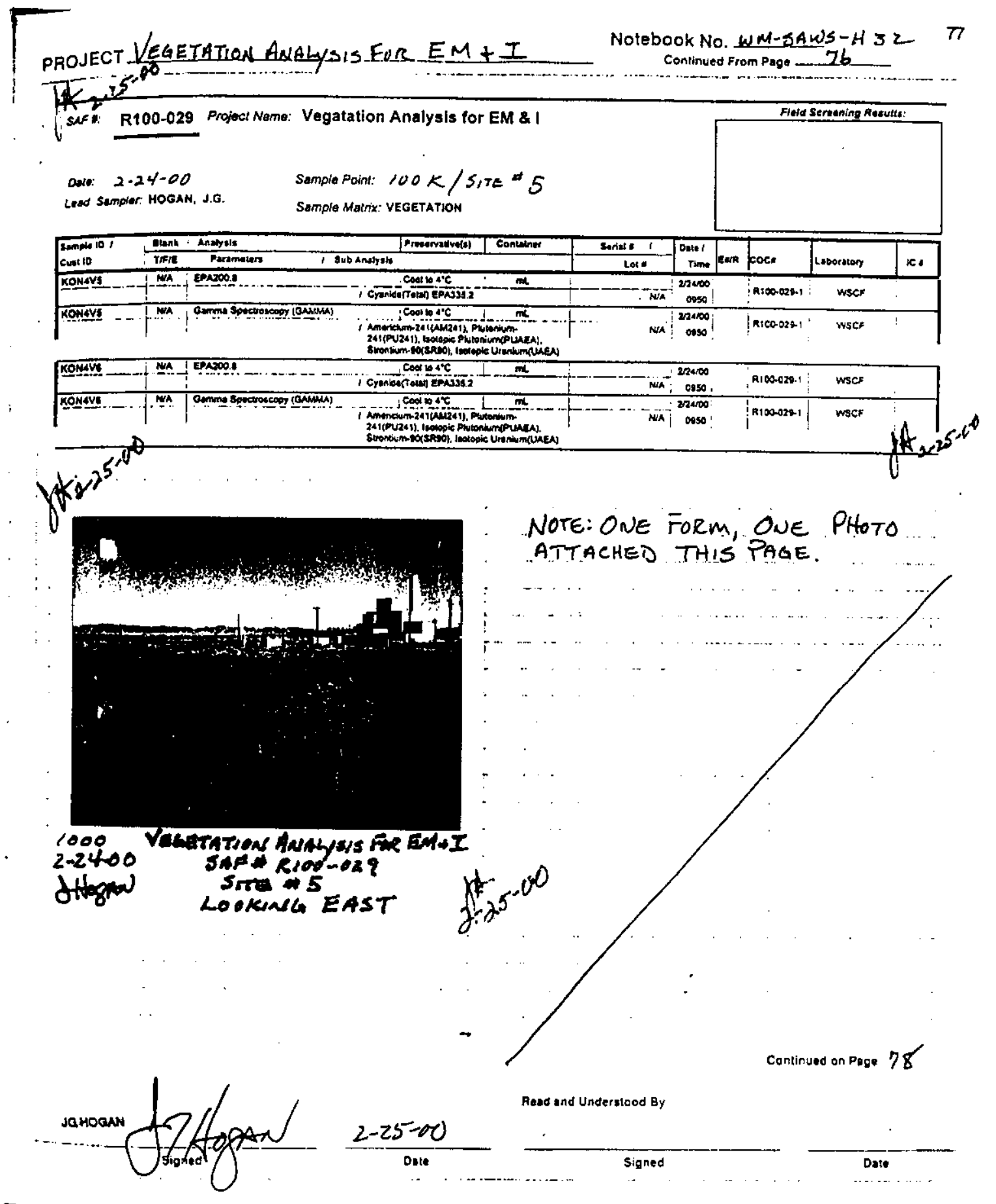




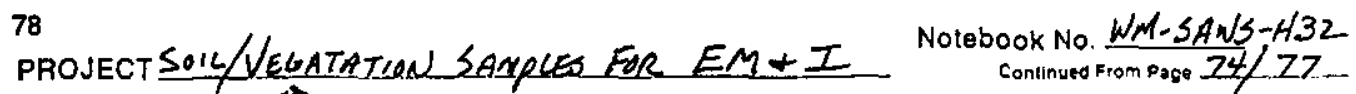

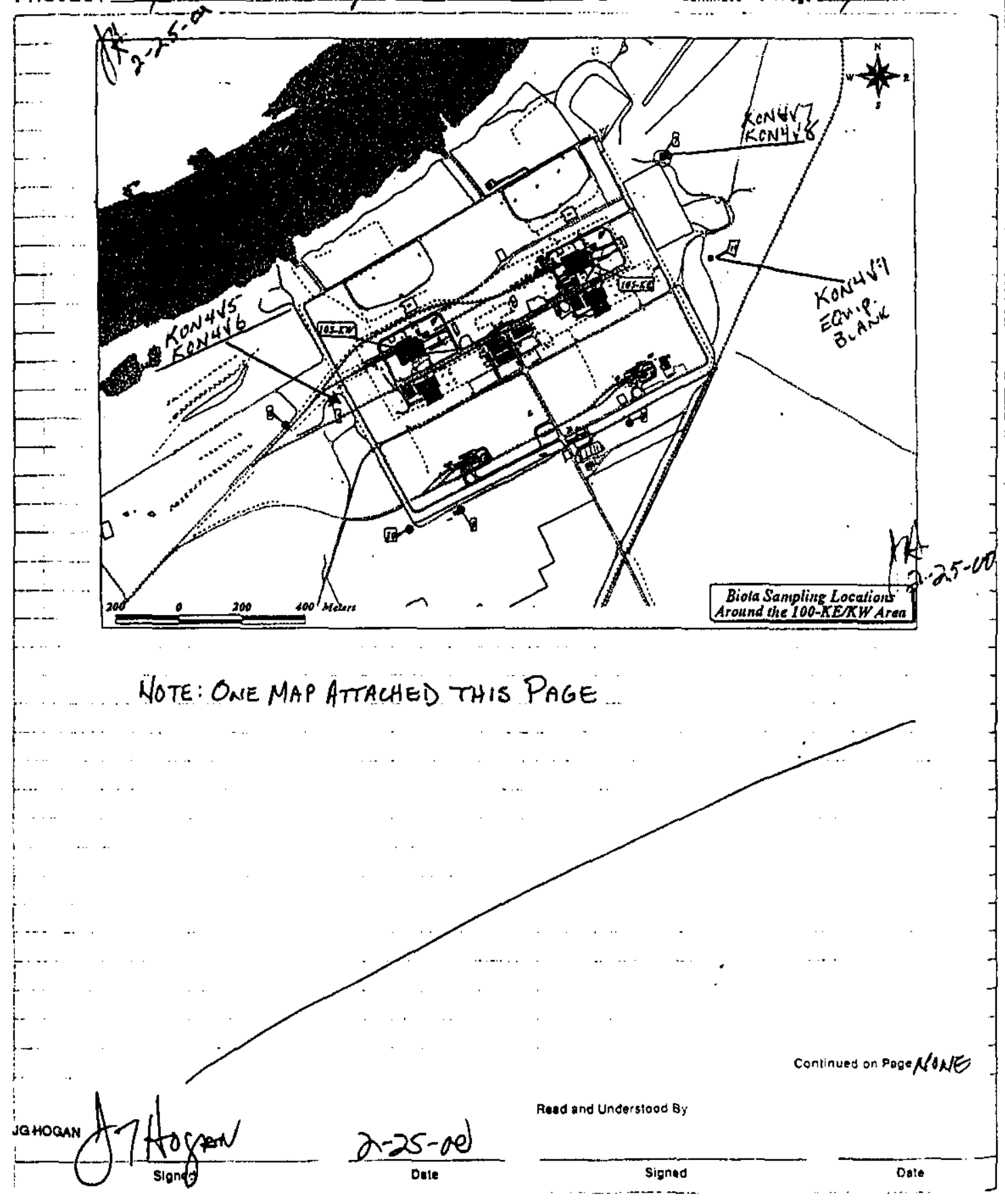



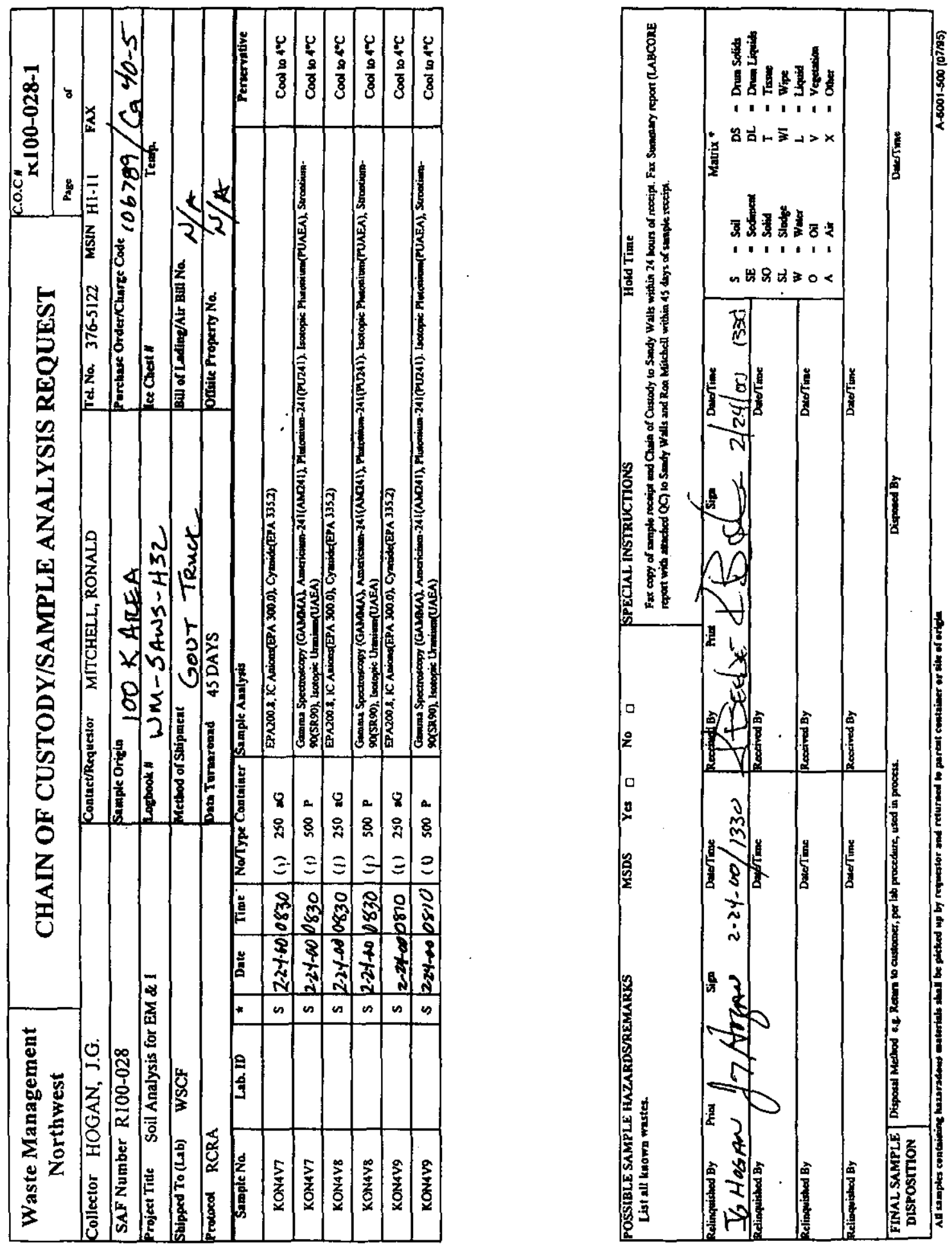

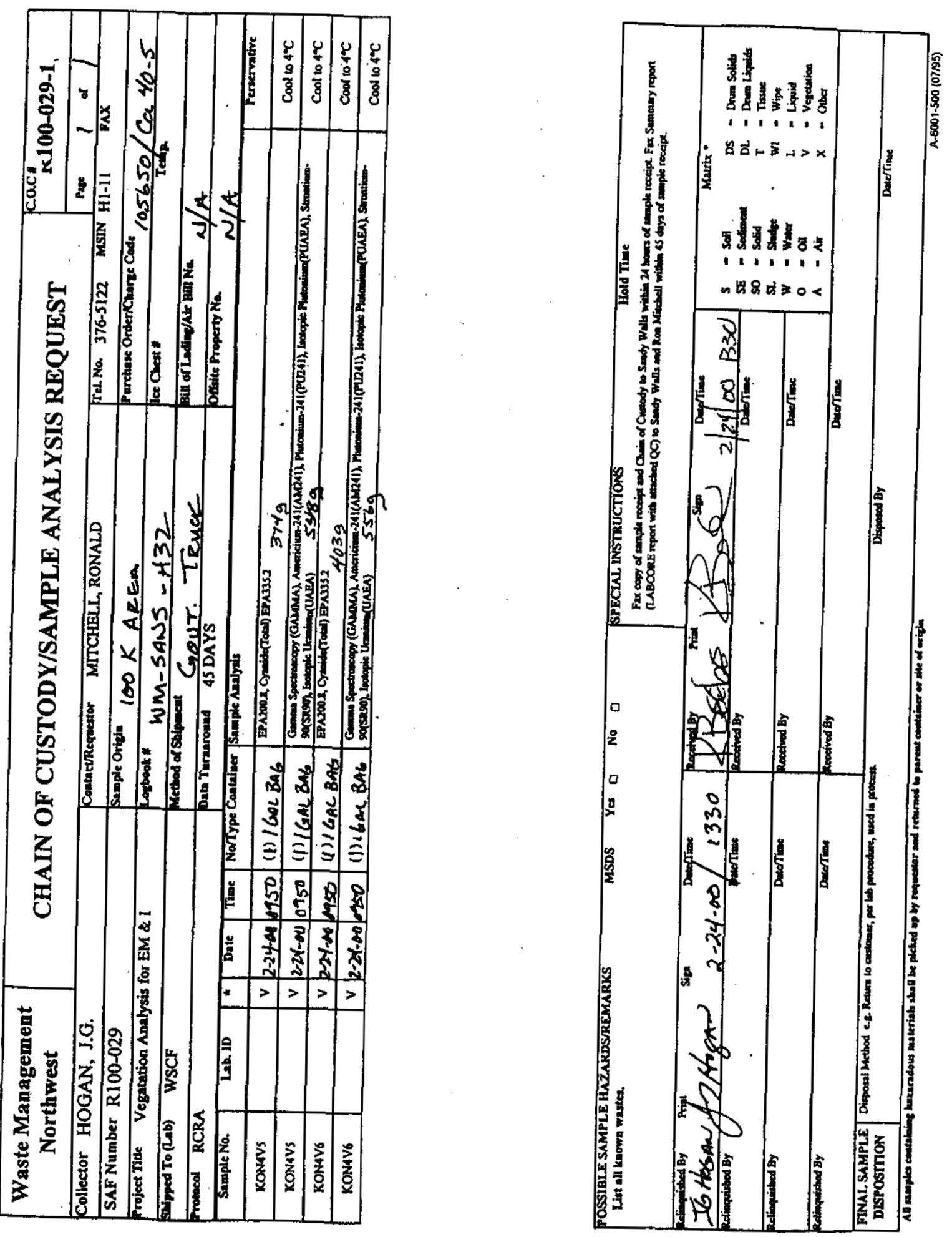
HNF-6150 Rev 0

This page intentionally left blank. 


\section{HNF-6150 Rev 0}

\section{APPENDIX C}

LABORATORY ANALYTICAL DATA

C-i 
HNF-6150 Rev 0

This page intentionally left blank.

C-ii 


\section{HNF-6150 Rev 0}

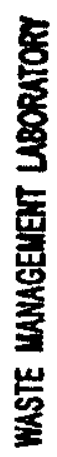
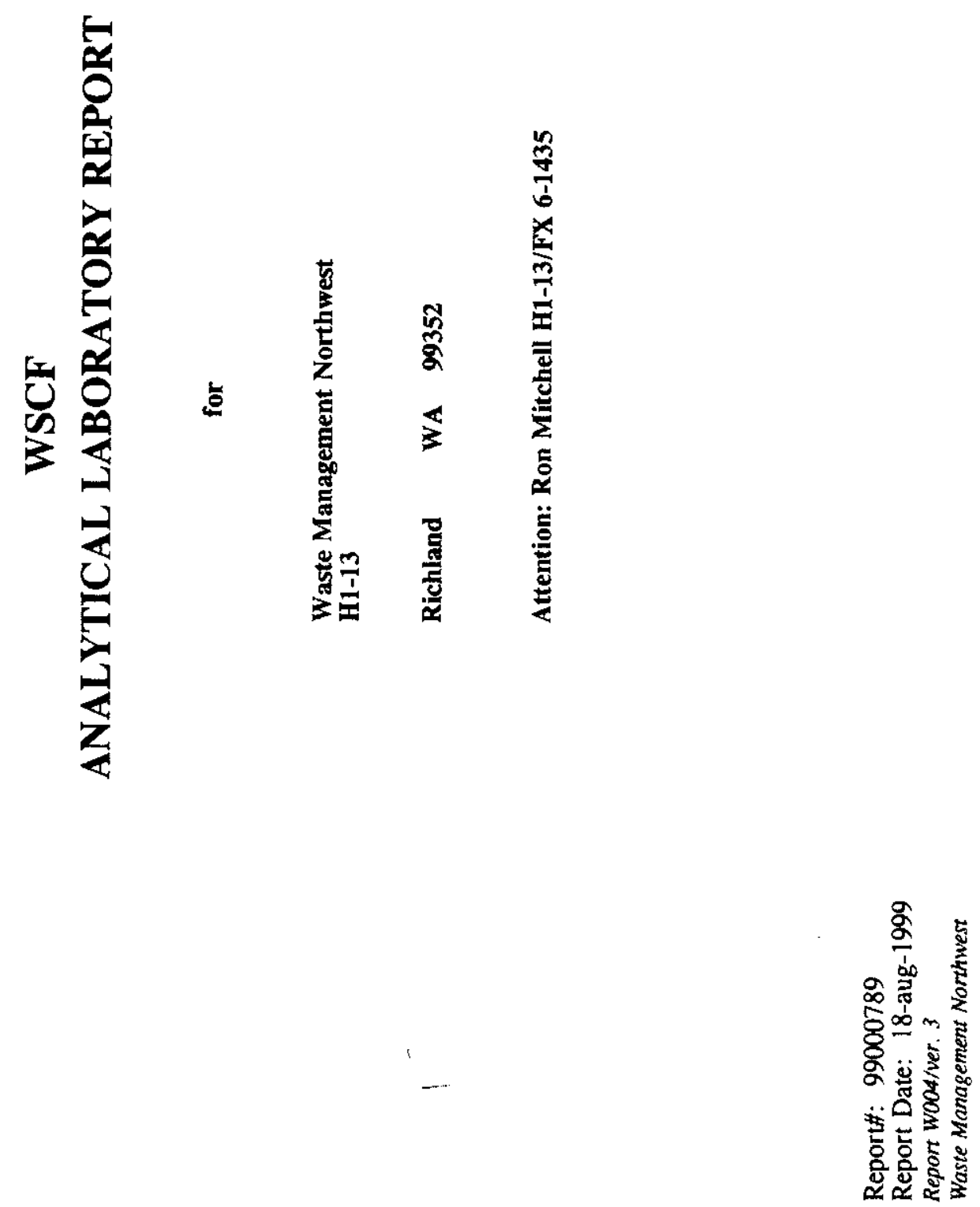

C-1 
HNF-6150 Rev 0

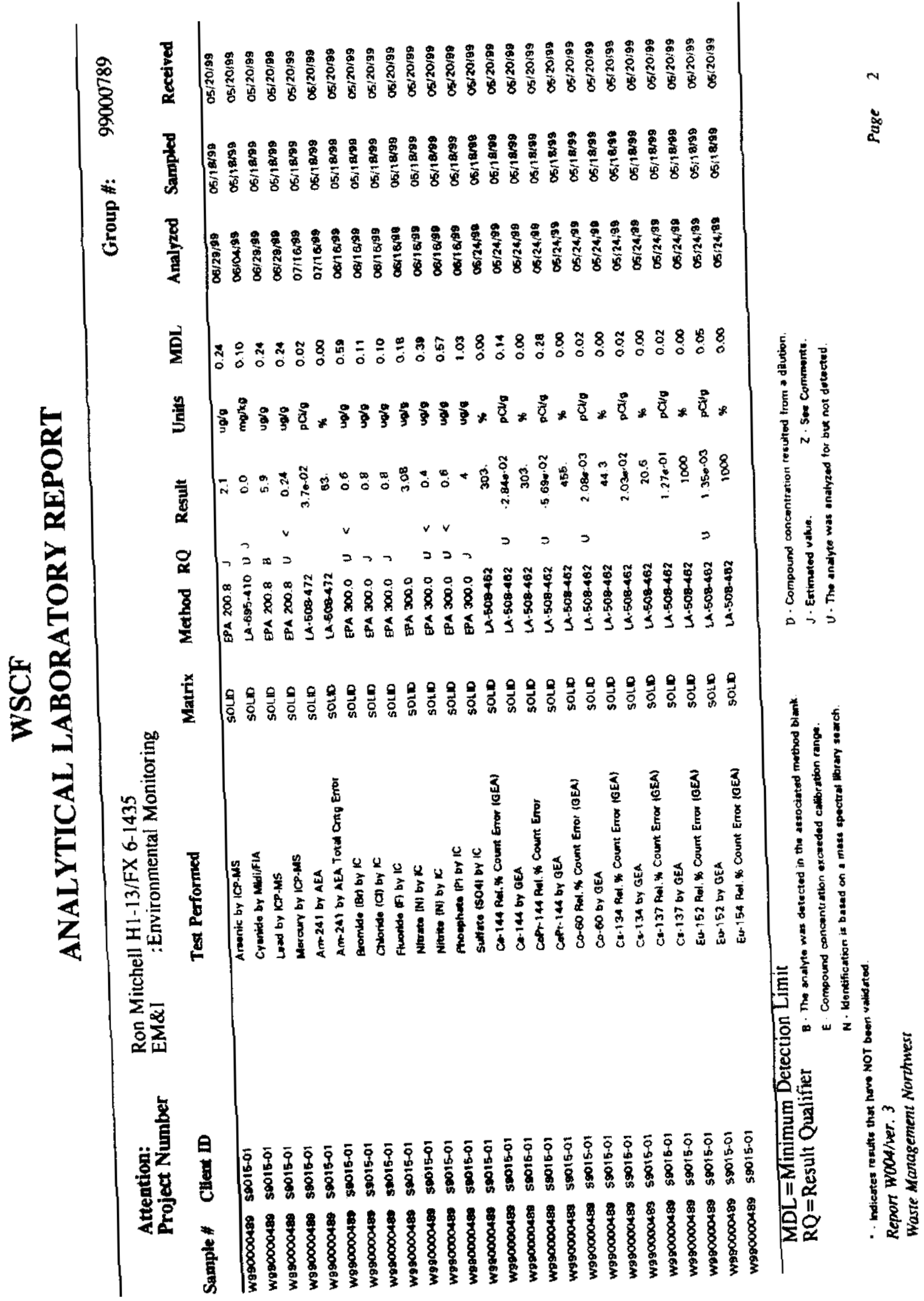

C-2 
HNF-6150 Rev 0

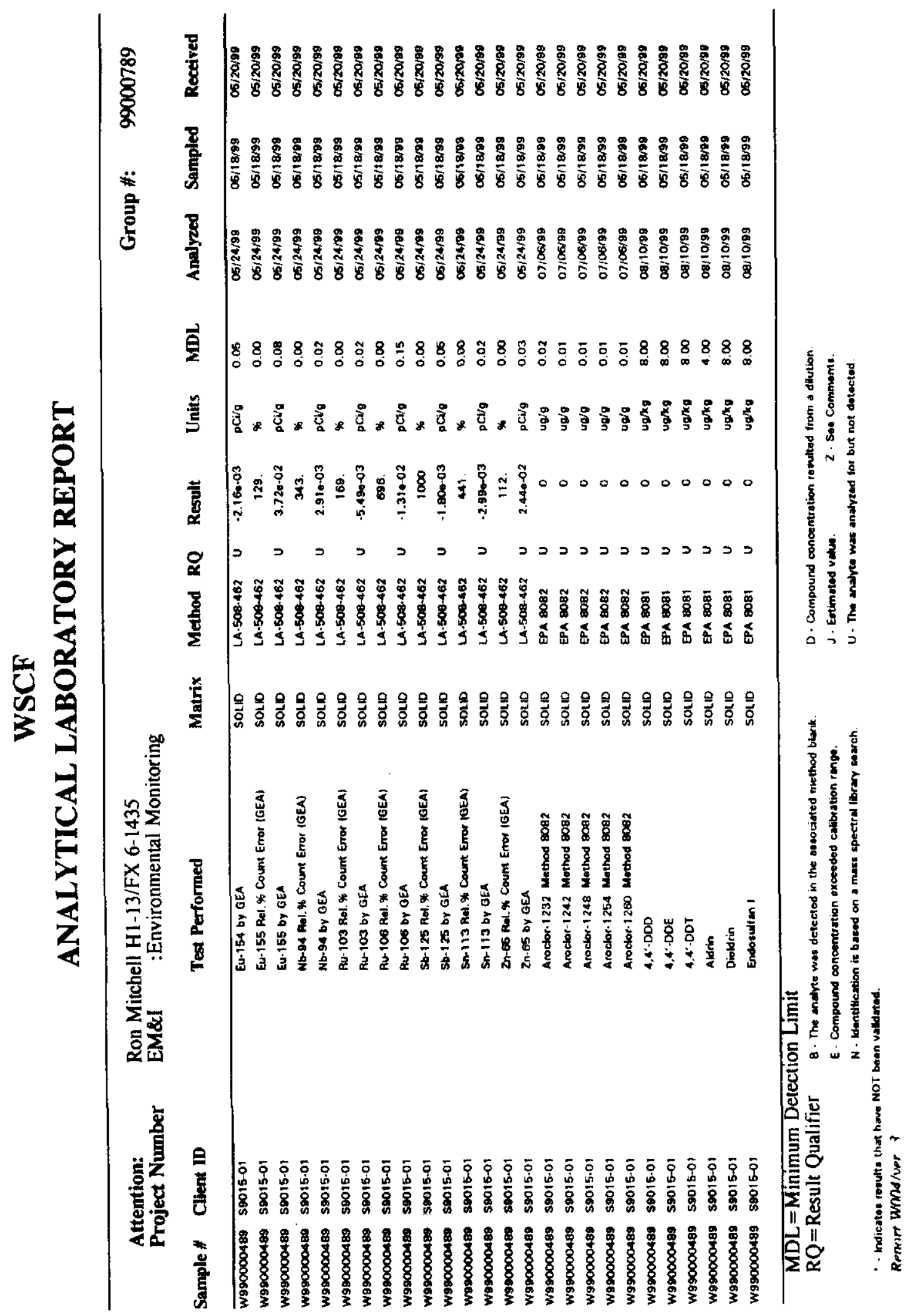


HNF-6150 Rev 0

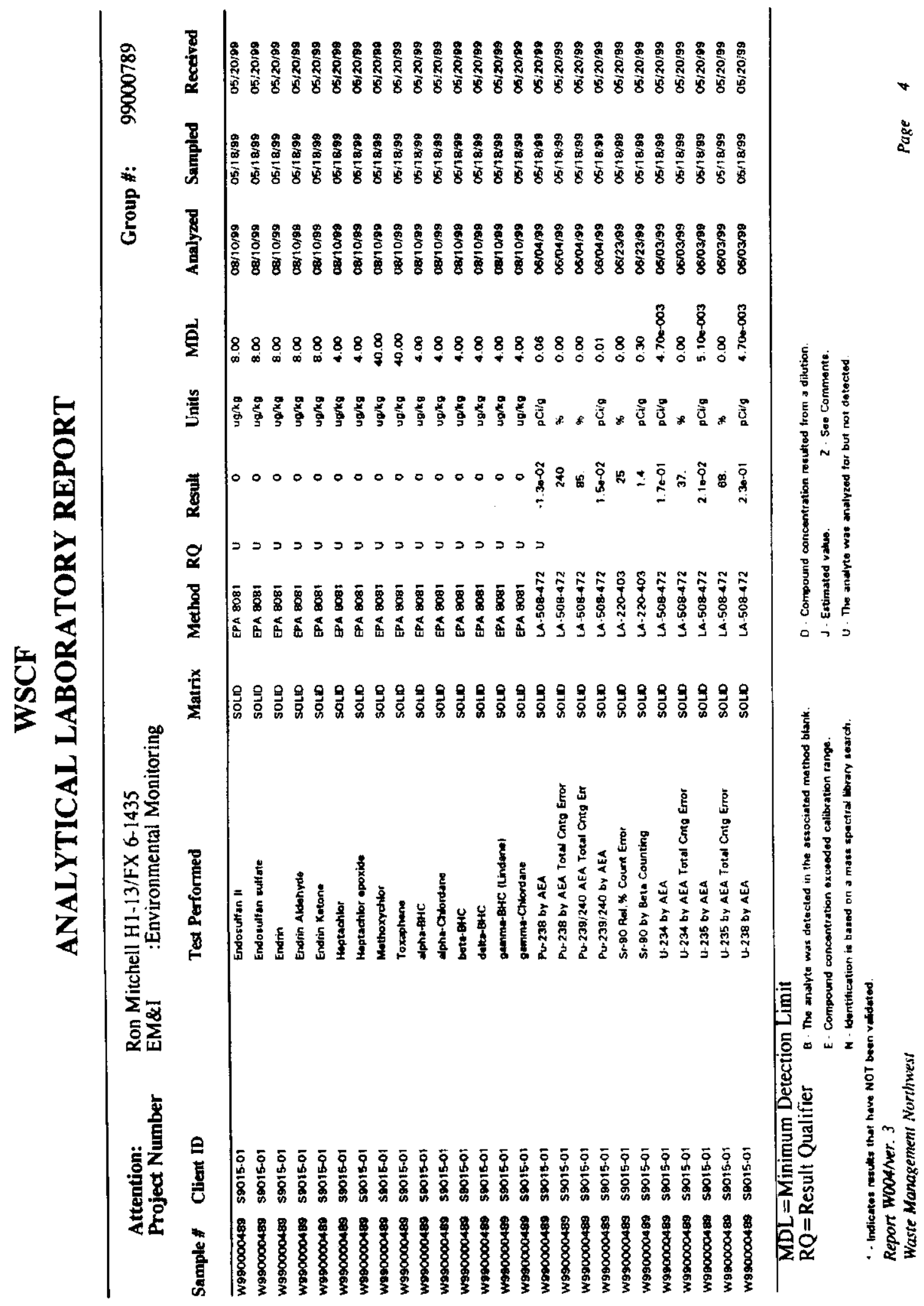


HNF-6150 Rev 0

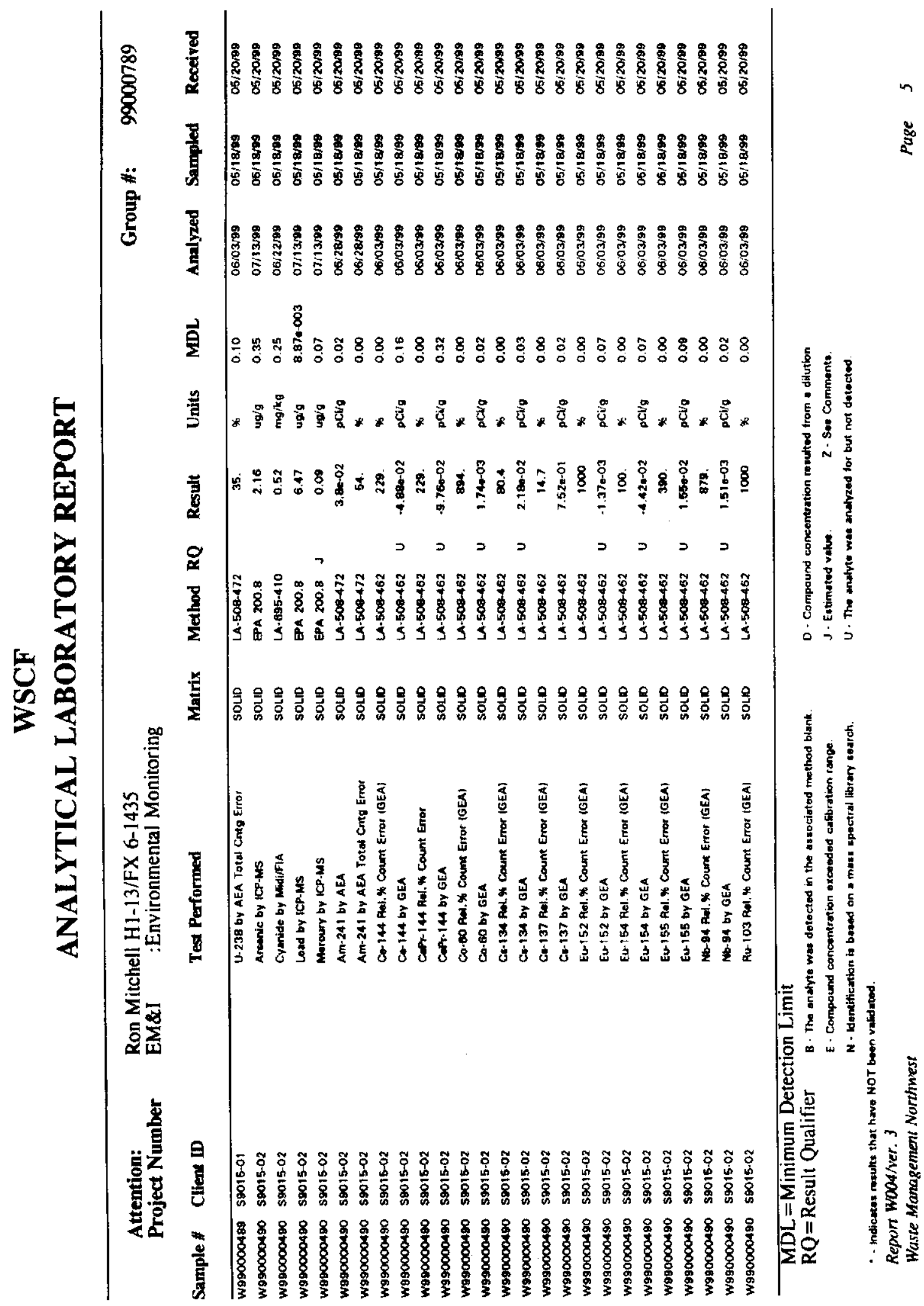


HNF-6150 Rev 0

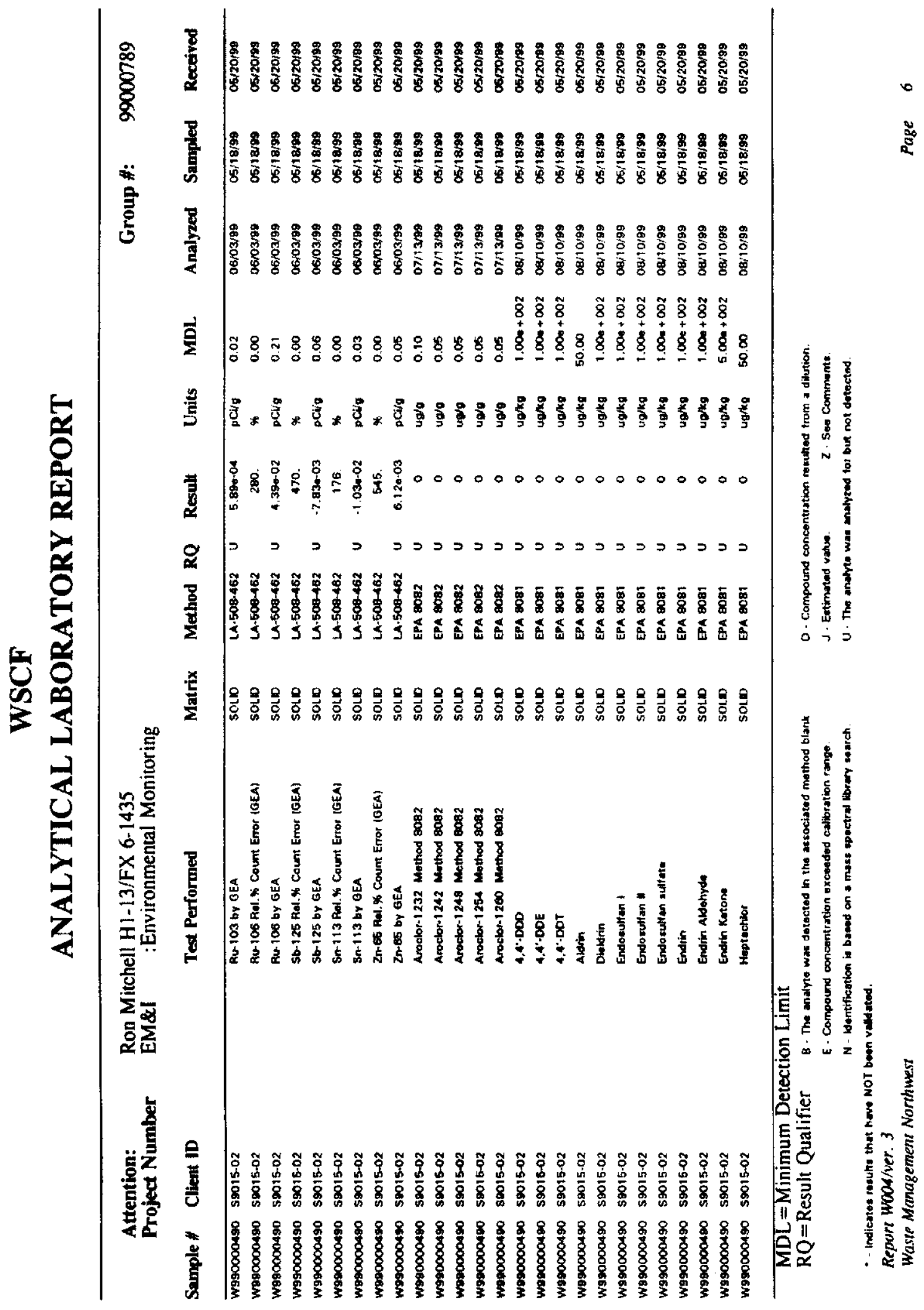


HNF-6150 Rev 0

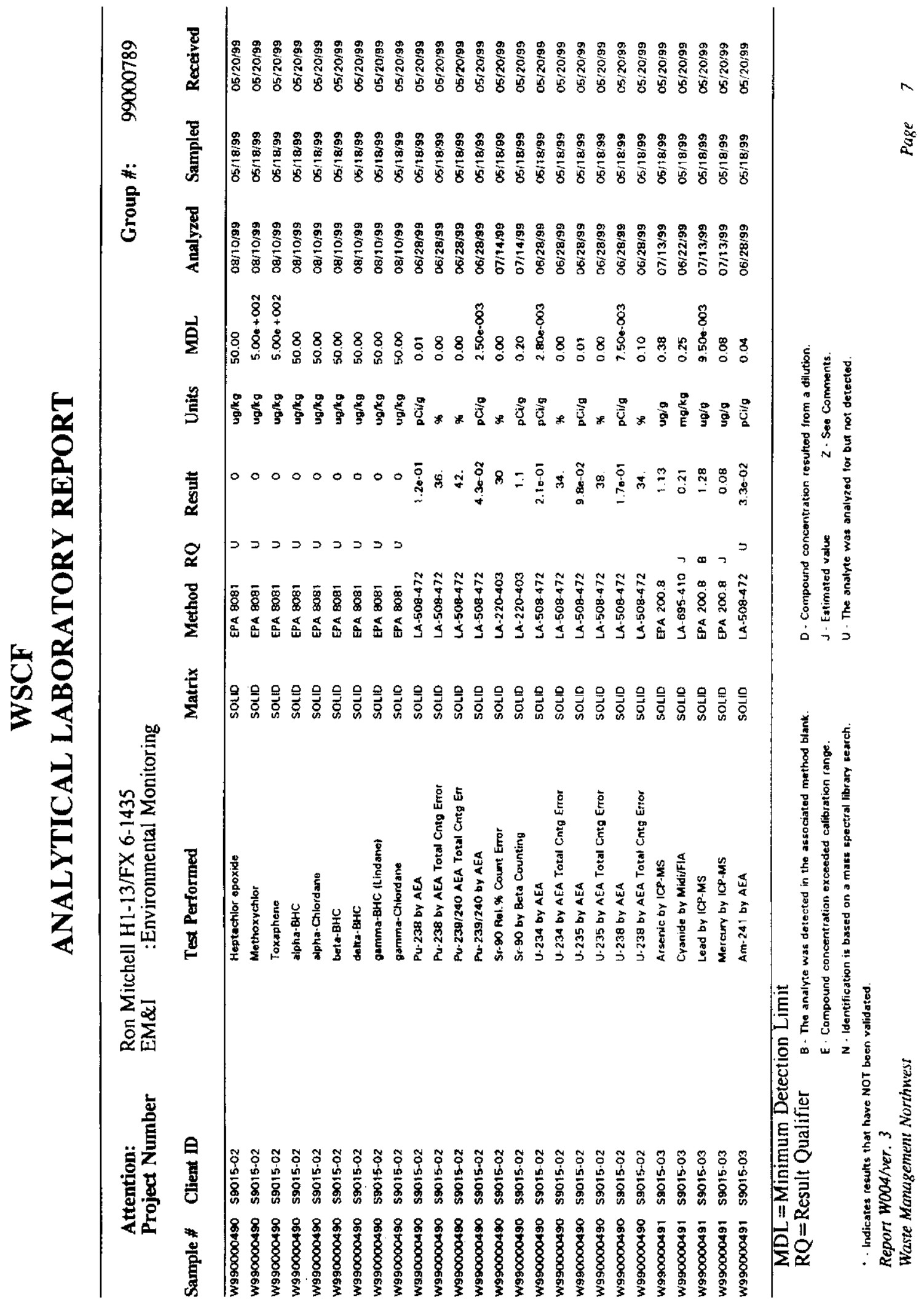


HNF-6150 Rev 0

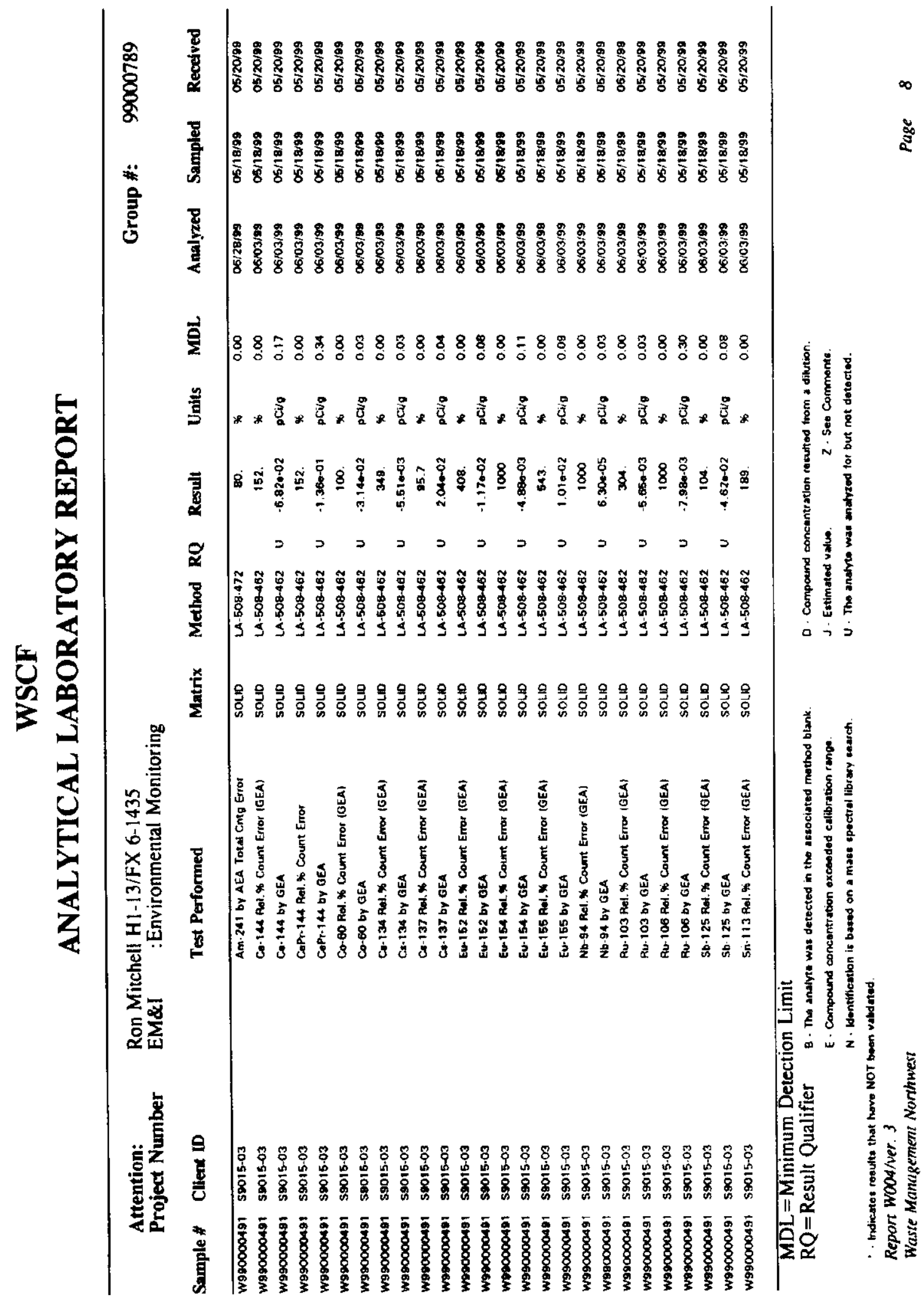


HNF-6150 Rev 0

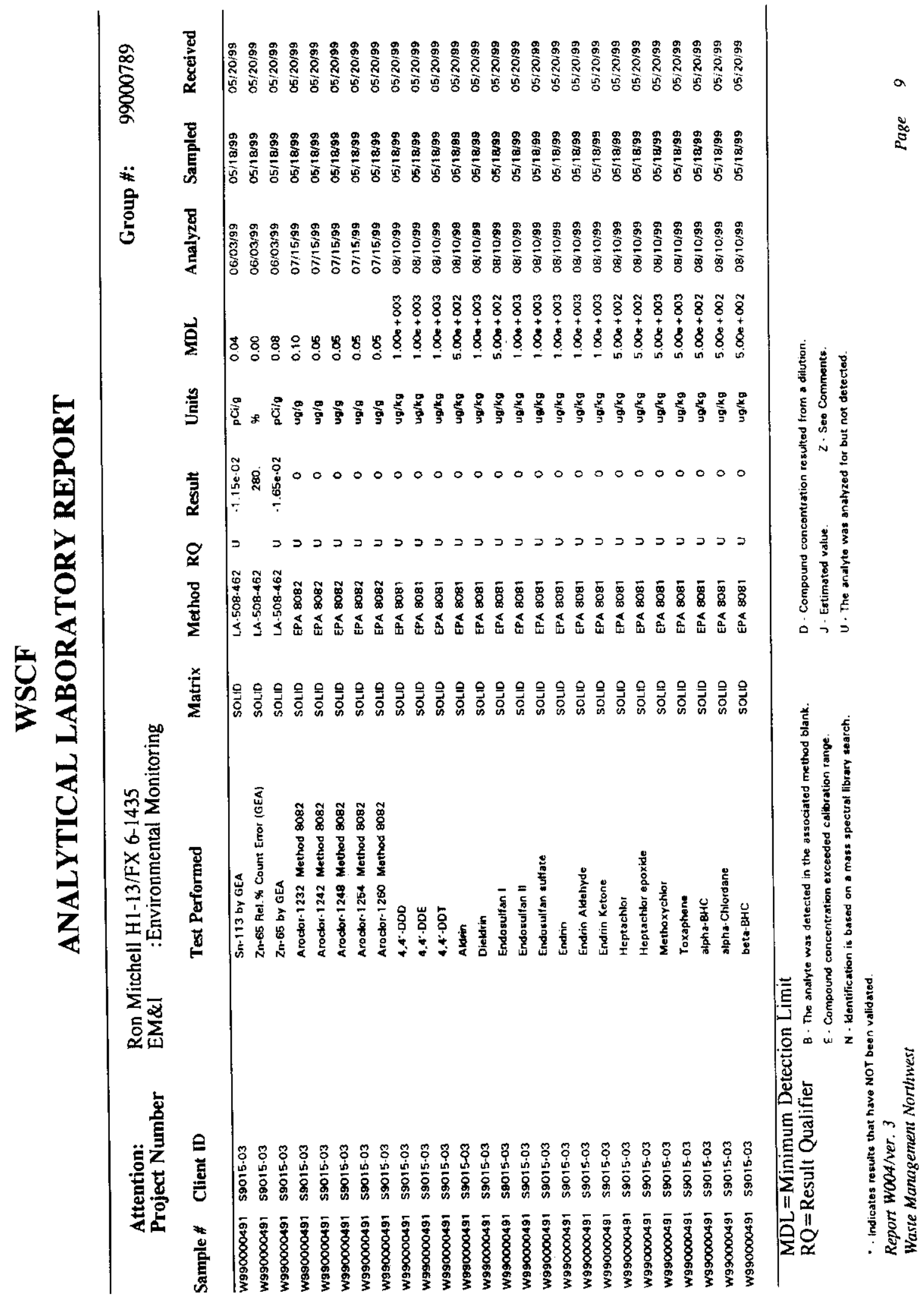


HNF-6150 Rev 0

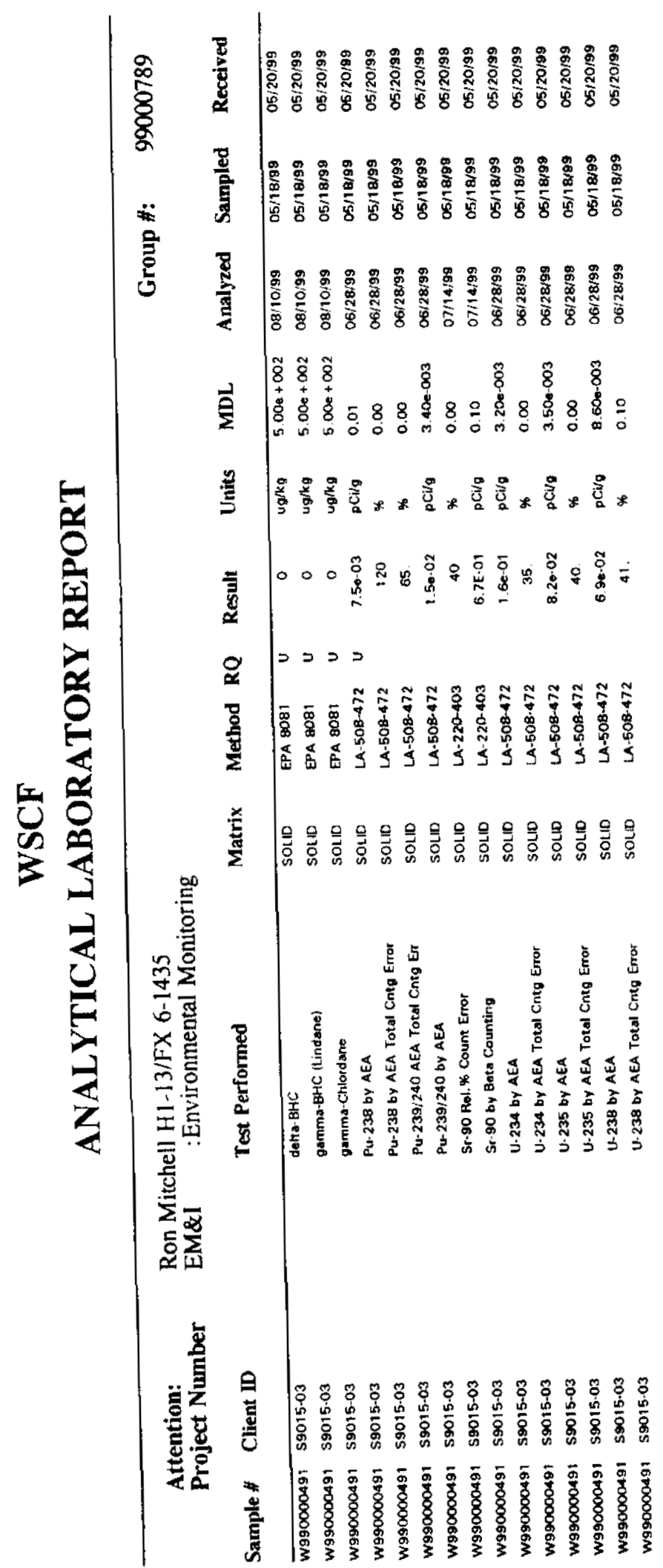

2
8
3
3

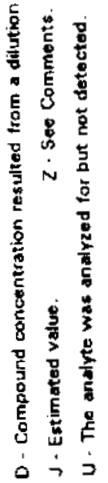

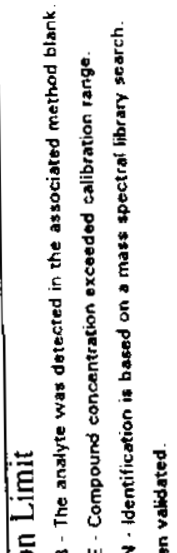

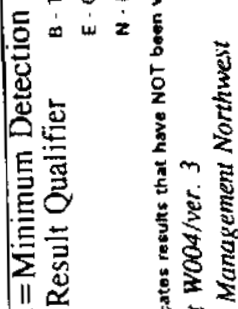

全唯 !

C-10 
HNF-6150 Rev 0

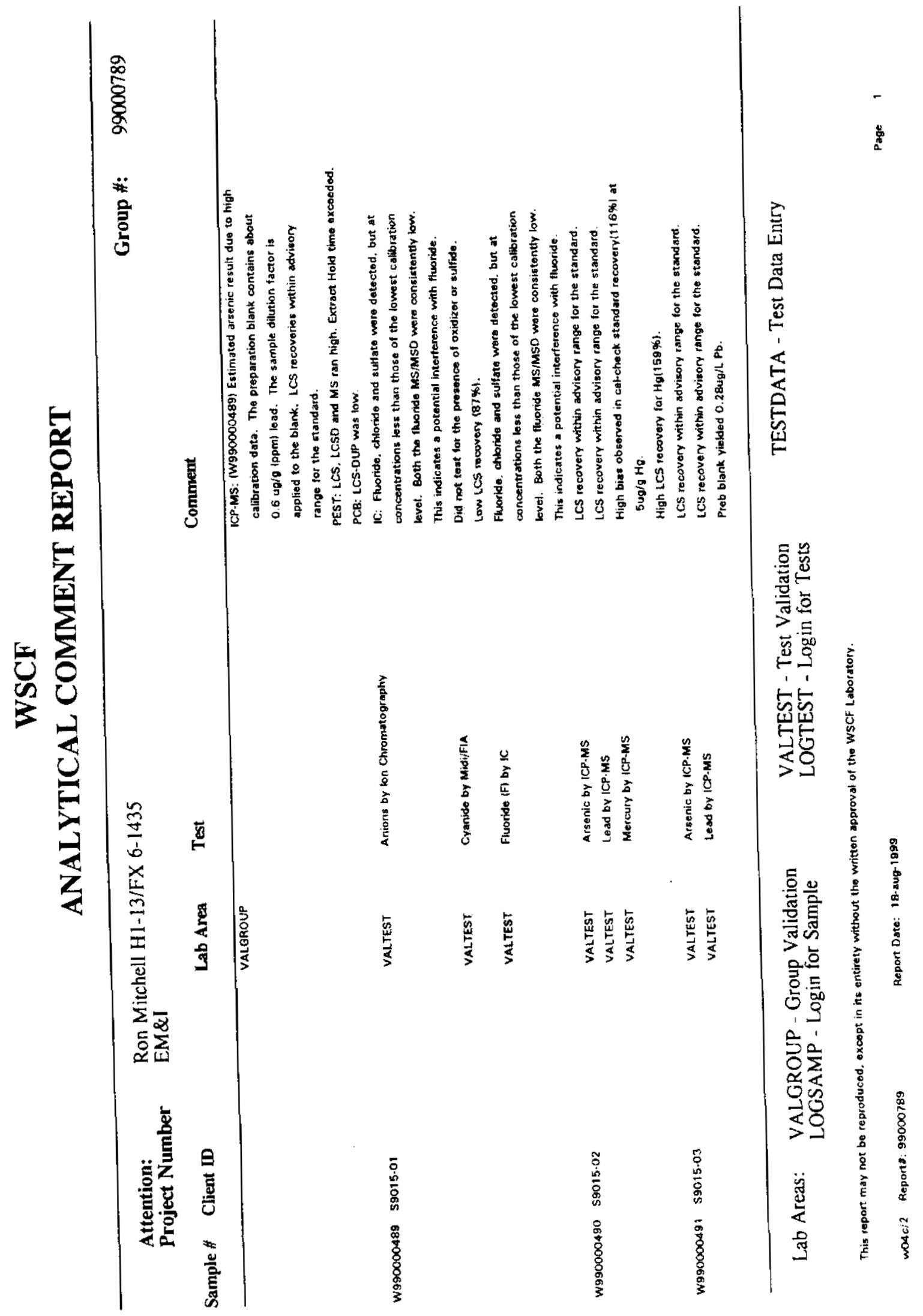


HNF-6150 Rev 0
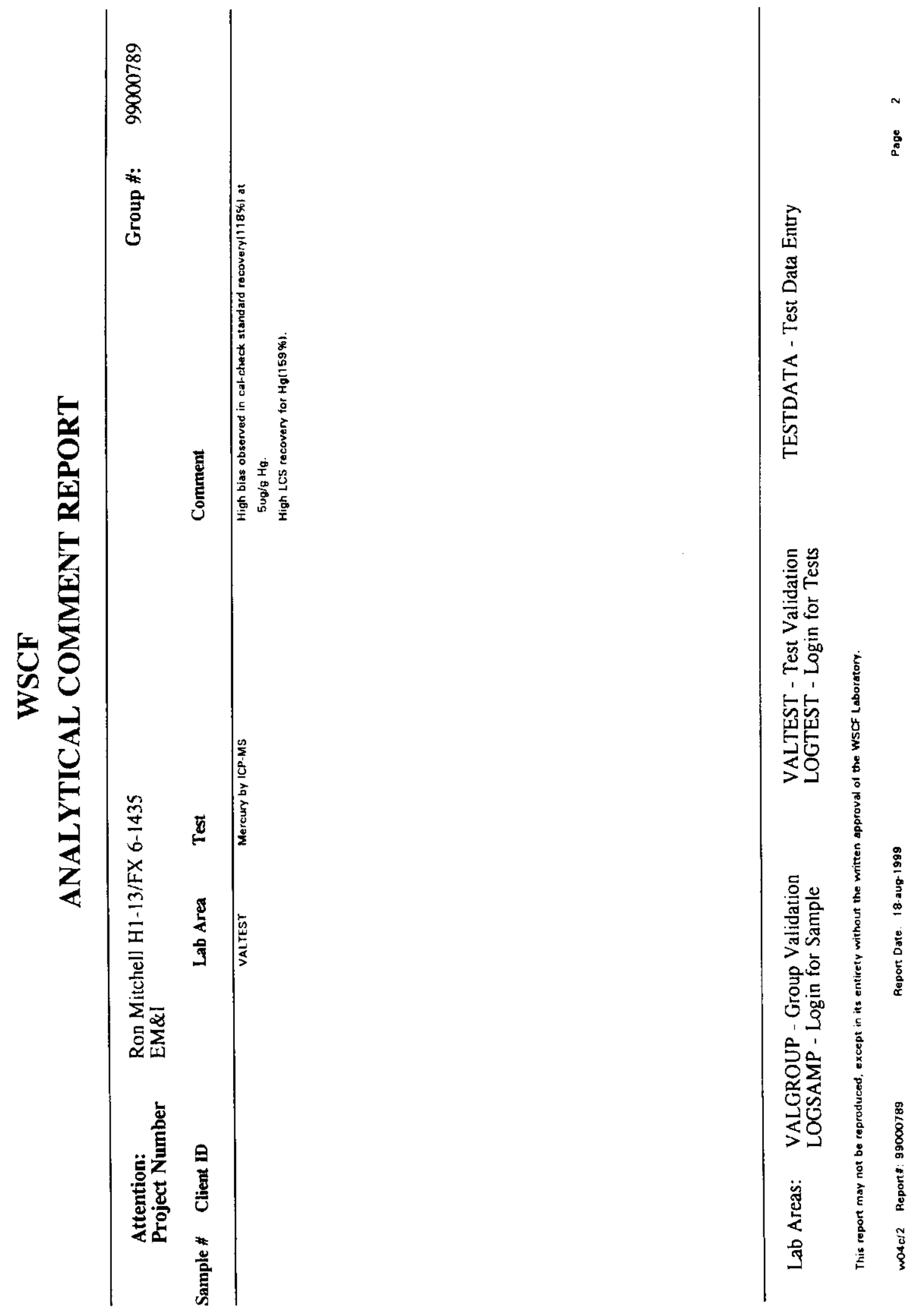
HNF-6150 Rev 0
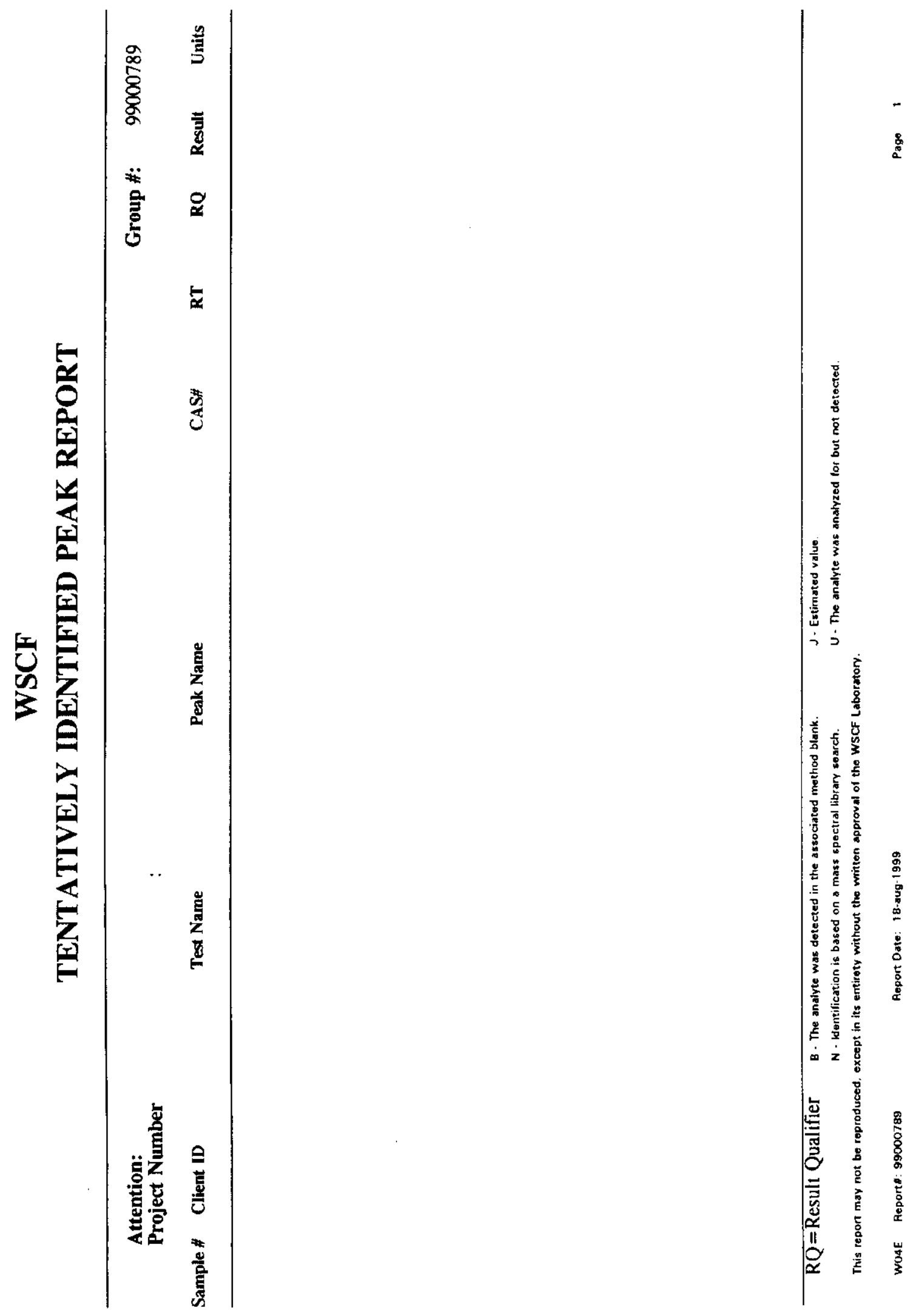


\section{HNF-6150 Rev 0}
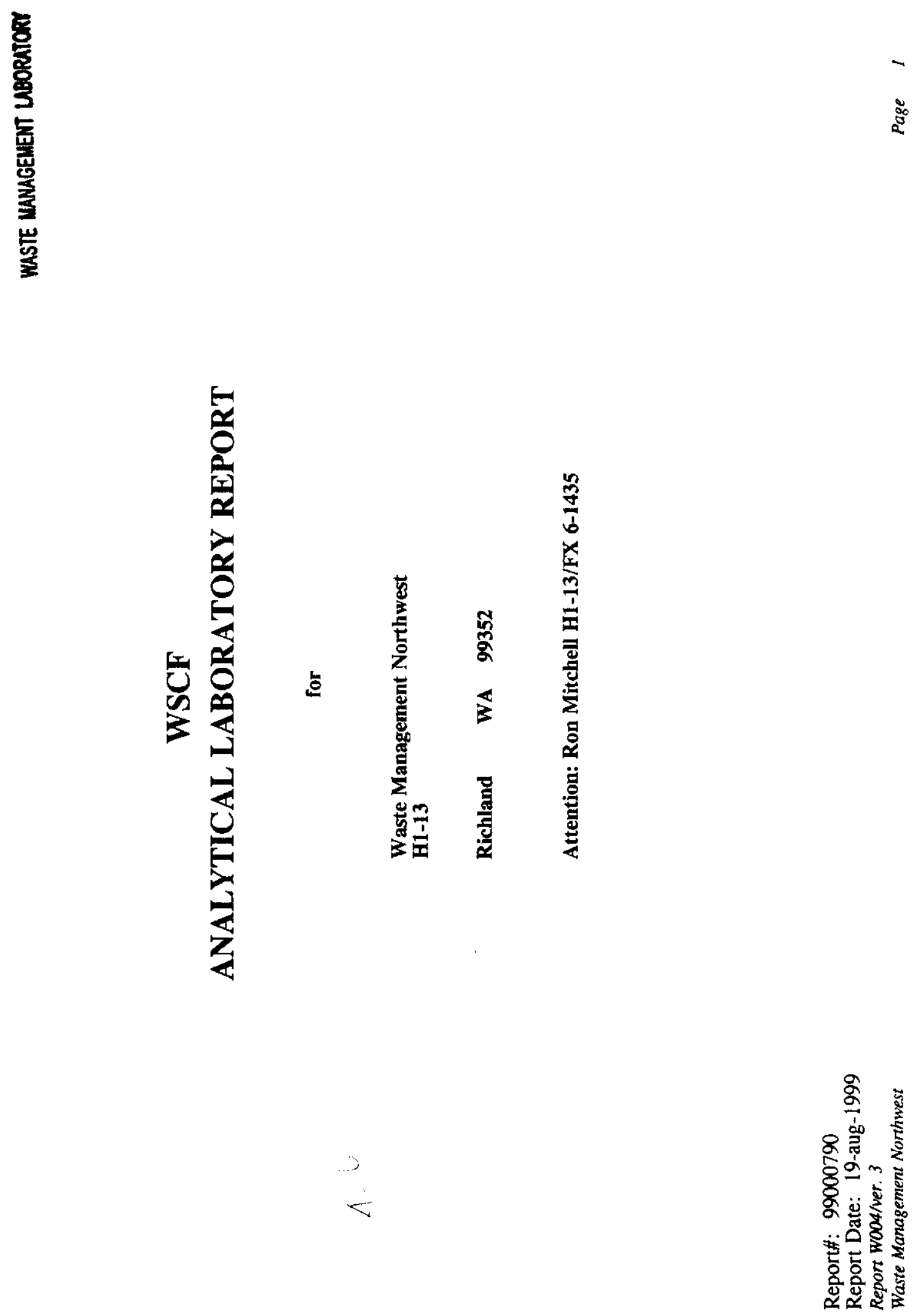
HNF-6150 Rev 0

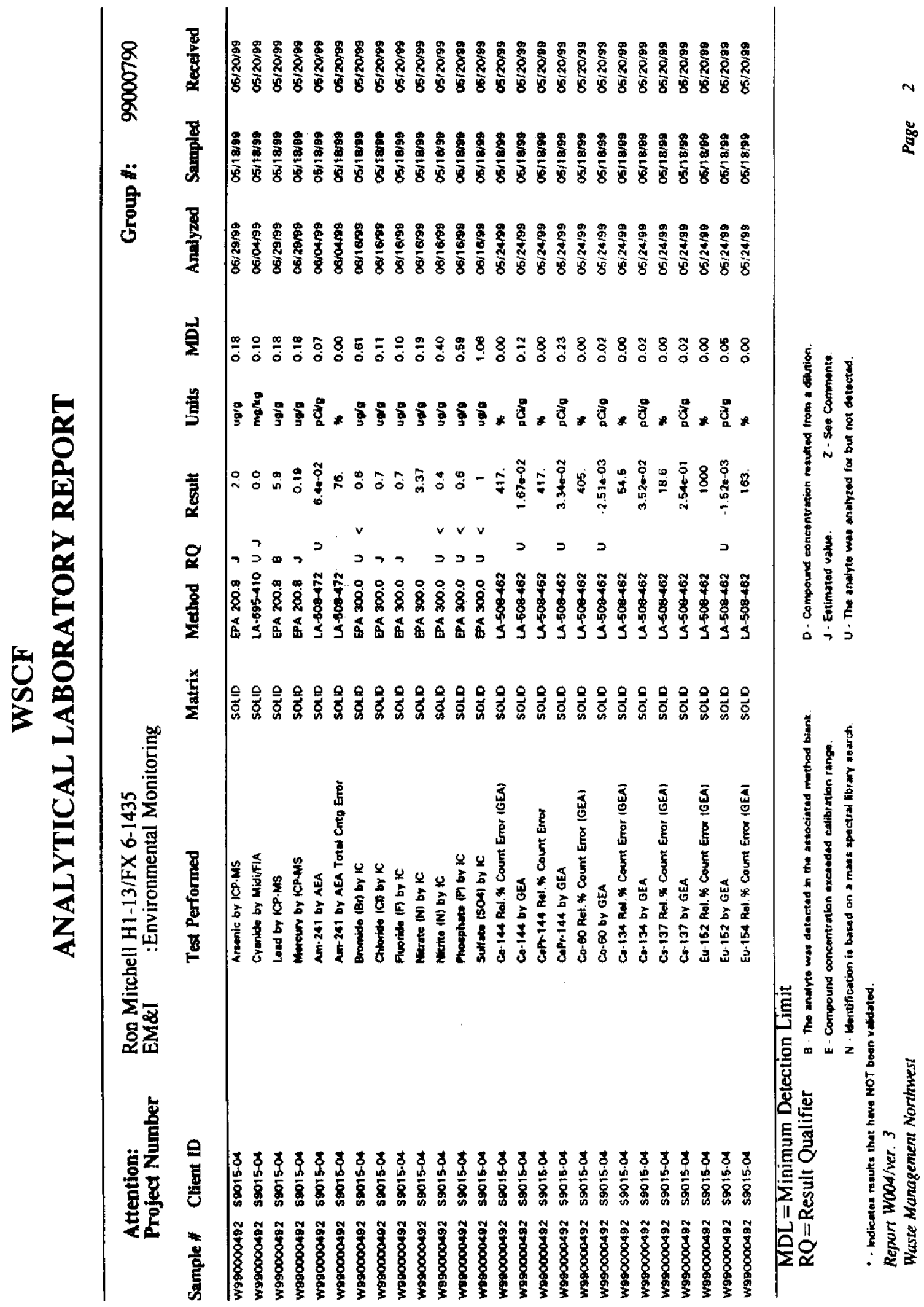


HNF-6150 Rev 0

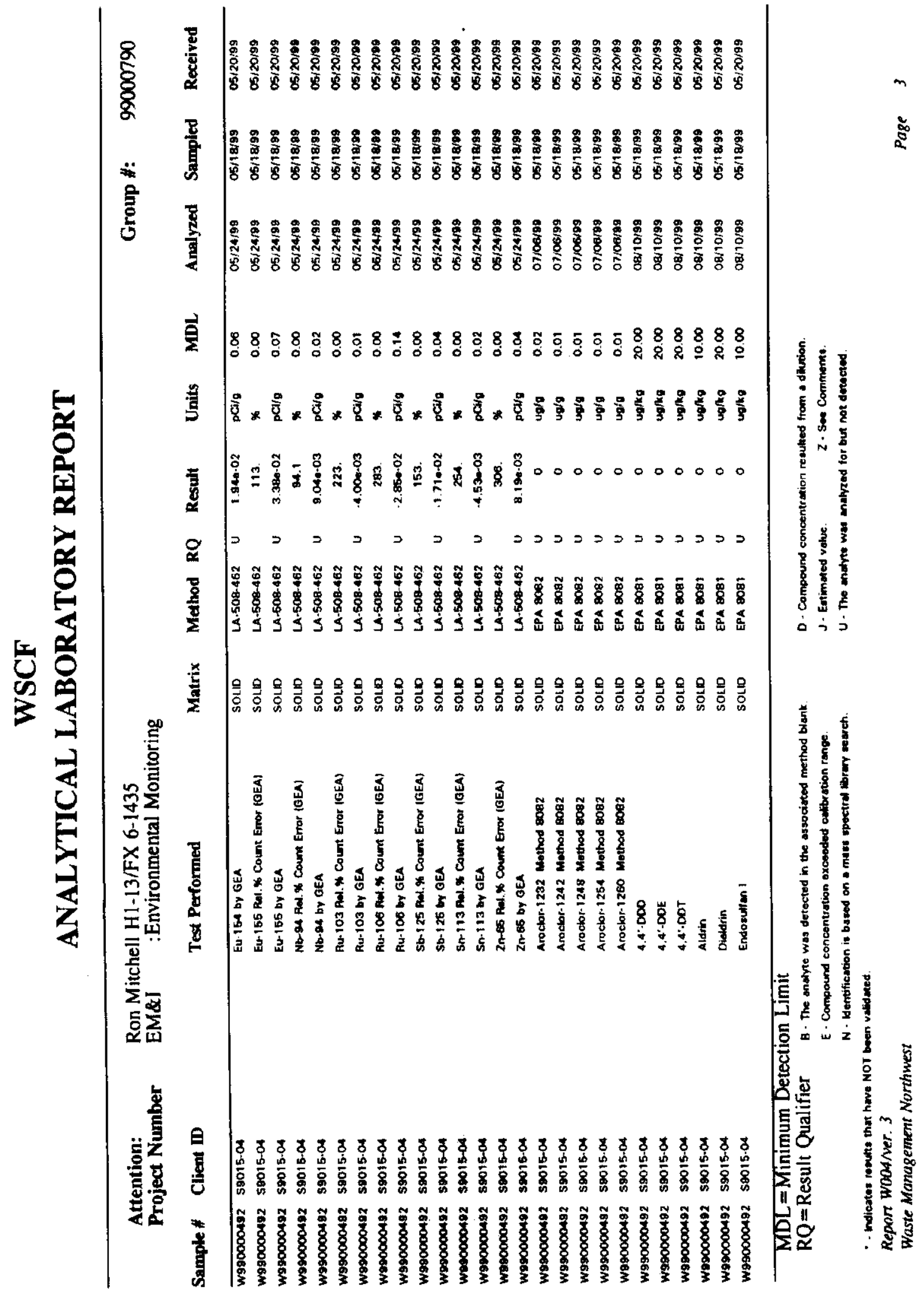


HNF-6150 Rev 0

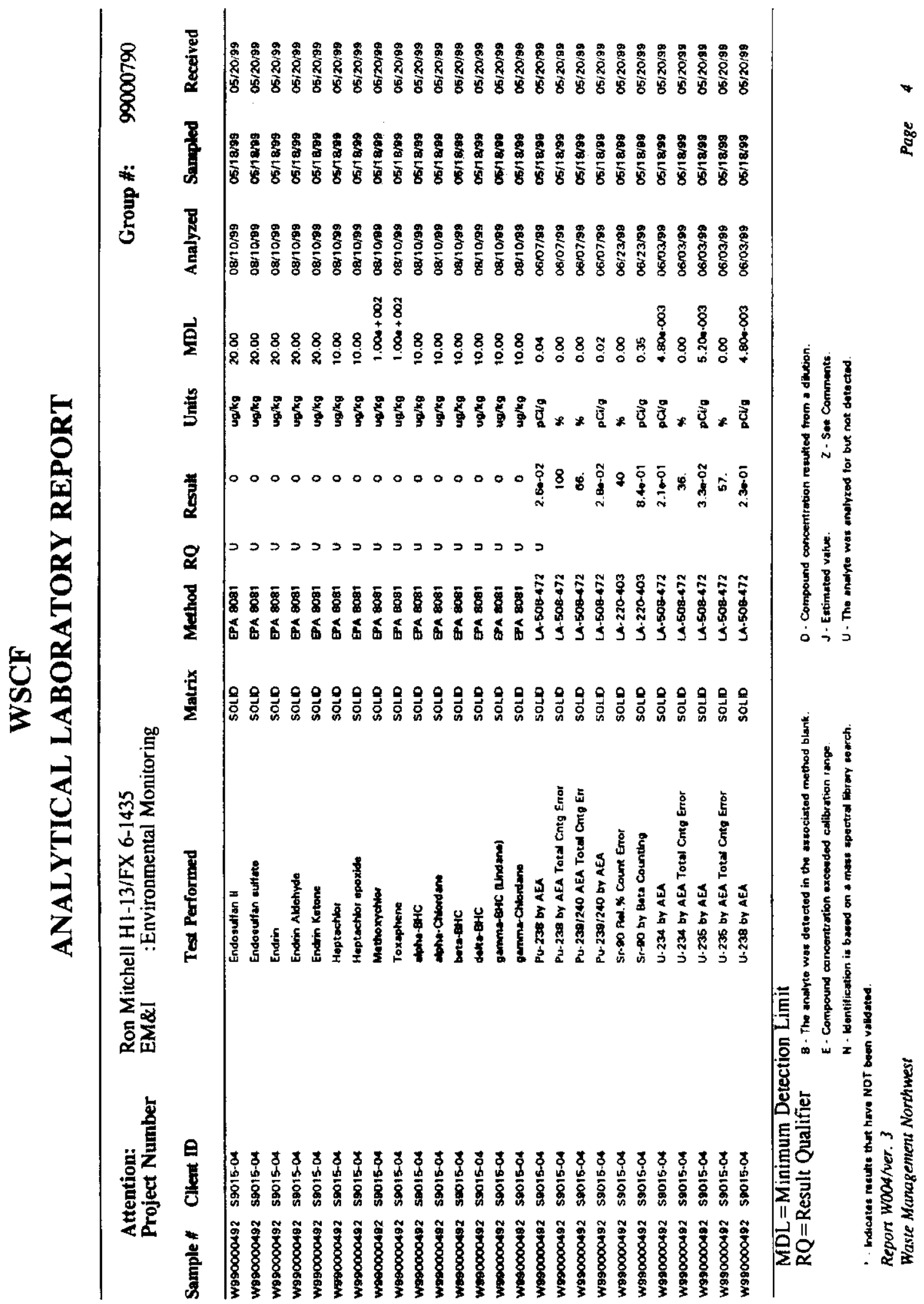


HNF-6150 Rev 0

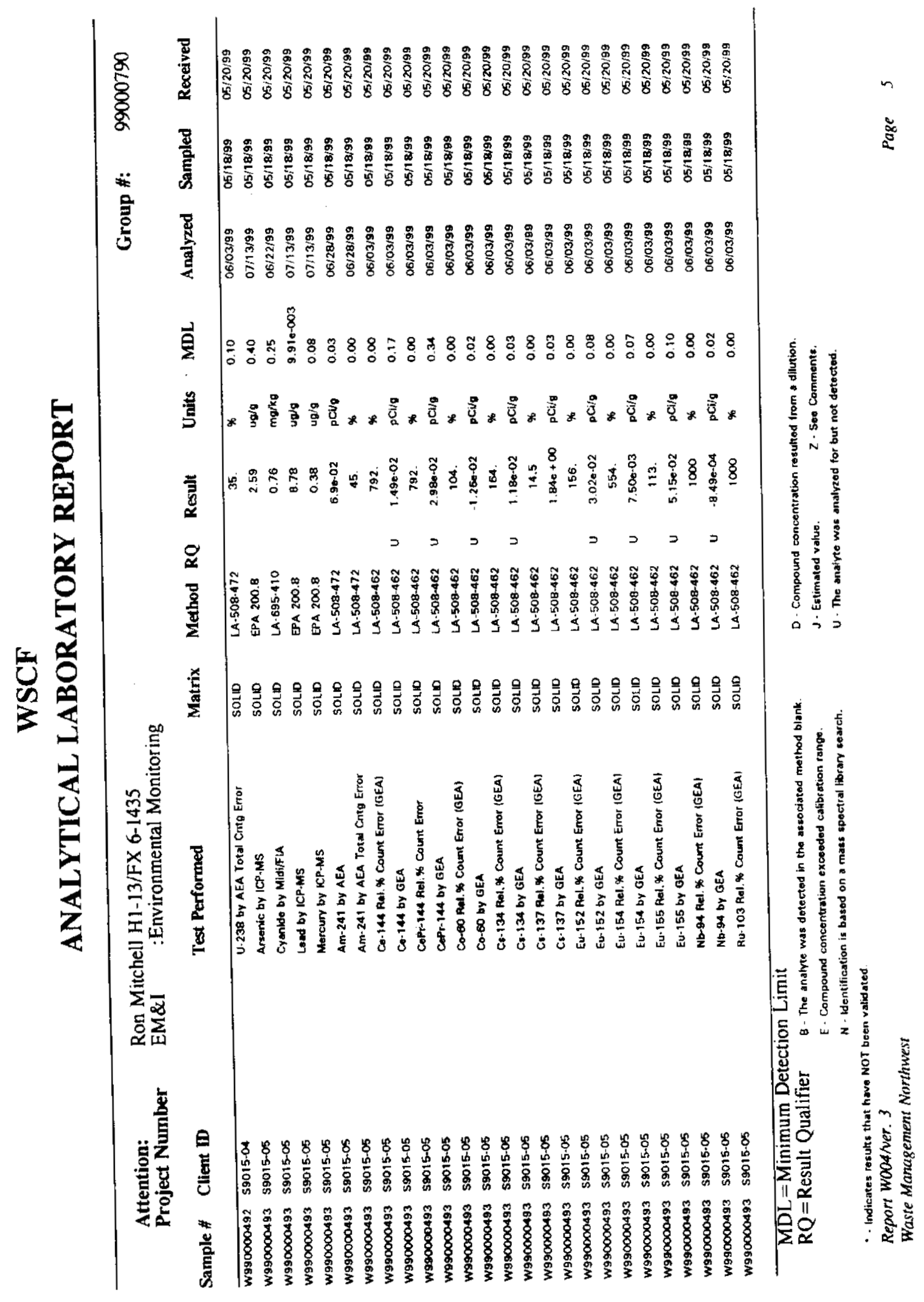


HNF-6150 Rev 0

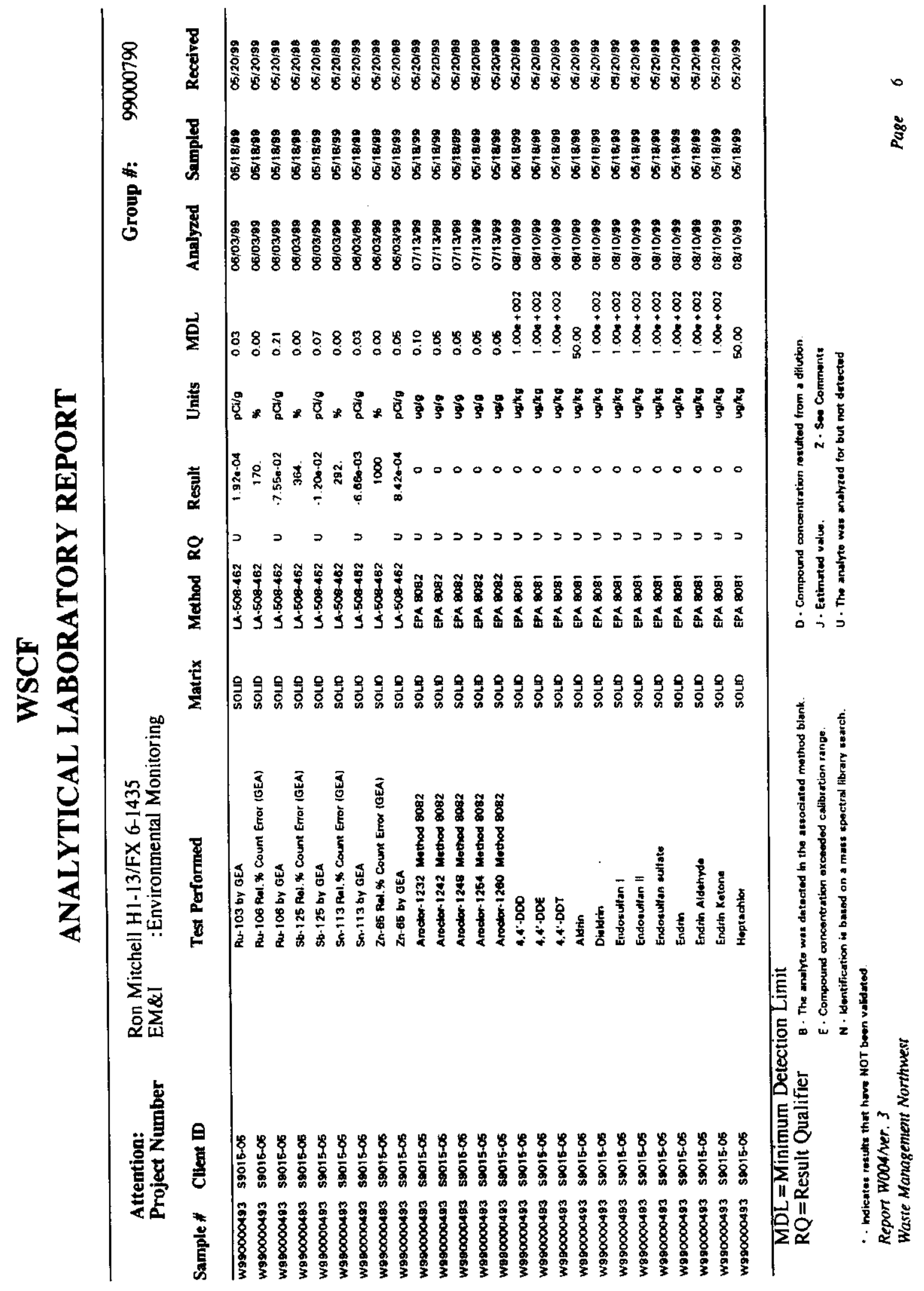


HNF-6150 Rev 0

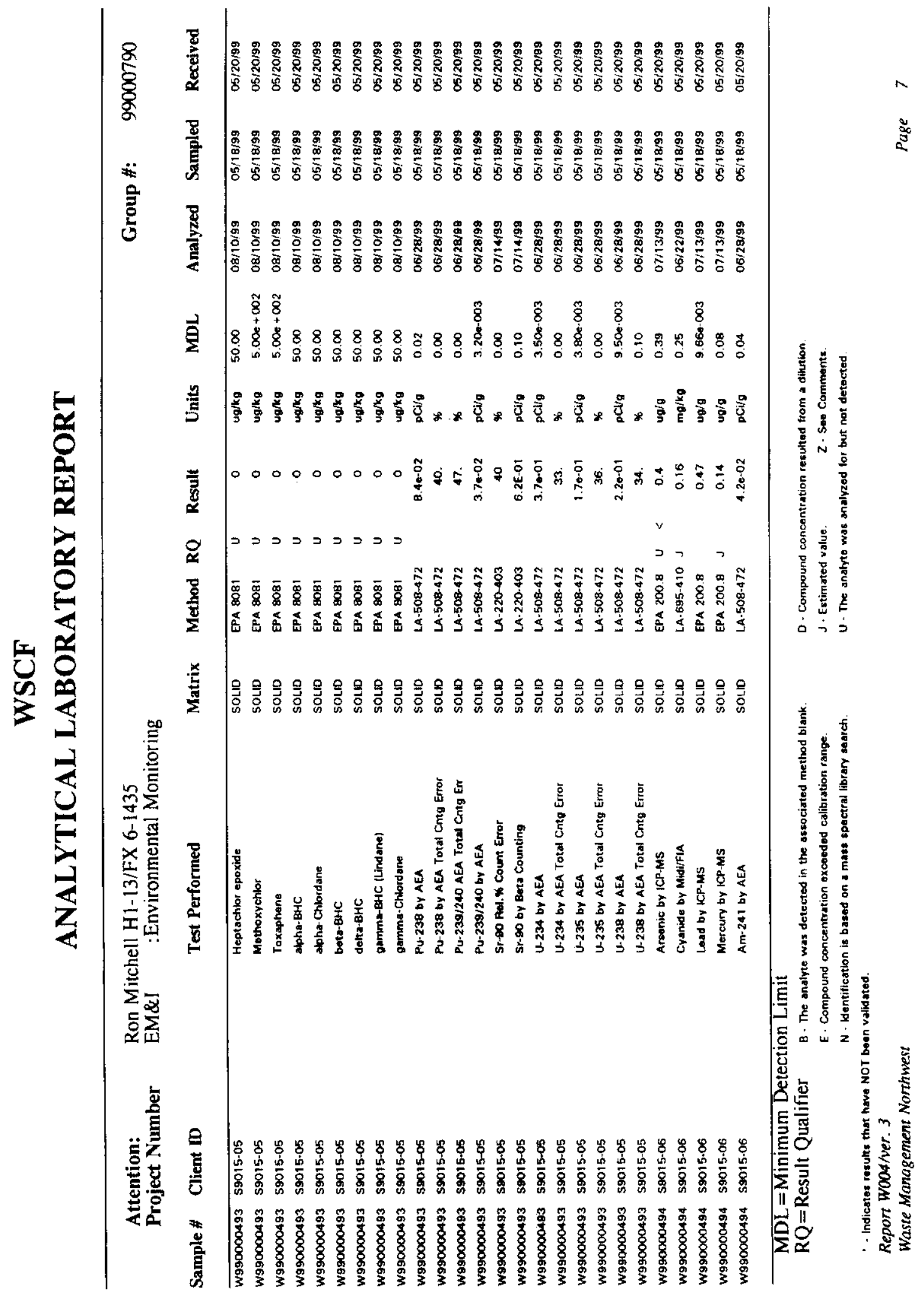


HNF-6150 Rev 0

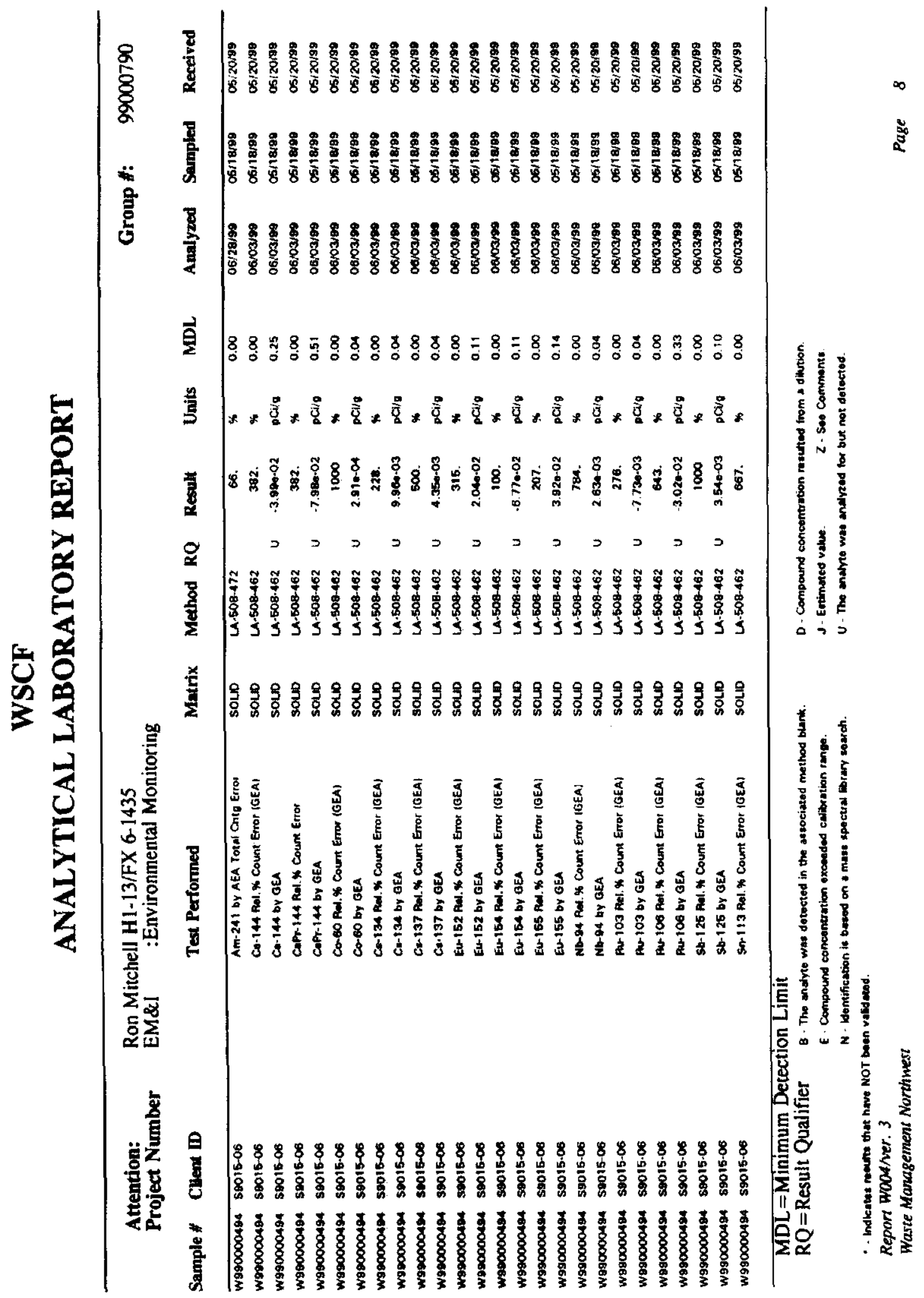


HNF-6150 Rev 0

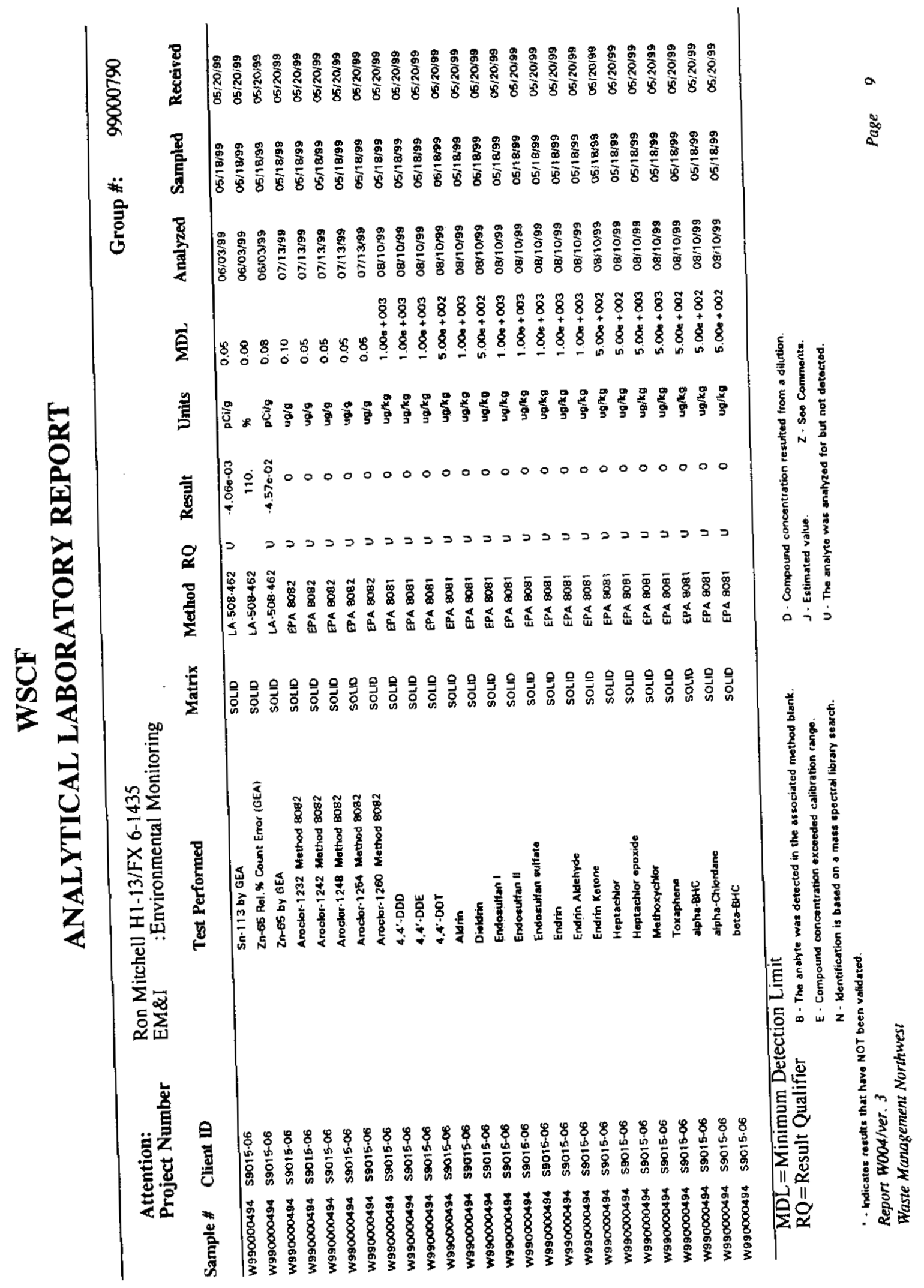


HNF-6150 Rev 0

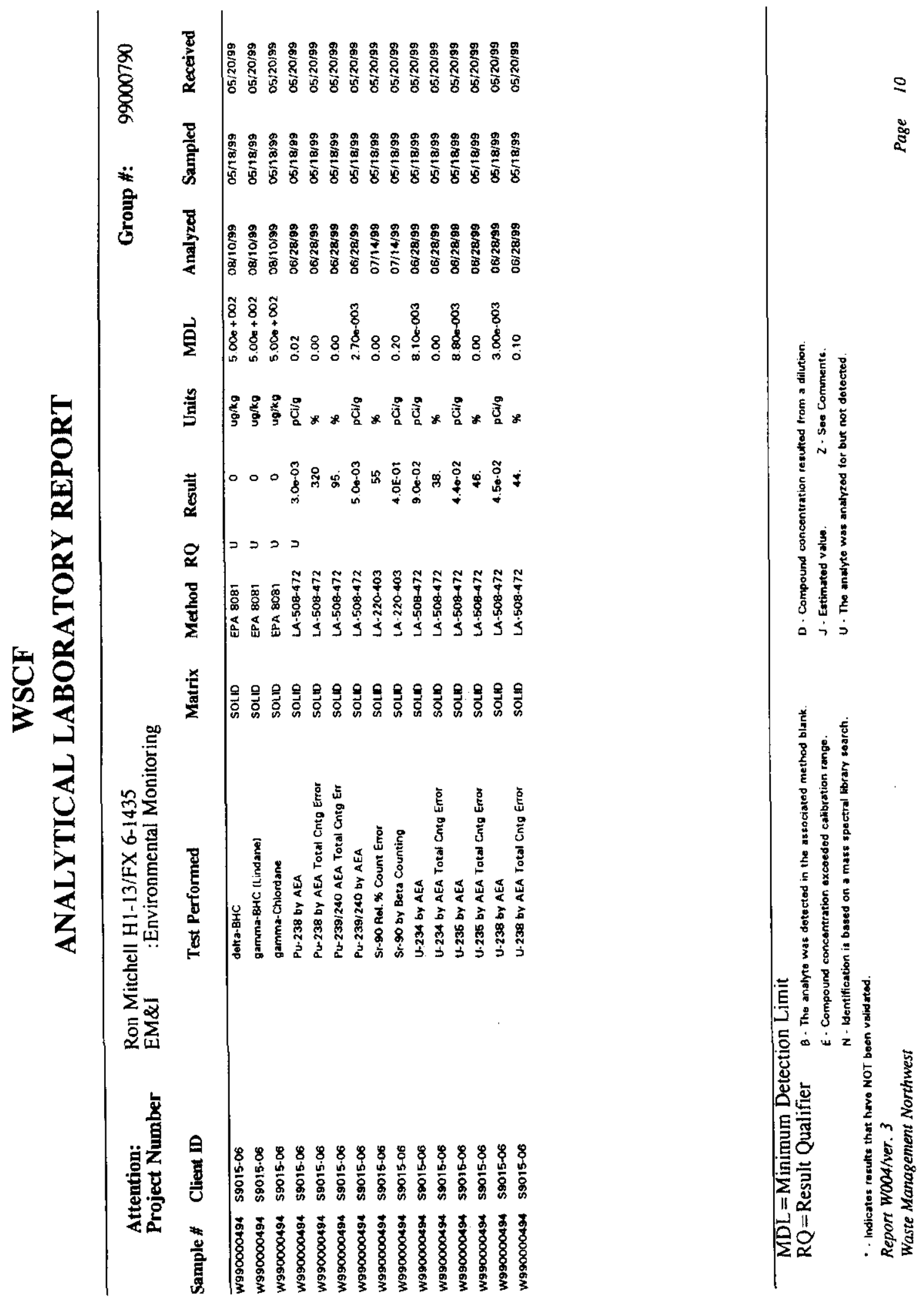


HNF-6150 Rev 0

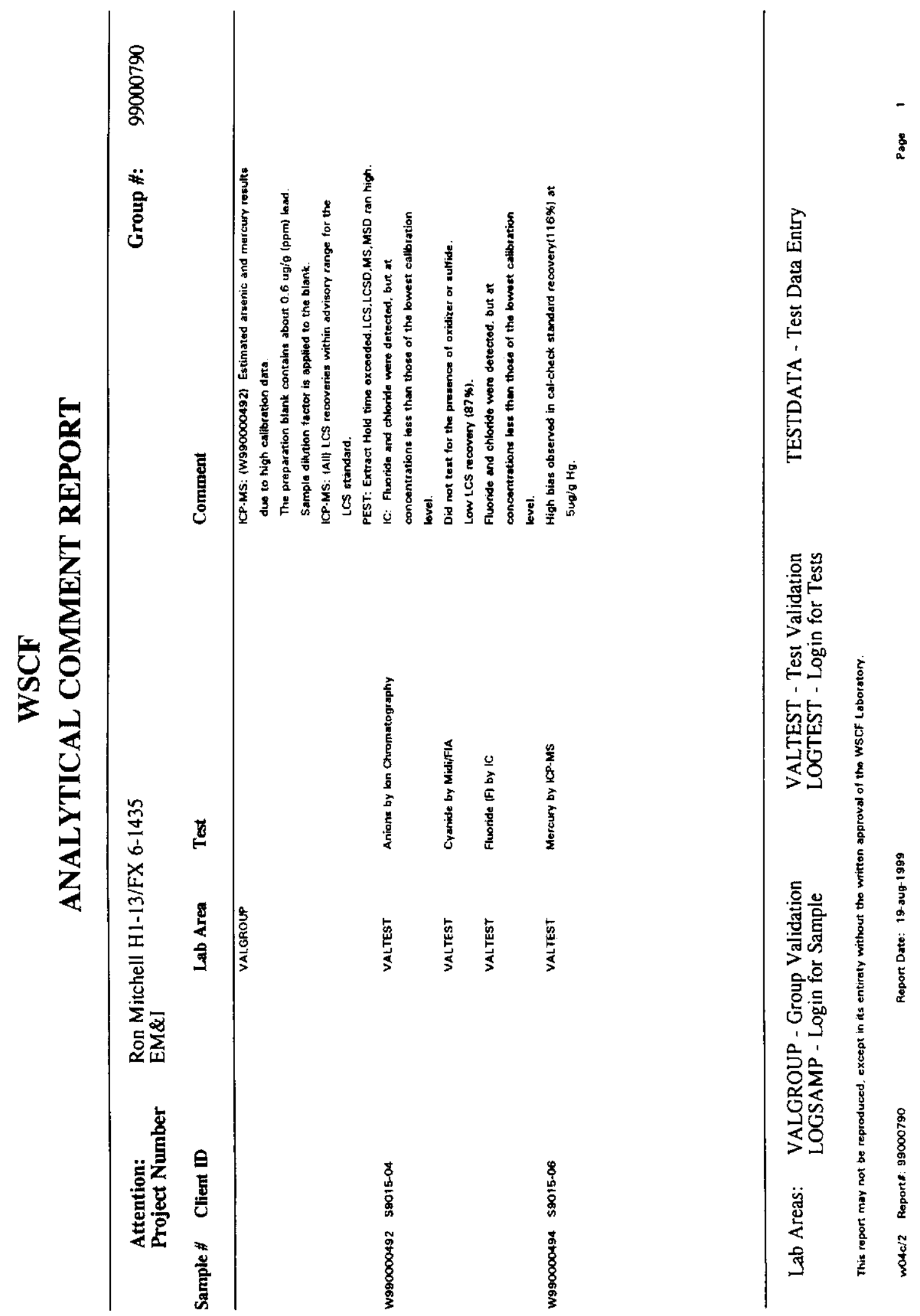


HNF-6150 Rev 0
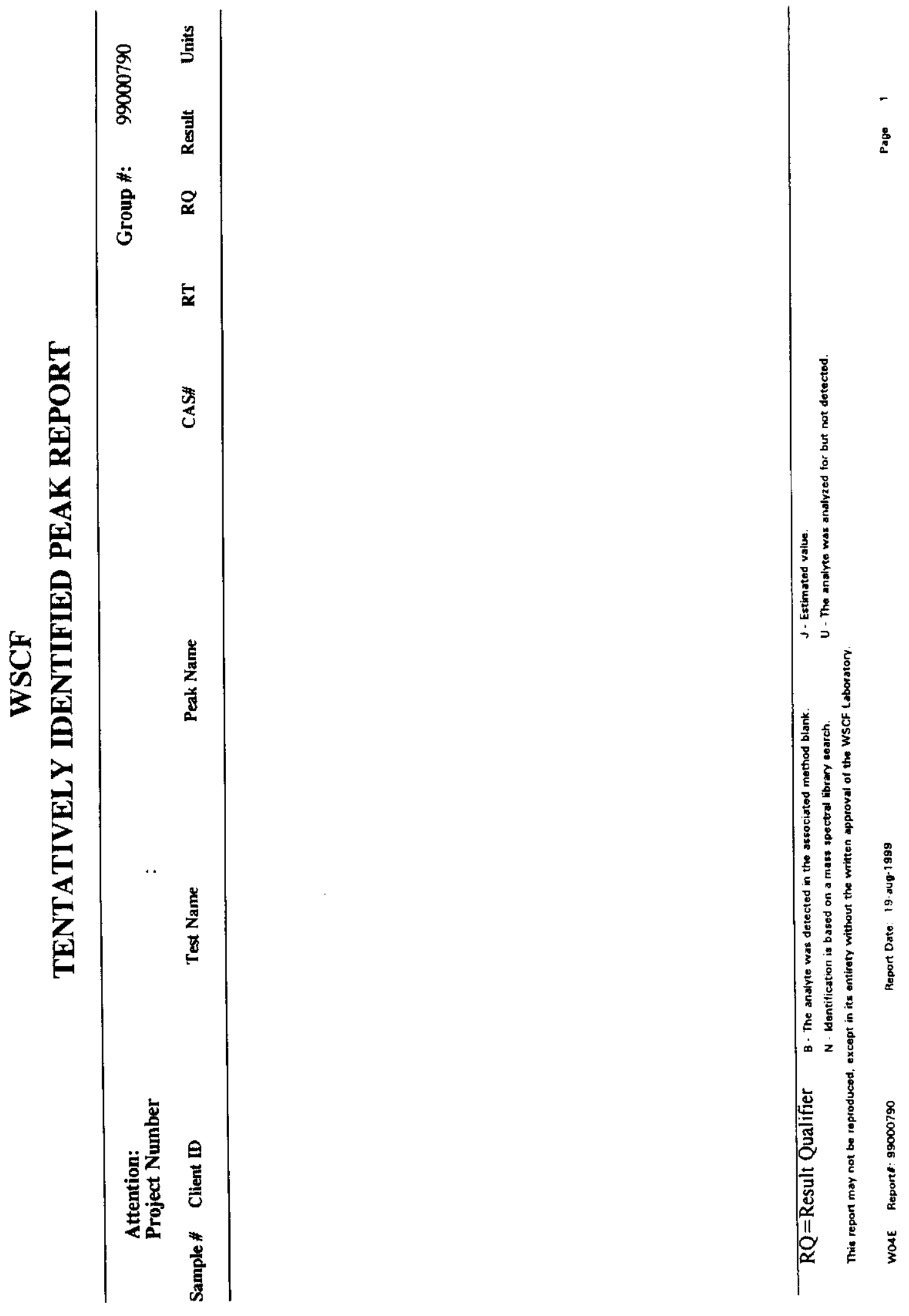
HNF-6150 Rev 0

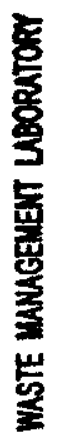
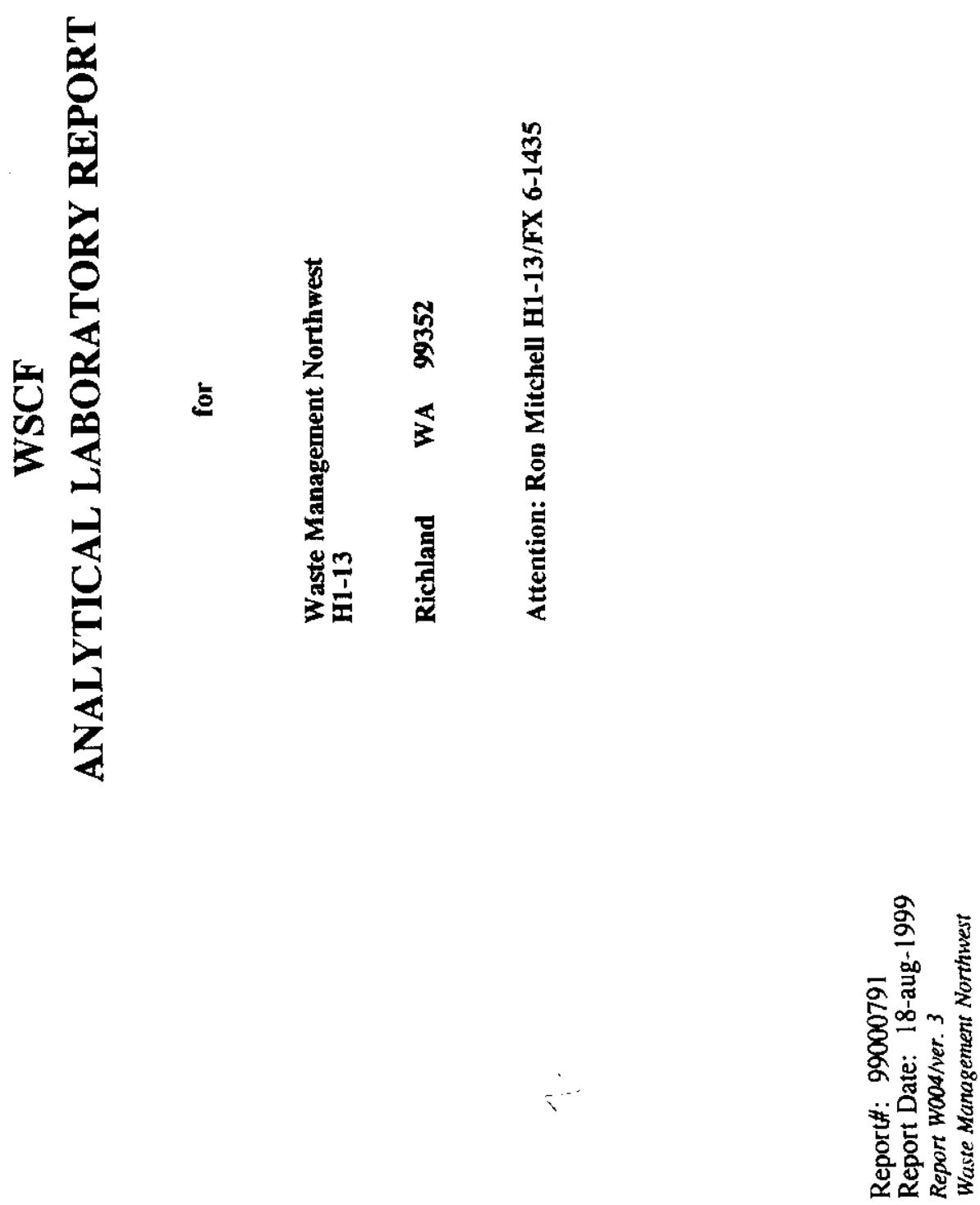
HNF-6150 Rev 0

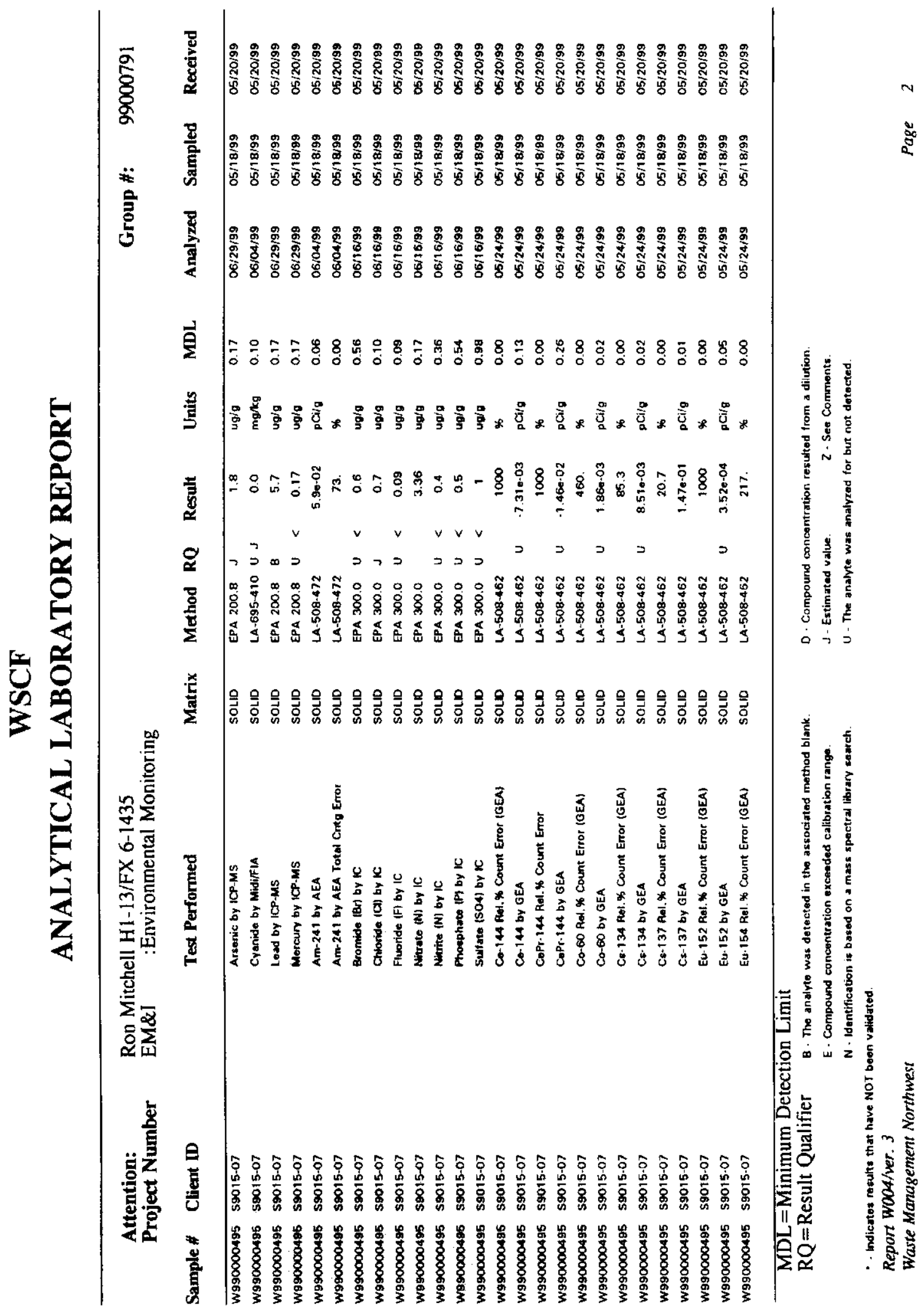


HNF-6150 Rev 0

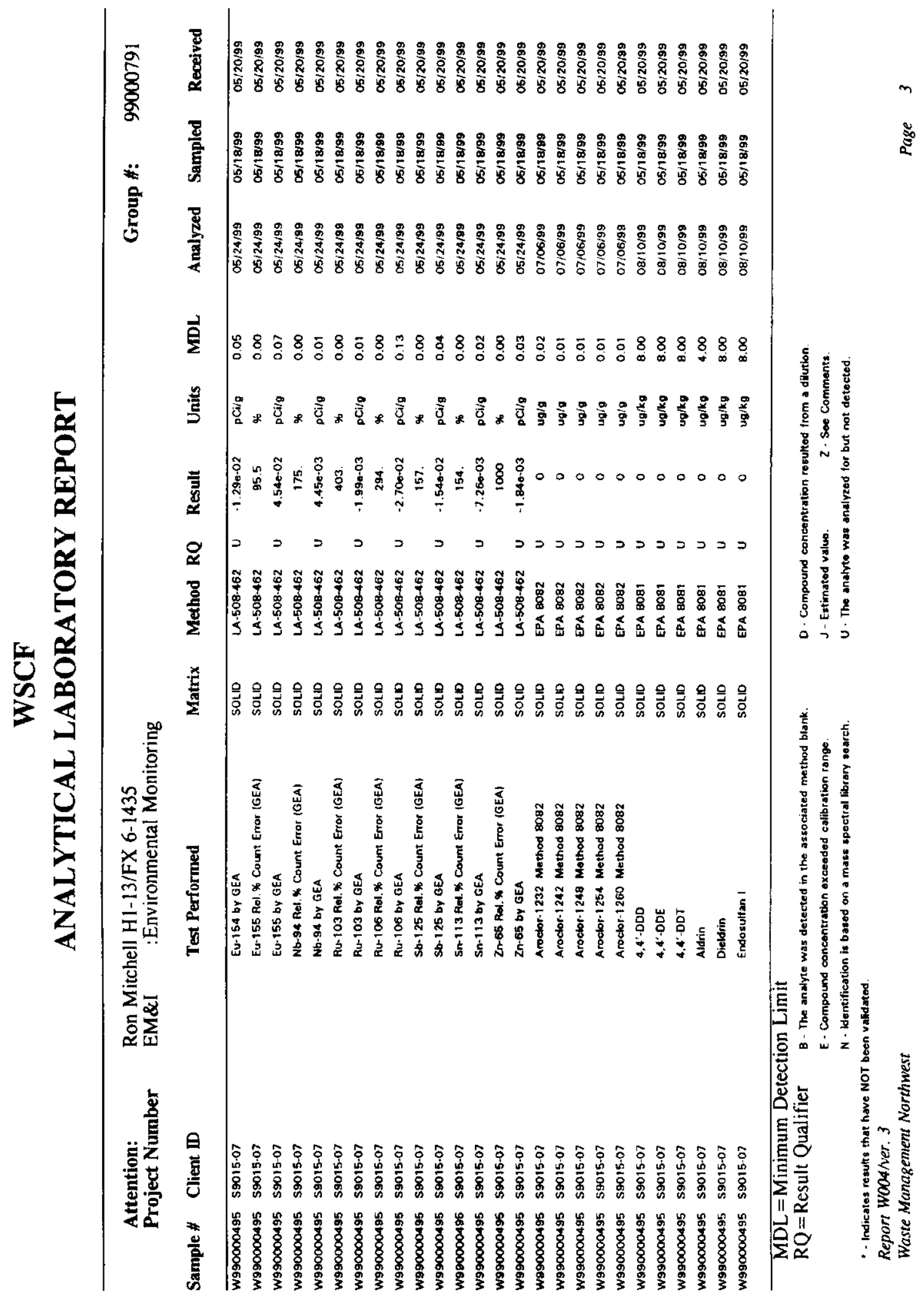


HNF-6150 Rev 0

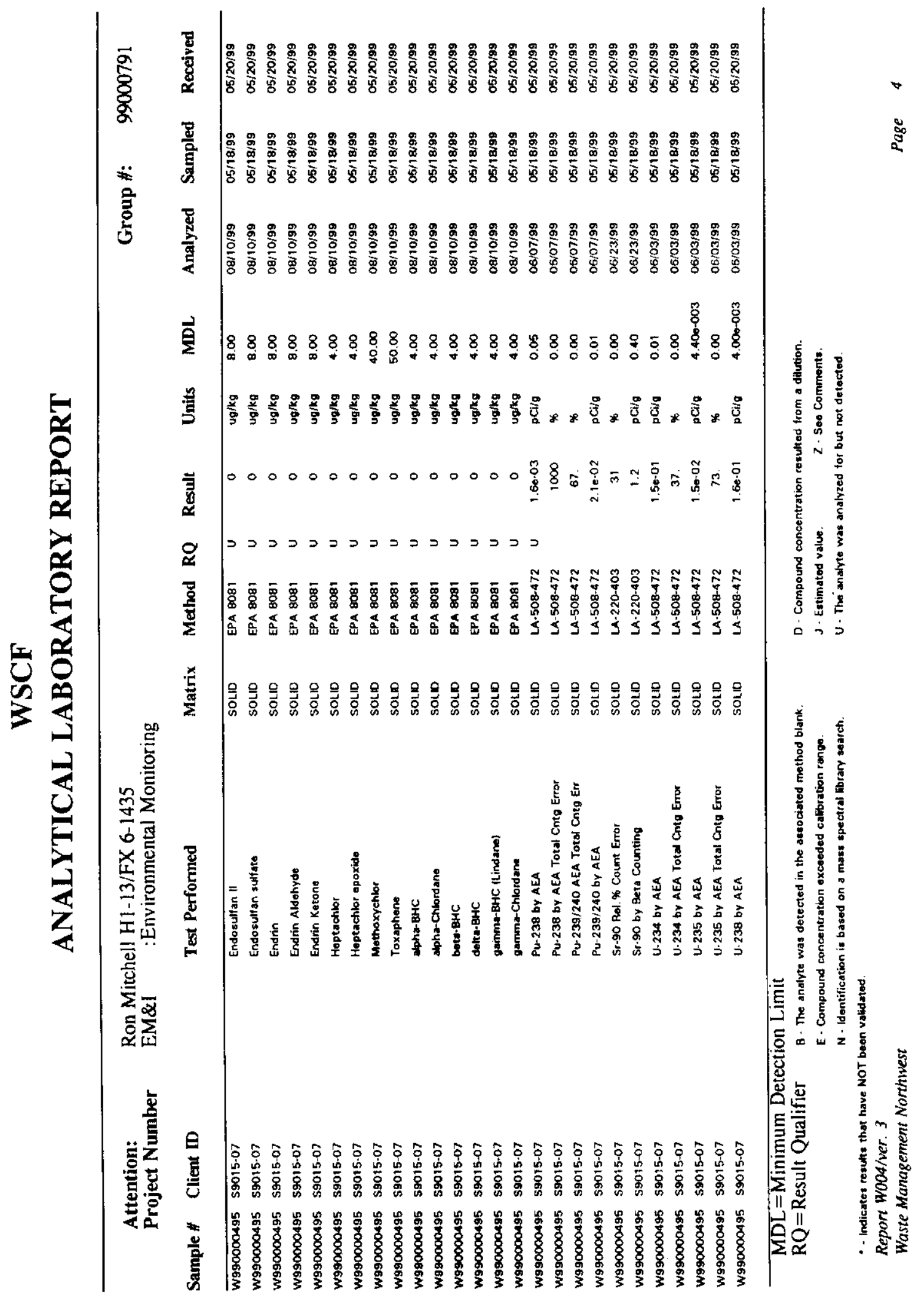


HNF-6150 Rev 0
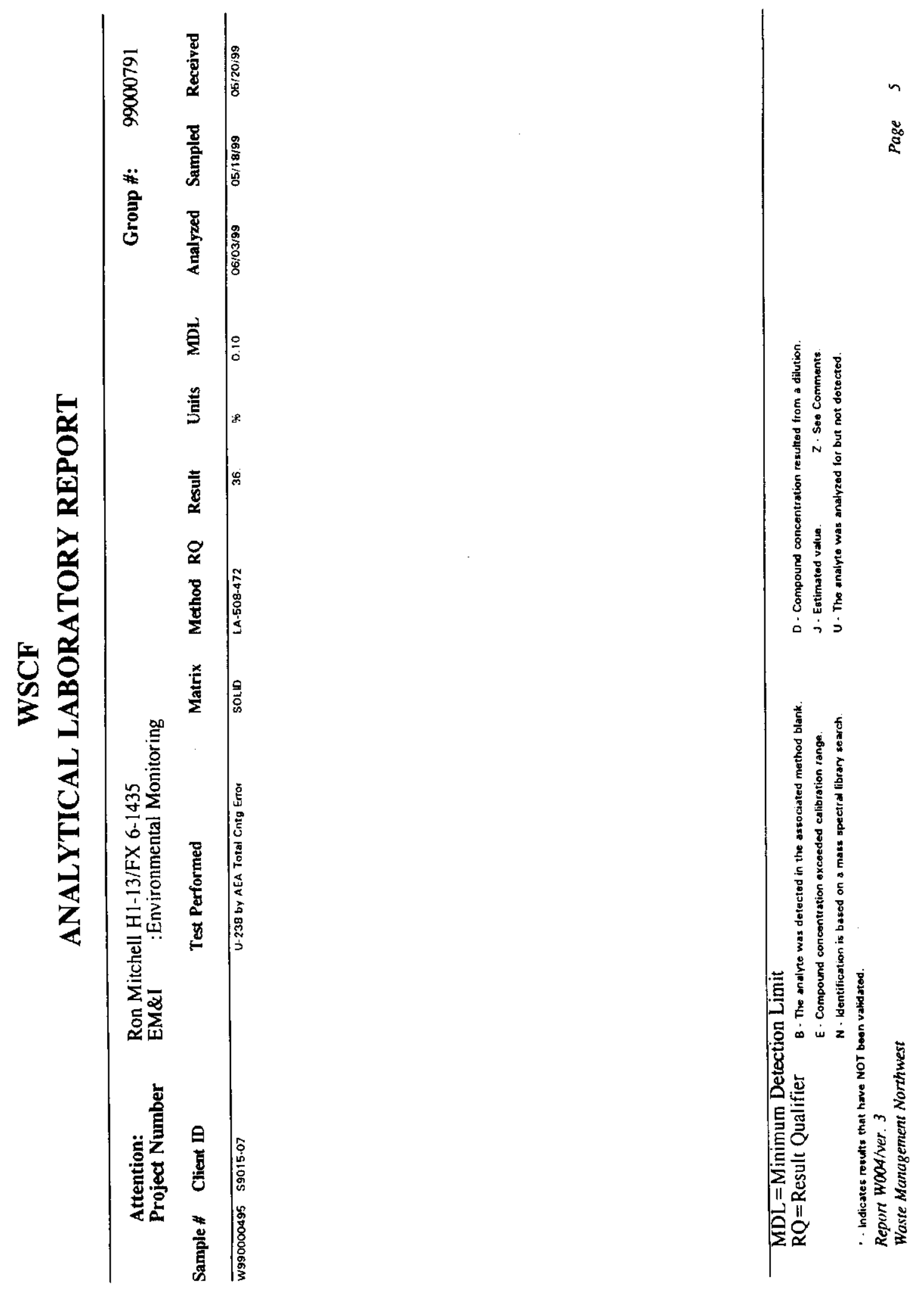
HNF-6150 Rev 0

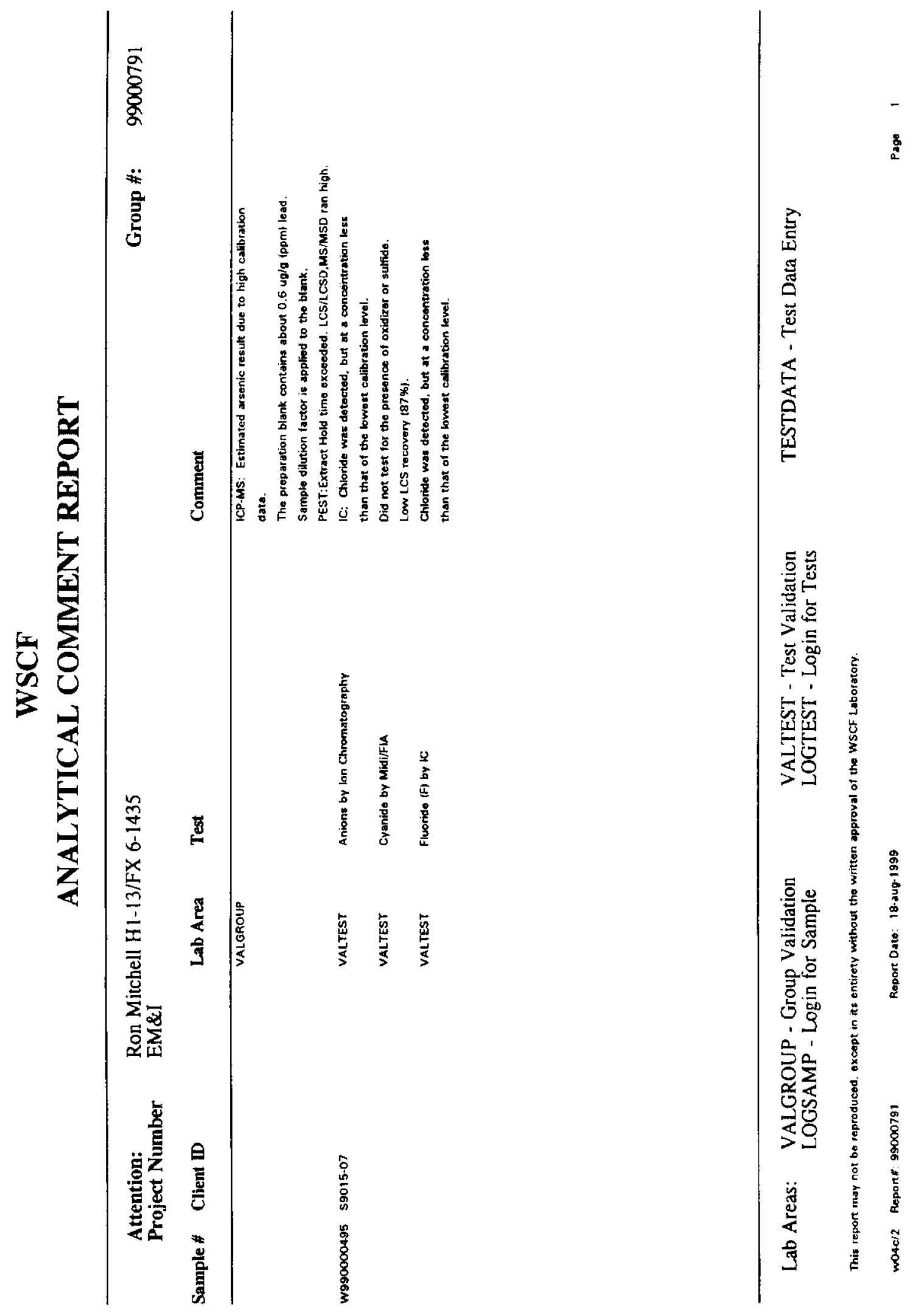




\section{HNF-6150 Rev 0}
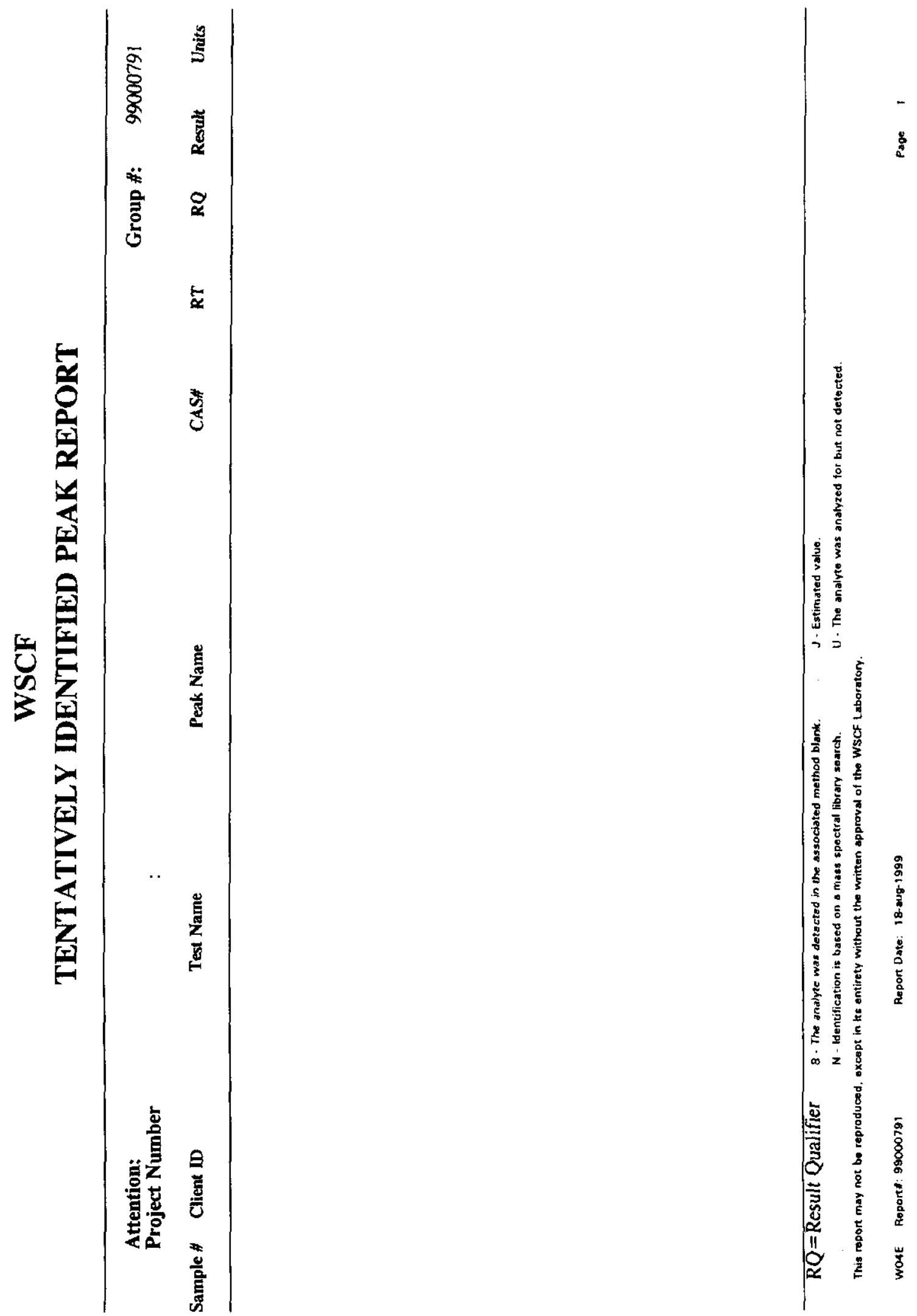
HNF-6150 Rev 0
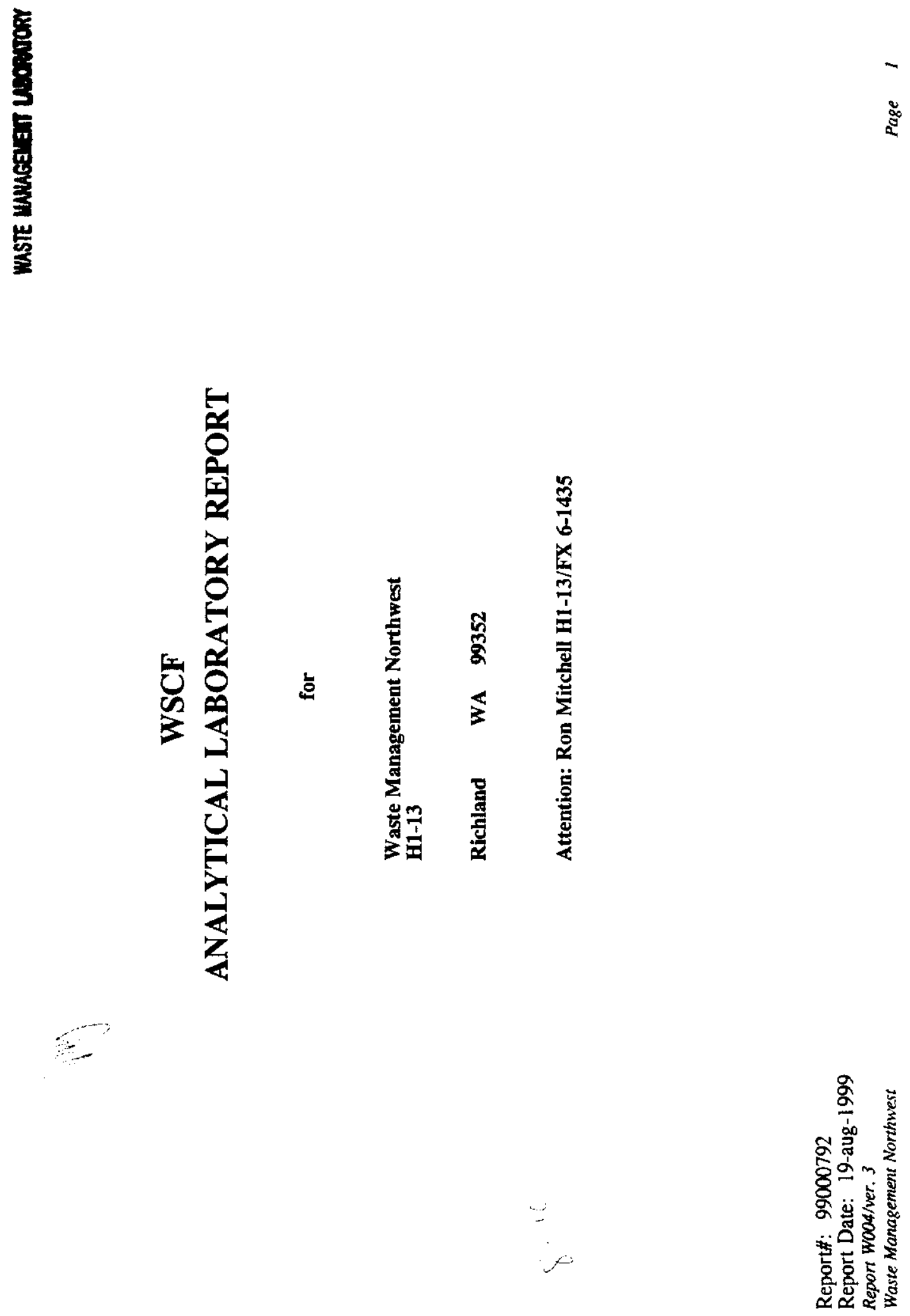
HNF-6150 Rev 0

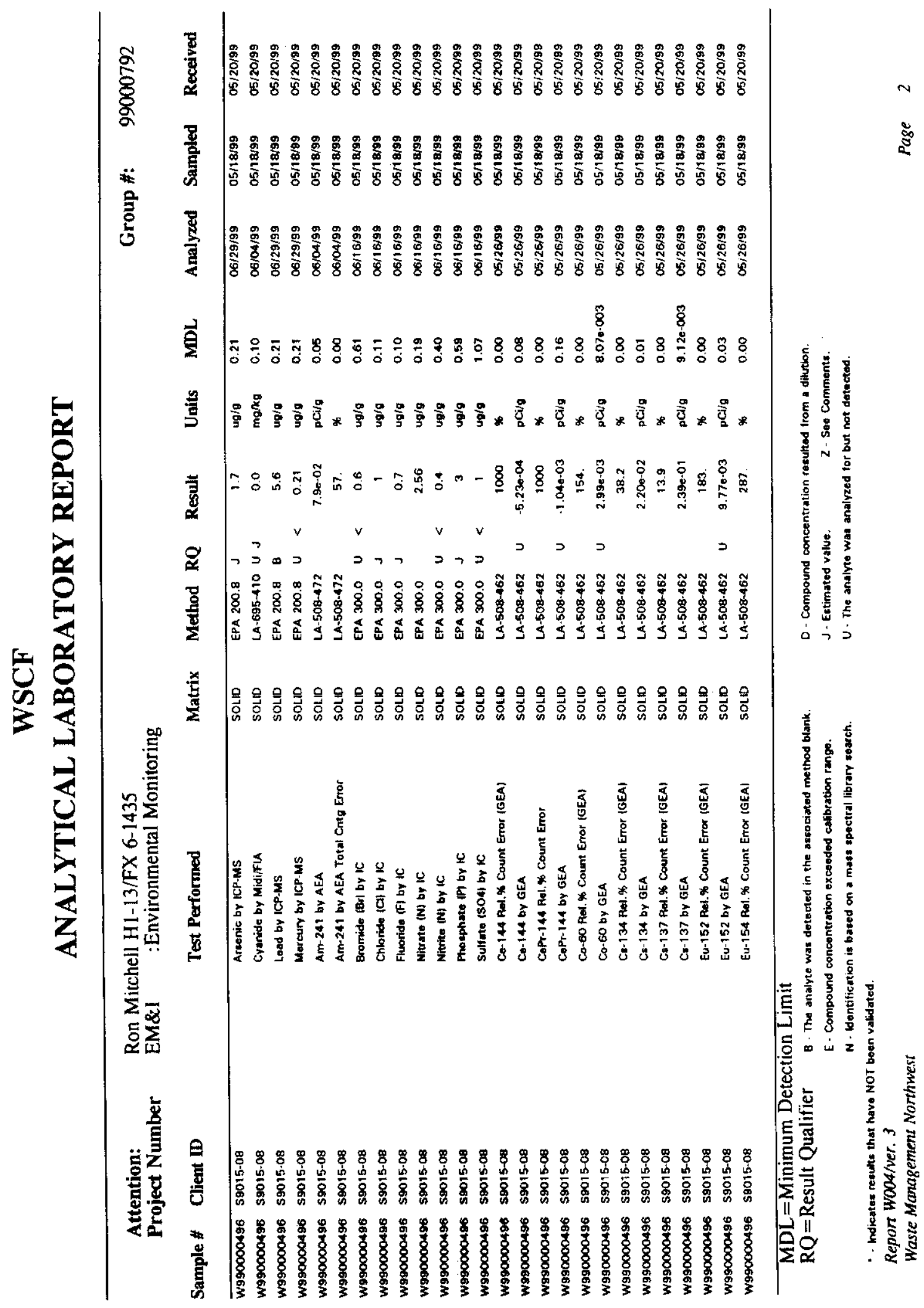


HNF-6150 Rev 0

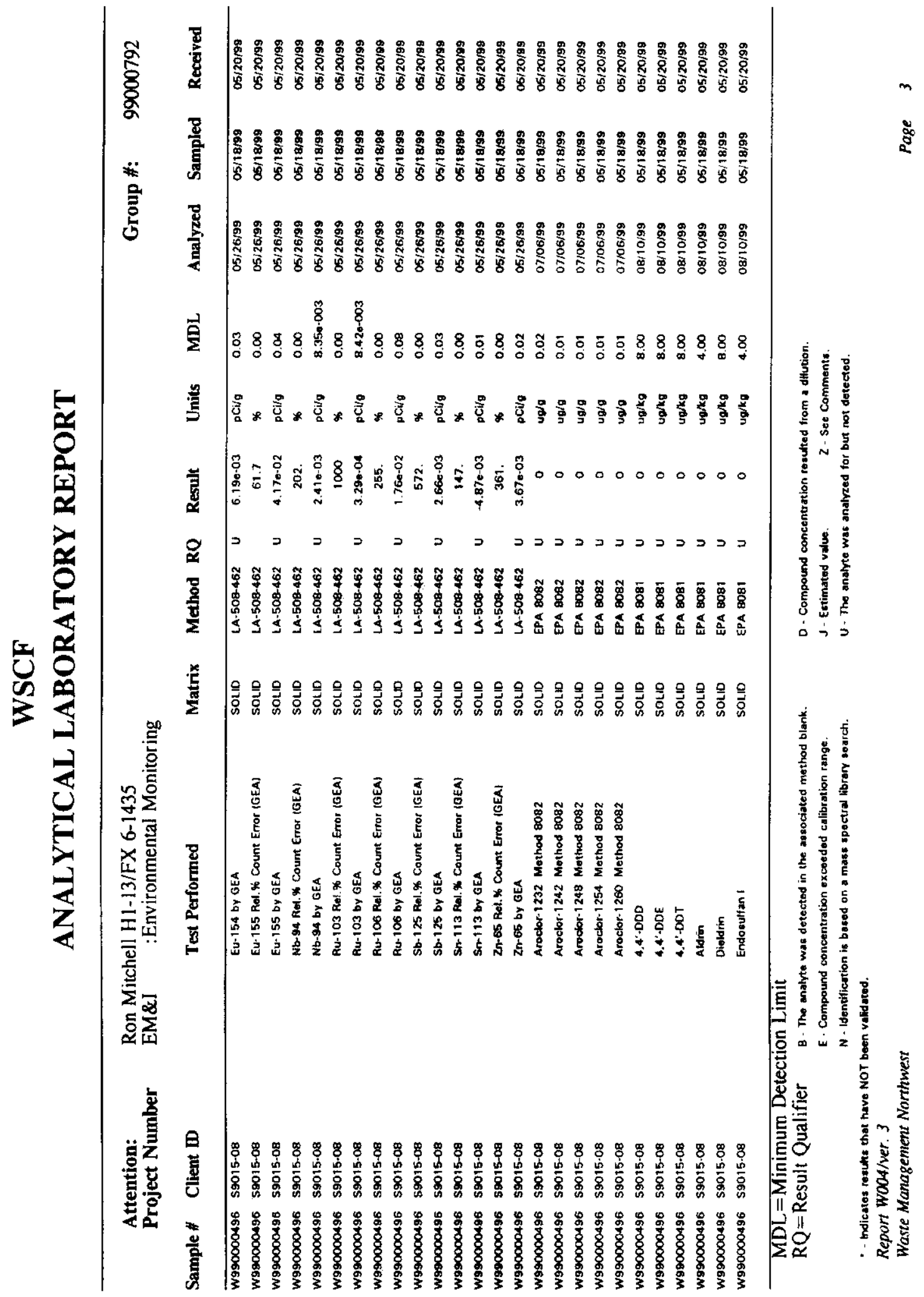


HNF-6150 Rev 0

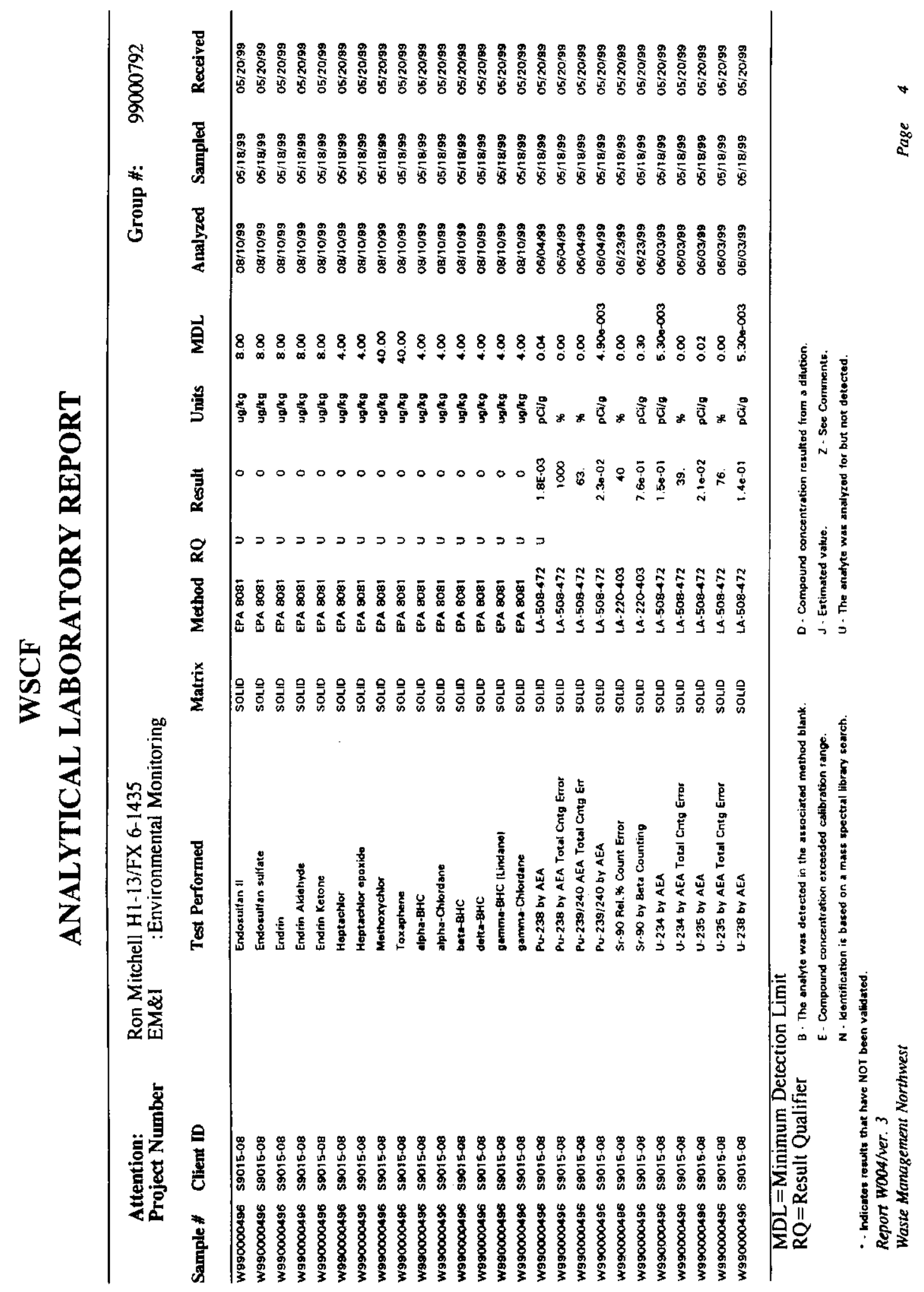


HNF-6150 Rev 0

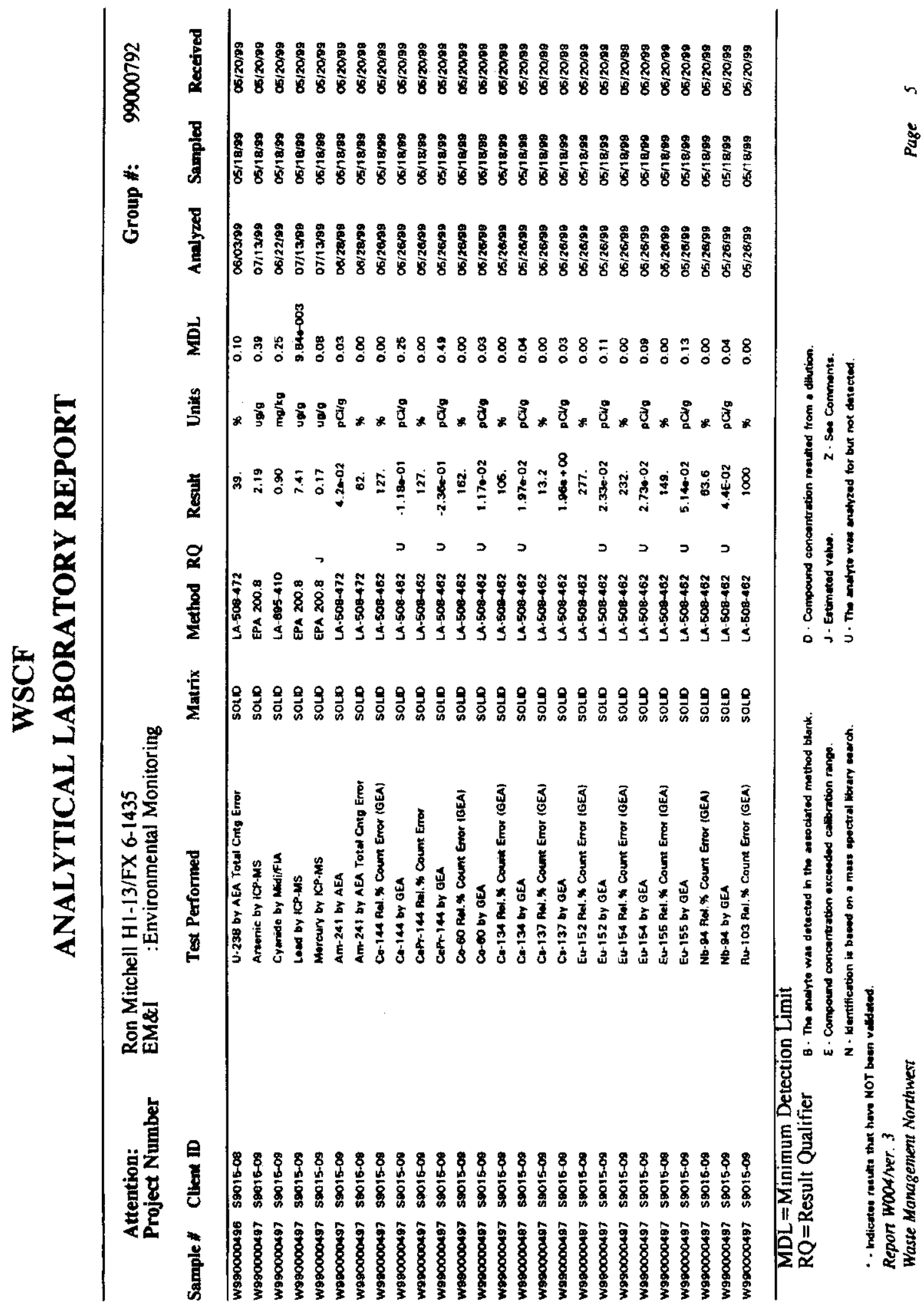


HNF-6150 Rev 0

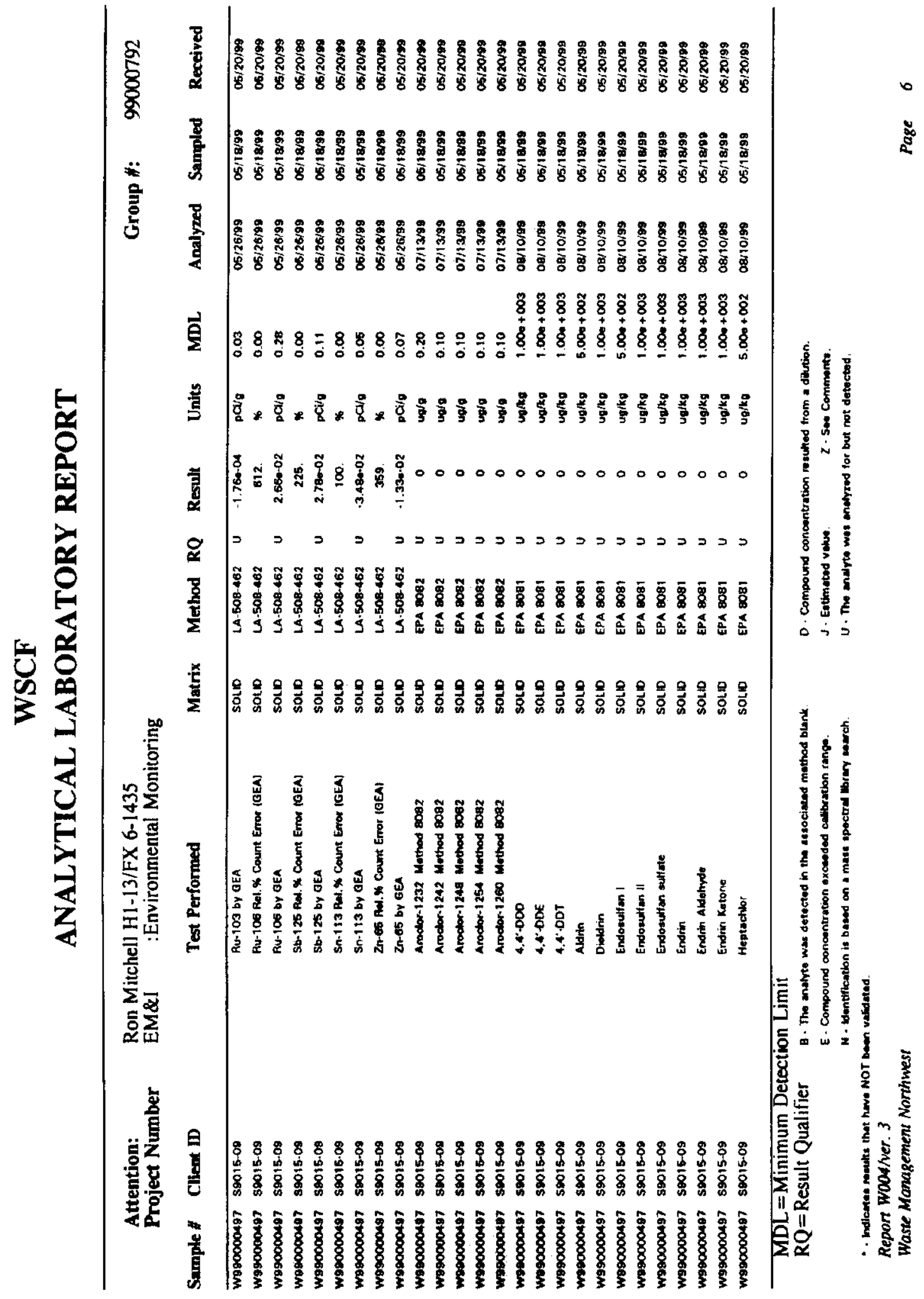


HNF-6150 Rev 0

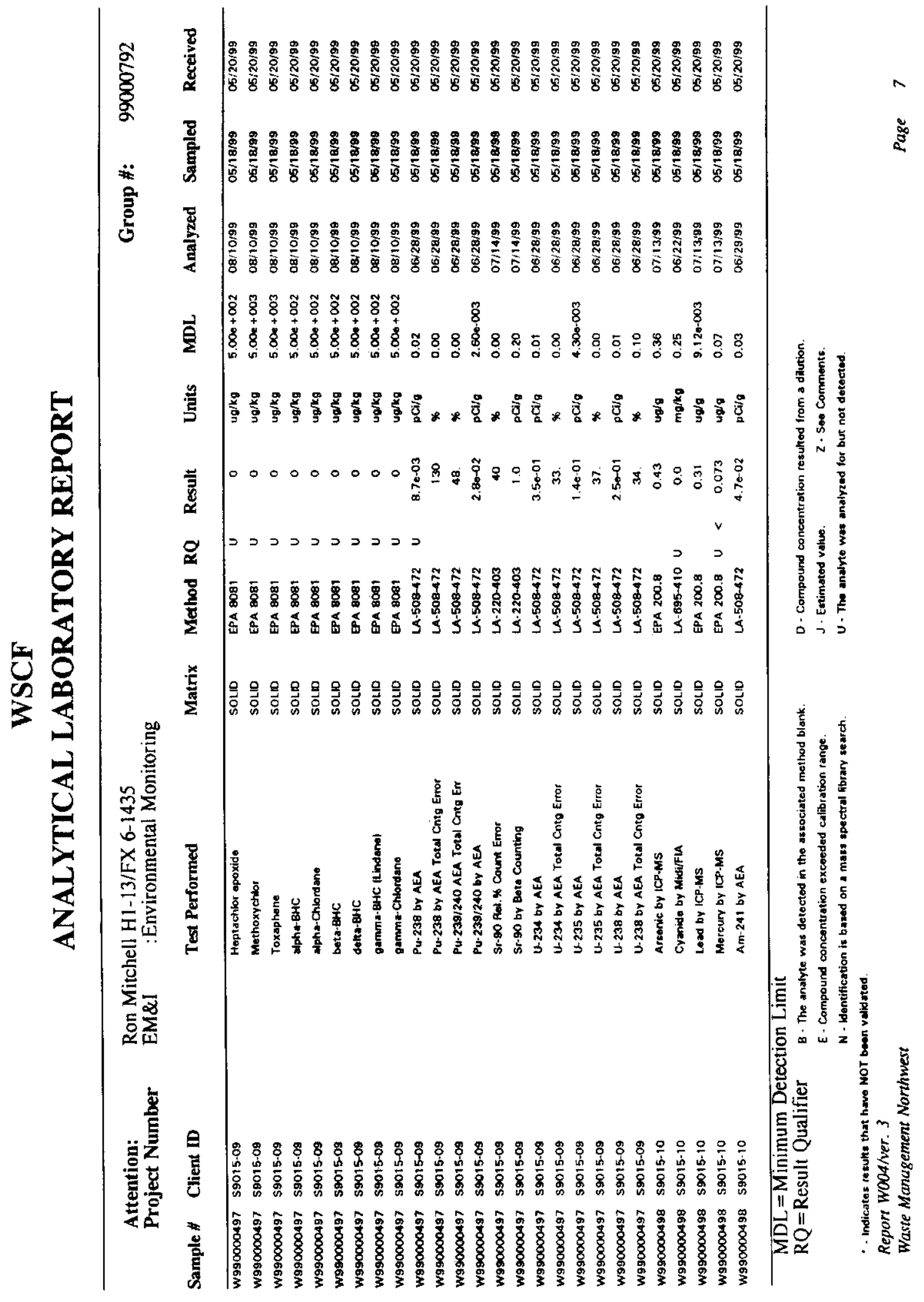


HNF-6150 Rev 0

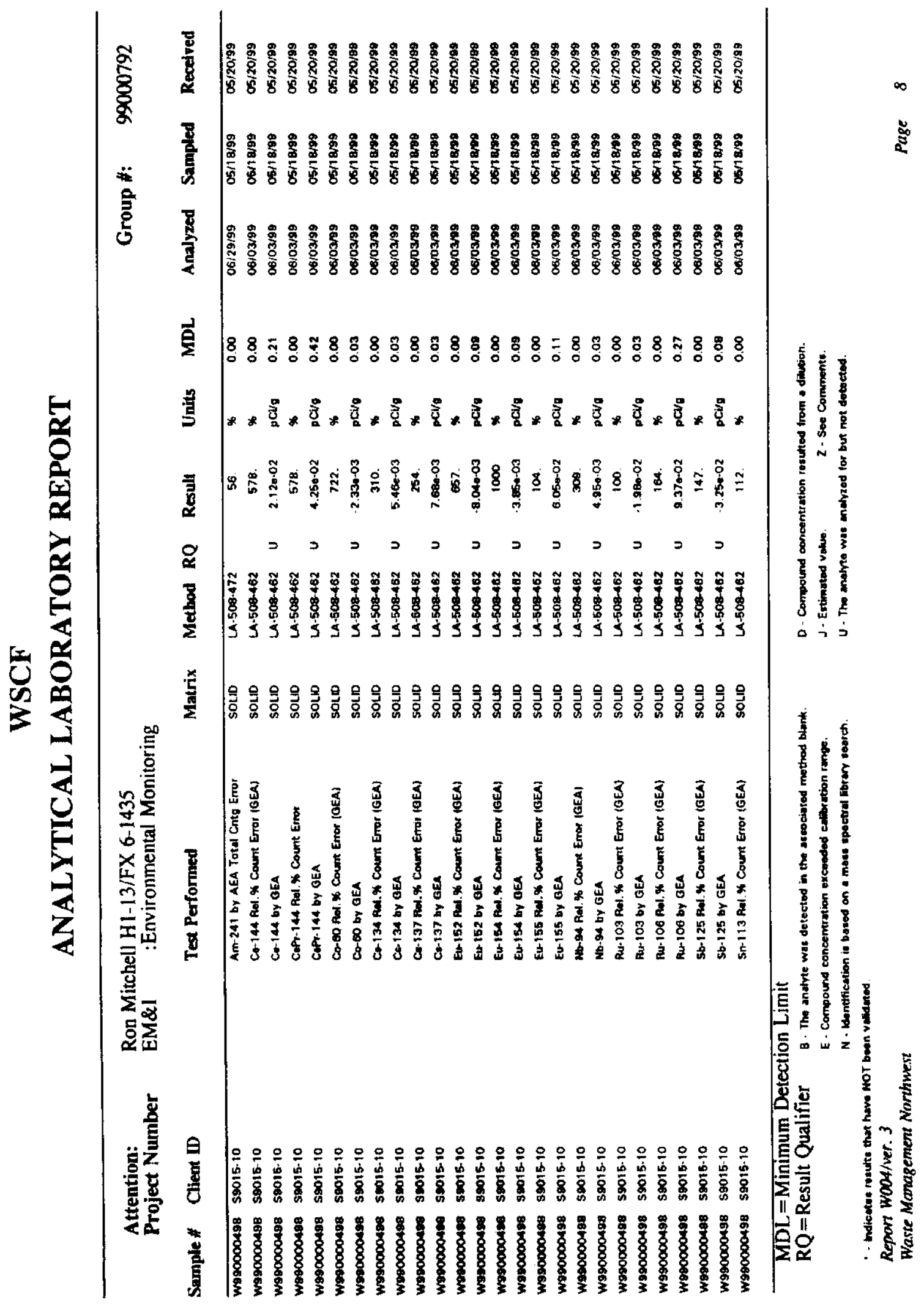


HNF-6150 Rev 0

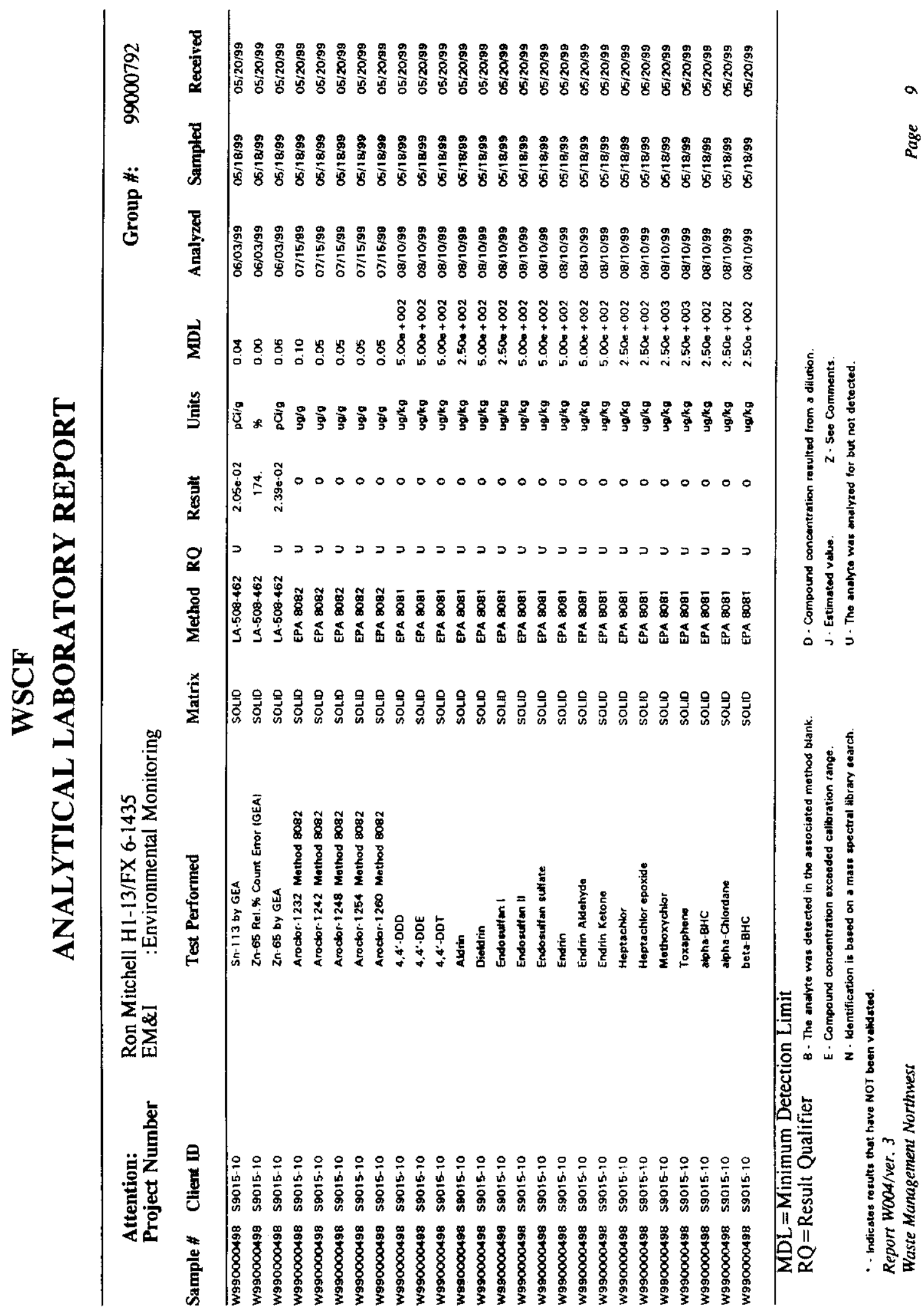


HNF-6150 Rev 0

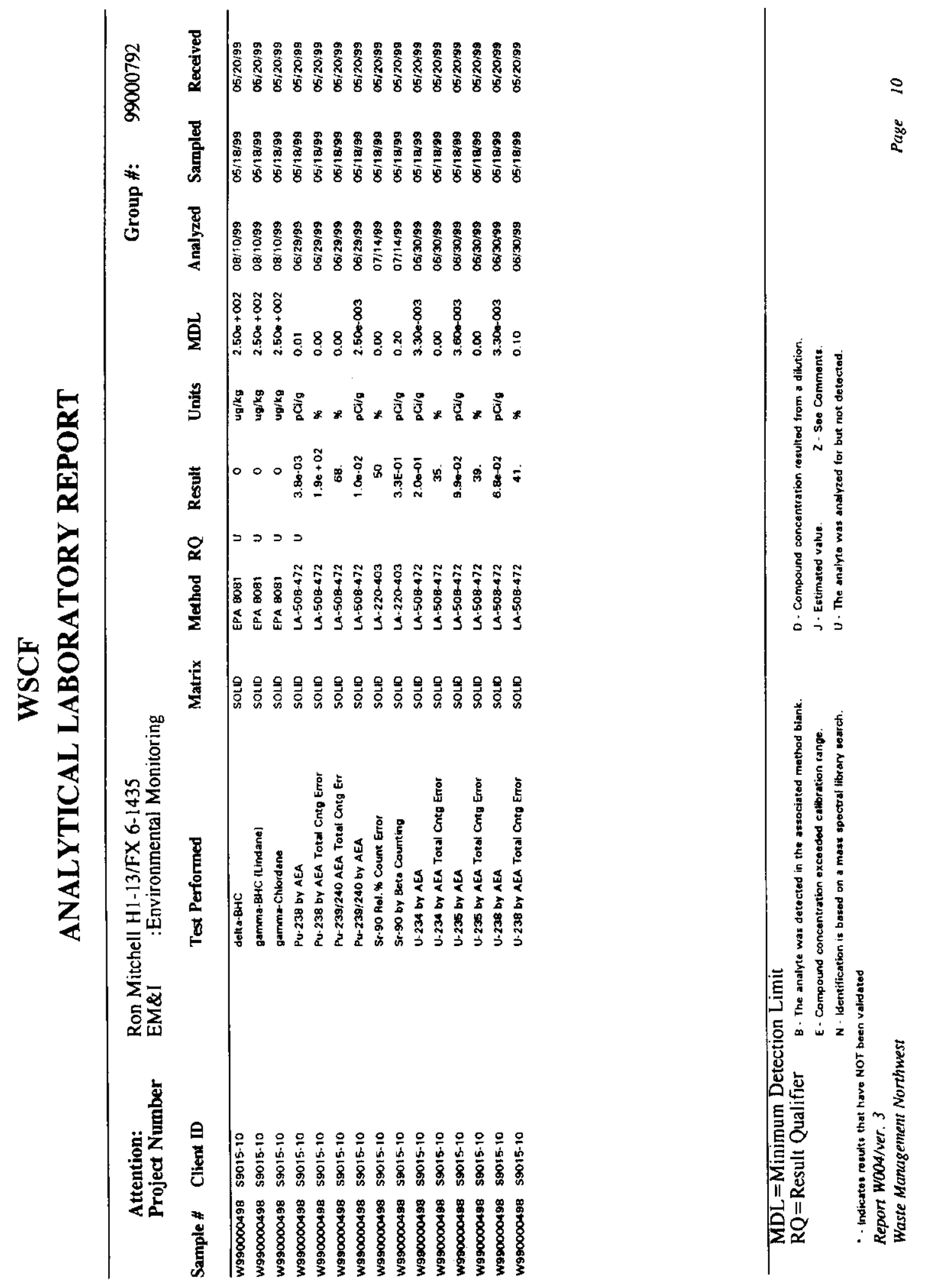


HNF-6150 Rev 0

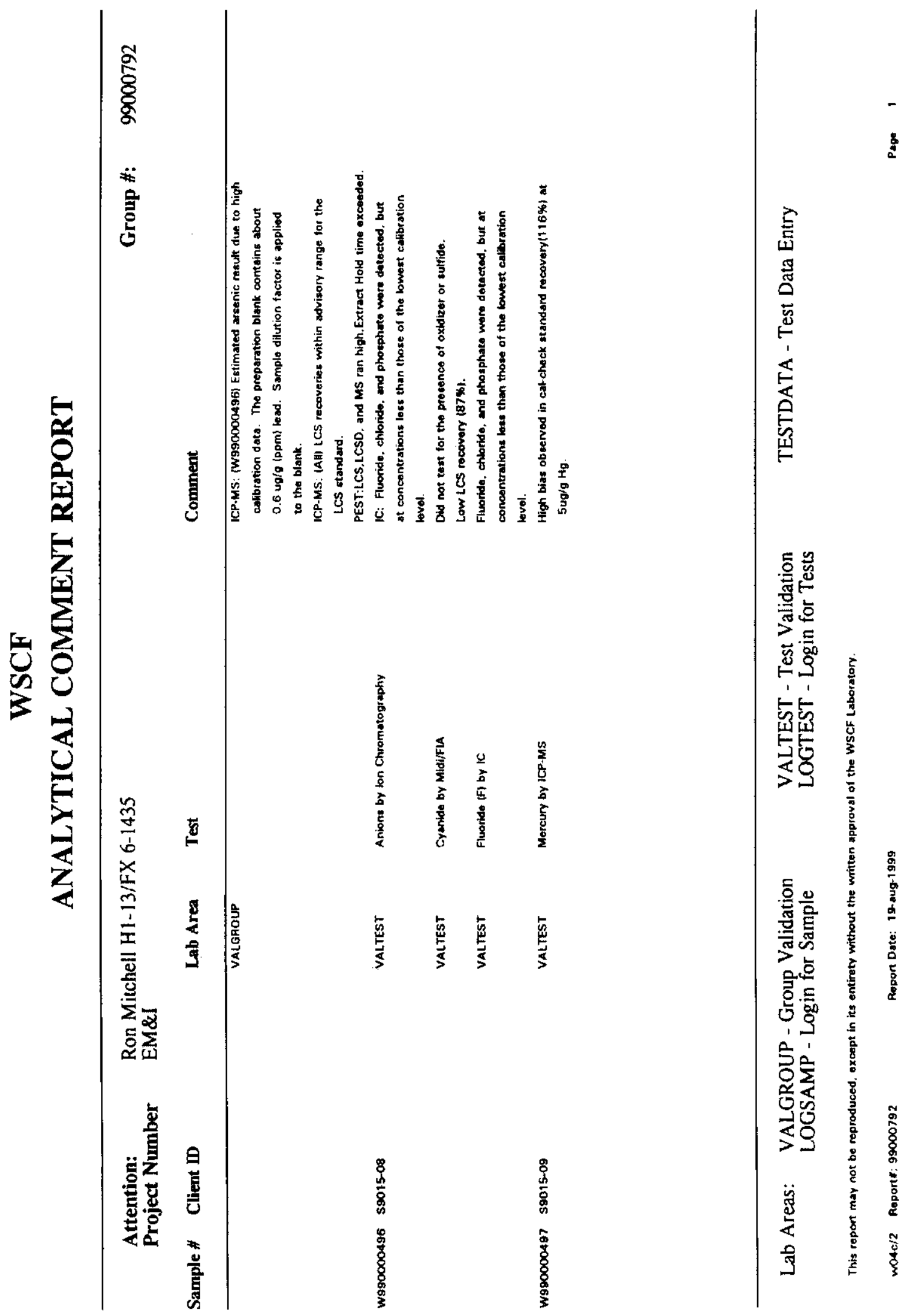


HNF-6150 Rev 0
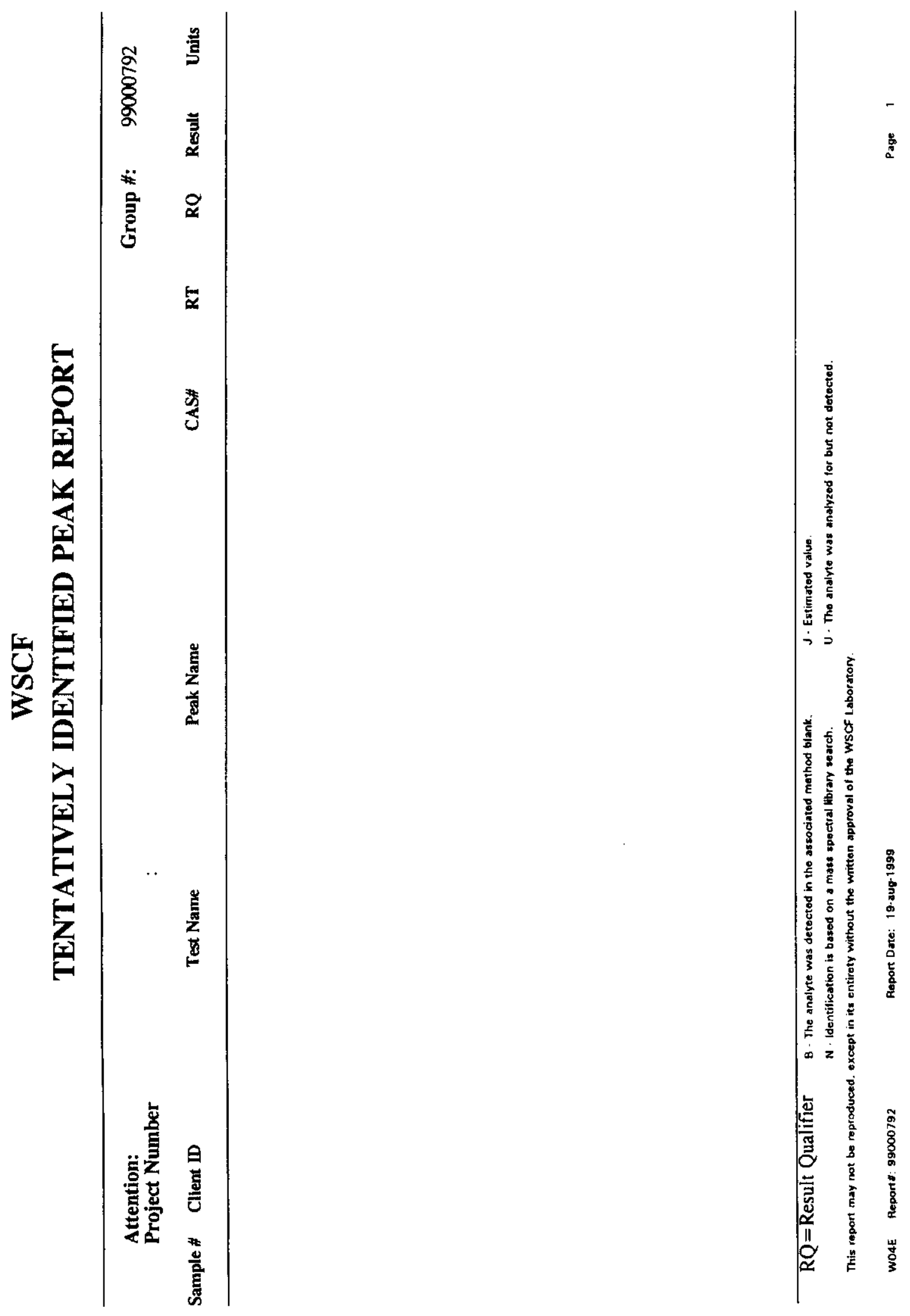
HNF-6150 Rev 0
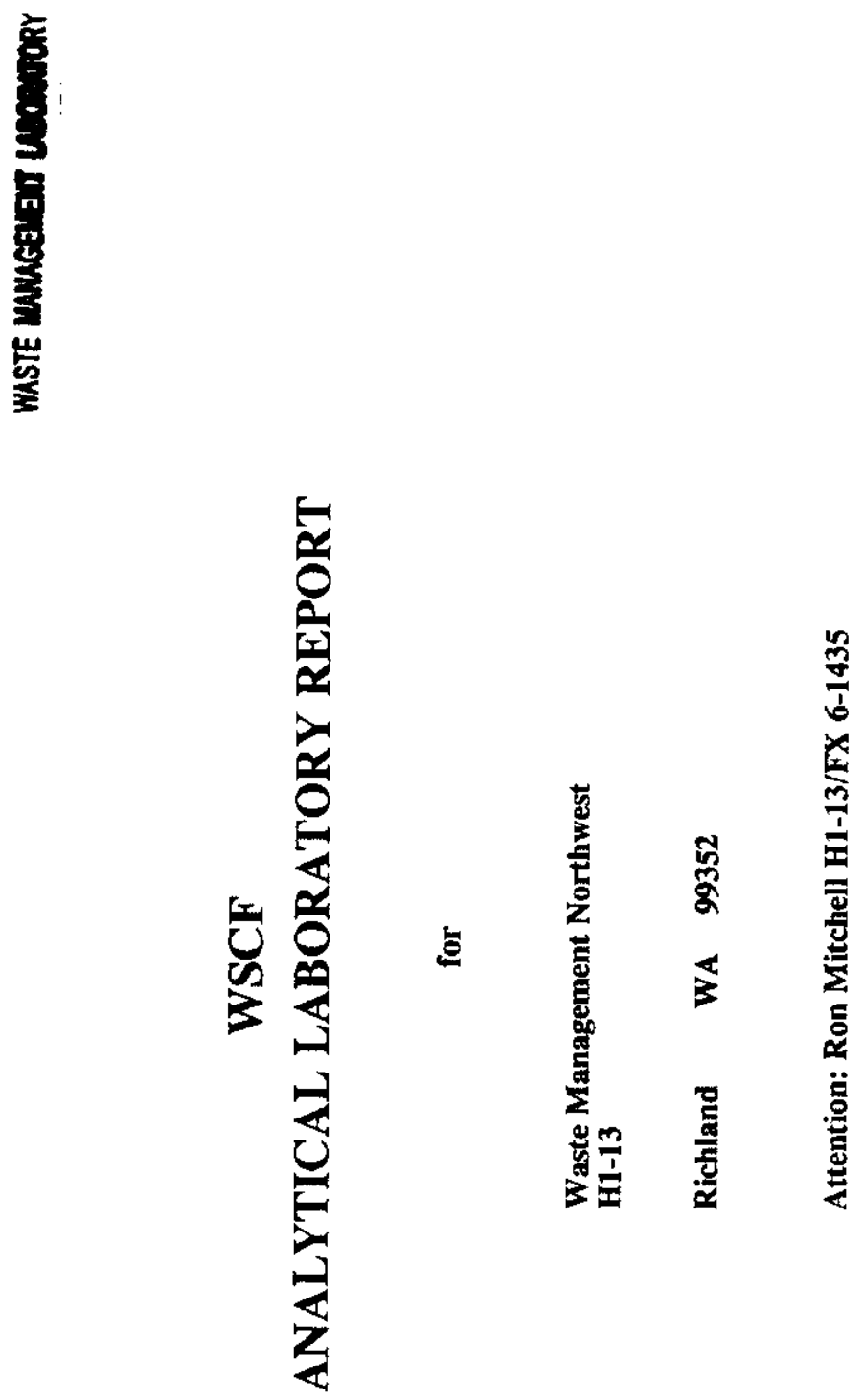
HNF-6150 Rev 0

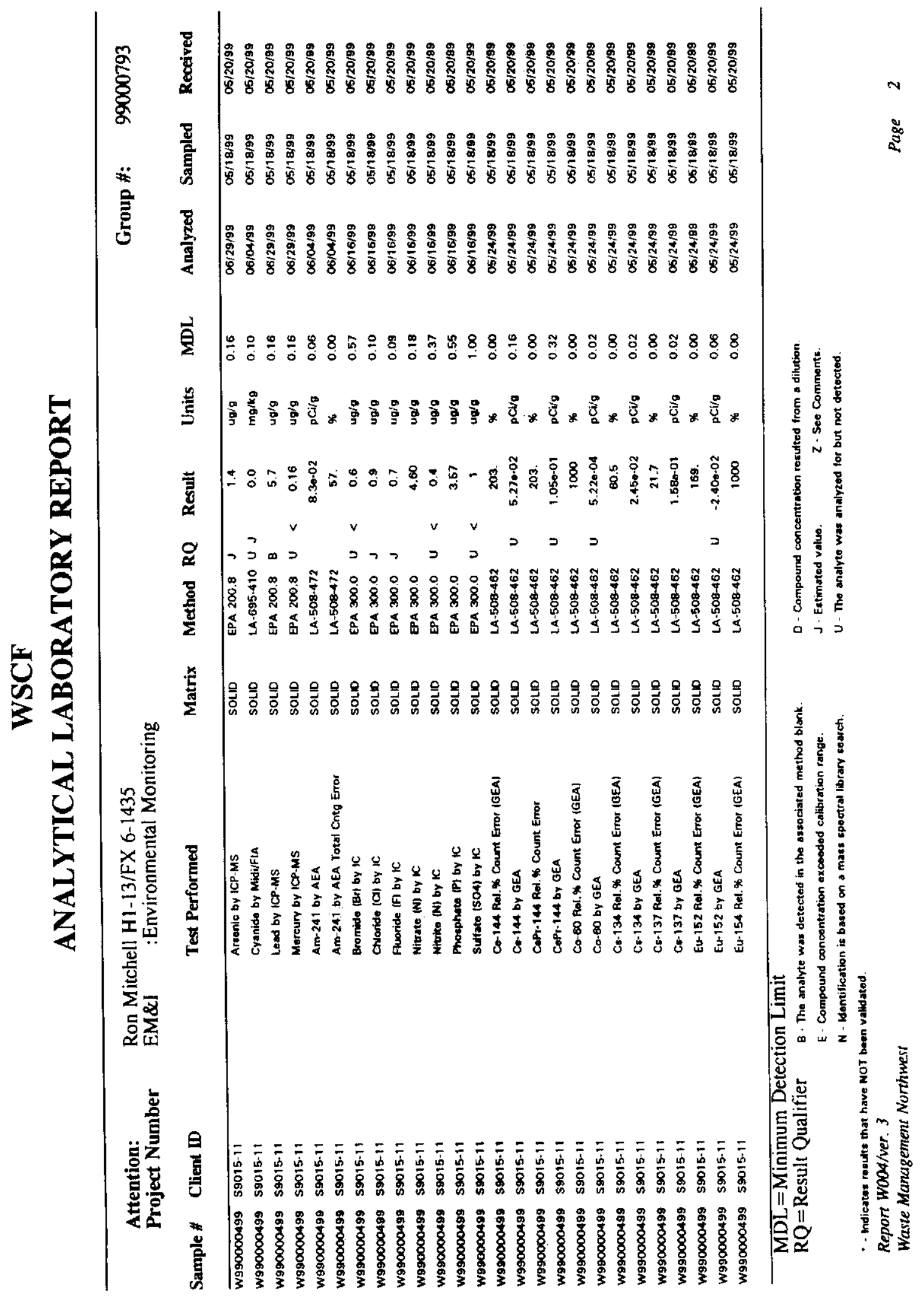


HNF-6150 Rev 0

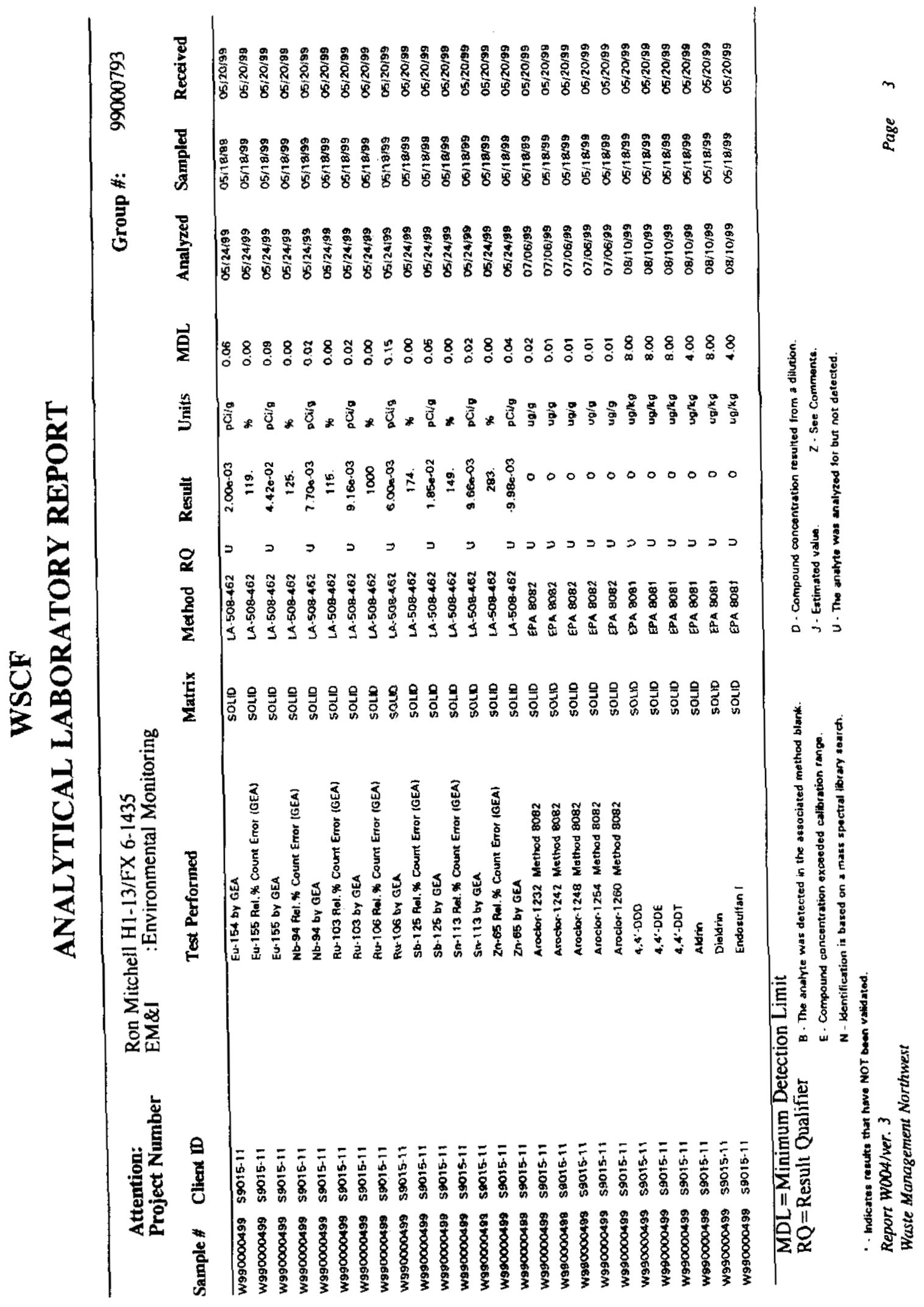


HNF-6150 Rev 0

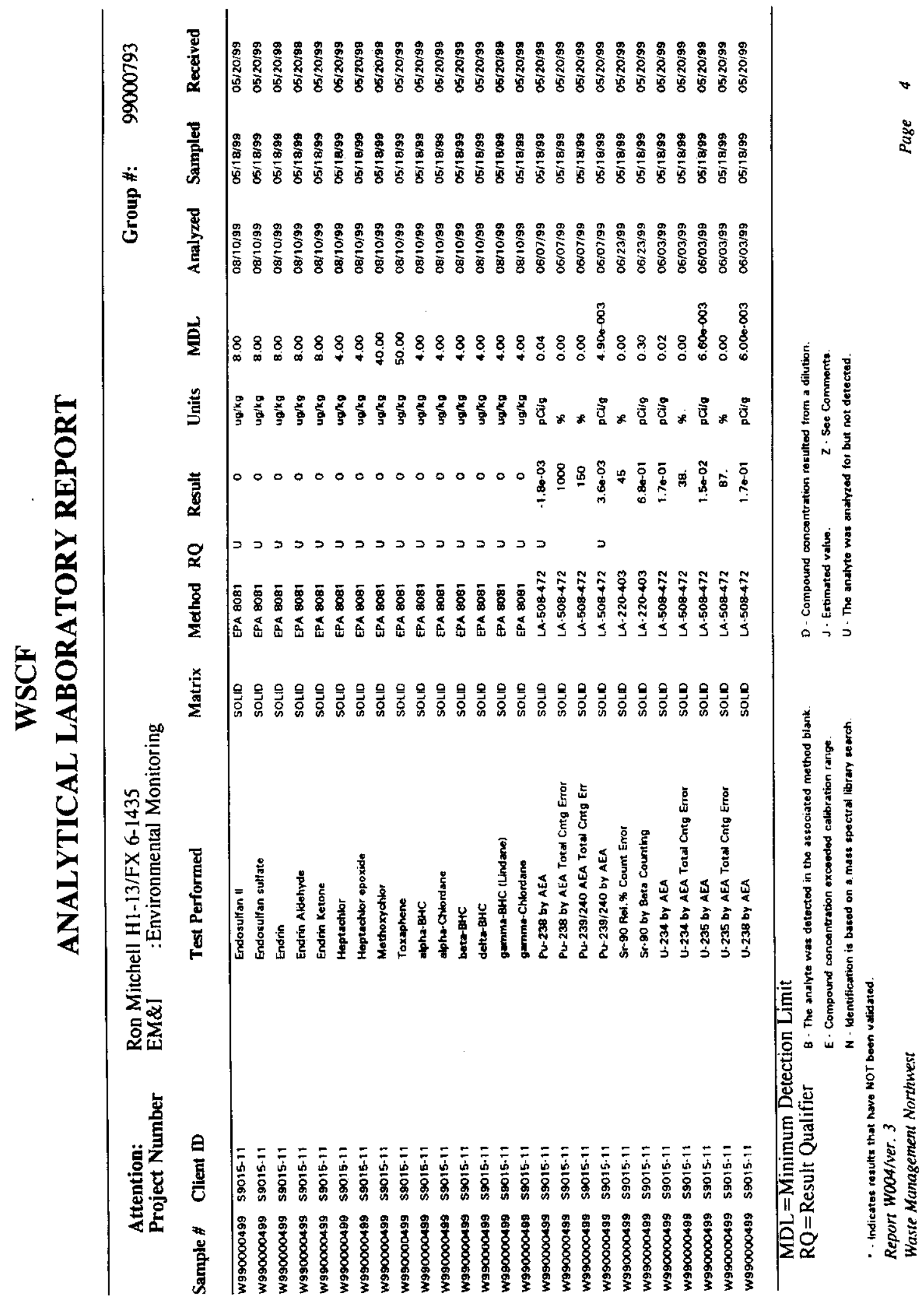


HNF-6150 Rev 0

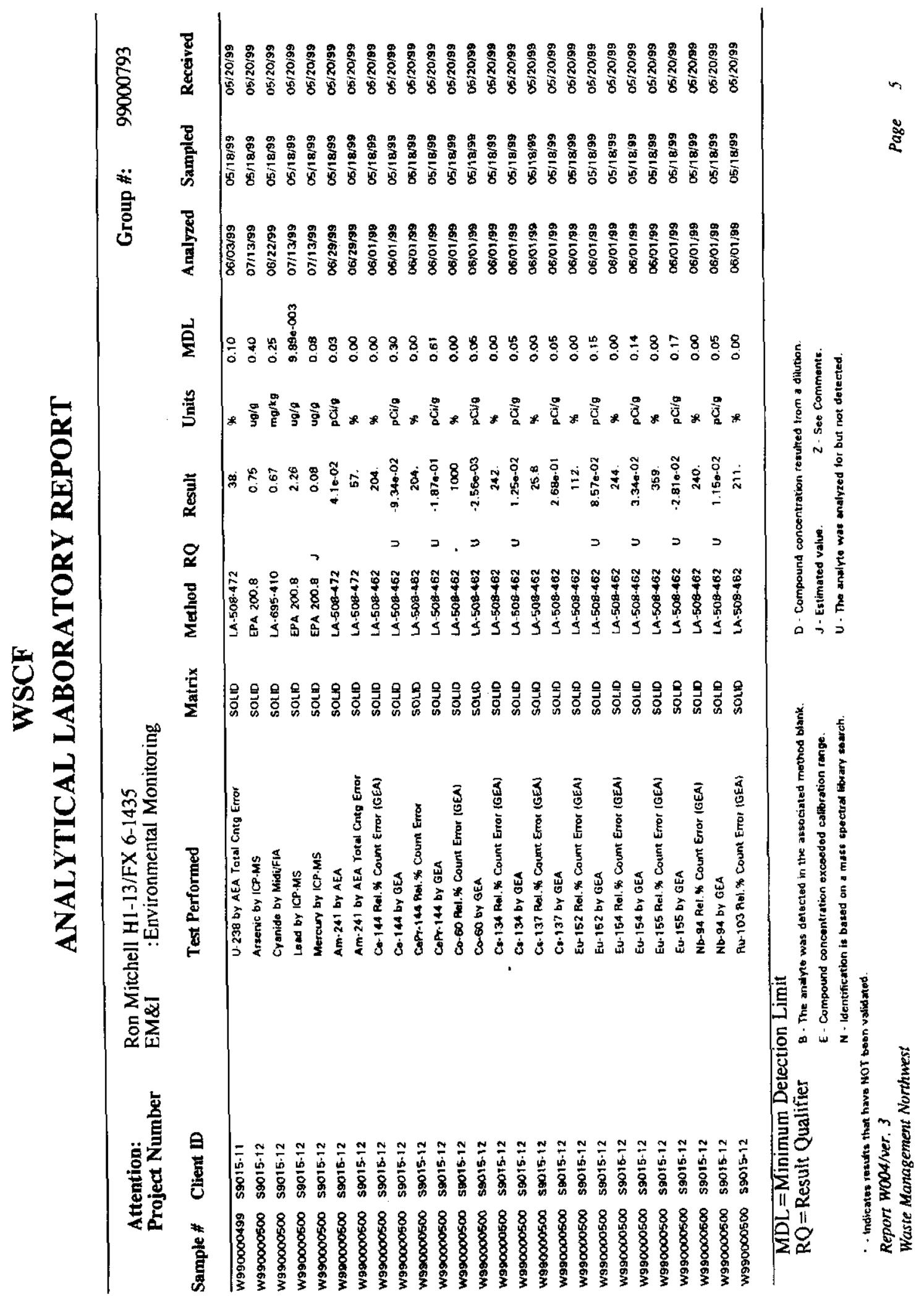


HNF-6150 Rev 0

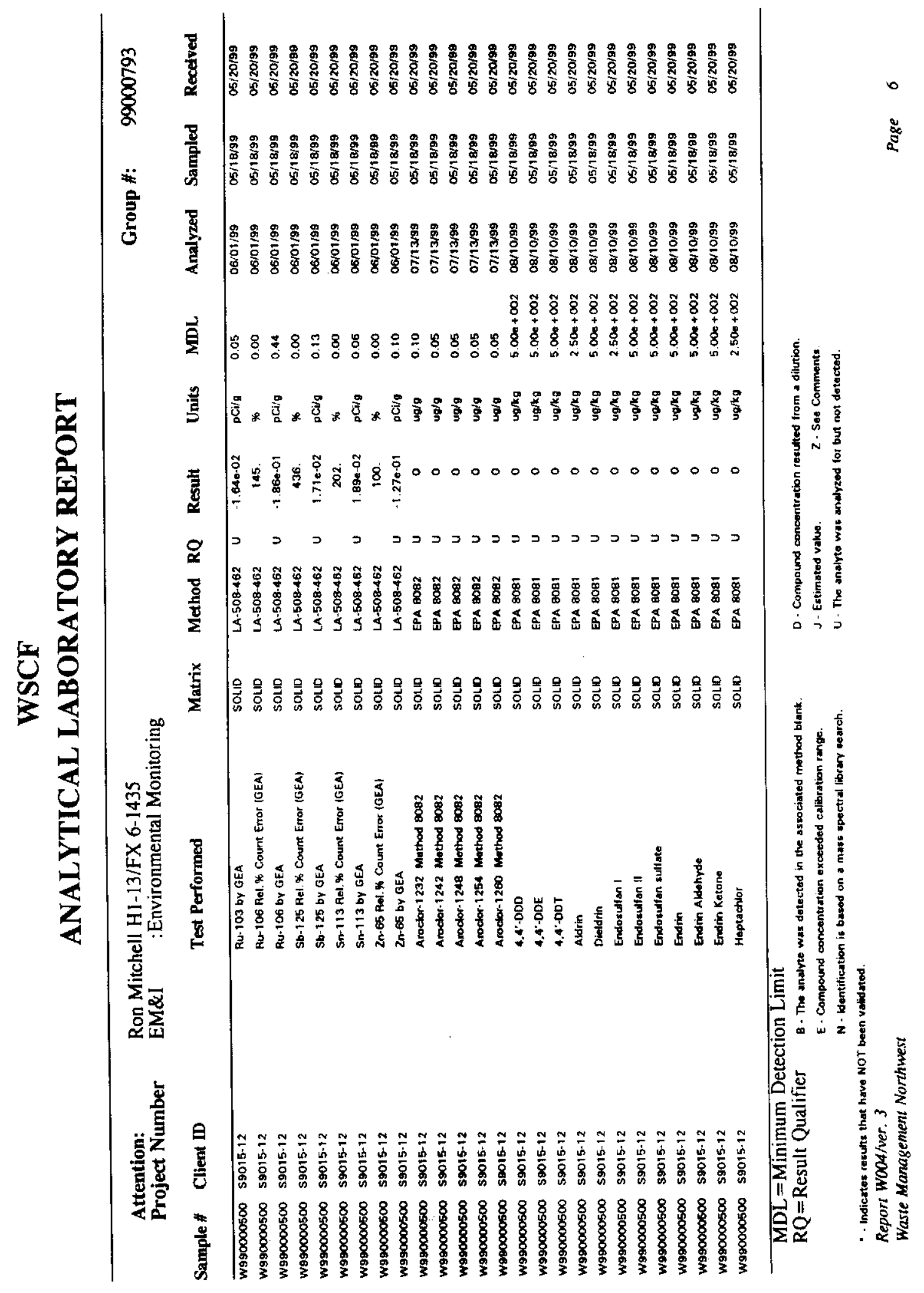


HNF-6150 Rev 0

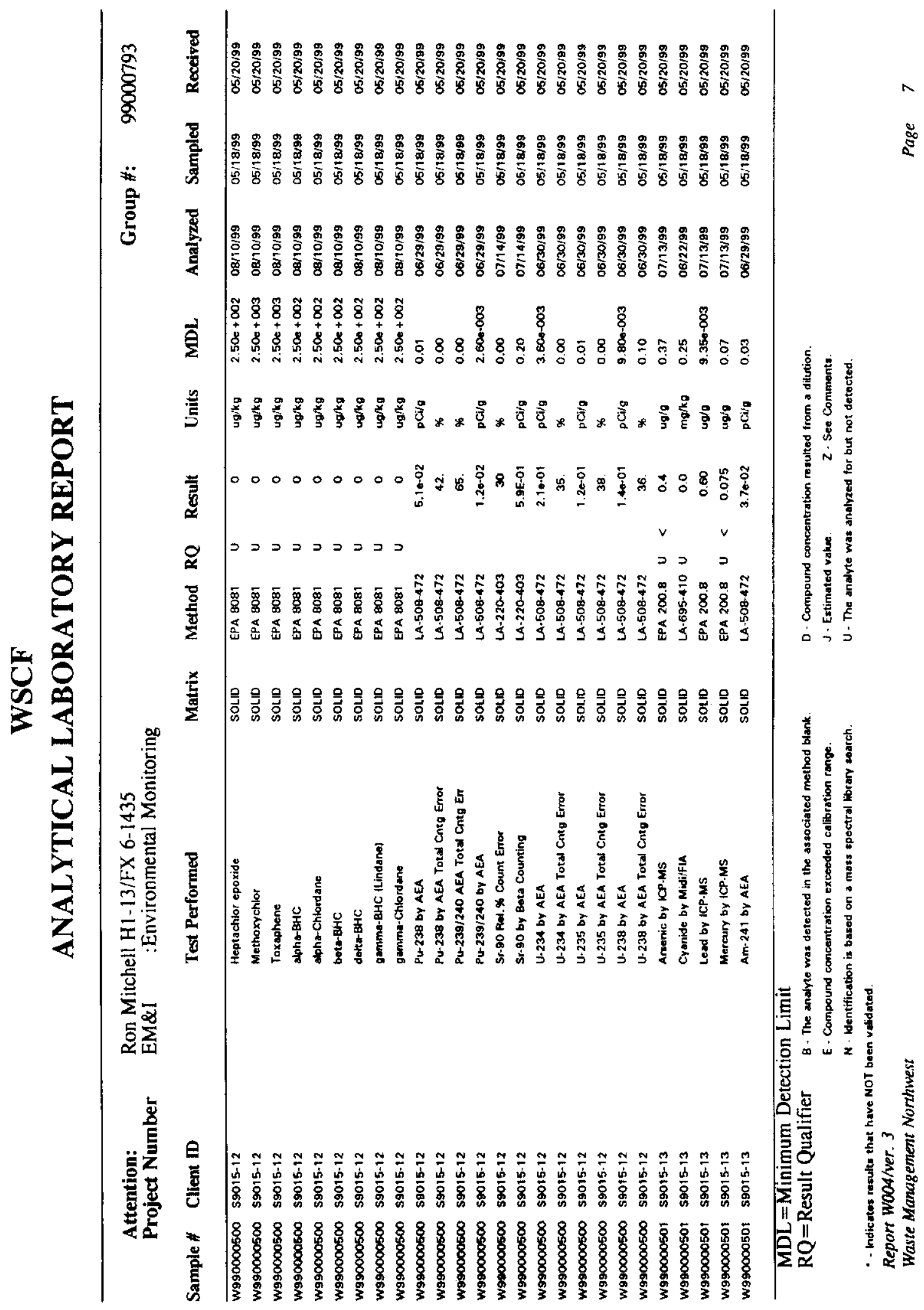


HNF-6150 Rev 0

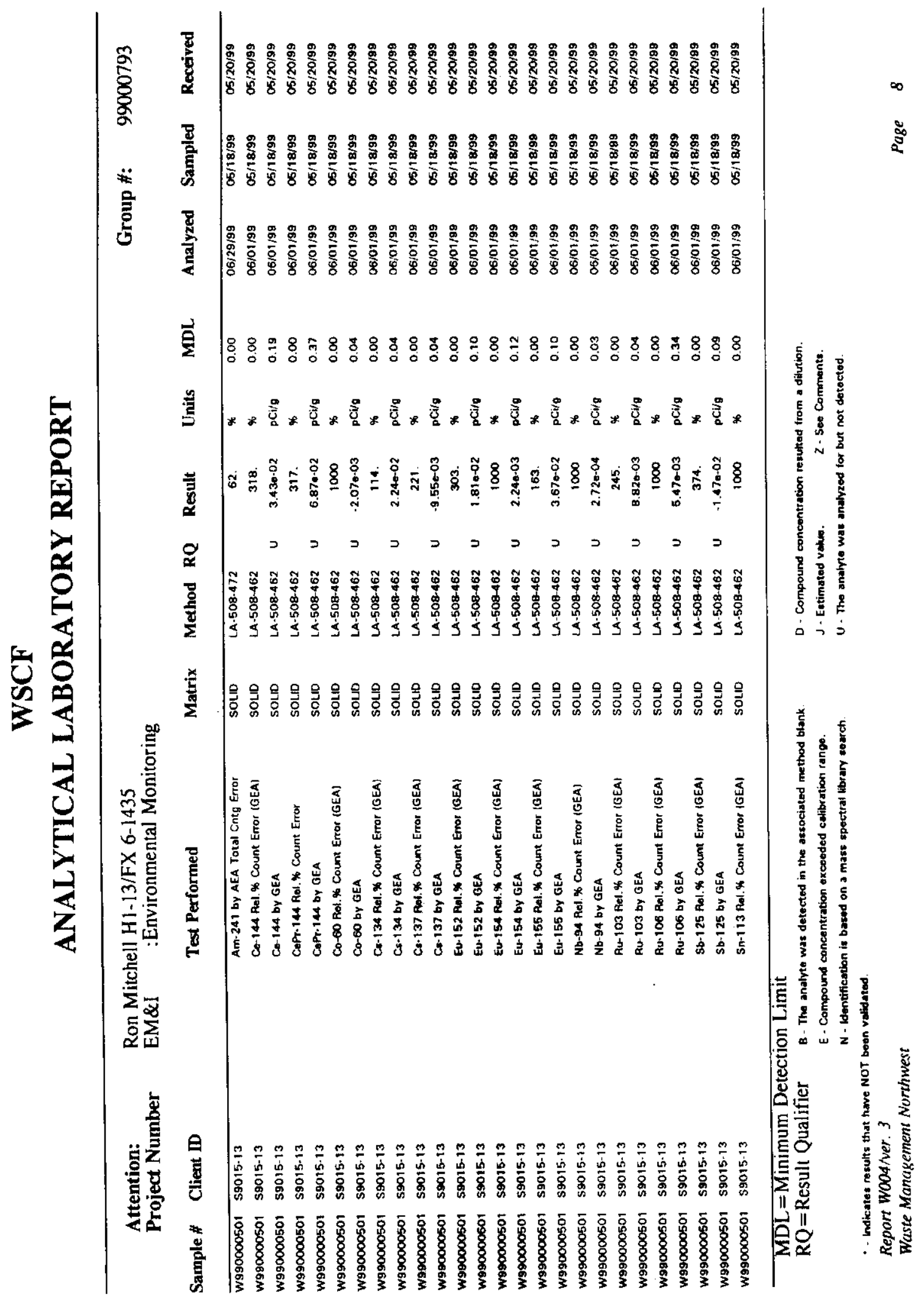


HNF-6150 Rev 0

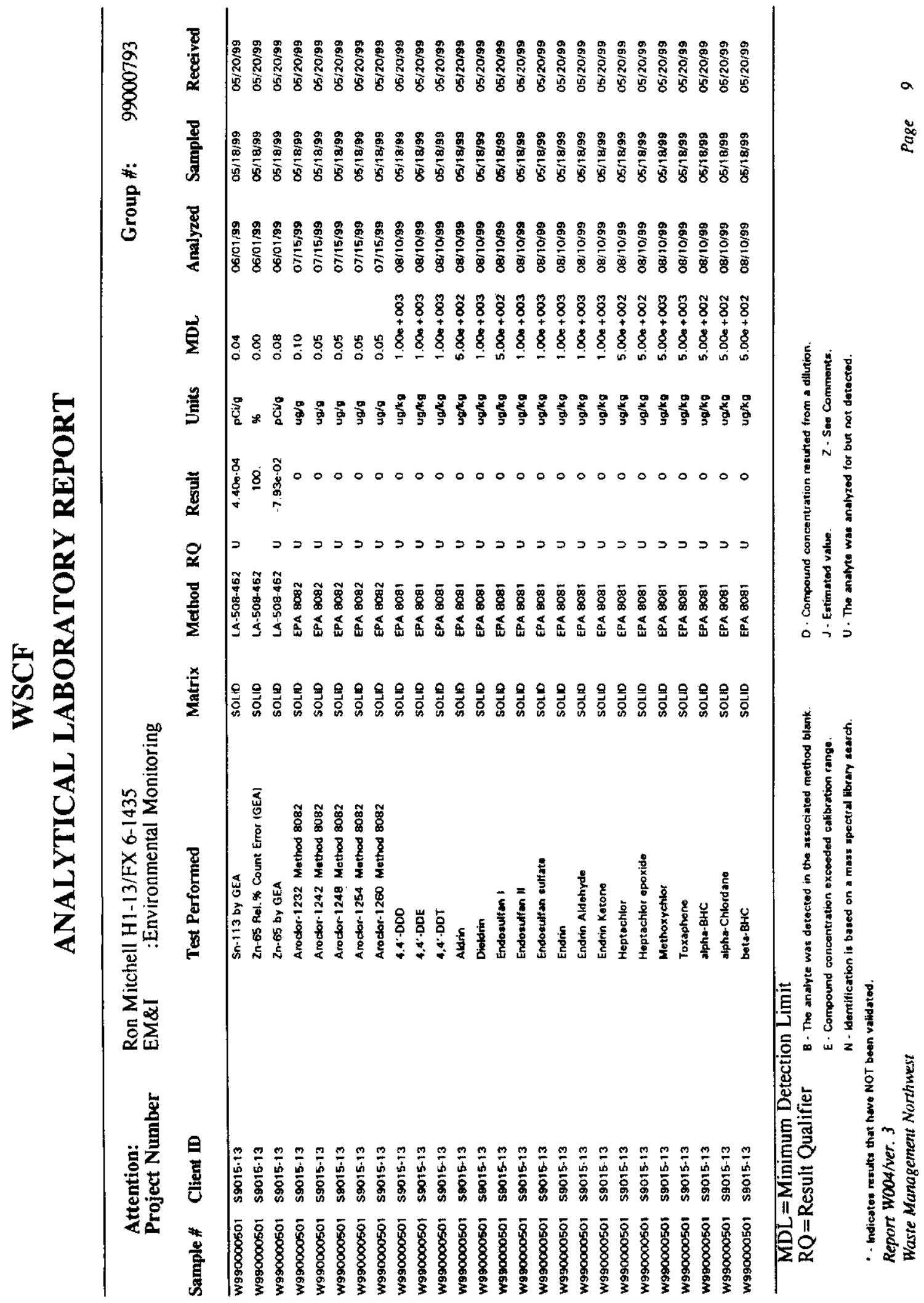


HNF-6150 Rev 0

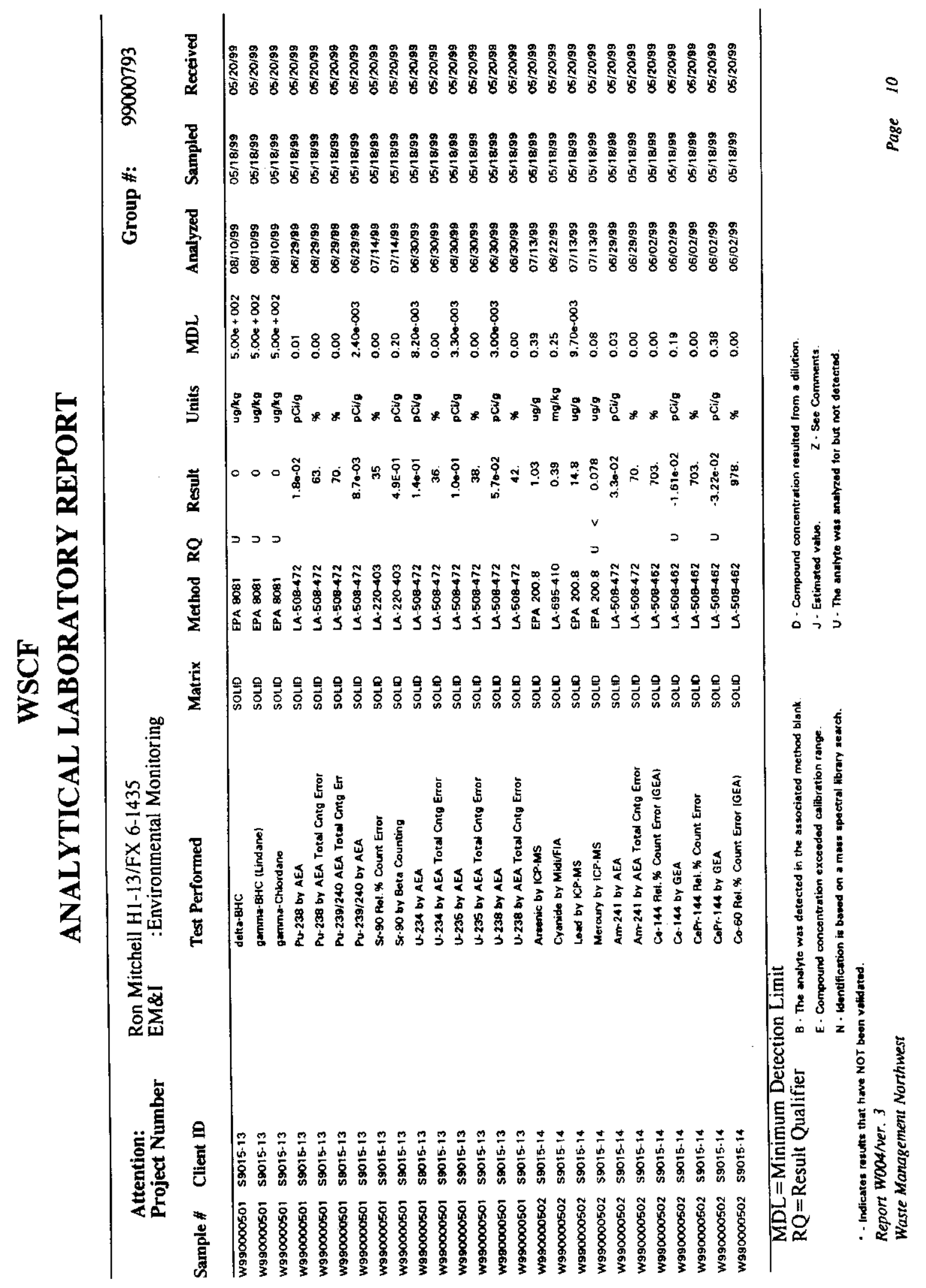


HNF-6150 Rev 0

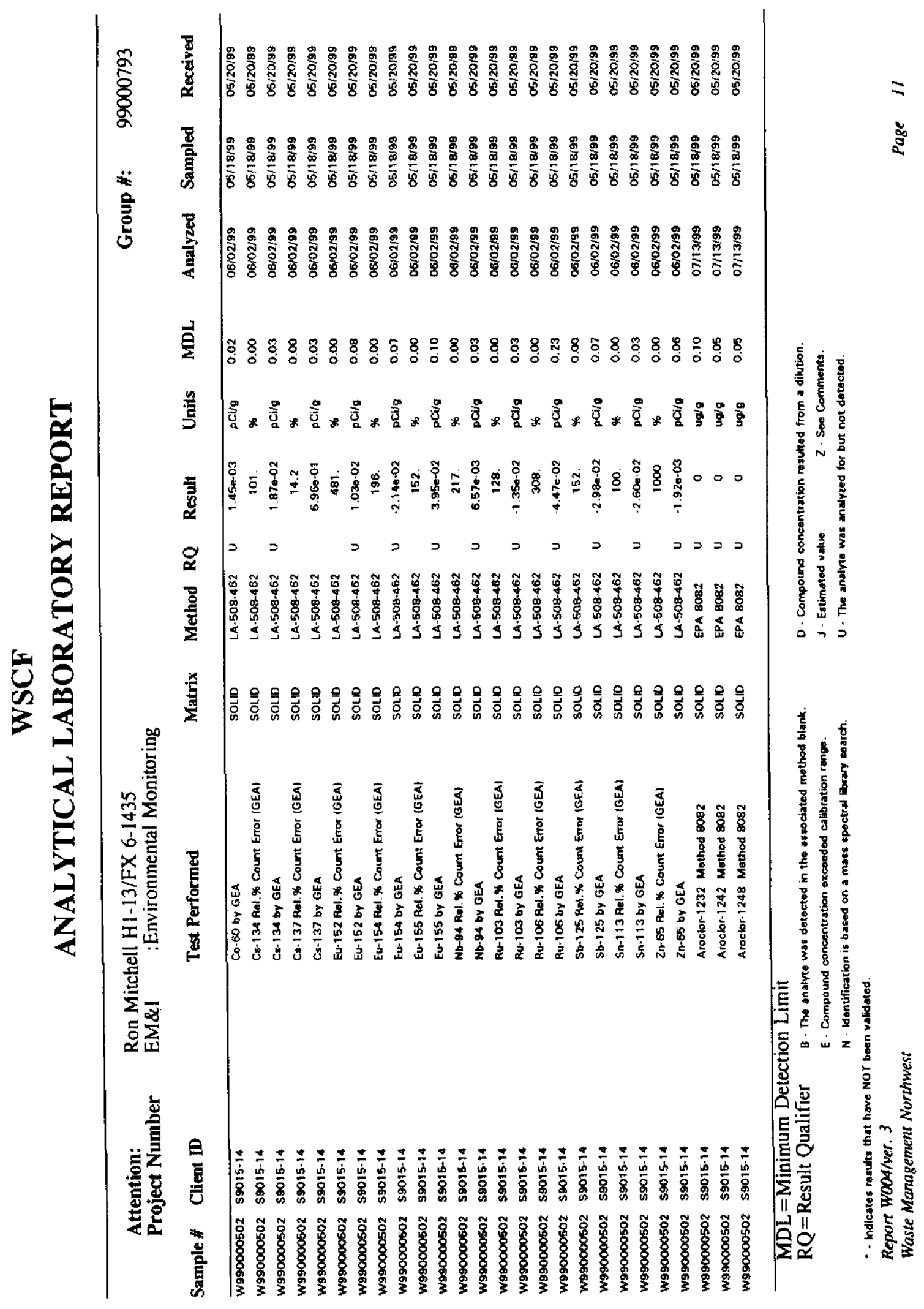


HNF-6150 Rev 0

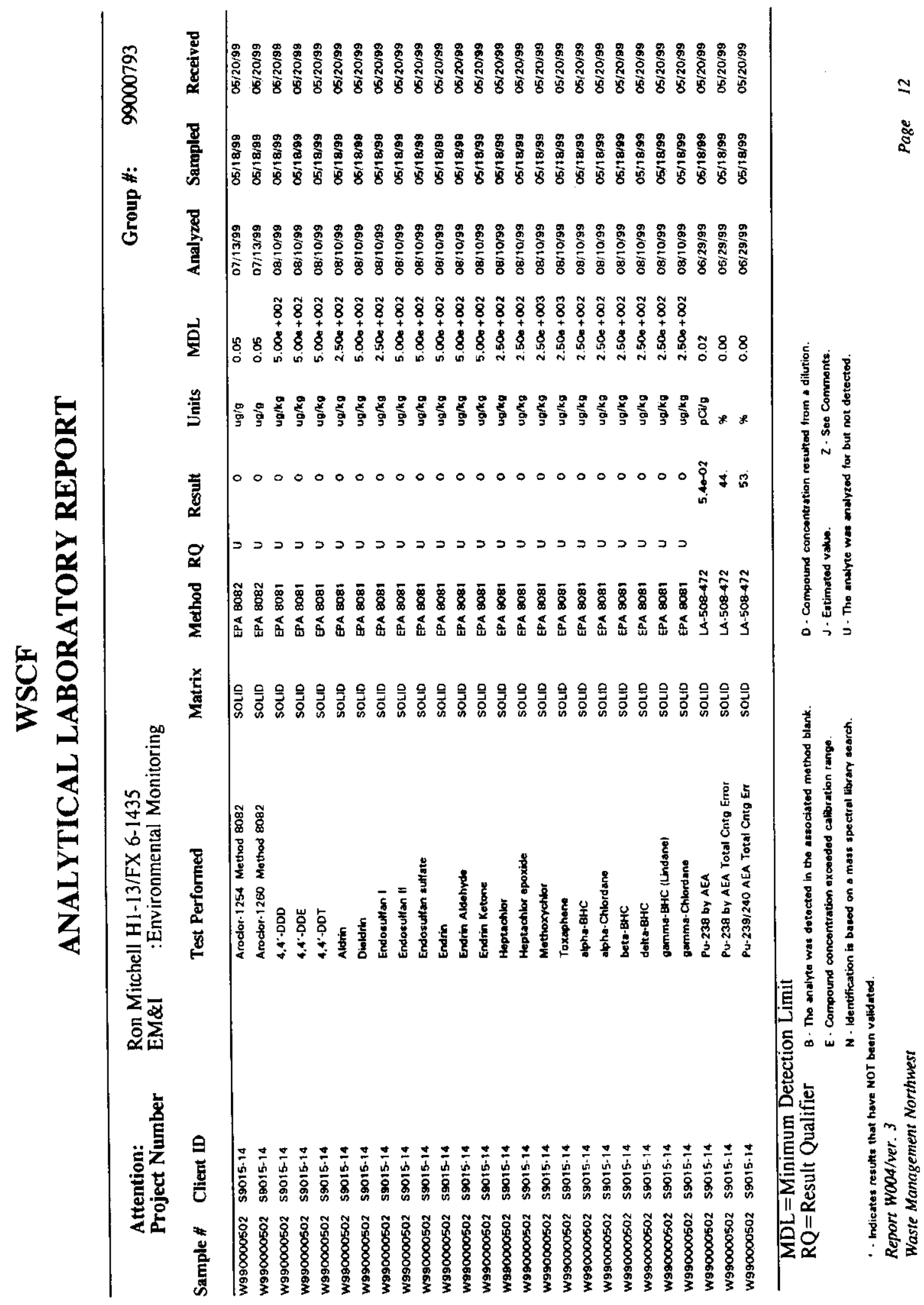


HNF-6150 Rev 0

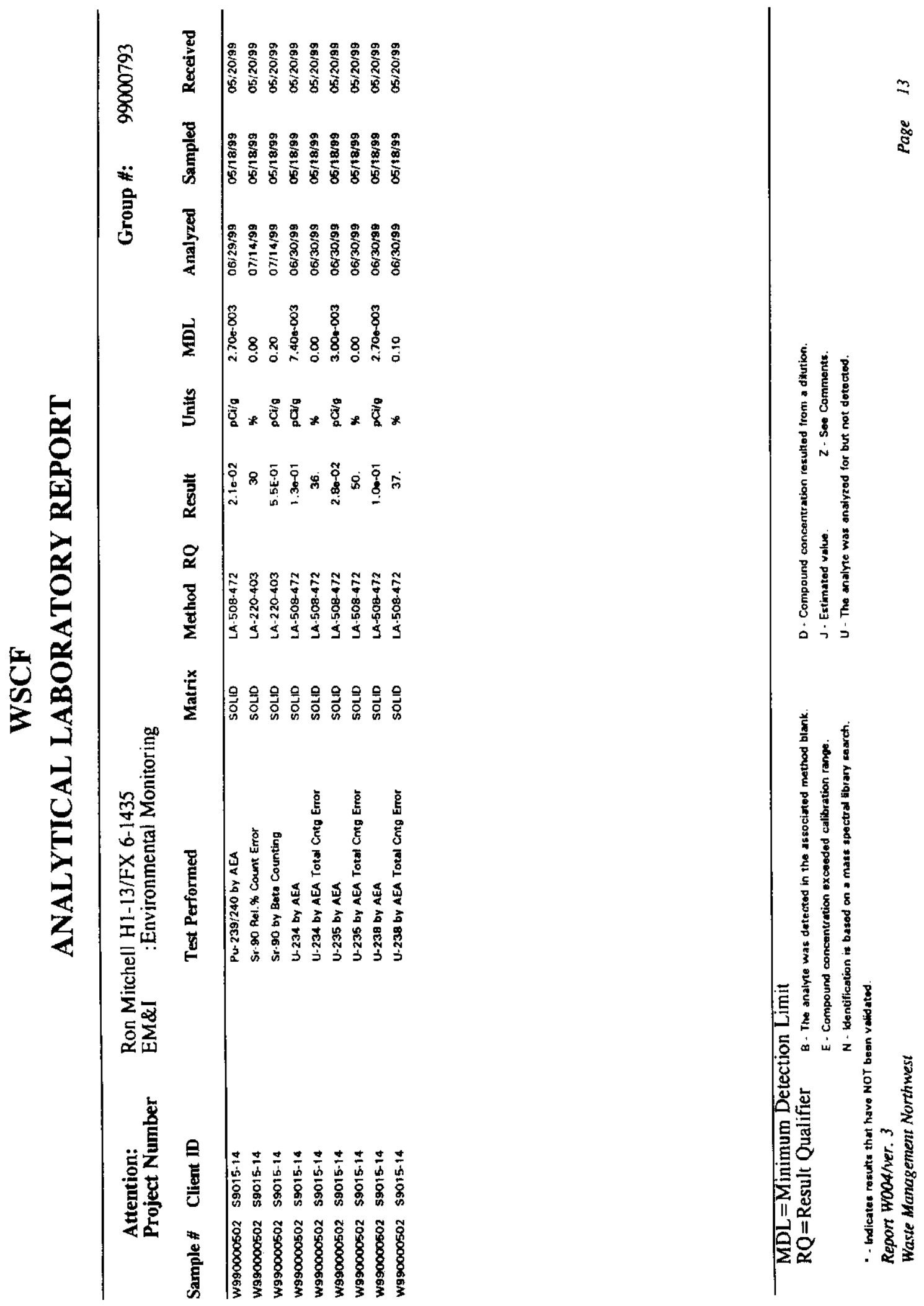


HNF-6150 Rev 0

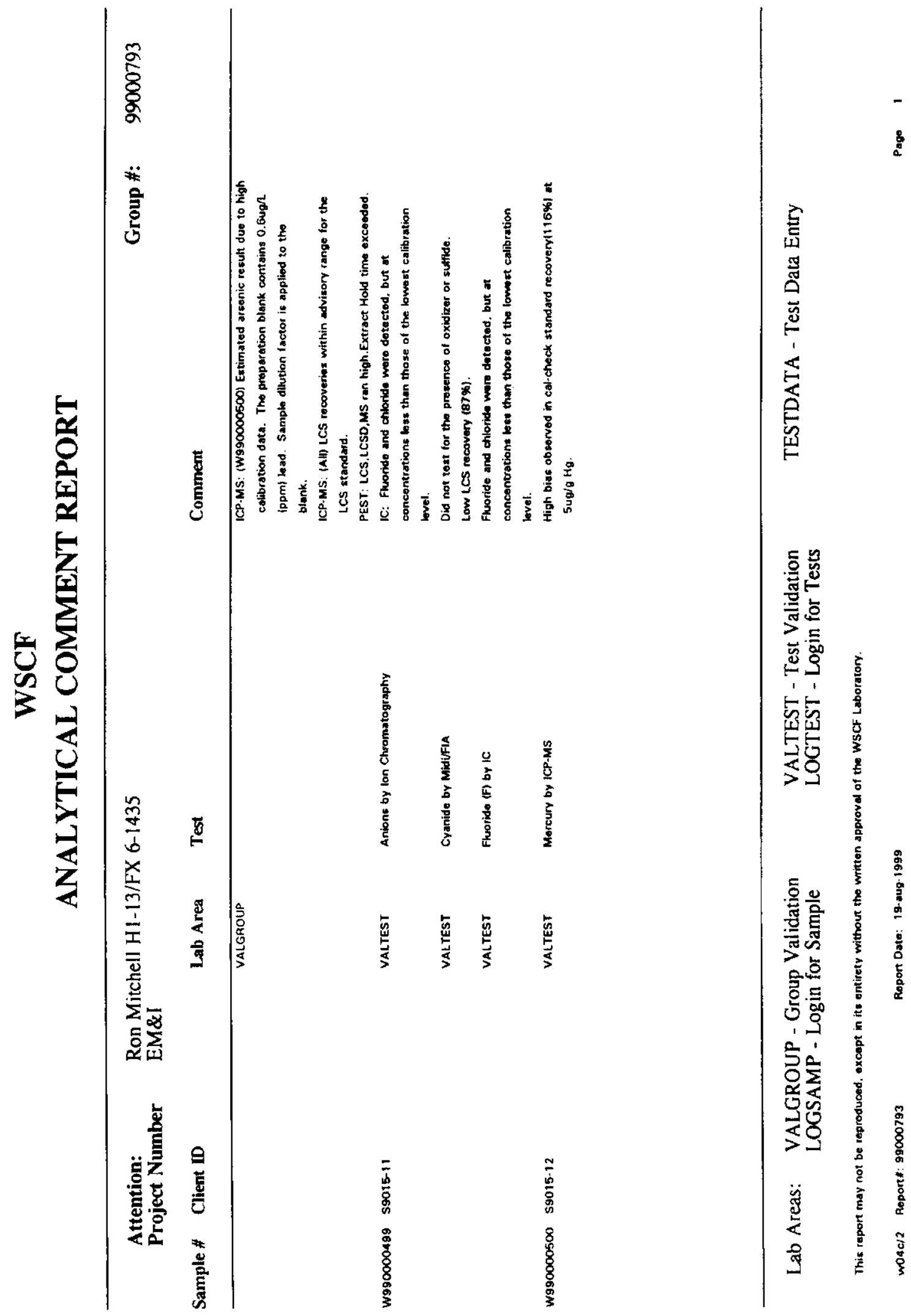


HNF-6150 Rev 0
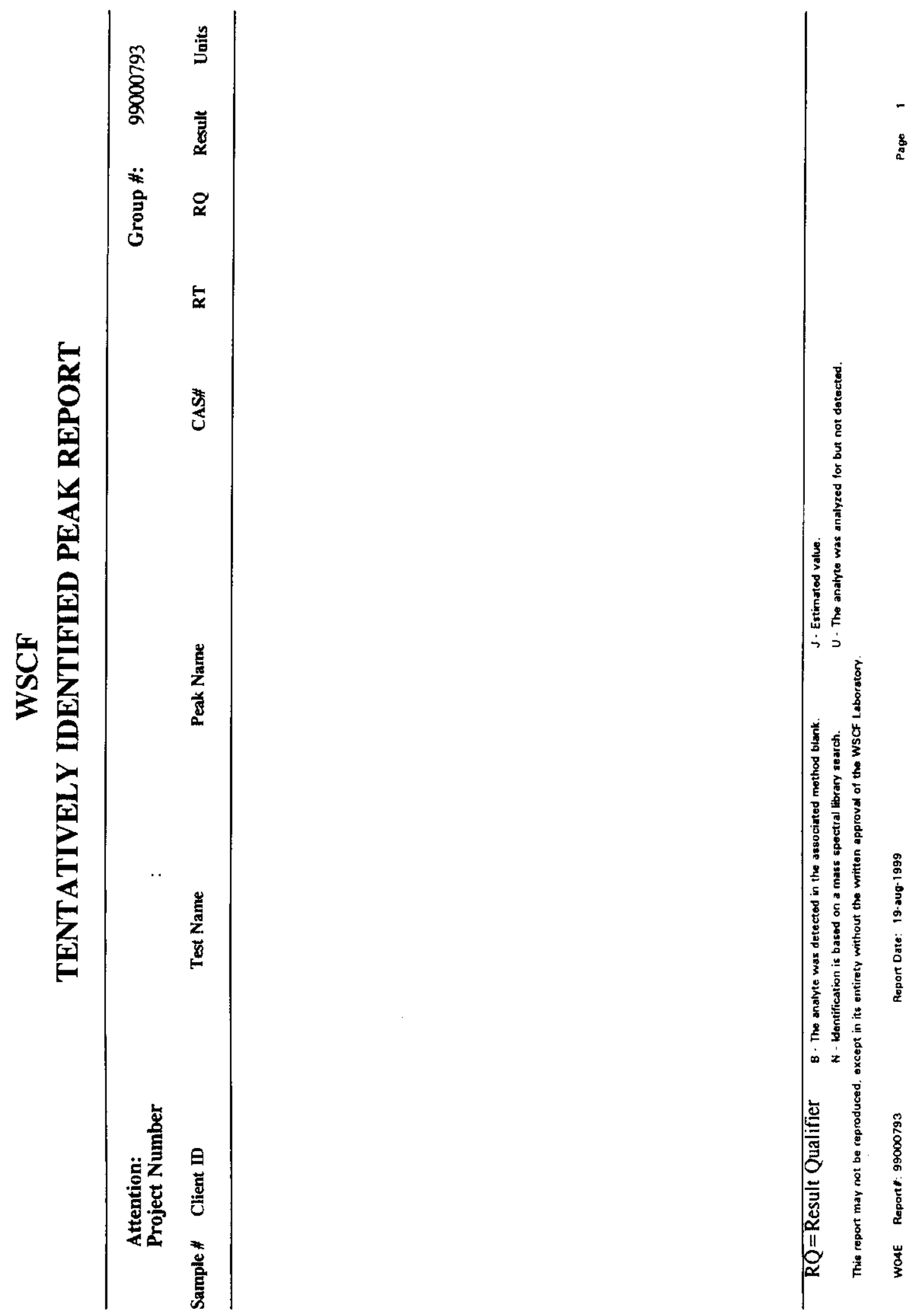
HNF-6150 Rev 0

홍
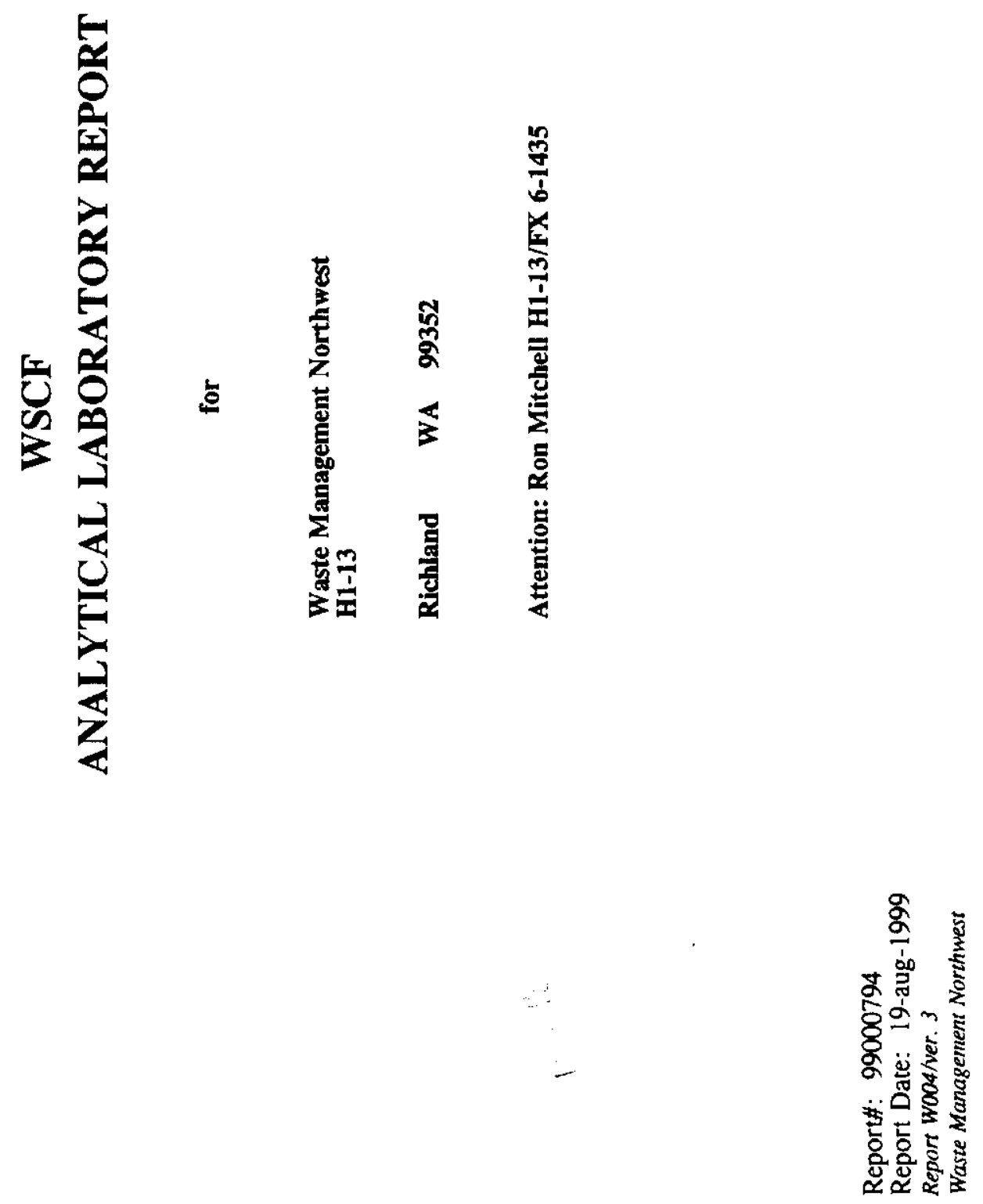

C-60 
HNF-6150 Rev 0

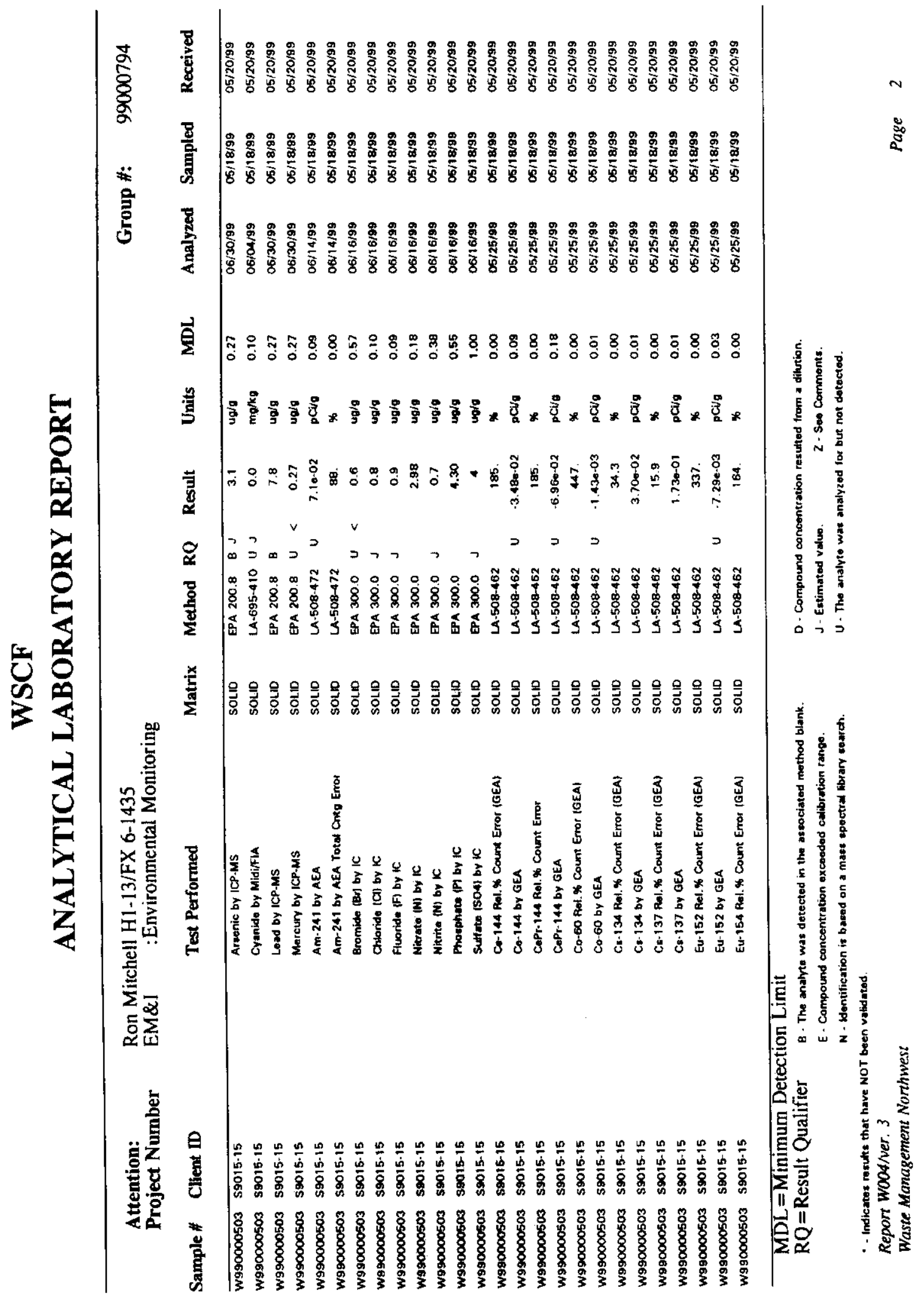


HNF-6150 Rev 0

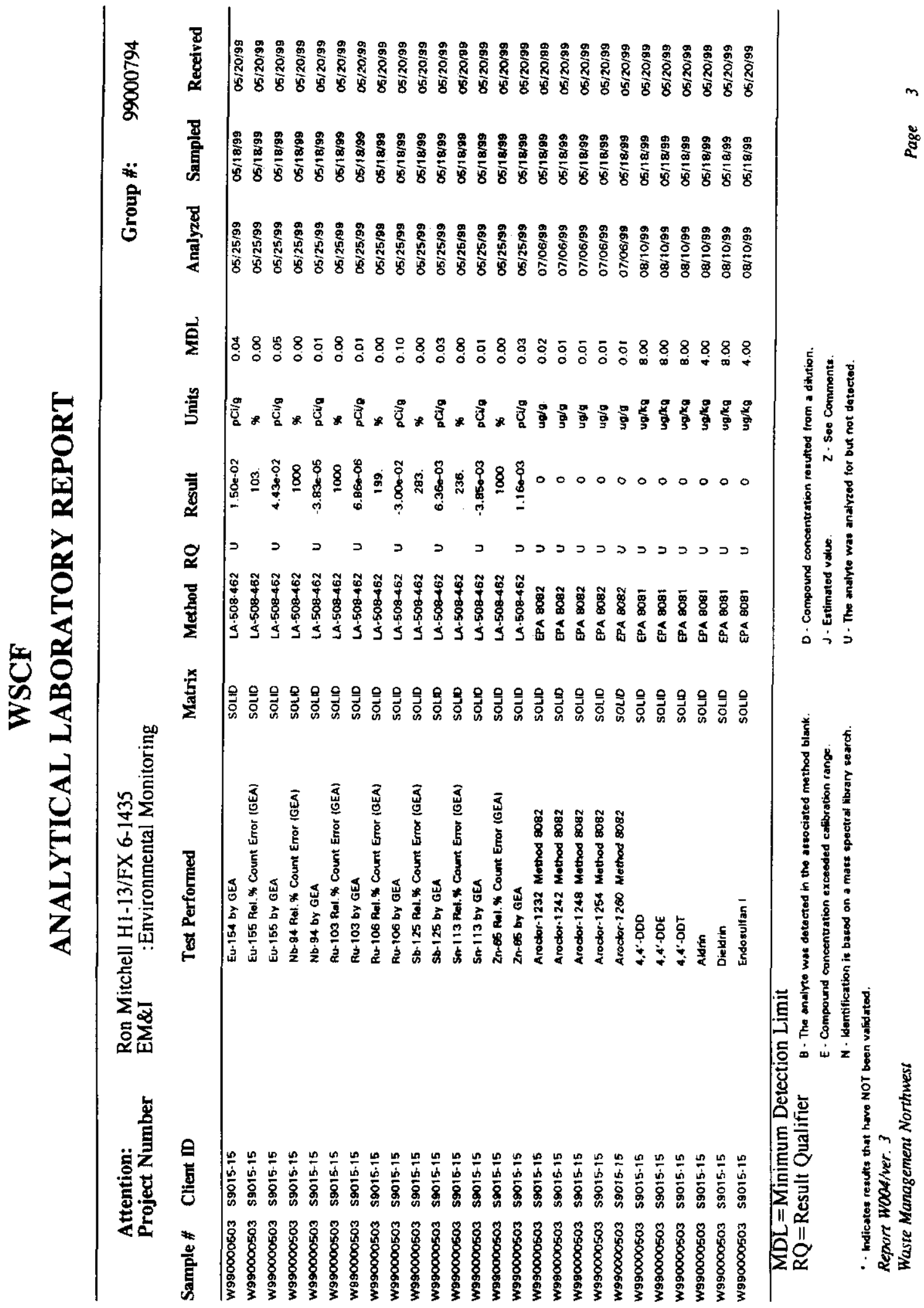


HNF-6150 Rev 0

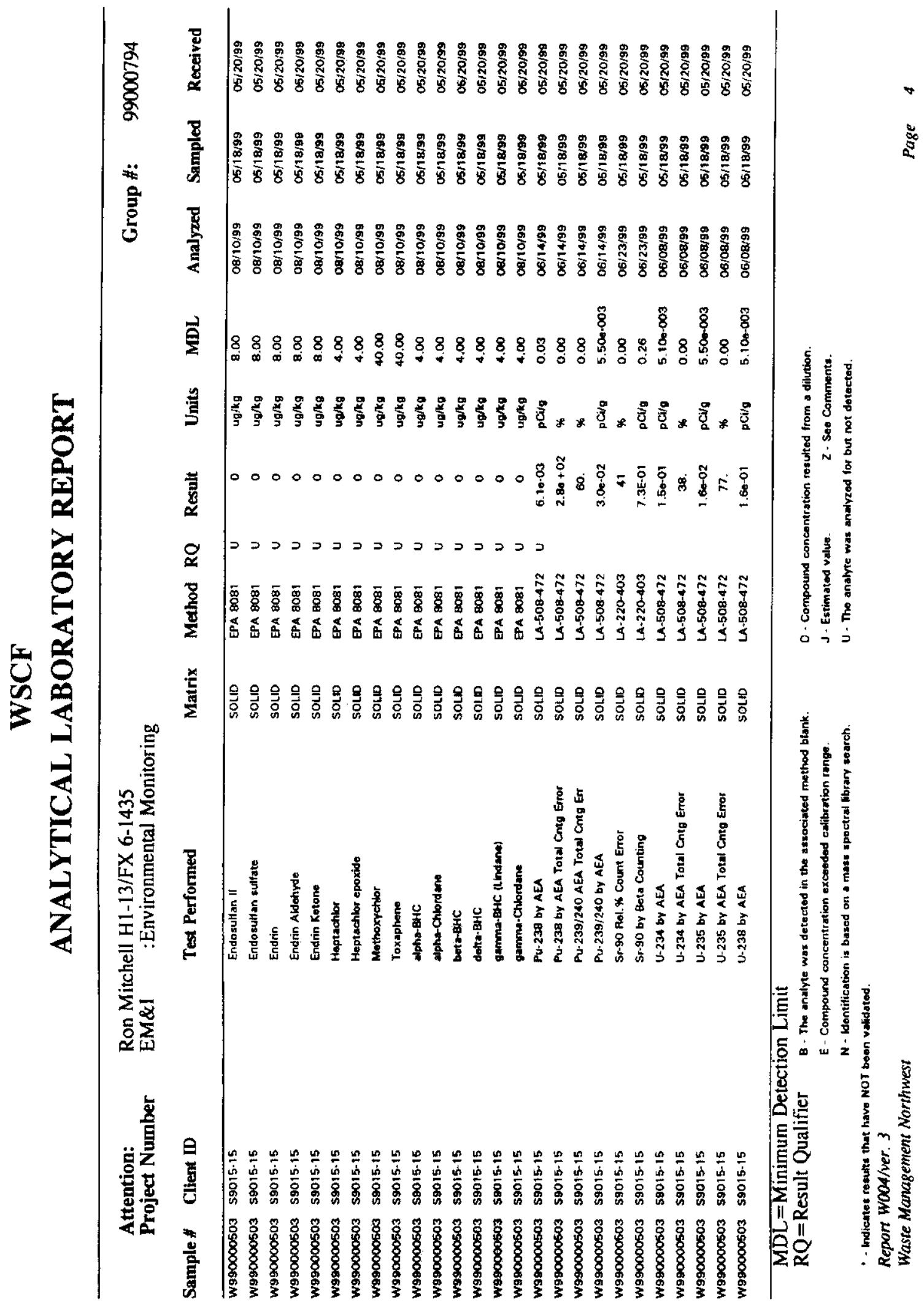


HNF-6150 Rev 0

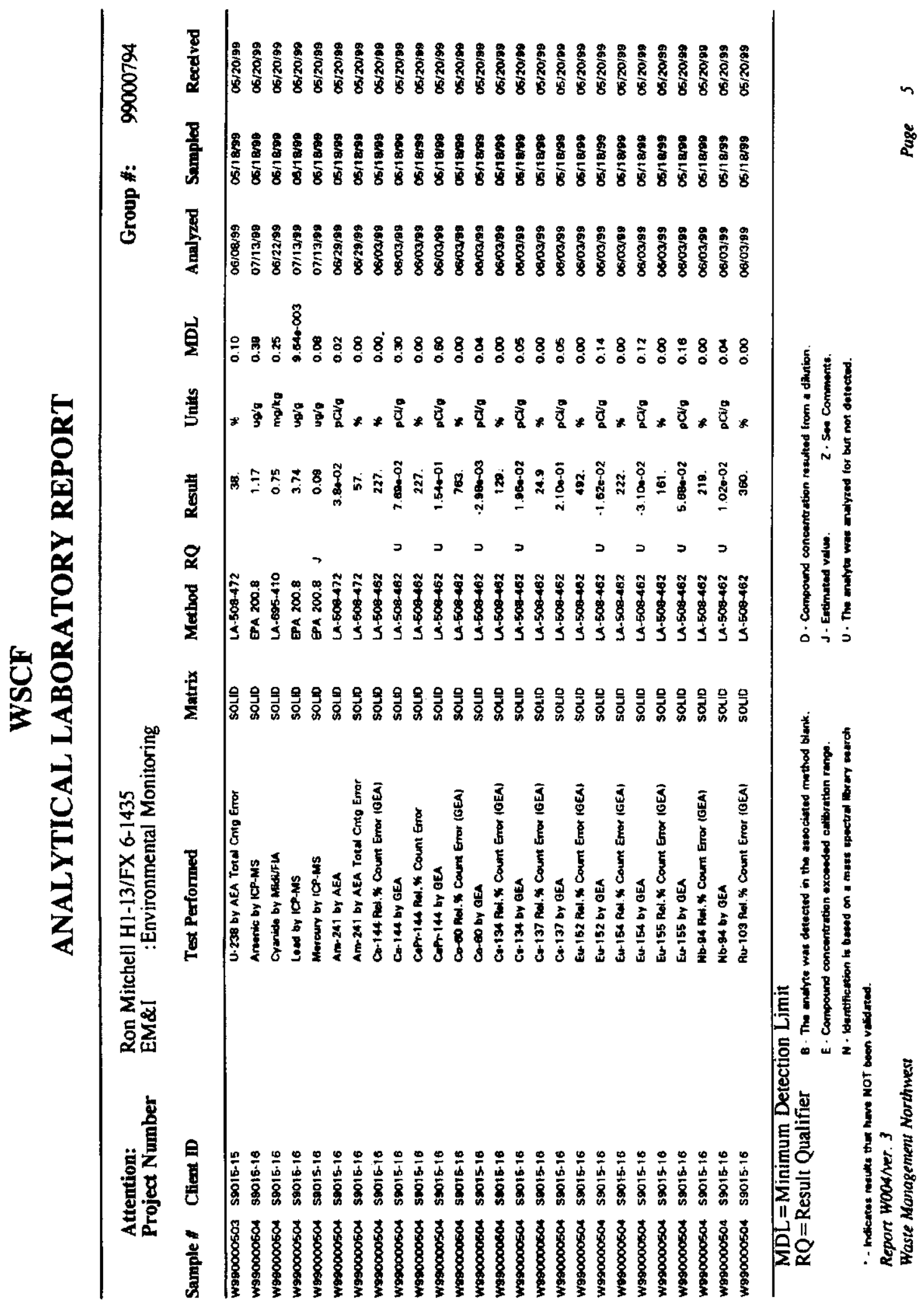


HNF-6150 Rev 0

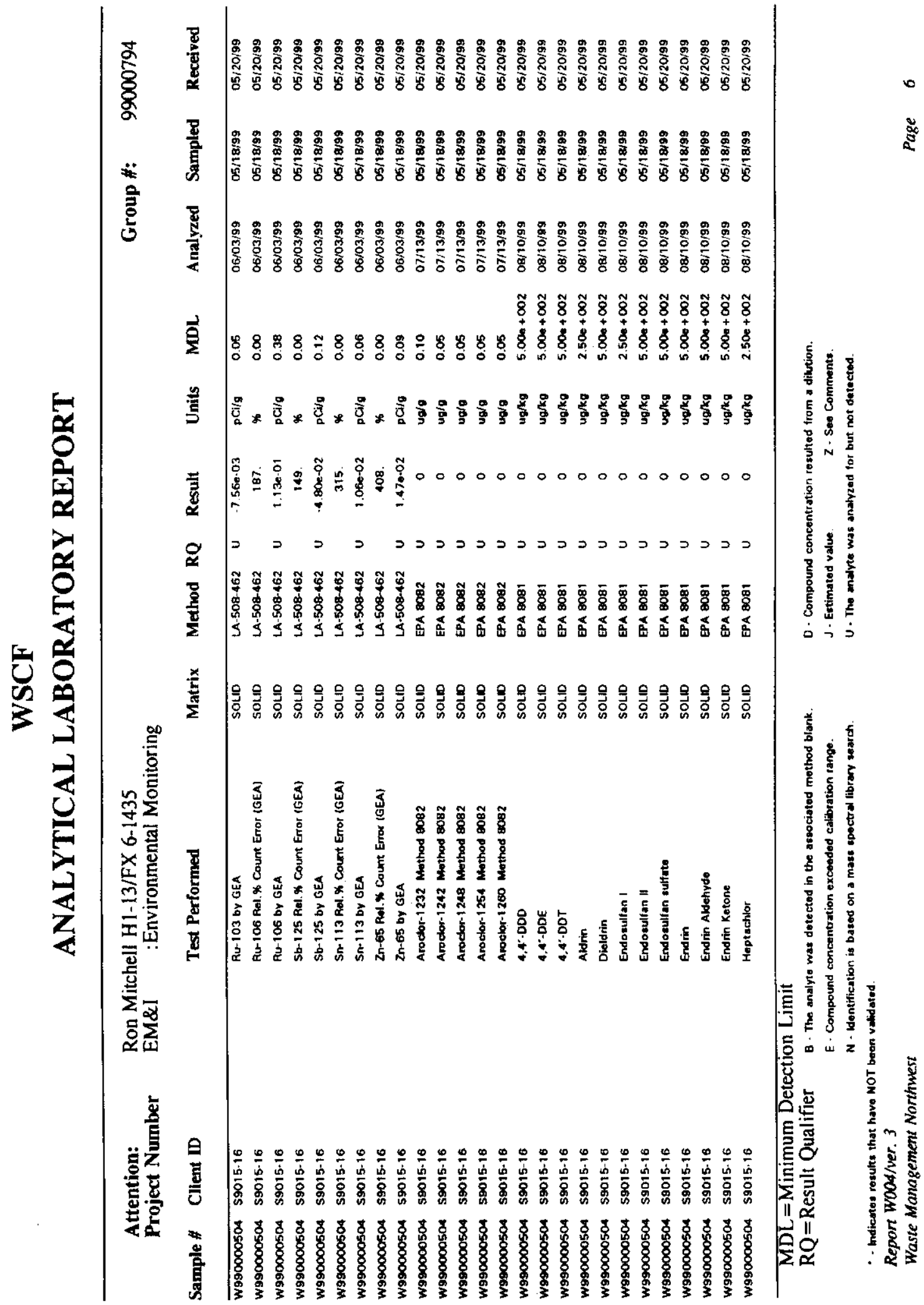


HNF-6150 Rev 0

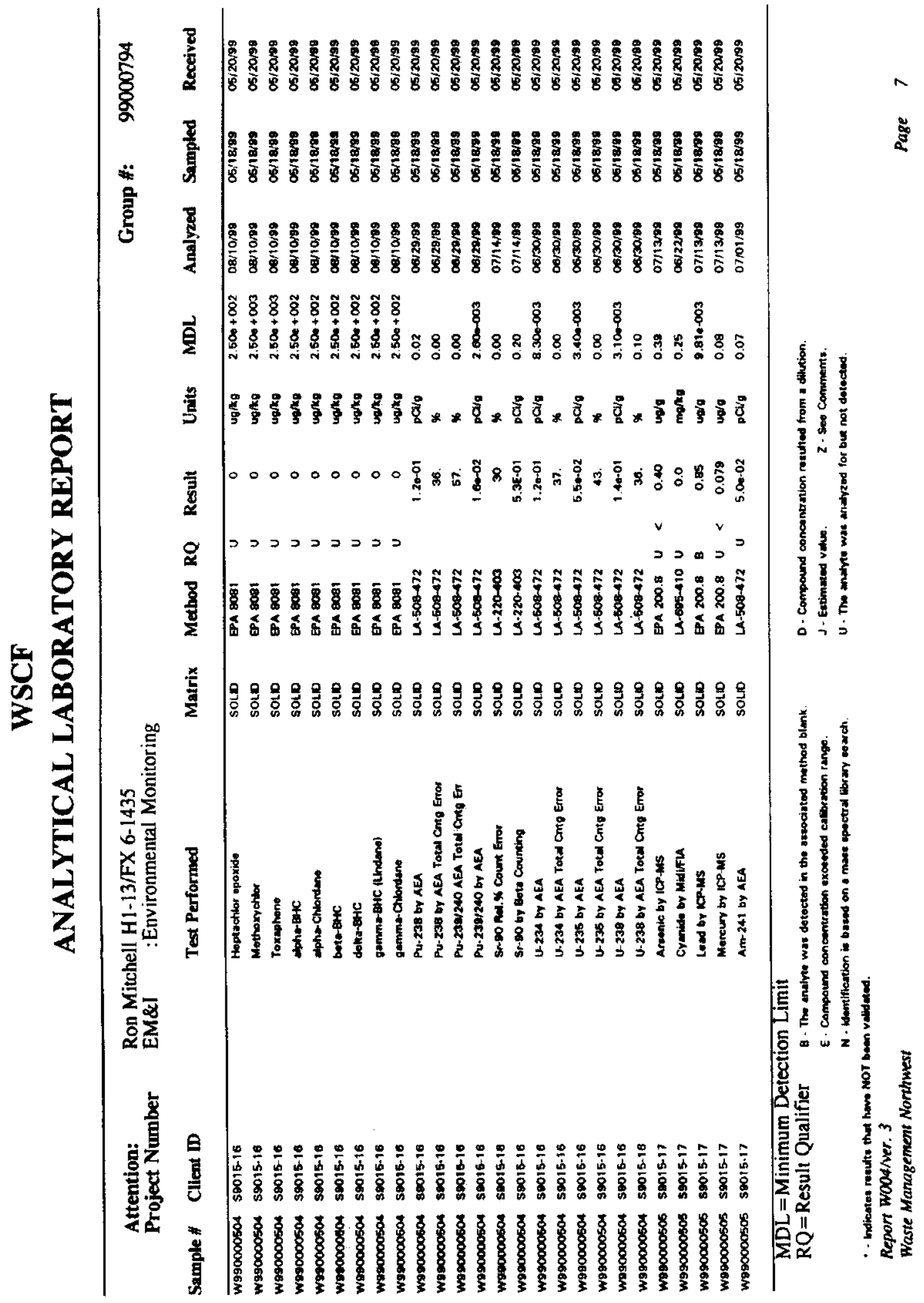


HNF-6150 Rev 0

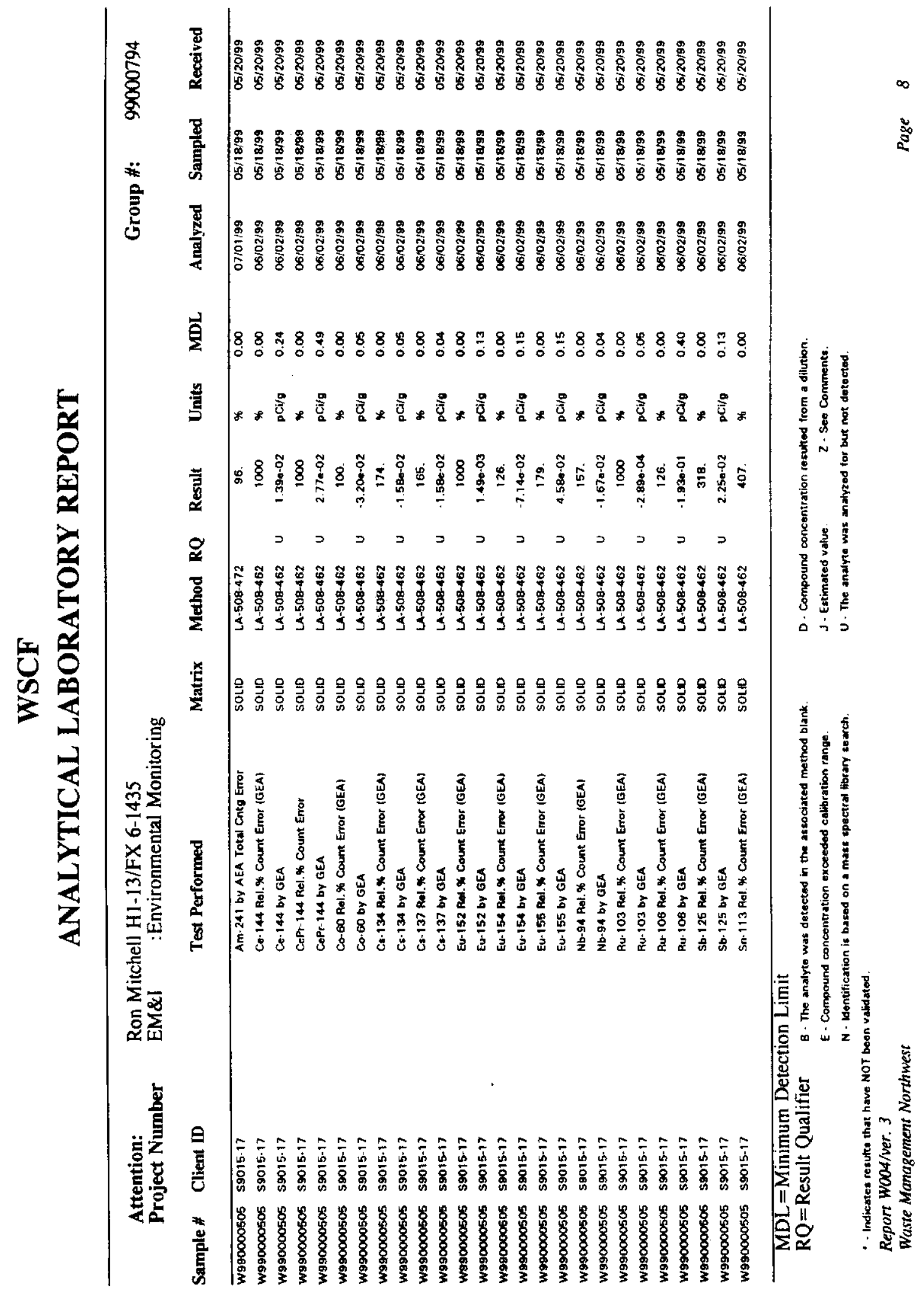


HNF-6150 Rev 0

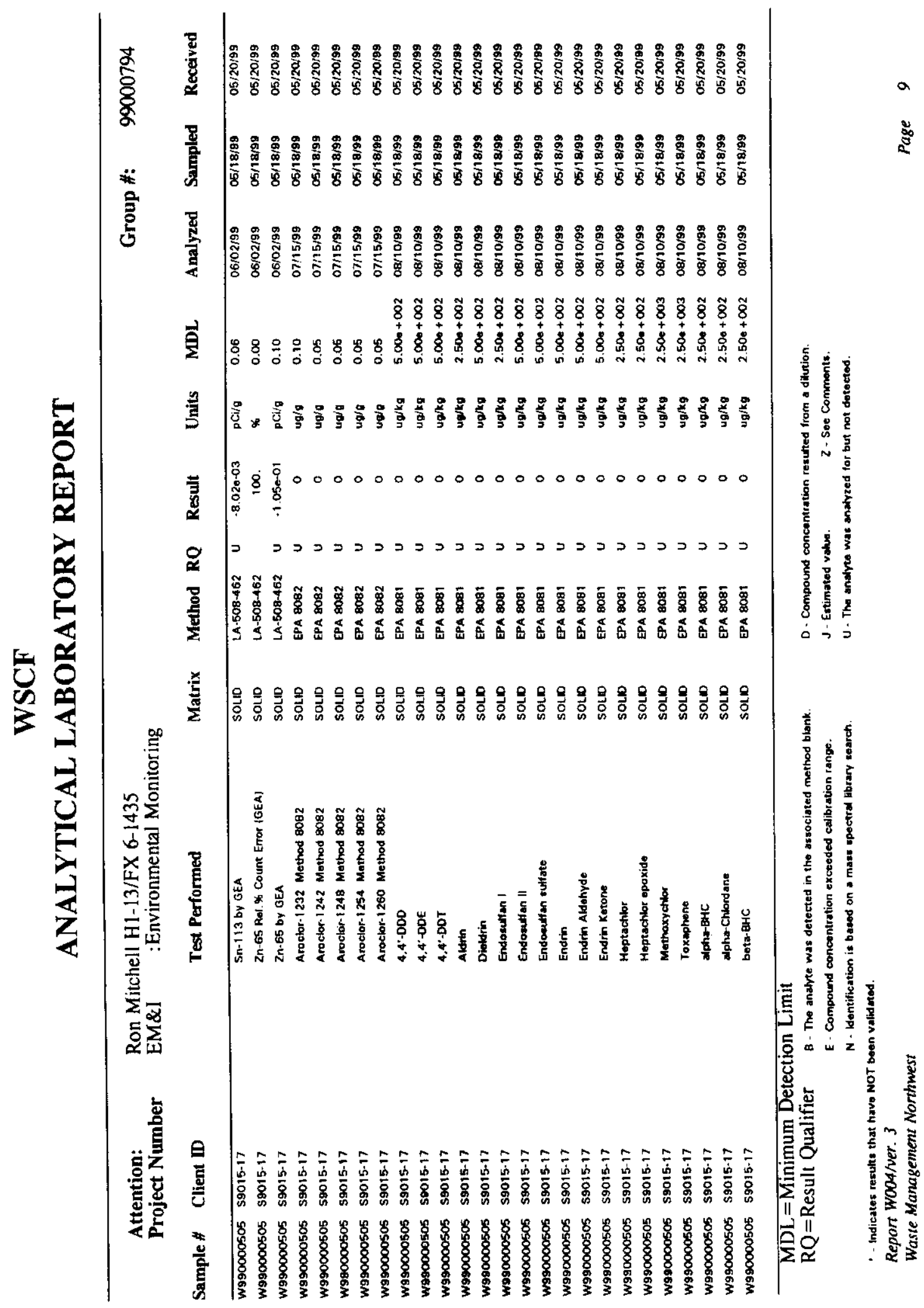


HNF-6150 Rev 0

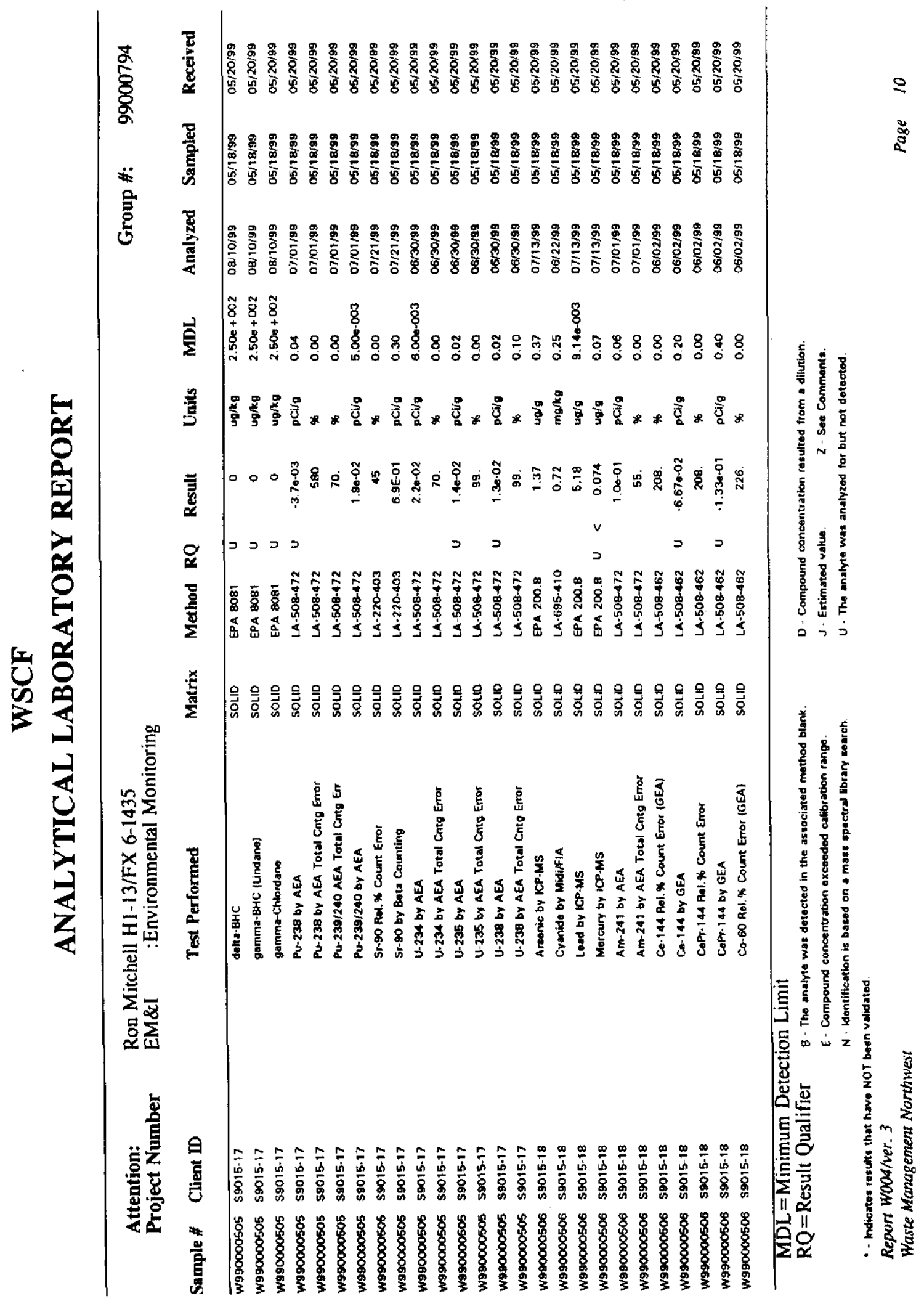


HNF-6150 Rev 0

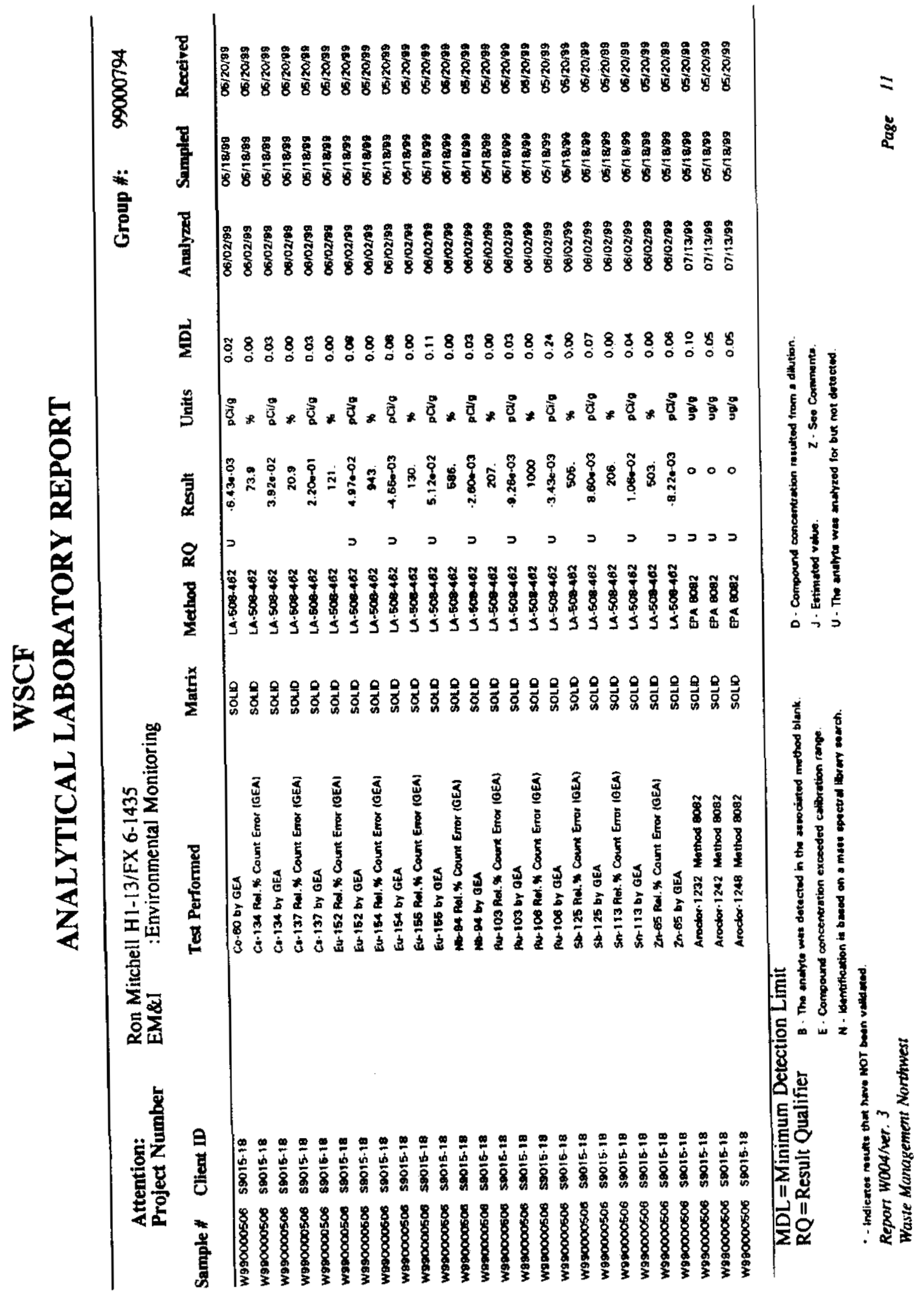


HNF-6150 Rev 0

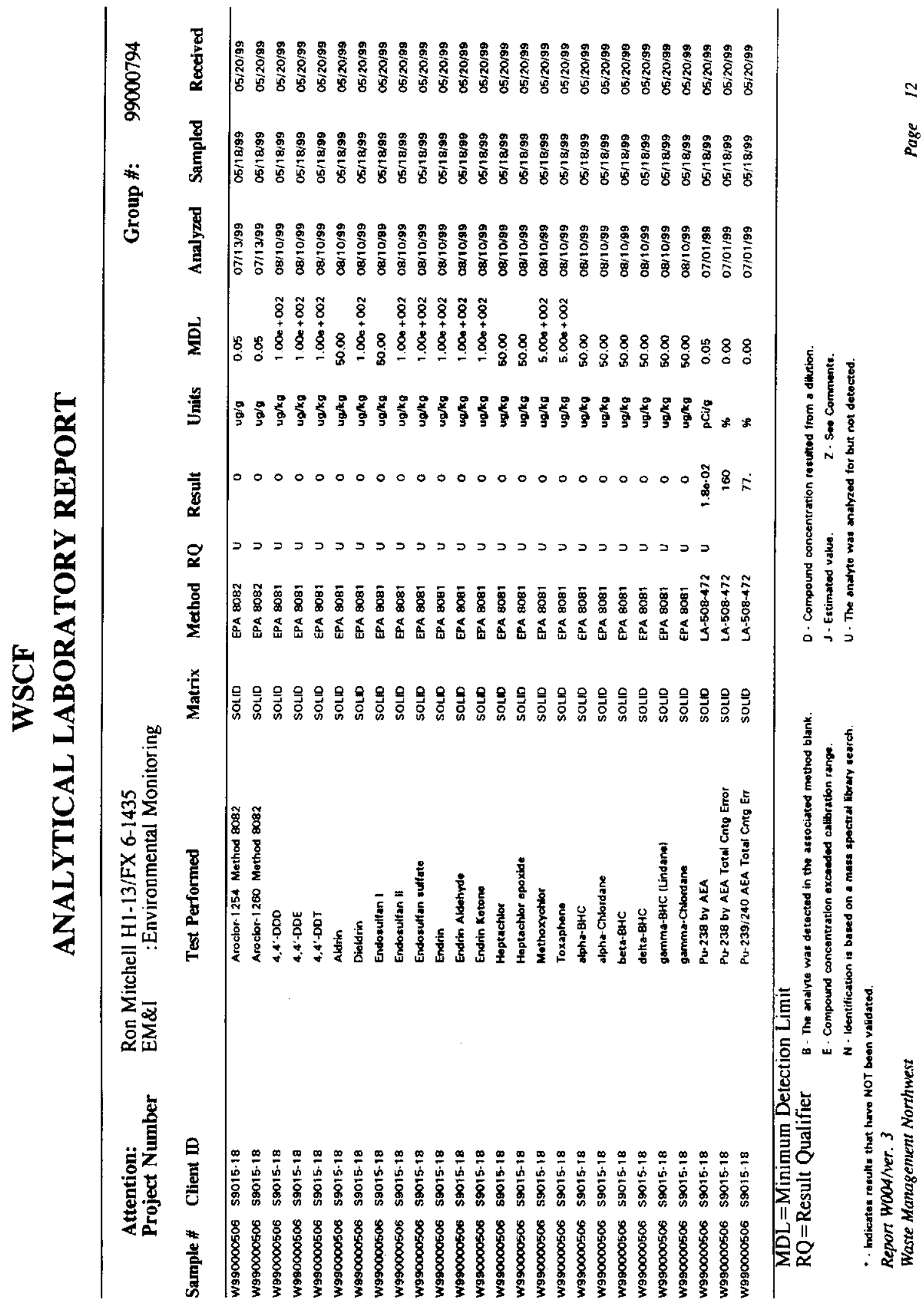


HNF-6150 Rev 0

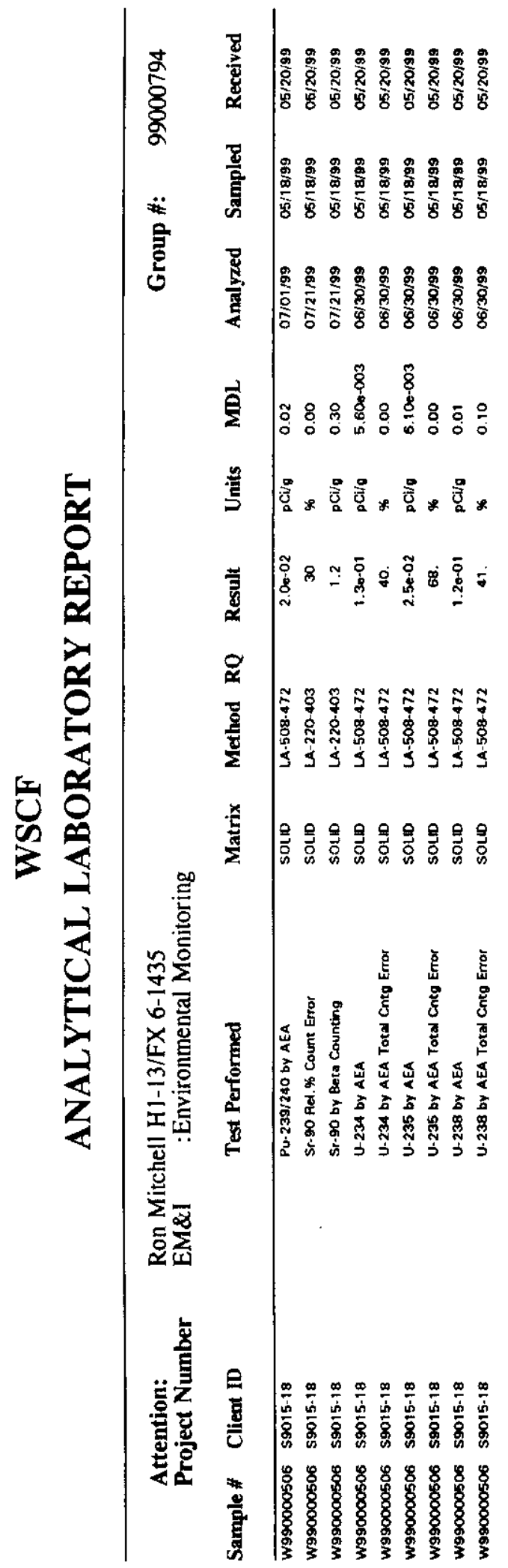

2
a
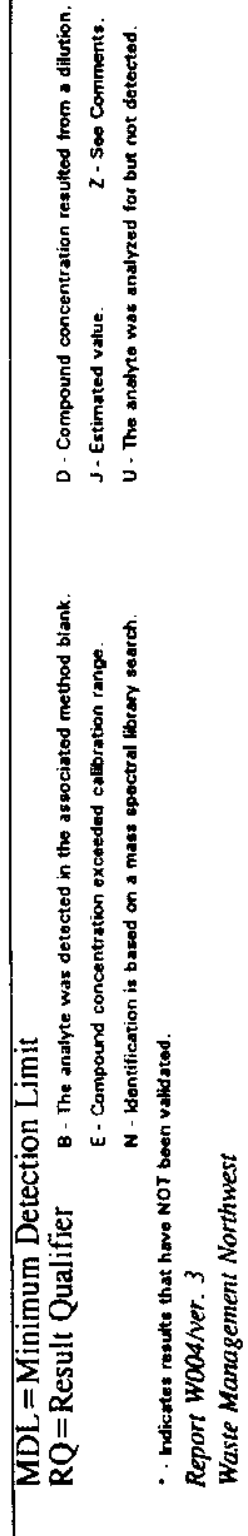
HNF-6150 Rev 0

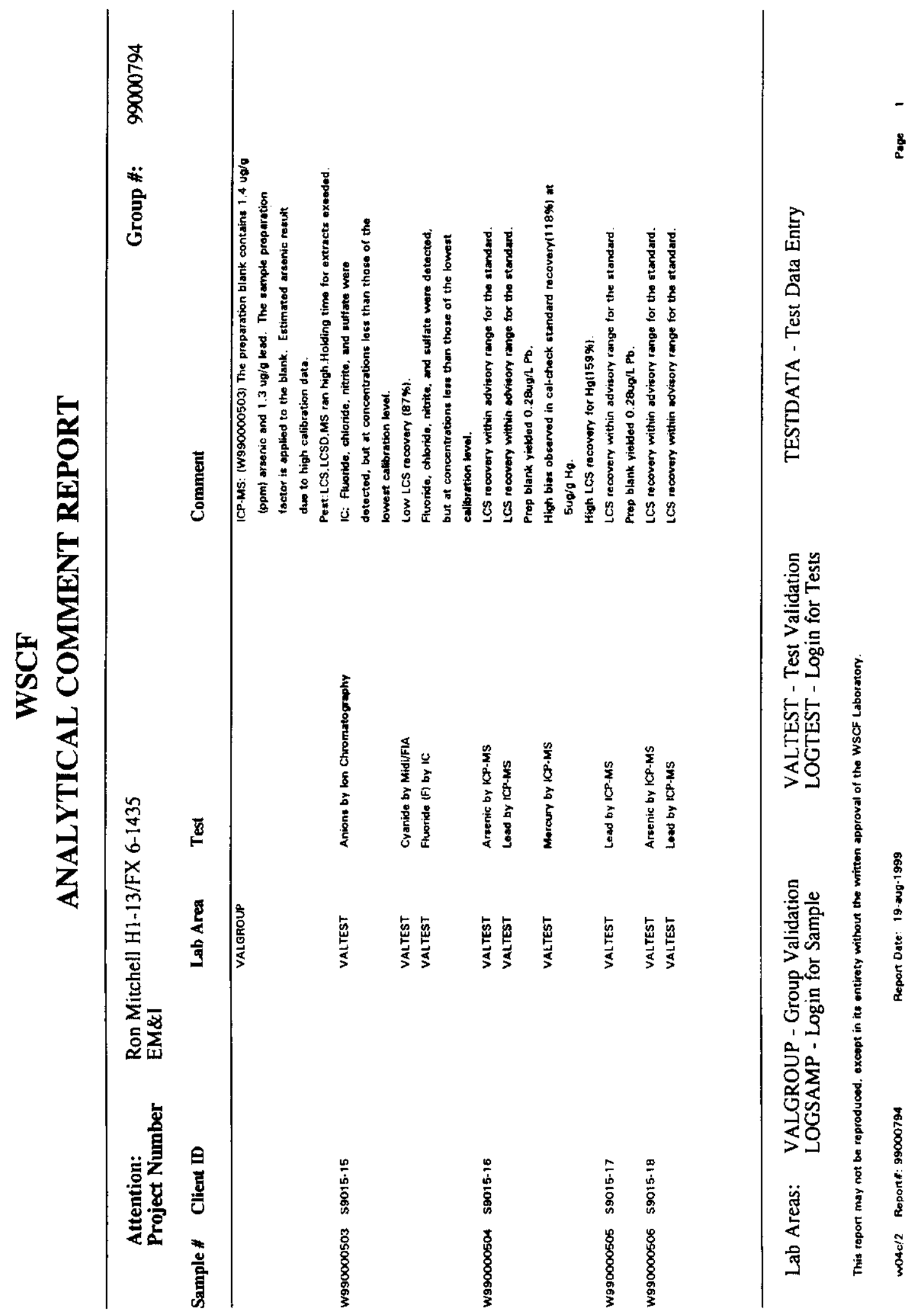


HNF-6150 Rev 0
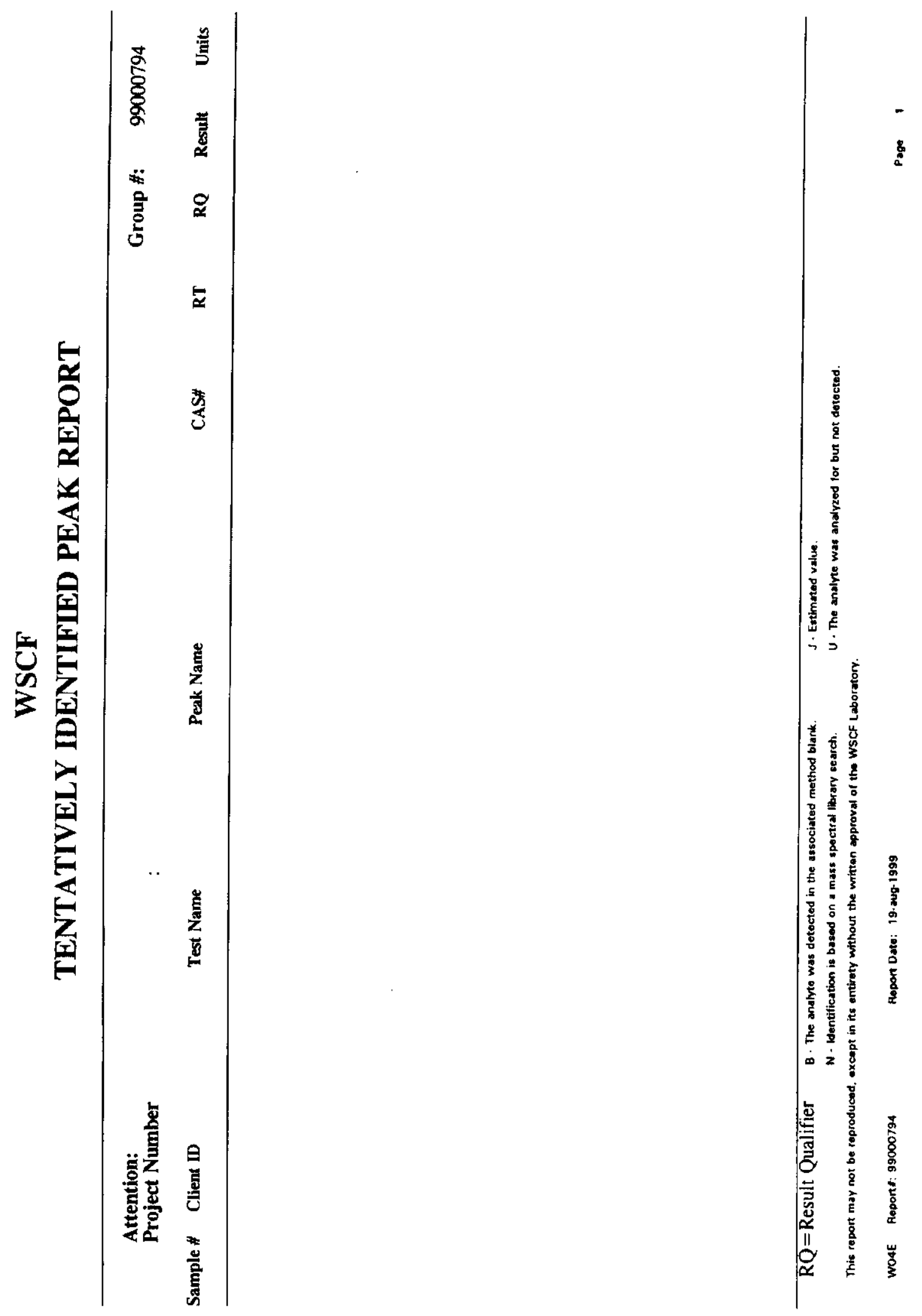
HNF-6150 Rev 0
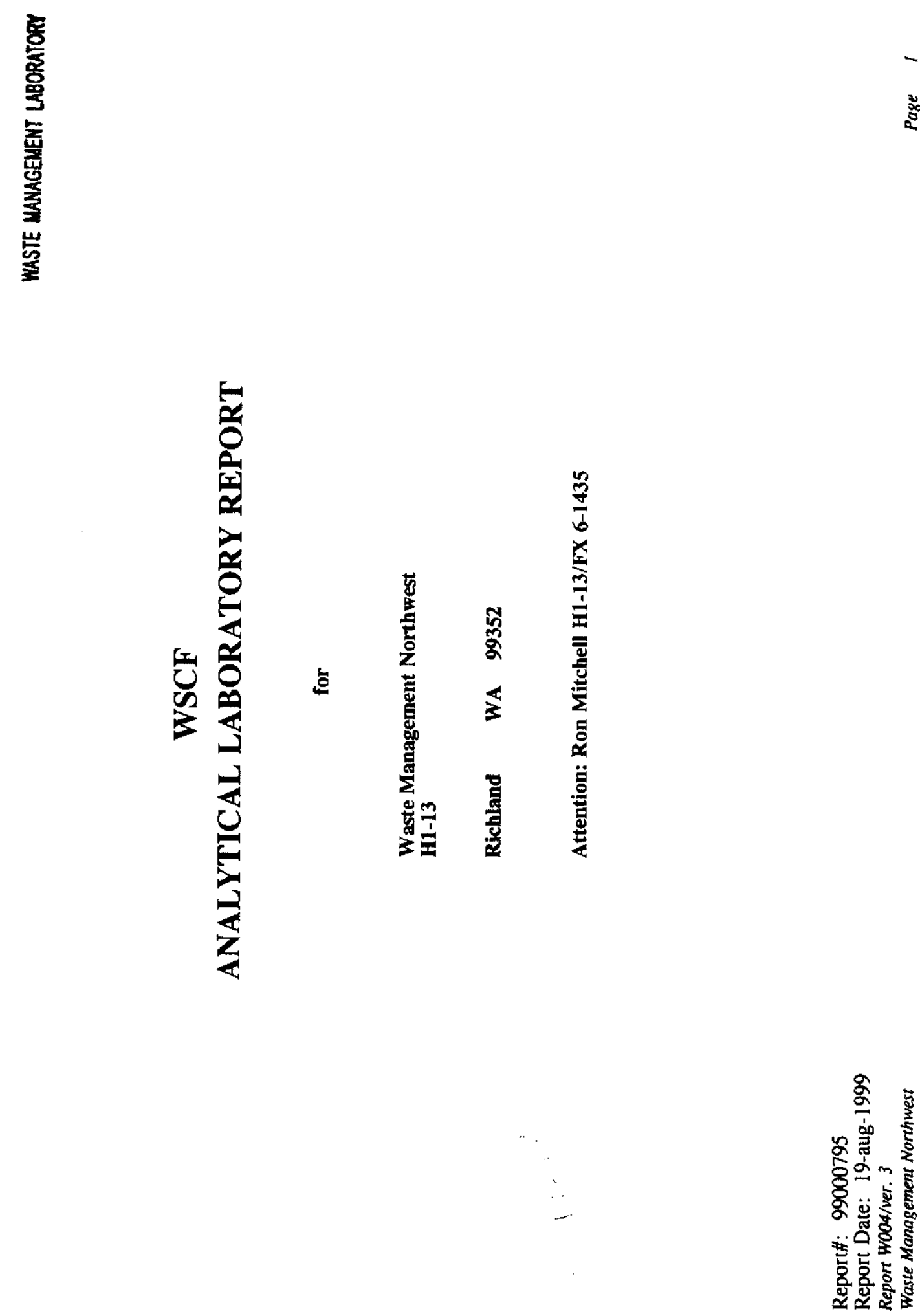
HNF-6150 Rev 0

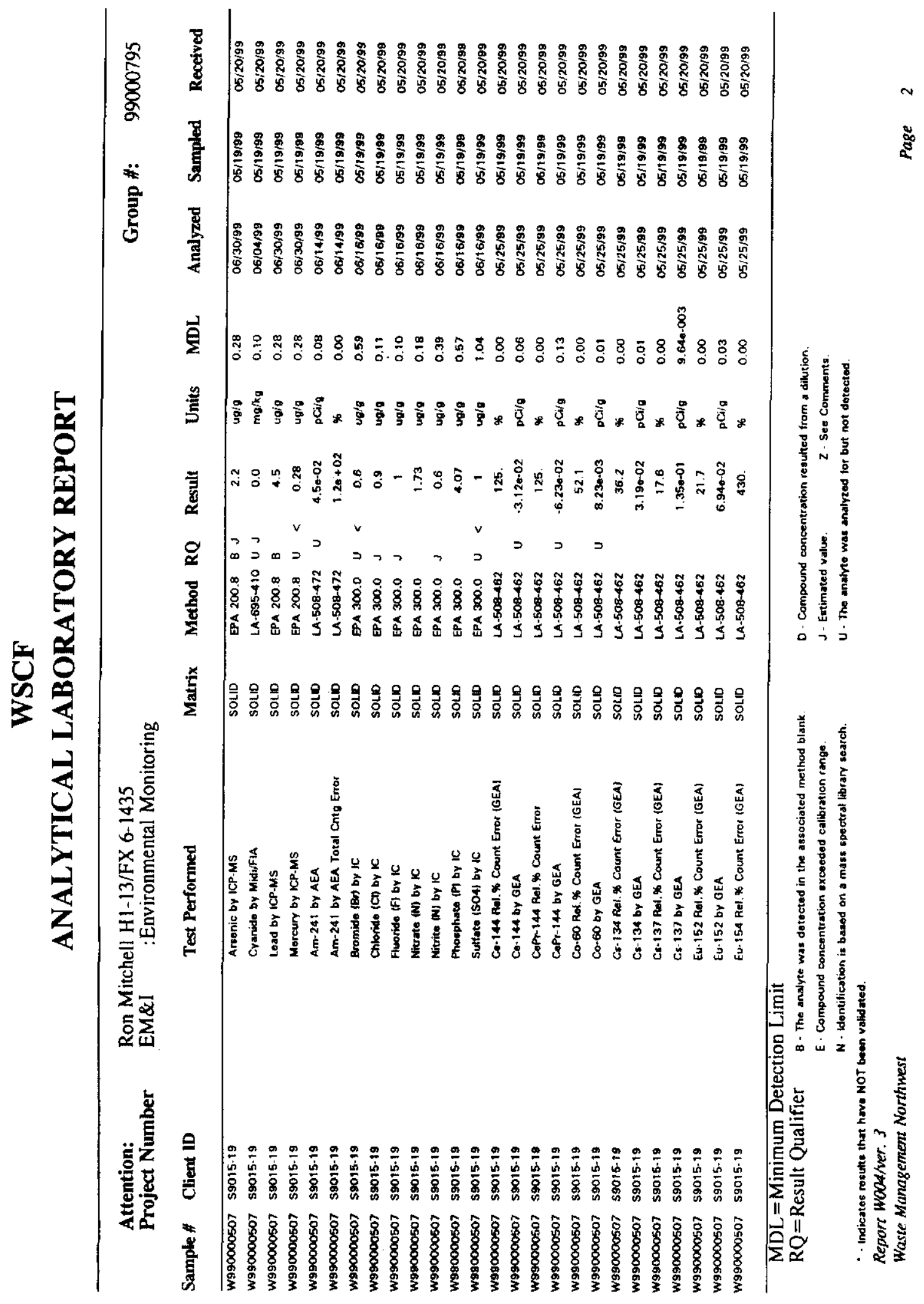


HNF-6150 Rev 0

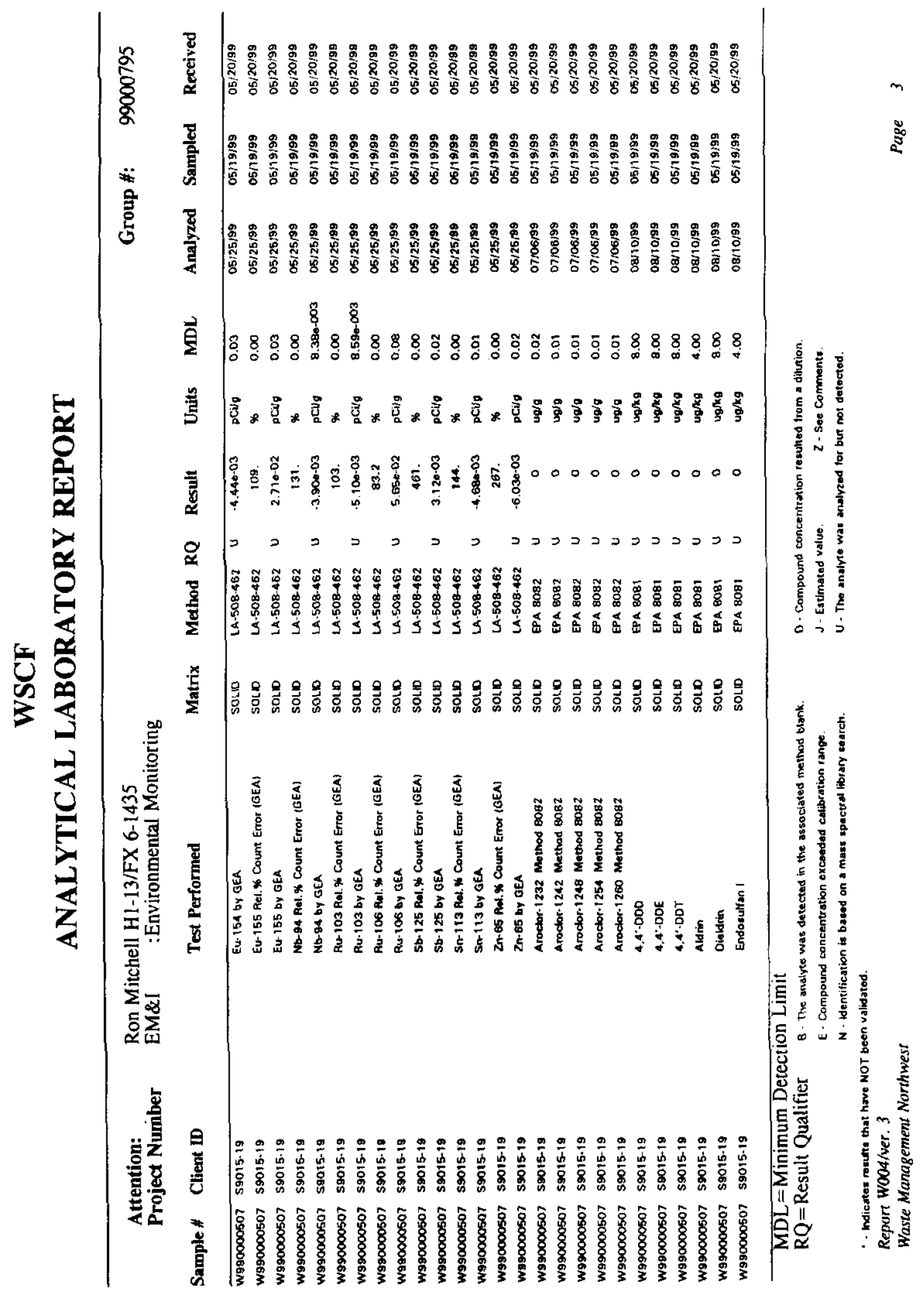


HNF-6150 Rev 0

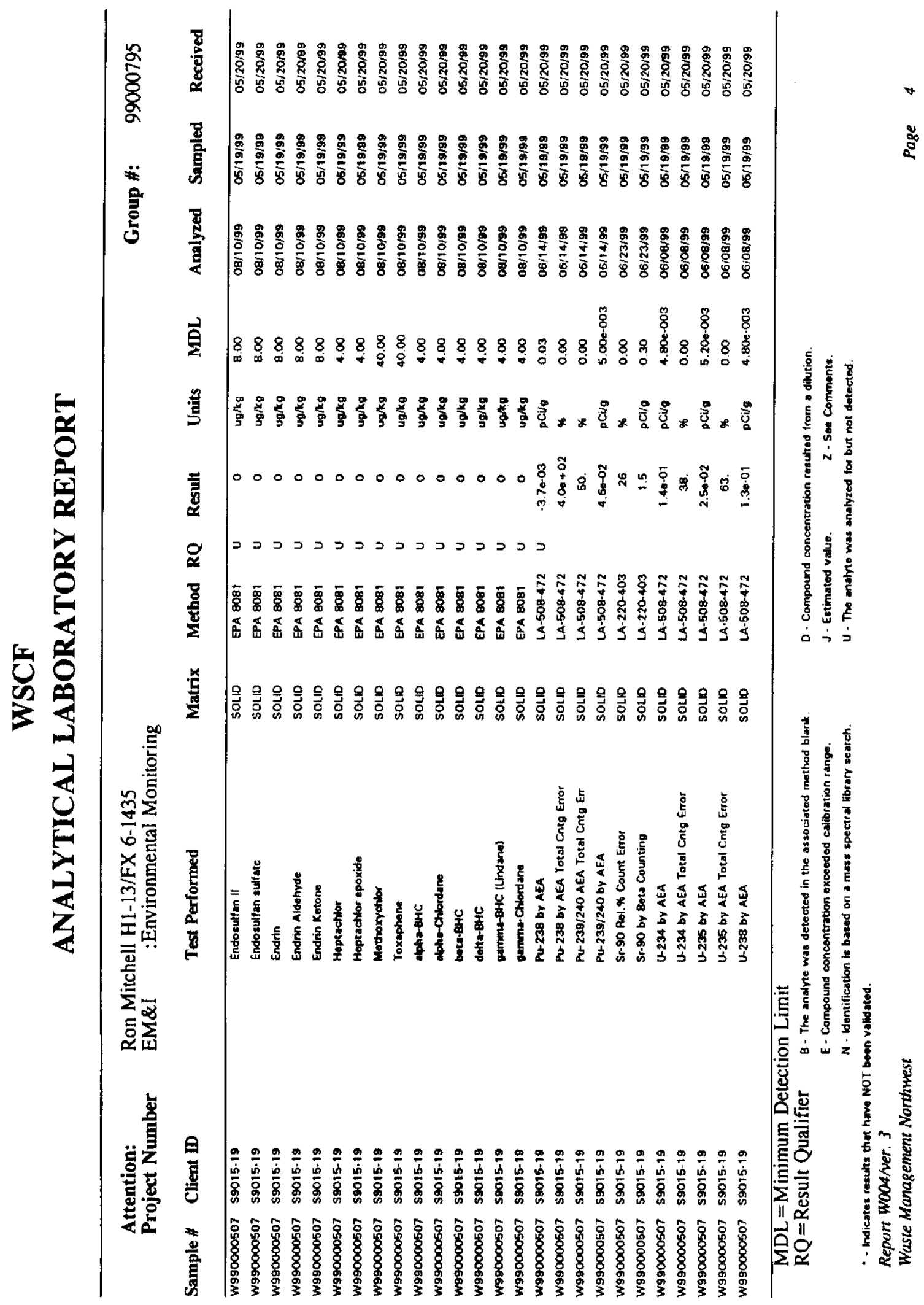


HNF-6150 Rev 0

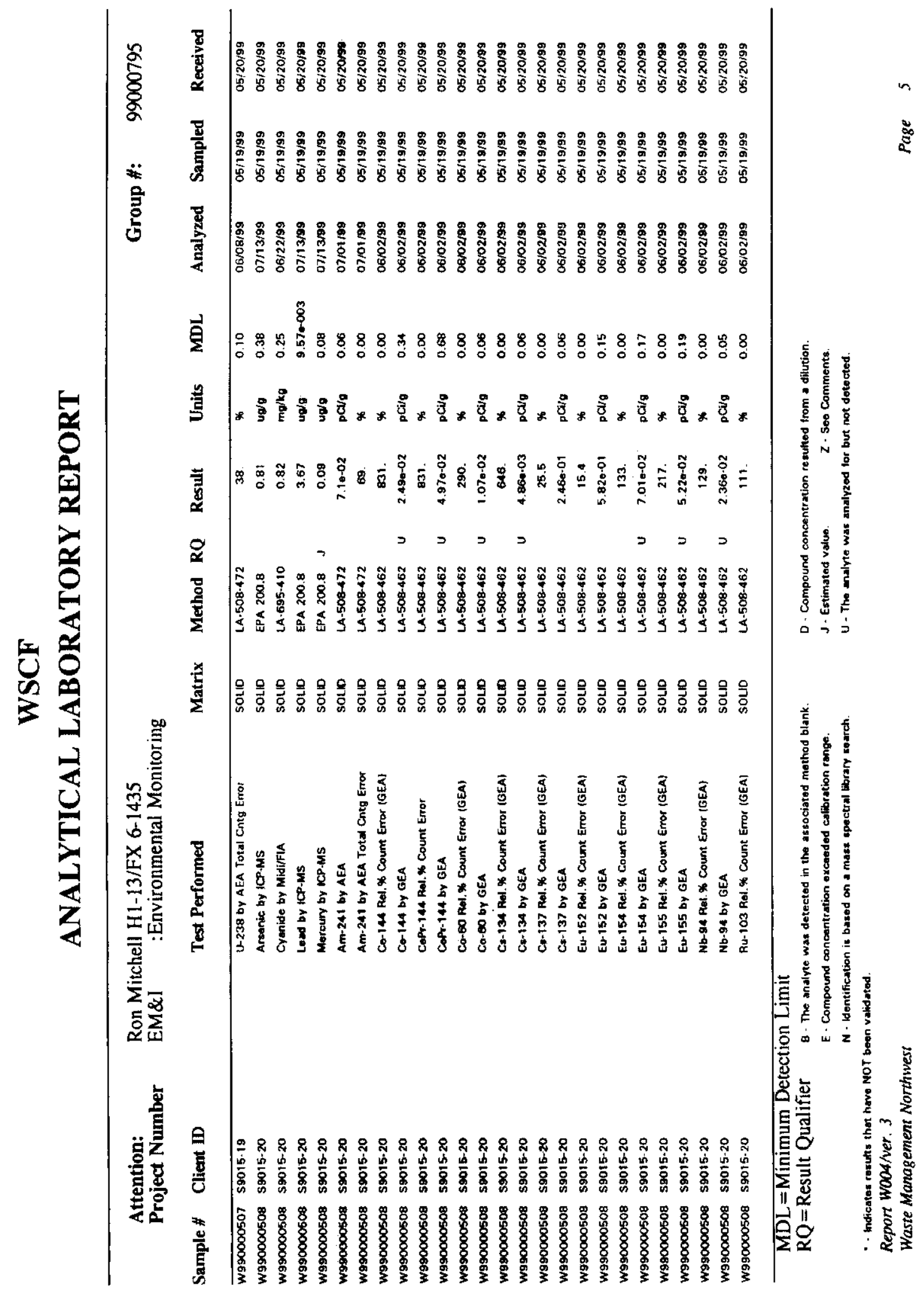


HNF-6150 Rev 0

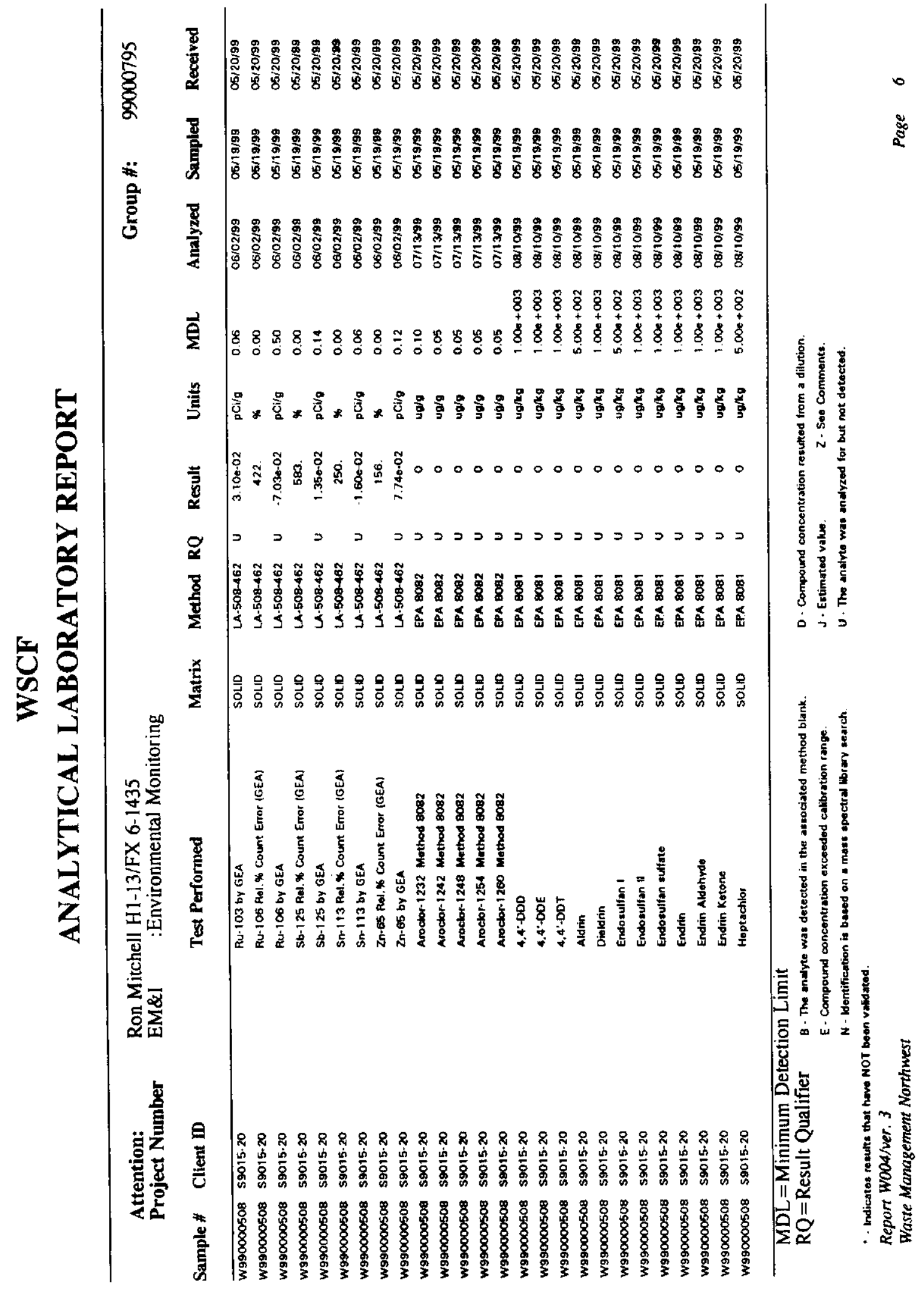


HNF-6150 Rev 0

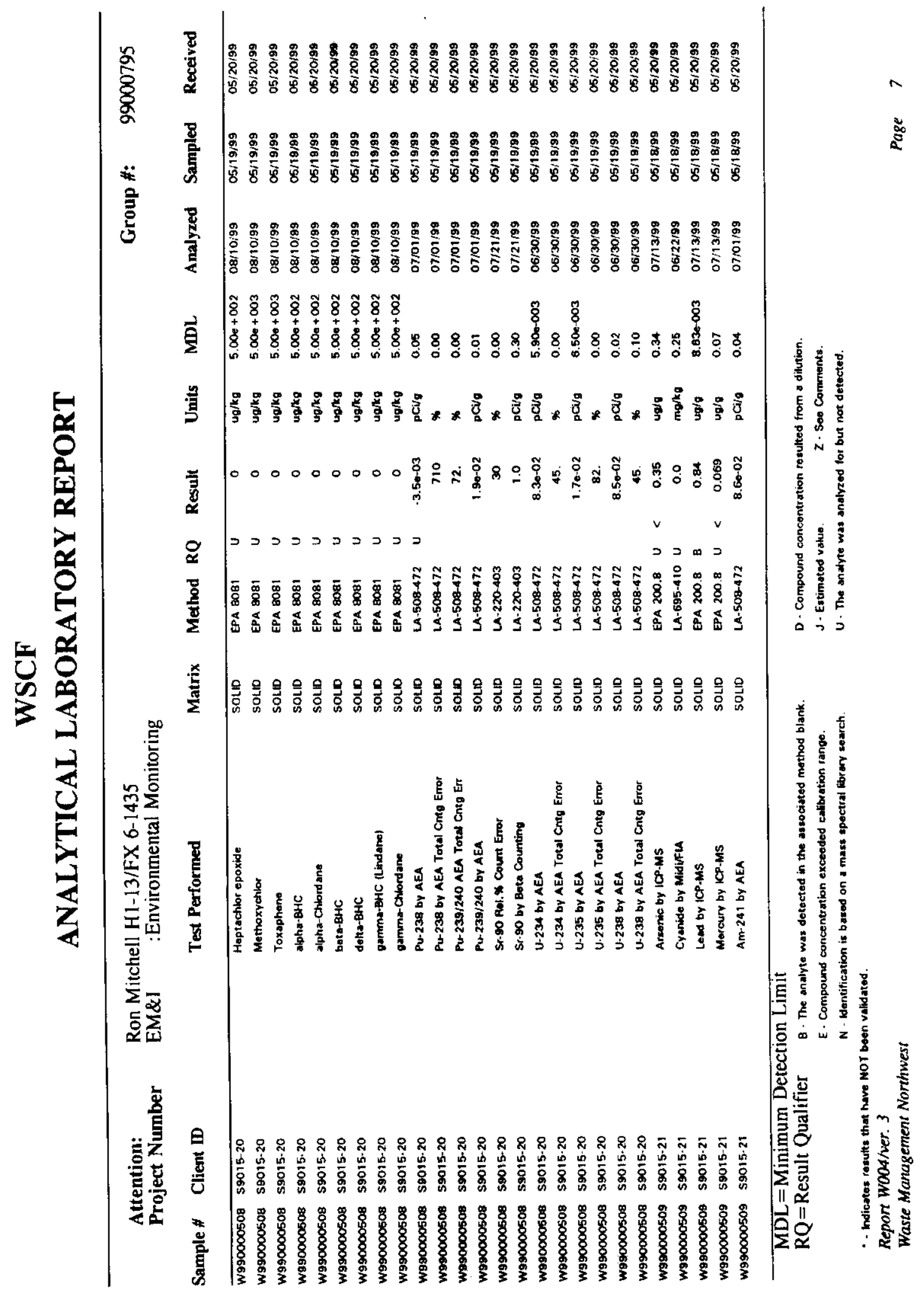


HNF-6150 Rev 0

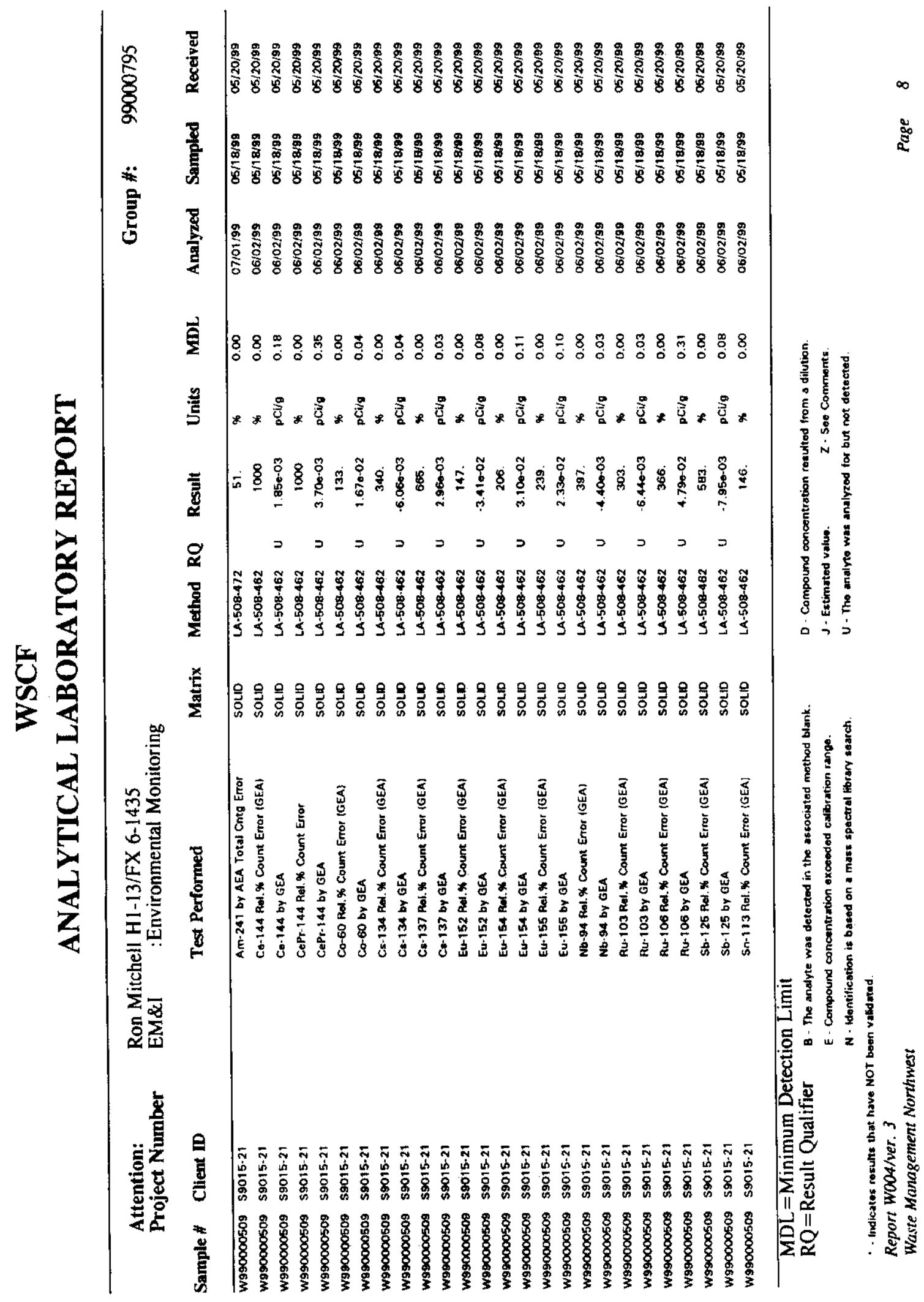


HNF-6150 Rev 0

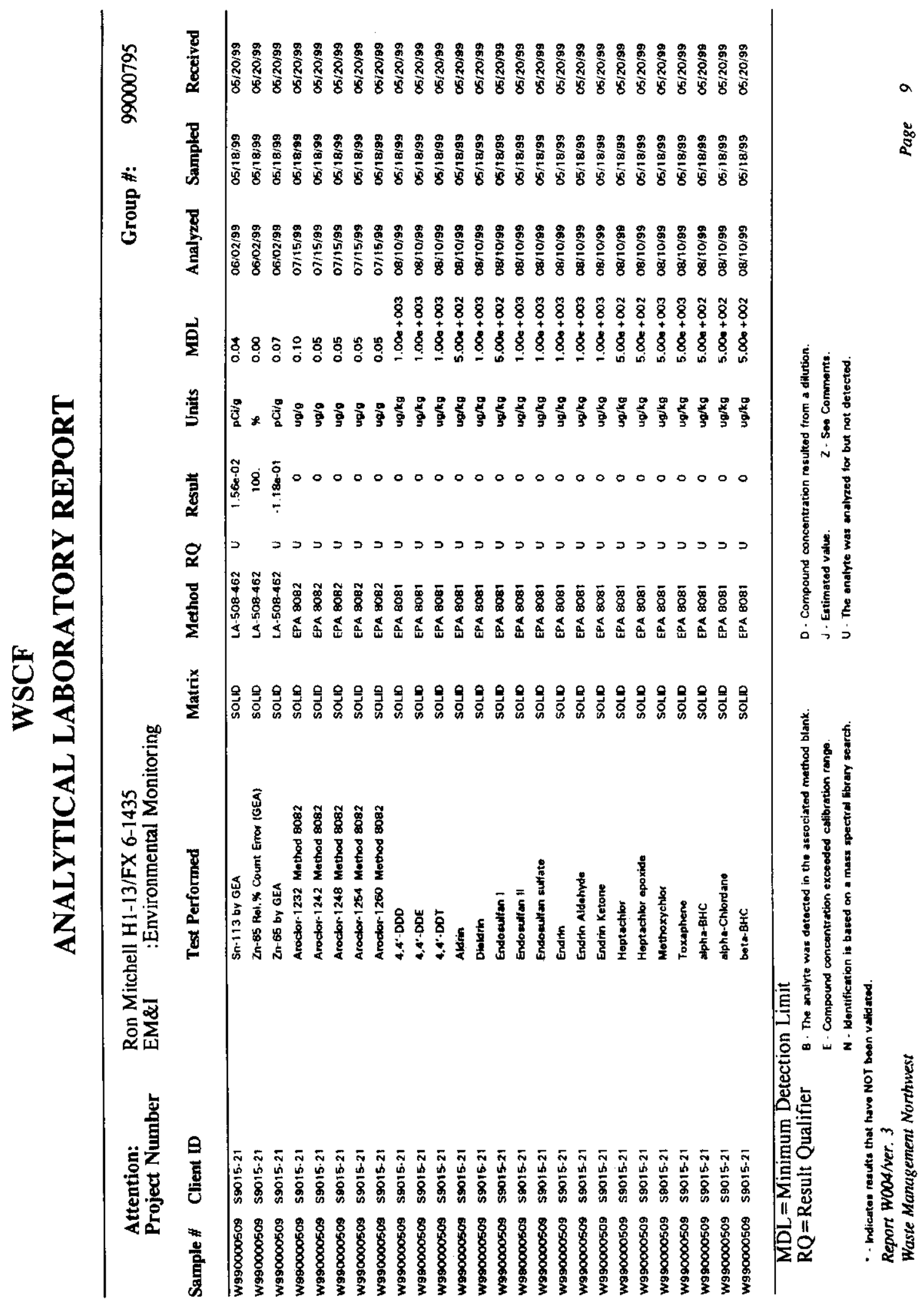


HNF-6150 Rev 0

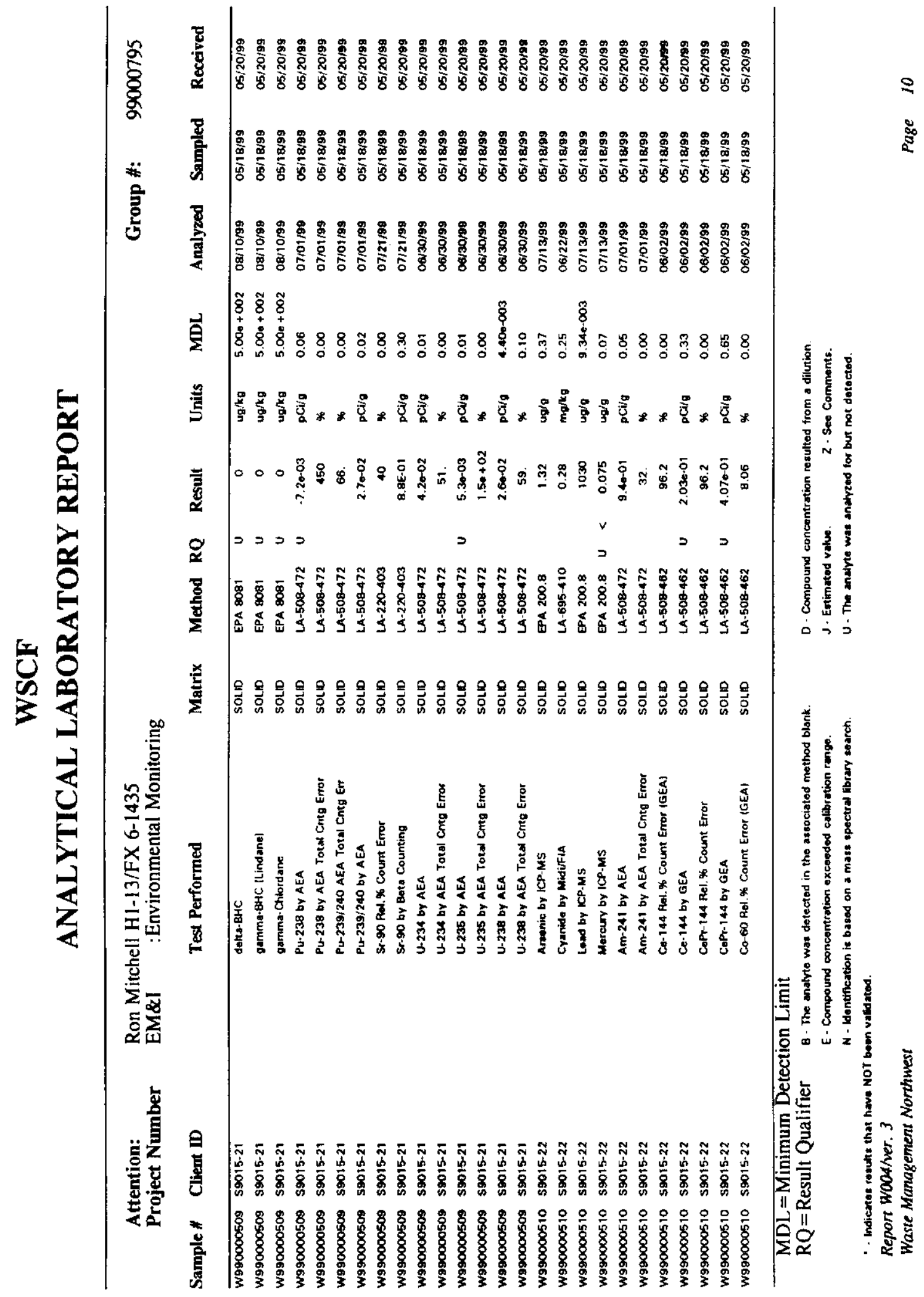


HNF-6150 Rev 0

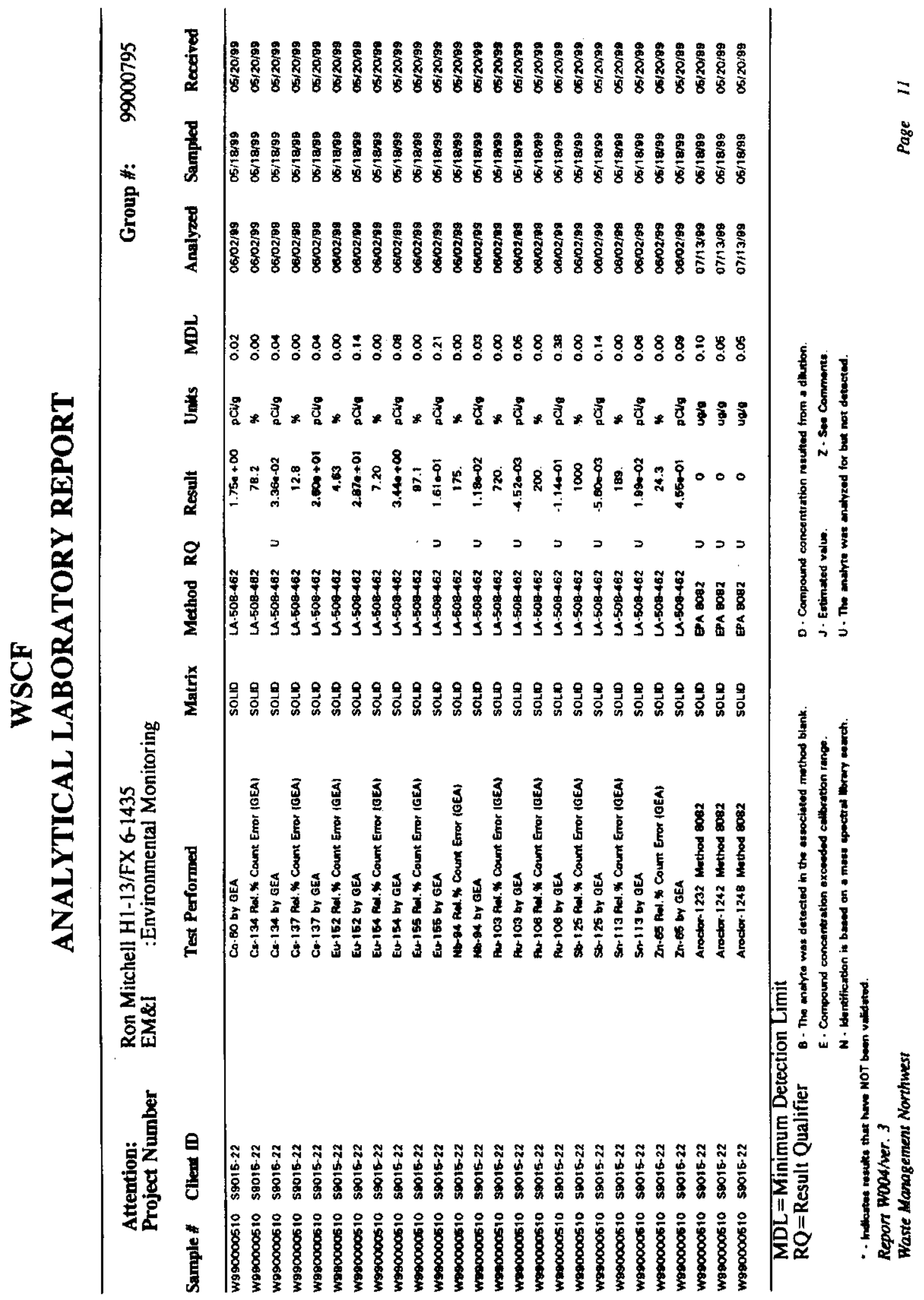


HNF-6150 Rev 0

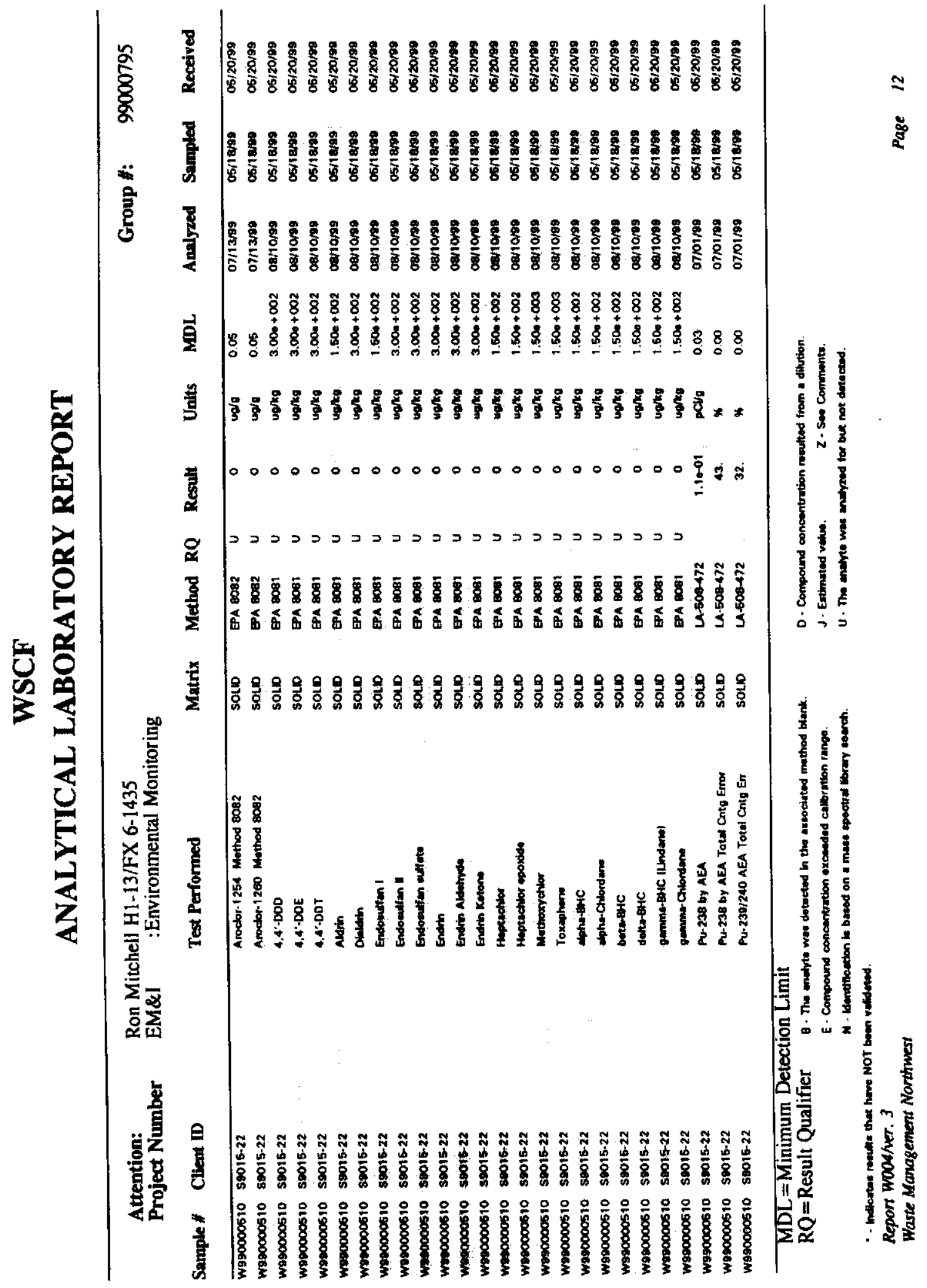


HNF-6150 Rev 0

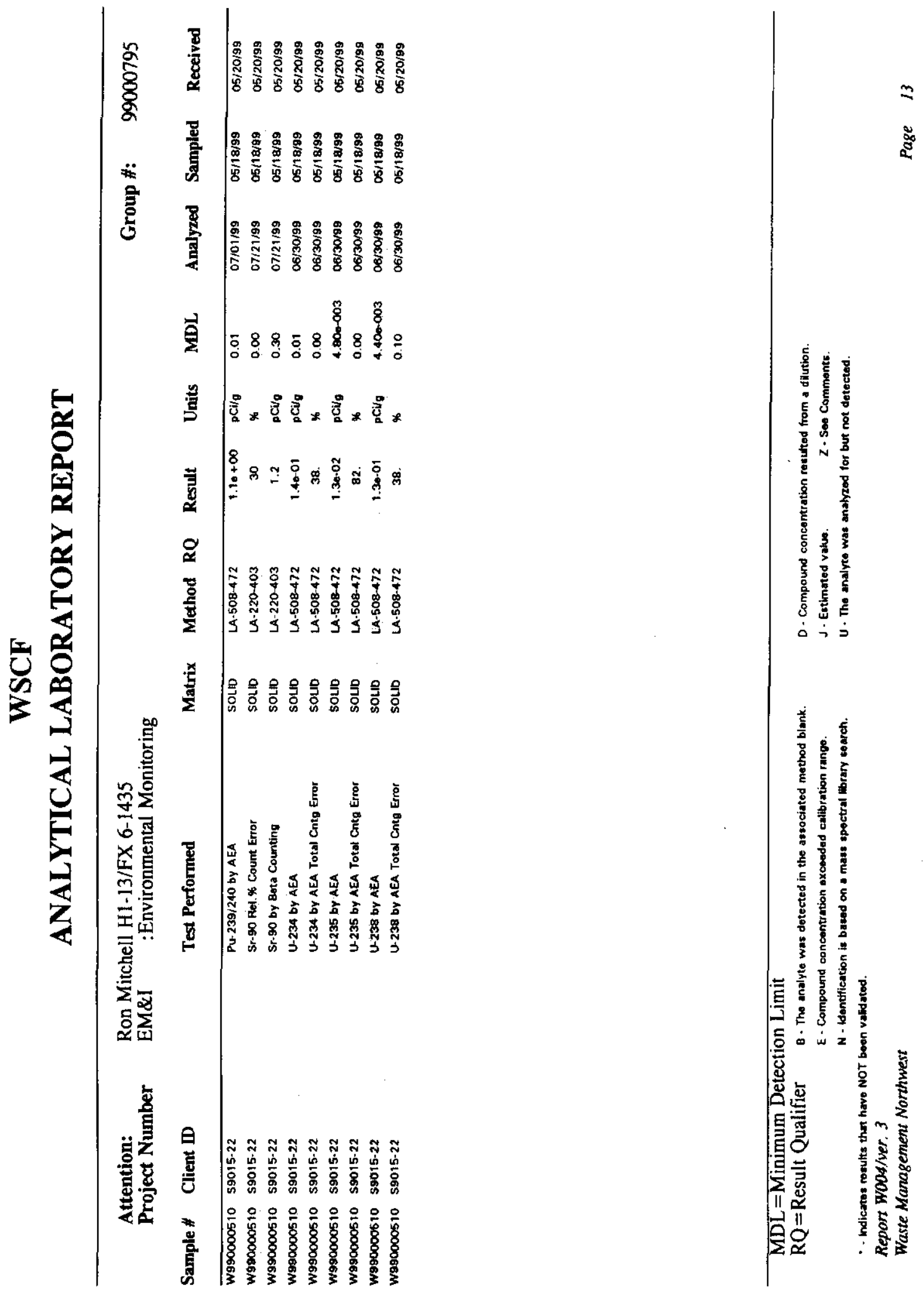


HNF-6150 Rev 0

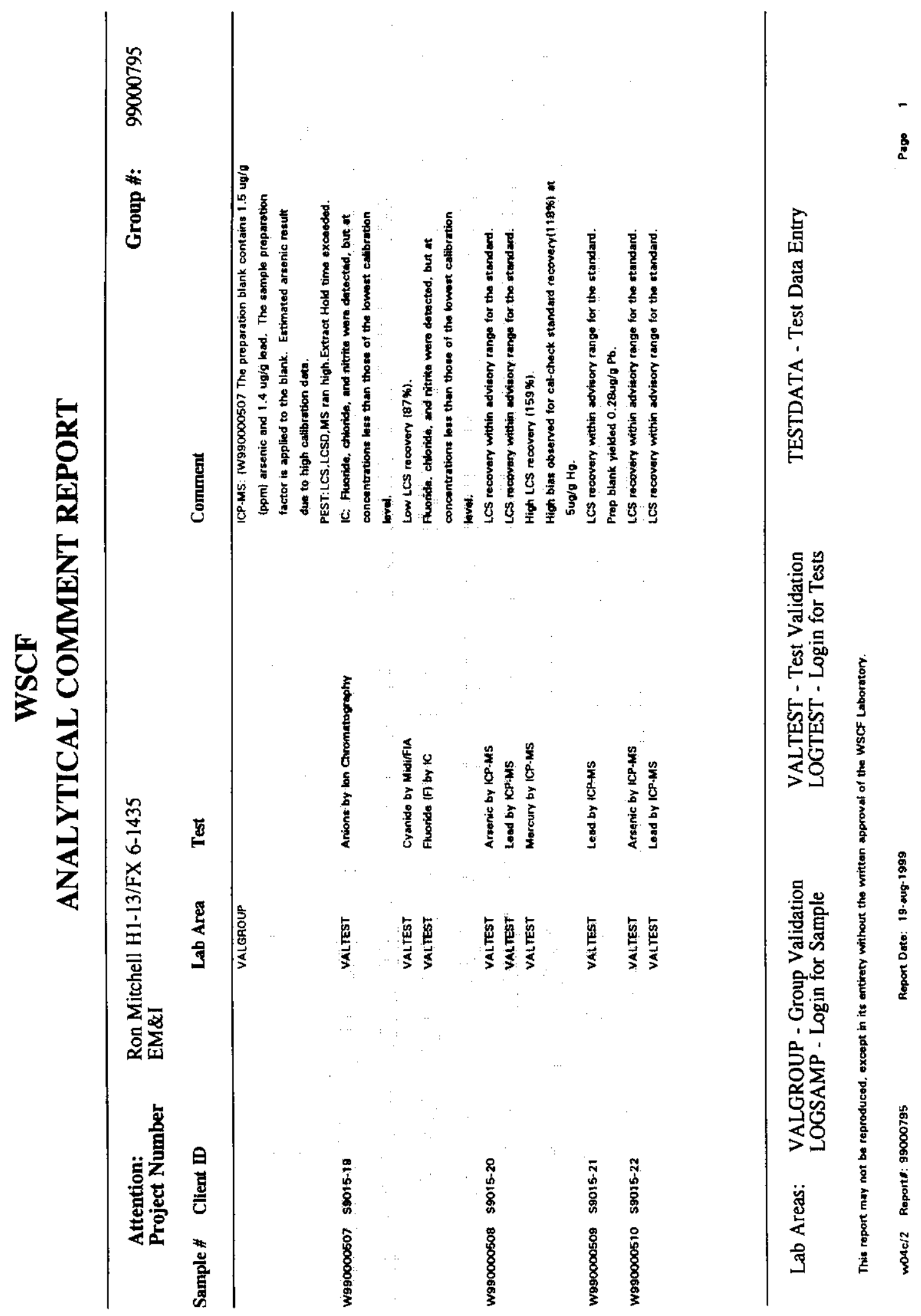


HNF-6150 Rev 0
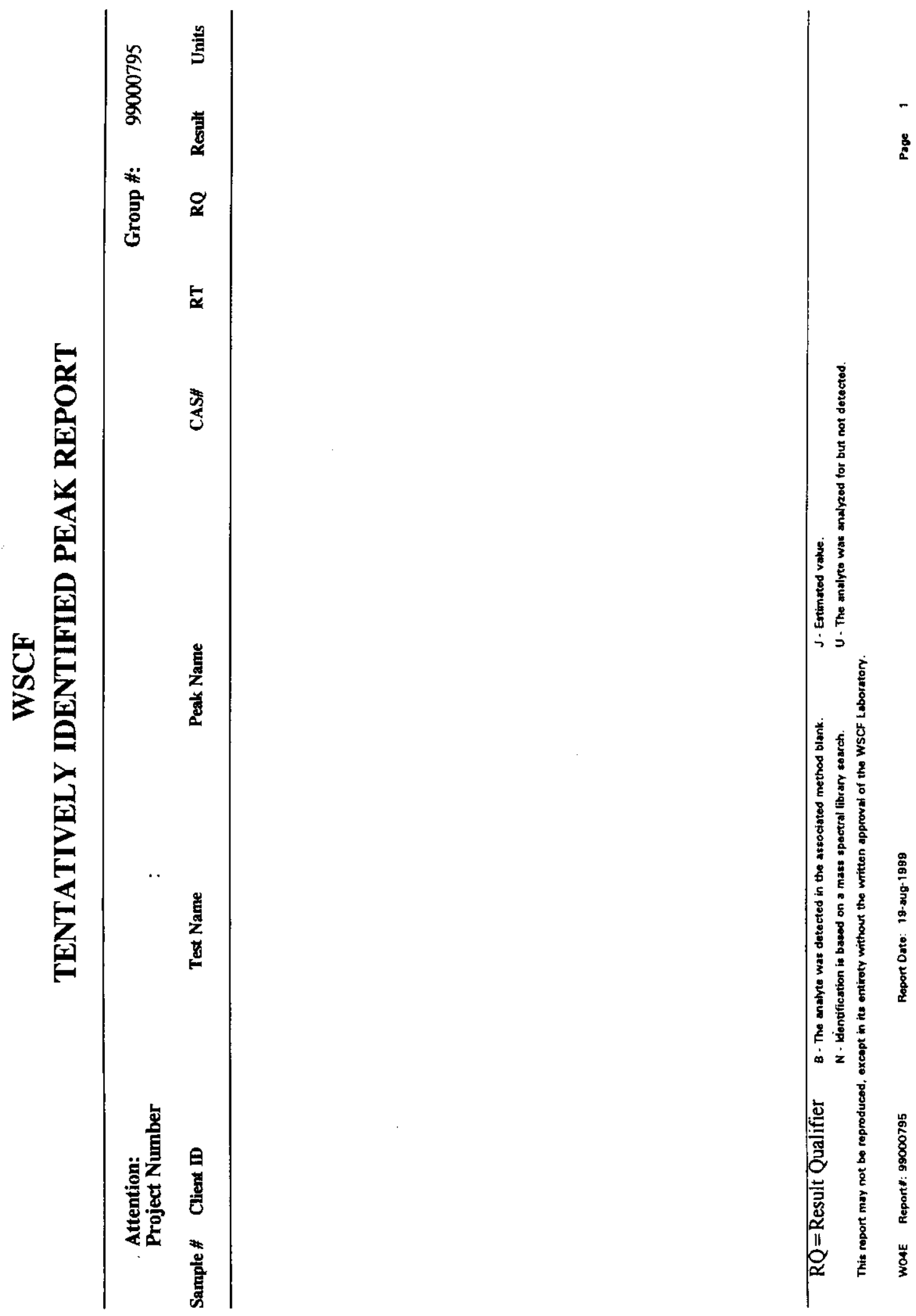


\section{HNF-6150 Rev 0}
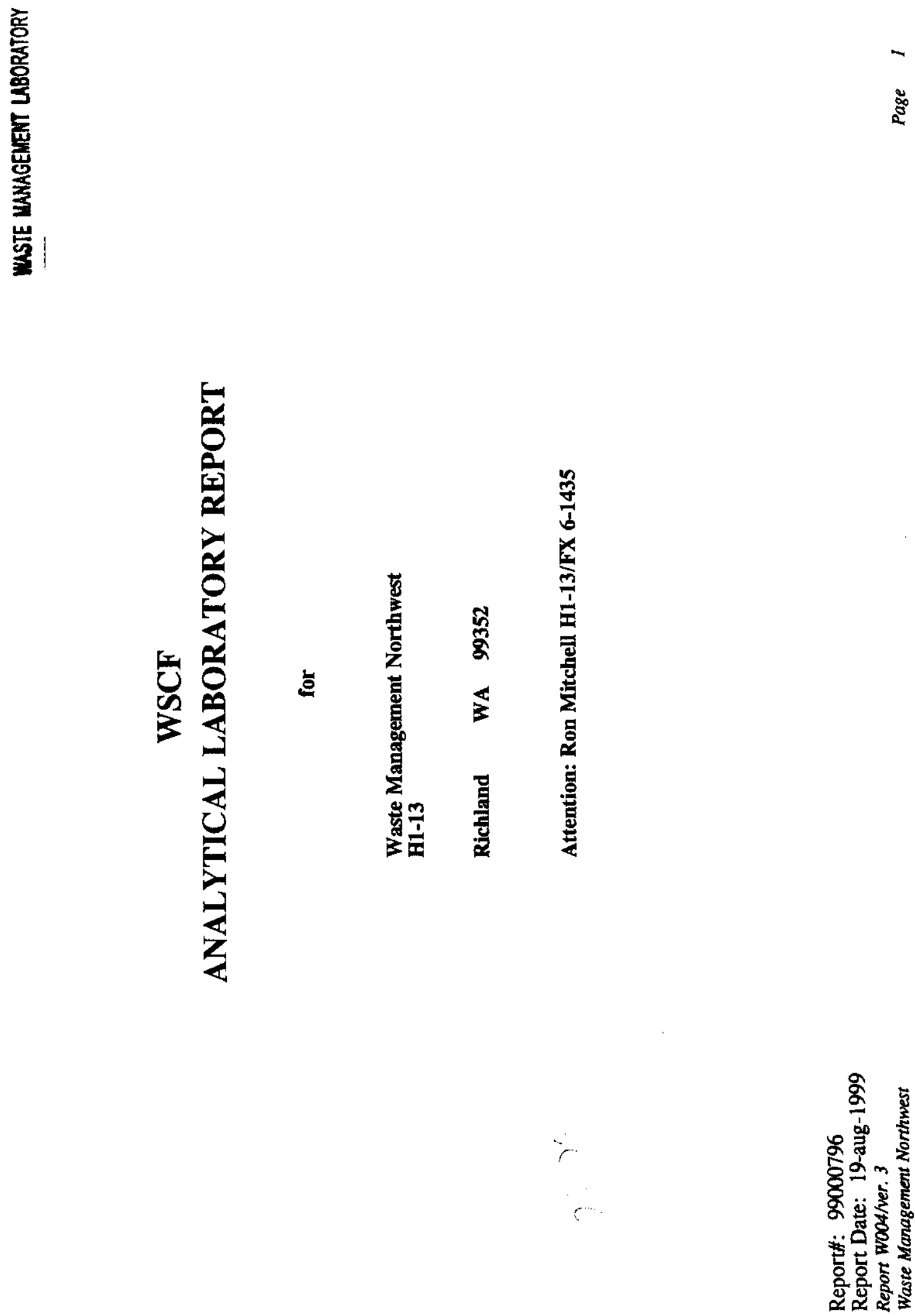

C-90 
HNF-6150 Rev 0

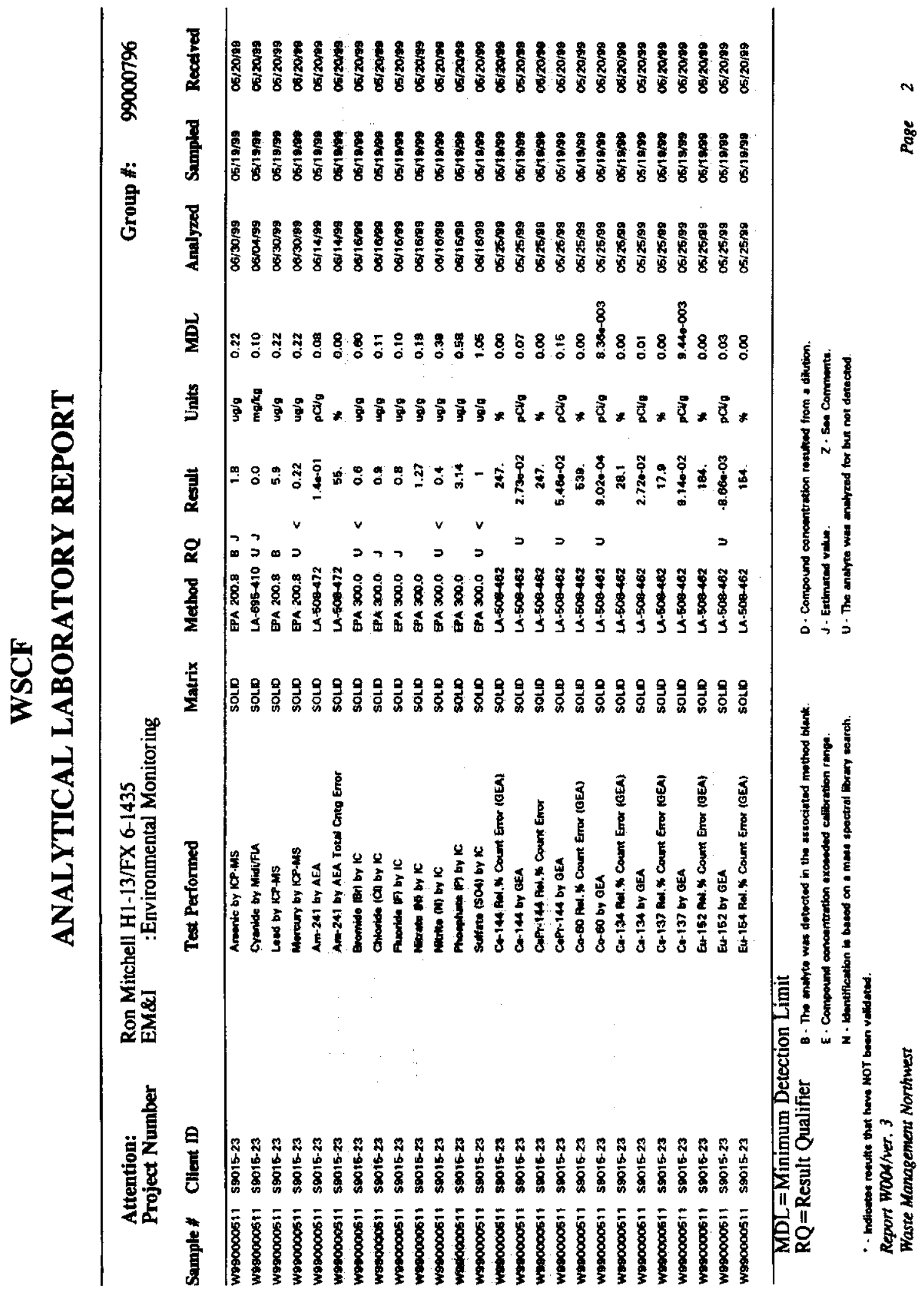


HNF-6150 Rev 0

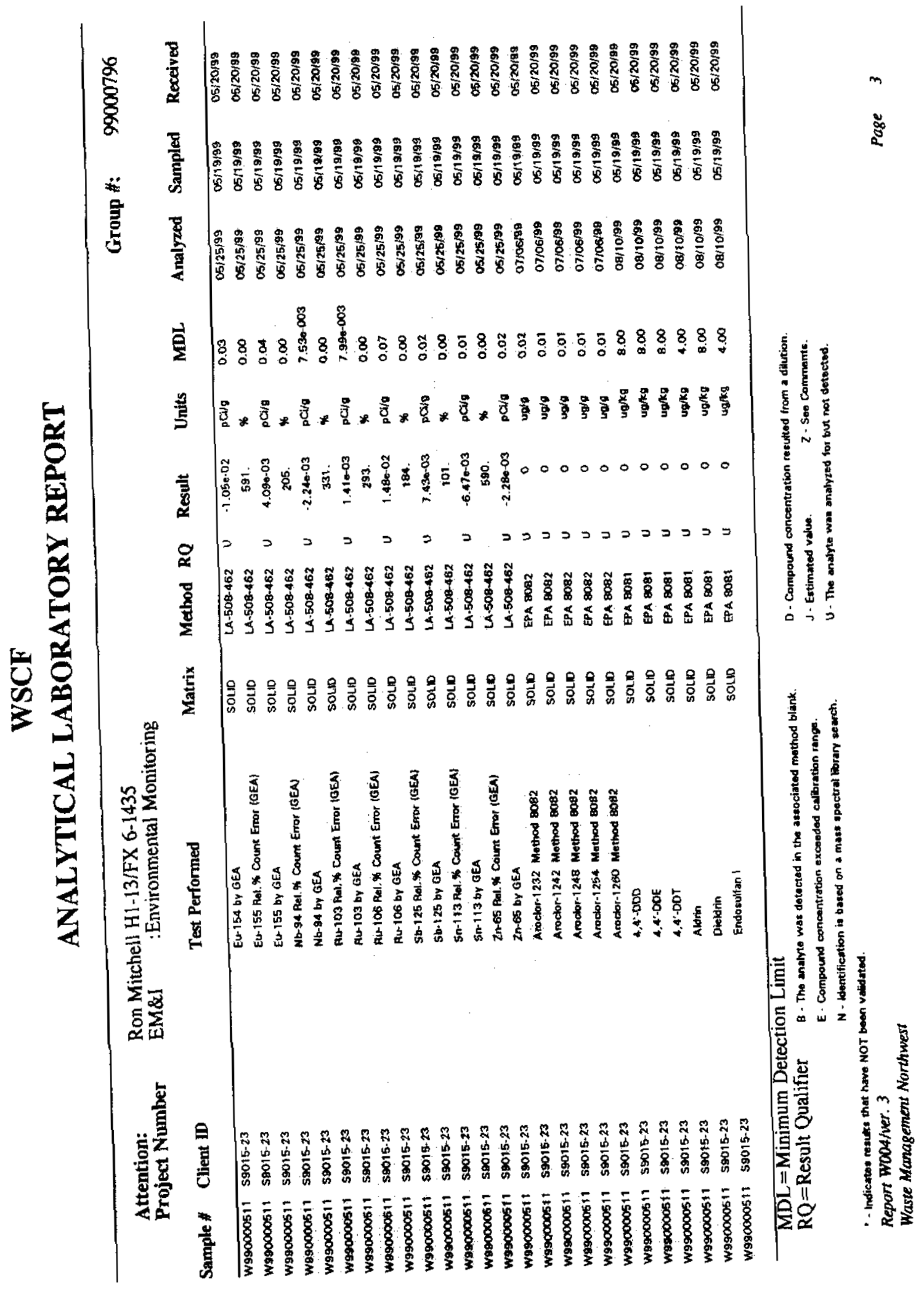


HNF-6150 Rev 0

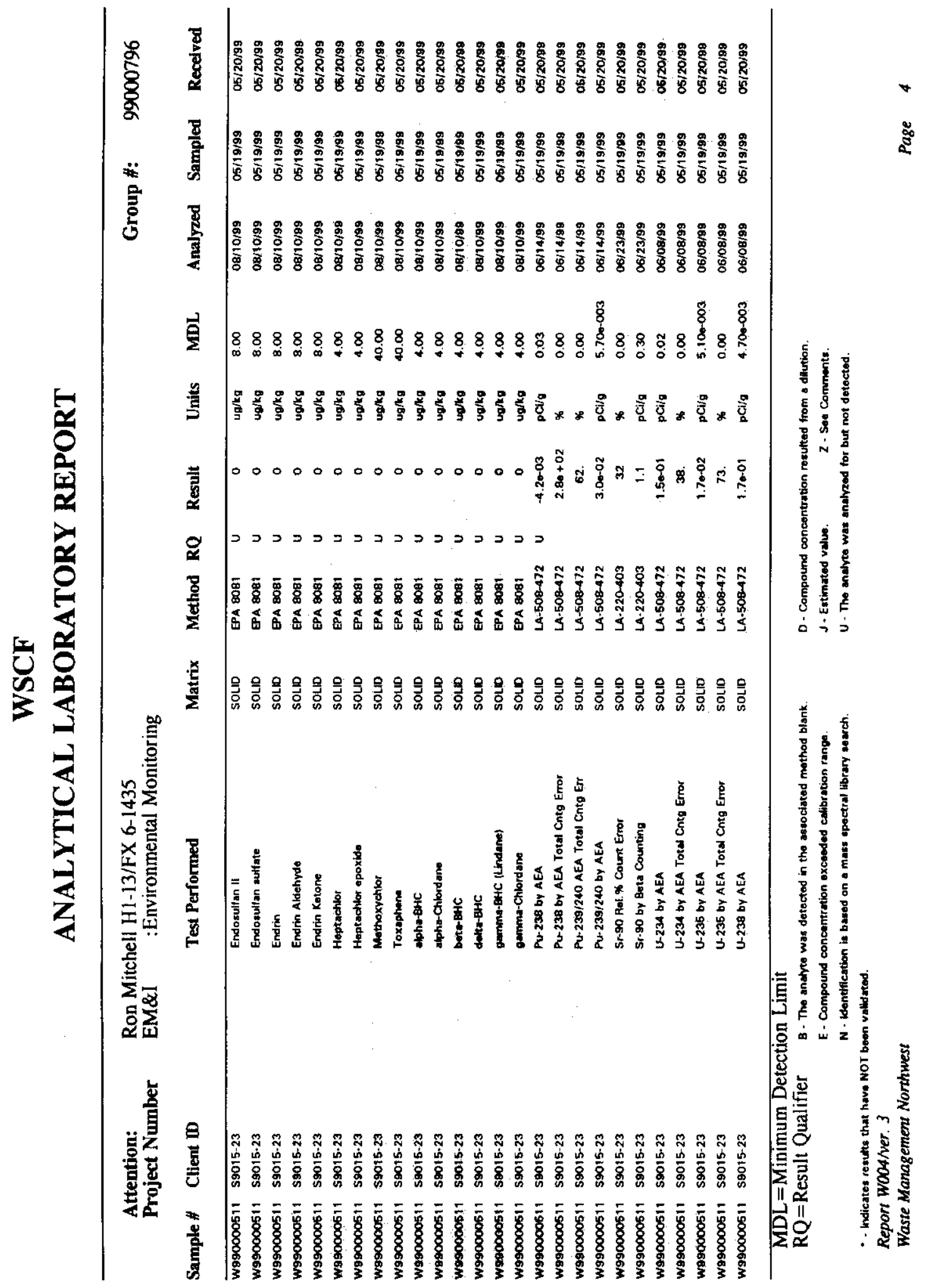


HNF-6150 Rev 0

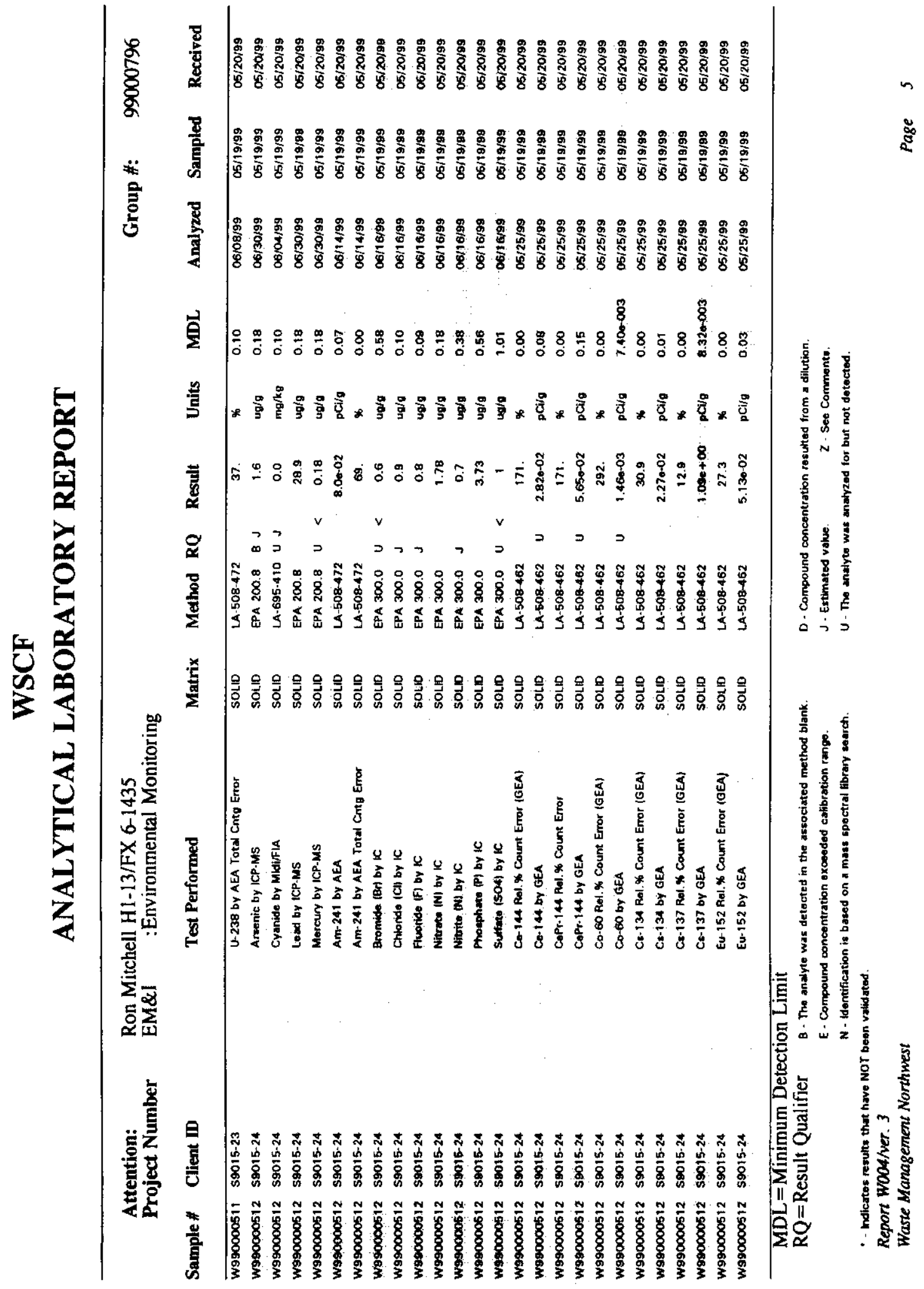


HNF-6150 Rev 0

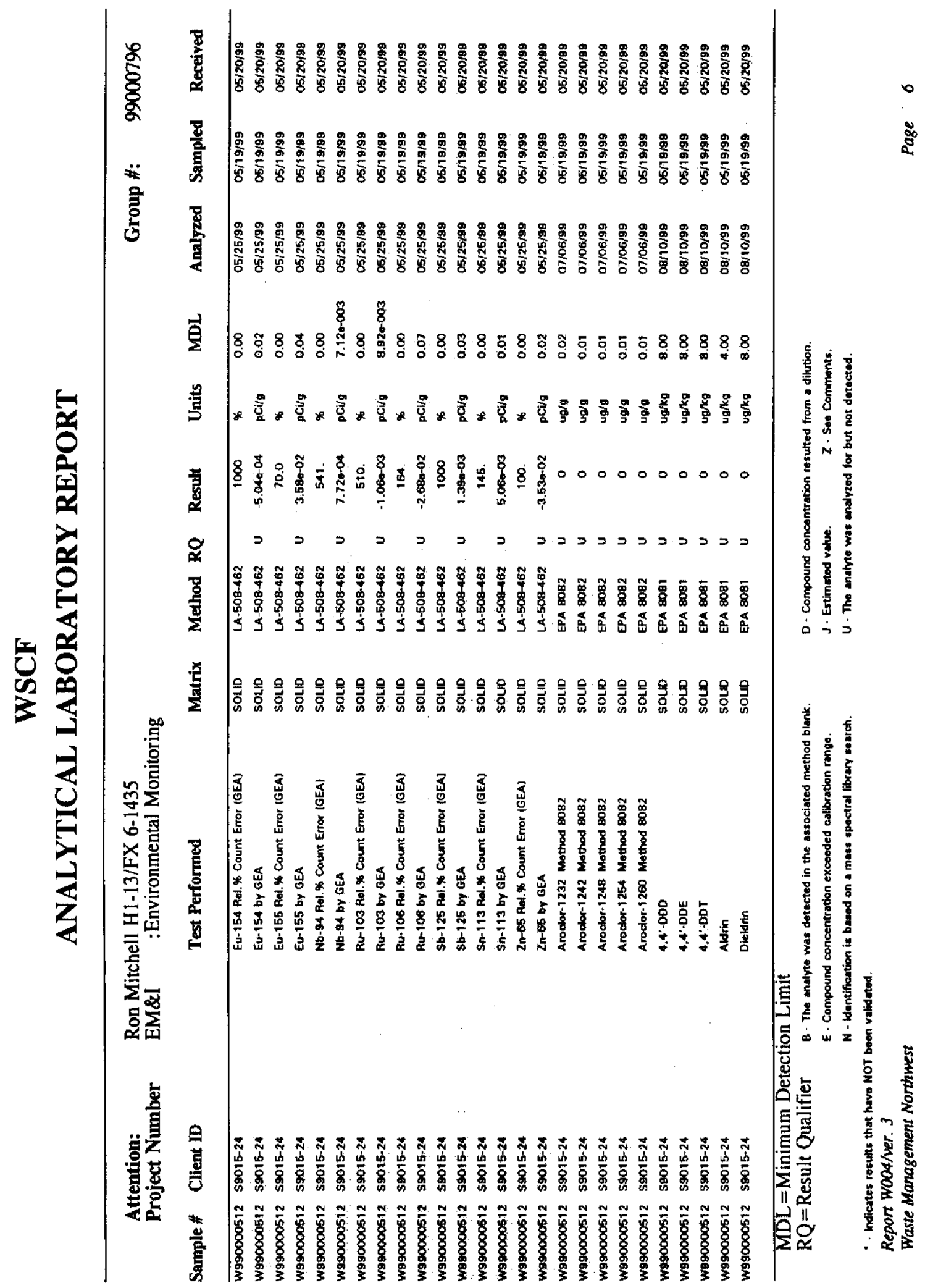


HNF-6150 Rev 0

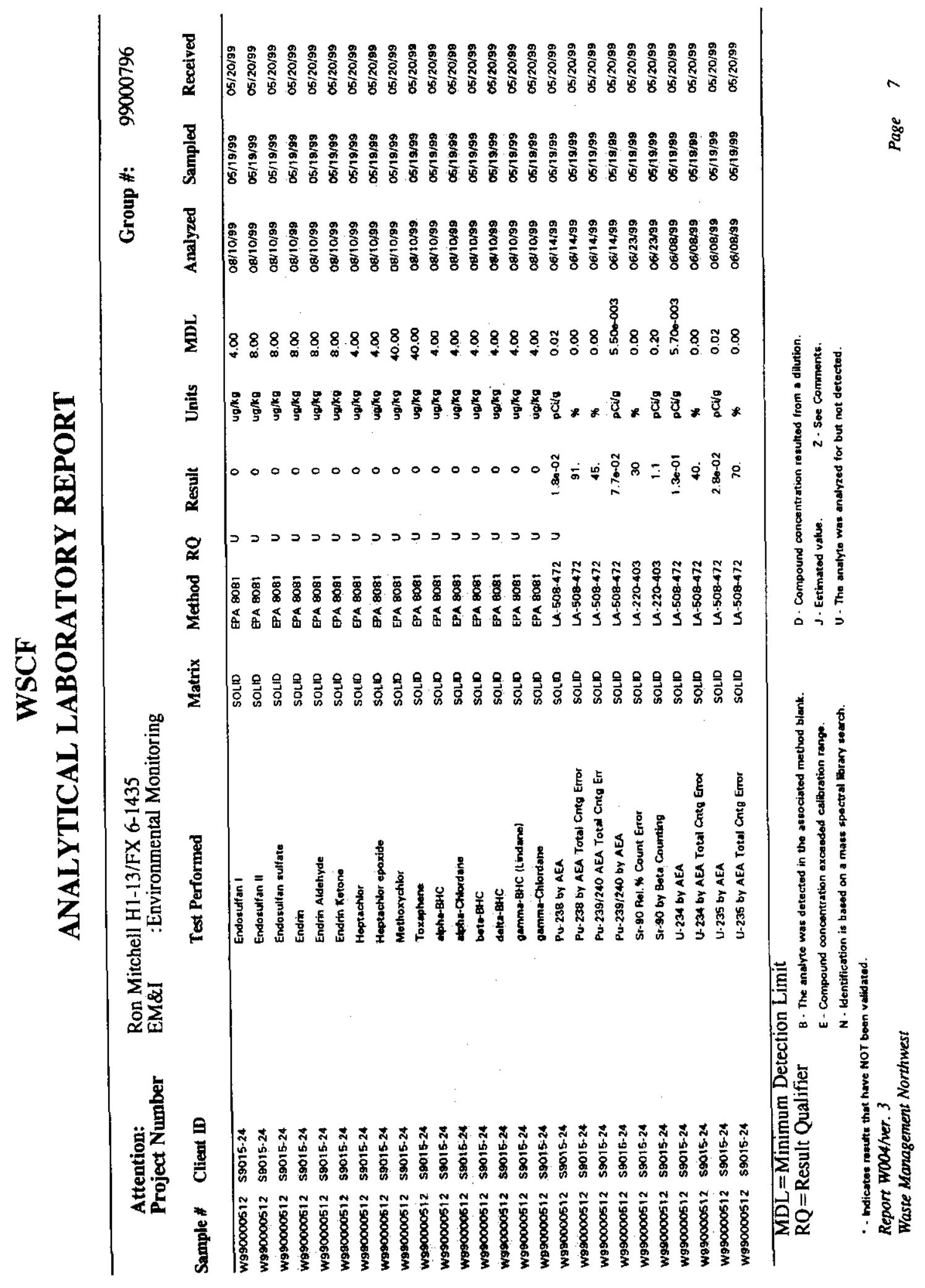


HNF-6150 Rev 0

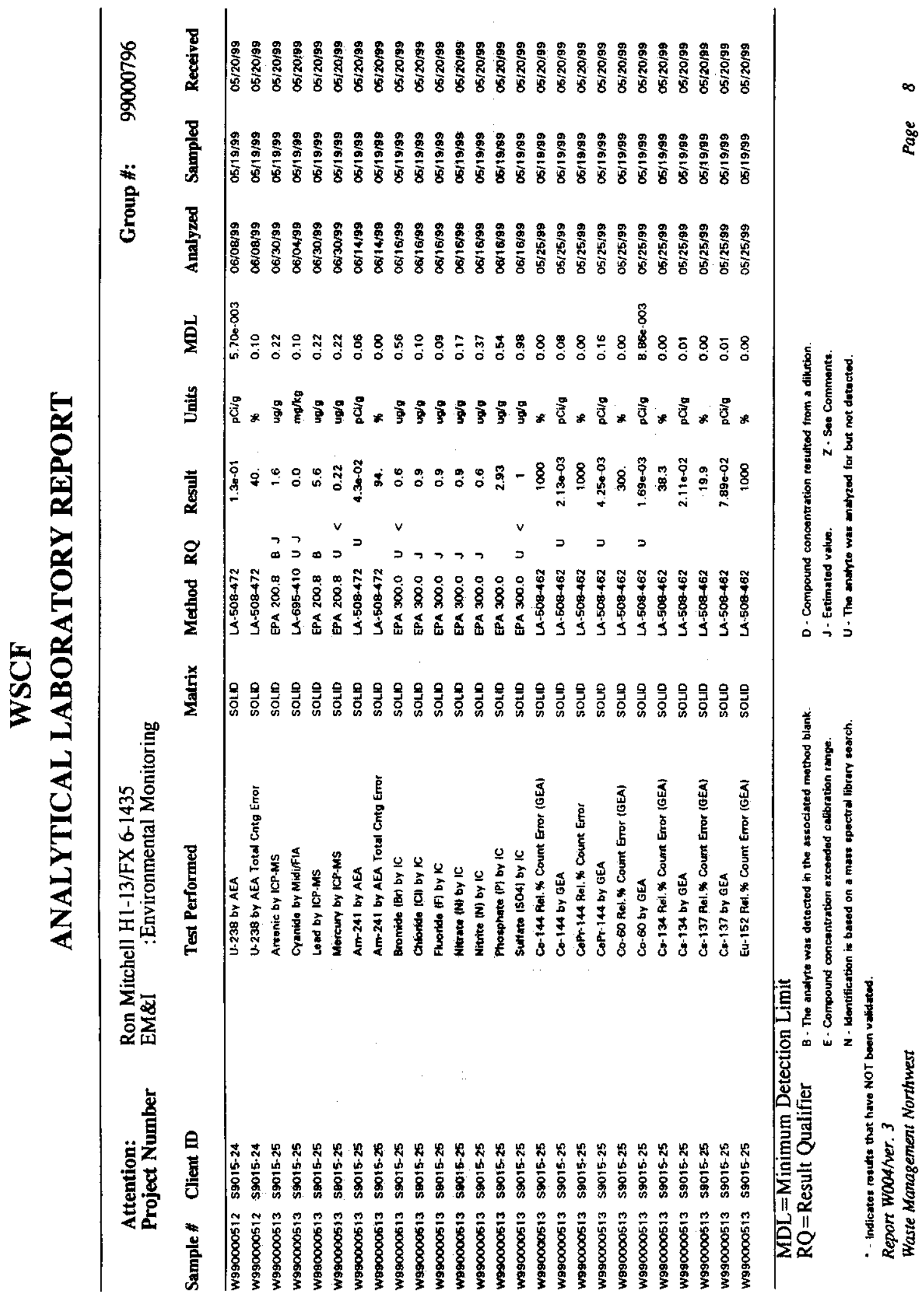


HNF-6150 Rev 0

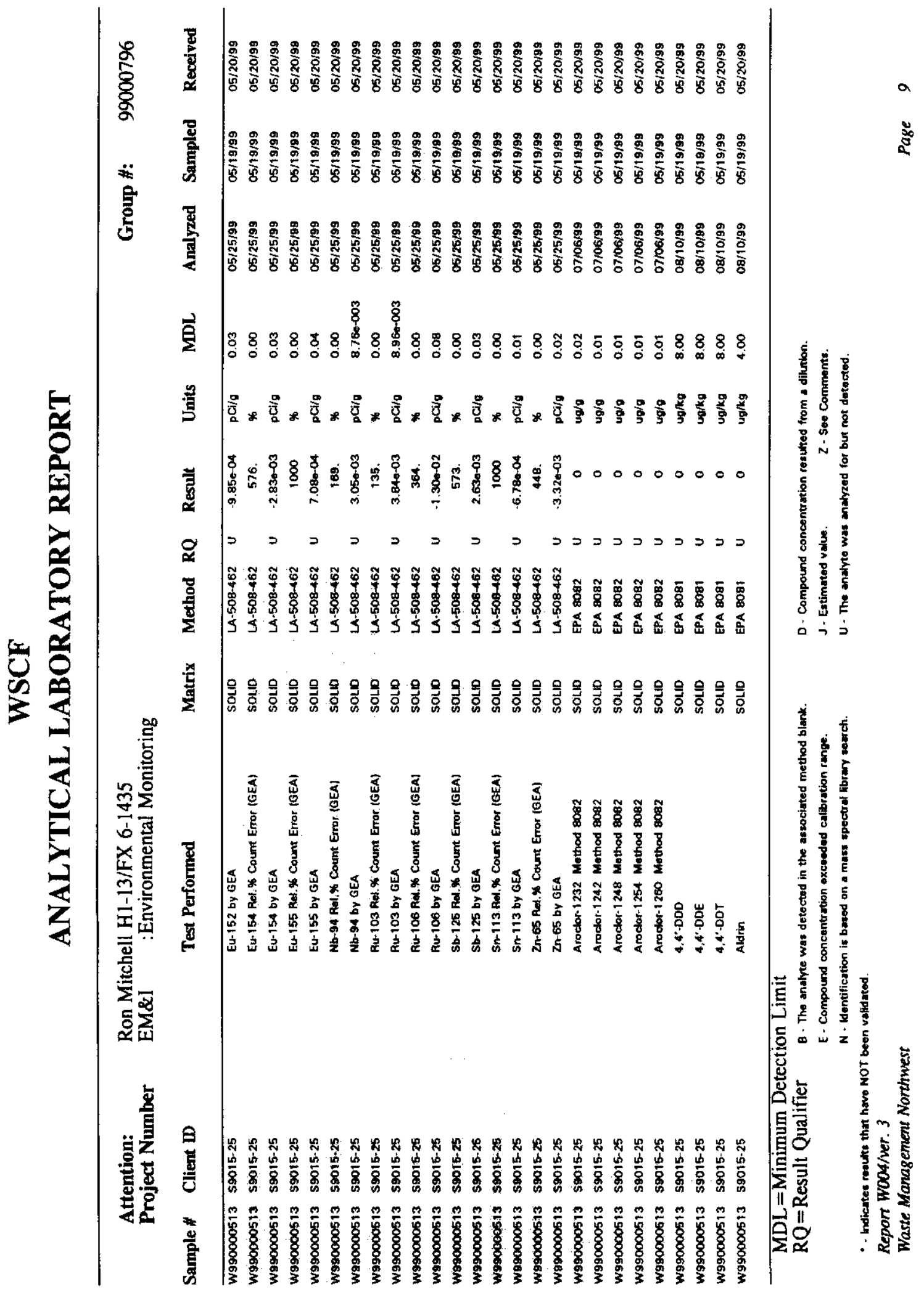


HNF-6150 Rev 0

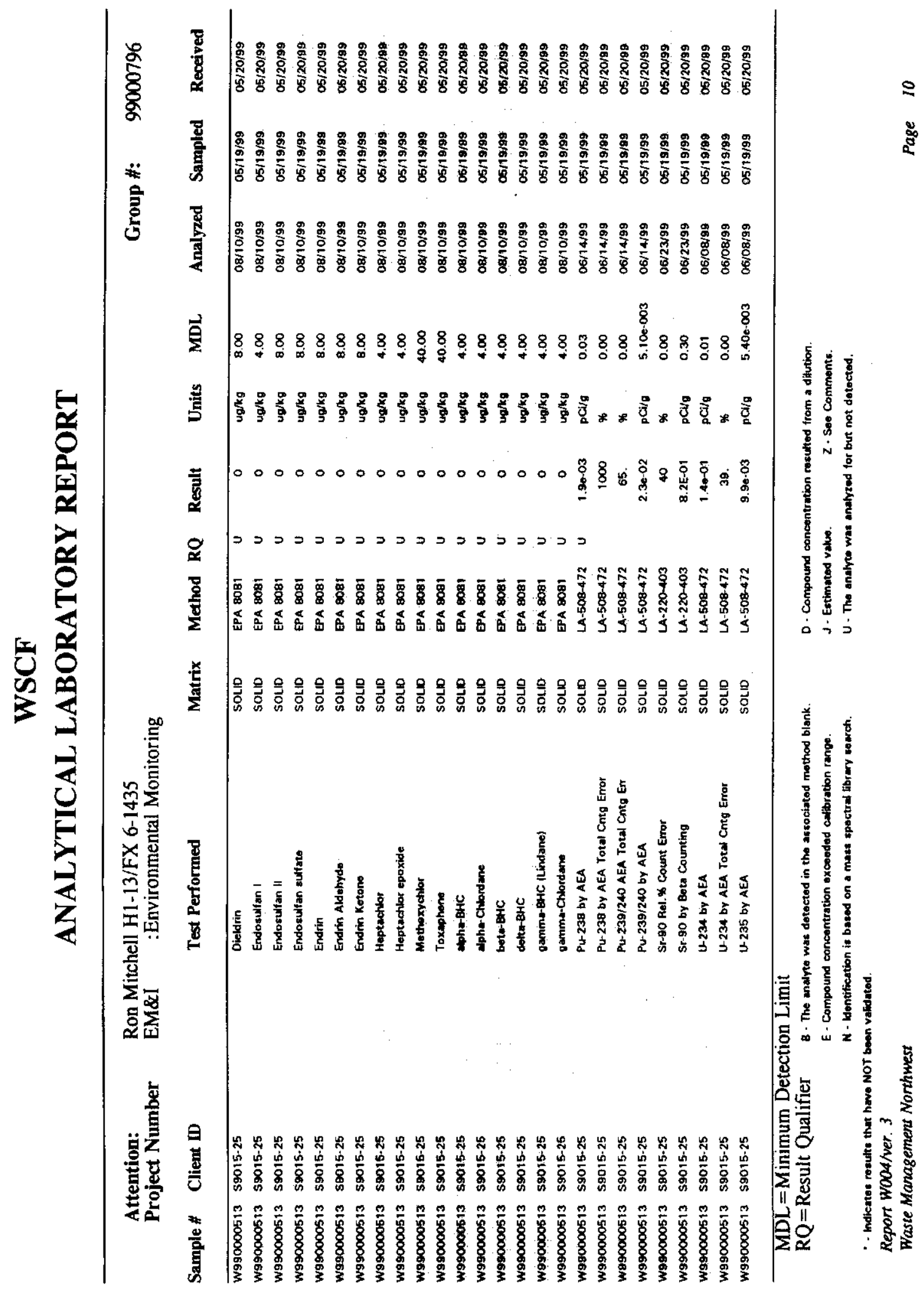


HNF-6150 Rev 0
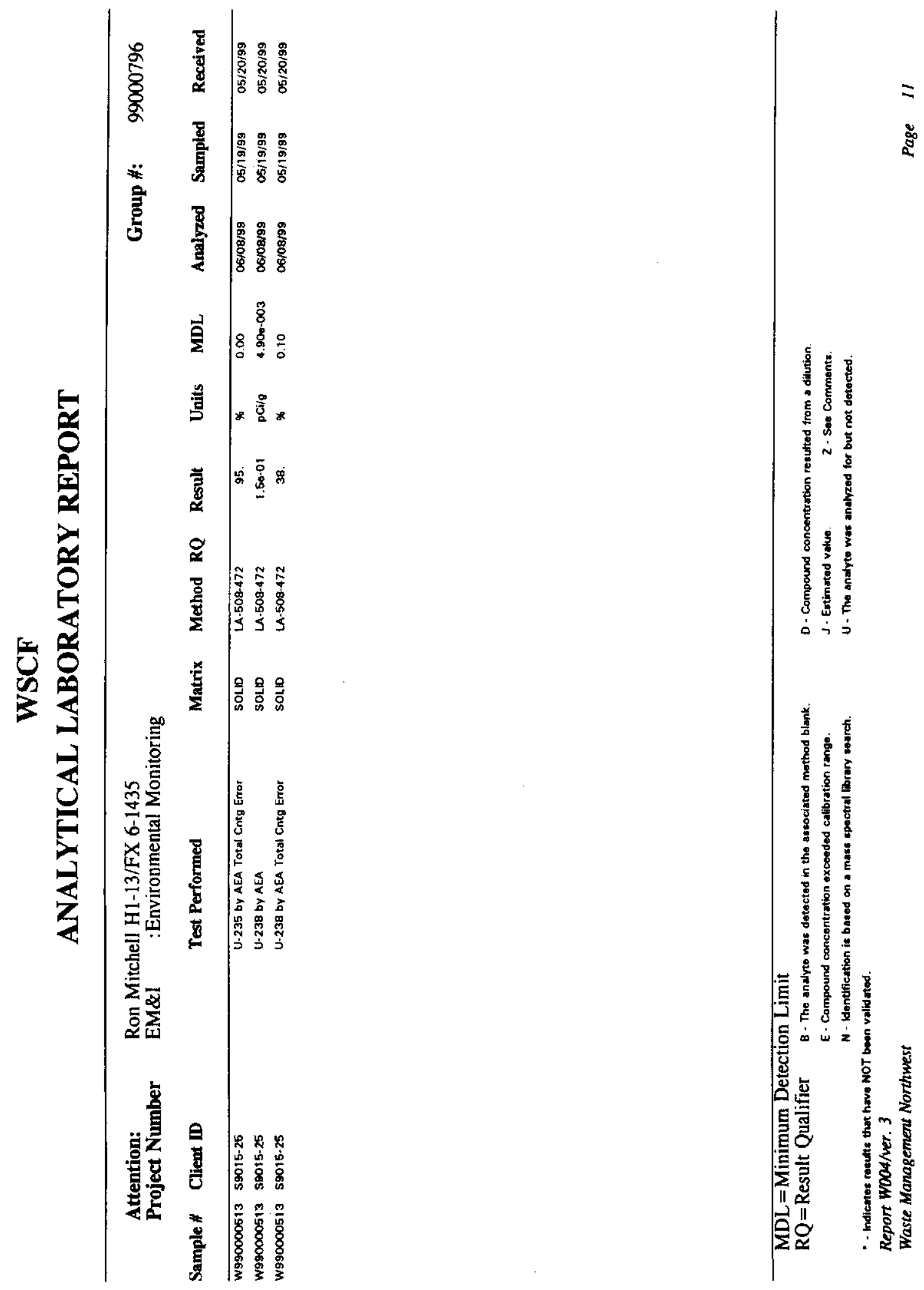
HNF-6150 Rev 0

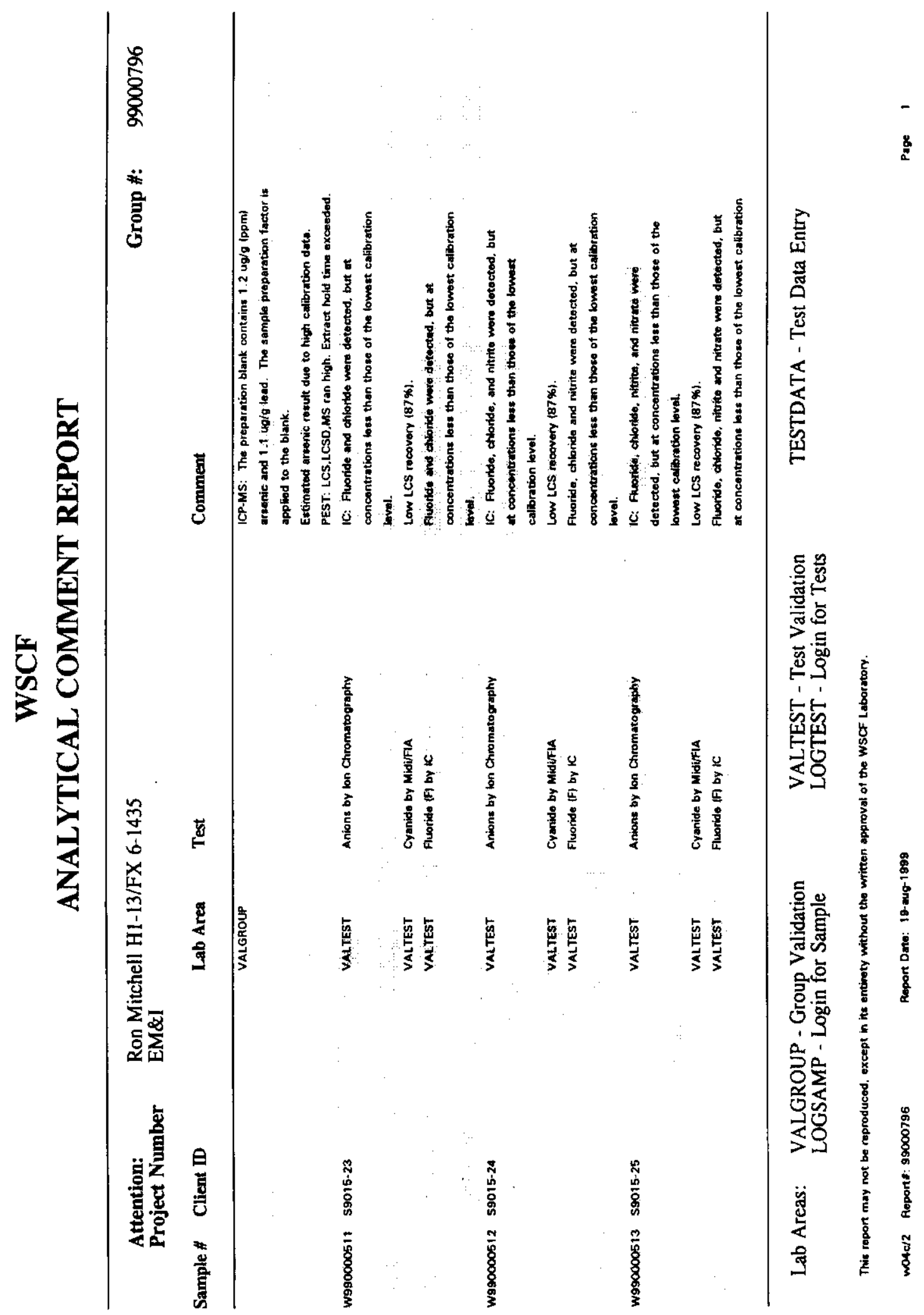


HNF-6150 Rev 0
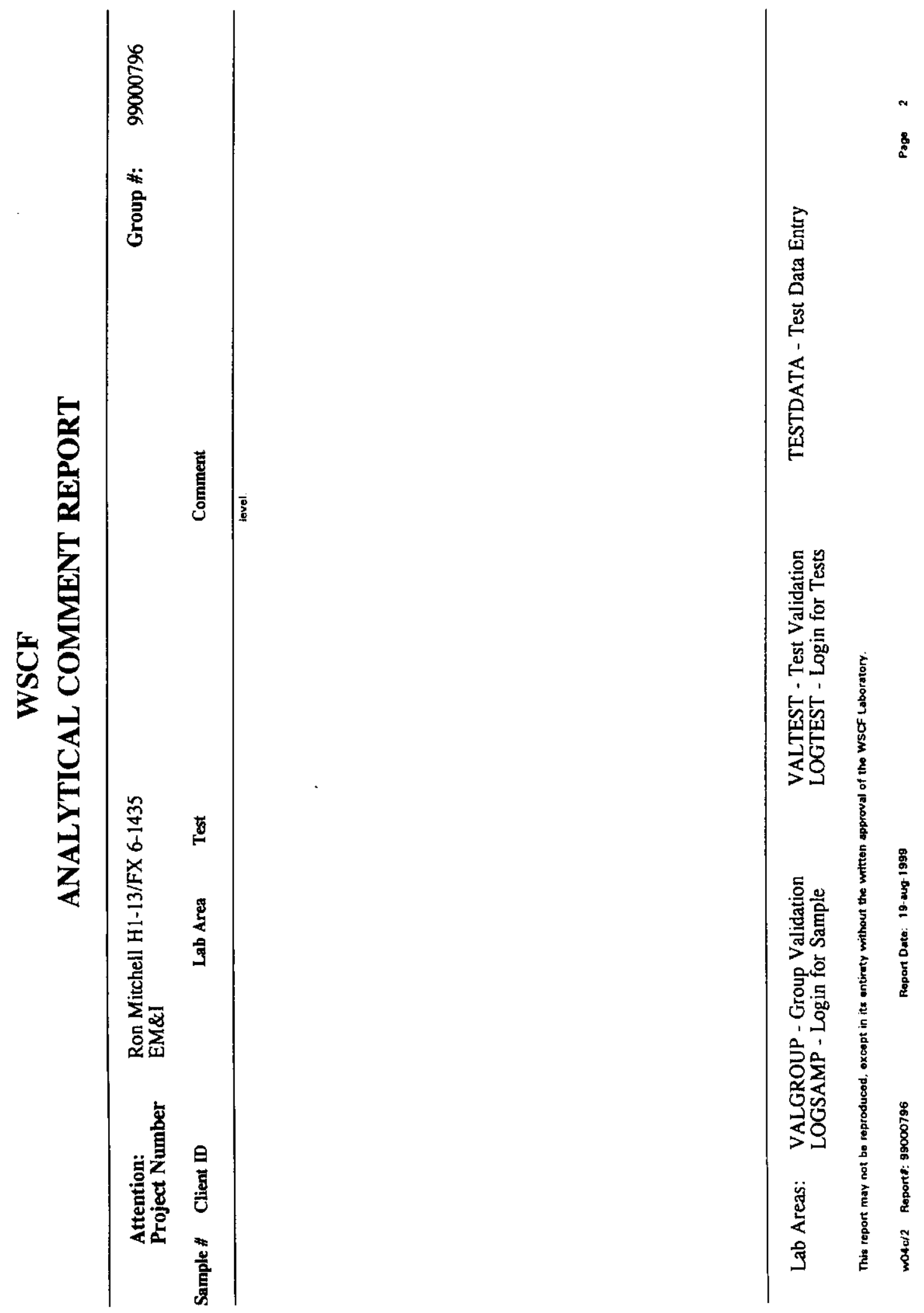
HNF-6150 Rev 0
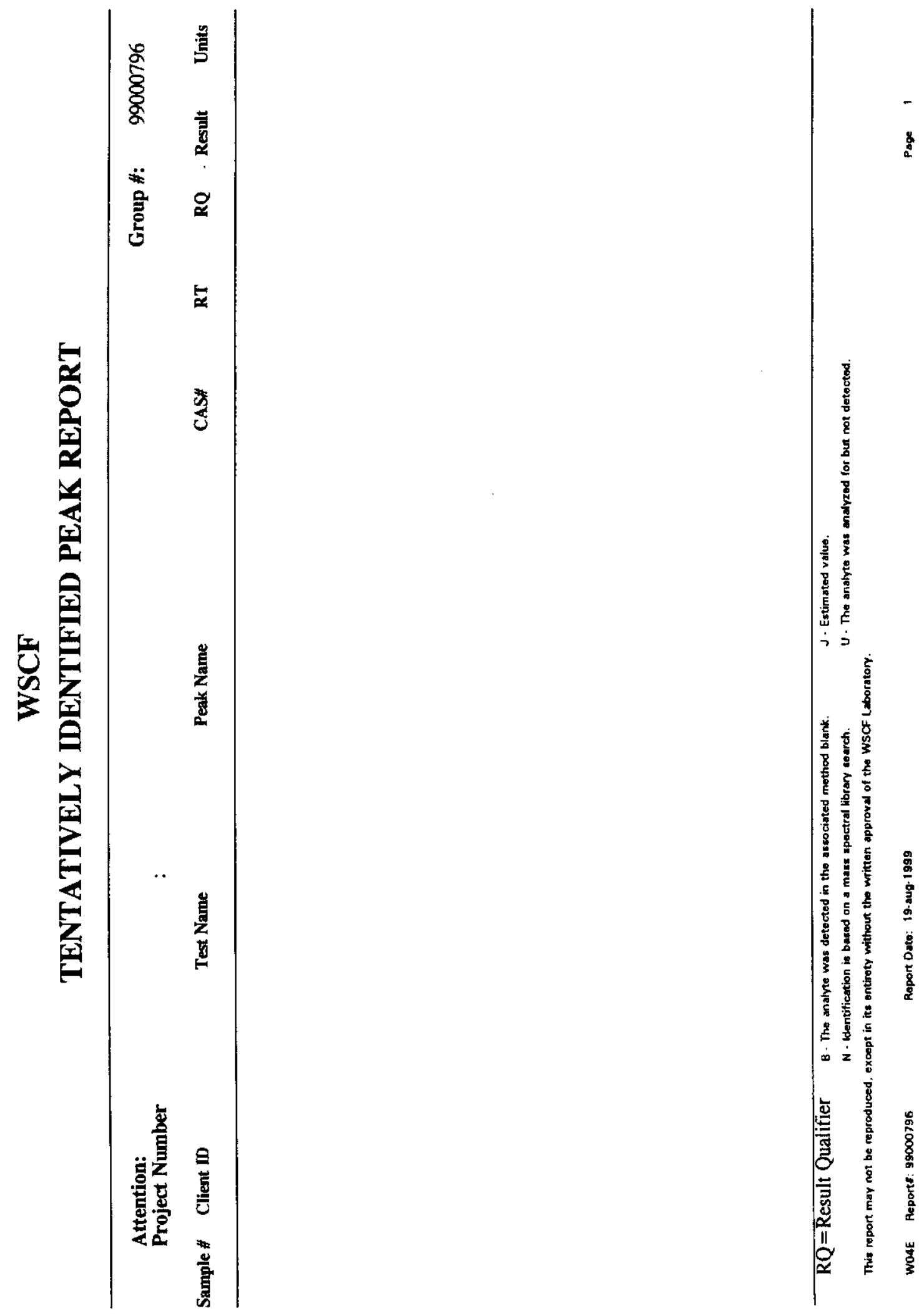
HNF-6150 Rev 0

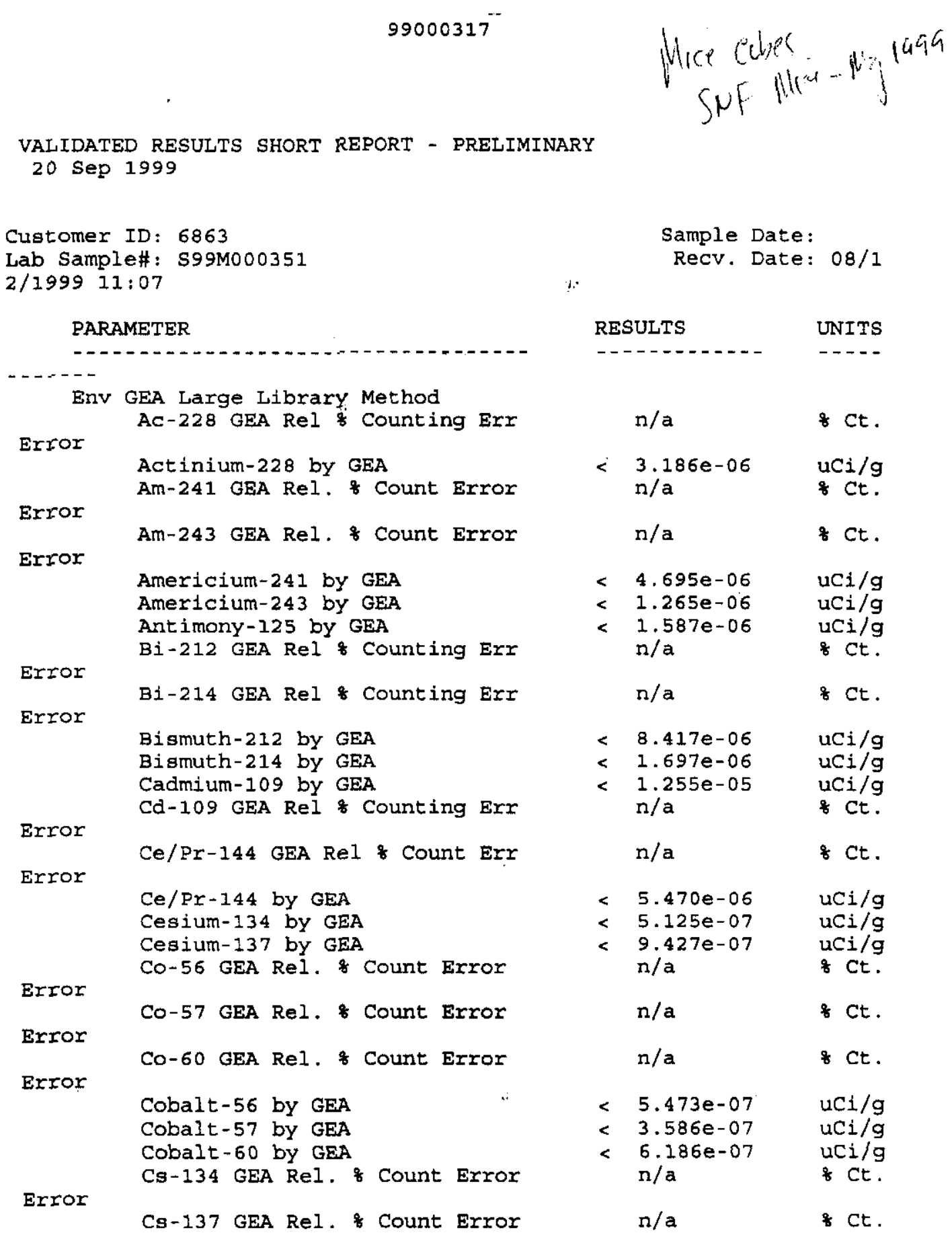

Page 1 


\section{HNF-6150 Rev 0}

99000317

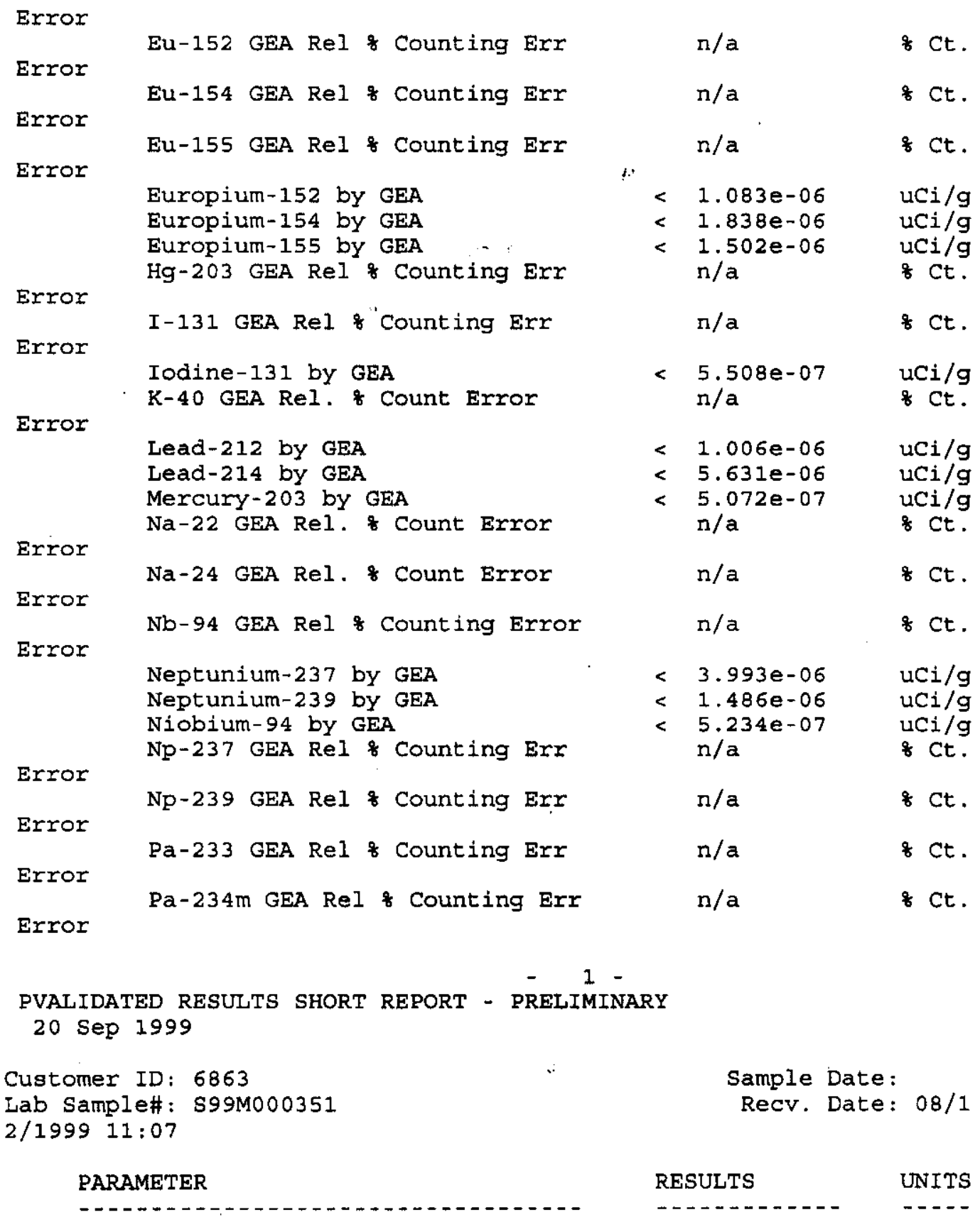

page 2 


\section{HNF-6150 Rev 0}

99000317

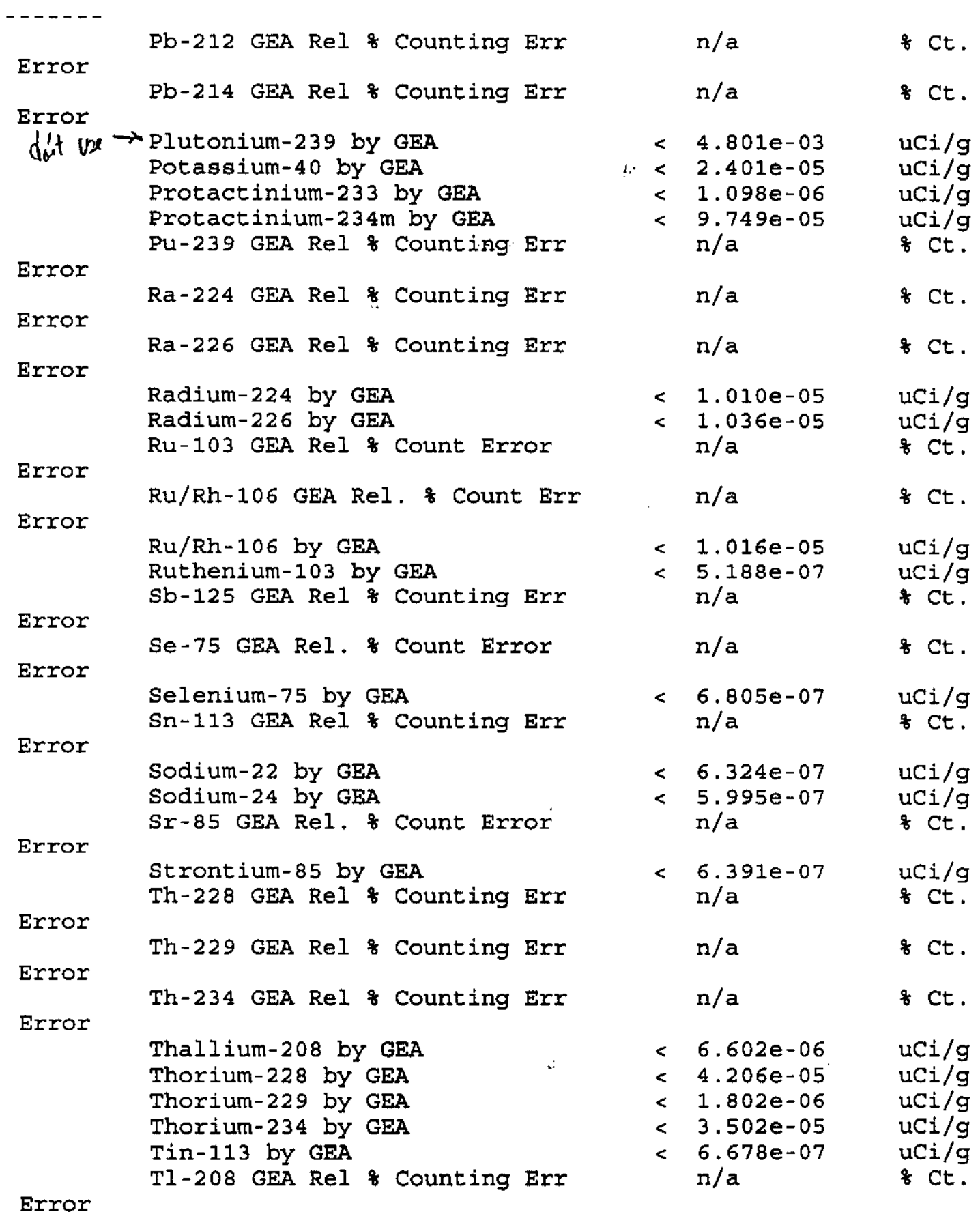

Page 3 
HNF-6150 Rev 0

99000317

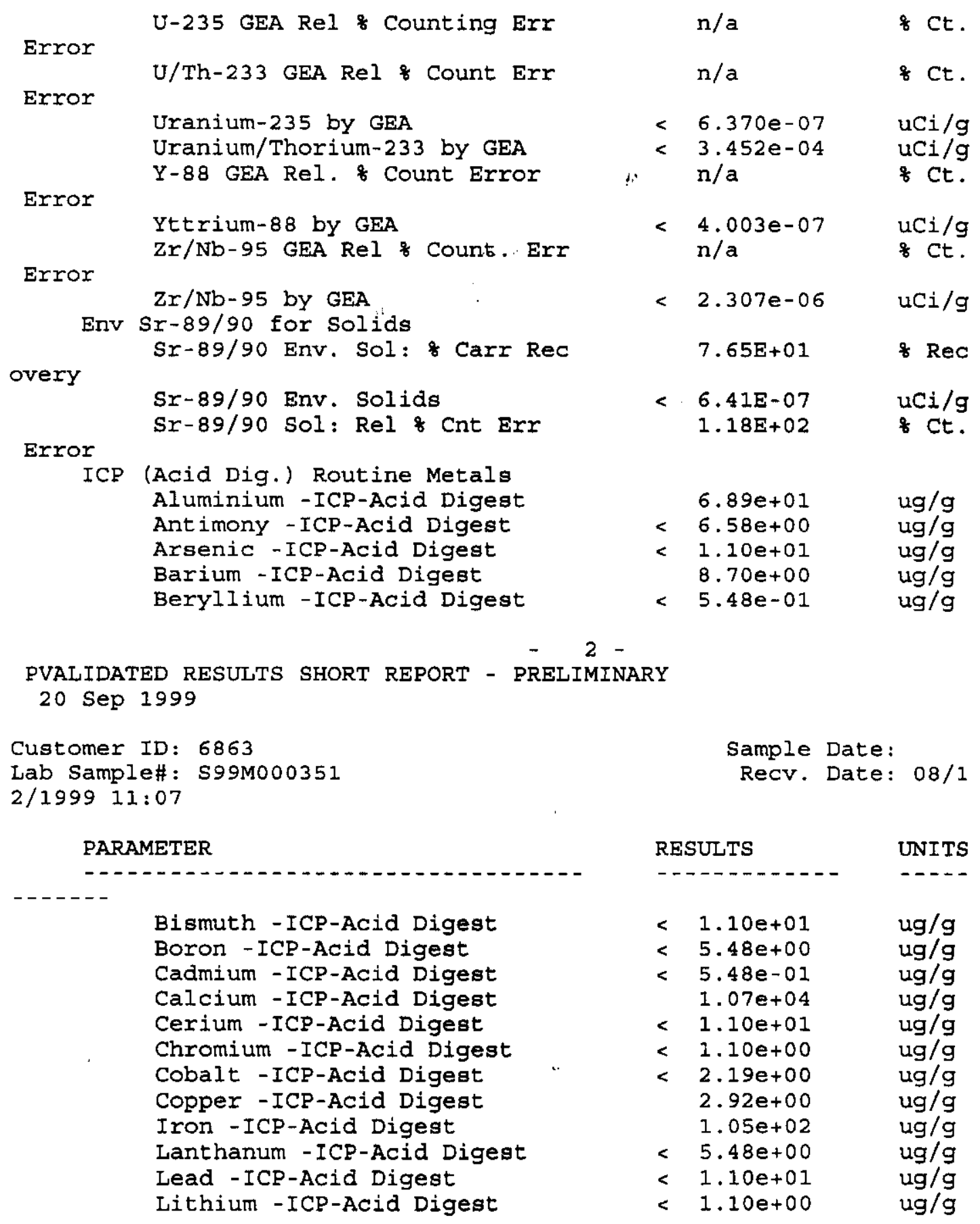

Page 4 
HNF-6150 Rev 0

99000317

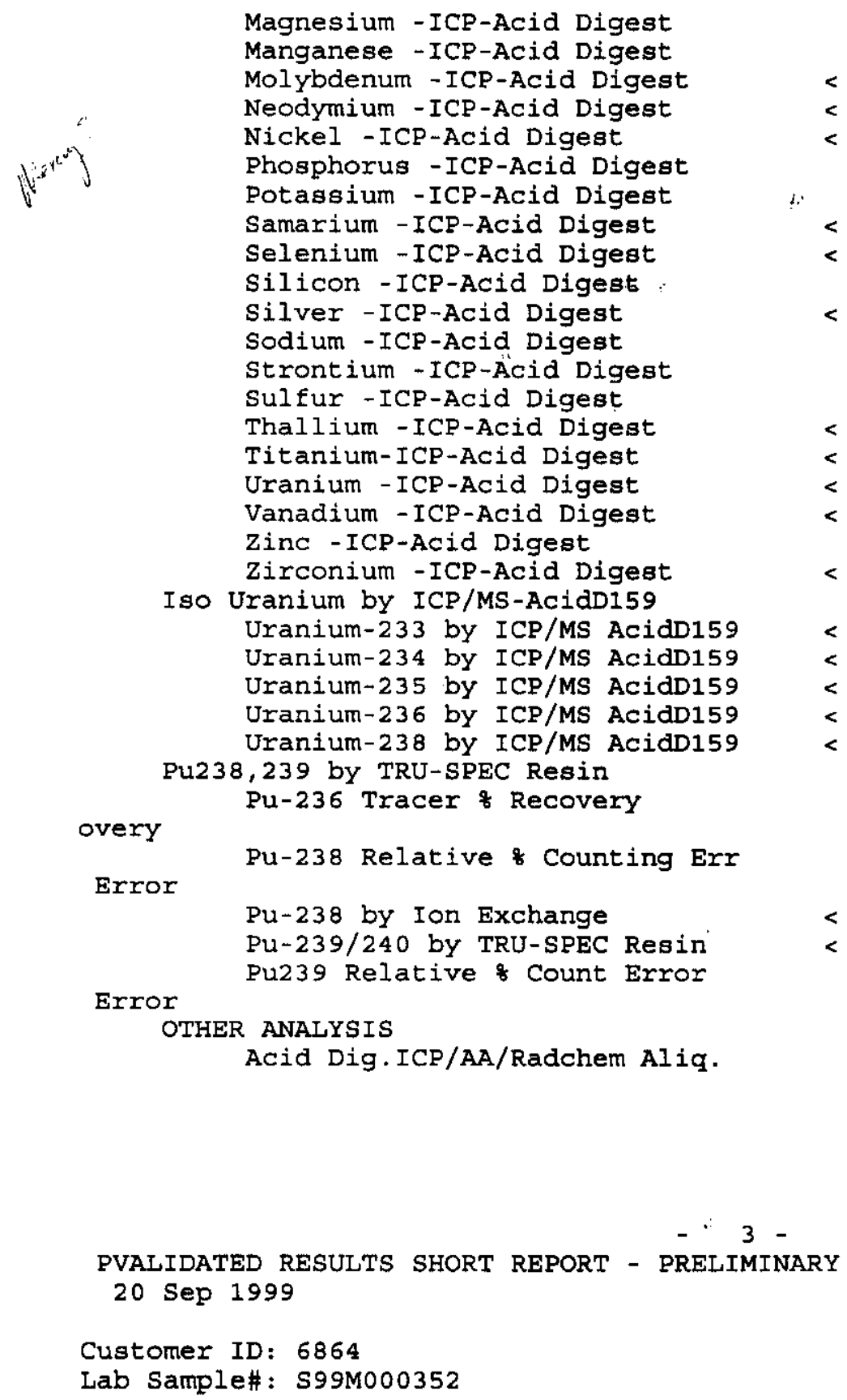

Magnesium - ICP-Acid Digest

Nickel -ICP-Acid Digest

Phosphorus -ICP-Acid Digest

otassium -ICP-Acid Digest

Silicon - ICP-Acid Digest

Silver -ICP-ACid Digest

Sodium -ICP-Acid Digest

Sulfur - ICP-Acid Digest

Thallium -ICP-Acid Digest

Titanium-ICP-Acid Digest

Uranium - ICP-Acid Digest

anadium - ICP-Acid Digest

Zinc - ICP-ACid Digest

Zirconium -ICP-Acid Digest

Uranium-233 by ICP/MS AcidD159

Uranium-234 by ICP/MS AcidD159

Uranium -235 by ICP/MS AcidD15

Uranium-236 by ICP/MS AcidD159

ium-238 by ICP/MS AcidD159

239 by TRU-SPEC Resin

Pu-238 Relative \& Counting Err

Pu-238 by Ion Exchange

Pu-239/240 by TRU-SPEC Resin

Pu239 Relative \& Count Error

OTHER ANALYSIS

Acid Dig. ICP/AA/Radchem Aliq.
$4.70 e+02$

$3.42 e+00$

$<5.48 e+00$

$<\quad 1.10 e+01$

$<2.19 e+00$

$7.95 e+03$

$\therefore \quad 3.06 e+03$

$<1.10 e+01$

$<1.10 e+01$

$9.12 e+00$

$<\quad 1.10 \mathrm{e}+00$

$1.65 e+03$

$5.35 e+00$

$1.43 e+03$

$<2.19 e+01$

$<\quad 1.10 e+00$

$<5.48 e+01$

< $5.48 \mathrm{e}+00$

$7.80 e+01$

$<1.10 e+00$

$<\quad 1.928 e-02$

$<\quad 1.928 e-02$

$<\quad 1.928 e-02$

$<2.571 e-02$

$<\quad 1.928 e-02$

$9.34 \mathrm{E}+01$

1. $00 \mathrm{E}+02$

< 2.04E-07

< 2.04E-07

1. $00 \mathrm{E}+02$

374.0 $\mathrm{g} / \mathrm{L}$

$u g / g$
$u g / g$
$u g / g$
$u g / g$
$u g / g$
$u g / g$
$u g / g$
$u g / g$
$u g / g$
$u g / g$
$u g / g$
$u g / g$
$u g / g$
$u g / g$
$u g / g$
$u g / g$
$u g / g$
$u g / g$
$u g / g$
$u g / g$

$\mathrm{ug} / \mathrm{g}$

$\mathrm{ug} / \mathrm{g}$

$\mathrm{ug} / \mathrm{g}$

$\mathrm{ug} / \mathrm{g}$

$\mathrm{ug} / \mathrm{g}$

$\mathrm{ug} / \mathrm{g}$

$\mathrm{ug} / \mathrm{g}$

$\mathrm{ug} / \mathrm{g}$

$\mathrm{ug} / \mathrm{g}$

$\mathrm{ug} / \mathrm{g}$

$\mathrm{ug} / \mathrm{g}$

$u g / g$

$\mathrm{ug} / \mathrm{g}$

$\mathrm{g} / \mathrm{g}$

$\mathrm{g} / \mathrm{g}$

$g / g$

$\mathrm{g} / \mathrm{g}$

$9 / 9$

Rec

Ct.

$\mathrm{Ci} / \mathrm{g}$

$\mathrm{Ci} / \mathrm{g}$

ct.

\author{
Sample Date: \\ Recv. Date: 08/1
}

Page 5 
HNF-6150 Rev 0

99000317

2/1999 11:07

PARAMETER

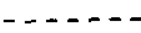

Customex ID: 6864

Lab Sample\#: S99M000352

2/1999 11:07

PARAMETER

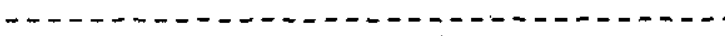

EnV GEA Large Library Method Ac-228 GEA Rel oounting Err Error Actinium-228 by GEA

Am-24I GEA Rel. Count Error

Error

Am-243 GEA Rel. * Count Error

Error

Americium-24I by GEA

Americium-243 by GEA

Antimony -125 by GEA

$\mathrm{Bi}-212$ GEA Rel $\%$ Counting Err

Error

Bi-214 GEA Rel Counting Err

Error

Bismuth-212 by GEA

Bismuth-214 by GEA

Cadmium-109 bY GEA

Cd-109 GEA Rel \& Counting Err

Error

Error

Error

Ce/Pr-144 GEA Rel \& Count Err

Ce/Pr-144 by GEA

Cesium-134 by GEA

Cesium-137 by GEA

Co-56 GEA Rel. \& Count Error

Error

Co-57 GEA Rel. \& Count Error

Error

Co-60 GEA Rel. \% Count Error

Cobalt-56 by GEA

Cobalt -57 by GEA

Cobalt -60 by GEA

Cs-134 GEA Re1. \& Count Exror
RESULTS UNITS

Sample Date:

Recv. Date: 08/1

\begin{tabular}{|c|c|c|}
\hline \multicolumn{2}{|c|}{ RESULTS } & UNITS \\
\hline & ------- & --- \\
\hline & $\mathrm{n} / \mathrm{a}$ & \& Ct. \\
\hline$<$ & $\begin{array}{l}3.735 e-06 \\
\mathrm{n} / \mathrm{a}\end{array}$ & $\begin{array}{l}u C i / g \\
\text { \& Ct. }\end{array}$ \\
\hline & $\mathrm{n} / \mathrm{a}$ & \& $\mathrm{Ct}$. \\
\hline < & $\begin{array}{l}5.653 e-06 \\
1.500 e-06 \\
1.855 e-06 \\
n / a\end{array}$ & $\begin{array}{l}u C i / g \\
u C i / g \\
u C i / g \\
\& \text { ct. }\end{array}$ \\
\hline & $\mathrm{n} / \mathrm{a}$ & $\& \mathrm{Ct}$ \\
\hline $\begin{array}{l}< \\
< \\
<\end{array}$ & $\begin{array}{l}1.030 e-05 \\
1.947 e-06 \\
1.503 e-05 \\
\pi / a\end{array}$ & $\begin{array}{l}u C i / g \\
u C i / g \\
u C i / g \\
\& \mathrm{Ct} .\end{array}$ \\
\hline & $n / a$ & $\Rightarrow \mathrm{Ct}$ \\
\hline$<$ & $\begin{array}{l}6.484 \mathrm{e}-06 \\
6.138 \mathrm{e}-07 \\
1.049 \mathrm{e}-06 \\
\mathrm{n} / \mathrm{a}\end{array}$ & $\begin{array}{l}u C i / g \\
u C i / g \\
u C i / g \\
\& \text { Ct. }\end{array}$ \\
\hline & $\mathrm{n} / \mathrm{a}$ & o Ct. \\
\hline & $n / a$ & $\approx \mathrm{Ct}$. \\
\hline$<$ & $\begin{array}{l}6.902 e-07 \\
4.327 e-07 \\
6.757 e-07 \\
\mathrm{n} / \mathrm{a}\end{array}$ & $\begin{array}{l}u C i / g \\
u C i / g \\
u C i / g \\
\& \text { Ct. }\end{array}$ \\
\hline
\end{tabular}

RESULTS

NITS

Ct.

$\mathrm{Ci} / \mathrm{g}$

$C t$.

uCi/g uCi/g uCi/g ter. Ct. $u C i / g$ $\mathrm{uCi} / \mathrm{g}$ $u C i / g$ - Ct. Ct. $\mathrm{Ci} / \mathrm{g}$ $\mathrm{Ci} / \mathrm{g}$ $\mathrm{aCi} / \mathrm{g}$ Ct. $\mathrm{uCi} / \mathrm{g}$ * $\mathrm{Ct}$.

Page 6 
HNF-6150 Rev 0

99000317

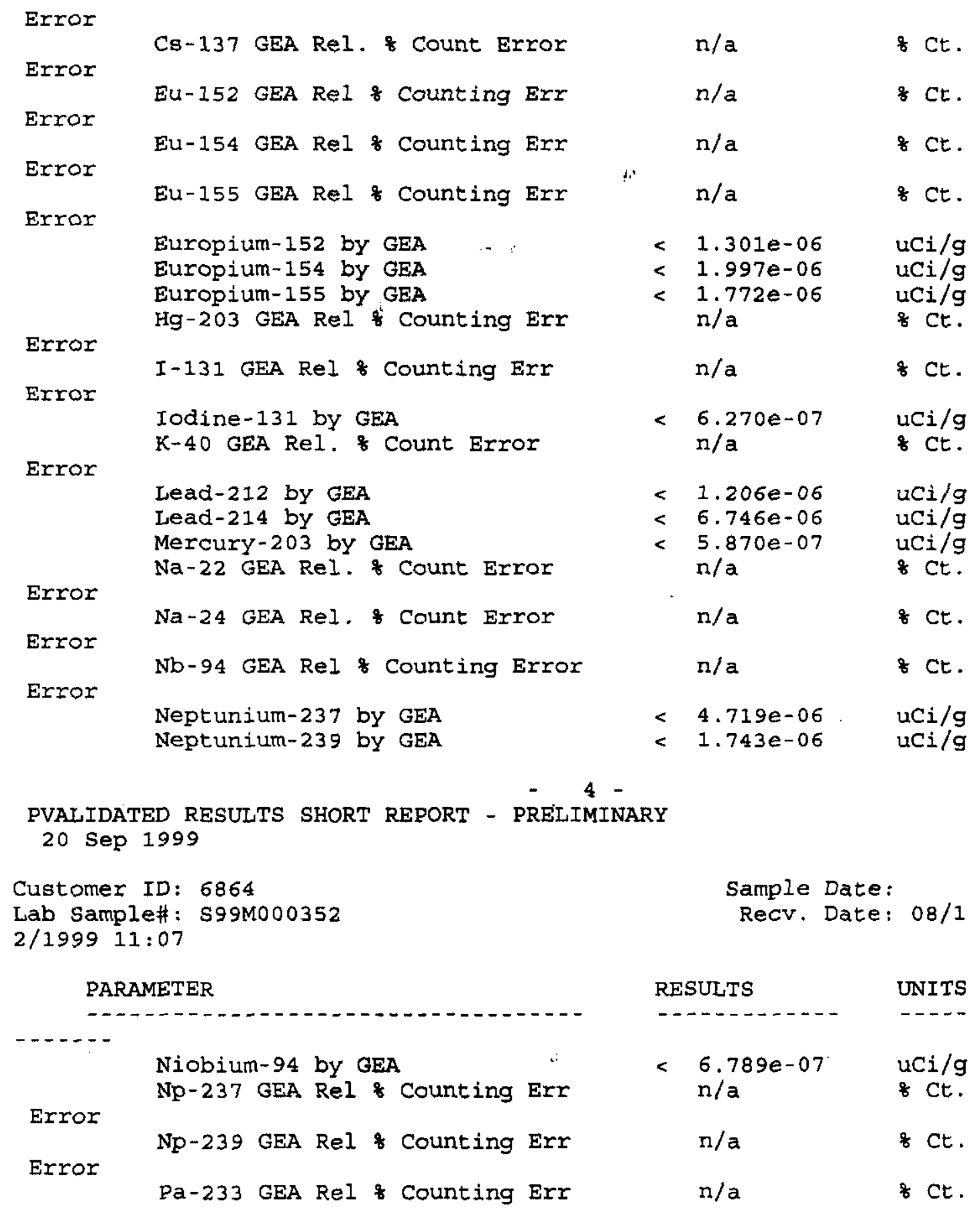

Page 7 
HNF-6150 Rev 0

99000317

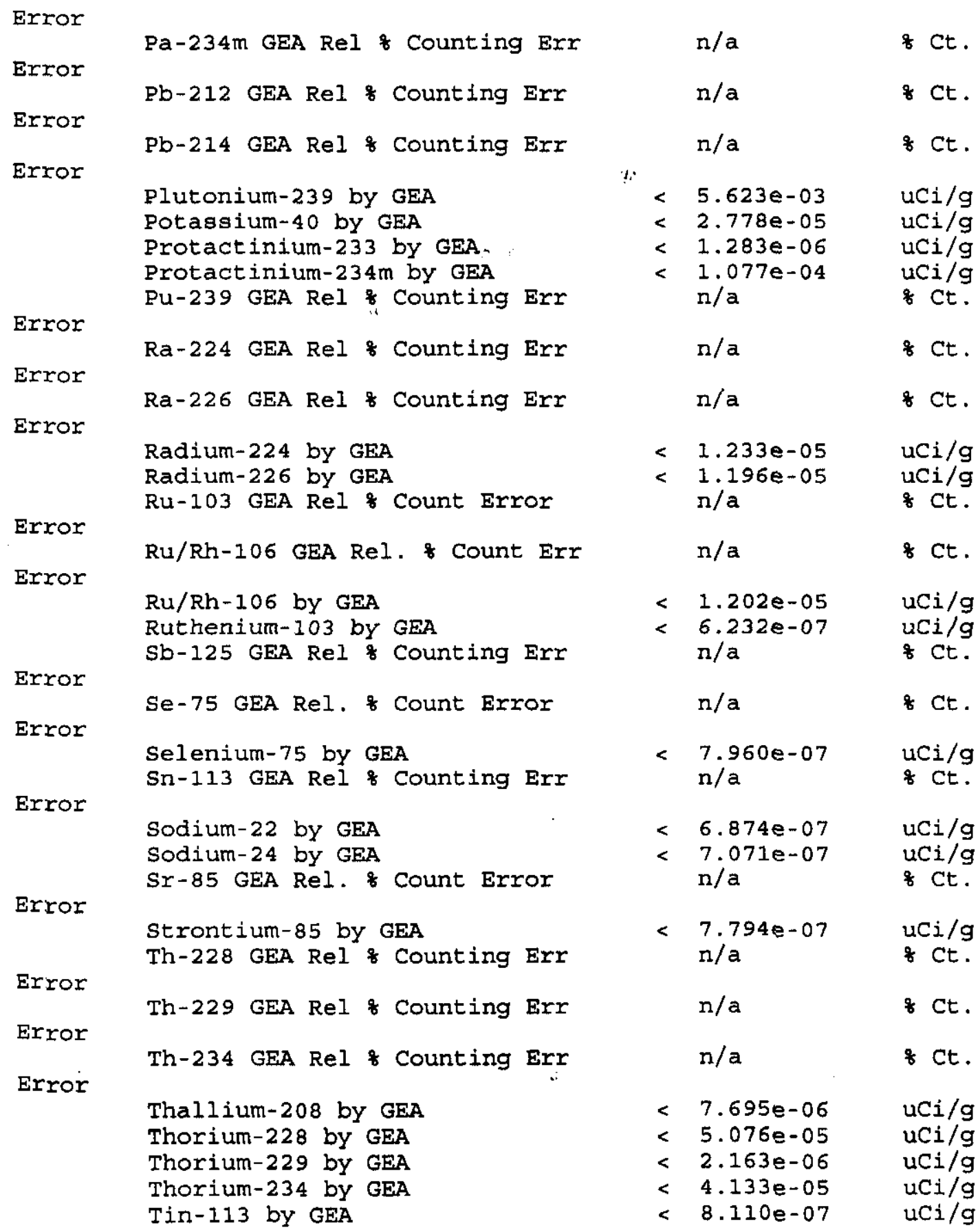

Page 8 


\section{HNF-6150 Rev 0}

99000317

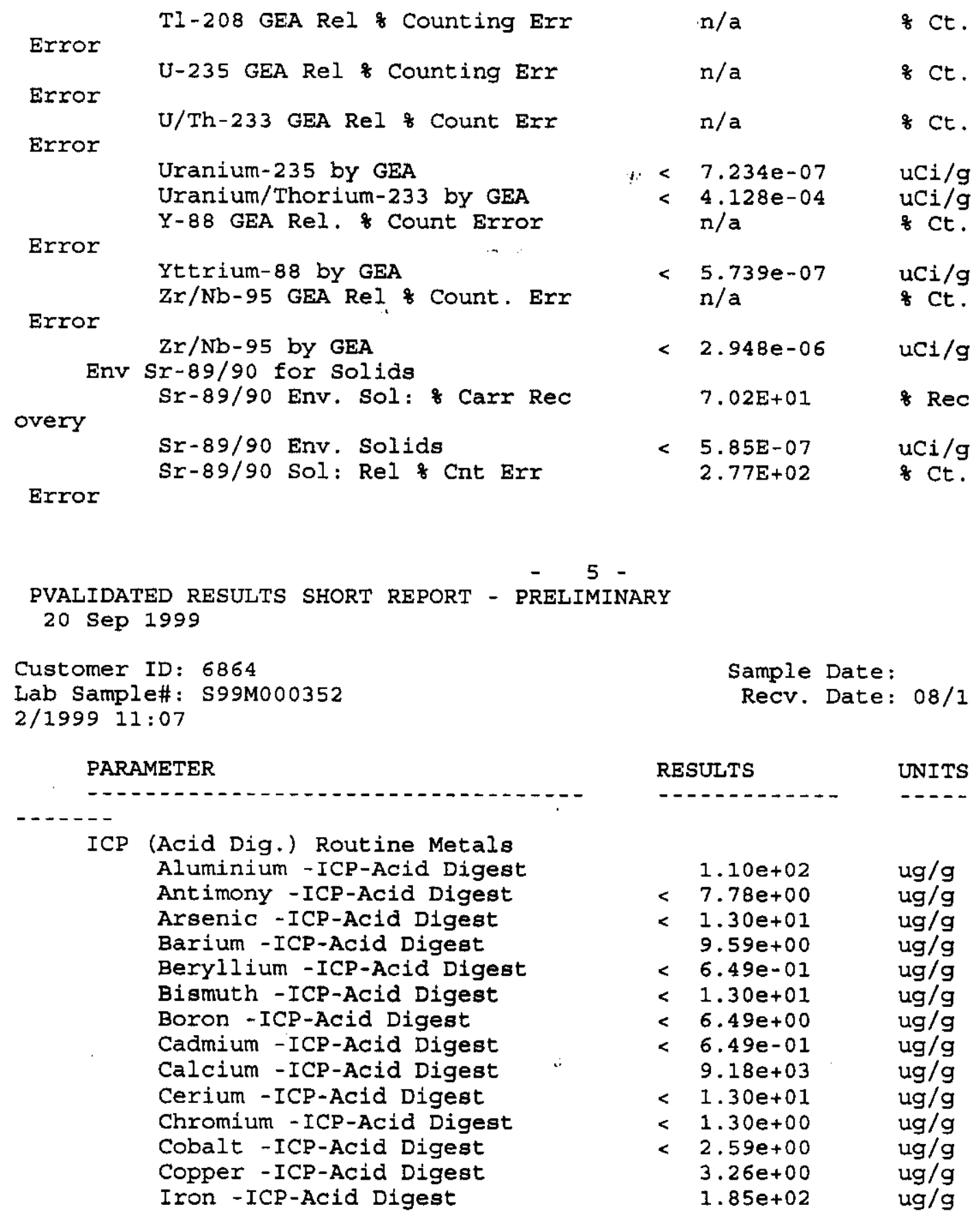

Page 9 
99000317

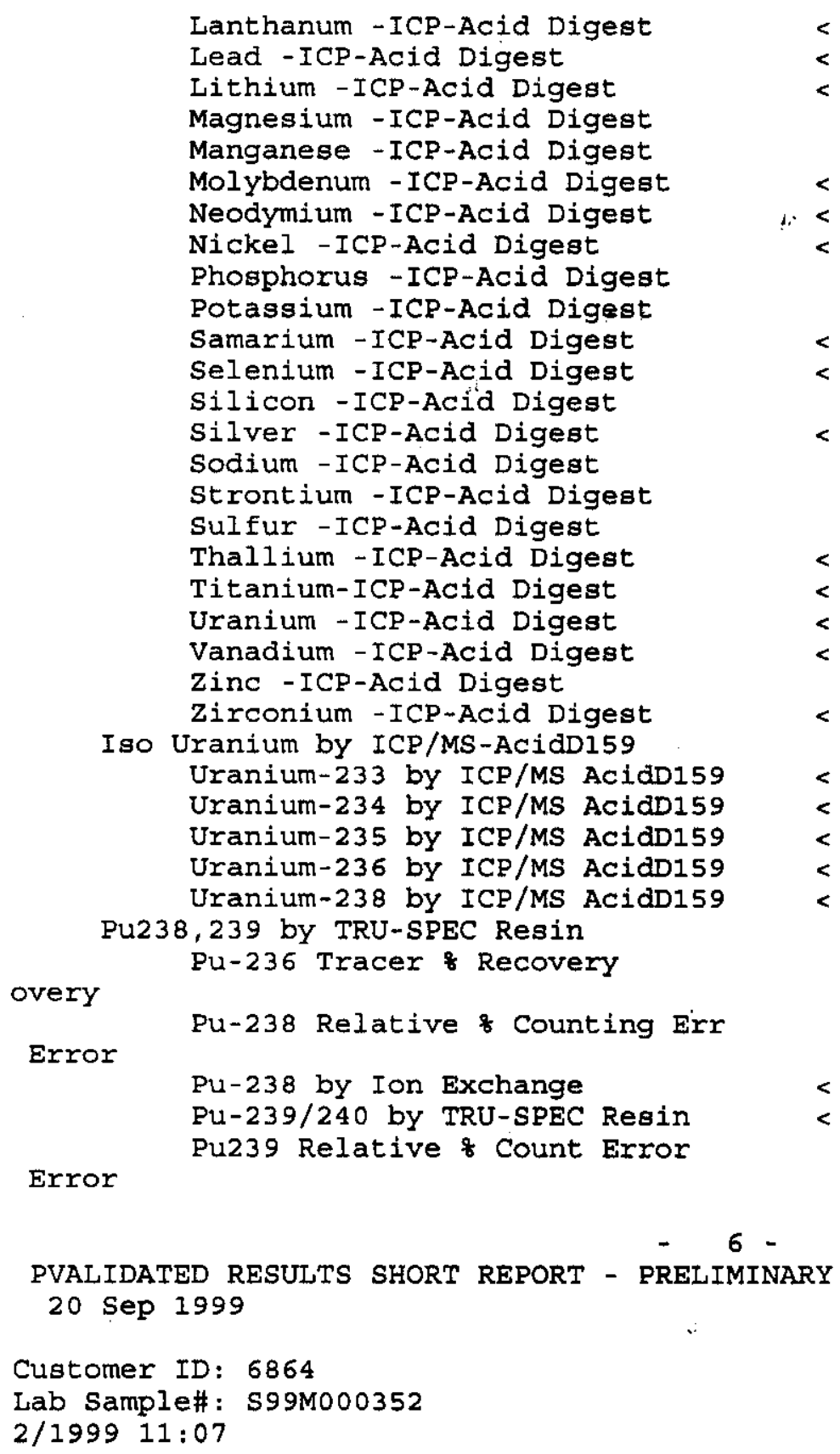

PARAMETER

Page 10 
HNF-6150 Rev 0

99000317

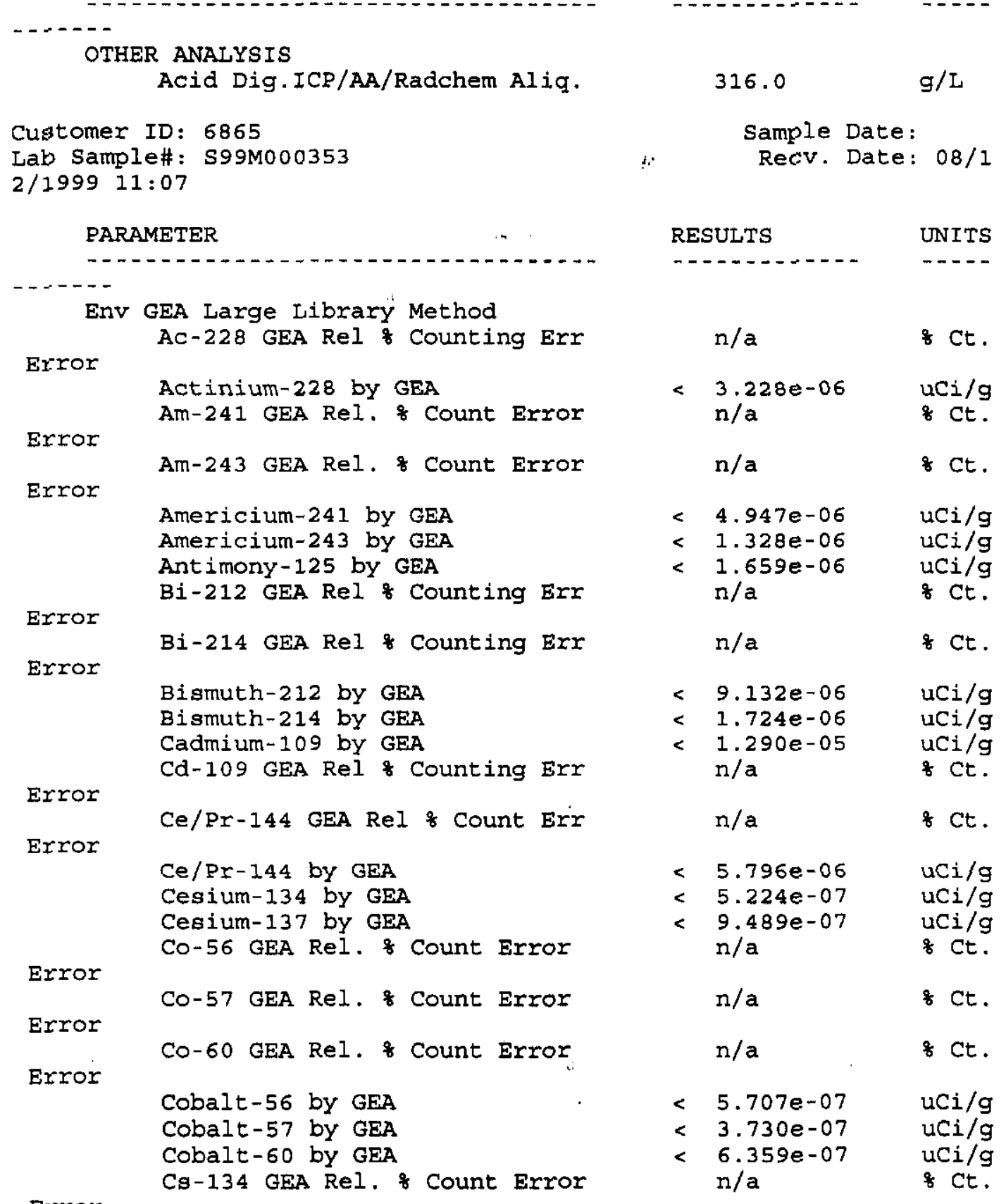

Page 11 


\section{HNF-6150 Rev 0}

$99000317^{--}$

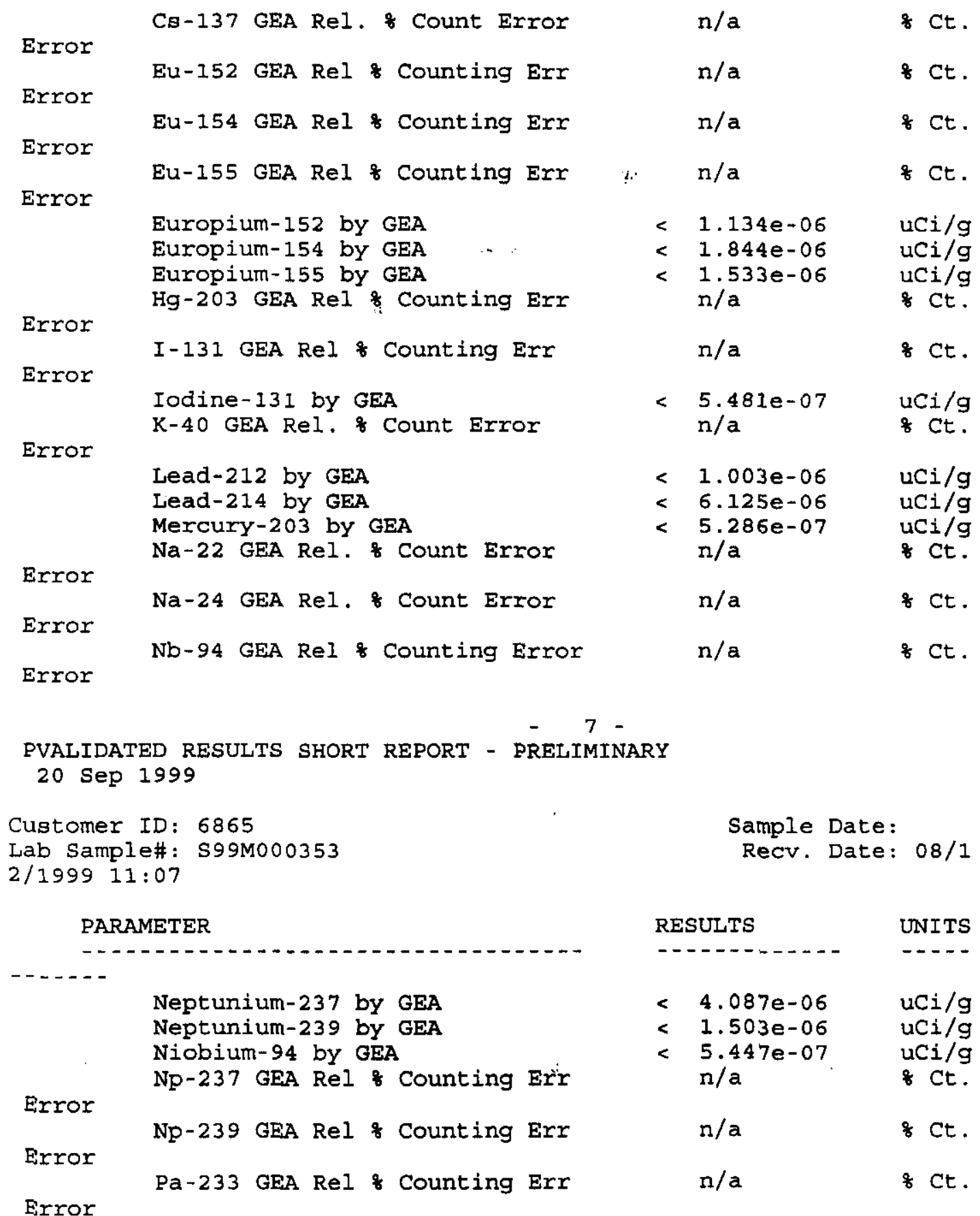

Page 12 


\section{HNF-6150 Rev 0}

99000317

\begin{tabular}{|c|c|}
\hline$-294 \mathrm{MI}$ GEA ket o COUnLING & $\mathrm{Pb}-212$ GEA Rel \& Counting $\mathrm{E}$ \\
\hline Error & $\mathrm{Pb}-214$ GEA Rel Counting Err \\
\hline Error & $\begin{array}{l}\text { Plutonium- } 239 \text { by GEA } \\
\text { Potassium- } 40 \text { by GEA } \\
\text { Protactinium-233 by GEA } \\
\text { Protactinium-234m by GEA } \\
\text { Pu-239 GEA Rel \& Counting Erx }\end{array}$ \\
\hline 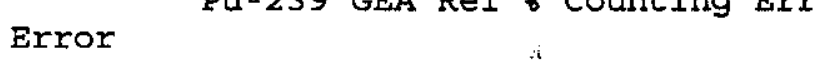 & 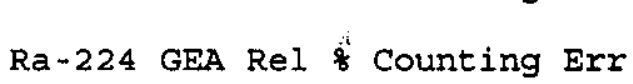 \\
\hline $\begin{array}{l}\text { Error } \\
\text { Error }\end{array}$ & Ra-226 GEA Rel of Counting \\
\hline & $\begin{array}{l}\text { Radium-224 by GEA } \\
\text { Radium-226 by GEA } \\
\text { Ru-103 GEA Rel \& Count Error }\end{array}$ \\
\hline Error & $\mathrm{Ru} / \mathrm{Rh}-106$ GEA Rel. Count \\
\hline & $\begin{array}{l}\text { Ru/Rh-106 by GEA } \\
\text { Ruthenium-103 by GEA } \\
\text { Sb-125 GEA Rel \& Counting Err }\end{array}$ \\
\hline Error & Se-75 GEA Rel. \& Count Error \\
\hline & $\begin{array}{l}\text { Selenium-75 by GEA } \\
\text { Sn-113 GEA Rel \& Counting Err }\end{array}$ \\
\hline Error & $\begin{array}{l}\text { Sodium-22 by GEA } \\
\text { Sodium-24 by GEA } \\
\text { Sx-85 GEA Rel. \& Count Error }\end{array}$ \\
\hline Error & $\begin{array}{l}\text { Strontium- } 85 \text { by GEA } \\
\text { Th-228 GEA Rel \& Counting }\end{array}$ \\
\hline & Th-229 GEA Rel $\%$ Counting \\
\hline Error & Th-234 GEA Rel \& Counting E \\
\hline & $\begin{array}{l}\text { Thallium-208 by GEA } \\
\text { Thorium-228 by GEA } \\
\text { Thorium-229 by GEA } \\
\text { Thorium-234 by GEA } \\
\text { Tin-113 by GEA } \\
\text { Tl-208 GEA Rel \& Counting }\end{array}$ \\
\hline
\end{tabular}

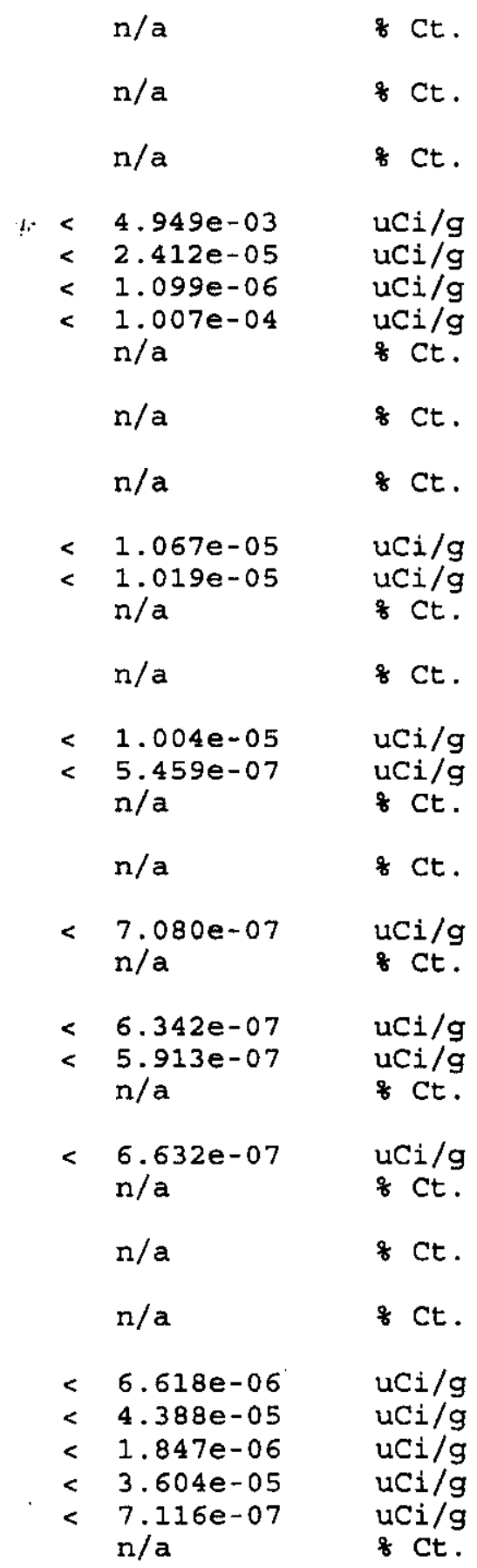

Page 13 


\section{HNF-6150 Rev 0}

99000317

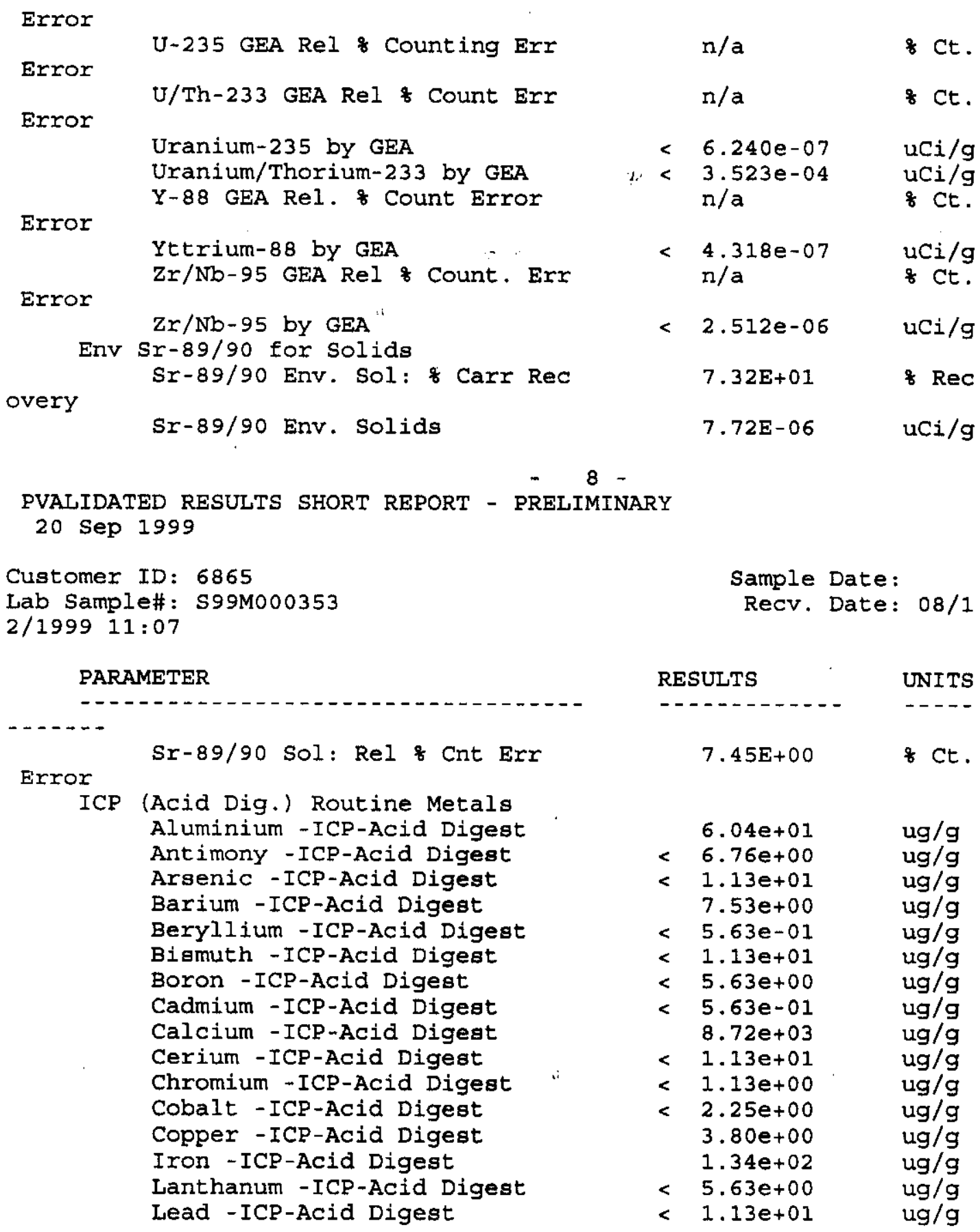

Page 14 


\section{HNF-6150 Rev 0}

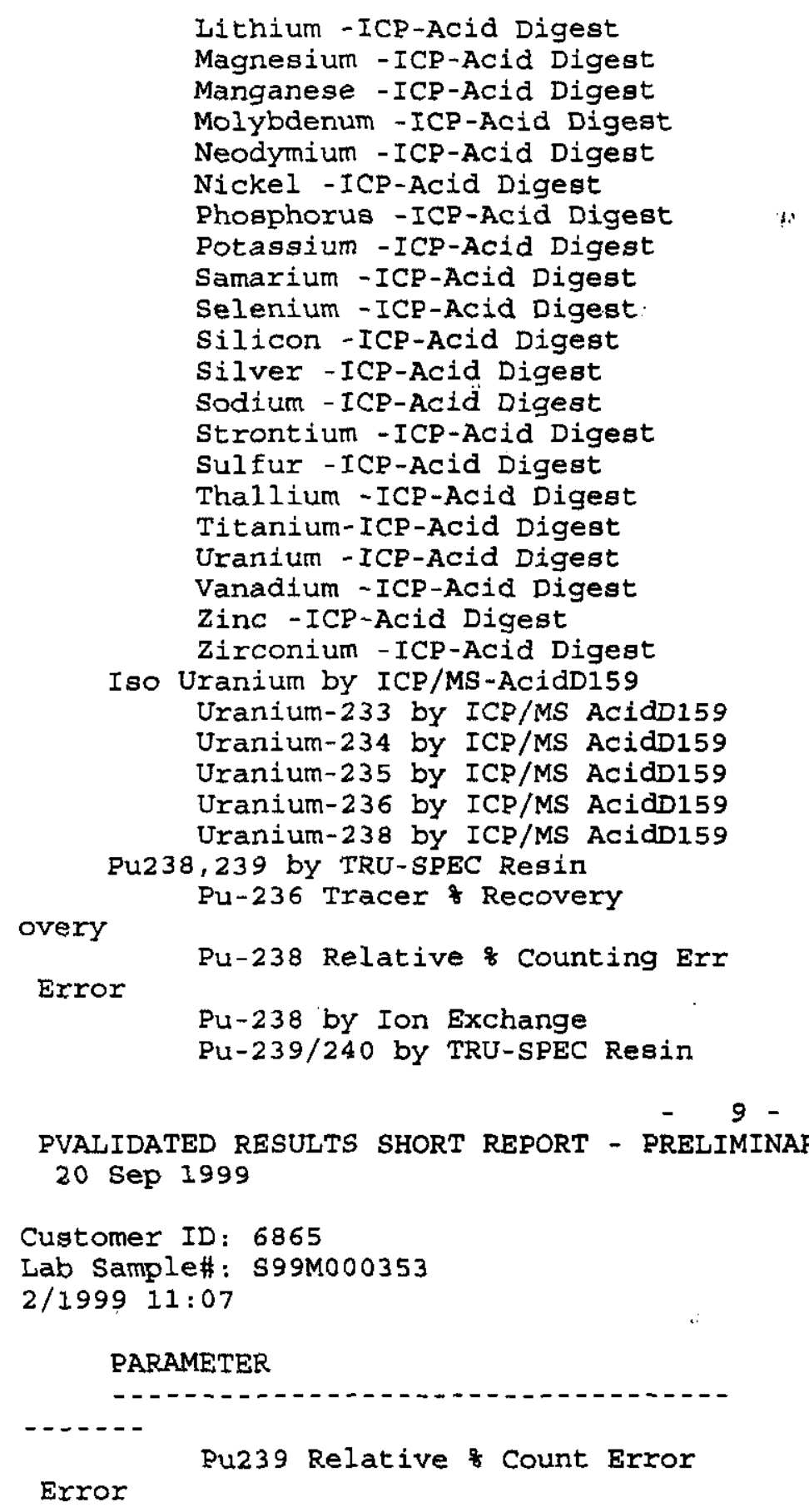

Iithium -ICP-ACid Digest Magnesium -ICP-ACid Digest Manganese -ICP-Acid Digest Molybdenum - ICP-ACid Digest Neodymium -ICP-Acid Digest tick-Acid Digest Sodium - ICP-ACid Digest Strontium -ICP-ACid Digest sulfur -ICP-ACid Digest Thallium -ICP-ACid Digest Zinc - ICP-ACid Digest Zirconium -ICP-ACid Digeat Uranium-236 by ICP/MS AcidD159 Uranium- 238 by ICP/MS AcidD159 Pu-236 Tracer of Recovery

Pu-238 Relative \& Counting Err Pu-238 by Ion Exchange Pu-239/240 by TRU-SPEC Resin $<\quad 1.13 e+00$

$5.45 e+02$

$2.69 e+00$

$<5.63 e+00$

$<1.13 e+01$

< $2.25 e+00$

(1) $\quad 7.44 e+03$

$2.97 \mathrm{e}+03$

$<1.13 e+01$

$<1.13 \mathrm{e}+01$

$9.03 e+00$

$<\quad 1.13 \mathrm{e}+00$

$1.23 e+03$

$4.07 e+00$

$1.35 e+03$

$<2.25 e+01$

$<1.13 \mathrm{e}+00$

$<5.63 \mathrm{e}+01$

$<5.63 \mathrm{e}+00$

$3.62 \mathrm{e}+01$

$<1.13 e+00$

$<\quad 1.981 e-02$

$<1.981 \mathrm{e}-02$

< $1.981 \mathrm{e}-02$

$<2.642 \mathrm{e}-02$

$<\quad 1.981 \mathrm{e}-02$

1. $12 \mathrm{E}+02$

$1.00 \mathrm{E}+02$

$<\quad 1.90 E-07$

$<\quad 1.90 \mathrm{E}-07$ ug/g

$\mathrm{ug} / \mathrm{g}$

$\mathrm{ug} / \mathrm{g}$

$u g / g$

ug/g

$\mathrm{ug} / \mathrm{g}$

ug/g

$\mathrm{ug} / \mathrm{g}$

$\mathrm{ug} / \mathrm{g}$

$\mathrm{ug} / \mathrm{g}$

$\mathrm{ug} / \mathrm{g}$

$\mathrm{ug} / \mathrm{g}$

$\mathrm{ug} / \mathrm{g}$

$\mathrm{ug} / \mathrm{g}$

$\mathrm{ug} / \mathrm{g}$

$\mathrm{ug} / \mathrm{g}$

$\mathrm{ug} / \mathrm{g}$

$\mathrm{ug} / \mathrm{g}$

$\mathrm{ug} / \mathrm{g}$

$\mathrm{ug} / \mathrm{g}$

$\mathrm{ug} / \mathrm{g}$

$u g / g$

$\mathrm{ug} / \mathrm{g}$

$\mathrm{ug} / \mathrm{g}$

$\mathrm{ug} / \mathrm{g}$

$\mathrm{ug} / \mathrm{g}$

\% Rec

\& Ct.

$\mathrm{uCi} / \mathrm{g}$

$\mathrm{uCi} / \mathrm{g}$
Sample Date:

Recv. Date: 08/1
RESULTS

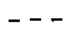

I. $00 \mathrm{E}+02$
UNITS

- - - -

\& Ct.

Page 15 


\section{HNF-6150 Rev 0}

99000317

OTHER ANALYSIS

Acid Dig. ICP/AA/Radchem Alig.

Customer ID: 6866

Lab Sample\#: S99M000354

2/1999 11:07

PARAMETER

364.0

$\mathrm{g} / \mathrm{L}$

Sample Date:

Recv. Date: 08/1

RESULTS

UNITS

$---\cdot-$

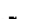

Env GEA Large Library Method AC-228 GEA Rel o Counting Err

Error

Actinium-228 by GEA

Error

Am-241 GEA Rel. \% Count Error

Error

Am-243 GEA Rel. Count Error

Americium-241 by GEA

Americium-243 by GEA

Antimony -125 by GEA

Bi-212 GEA Rel Counting Err

Error

Bi-214 GEA Rel \& Counting Err

Error

Bismuth-212 by GEA

Bismuth-214 by GEA

Cadmium-109 by GEA

Error

Cd-109 GEA Rel o Counting Err

Error

Ce/Pr-144 GEA Rel \& Count Err

Ce/Pr-144 by GEA

Cesium-134 by GEA

Cesium-137 by GEA

Co-56 GEA Rel. \% Count Error

Error

Co-57 GEA Rel. \& Count Error

Error

Co-60 GEA Rel. क count Error

Error

Cobalt-56 by GEA

Cobalt -57 by GEA

Cobalt -60 by GEA

Error

Cs-134 GEA Rel. \& Count Error

Error

Cs-137 GEA Rel. \% Count Error

Page 16 


\section{HNF-6150 Rev 0}

99000317

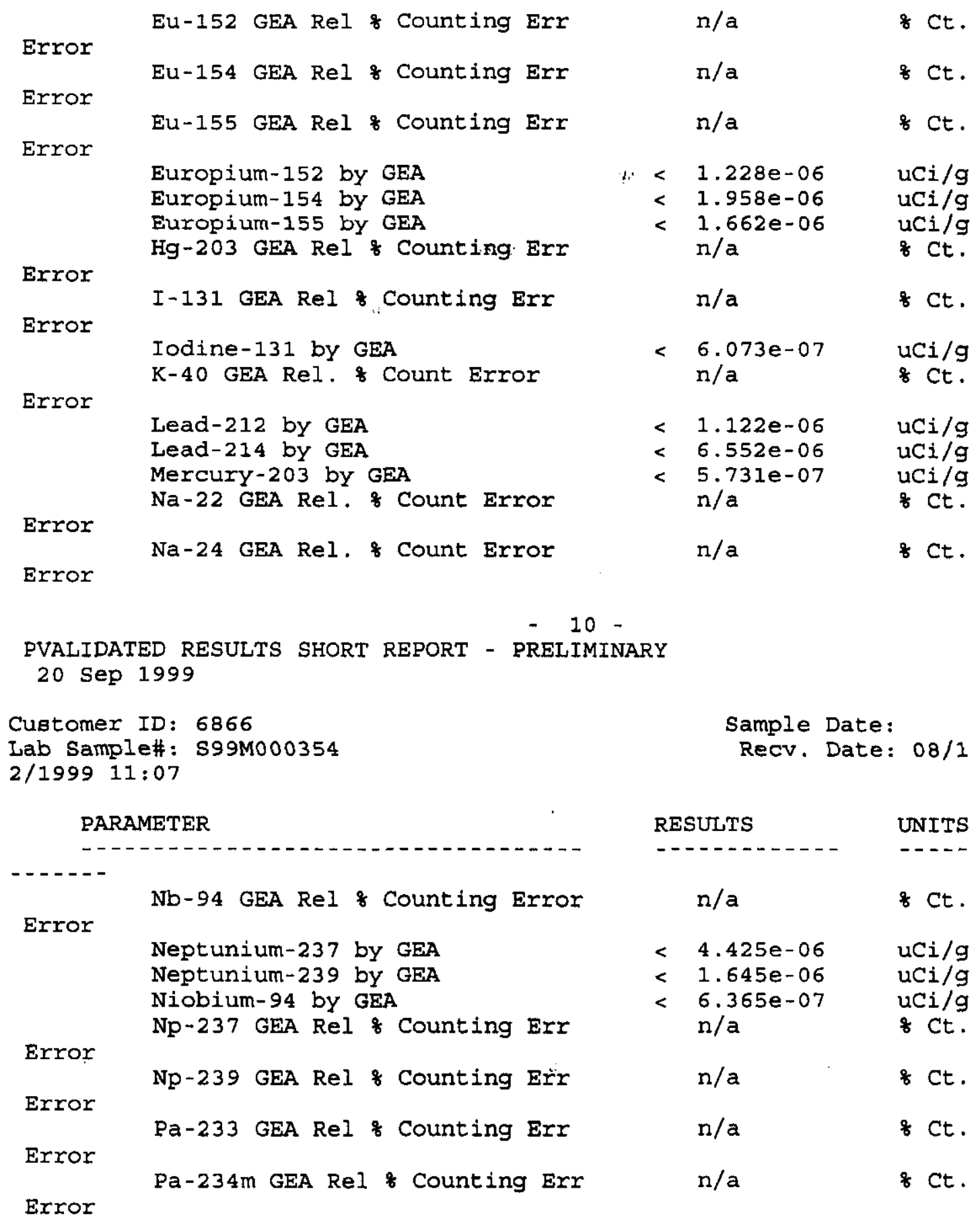

Page 17 


\section{HNF-6150 Rev 0}

99000317

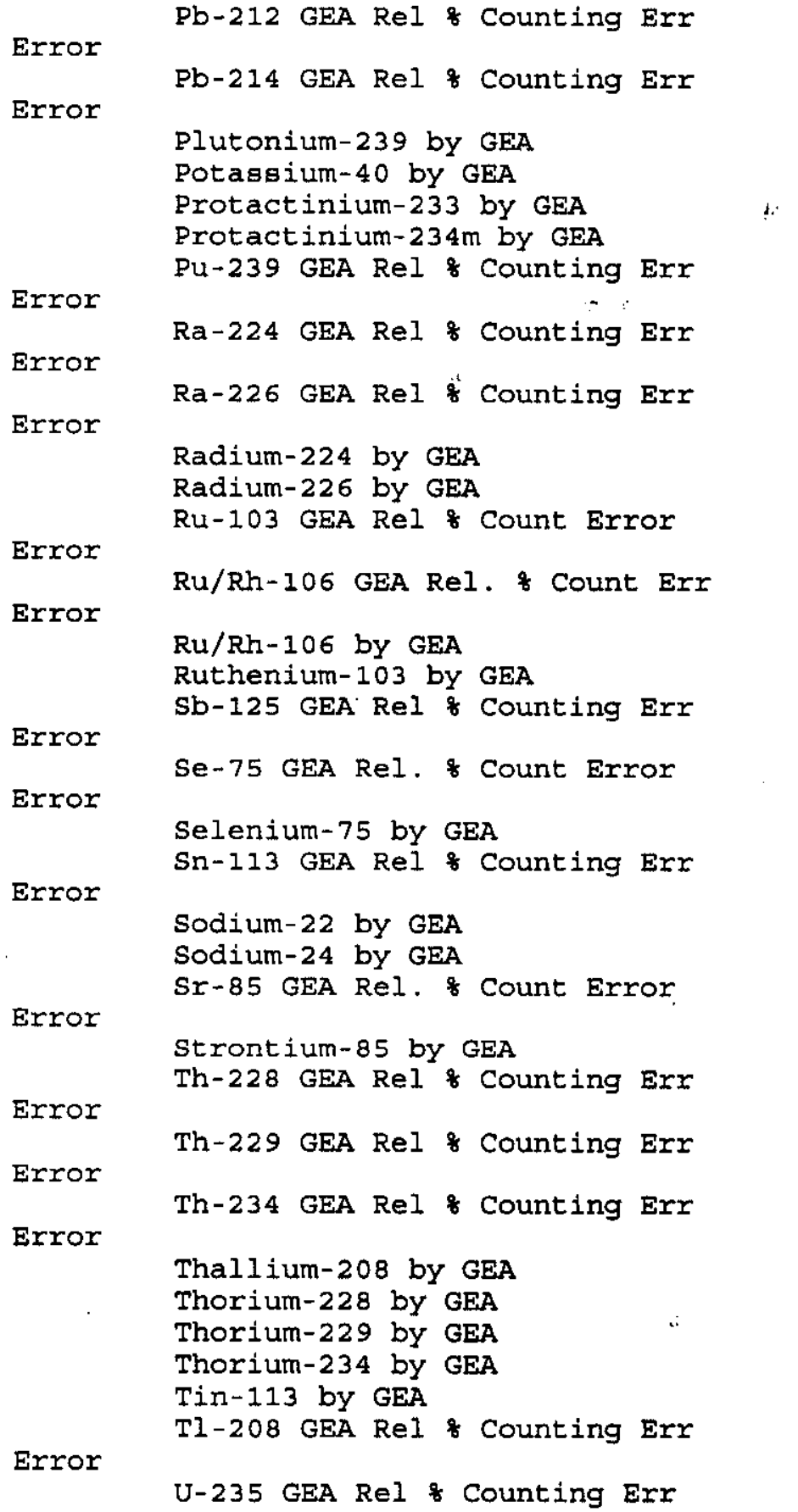

\begin{tabular}{|c|c|c|}
\hline & $\mathrm{n} / \mathrm{a}$ & $\& \mathrm{Ct}$. \\
\hline & $\mathrm{n} / \mathrm{a}$ & $\approx \mathrm{Ct}$. \\
\hline$<$ & $5.440 e-03$ & $\mathrm{uCi} / \mathrm{g}$ \\
\hline$<$ & $2.607 e-05$ & $\mathrm{uCi} / \mathrm{g}$ \\
\hline$<$ & $1.177 e-06$ & $\mathrm{uCi} / \mathrm{g}$ \\
\hline$<$ & $\begin{array}{l}9.969 \mathrm{e}-05 \\
\mathrm{n} / \mathrm{a}\end{array}$ & $\begin{array}{l}\mathrm{uCi} / \mathrm{g} \\
\text { o } \mathrm{Ct} .\end{array}$ \\
\hline & $\mathrm{n} / \mathrm{a}$ & $\& \mathrm{Ct}$. \\
\hline & $\mathrm{n} / \mathrm{a}$ & \& Ct. \\
\hline$<$ & $1.143 e-05$ & $\mathrm{uCi} / \mathrm{g}$ \\
\hline$<$ & $\begin{array}{l}1.147 \mathrm{e}-05 \\
\mathrm{n} / \mathrm{a}\end{array}$ & $\begin{array}{l}\mathrm{uCi} / \mathrm{g} \\
\text { \& Ct. }\end{array}$ \\
\hline & $\mathrm{n} / \mathrm{a}$ & \& Ct. \\
\hline$<$ & $1.062 e-05$ & $\mathrm{uCi} / \mathrm{g}$ \\
\hline$<$ & $\begin{array}{l}5.826 e-07 \\
n / a\end{array}$ & $\begin{array}{l}\mathrm{uCi} / \mathrm{g} \\
\text { \& Ct. }\end{array}$ \\
\hline & $\mathrm{n} / \mathrm{a}$ & \& ct \\
\hline$<$ & $\begin{array}{l}7.657 e-07 \\
\mathrm{n} / \mathrm{a}\end{array}$ & $\begin{array}{l}\mathrm{uCi} / \mathrm{g} \\
\& \mathrm{Ct} .\end{array}$ \\
\hline$<$ & $6.741 e-07$ & $\mathrm{uCi} / \mathrm{g}$ \\
\hline$<$ & $\begin{array}{l}5.868 e-07 \\
\mathrm{n} / \mathrm{a}\end{array}$ & $\begin{array}{l}\mathrm{uCi} / \mathrm{g} \\
\& \mathrm{Ct} .\end{array}$ \\
\hline$<$ & $\begin{array}{l}7.073 e-07 \\
\mathrm{n} / \mathrm{a}\end{array}$ & $\begin{array}{l}\mathrm{uCi} / \mathrm{g} \\
\text { o Ct. }\end{array}$ \\
\hline & $\mathrm{n} / \mathrm{a}$ & $q \mathrm{Ct}$. \\
\hline & $\mathrm{n} / \mathrm{a}$ & $\& \mathrm{Ct}$ \\
\hline$<$ & $7.360 e-06$ & $\mathrm{uCi} / \mathrm{g}$ \\
\hline$<$ & $4.644 e-05$ & $\mathrm{uCi} / \mathrm{g}$ \\
\hline$<$ & $2.056 e-06$ & $\mathrm{uCi} / \mathrm{g}$ \\
\hline$<$ & $3.769 e-05$ & $\mathrm{uCi} / \mathrm{g}$ \\
\hline$<$ & $\begin{array}{l}7.868 e-07 \\
n / a\end{array}$ & $\begin{array}{l}\mathrm{uCi} / \mathrm{g} \\
\& \mathrm{Ct} .\end{array}$ \\
\hline & $\mathrm{n} / \mathrm{a}$ & \& C \\
\hline
\end{tabular}

Page 18 
HNF-6150 Rev 0

99000317

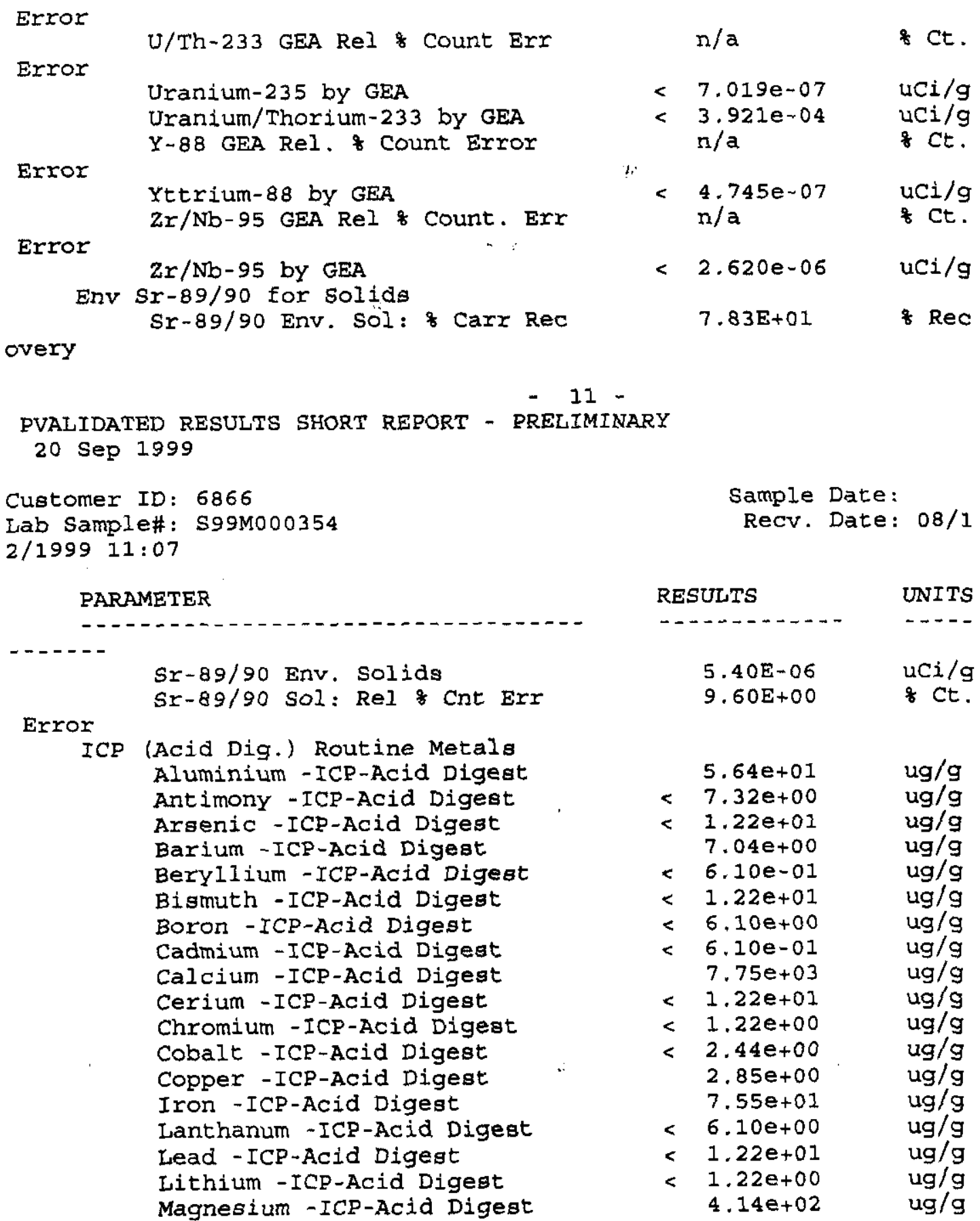


HNF-6150 Rev 0

99000317

\begin{abstract}
Manganese -ICP-ACid Digest
Molybdenum - ICP-Acid Digest Neodymium - ICP-Acid Digest

Nickel -ICP-Acid Digest

Phosphorus - ICP-Acid Digest

Potassium - ICP-ACid Digest

Samarium -ICP-Acid Digest

Selenium -ICP-Acid Digest

Silicon -ICP-ACid Digest

Silver -ICP-ACid Digest.

Sodium -ICP-ACid Digest

Strontium -ICP-ACid Digest

Sulfur -ICP-ACid Digest

Thallium - ICP-Acid Digest

Titanium-ICP-Acid Digest

Uranium - ICP-Acid Digest

Vanadium -ICP-Acid Digest

Zinc -ICP-Acid Digest

Zirconium -ICP-ACid Digest
\end{abstract}

Iso Uranium by ICP/MS-AcidD159

Uranium-233 by ICP/MS AcidD159

Uranium-234 by ICP/MS AcidD159

Uranium-235 by ICP/MS AcidD159

Uranium-236 by ICP/MS AcidD159

Uranium-238 by ICP/MS AcidD159

Pu238,239 by TRU-SPEC Resin

$\mathrm{Pu}-236$ Tracer \&ecovery

overy

Error

Pu-238 Relative of Counting Err

Pu-238 by Ion Exchange

\begin{tabular}{|c|c|c|}
\hline & $2.64 \mathrm{e}+00$ & $\mathrm{ug} / \mathrm{g}$ \\
\hline$<$ & $6.10 e+00$ & $\mathrm{ug} / \mathrm{g}$ \\
\hline$<$ & $1.22 \mathrm{e}+01$ & $u g / q$ \\
\hline$<$ & $2.44 e+00$ & $\mathrm{ug} / \mathrm{g}$ \\
\hline & $6.85 e+03$ & $u g / g$ \\
\hline & $2.84 e+03$ & $u g / g$ \\
\hline$<$ & $1.22 e+01$ & $\mathrm{ug} / \mathrm{g}$ \\
\hline$<$ & $1.22 e+01$ & $\mathrm{ug} / \mathrm{g}$ \\
\hline & $7.42 e+00$ & $\mathrm{ug} / \mathrm{g}$ \\
\hline$<$ & $1.22 e+00$ & $\mathrm{ug} / \mathrm{g}$ \\
\hline & $1.23 e+03$ & $\mathrm{ug} / \mathrm{g}$ \\
\hline & $2.06 e+00$ & $\mathrm{ug} / \mathrm{g}$ \\
\hline & $1.27 e+03$ & $\mathrm{ug} / \mathrm{g}$ \\
\hline$<$ & $2.44 e+01$ & $\mathrm{ug} / \mathrm{g}$ \\
\hline$<$ & $1.22 e+00$ & $u g / g$ \\
\hline$<$ & $6.10 e+01$ & $\mathrm{ug} / \mathrm{g}$ \\
\hline$<$ & $6.10 \mathrm{e}+00$ & $\mathrm{ug} / \overrightarrow{\mathrm{g}}$ \\
\hline & $3.68 e+01$ & $\mathrm{ug} / \mathrm{g}$ \\
\hline$<$ & $1.22 e+00$ & $\mathrm{ug} / \mathrm{g}$ \\
\hline$<$ & $2.146 e-02$ & $u g / g$ \\
\hline$<$ & $2.146 e-02$ & $\mathrm{ug} / \mathrm{g}$ \\
\hline$<$ & $2.146 e-02$ & $\mathrm{ug} / \bar{g}$ \\
\hline$<$ & $2.862 e-02$ & $u g / g$ \\
\hline$<$ & $2.146 e-02$ & $\mathrm{ug} / \mathrm{g}$ \\
\hline & $1.07 E+02$ & \& Rec \\
\hline & 1. $00 E+02$ & \& $\mathrm{Ct}$. \\
\hline$<$ & 2. $10 \mathrm{E}-07$ & $\mathrm{uCi} / \mathrm{g}$ \\
\hline
\end{tabular}

$-12-$

PVALIDATED RESULTS SHORT REPORT - PRELIMINARY

20 Sep 1999

Customer ID: 6866

Lab Sample\#: S99M000354

2/1999 11:07

Sample Date:

Recv. Date: $08 / 1$

Page 20 
Customer ID: 6867

Lab Sample\#: S99M000355

Sample Date:

Recv. Date: 08/1

2/1999 11:07

PARAMETER

RESULTS

UNITS

PARAMETER

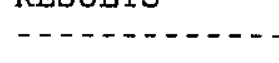

- -...

Env GEA Large Library Method

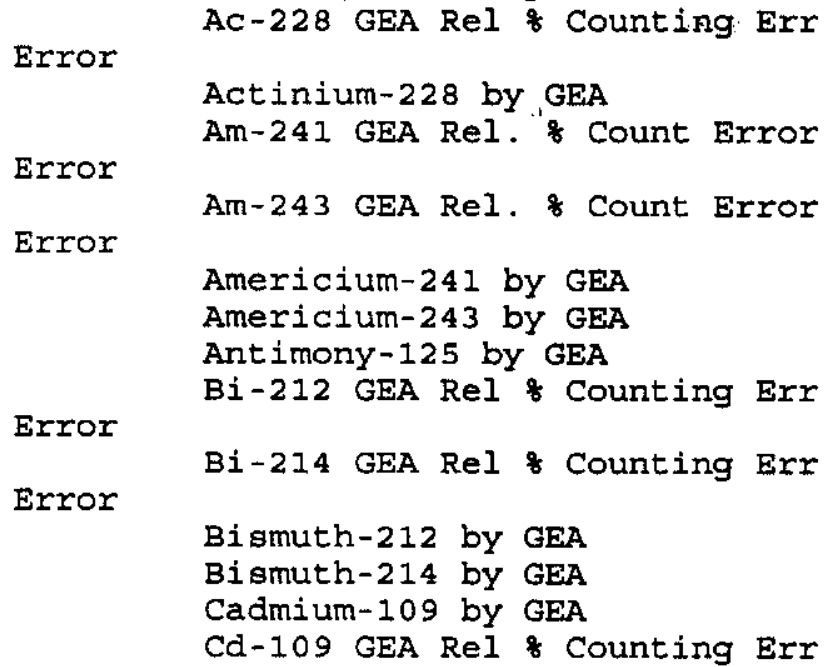

\begin{tabular}{|c|}
\hline $\begin{array}{l}3.190 \mathrm{e}-06 \\
\mathrm{n} / \mathrm{a}\end{array}$ \\
\hline
\end{tabular}

$<5.074 \mathrm{e}-06 \quad$ uCi $/ \mathrm{g}$

$<1.346 \mathrm{e}-06 \quad \mathrm{uC} 1 / \mathrm{g}$

$<1.583 e-06 \quad \mathrm{uCi} / \mathrm{g}$ $\mathrm{n} / \mathrm{a}$ \& $\mathrm{Ct}$.

Error

Ce/Pr-144 GEA Rel \& Count Err

Error

$\mathrm{Ce} / \mathrm{Pr}-144$ by GEA

Cesium-134 by GEA

Cesium-137 by GEA

Co-56 GEA Rel. Count Error

Error

Co-57 GEA Rel. Count Exror

Error

Co-60 GEA Rel. \% Count Error

Error

Cobalt -56 by GEA

Cobalt -57 by GEA

Cobalt -60 by GEA

Error

Cs-134 GEA Rel. \% Count Error

$\mathrm{n} / \mathrm{a}$

\& Ct.

$<8.690 \mathrm{e}-06$

$\mathrm{uCi} / \mathrm{g}$

$<4.130 \mathrm{e}-06 \quad \mathrm{uCi} / \mathrm{g}$

$<\quad 1.259 \mathrm{e}-05$ uCi/g

$\mathrm{n} / \mathrm{a} \quad$ o $\mathrm{Ct}$.

$\mathrm{n} / \mathrm{a} \quad$ \& $\mathrm{Ct}$.

$<5.585 e-06 \quad$ uCi/g

$<5.270 \mathrm{e}-07 \quad \mathrm{uCi} / \mathrm{g}$

$<9.422 e-07 \quad \mathrm{uCi} / \mathrm{g}$

$\mathrm{n} / \mathrm{a} \quad \mathrm{Ct}$.

$\mathrm{n} / \mathrm{a} \quad$ o $\mathrm{Ct}$.

$\mathrm{n} / \mathrm{a} \quad \& \mathrm{Ct}$.

$<5.333 e-07 \quad \mathrm{uCi} / \mathrm{g}$

$<3.702 \mathrm{e}-07 \quad \mathrm{uCi} / \mathrm{g}$

$<5.515 e-07 \quad \mathrm{uCi} / \mathrm{g}$ $\mathrm{n} / \mathrm{a}$ \& $\mathrm{Ct}$.

Cs-137 GEA Rel. \& Count Error n/a \& Ct.

Error

Eu-152 GEA Rel Counting Err

$\mathrm{n} / \mathrm{a} \quad$ \& $\mathrm{Ct}$.

Error

Page 21 


\section{HNF-6150 Rev 0}

99000317

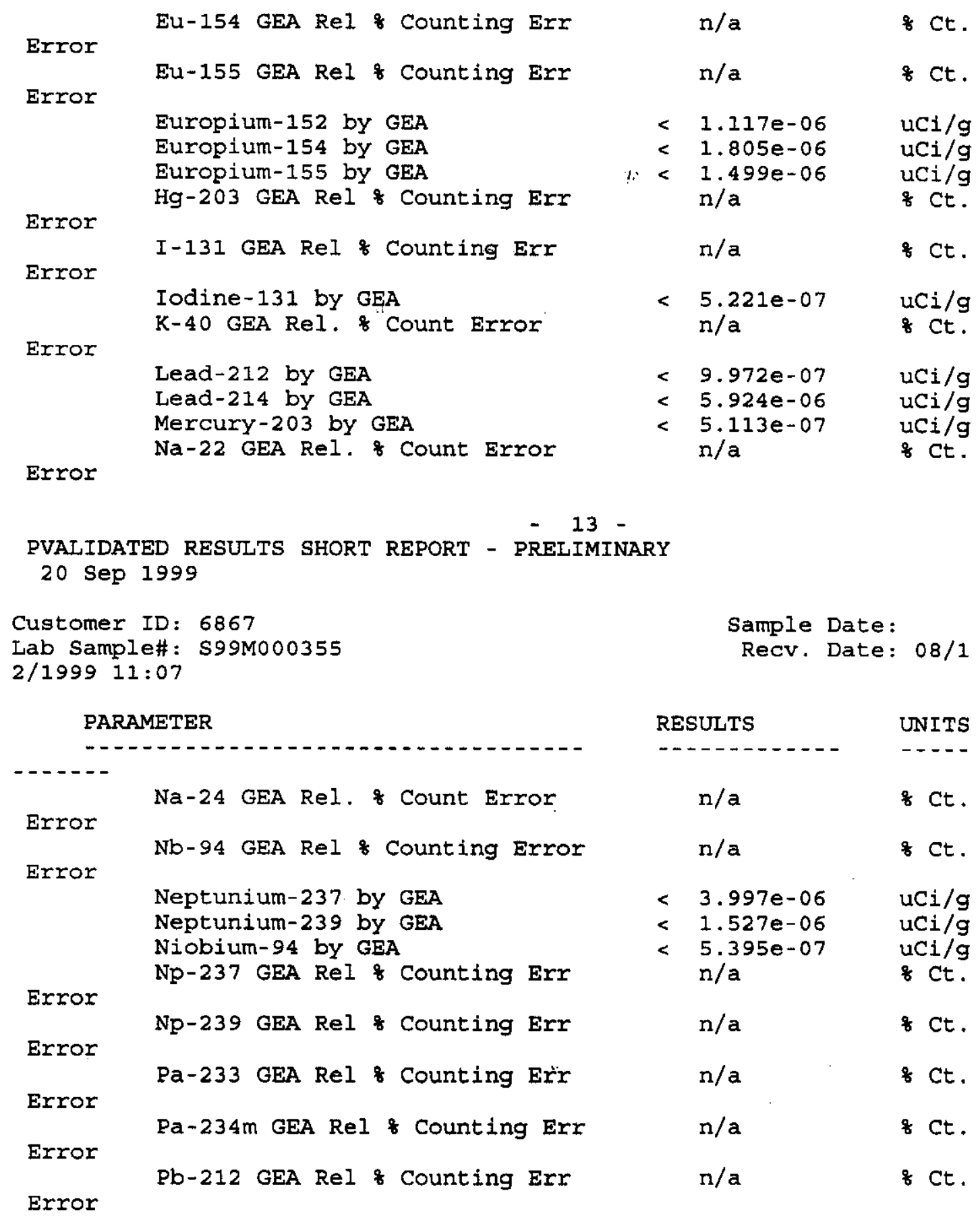


99000317

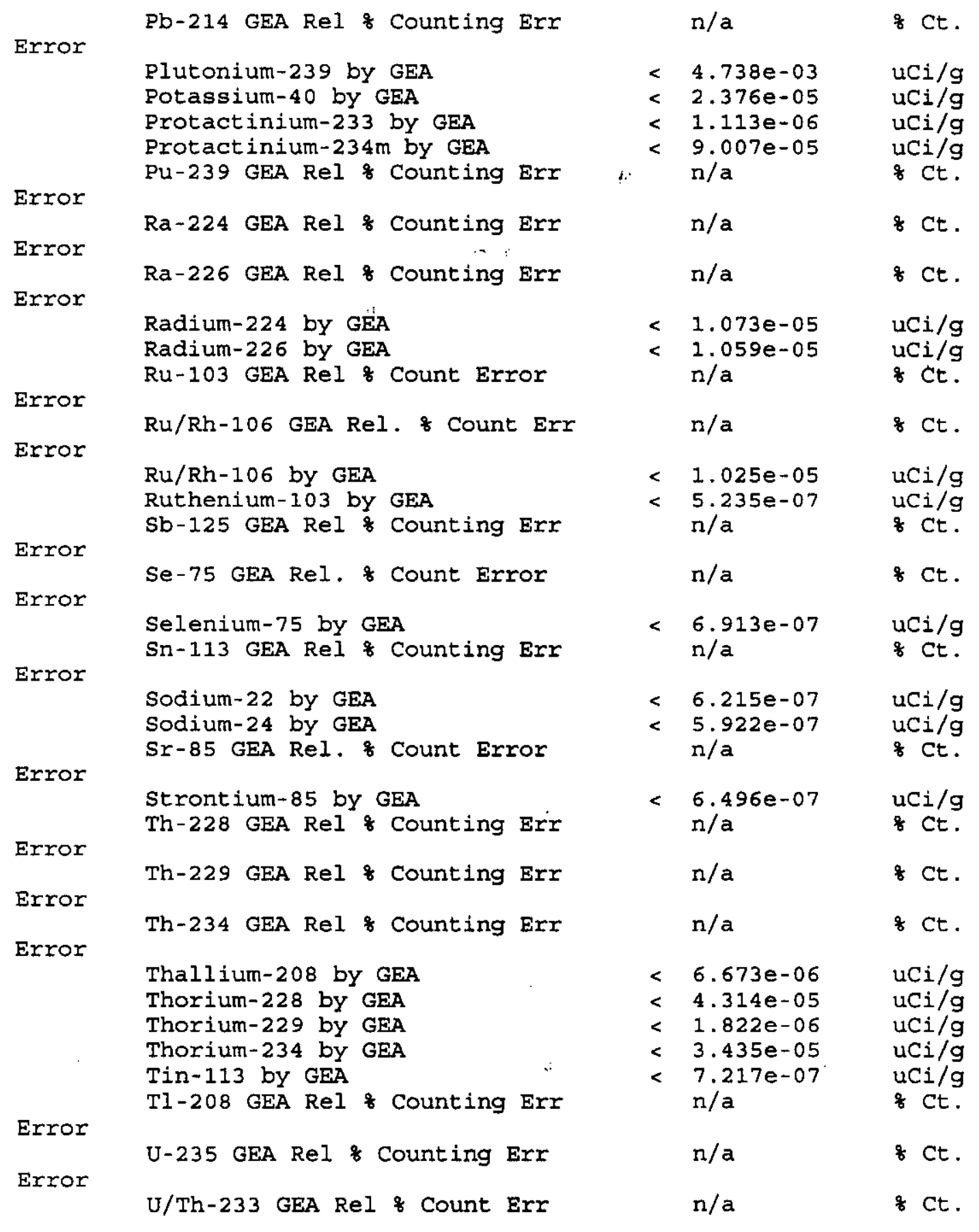




\section{HNF-6150 Rev 0}

99000317

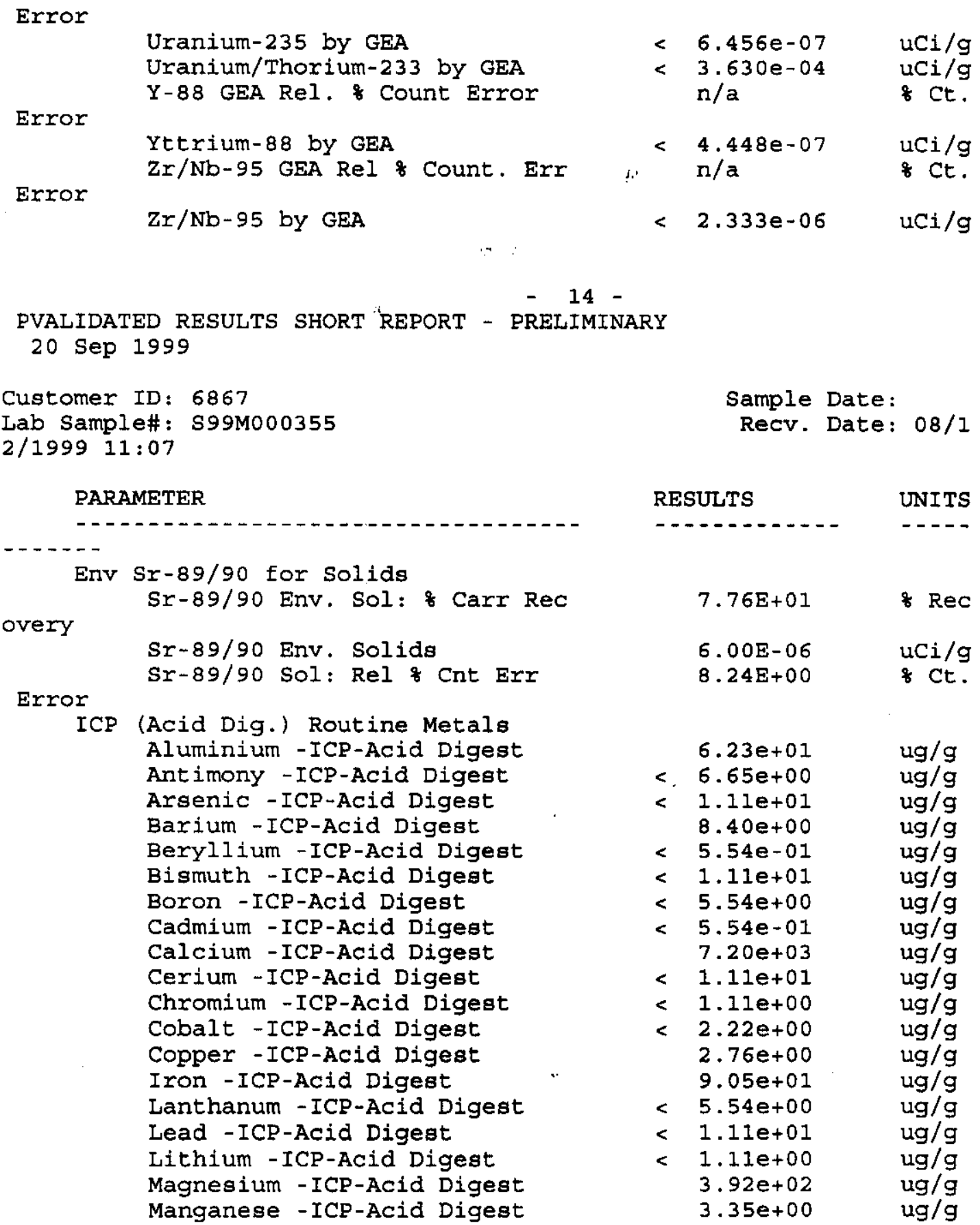




\footnotetext{
Molybdenum -ICP-ACid Digest Neodymium -ICP-Acid Digest Nickel -ICP-Acid Digest Phosphorus -ICP-ACid Digest Potassium -ICP-Acid Digest Samarium - ICP-ACid Digest Selenium -ICP-Acid Digeat Silicon - ICP-Acid Digest Silver -ICP-ACid Digest Sodium - ICP-Acid Digest. Strontium -ICP-ACid Digest Sulfur - ICP-ACid Digest Thallium - ICP-ACid Digest Titanium-ICP-Acid Digest Uranium -ICP-ACid Digest Vanadium - ICP-ACid Digegt Zinc - ICP-Acid Digest Zirconium -ICP-Acid Digest

Iso Uranium by ICP/MS-AcidD159 Uranium-233 by ICP/MS AcidD159 Uranium-234 by ICP/MS AcidD159 Uranium-235 by ICP/MS AcidD159 Uranium-236 by ICP/MS AcidD159 Uranium-238 by ICP/MS ACidD159 Pu238,239 by TRU-SPEC Resin Pu-236 Tracer \& Recovery
}

overy
$<5.54 \mathrm{e}+00$

$<\quad 1.11 e+01$

< $2.22 e+00$

$6.28 e+03$

$2.67 e+03$

$<1.11 \mathrm{e}+01$

$1 .<1.11 e+01$

$<5.54 e+00$

$<\quad 1.11 e+00$

$1.33 e+03$

3. $63 e+00$

$8.84 \mathrm{e}+02$

$<\quad 2.22 e+01$

$<\quad 1.11 e+00$

$<5.54 e+01$

$<5.54 e+00$

$3.23 e+01$

$<\quad 1.11 e+00$

< $1.949 e-02$

< $1.949 \mathrm{e}-02$

$<\quad 1.949 e-02$

< 2.599e-02

< $1.949 e-02$

$9.93 E+01$ $u g / g$

$\mathrm{ug} / \mathrm{g}$

$\mathrm{ug} / \mathrm{g}$

$\mathrm{ug} / \mathrm{g}$

$\mathrm{ug} / \mathrm{g}$

$\mathrm{ug} / \mathrm{g}$

$\mathrm{ug} / \mathrm{g}$

$\mathrm{ug} / \mathrm{g}$

$\mathrm{ug} / \mathrm{g}$

$\mathrm{ug} / \mathrm{g}$

$\mathrm{ug} / \mathrm{g}$

$\mathrm{ug} / \mathrm{g}$

ug/g

$\mathrm{ug} / \mathrm{g}$

ug/g

$\mathrm{ug} / \mathrm{g}$

$\mathrm{ug} / \mathrm{g}$

$\mathrm{ug} / \mathrm{g}$

$\mathrm{ug} / \mathrm{g}$

$\mathrm{ug} / \mathrm{g}$

ug/g

$\mathrm{ug} / \mathrm{g}$

ug/g

\& Rec

\footnotetext{
- 15 -

PVALIDATED RESULTS SHORT REPORT - PRELIMINARY 20 Sep 1999
}

Customer ID: 6867

Lab Sample\#: S99M000355

2/1999 11:07

Sample Date:
Recv. Date: $08 / 1$

RESULTS

UNITS

PARAMETER

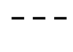

Pu-238 Relative $\%$ Counting Err

Error

Pu-238 by Ion Exchange

Pu-239/240 by TRU-SPEC Resin

Error

Pu239 Relative \& Count Error

OTHER ANALYSIS

Acid Dig. ICP/AA/Radchem Aliq.$$
<+
$$

\& Ct.

< $\quad 1.97 \mathrm{E}-07$

$1.97 \mathrm{E}-07$

1. $00 \mathrm{E}+02$

$\mathrm{uCi} / \mathrm{g}$

$\mathrm{uCi} / \mathrm{g}$

\& $\mathrm{Ct}$.
370.0

$\mathrm{g} / \mathrm{L}$

Page 25 
HNF-6150 Rev 0

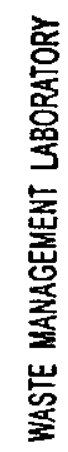
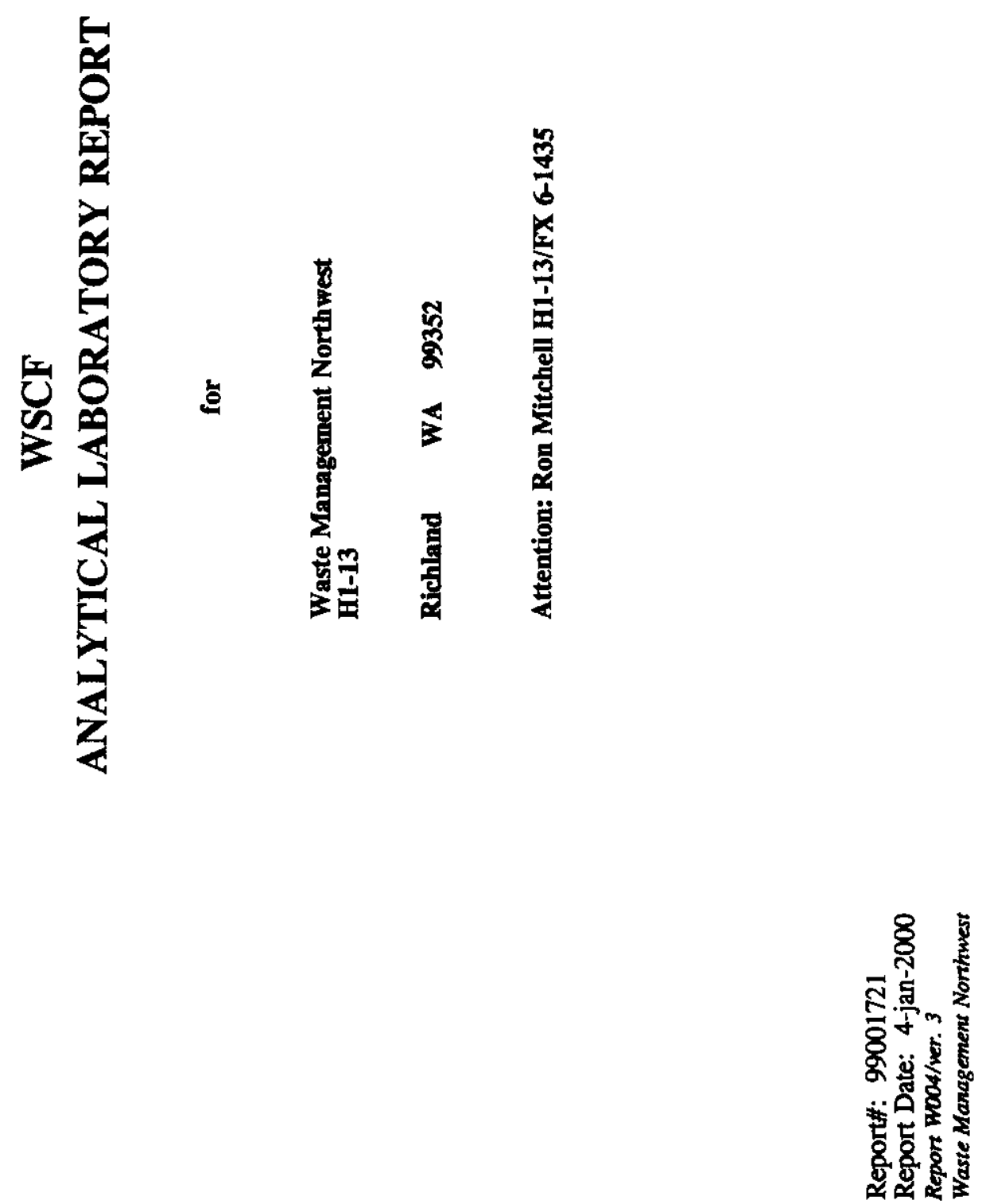
HNF-6150 Rev 0

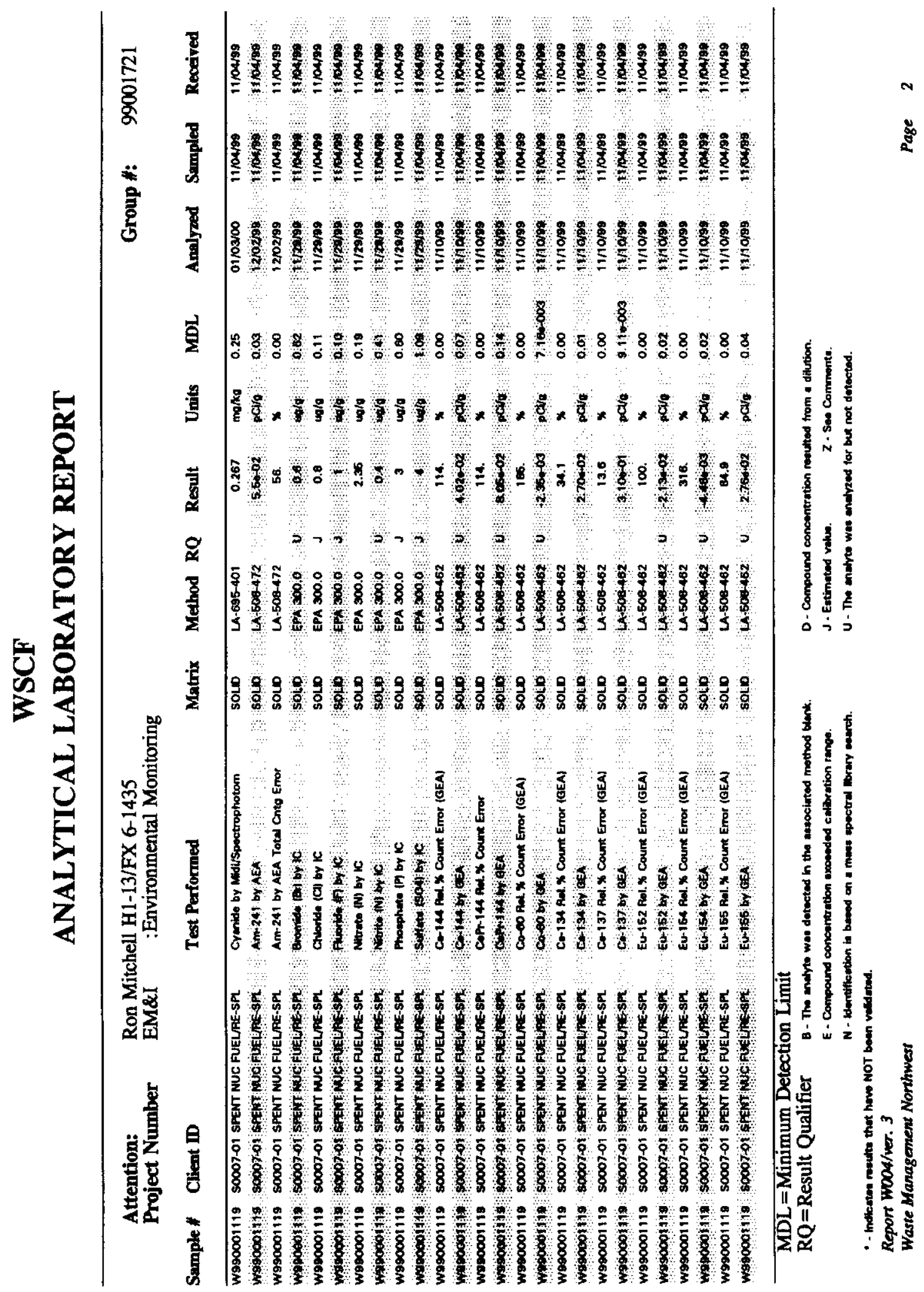


HNF-6150 Rev 0

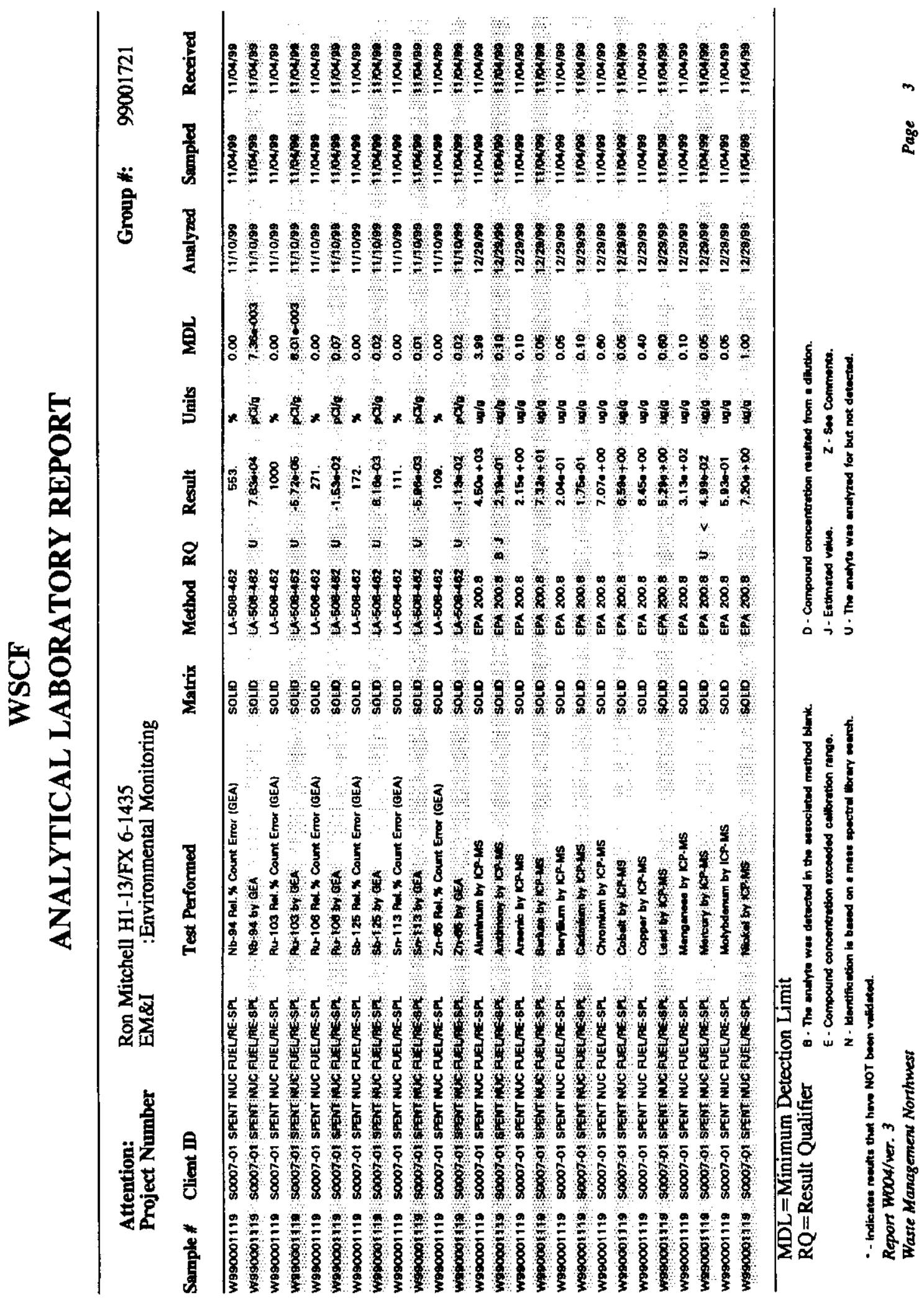




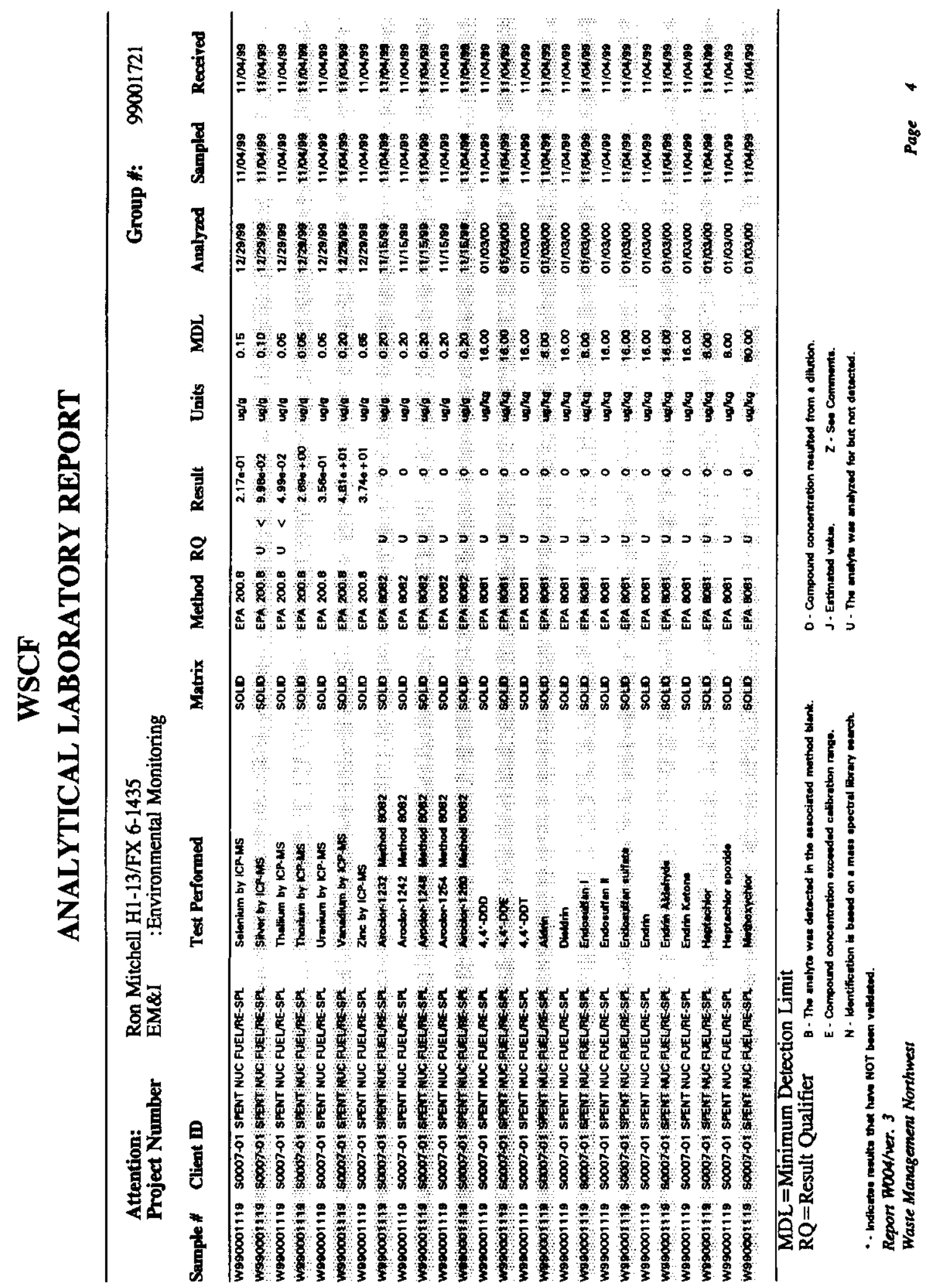


HNF-6150 Rev 0

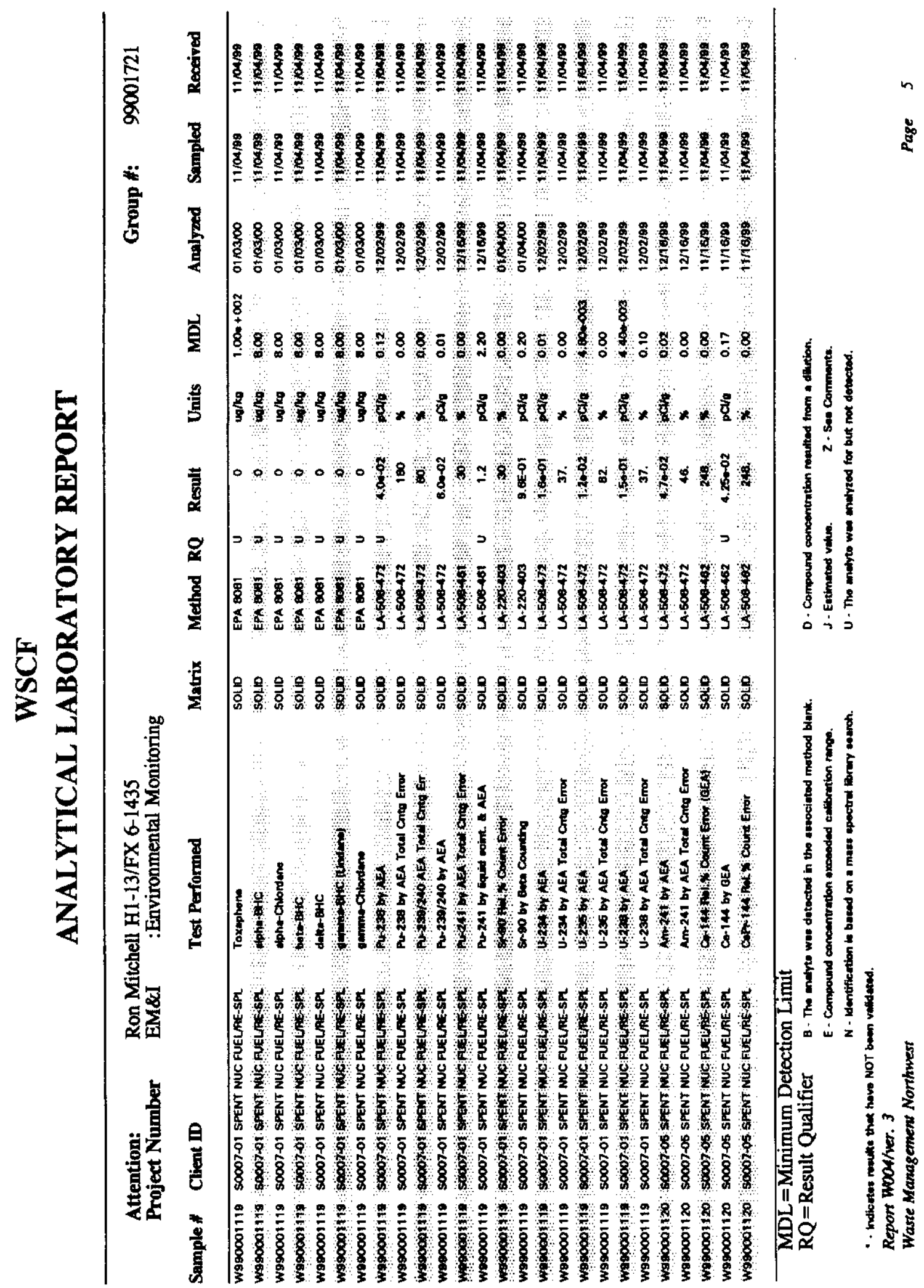


HNF-6150 Rev 0

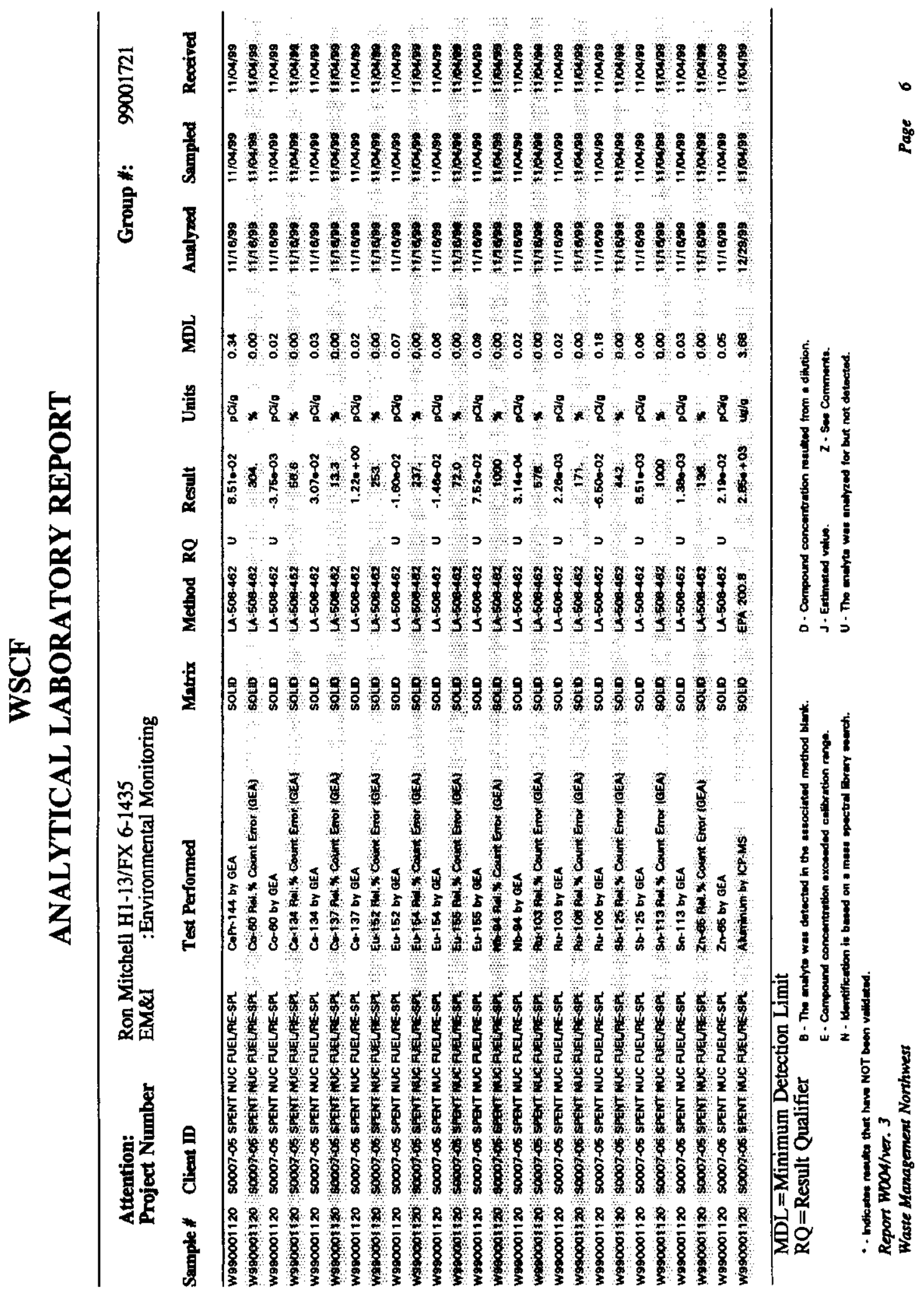




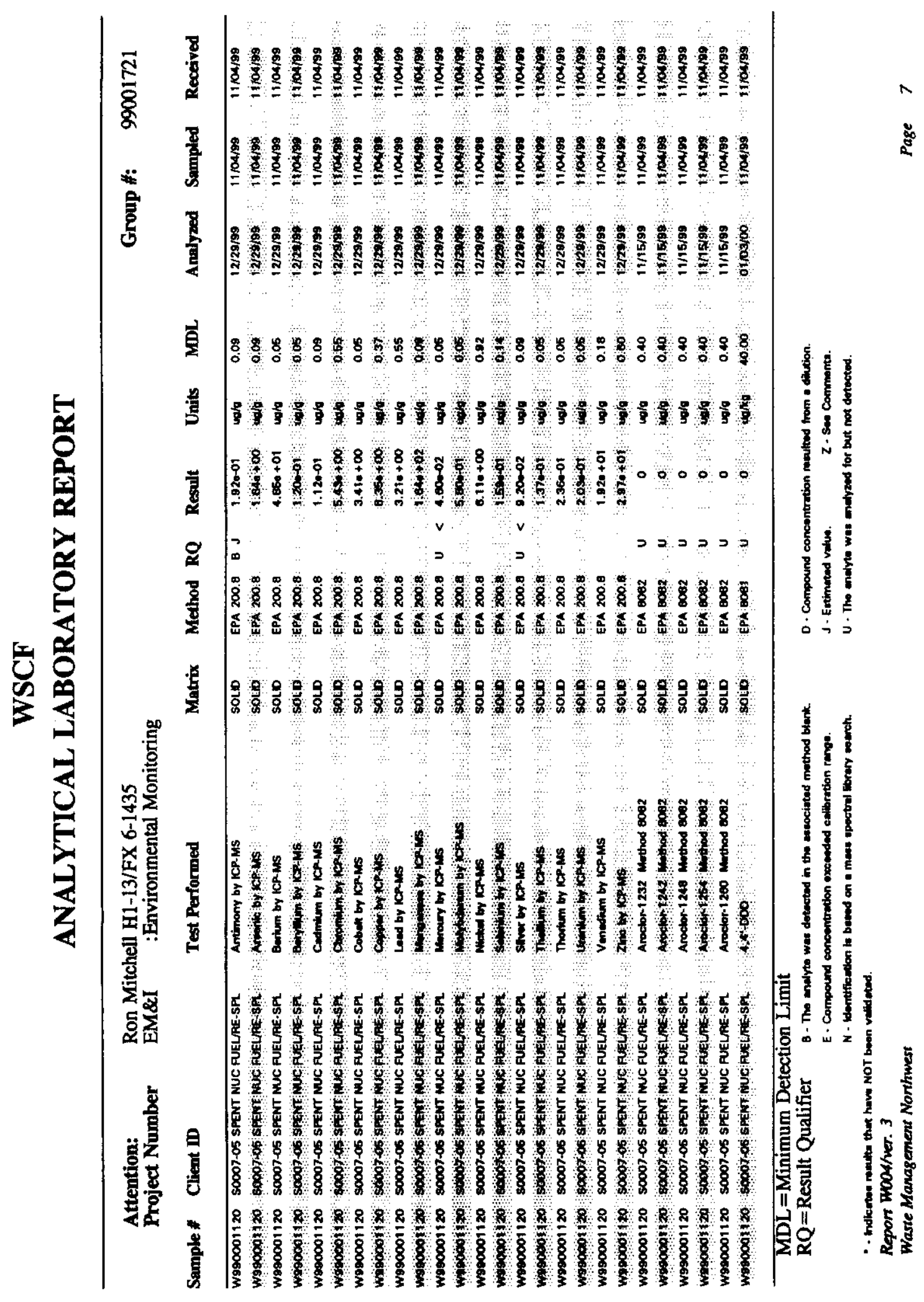


HNF-6150 Rev 0

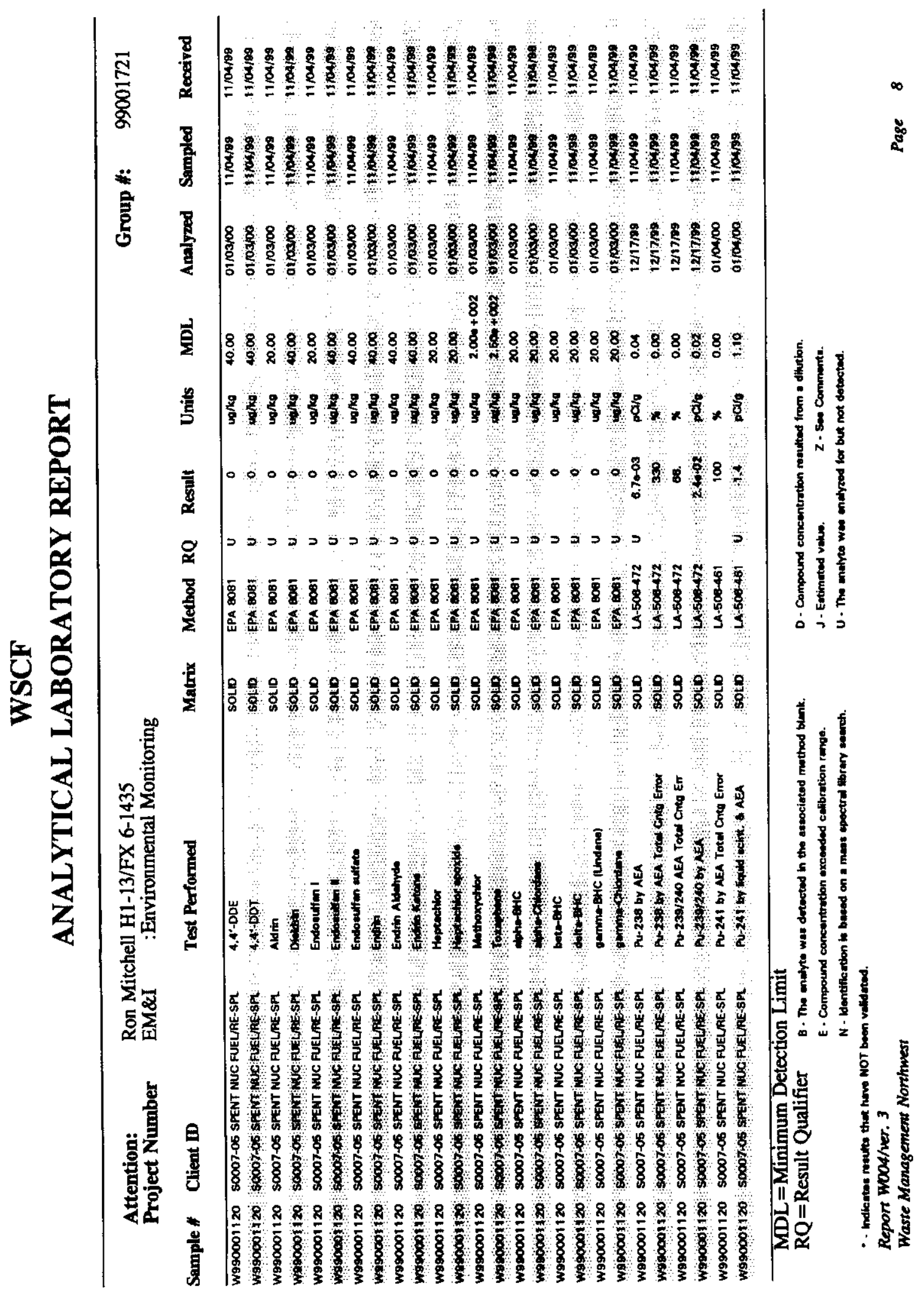


HNF-6150 Rev 0
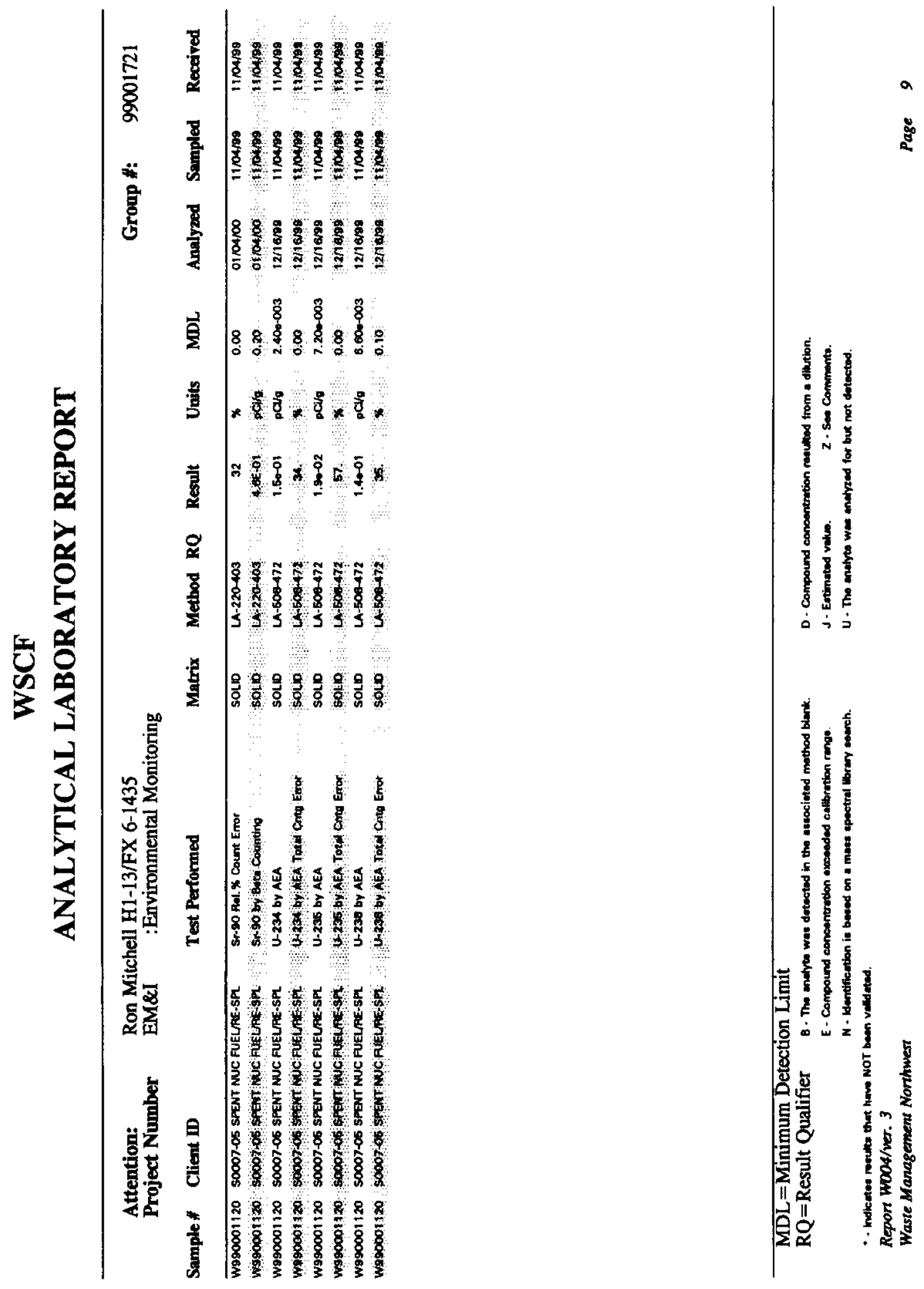
HNF-6150 Rev 0

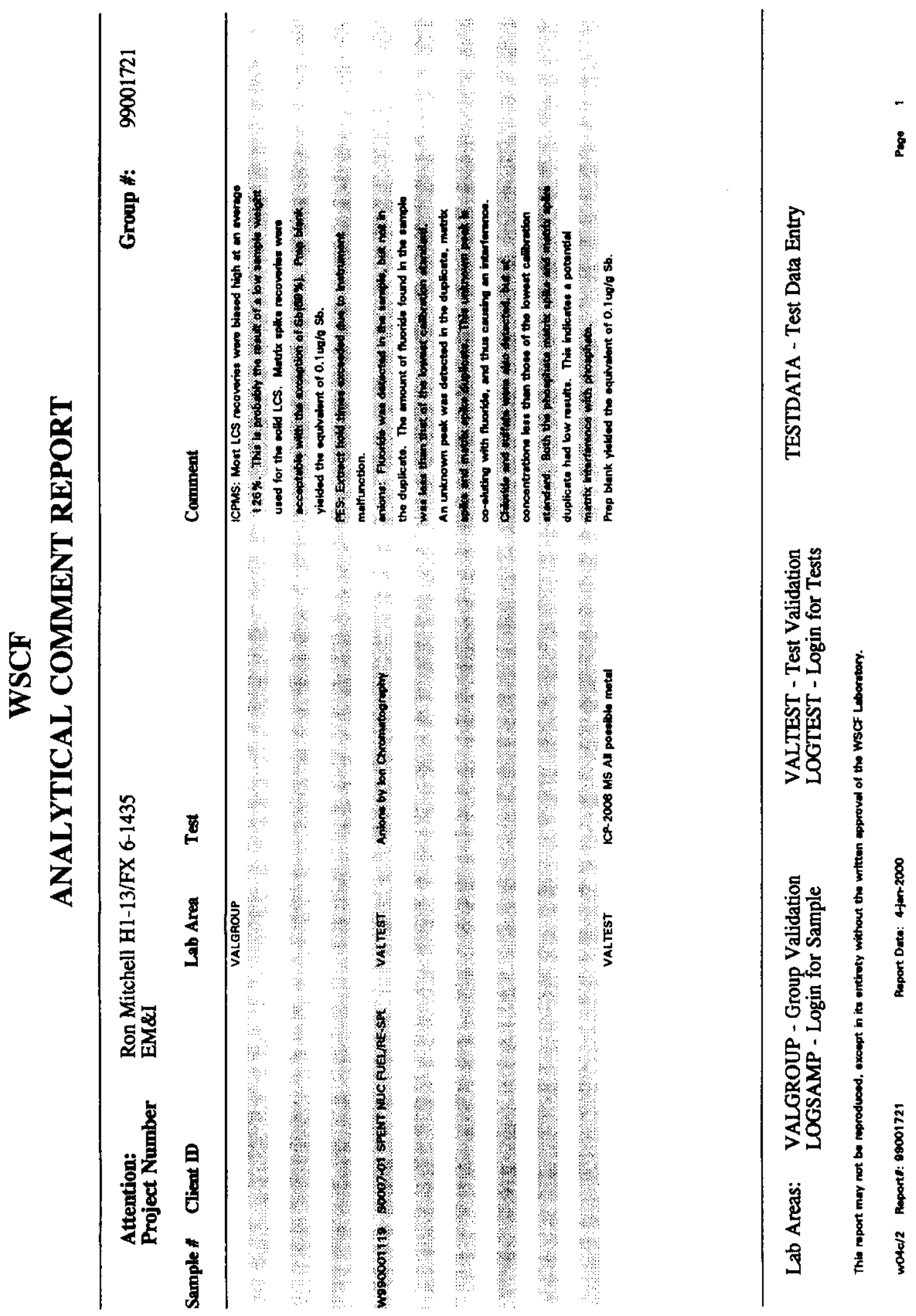


HNF-6150 Rev 0
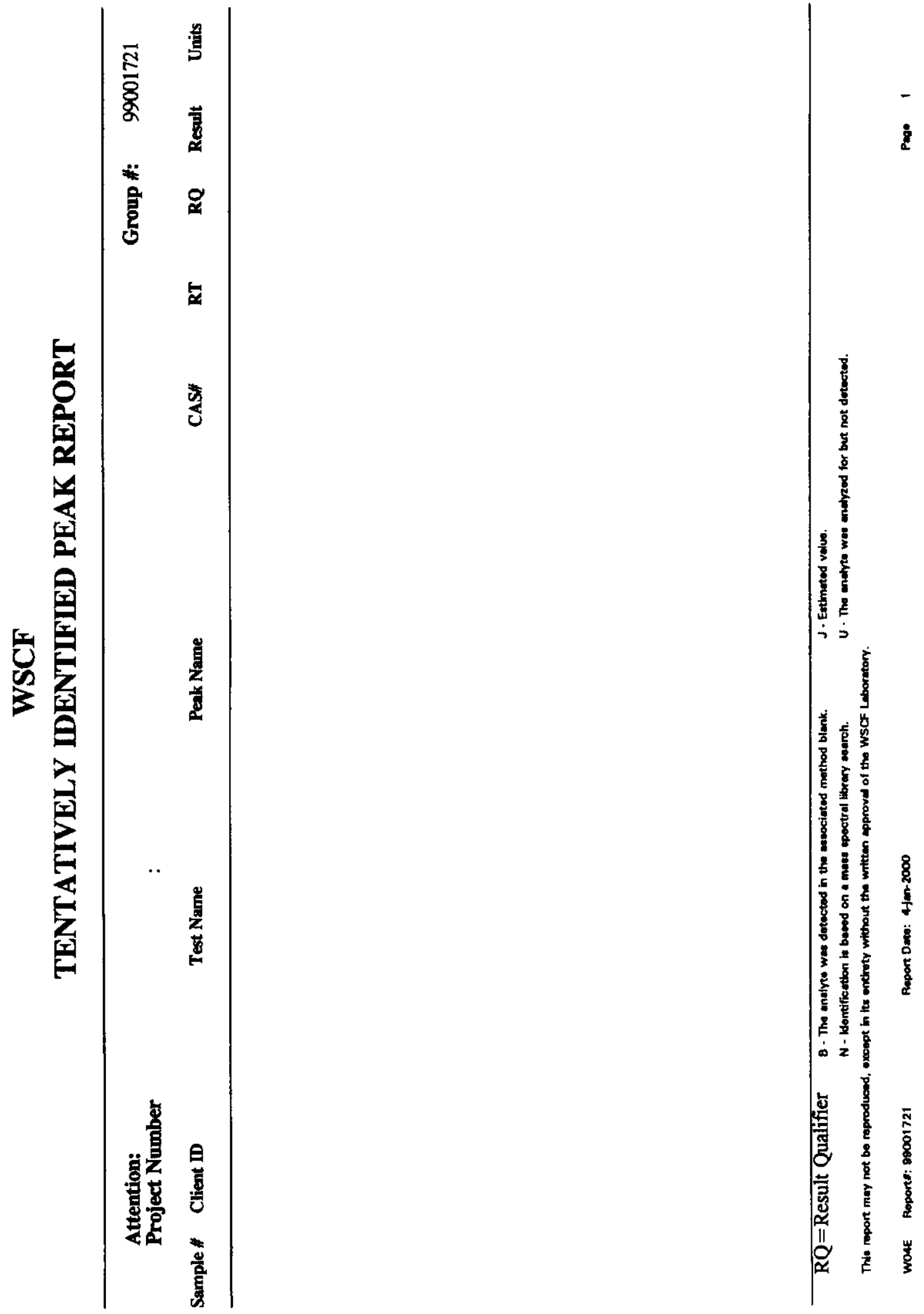


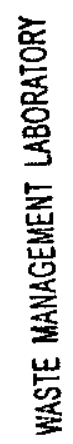
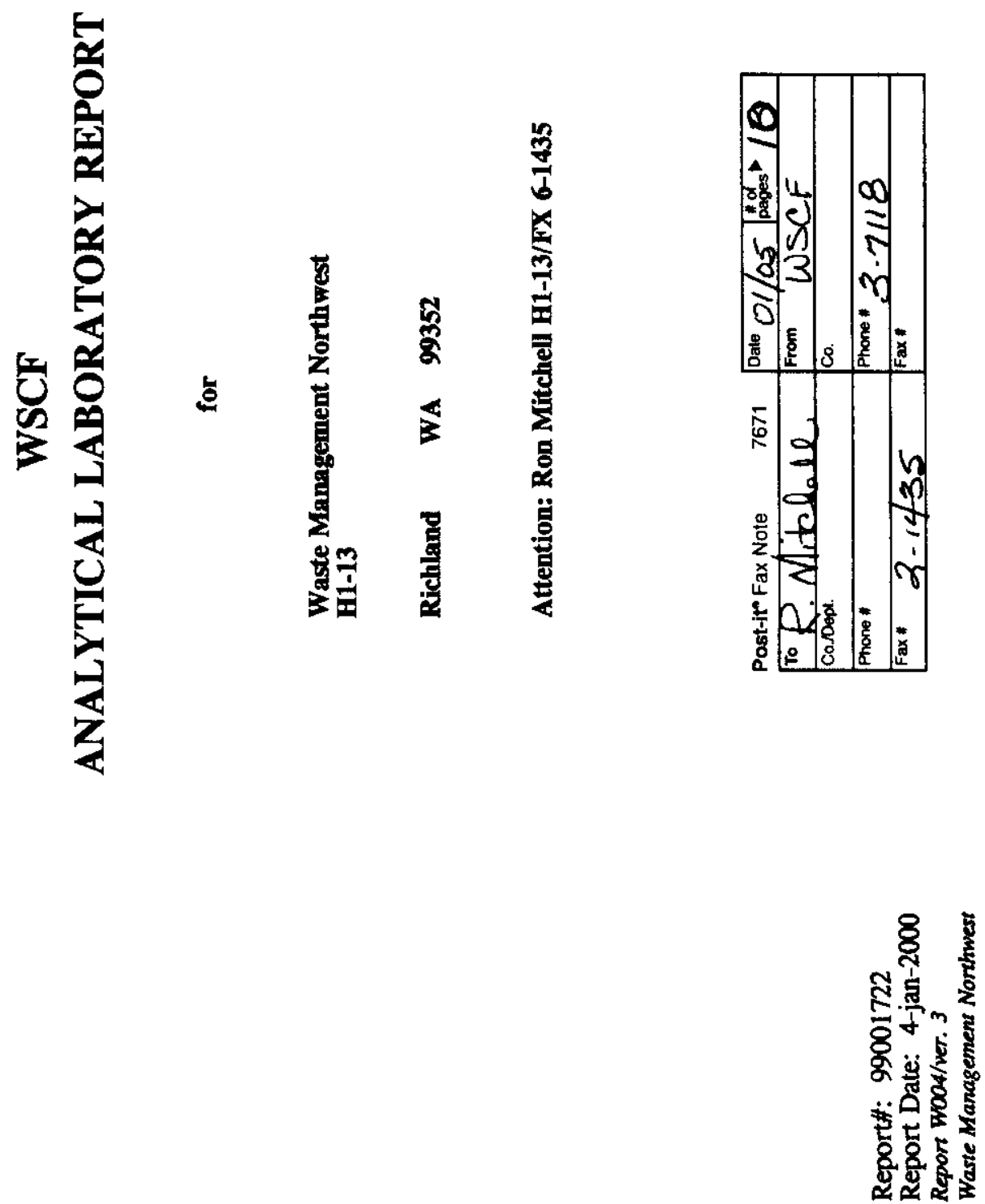
HNF-6150 Rev 0

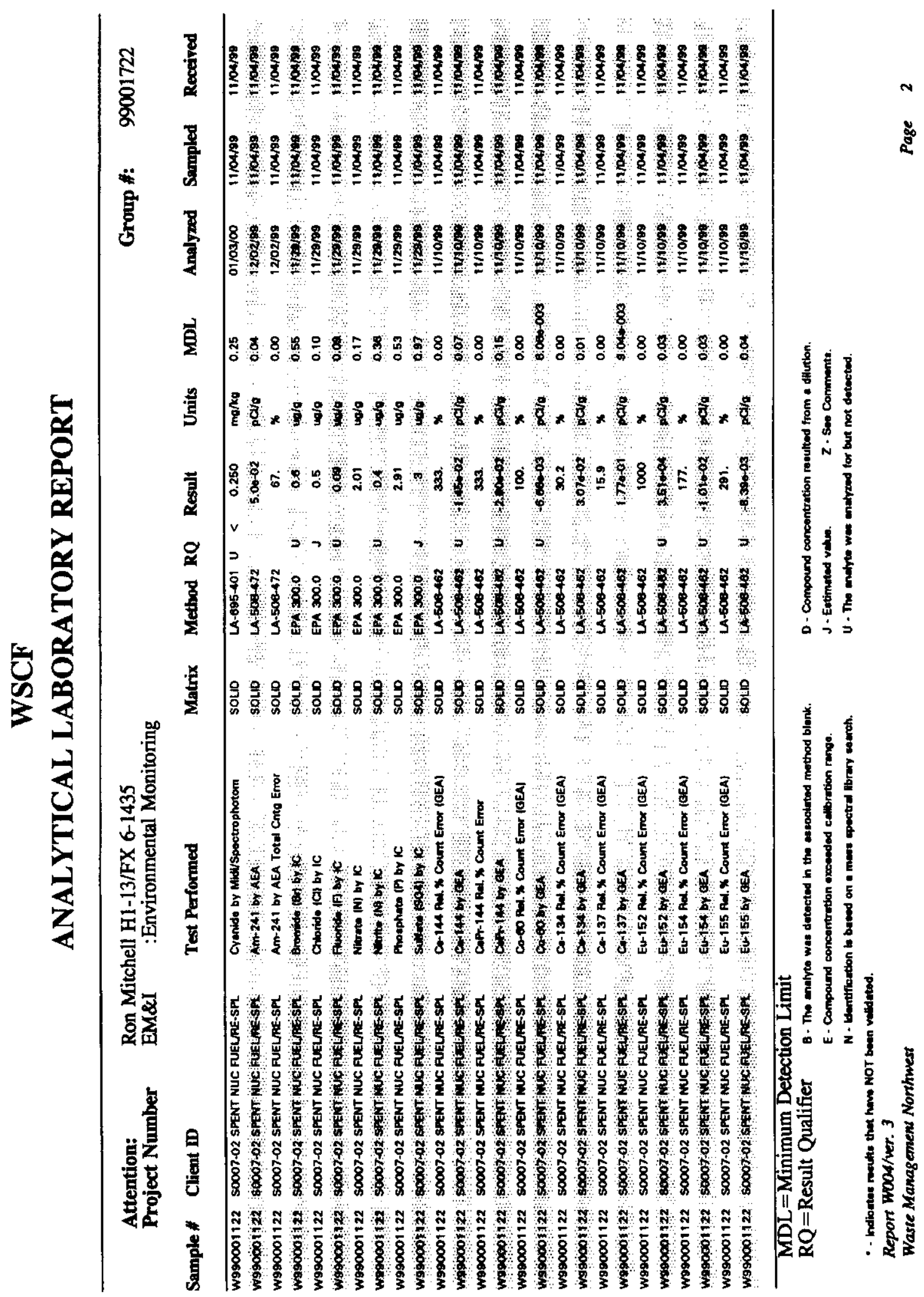


HNF-6150 Rev 0

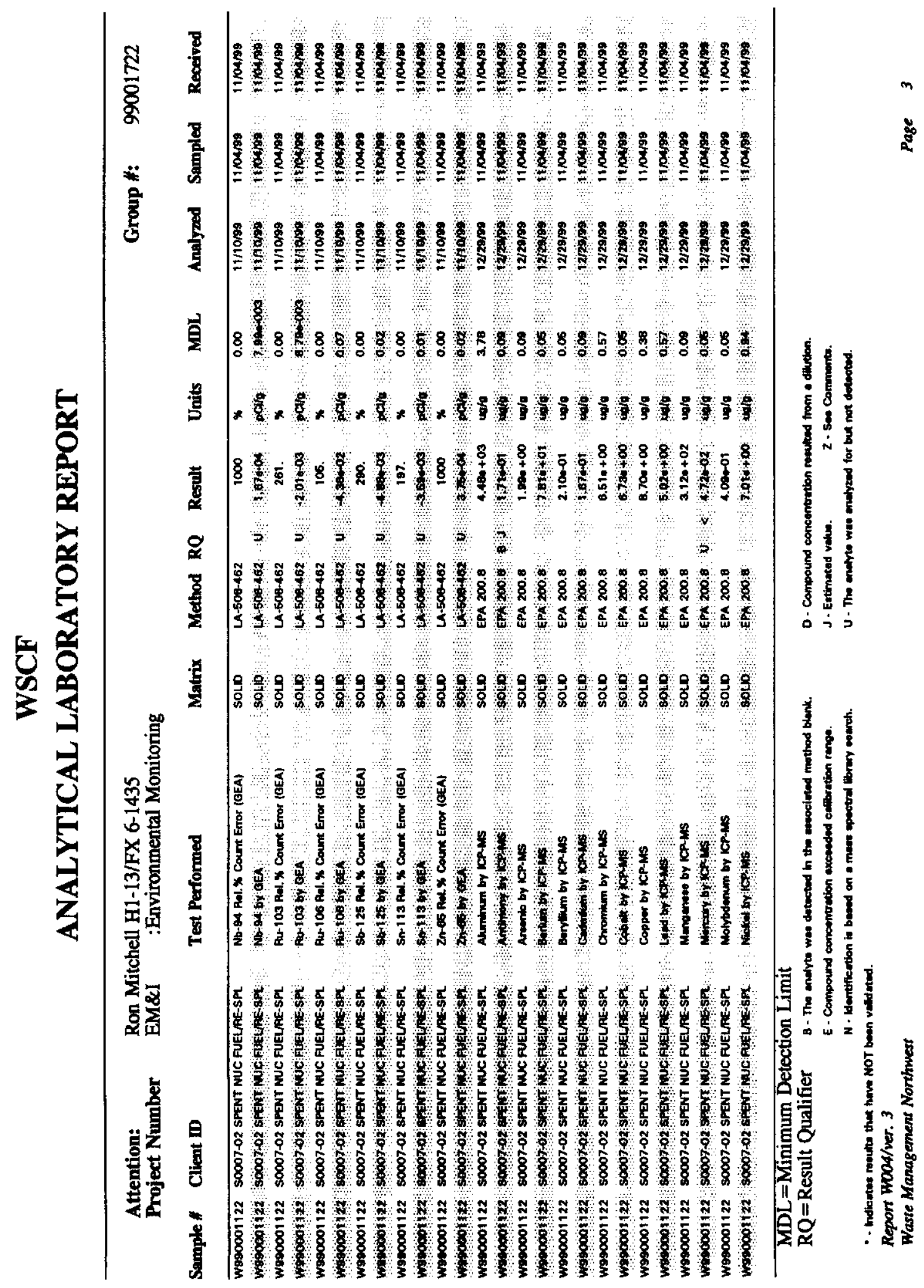


HNF-6150 Rev 0

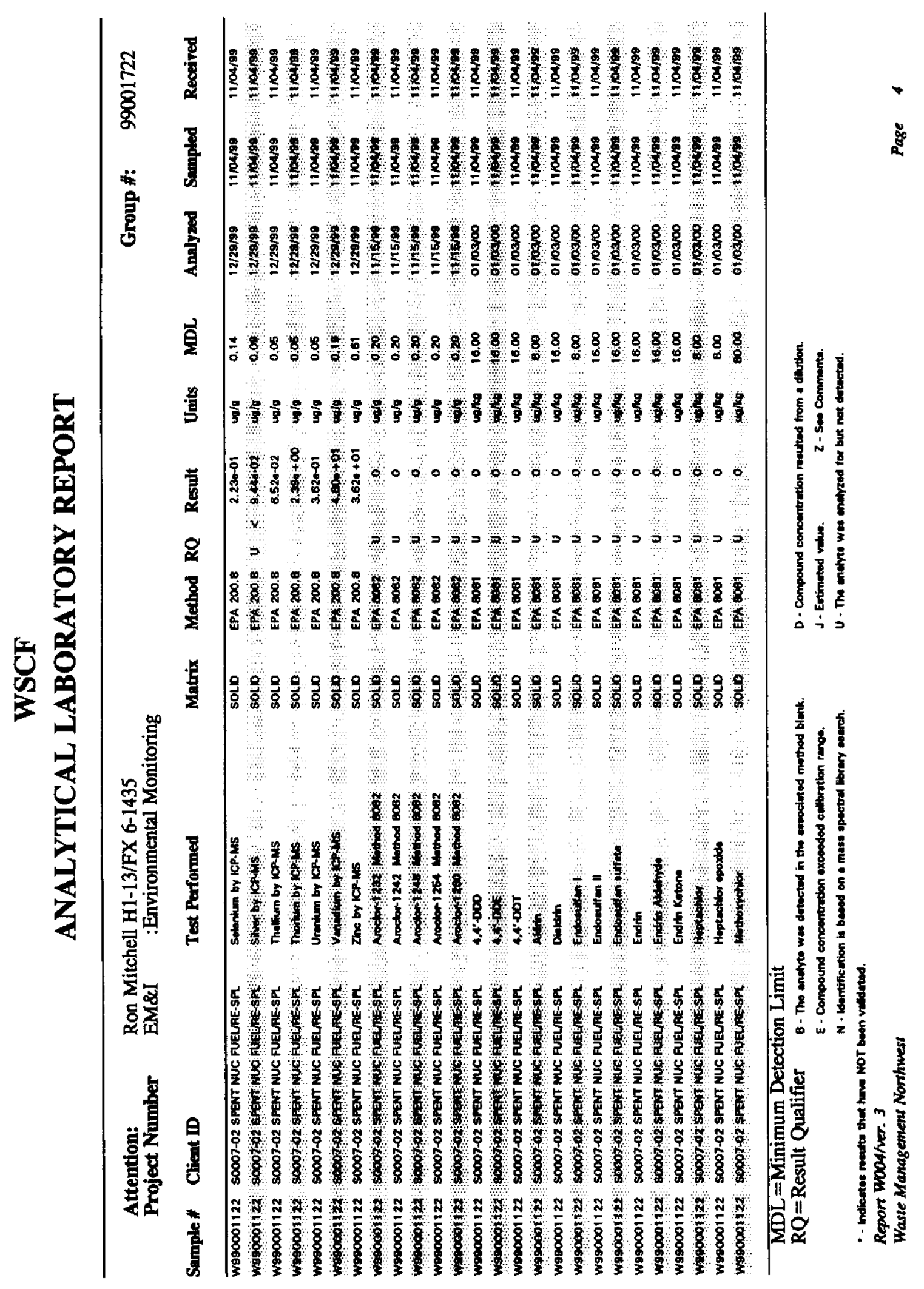


HNF-6150 Rev 0

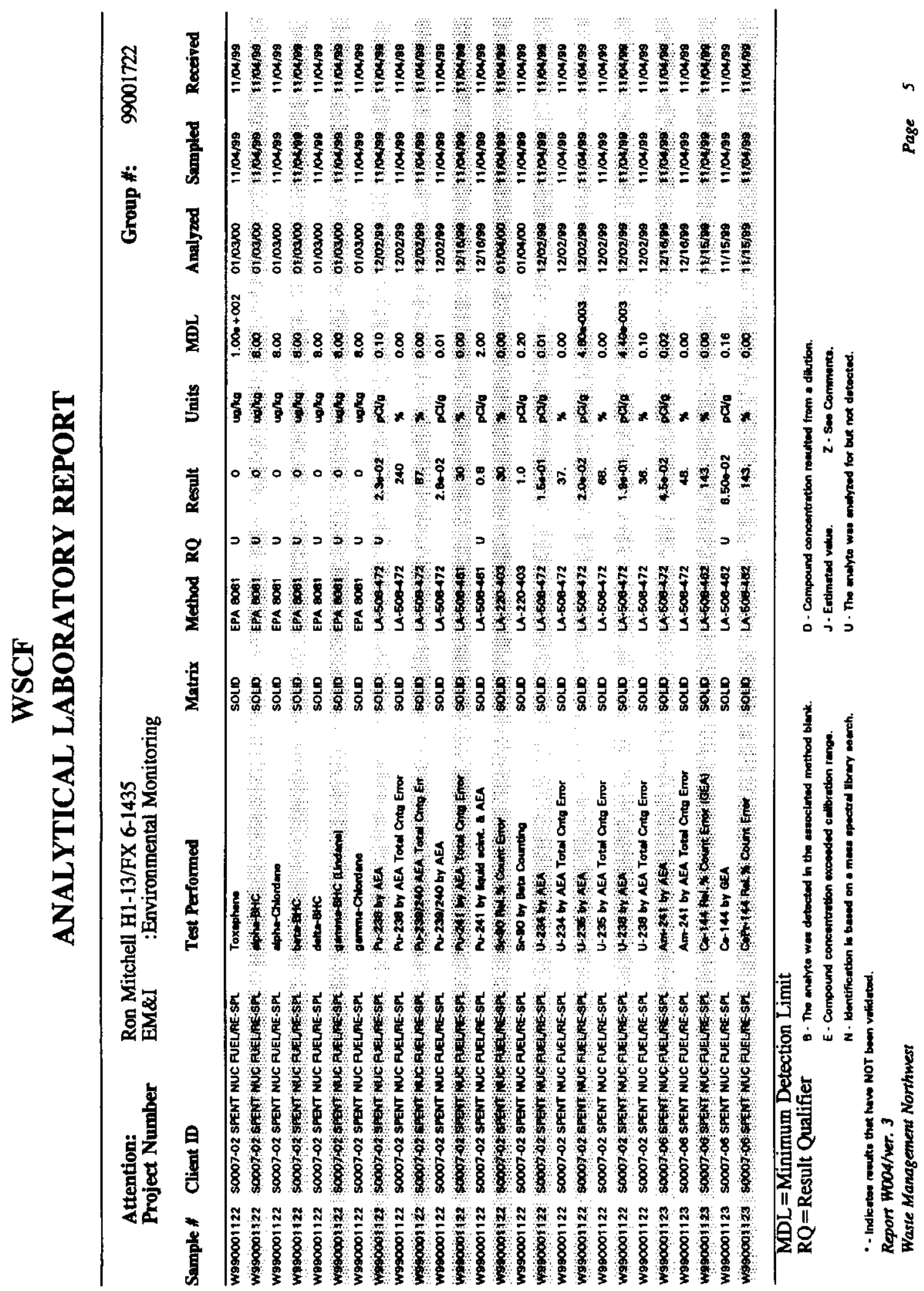


HNF-6150 Rev 0

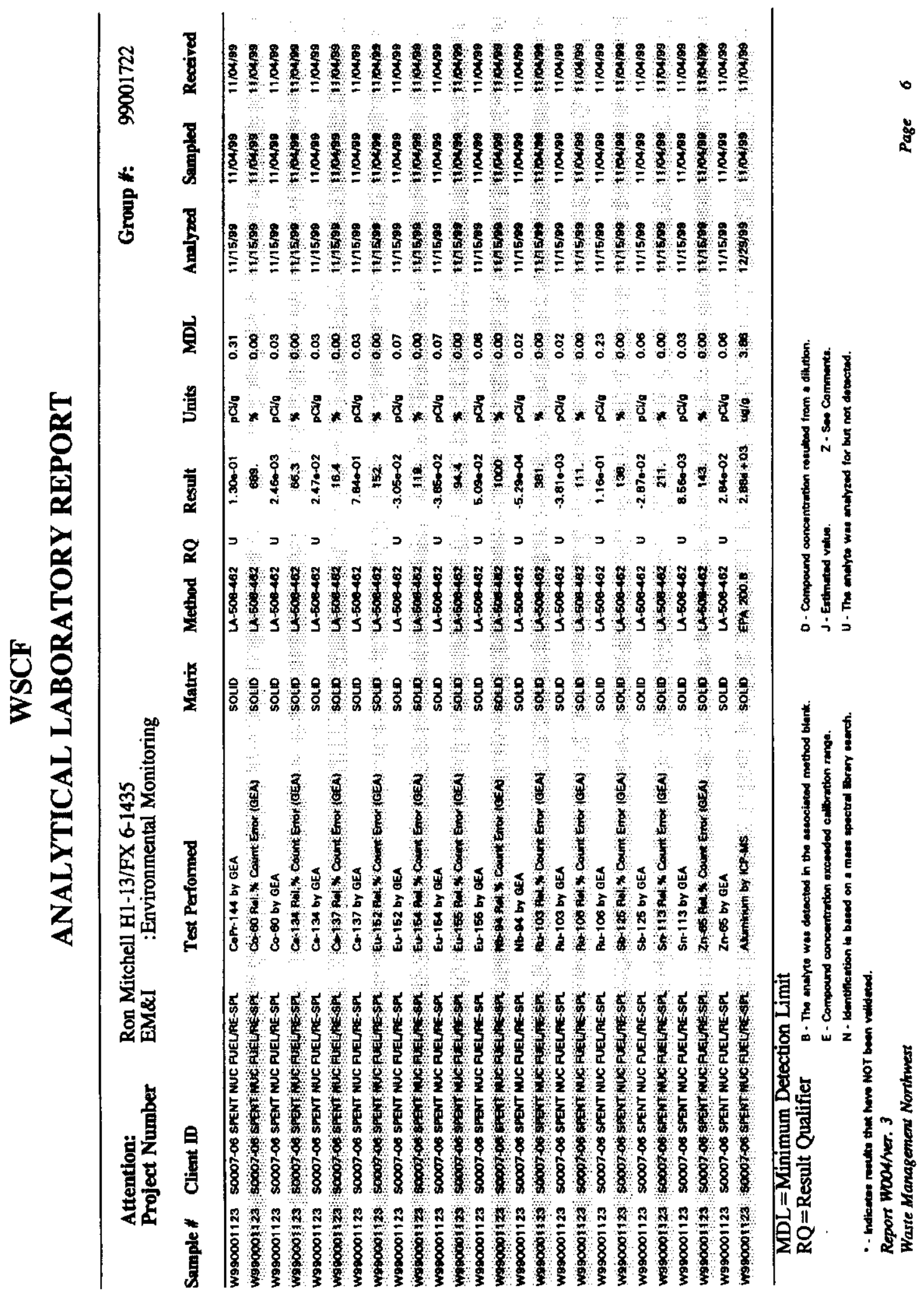


HNF-6150 Rev 0

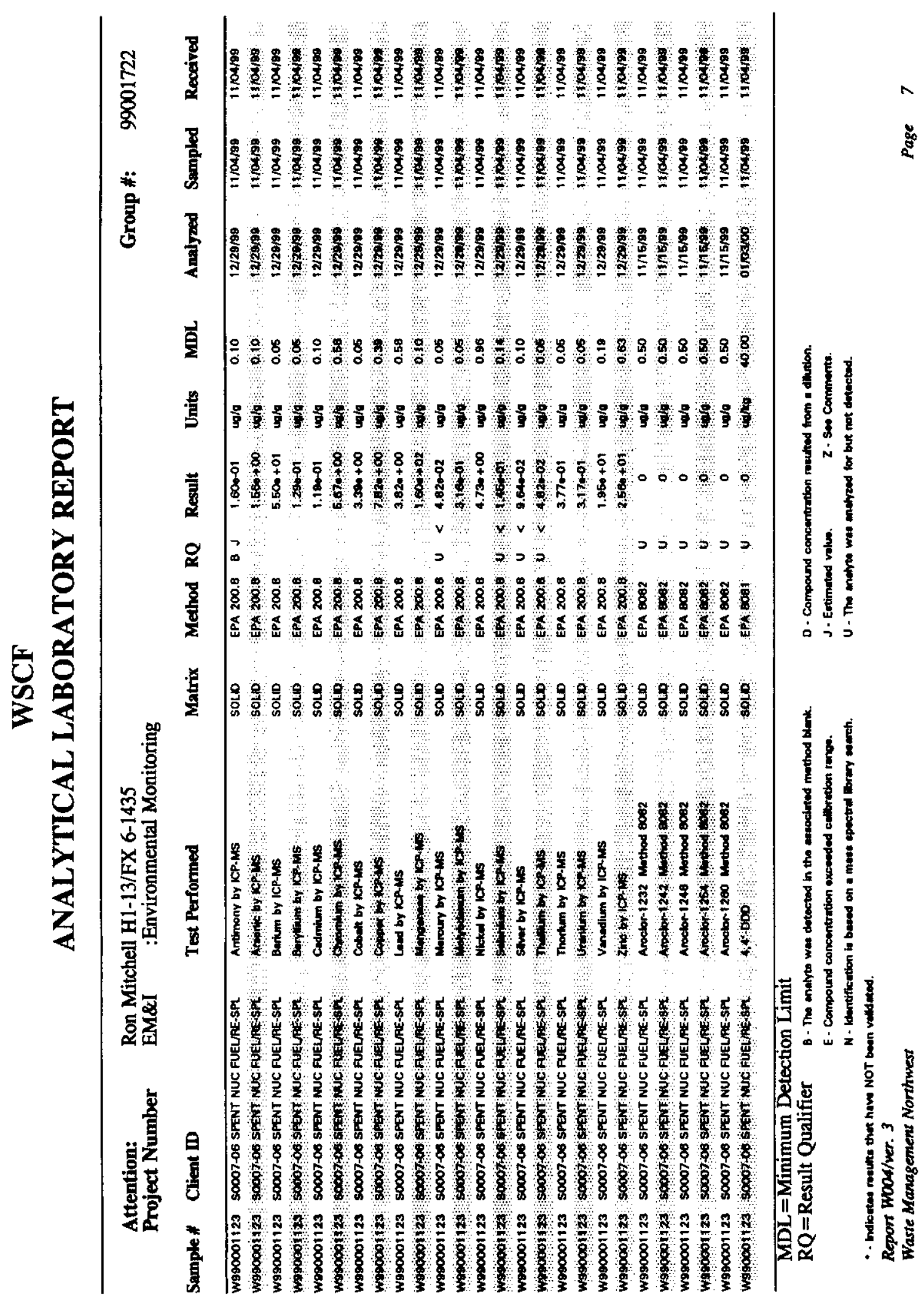


HNF-6150 Rev 0

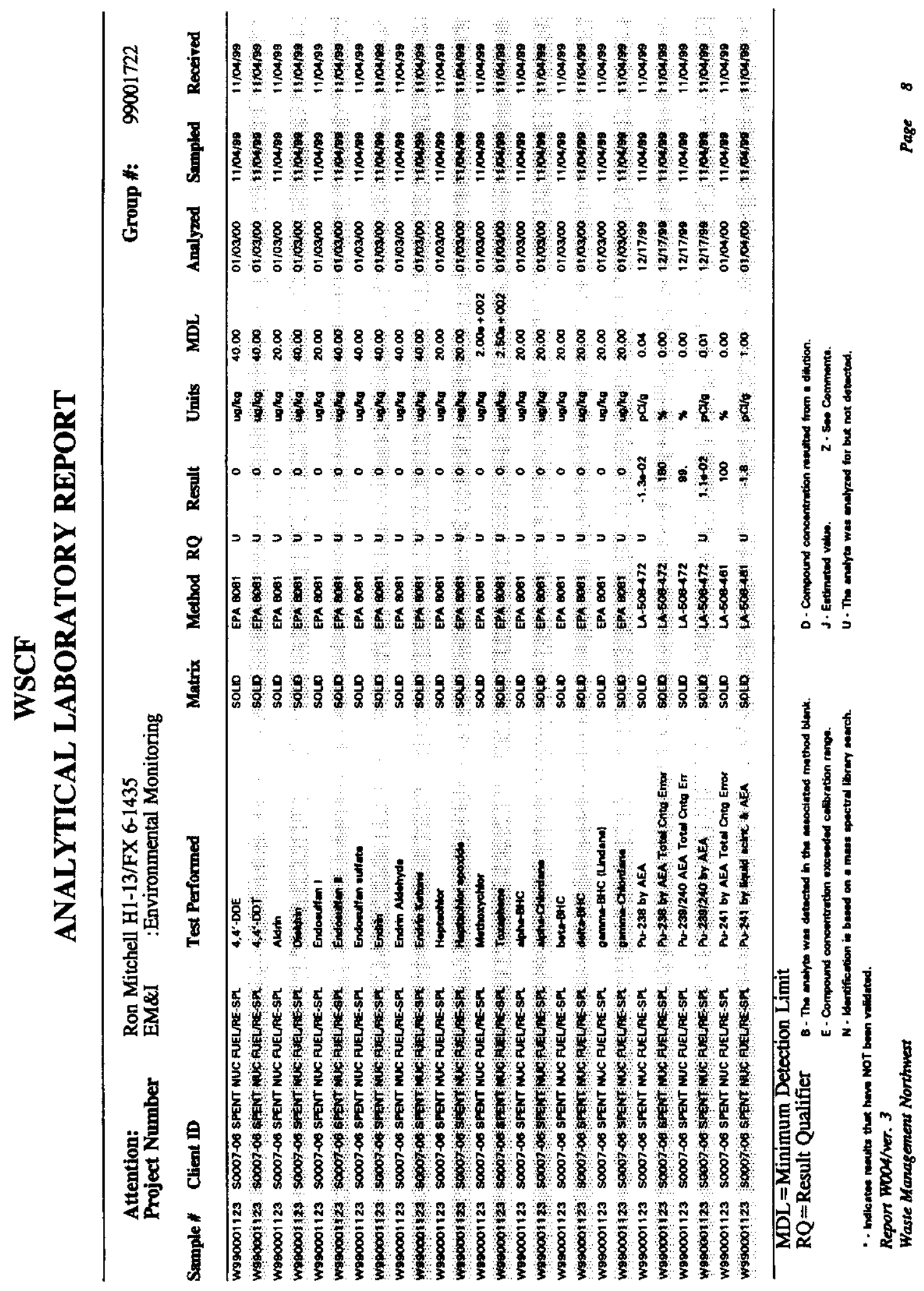


HNF-6150 Rev 0
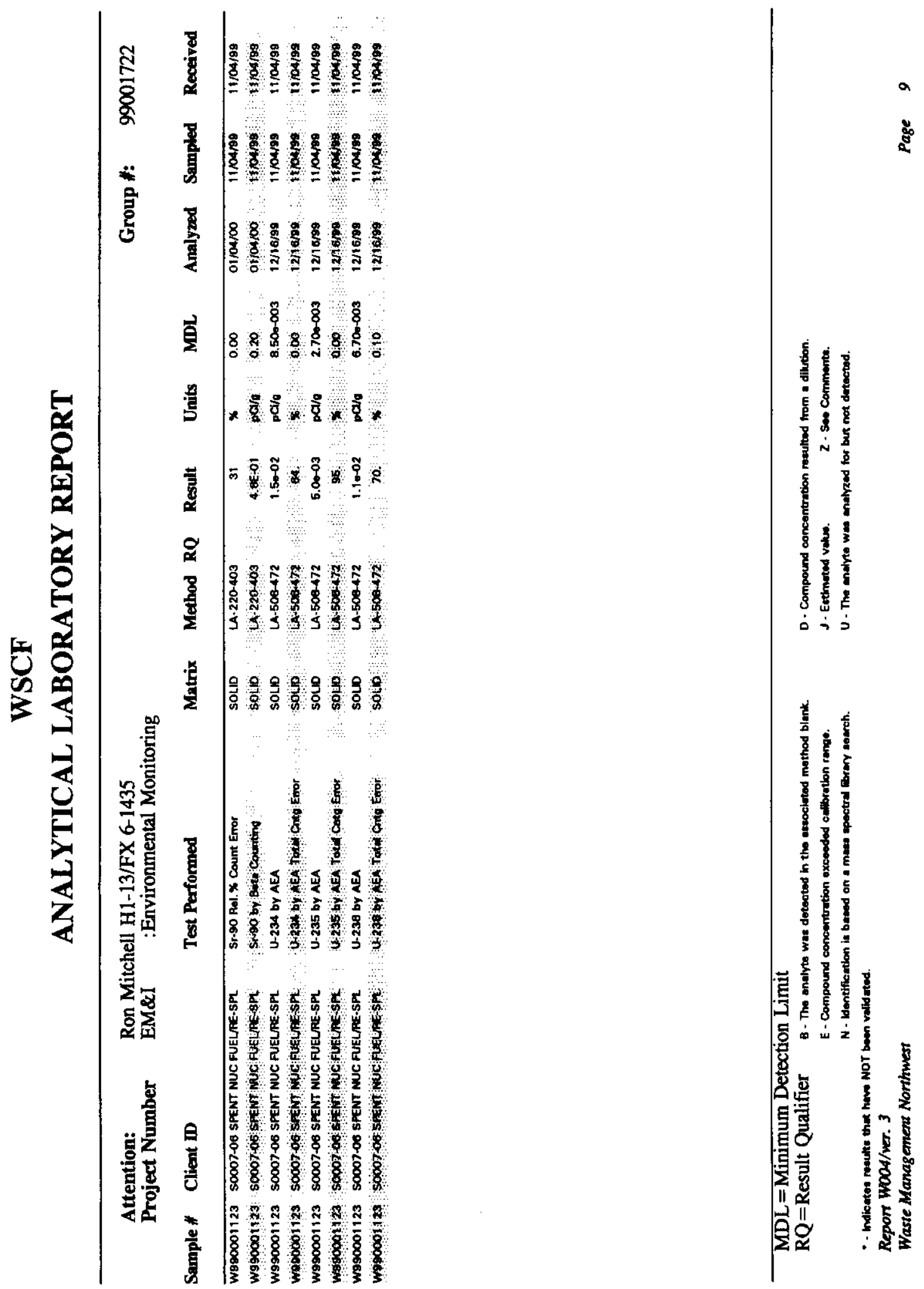
HNF-6150 Rev 0
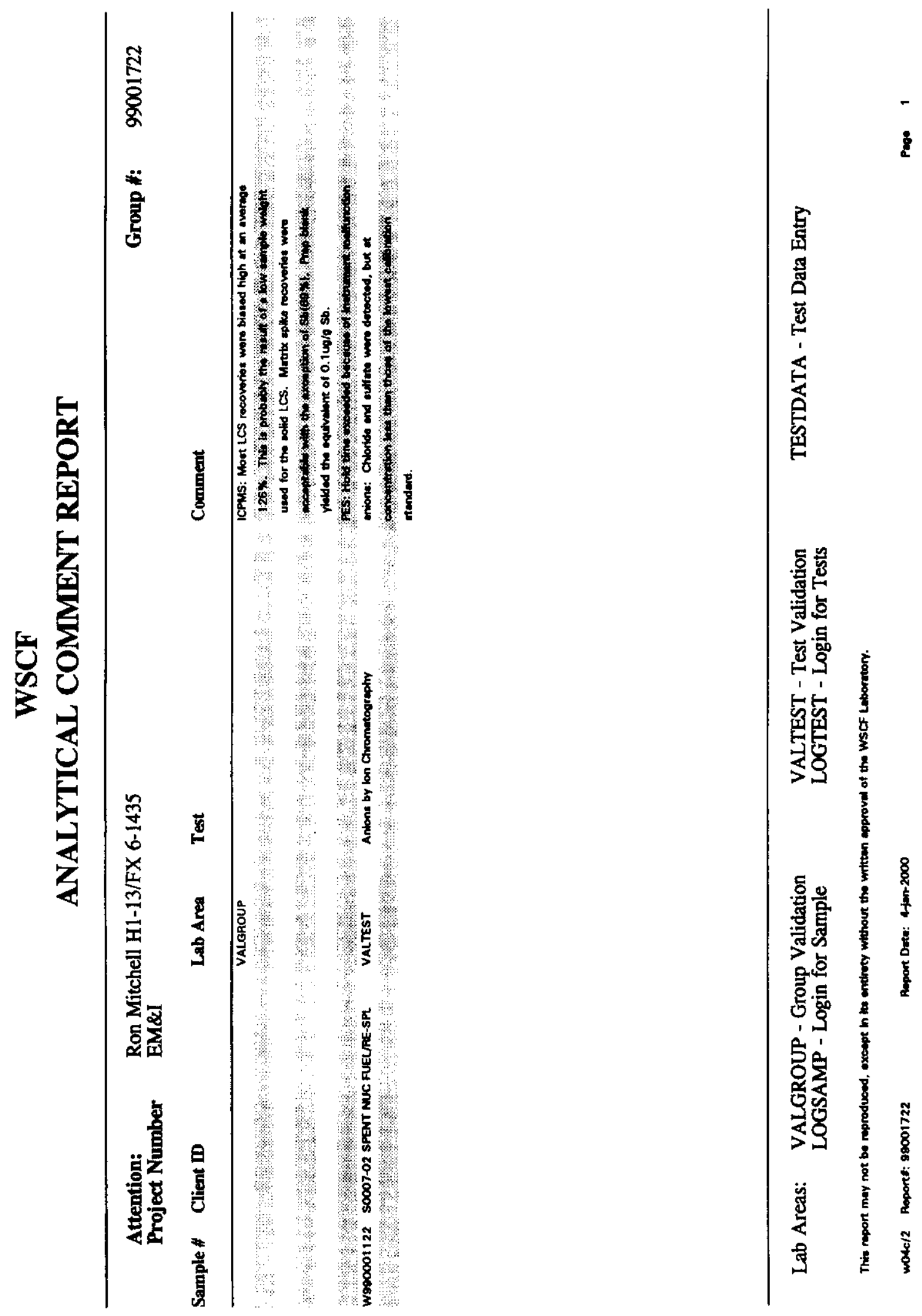
HNF-6150 Rev 0
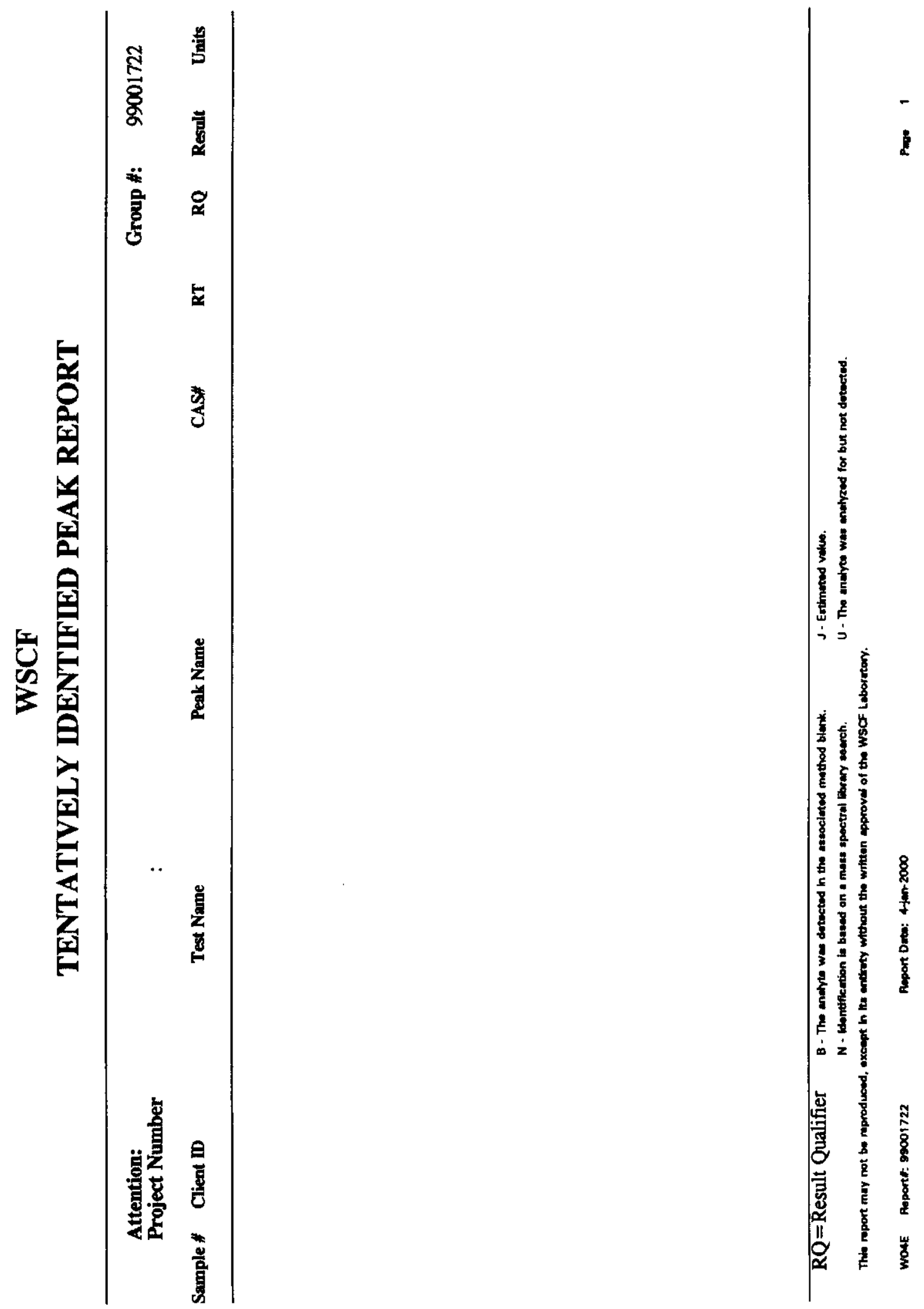
HNF-6150 Rev 0

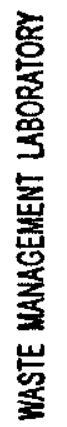
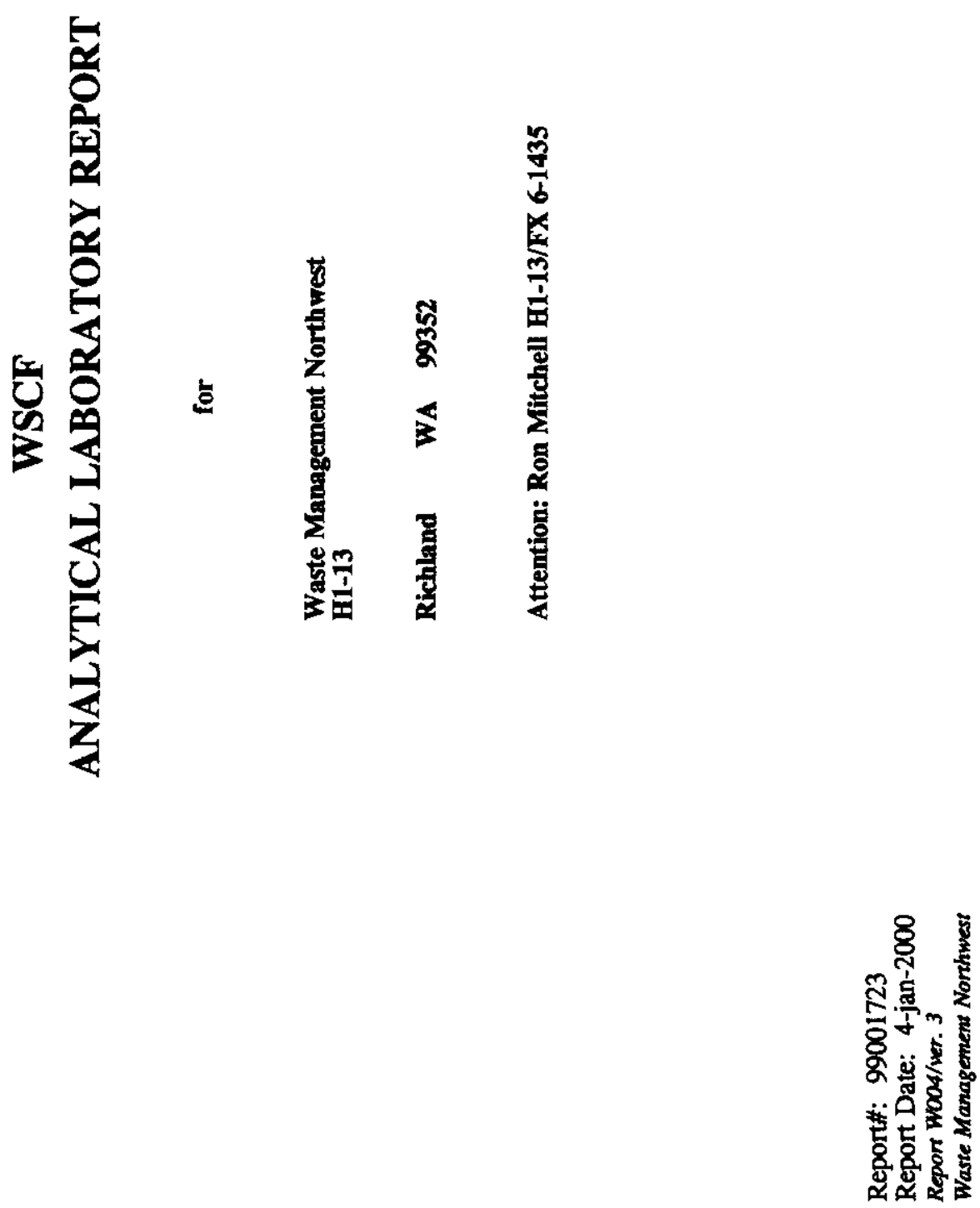

C-151 


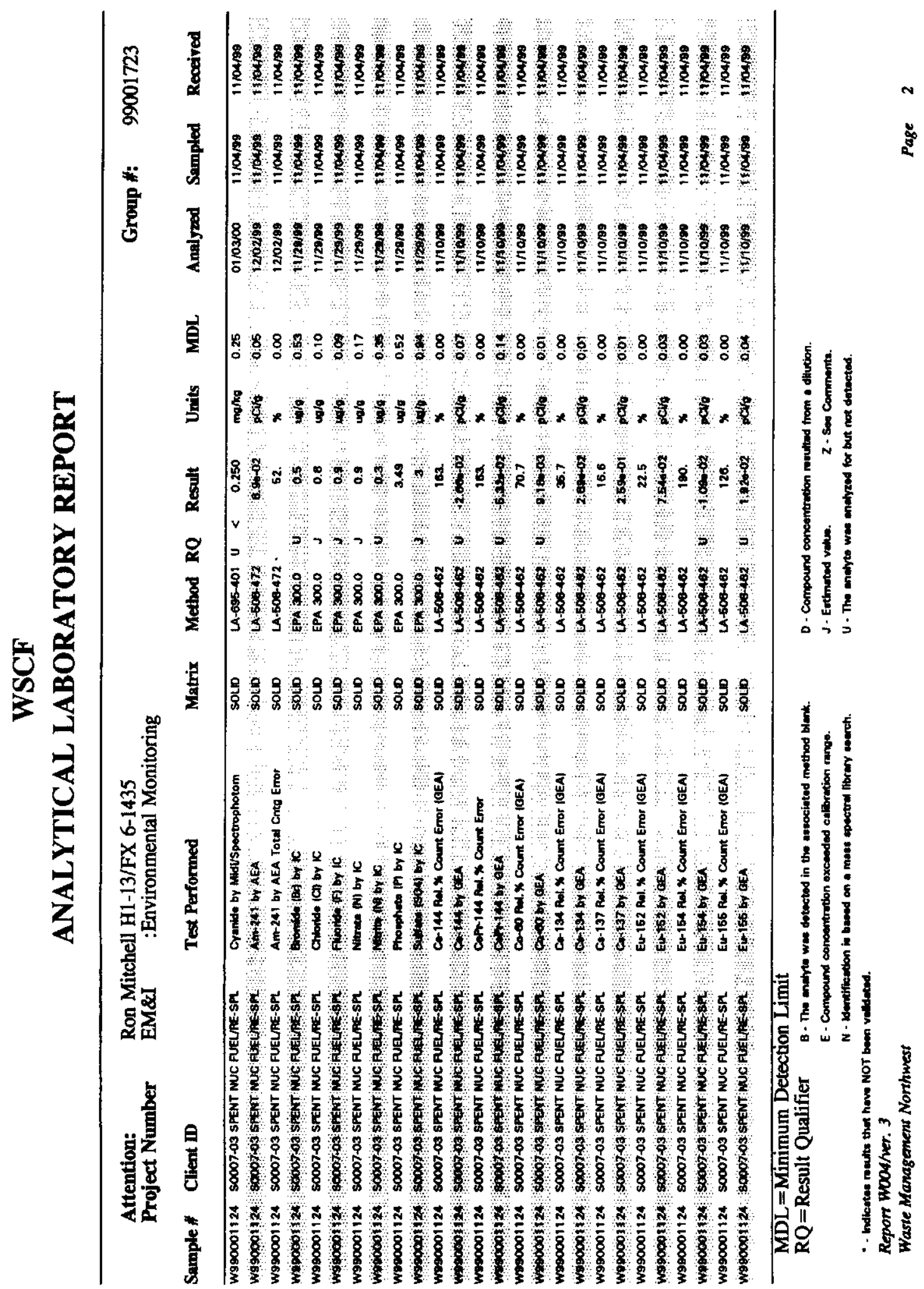


HNF-6150 Rev 0

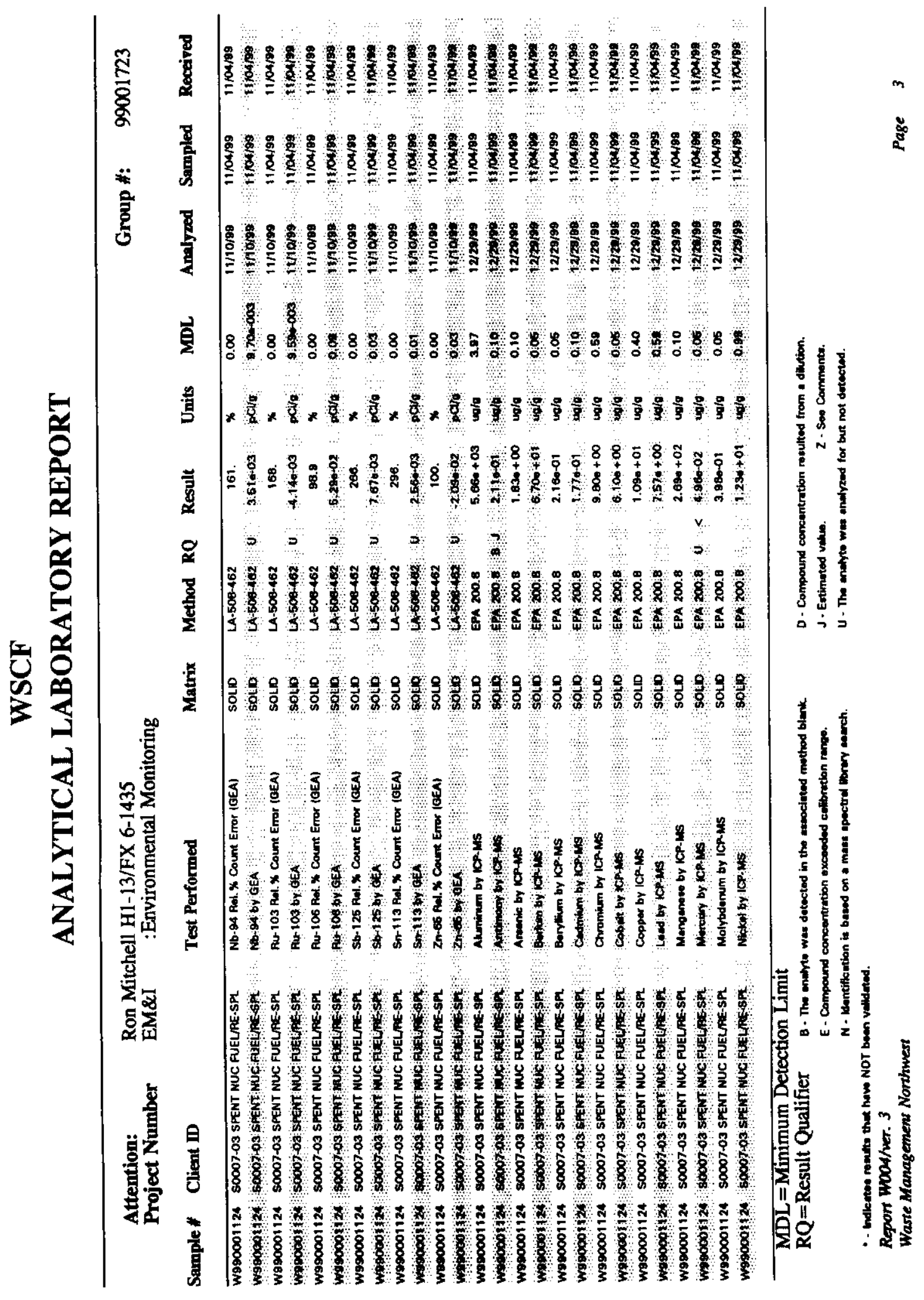


HNF-6150 Rev 0

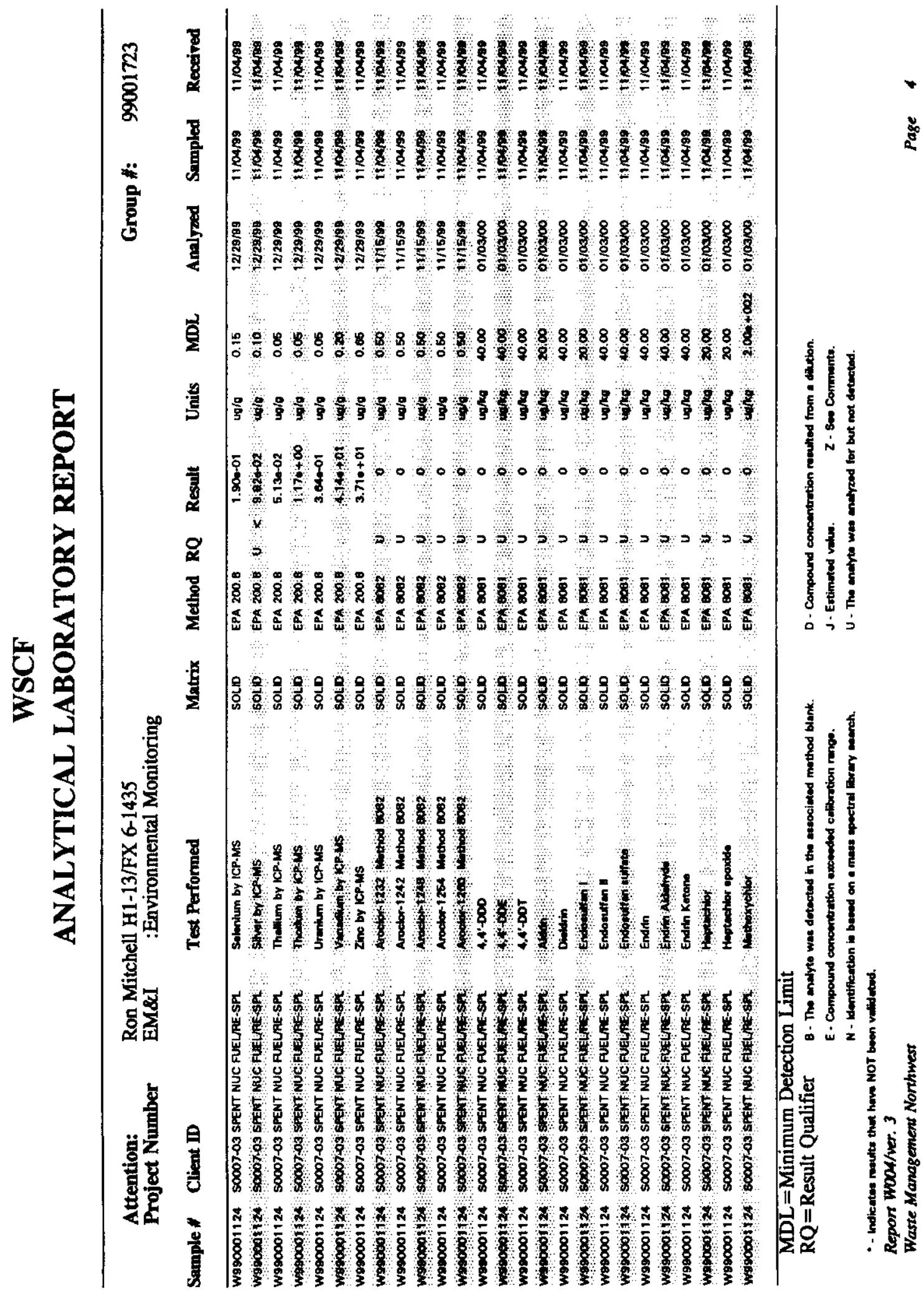


HNF-6150 Rev 0

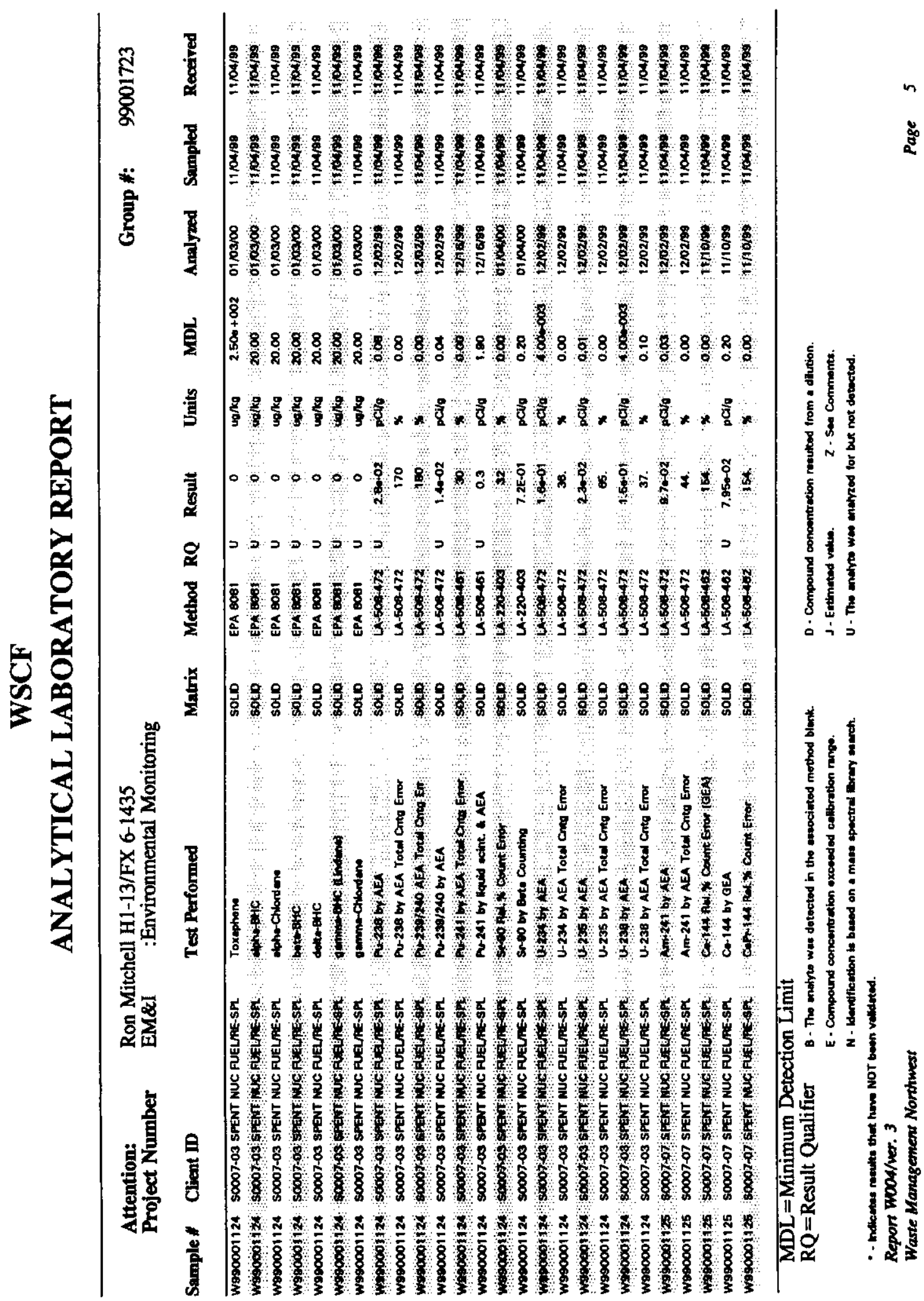


HNF-6150 Rev 0

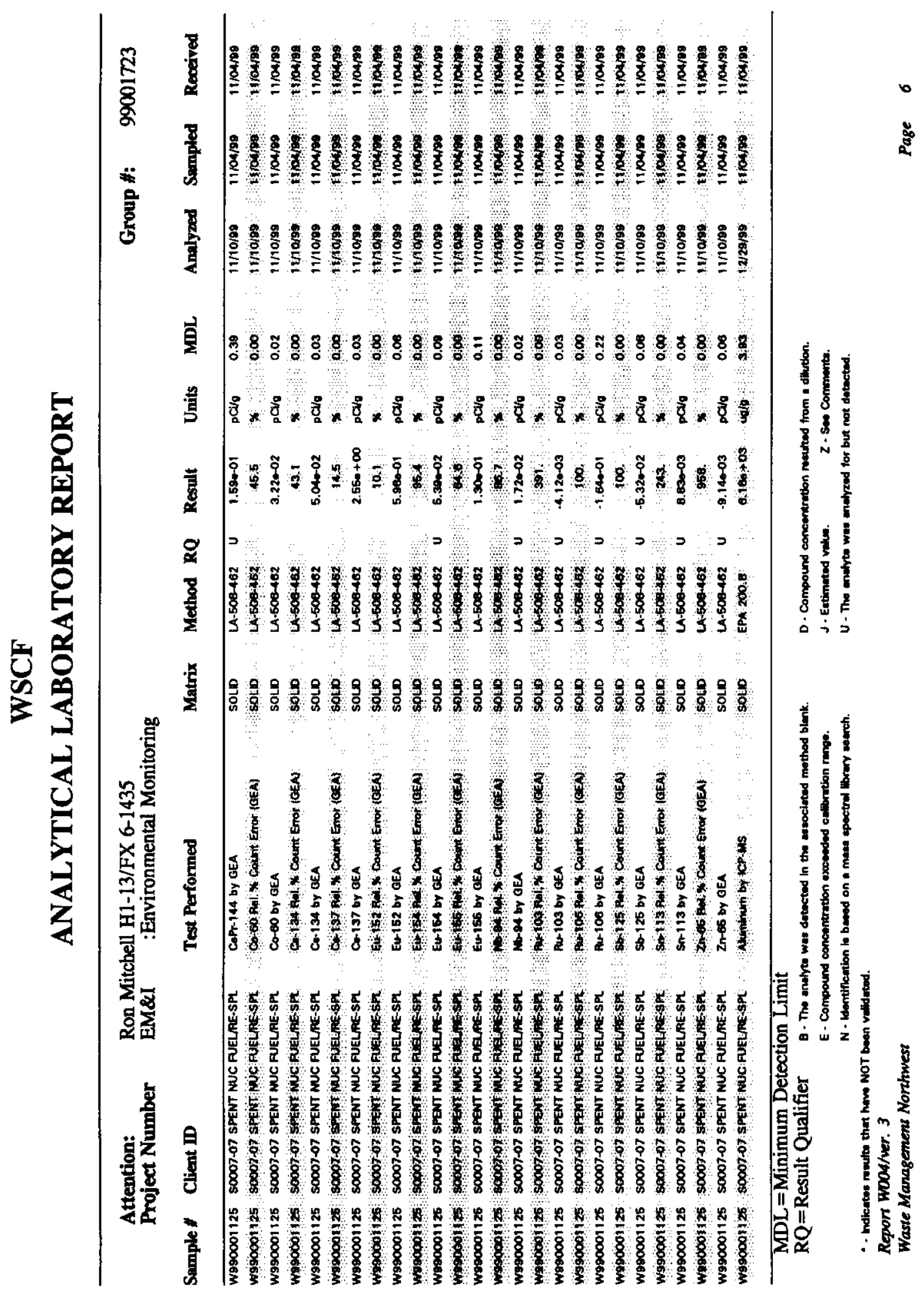


HNF-6150 Rev 0

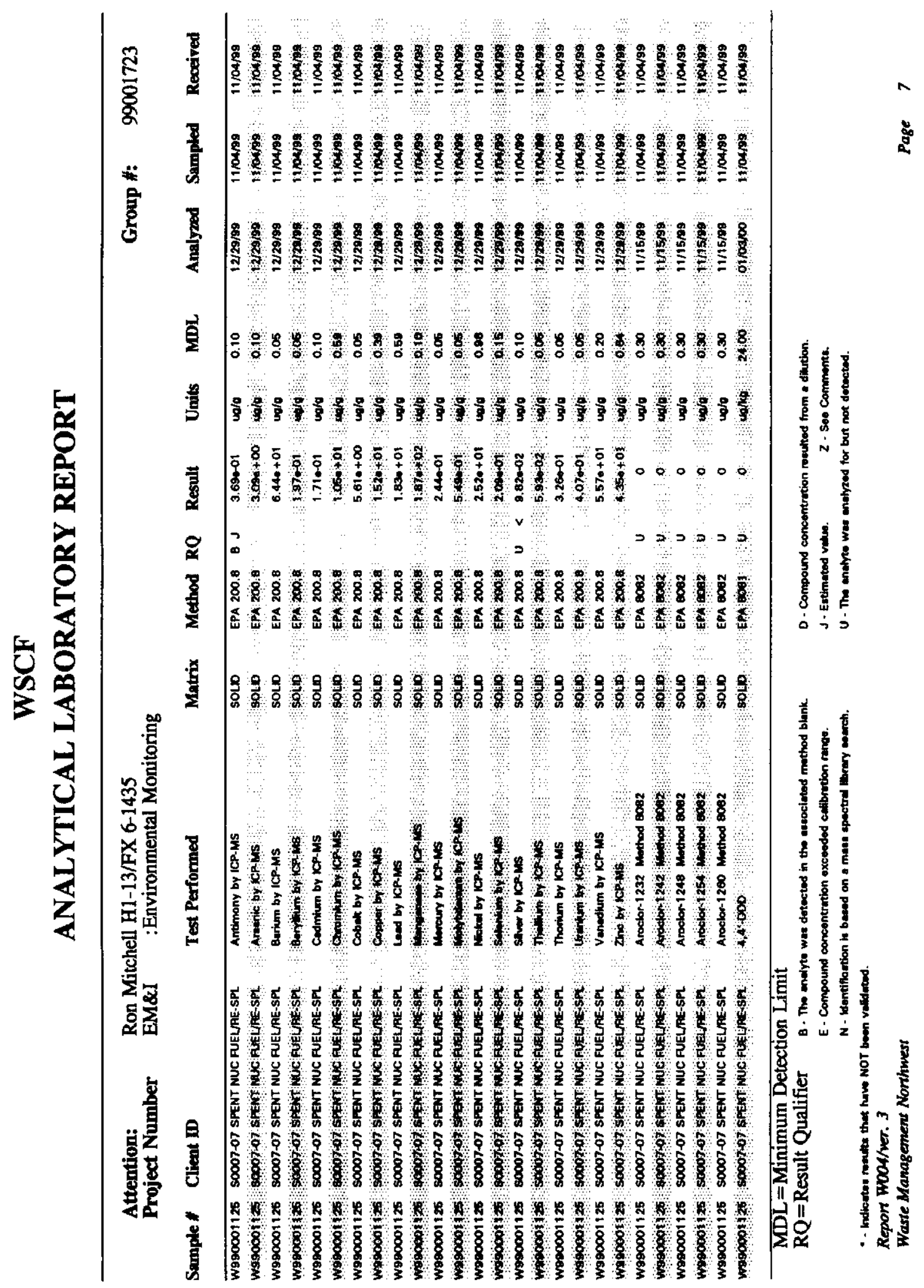


HNF-6150 Rev 0

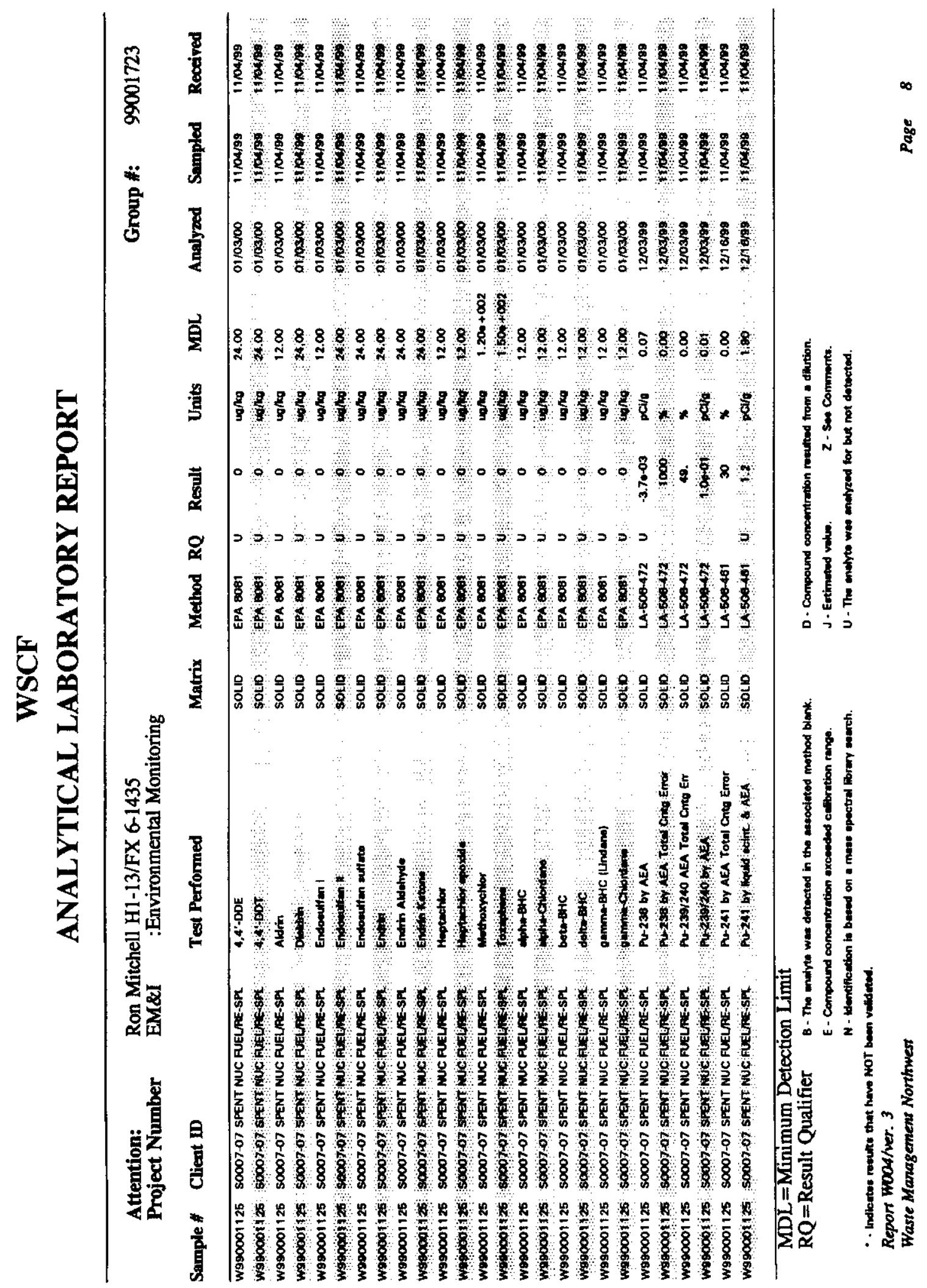


HNF-6150 Rev 0

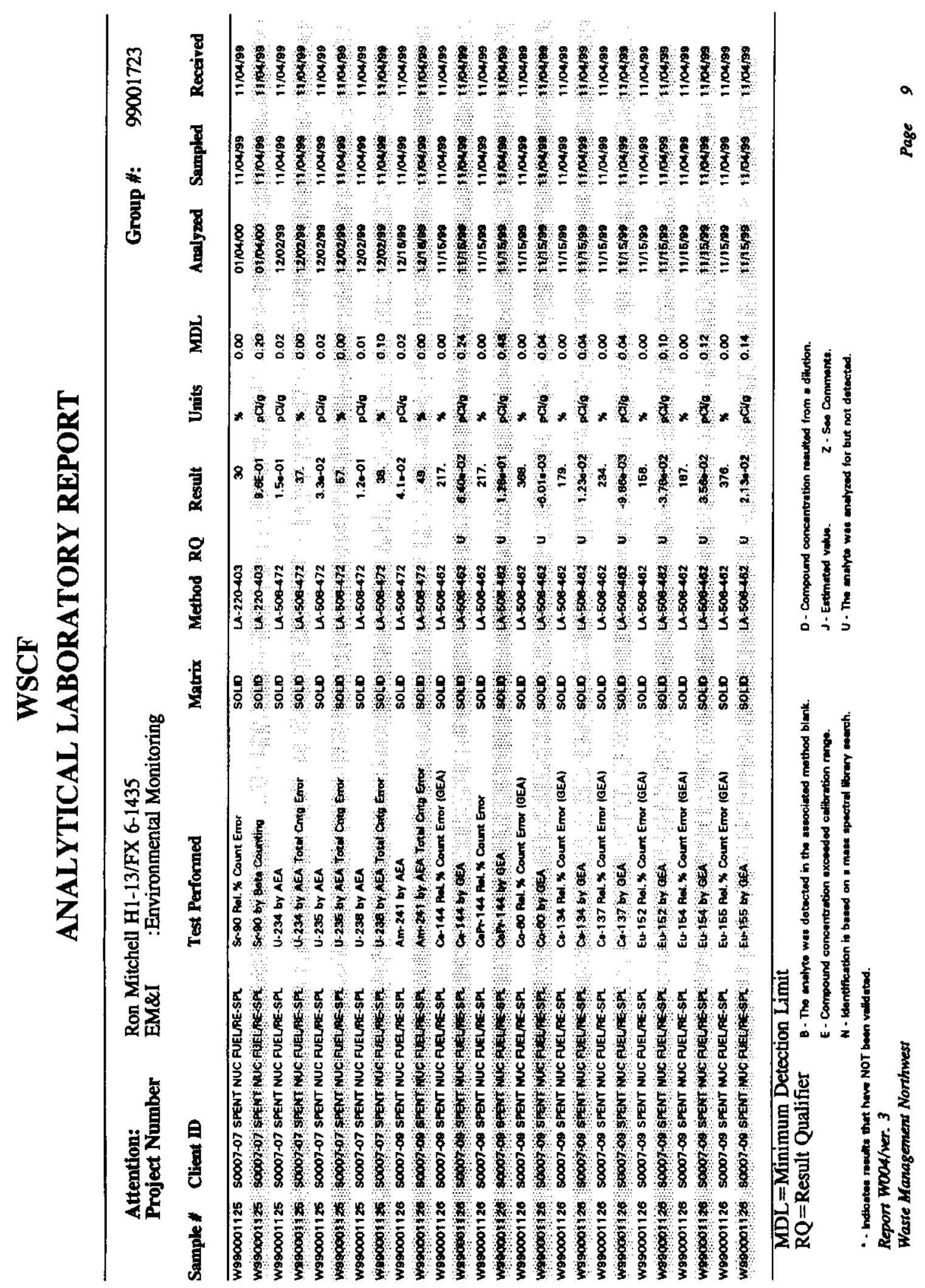


HNF-6150 Rev 0

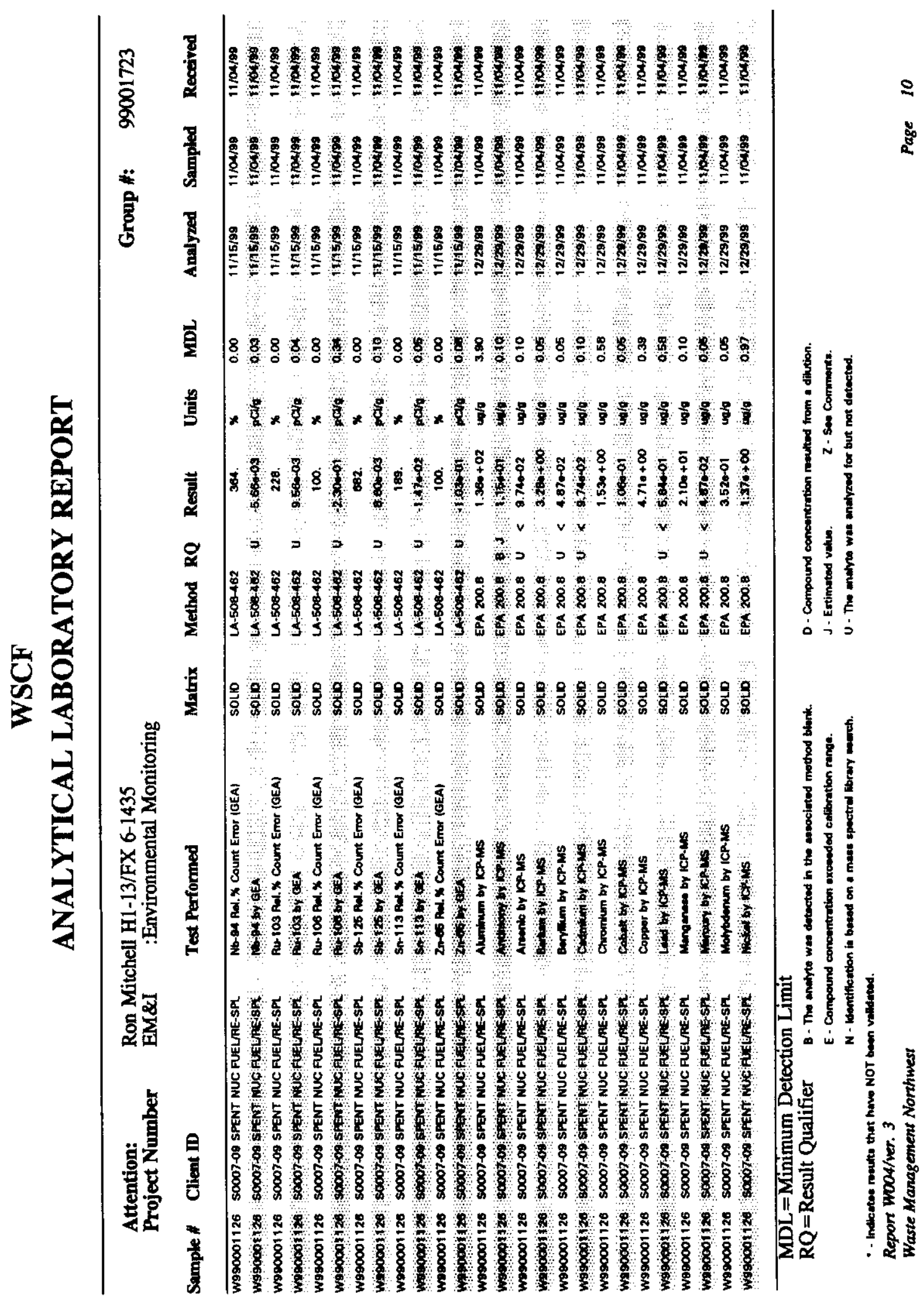




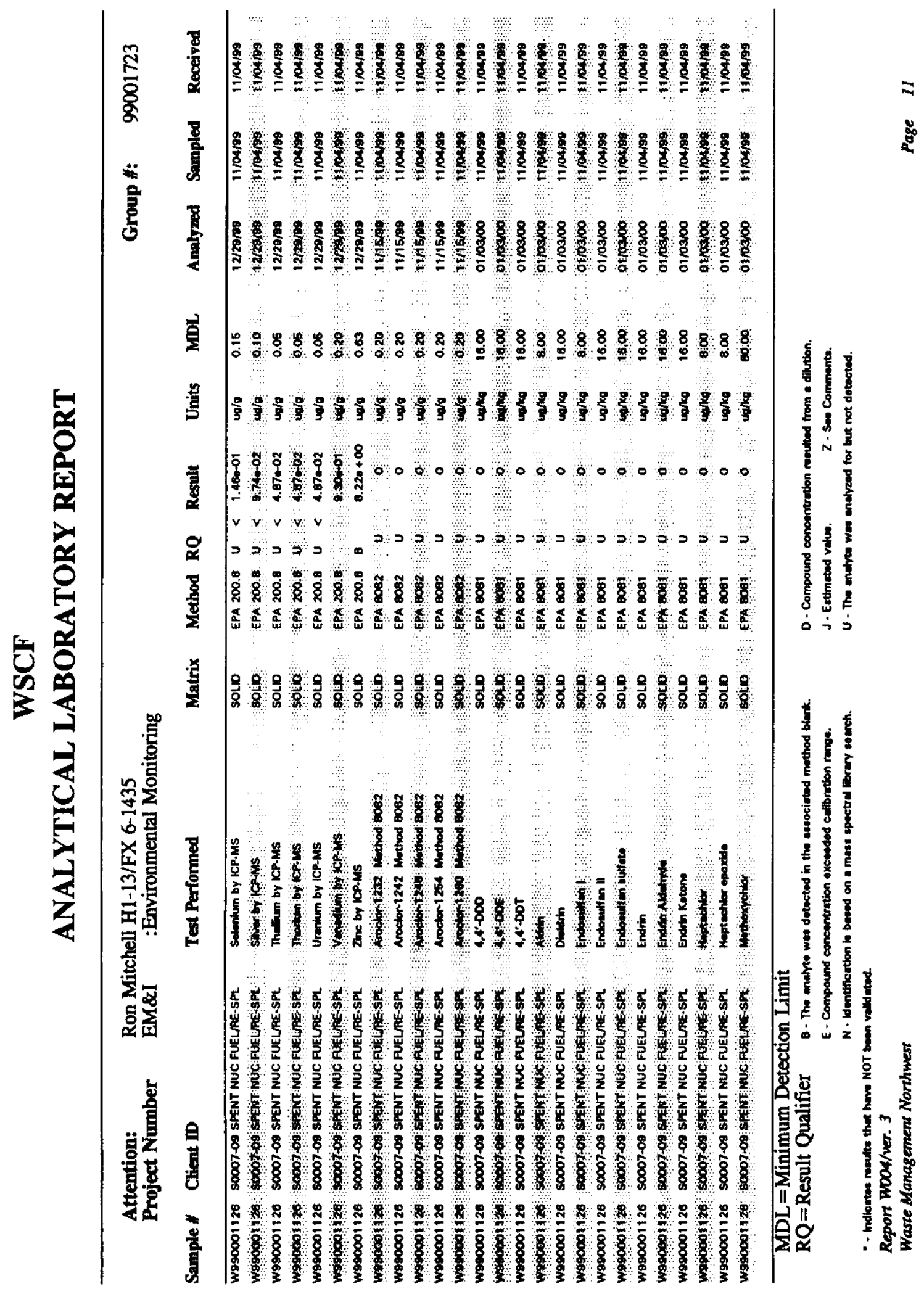


HNF-6150 Rev 0

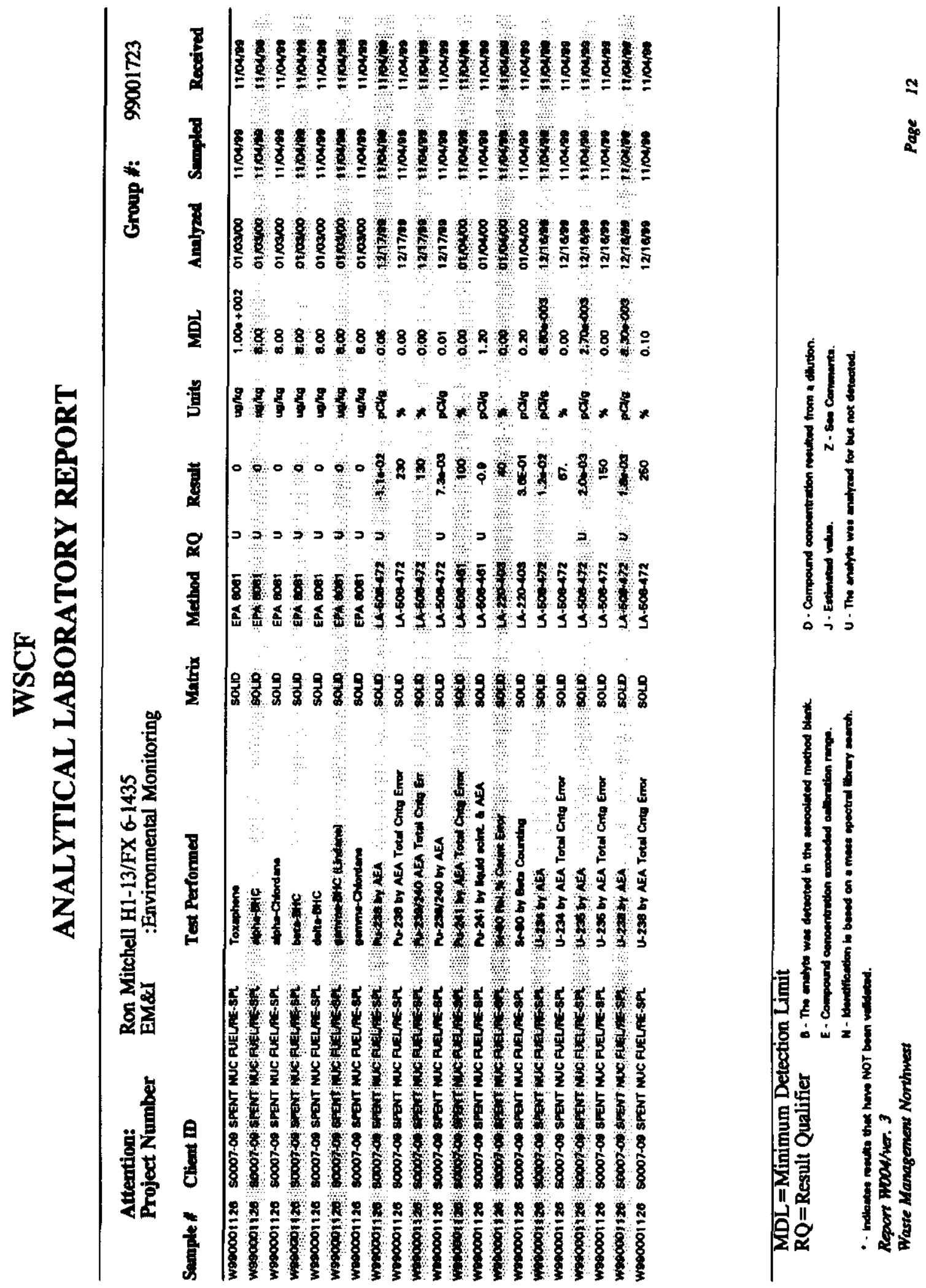


HNF-6150 Rev 0
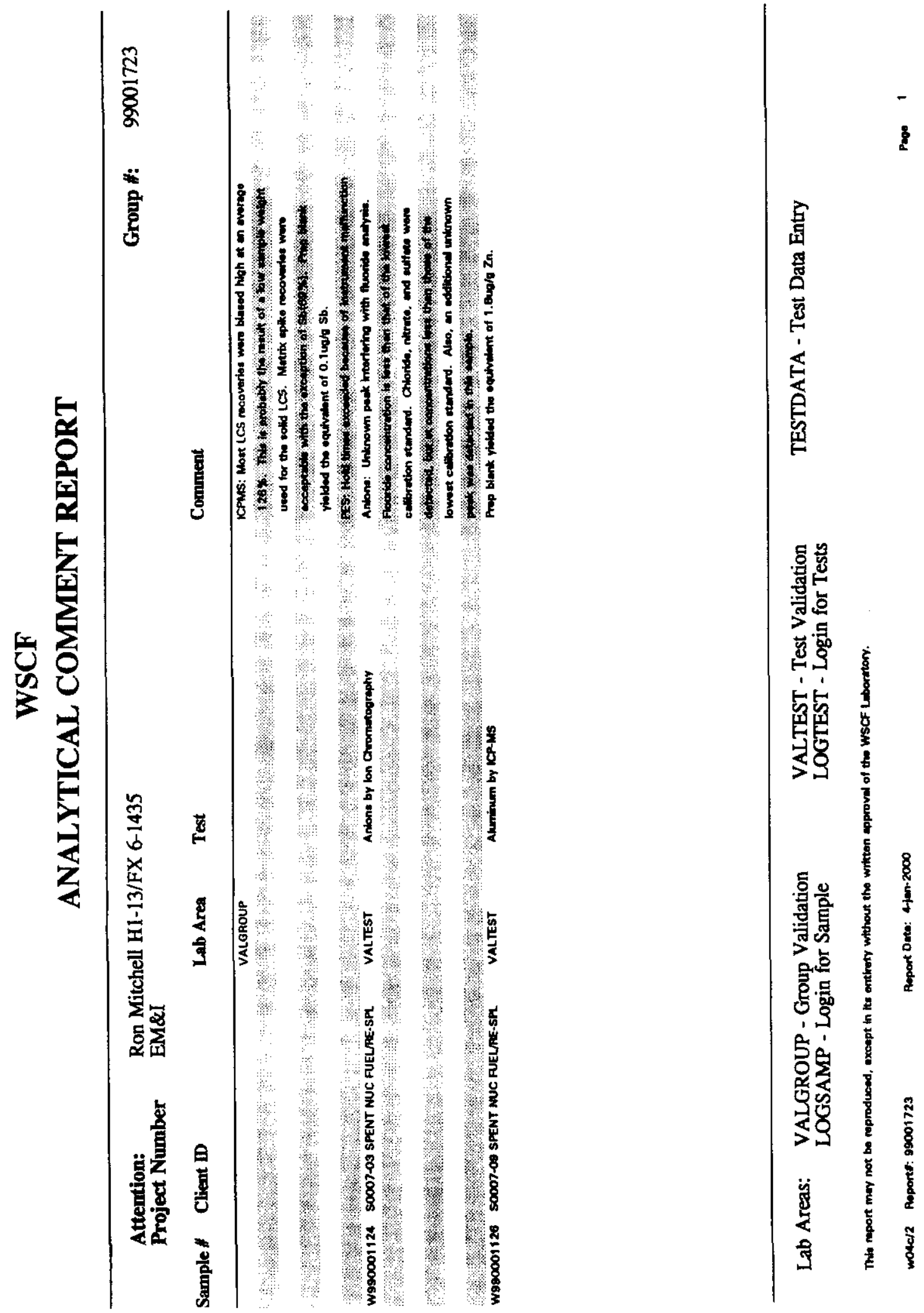
HNF-6150 Rev 0
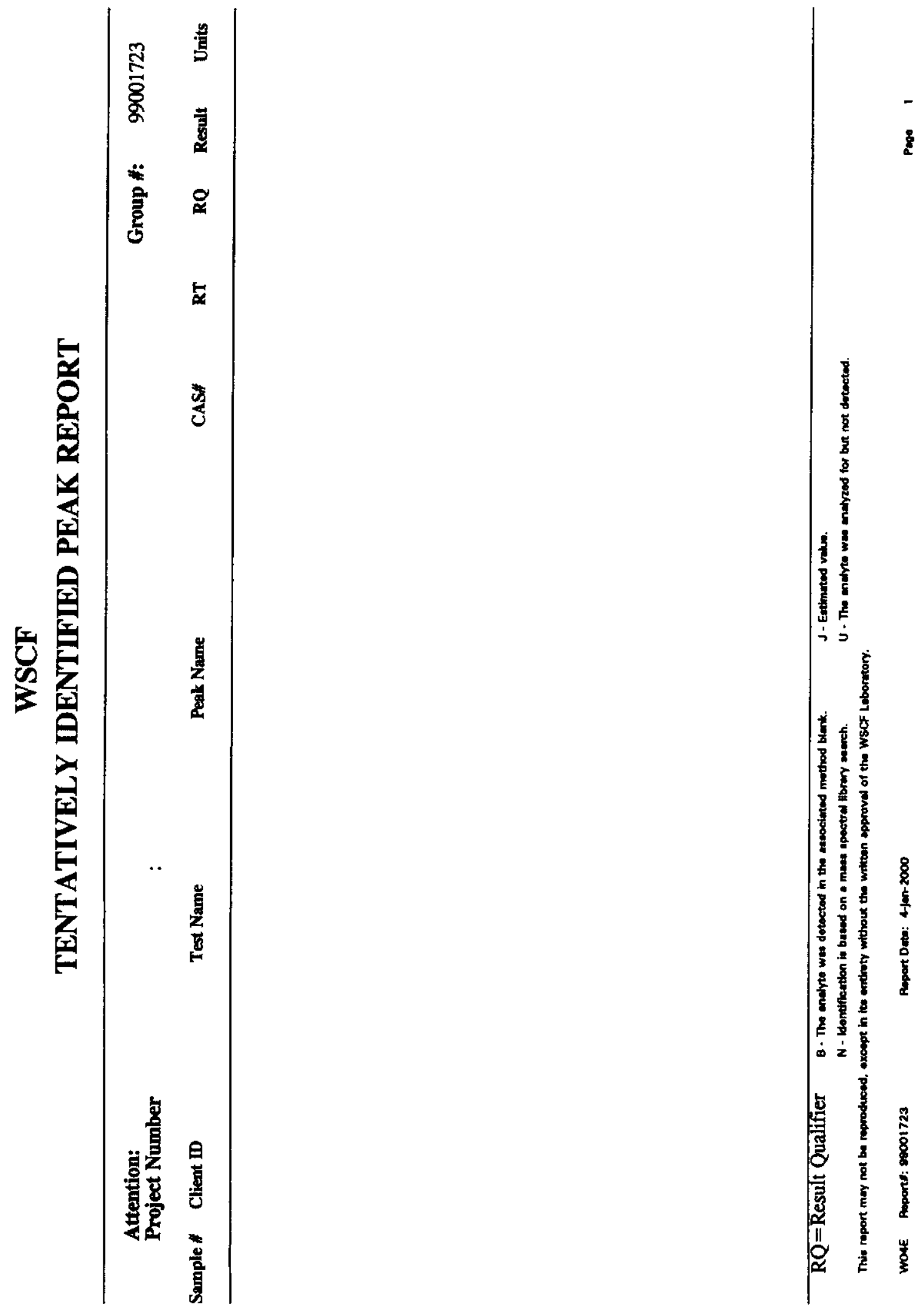


\section{HNF-6150 Rev 0}

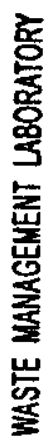
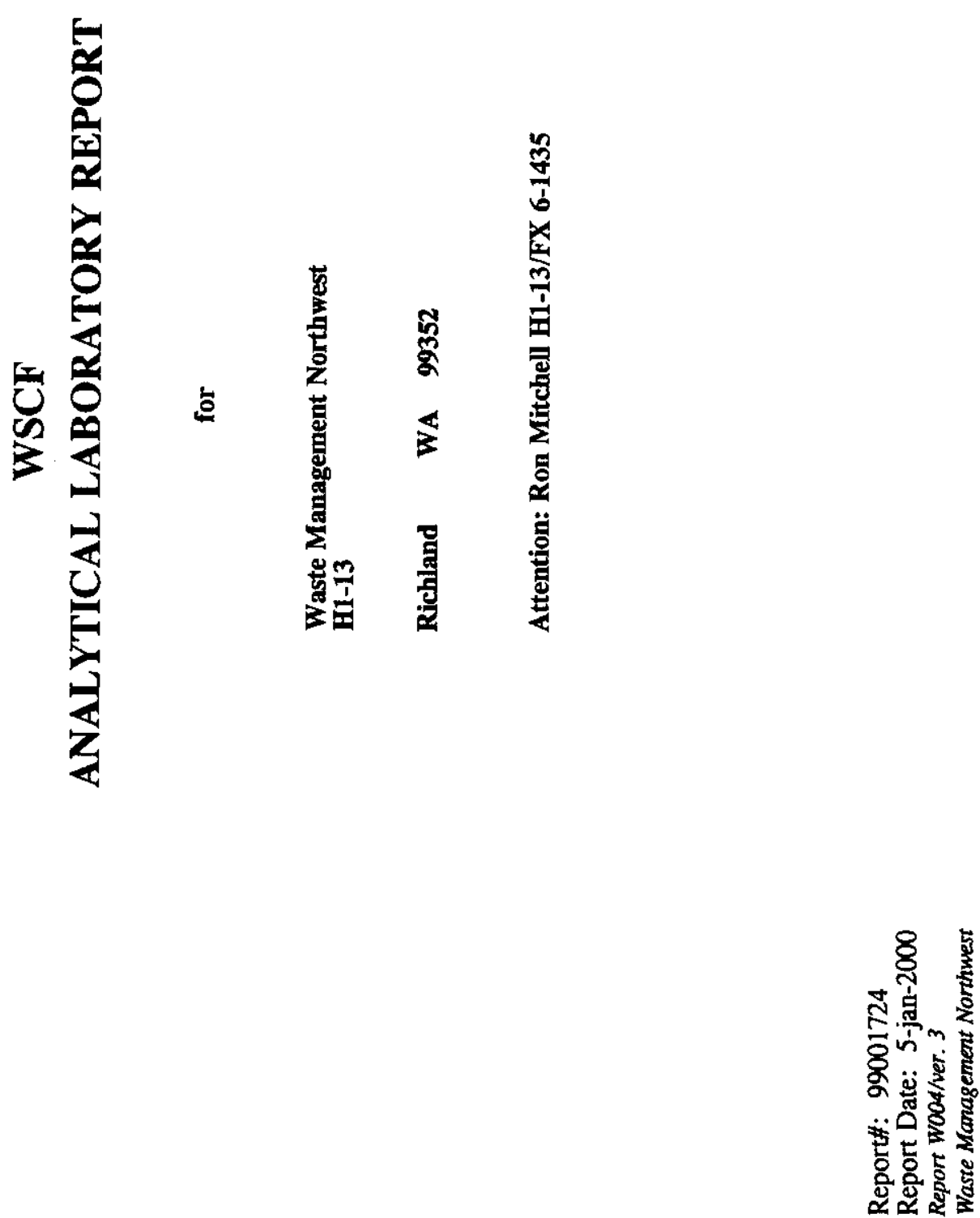

C-165 
HNF-6150 Rev 0

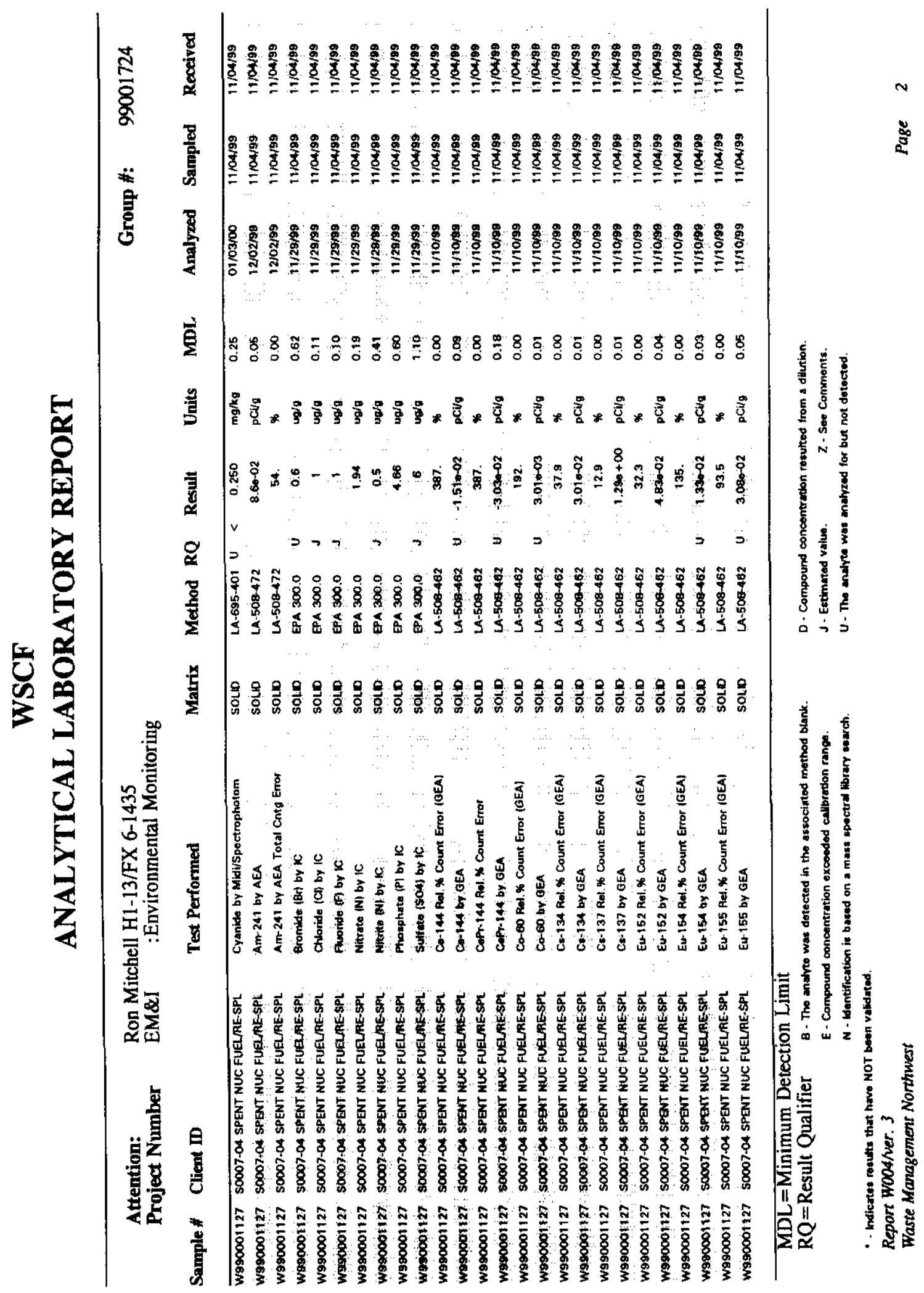


HNF-6150 Rev 0

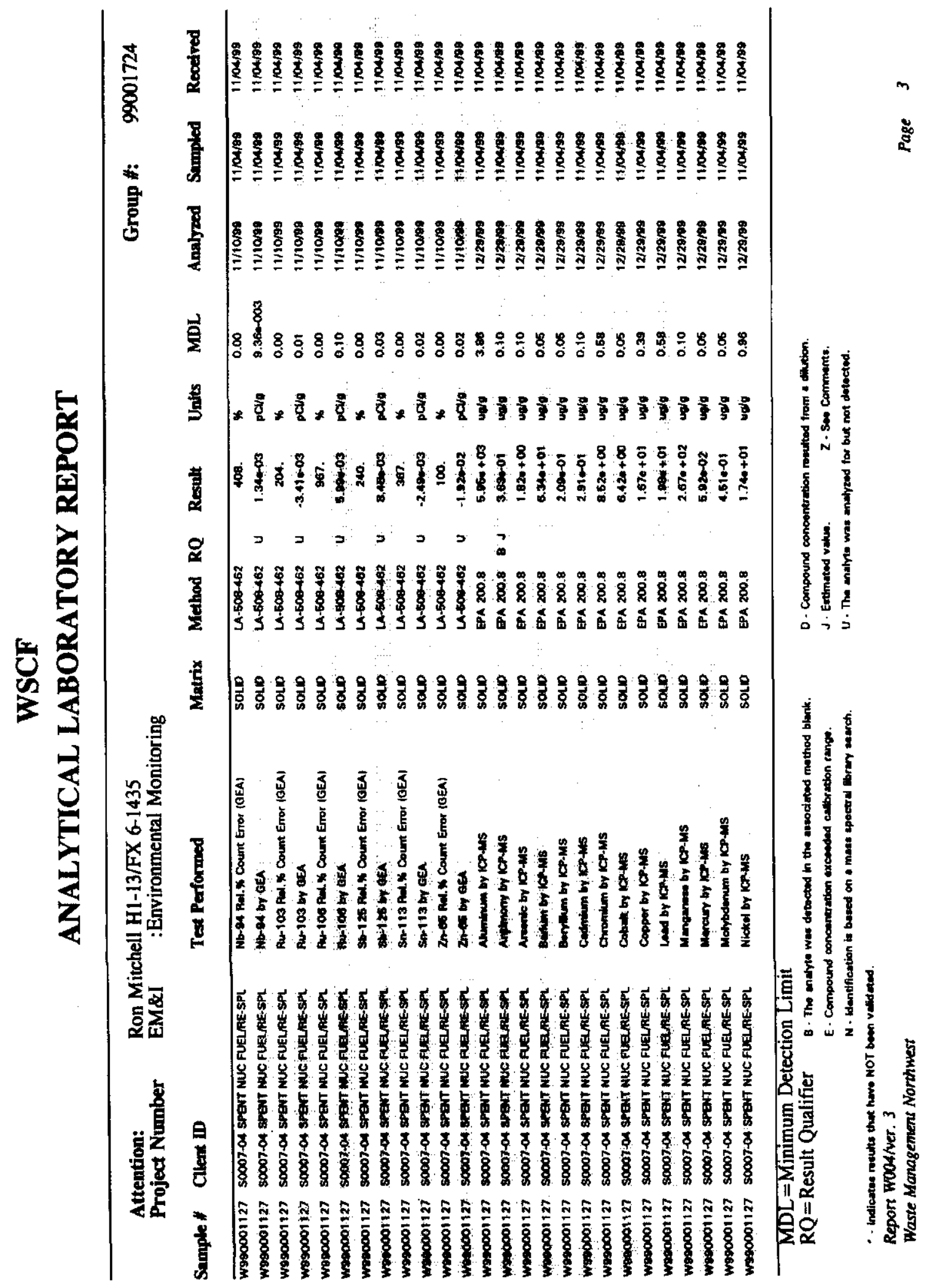


HNF-6150 Rev 0

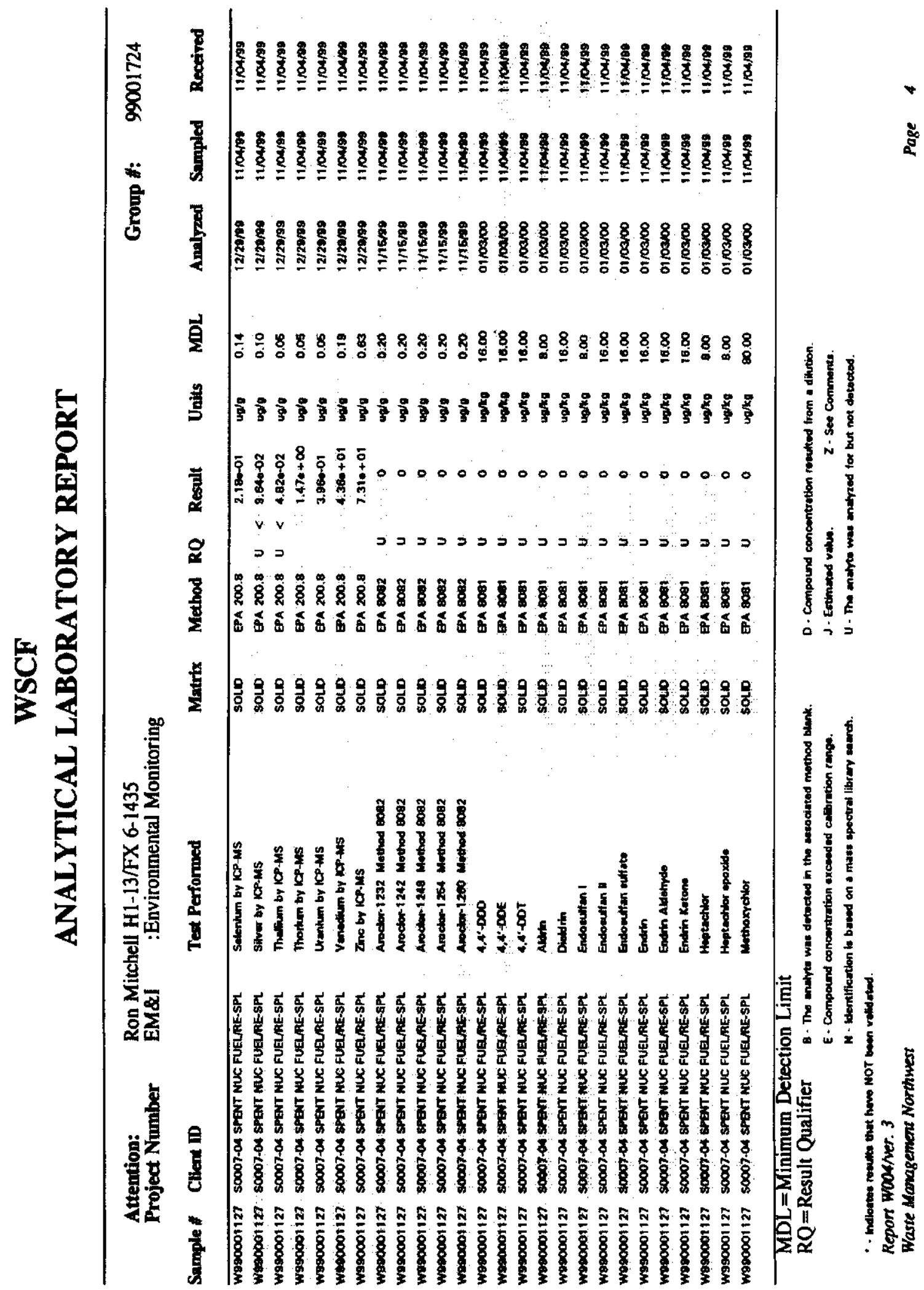


HNF-6150 Rev 0

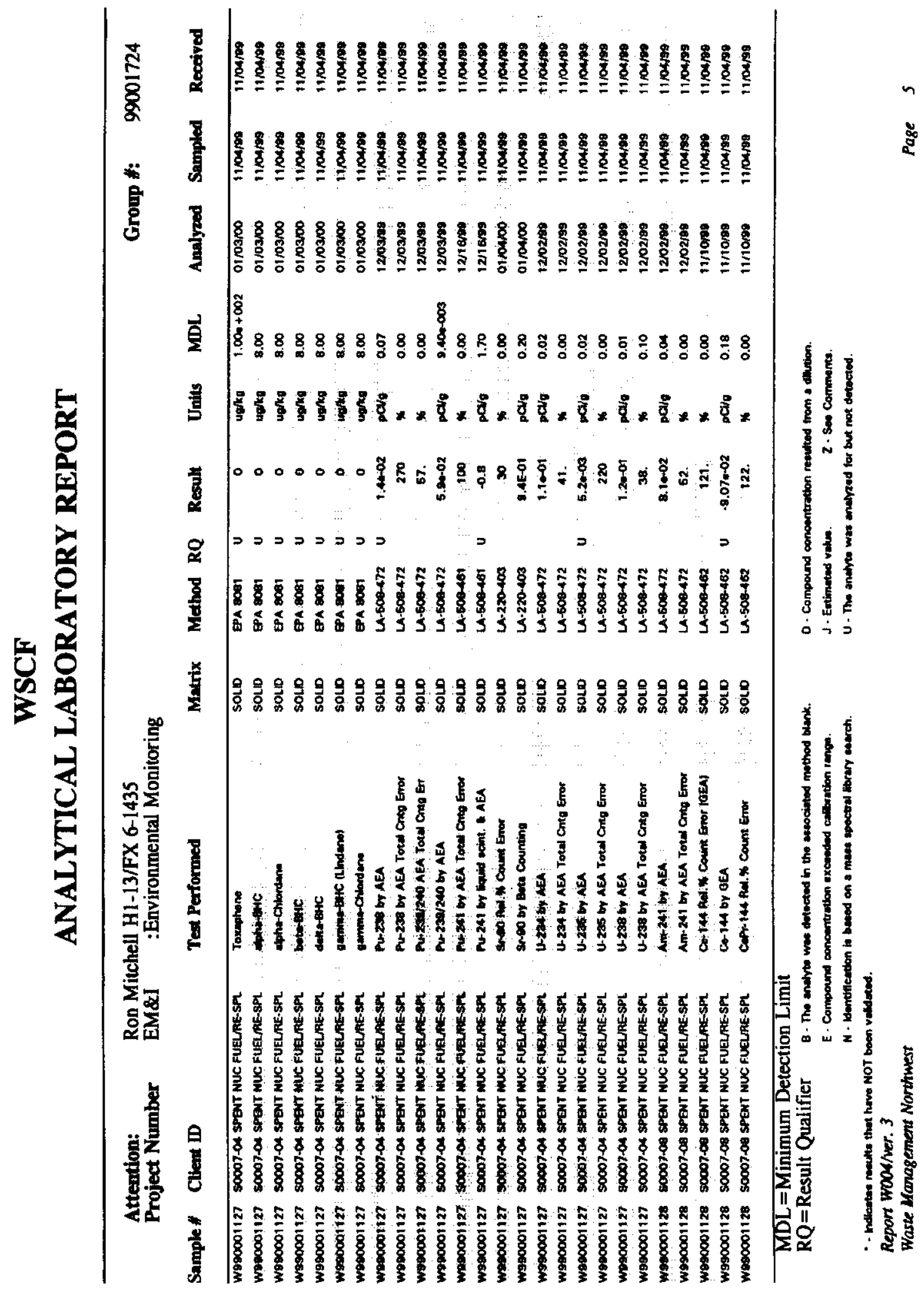


HNF-6150 Rev 0

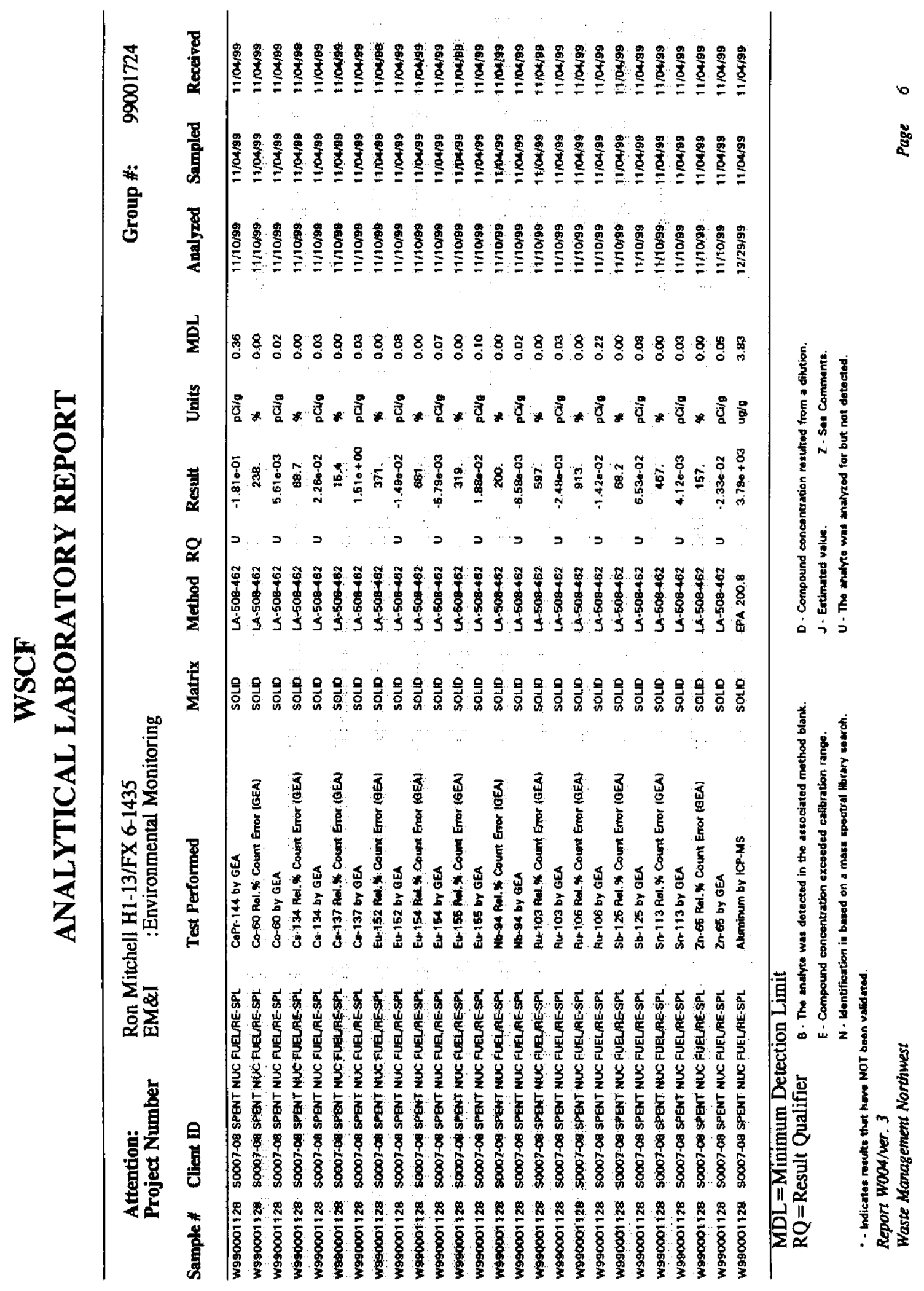


HNF-6150 Rev 0

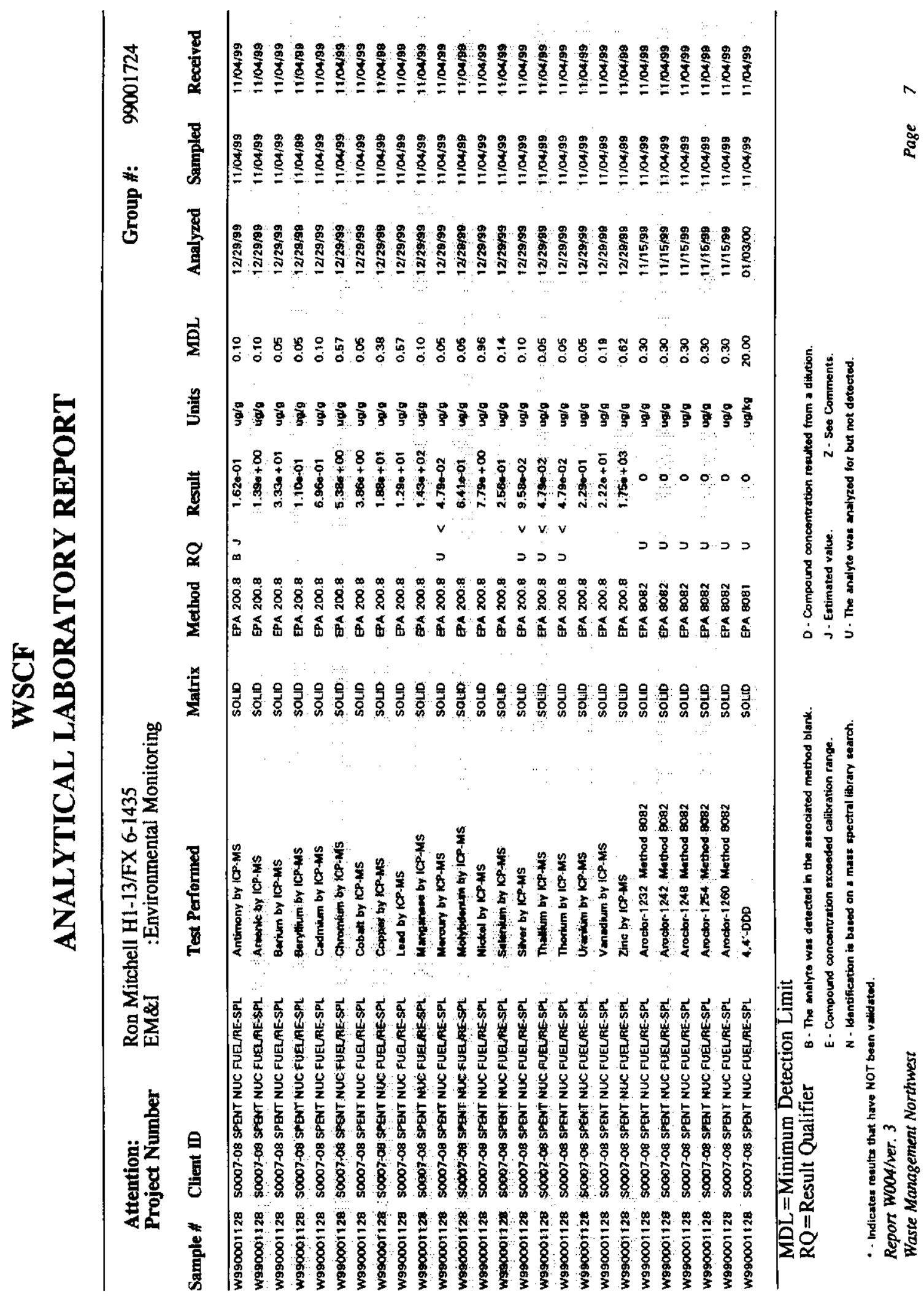


HNF-6150 Rev 0

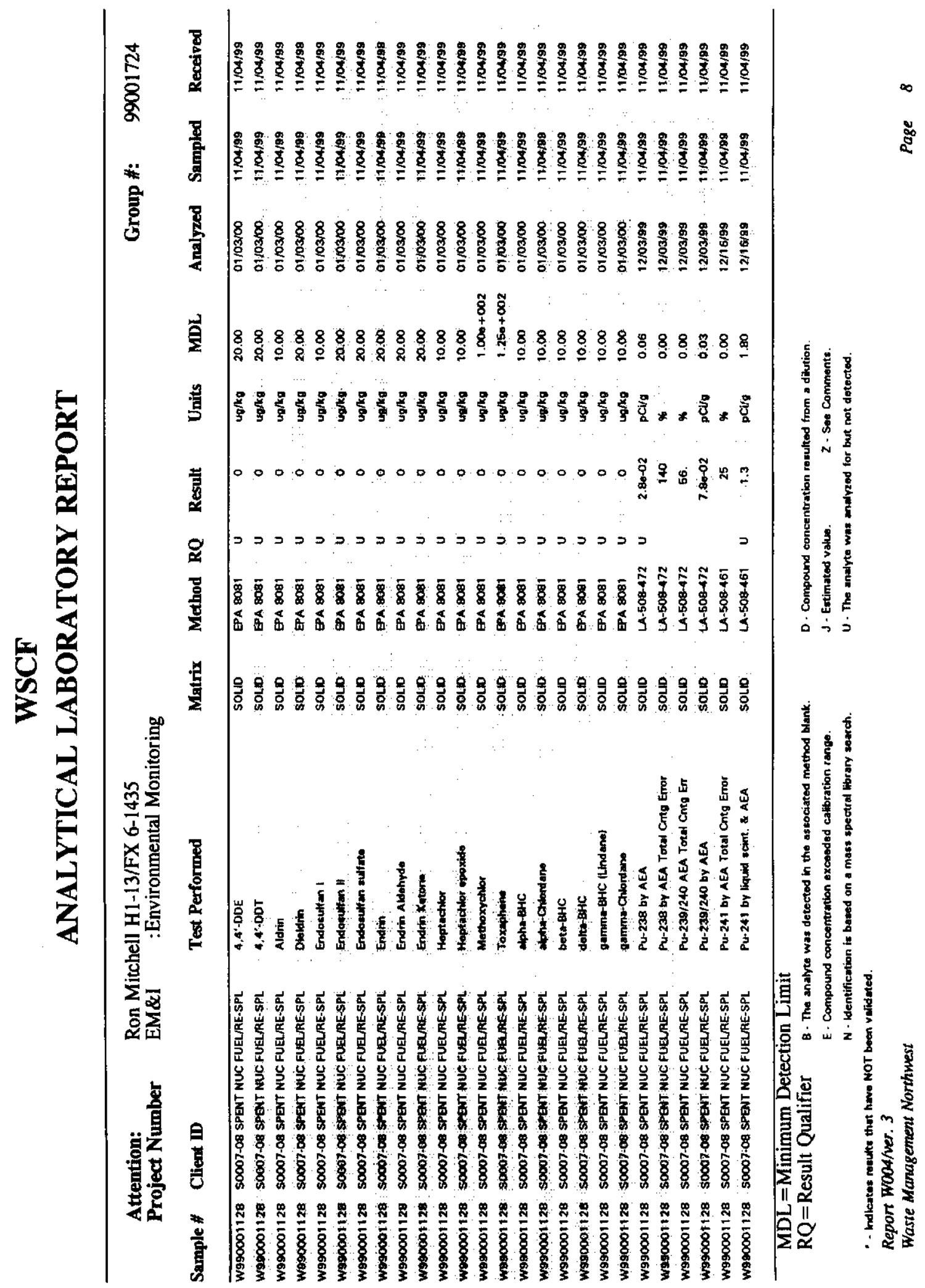


HNF-6150 Rev 0

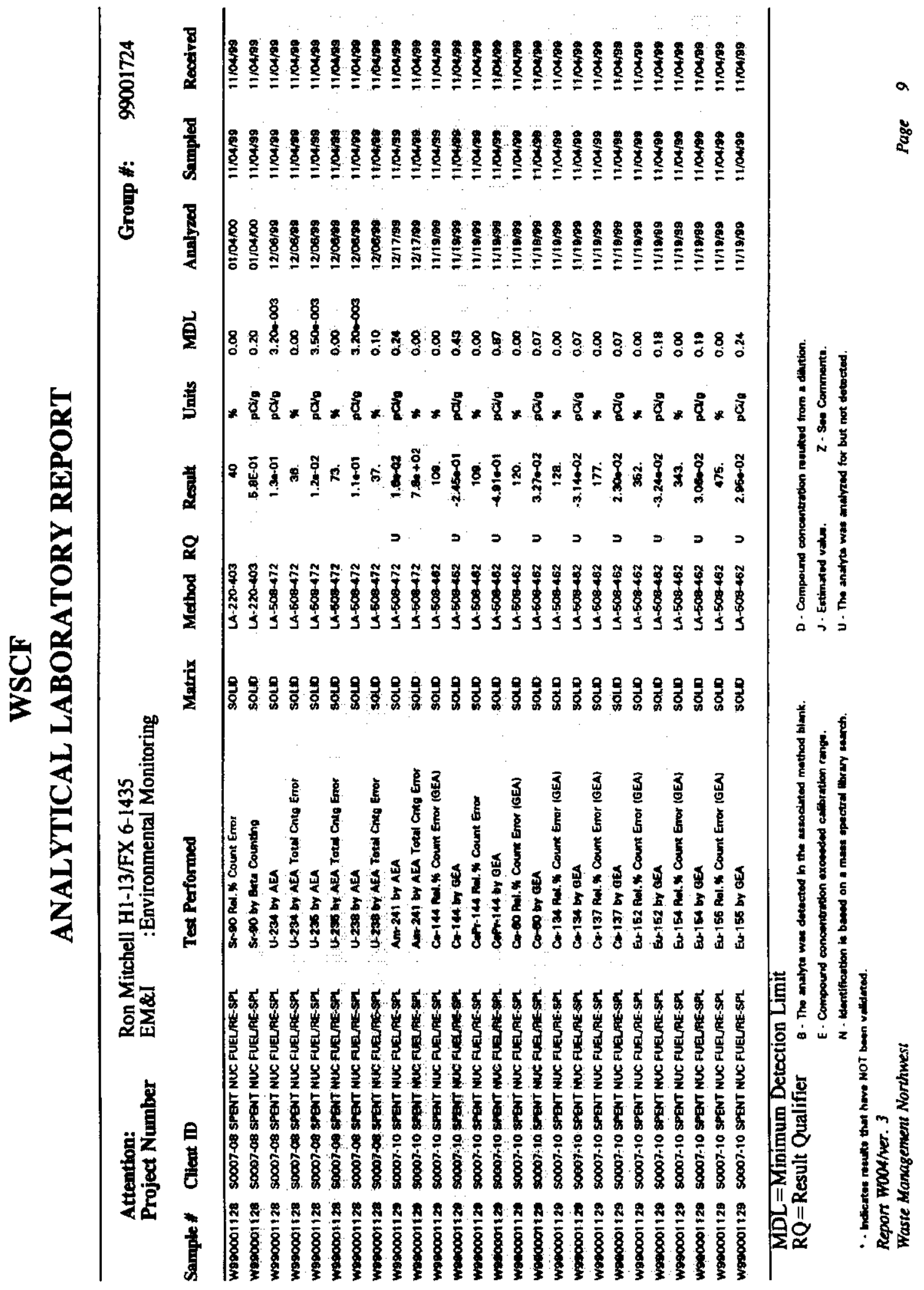


HNF-6150 Rev 0

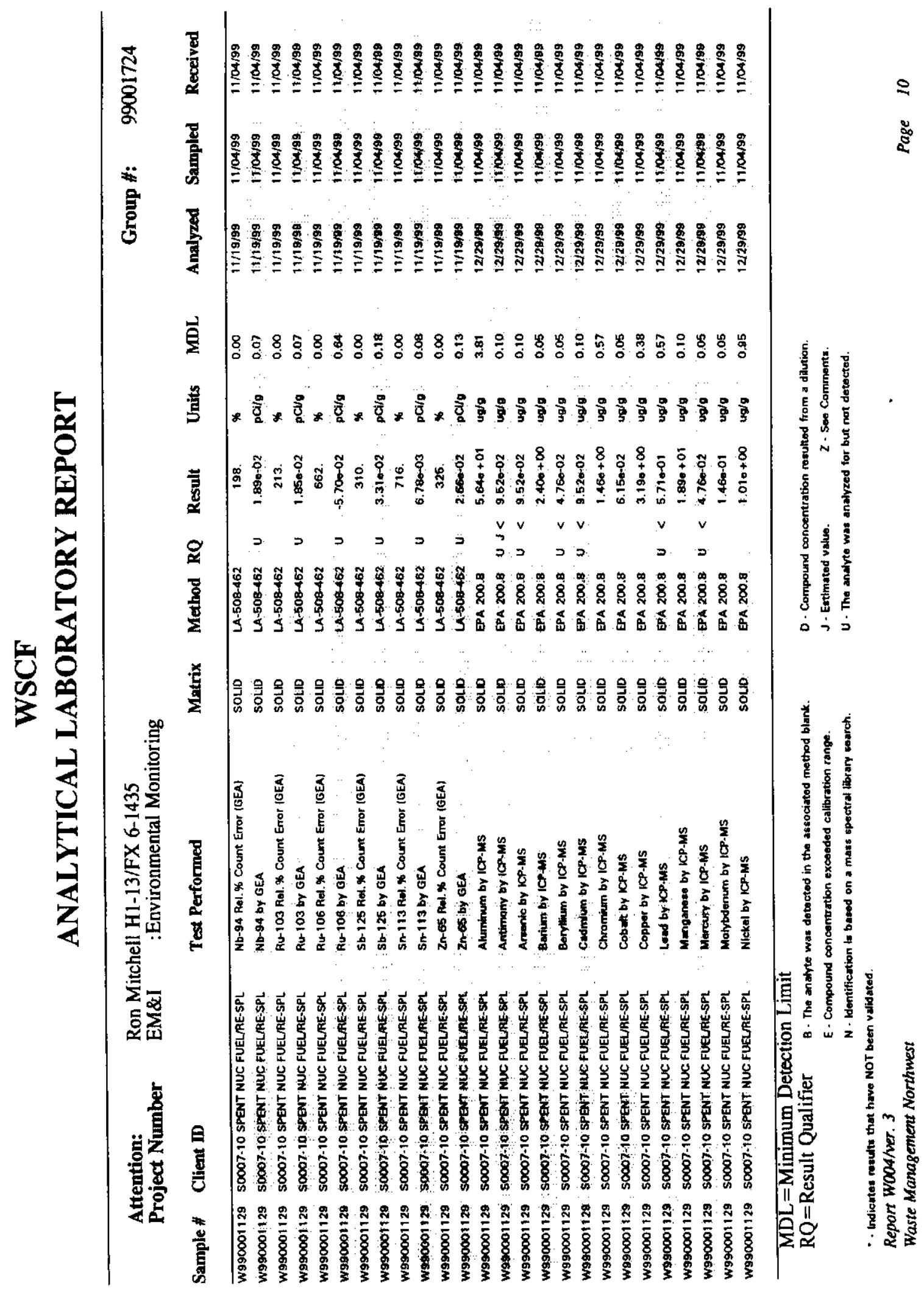


HNF-6150 Rev 0

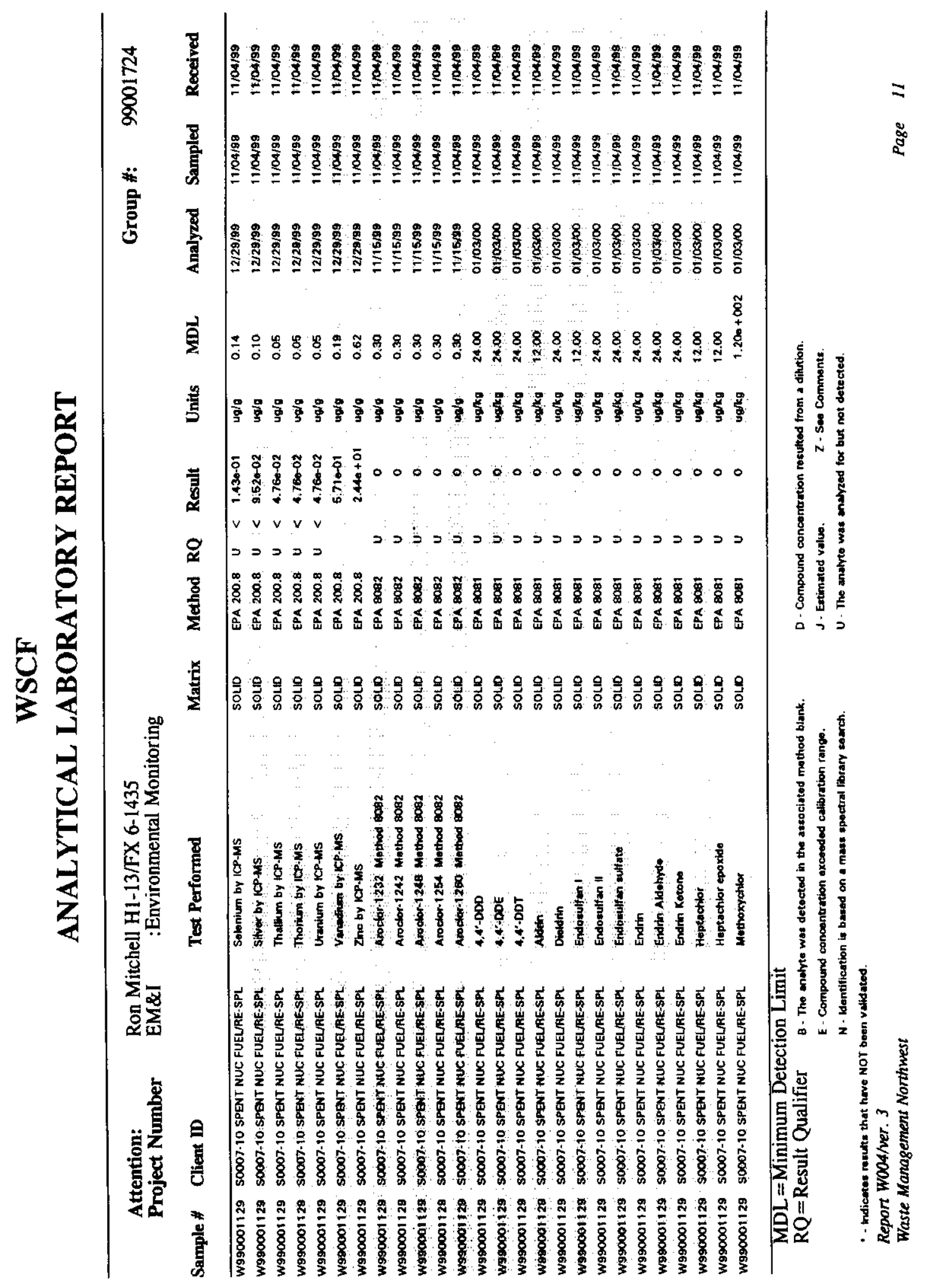


HNF-6150 Rev 0

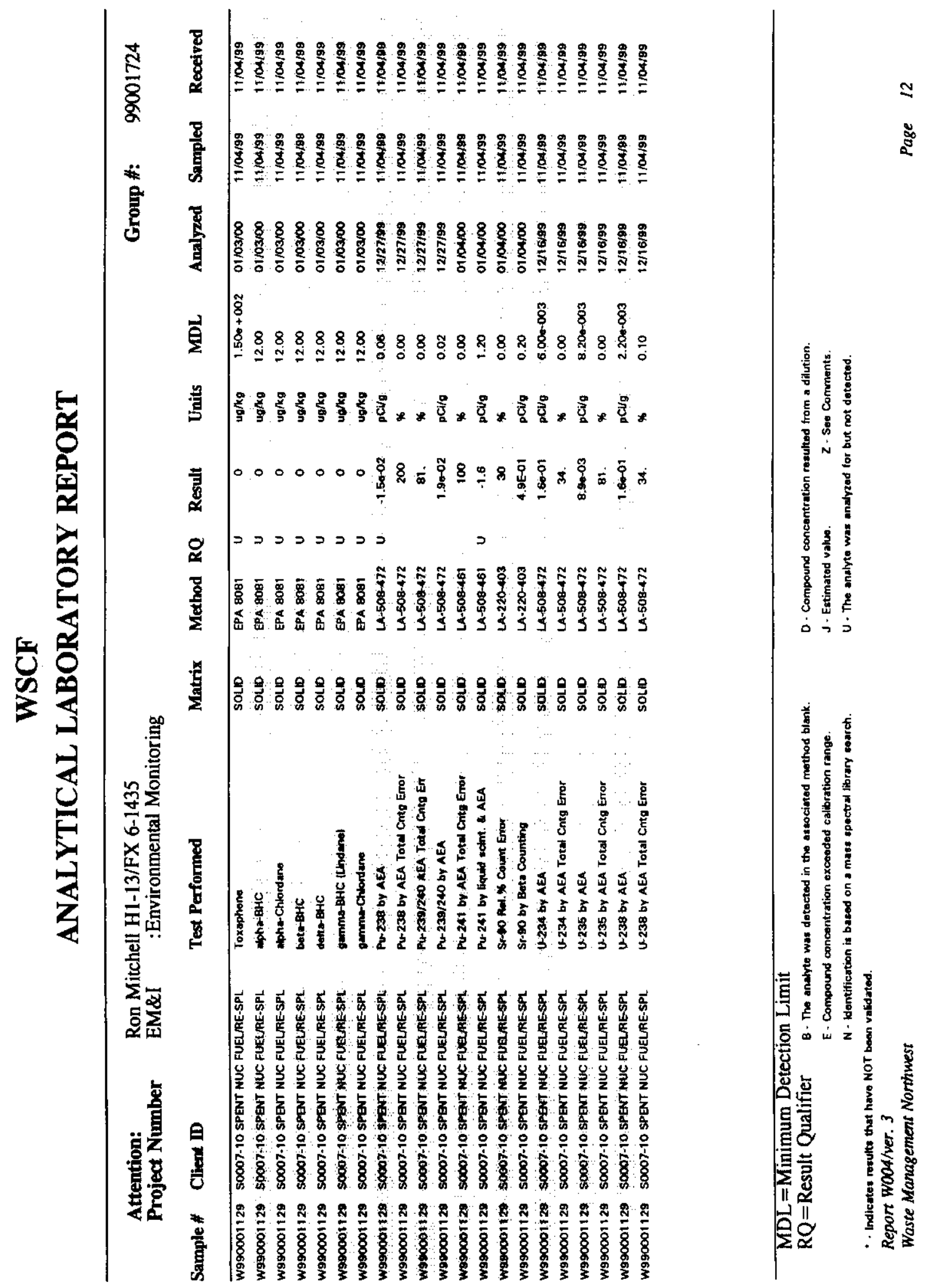


HNF-6150 Rev 0

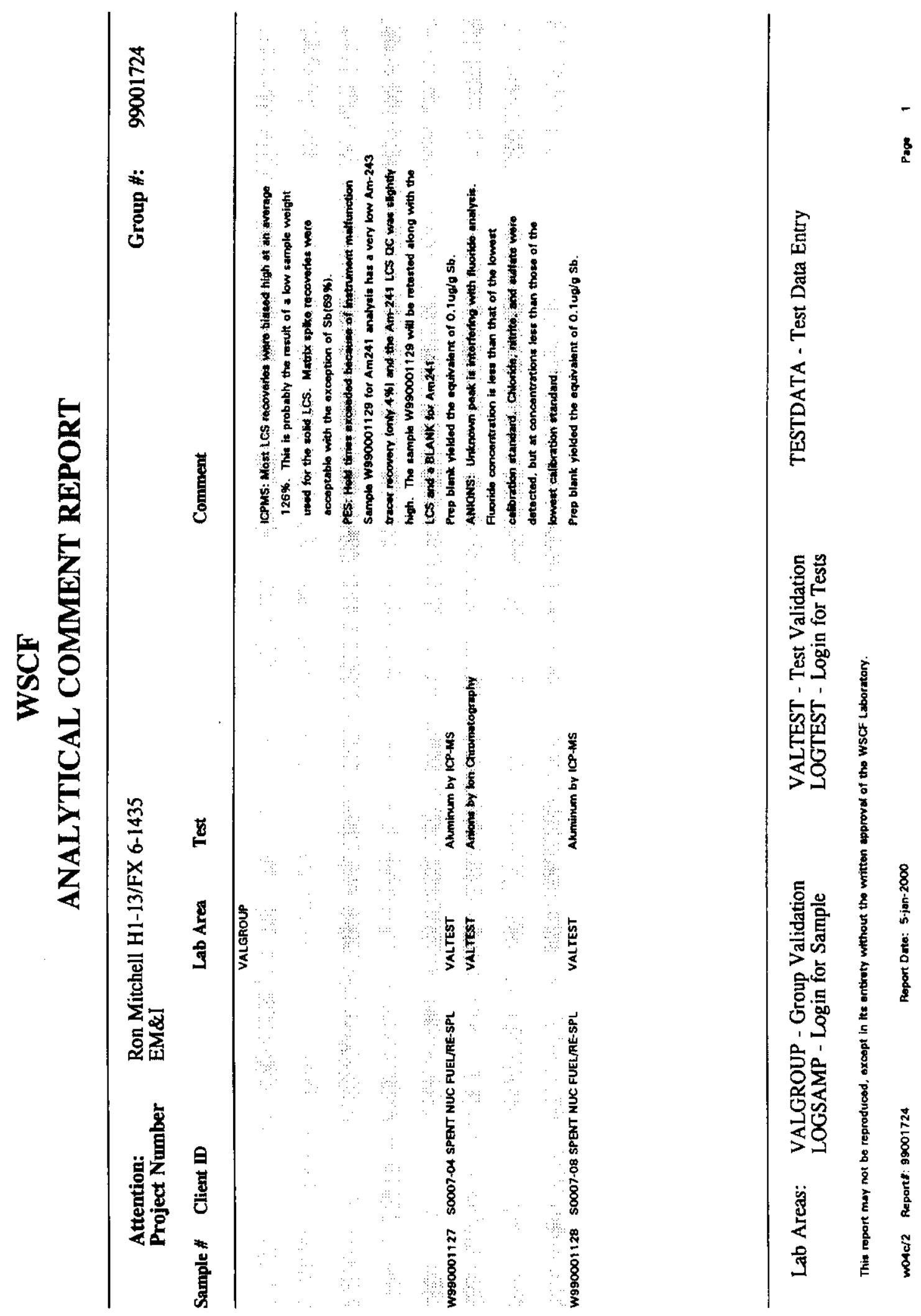


HNF-6150 Rev 0
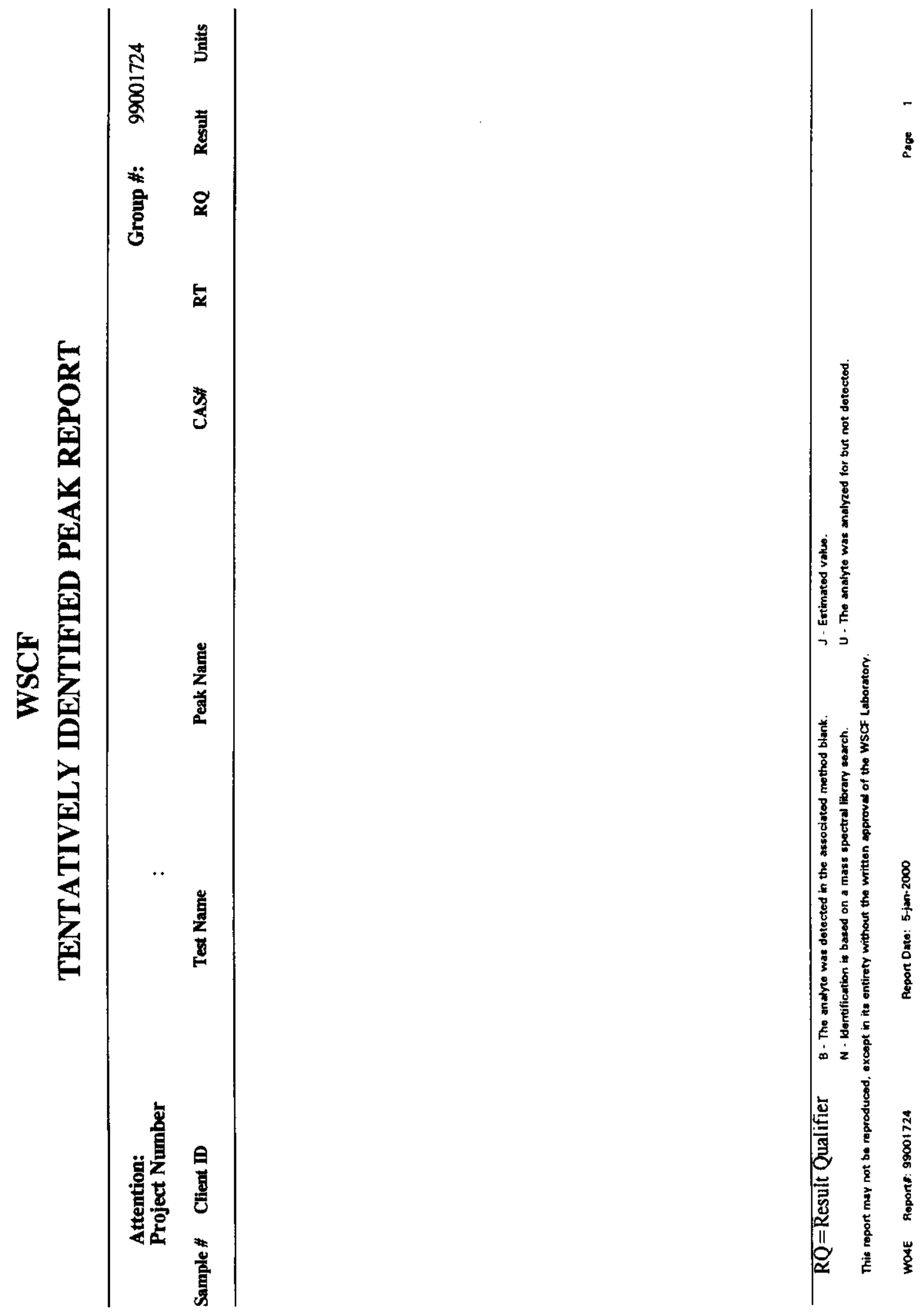
HNF-6150 Rev 0
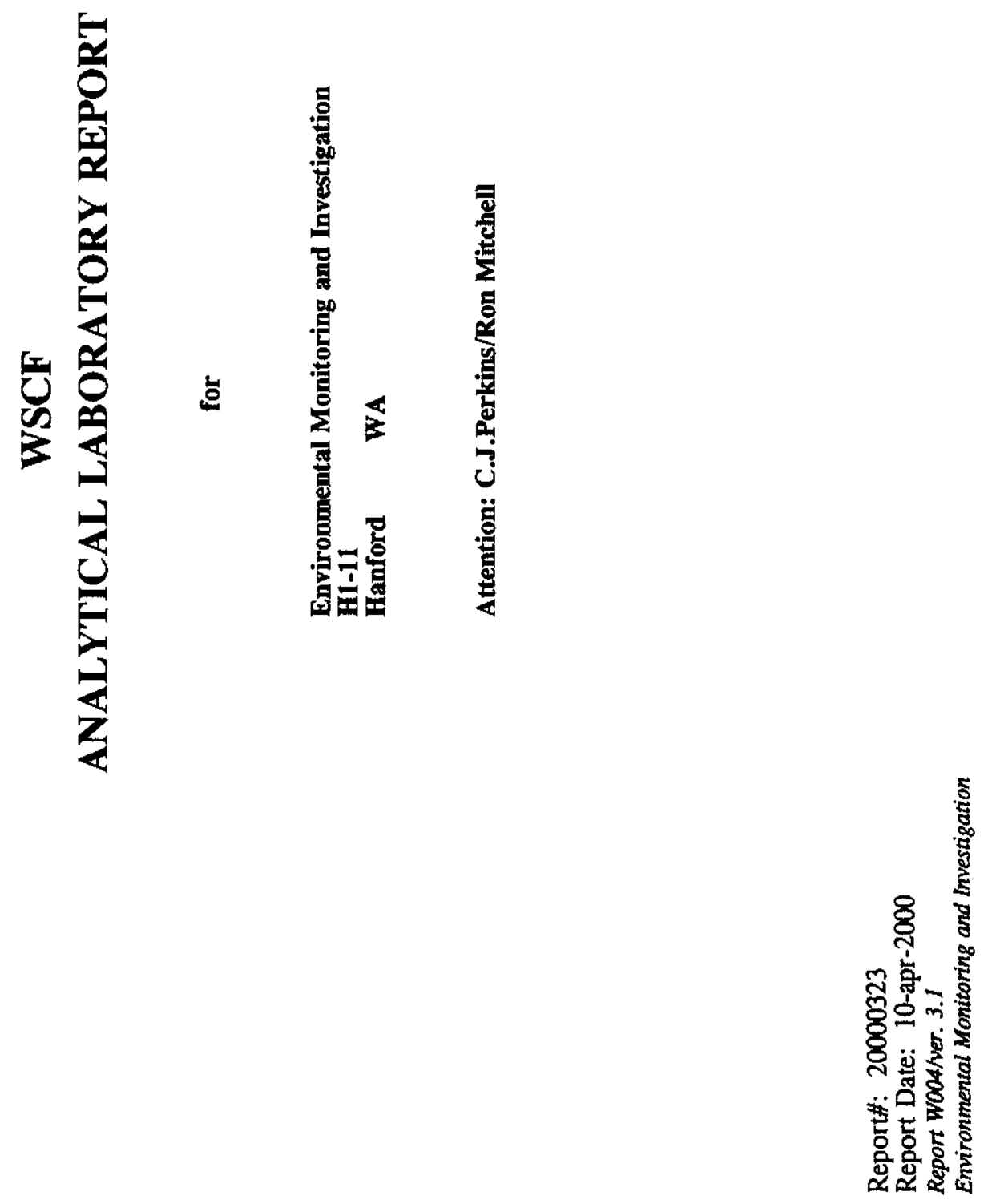
HNF-6150 Rev 0

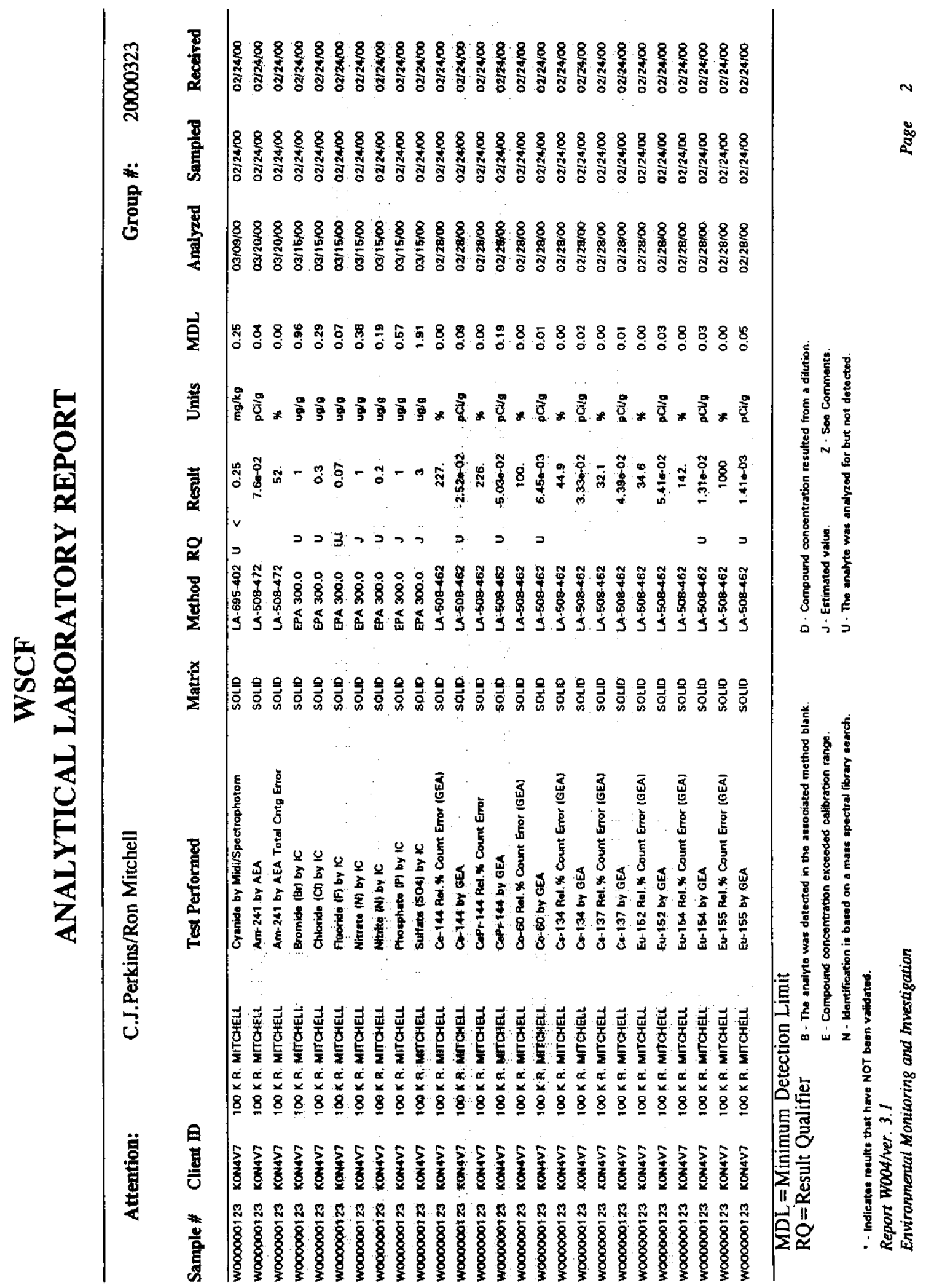


HNF-6150 Rev 0

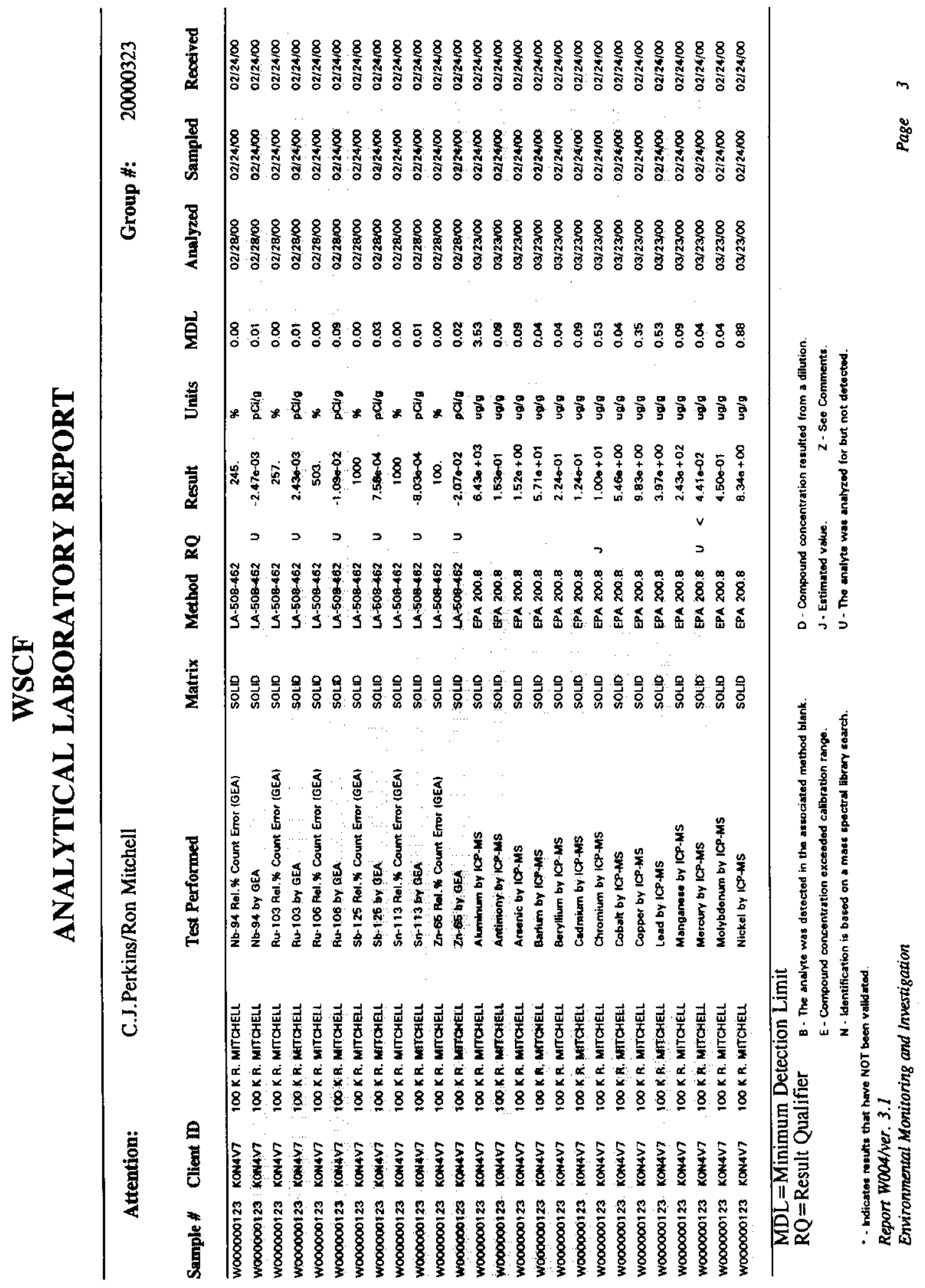


HNF-6150 Rev 0

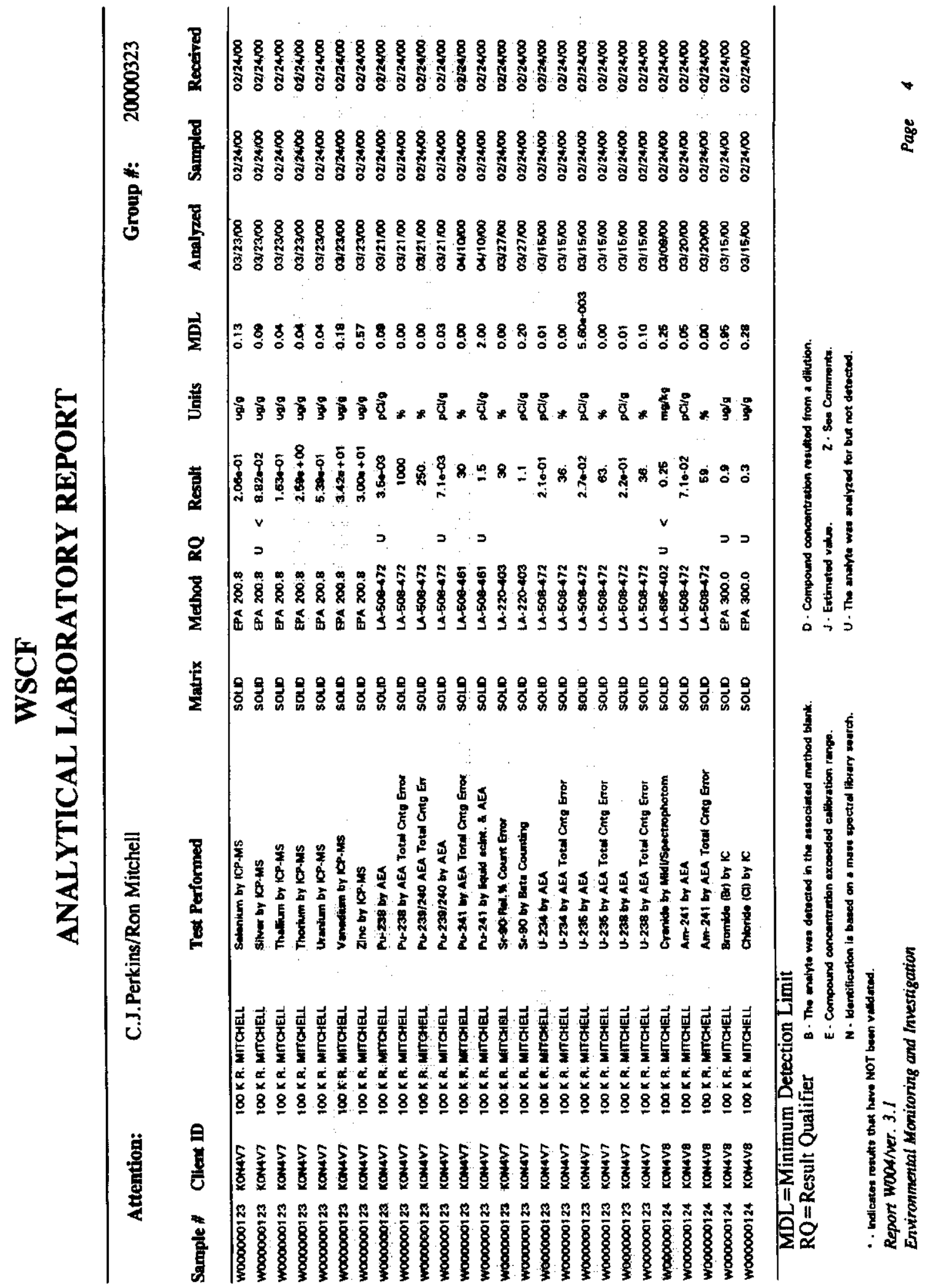




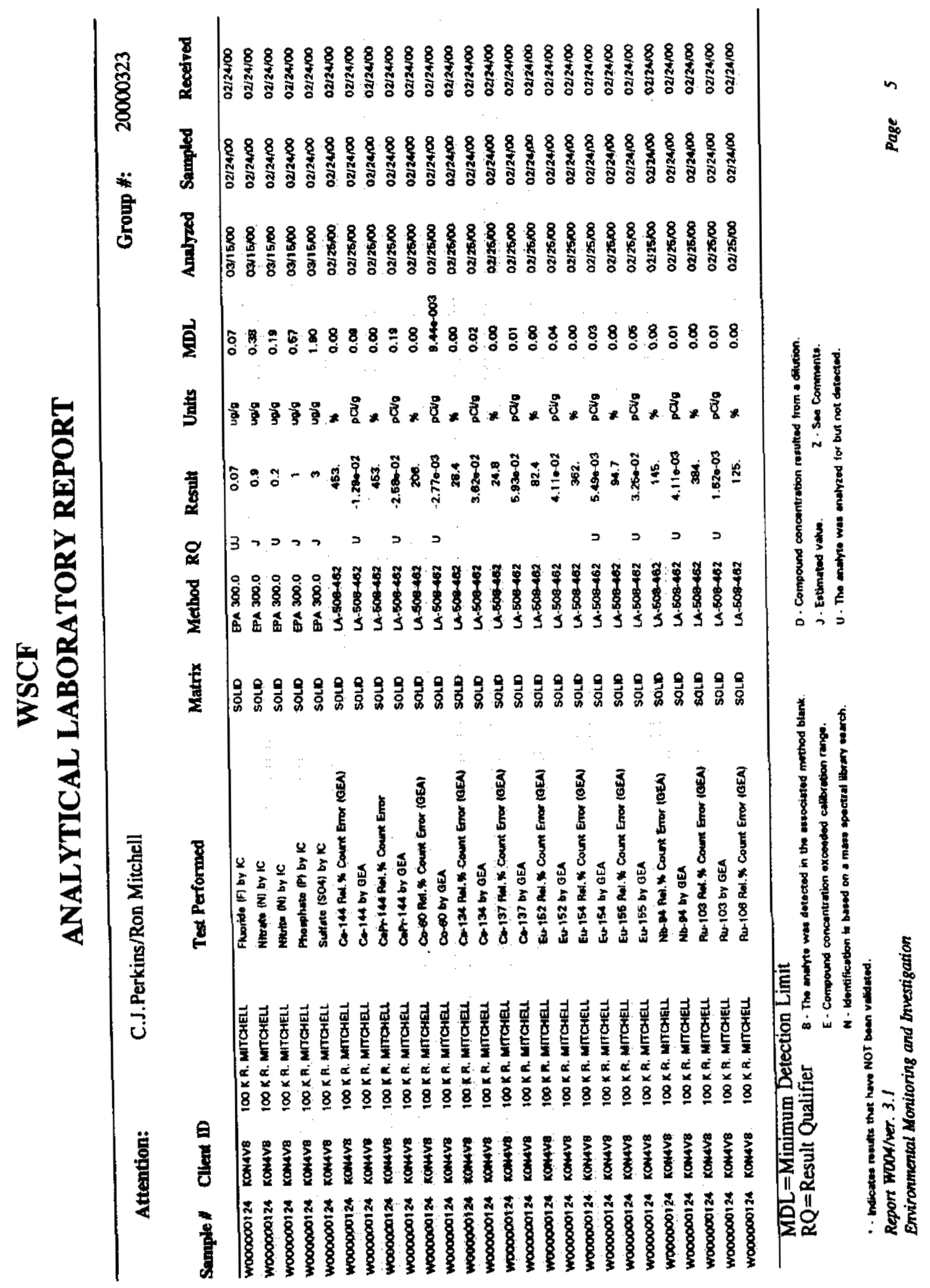


HNF-6150 Rev 0

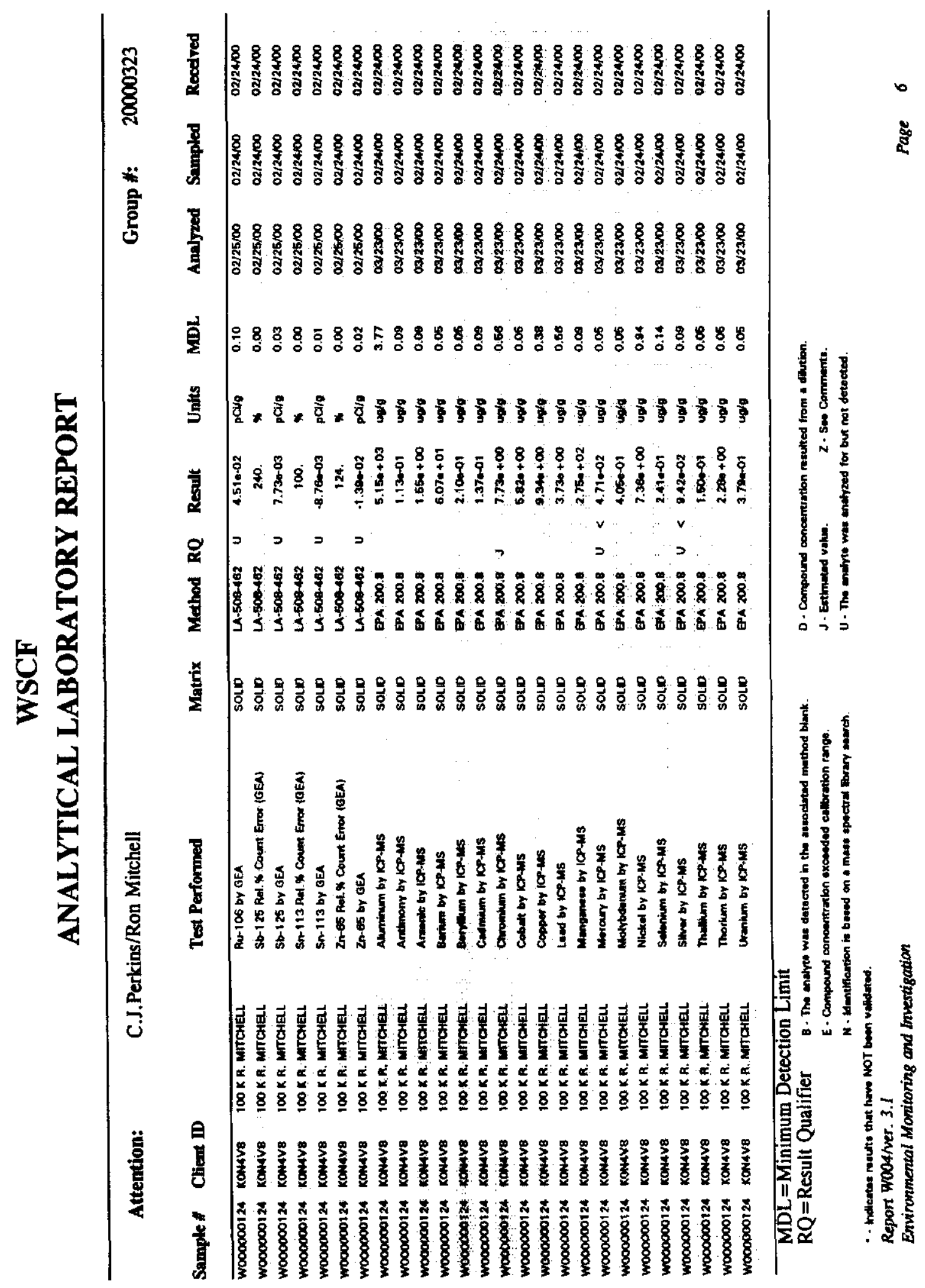


HNF-6150 Rev 0

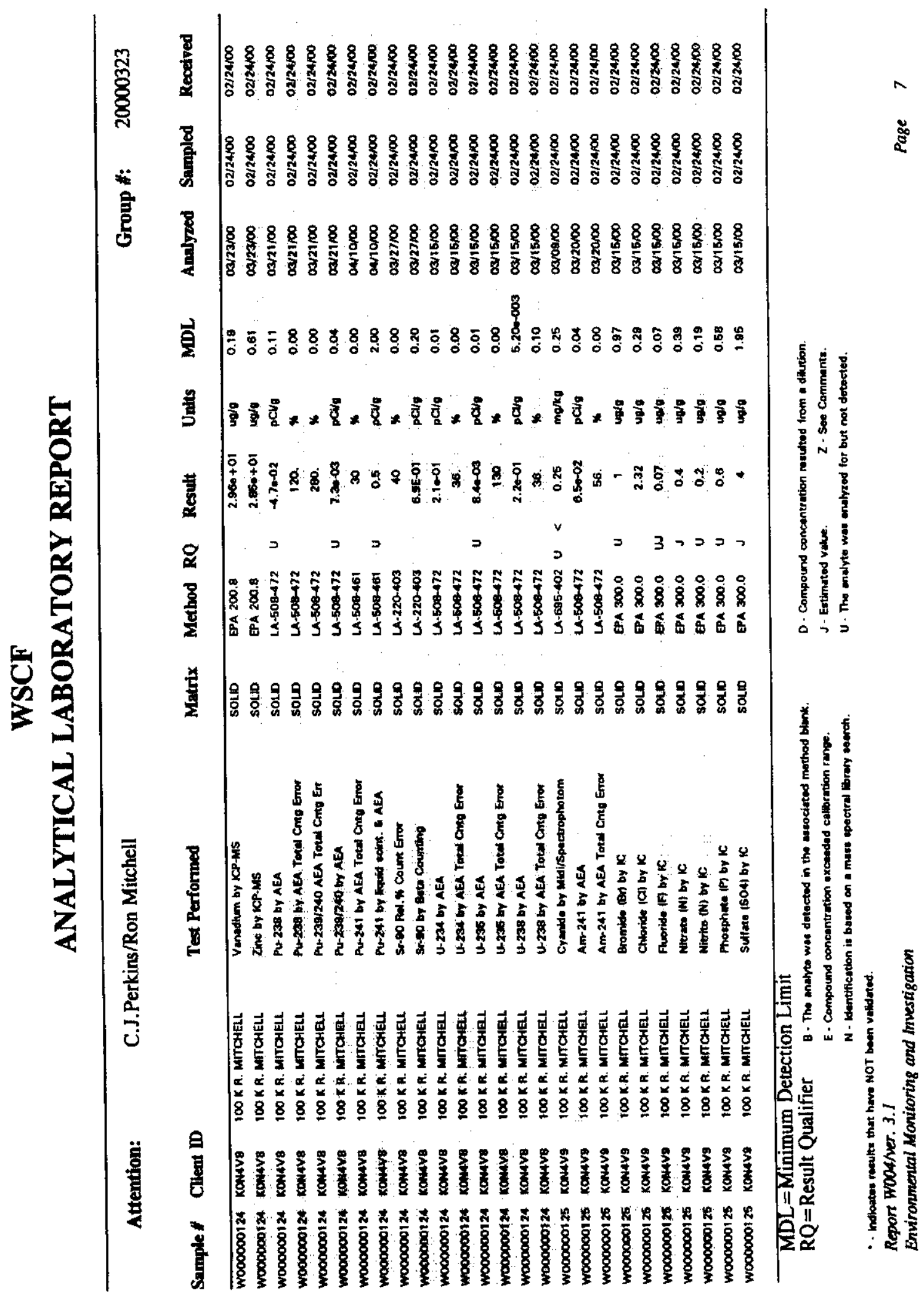


HNF-6150 Rev 0

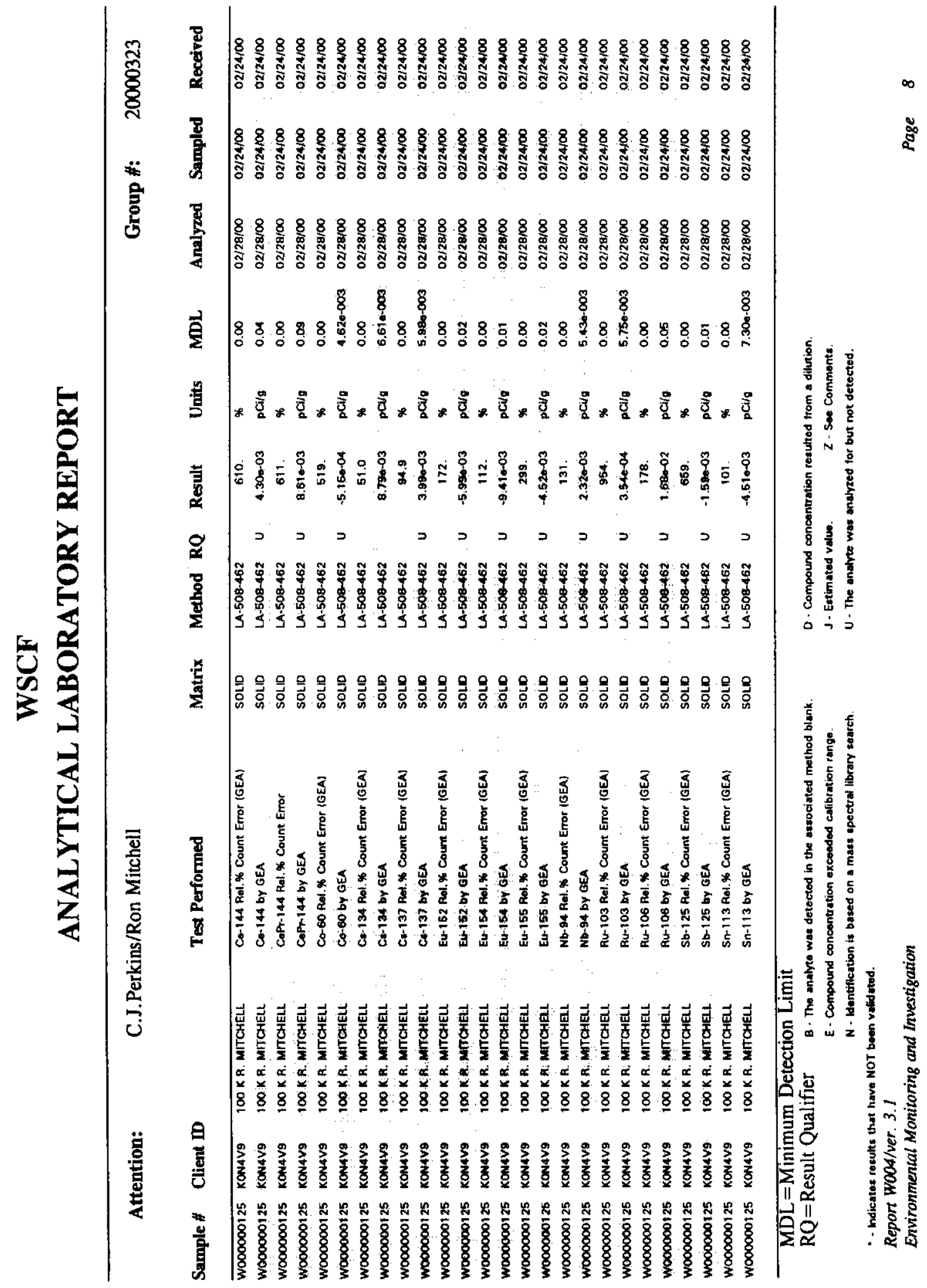


HNF-6150 Rev 0

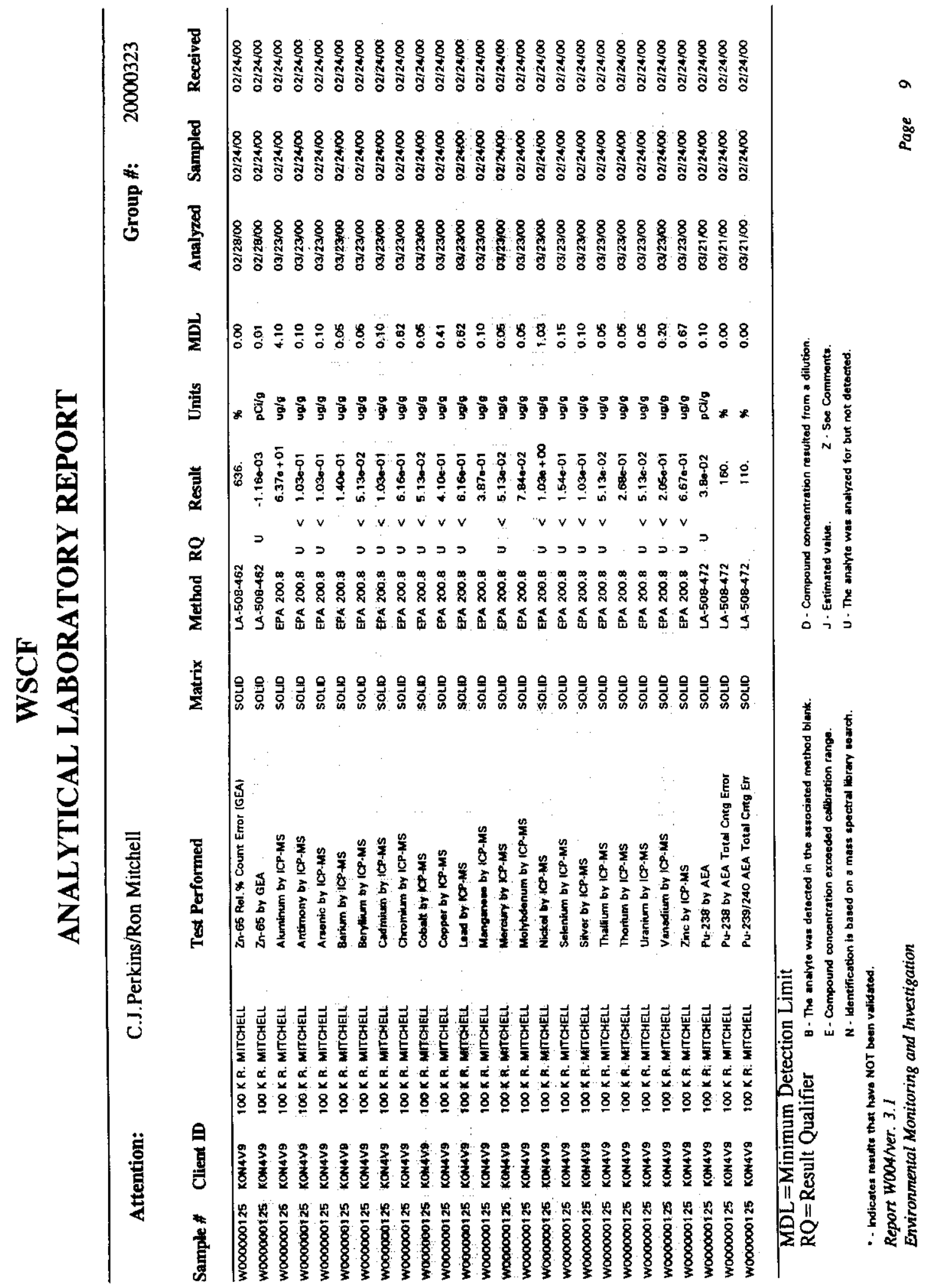


HNF-6150 Rev 0

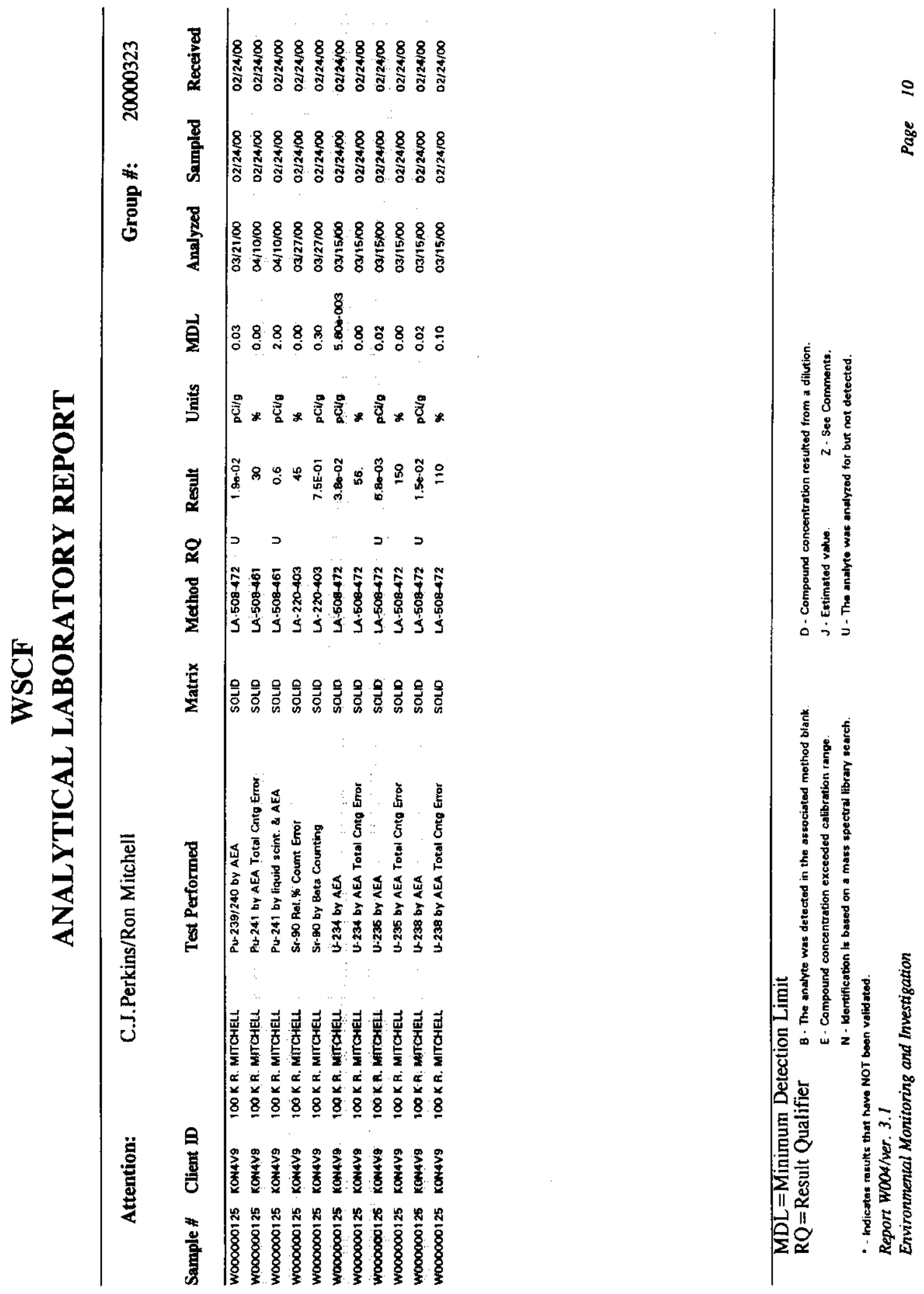


HNF-6150 Rev 0

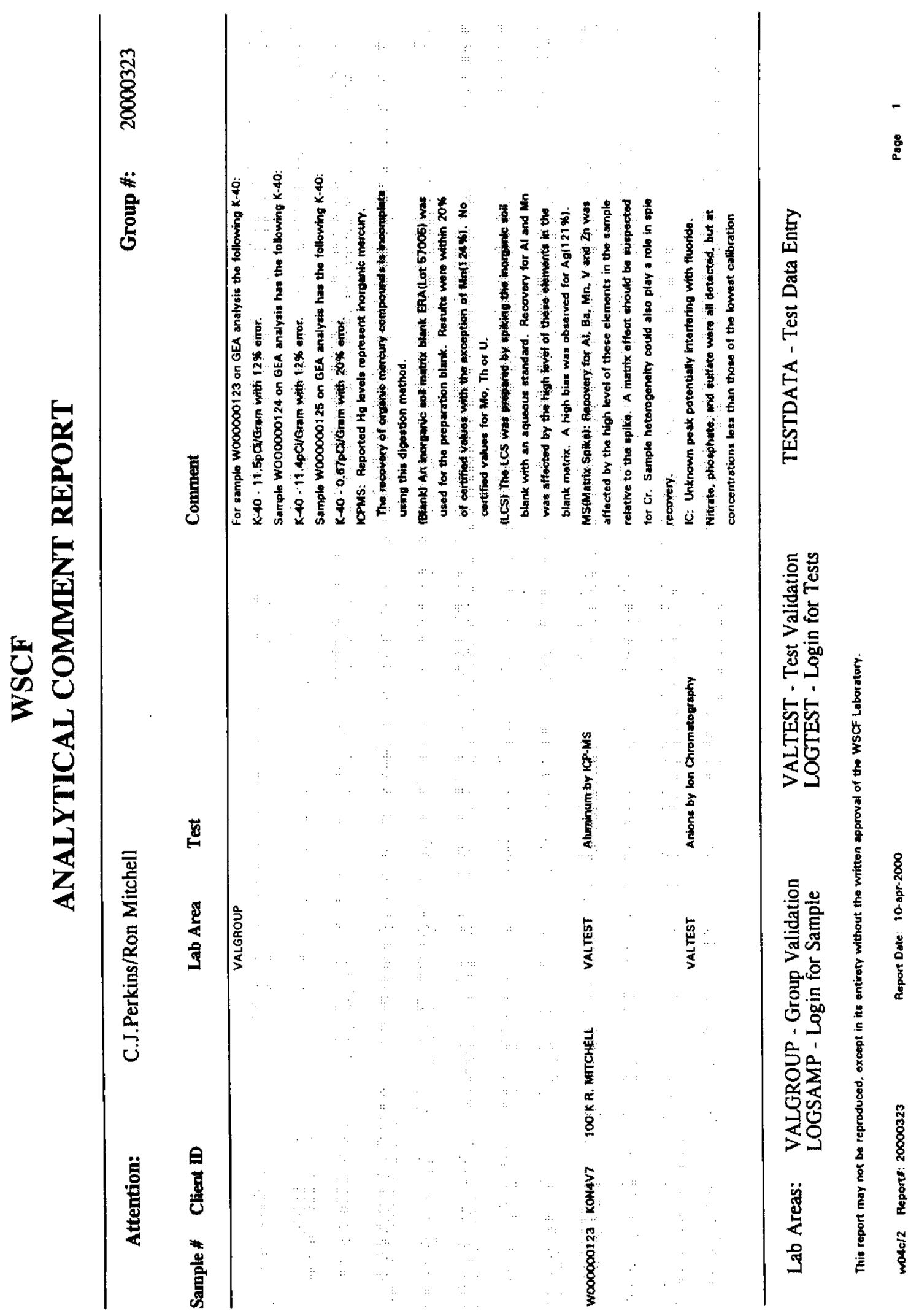


HNF-6150 Rev 0

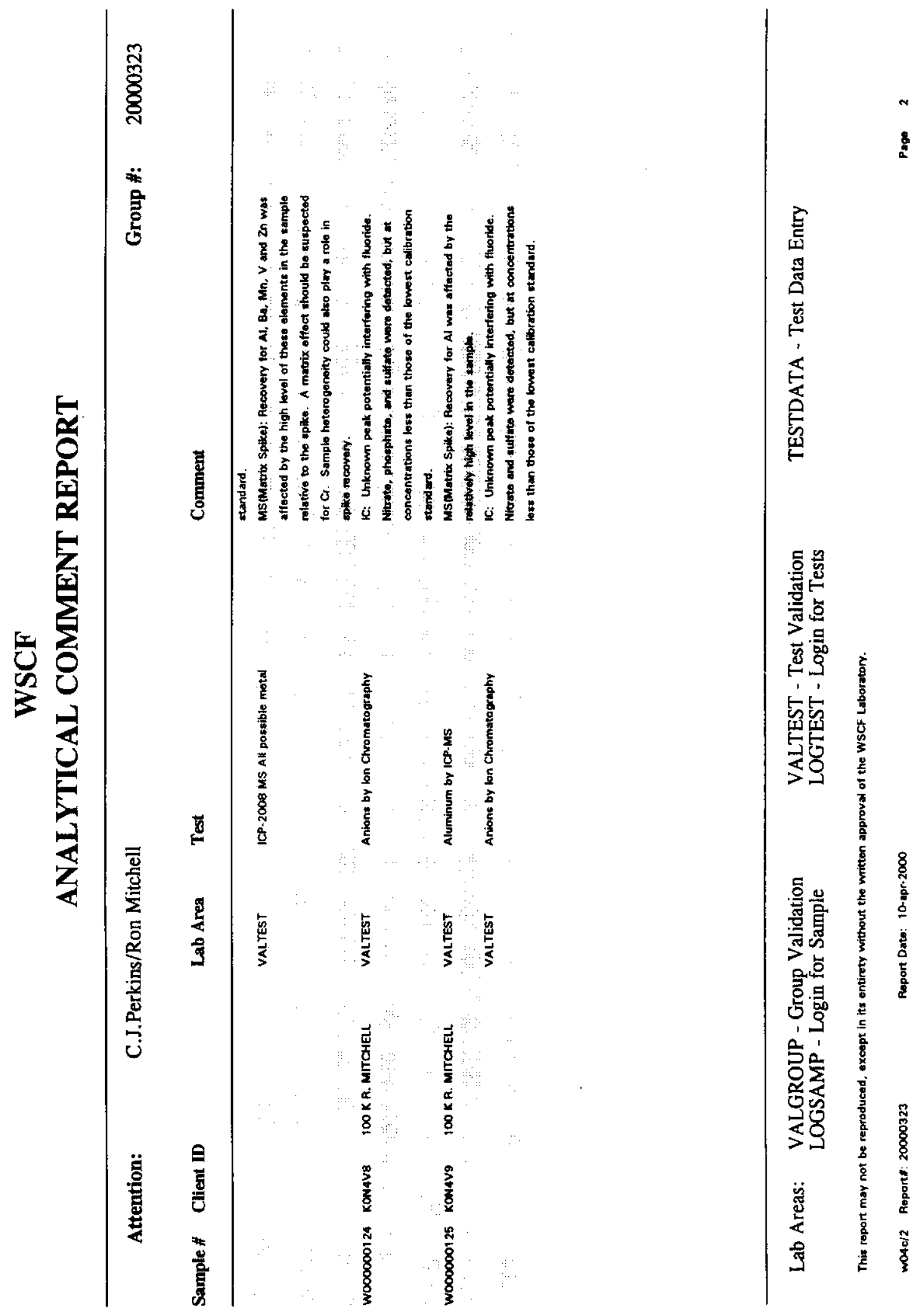


HNF-6150 Rev 0
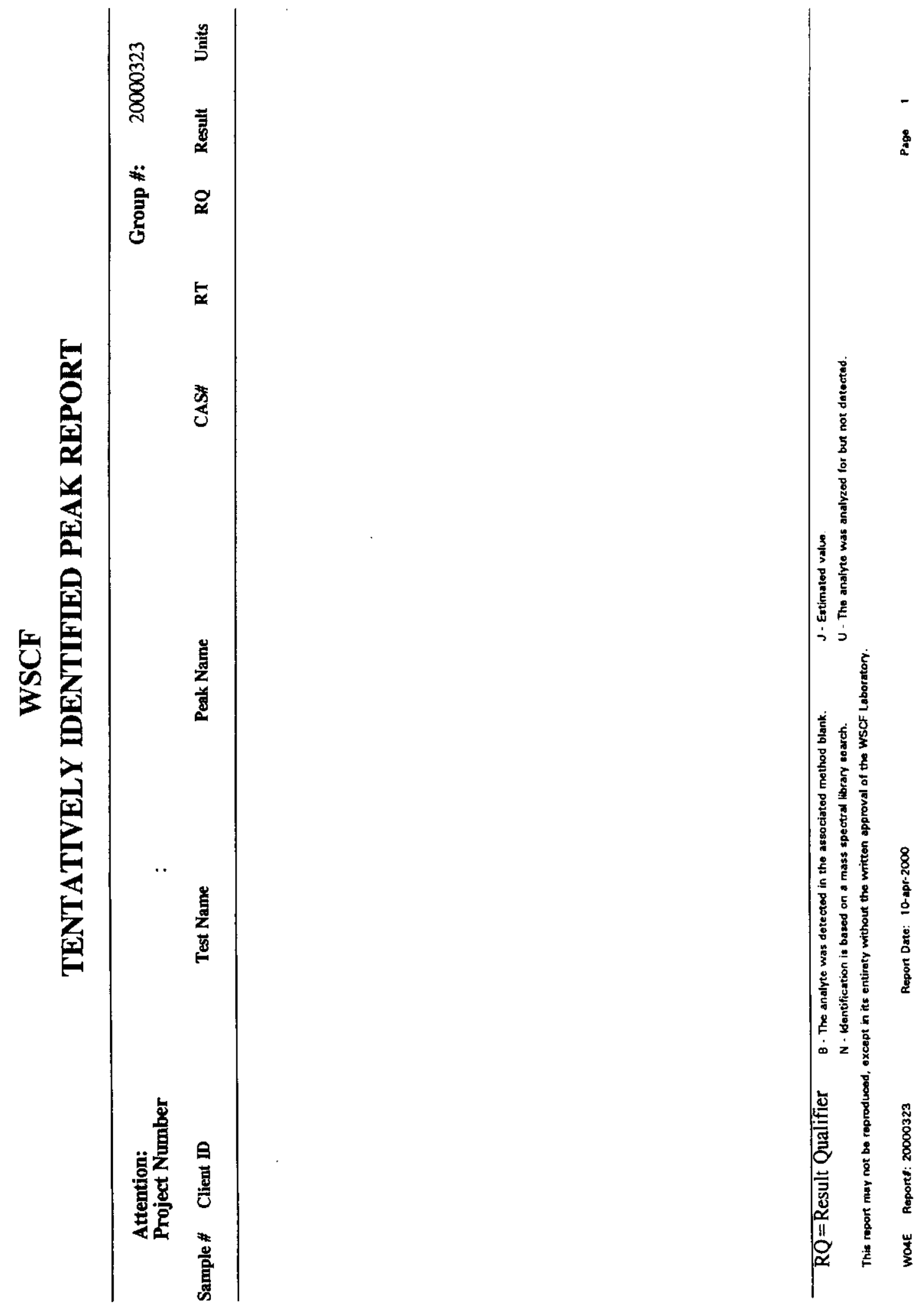
HNF-6150 Rev 0

\section{WSCF ANALYTICAL LABORATORY QC REPORT}

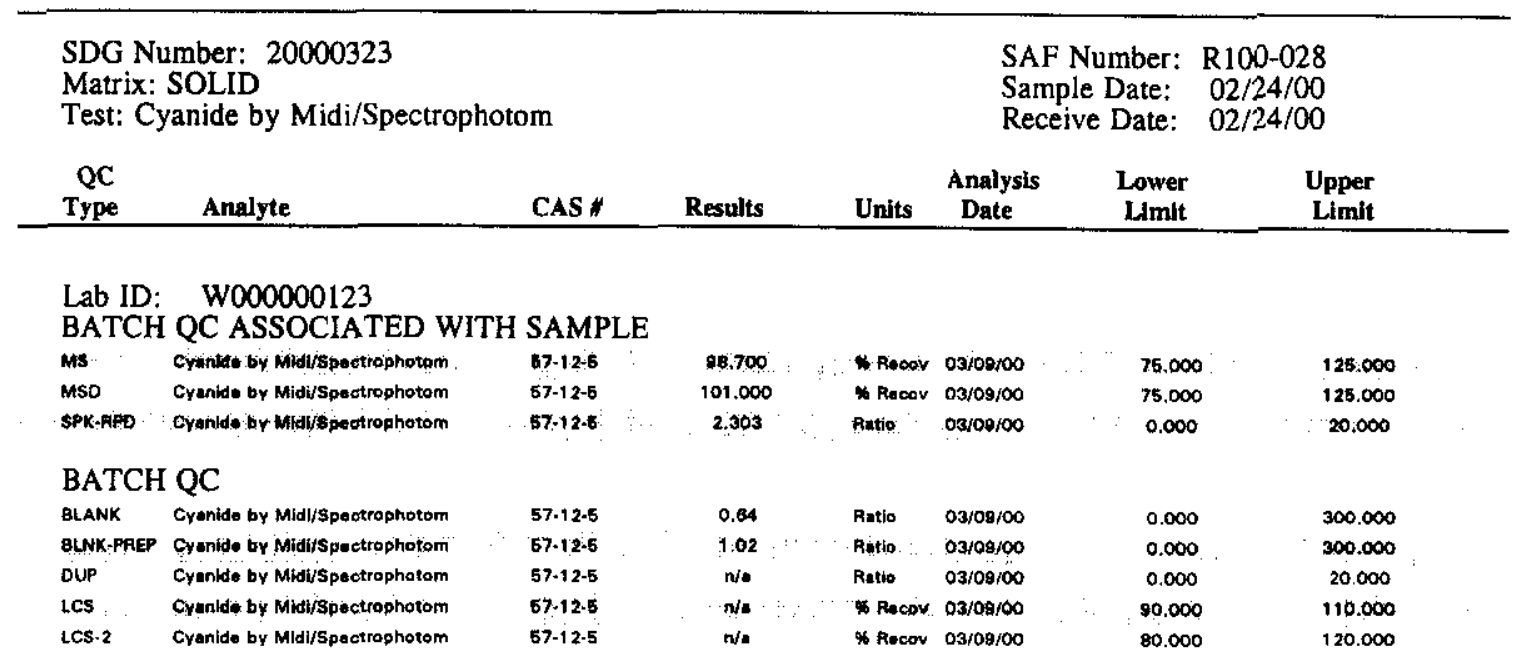

Repors w13qirev. 4 p 1

10.2pr-2000 13:46:20 
WSCF ANALYTICAL LABORATORY QC REPORT

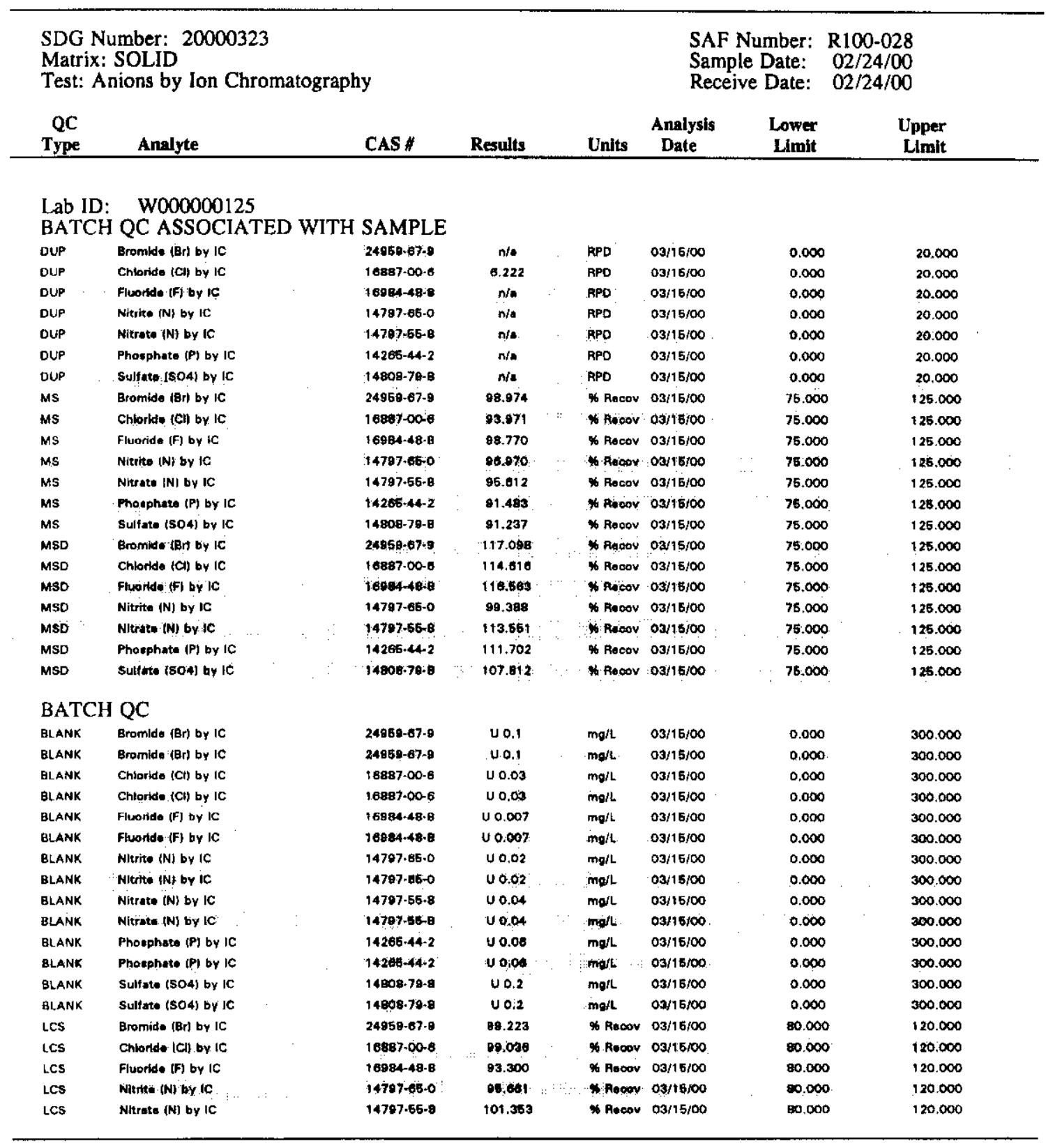

Report wi 3q/rov.4 2

10.apr-2000 13:45:20 
HNF-6150 Rev 0

\section{WSCF ANALYTICAL LABORATORY QC REPORT}

\begin{tabular}{|c|c|c|c|c|c|c|c|}
\hline \multicolumn{5}{|c|}{$\begin{array}{l}\text { SDG Number: } 20000323 \\
\text { Matrix: SOLID } \\
\text { Test: Anions by Ion Chromatography }\end{array}$} & \multicolumn{2}{|c|}{$\begin{array}{l}\text { SAF Number: } \\
\text { Sample Date: } \\
\text { Receive Date: }\end{array}$} & \multirow{2}{*}{$\begin{array}{r}\text { R100-028 } \\
\text { Upper } \\
\text { Limit }\end{array}$} \\
\hline $\begin{array}{c}\text { QC } \\
\text { Type }\end{array}$ & Analyte & CAS \# & Results & Units & $\begin{array}{c}\text { Analysts } \\
\text { Date }\end{array}$ & $\begin{array}{l}\text { Lower } \\
\text { Limit }\end{array}$ & \\
\hline tes & Prosphit (A by ic & $14208 \div 4-2$ & $102: 128$ & \% Recoov. & $03 / 15 / 00$ & 80.000 & 120.000 \\
\hline LCS & Sulfute (SOA) by IC & 14809-79-8 & 102.879 & \% Recor & $03 / 15 / 00$ & 80.000 & 120.000 \\
\hline
\end{tabular}

Fleport w13q/rev.4 P 3

10-apr.2000 13:45:20 
HNF-6150 Rev 0

\section{WSCF ANALYTICAL LABORATORY QC REPORT}

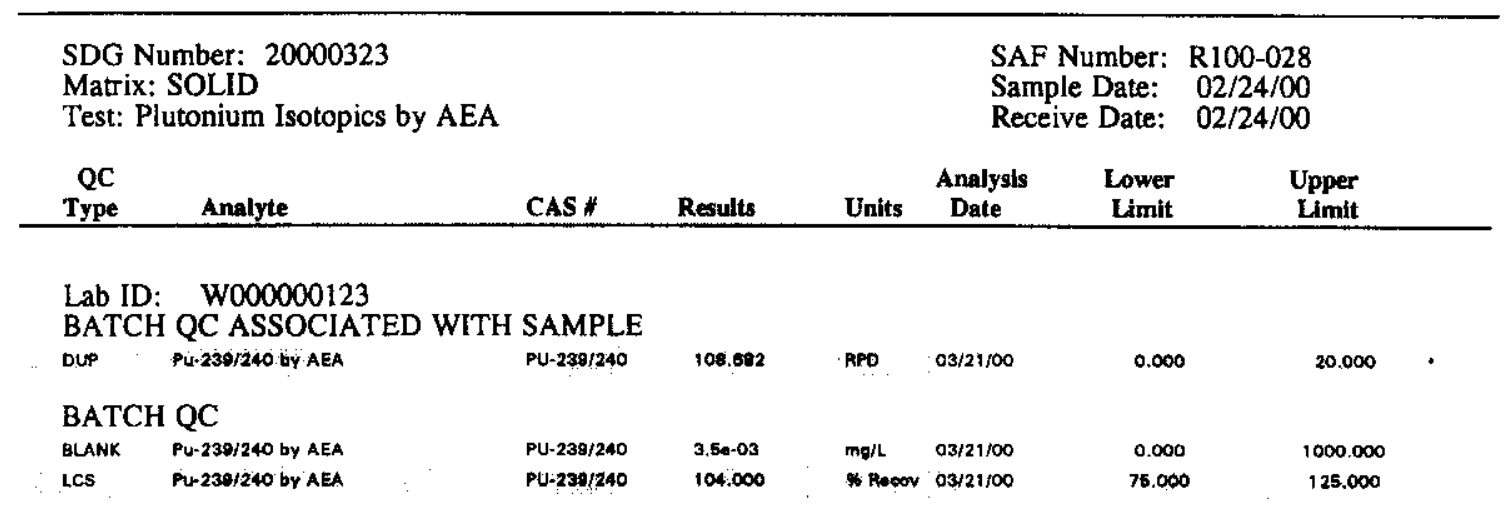

Report w13q/rov. 4 p 4

10-spr-2000 13:45:20 
HNF-6150 Rev 0

\section{WSCF ANALYTICAL LABORATORY QC REPORT}

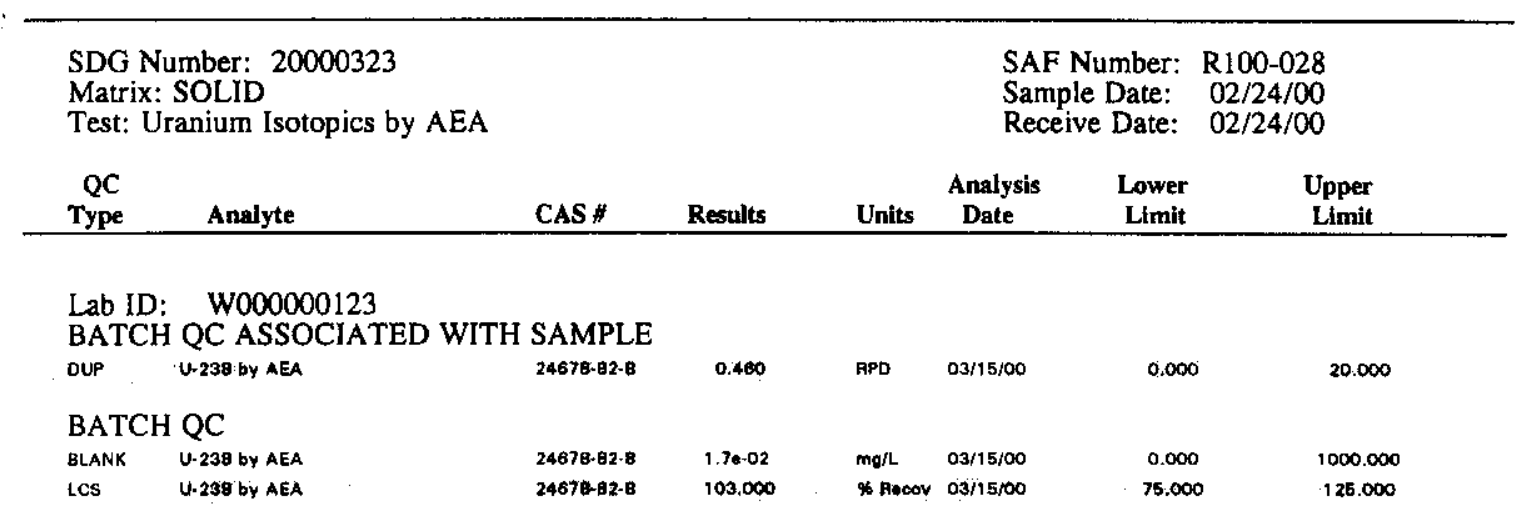

Repore wi3girev.4 5

10-spp-2000 13:45:20 
HNF-6150 Rev 0

\section{WSCF ANALYTICAL LABORATORY QC REPORT}

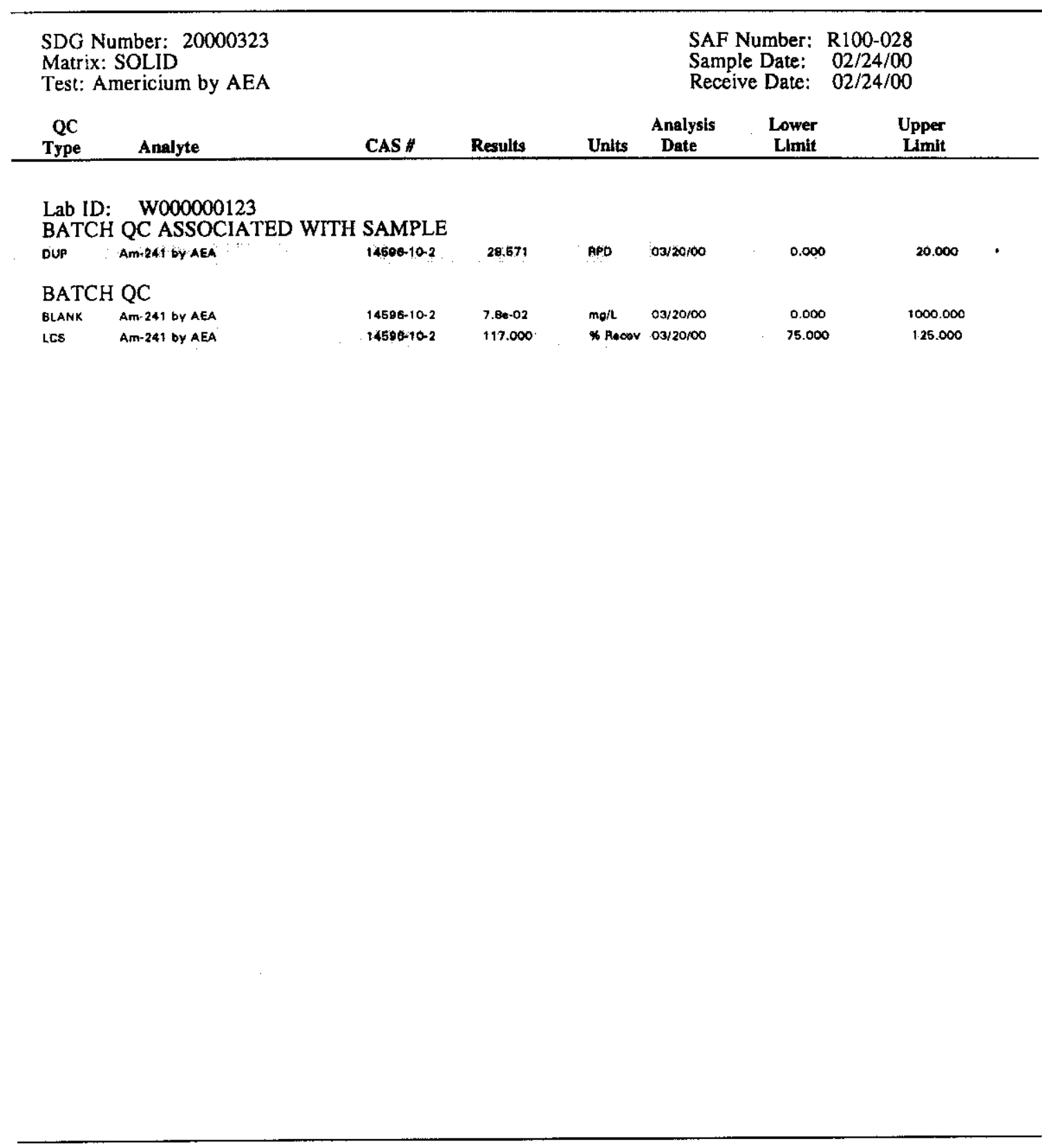

Report w13qurev.4 p 6

10-apr-2000 13:45:20 
HNF-6150 Rev 0

WSCF ANALYTICAL LABORATORY QC REPORT

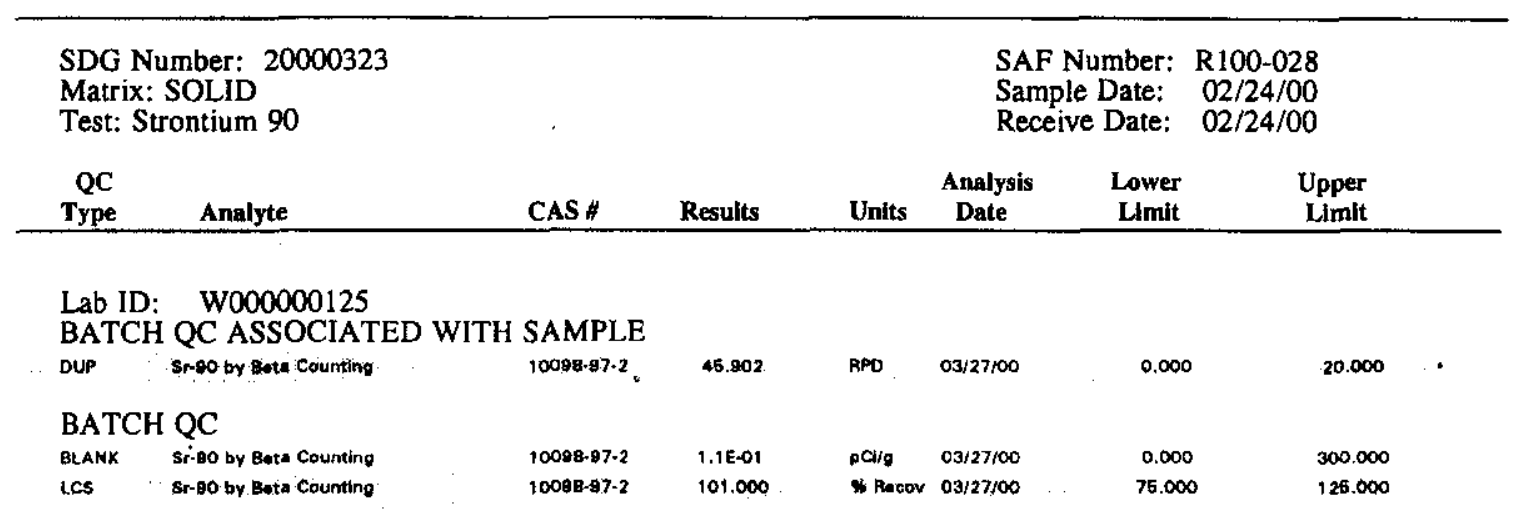

Alaport w13q/rov.4 D 7

10.spr-2000 13:45:20 


\section{WSCF ANALYTICAL LABORATORY QC REPORT}

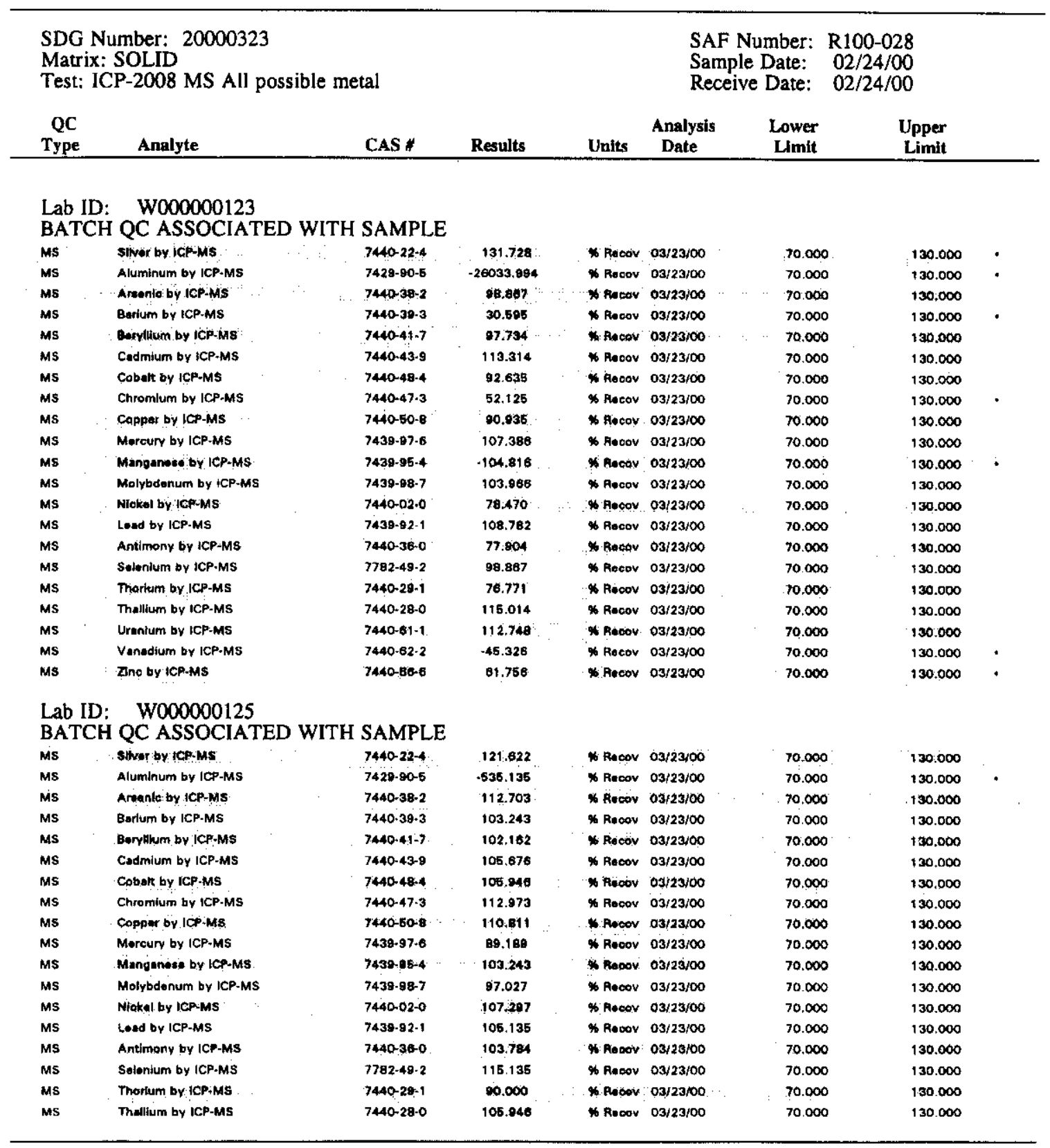

Report w13qirev.4 8

to-apr-2000 13:45:20 


\section{WSCF ANALYTICAL LABORATORY QC REPORT}

\begin{tabular}{|c|c|c|c|c|c|c|c|c|c|c|}
\hline \multicolumn{7}{|c|}{$\begin{array}{l}\text { SDG Number: } 20000323 \\
\text { Matrix: SOLID } \\
\text { Test: ICP-2008 MS All possible metal }\end{array}$} & \multicolumn{4}{|c|}{$\begin{array}{lr}\text { SAF Number: } & \text { R100-028 } \\
\text { Sample Date: } & 02 / 24 / 00 \\
\text { Receive Date: } & 02 / 24 / 00\end{array}$} \\
\hline $\begin{array}{c}\mathrm{QC} \\
\text { Type }\end{array}$ & Analyte & & CAS \# & Results & & Units & $\begin{array}{c}\text { Analysis } \\
\text { Date }\end{array}$ & $\begin{array}{l}\text { Lower } \\
\text { Lintt }\end{array}$ & $\begin{array}{c}\text { Upper } \\
\text { Limit }\end{array}$ & \\
\hline $\mathrm{MS}$ & Uennium by ICR-MS & & $74001: t$ & 101 bo2 & & S Aleóor & $03 / 23 / 00$ & $70: 000$ & 130.000 & \\
\hline Ms & Vonedlum by ICP-MS & & $7440-02-2$ & 107.568 & & * Rocov & $03 / 23 / 00$ & 70.000 & 130.000 & \\
\hline Ms & Zno by ICPins & & $7440-60-6$ & 112.973 & & \% Racov & $03 / 23 / 00$ & 70.000 & 130.000 & \\
\hline \multicolumn{11}{|c|}{ BATCH QC } \\
\hline BLANK & SHvor by ICP-MS & & $7440-22-4$ & $<4.060-1$ & & Ug/L & $03 / 23 / 00$ & $-0,100$ & 0.100 & \\
\hline BLANK & Aluminum by ICP.MS & & $7429-00-5$ & $4.220+03$ & & ug/h & $03 / 23 / 00$ & $-0,100$ & 0.100 & \\
\hline BLANK & Areanio by ICP-MS & & $7440-38-2$ & $1.630+\infty$ & & $u g / L$ & $03 / 23 / 00$ & $.0,100$ & 0.100 & \\
\hline BLANAK & Berium by LCP.MS & & $7440-39-3$ & $5.32 \%+01$ & & 49 & $03 / 23 / 00$ & .0 .100 & 0.100 & \\
\hline BLANK & Borylliam by ICP-MS & & 7440.41 .7 & $3,460-01$ & & $\mathrm{ug} / \mathrm{L}$ & $03 / 23 / 00$ & .0 .100 & 0.100 & \\
\hline GLANK & Ondmium by ICP-MS & & $7440-43 \cdot 9$ & $<4,680.1$ & & ugh & $03 / 23 / 100$ & 0.100 & 0.100 & \\
\hline BLANK & Cobutt by ICP-MS & & $7440-48 \cdot 4$ & $2.030+\infty$ & & $u g / L$ & $03 / 23 / 100$ & -0.100 & 0.100 & \\
\hline BLAPKK & Chromlum by ICP-MS & & $7440-47-3$ & $7.41,+\infty$ & & $4 \mathrm{~g} / \mathrm{L}$ & $03 / 23 / 00$ & -0.100 & 0.100 & \\
\hline BLANK & Copper by ICP-MS & & $7440-60-8$ & $5.060+\infty$ & & ug/L & $03 / 23 / 00$ & .0 .100 & 0.100 & \\
\hline BLANK & Moreiny by KCP-MS & & $7439-97-6$ & $<2.340: 1$ & $\therefore$ & uQ/L. & $03 / 23 / 00$ & .0 .100 & 0.100 & \\
\hline BLANK & Mnnganceso by ICP.MS & & $7439-95-4$ & $1,980+02$ & & ugih & $03 / 23 / 00$ & .0 .100 & 0.100 & \\
\hline GLANK & Motybuanum by ICP-kis & & $7439-99-7$ & $4.25 \%-0 \mathrm{i}$ & $\because$ & Ut: & $03 / 23 / 00$ & $.0: 100$ & 0.100 & \\
\hline BLANK & Nickol by ICP.MS & & $7440-02-0$ & $<4.6800$ & & ua/L & $03 / 23 / 00$ & .0 .100 & 0.100 & \\
\hline BLANK & Lind by lap Ms & . & $2430.92-1$ & $9.650+\infty$ & & verli: & $03 / 23 / 00$ & 0.100 & 0.100 & \\
\hline BLANK & Anthony by ICP-MS & & $7440-36-0$ & $<4.880 .1$ & & ugil & $03 / 23 / 00$ & .0 .100 & 0.100 & \\
\hline GLANK & Sulonium by ICP-MS & & $7782-402$ & $<7.020 .1$ & & uqd $/ \mathrm{L}$ & $03 / 23 / 00$ & -0.100 & 0.100 & \\
\hline BLANK & Therium by ICP-MS & & 7440-29-1 & $5.83 a+\infty 0$ & & ug/h & $03 / 23 / 00$ & .0 .100 & 0.100 & \\
\hline BLANK & Thallum by ICP-MS & & $7440-28.0$ & $2.540-01$ & & ug/h & $03 / 23 \% 00$ & .0 .100 & 0.100 & \\
\hline BLANK & Uranium by icP-MS & & $7440-81-1$ & $0.890-01$ & & $u g / L$ & $03 / 23 / 00$ & .0 .100 & 0.100 & \\
\hline BLANK & Vanedlum by ICP-MS & & $7440-82: 2$ & $1.730+01$ & & บe/t & $03 / 23 / 00$ & -0.100 & 0.100 & \\
\hline BLANK & Zine by ICP-MS & & $7440-68-6$ & $2.57 \bullet+01$ & & ug/t & $03 / 23 / 00$ & -0.100 & 0.100 & \\
\hline Lcs & Elver by ICP-Ms & & $7440-22-4$ & 120.808 & & * Aacor & $03 / 23 / 00$ & 85.000 & 115.000 & - \\
\hline LCS & Aluminum by ICP-MS & & $7429-80-5$ & 1791.908 & & * Recov & $03 / 23 / 00$ & 85.000 & 115.000 & - \\
\hline LCS & Arikenlo by ICP-MS & . & $7440-38-2$ & 100.000 & & \$ Recov & $03 / 23 / 00$ & 86.000 & 118.000 & \\
\hline LCS & Berkum by ICP-MS & & $7440-39-3$ & 101.158 & & * Rocor & $03 / 23 / 00$ & 85.000 & 115.000 & \\
\hline LCS & Boryllum by ICPAMs & & $7440-49.7$ & 29.268 & & * Rouon & $03 / 23 / 00$ & 85.000 & 116.000 & \\
\hline LCS & Cudmium by ICP-MS & & 7440.43 .0 & 104,048 & & 9o Recov & $03 / 23 / 00$ & 86.000 & 116.000 & \\
\hline Les & Cobatt by ICP-MS & & $7440 \cdot 48 \cdot 4$ & 98.5332 & & * Recoov & $03 / 23 / 00$ & 85.000 & 118.000 & \\
\hline LCS & Chromlum by ICP-MS & & $7440 \cdot 47-3$ & 102.890 & & * Recor & $03 / 23 / 00$ & 85.000 & 116.000 & \\
\hline LCS & Copper by ICP-MS & & $7440-60-8$ & 101.734 & & Theoov & $03 / 23 / 00$ & 86.000 & 116.000 & \\
\hline LCS & Marcury by ICP-MS & & 7439.97 .6 & $106.82 \theta$ & & H Recor & $03 / 23 / 00$ & 85.000 & 116.000 & \\
\hline LCS & Manganewa by ICP-MS & & $7439-95: 4$ & $n / m$ & & \% Rocor & $03 / 23 / 00$ & 65.000 & 116.000 & \\
\hline Les & Malybodenim oy ICP-MS & & $7438-98-7$ & 88.422 & & \% Pocor & $03 / 23 / 00$ & 85.000 & 115.000 & \\
\hline LCS & Nloknf by ICPMAs : & & $744002: 0$ & $100: 150$ & & N Rooov & $03 / 23 / 00$ & 80.000 & .115 .000 & \\
\hline LCS & Lond by ICP-MS & & $7439-92.1$ & 98.266 & & \% Recov & $03 / 23 / 00$ & 86.000 & 115.000 & \\
\hline tes & Antwiony by cemis & $\ldots \ldots$. & 74030 & 301,150 & & $*$ ftoov & $03 / 23 / 00$ & 85,000 & $118: 000$ & \\
\hline LCS & Solenium by ICP-MS & & $7782-49-2$ & 105.780 & & \% Rocov & $03 / 23 / 00$ & 85.000 & 115.000 & \\
\hline Les & Thatum by ICP-MS & & $7440-2 \%-1$ & $.07: 110$ & & *:Ropor & $03 / 23100$ & $85: 000$ & 116.000 & \\
\hline LCS & Thellum by ICP-MS & & $7440-28-0$ & 103.468 & & \% Recoov & $03 / 23 / 00$ & 85.000 & 115.000 & \\
\hline LCSS & Urankem by tCP:MS & & $7440-61 \cdot 1$ & 96.804 & & * Recov & $03 / 23 / 00$ & 85.000 & 118.000 & \\
\hline L.CS & Vanadium by ICP.MS & & $7440-62-2$ & 05.054 & & \% Rocov & $03 / 23 / 00$ & 85.000 & 115.000 & \\
\hline
\end{tabular}

Roport w13q/rev.4 p g

10.apr-2000 13:45:20 
HNF-6150 Rev 0

WSCF ANALYTICAL LABORATORY QC REPORT

\begin{tabular}{|c|c|c|c|c|c|c|c|}
\hline \multicolumn{5}{|c|}{$\begin{array}{l}\text { SDG Number: } 20000323 \\
\text { Matrix: SOLID } \\
\text { Test: ICP-2008 MS All possible metal }\end{array}$} & \multicolumn{2}{|c|}{$\begin{array}{l}\text { SAF Number: } \\
\text { Sample Date: } \\
\text { Receive Date: }\end{array}$} & \multirow{2}{*}{$\begin{array}{l}\text { R100-028 } \\
\text { Upper } \\
\text { Limit }\end{array}$} \\
\hline $\begin{array}{c}\text { QC } \\
\text { Type }\end{array}$ & Analyte & CAS \# & Results & Units & $\begin{array}{l}\text { Analysis } \\
\text { Date }\end{array}$ & $\begin{array}{l}\text { Lower } \\
\text { Limit }\end{array}$ & \\
\hline
\end{tabular}

Repon w13qtrev.4 p 10

10-apr-2000 13:45:20 
HNF-6150 Rev 0

\section{WSCF ANALYTICAL LABORATORY QC REPORT}

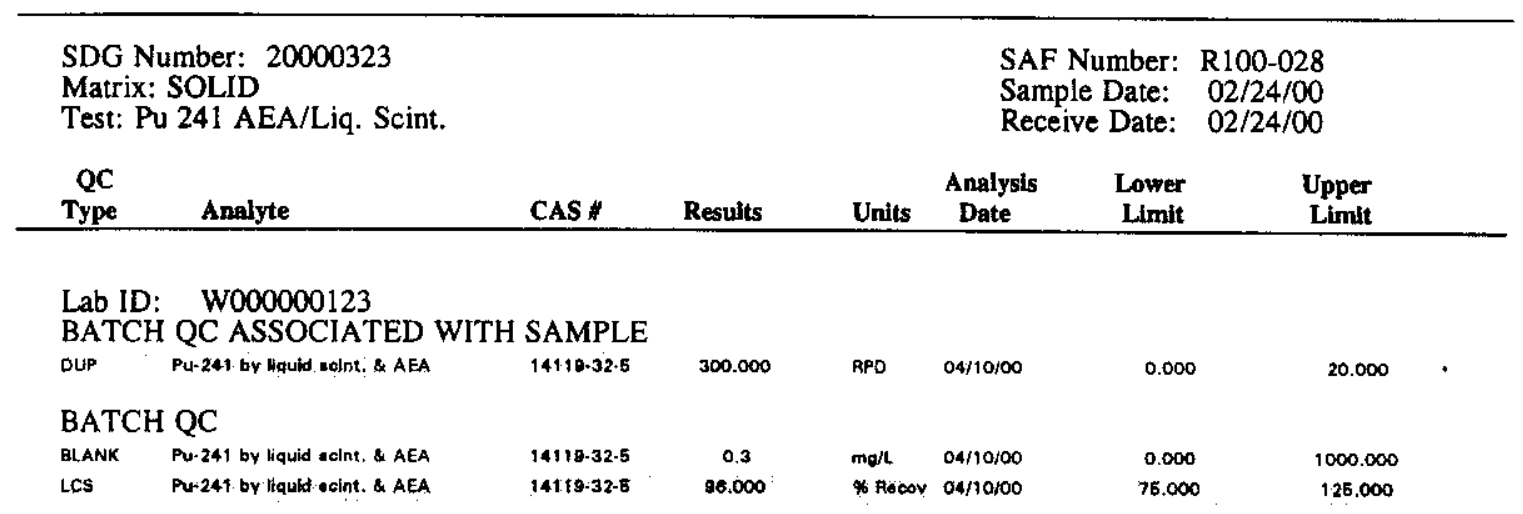

Report w13q/rov.4 p 11

10-npr-2000 13:46:20 
HNF-6150 Rev 0

\section{WSCF ANALYTICAL LABORATORY QC REPORT}

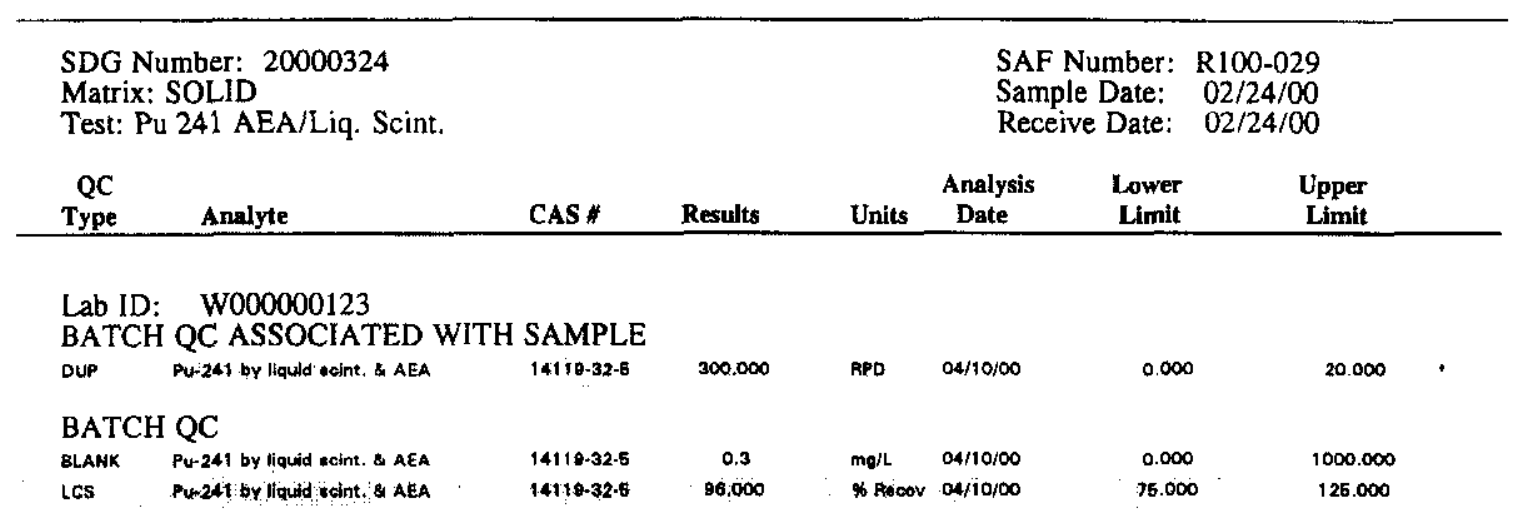

Report w13q/rev. 4 p 8

10-apr-2000 13:45:42 
HNF-6150 Rev 0
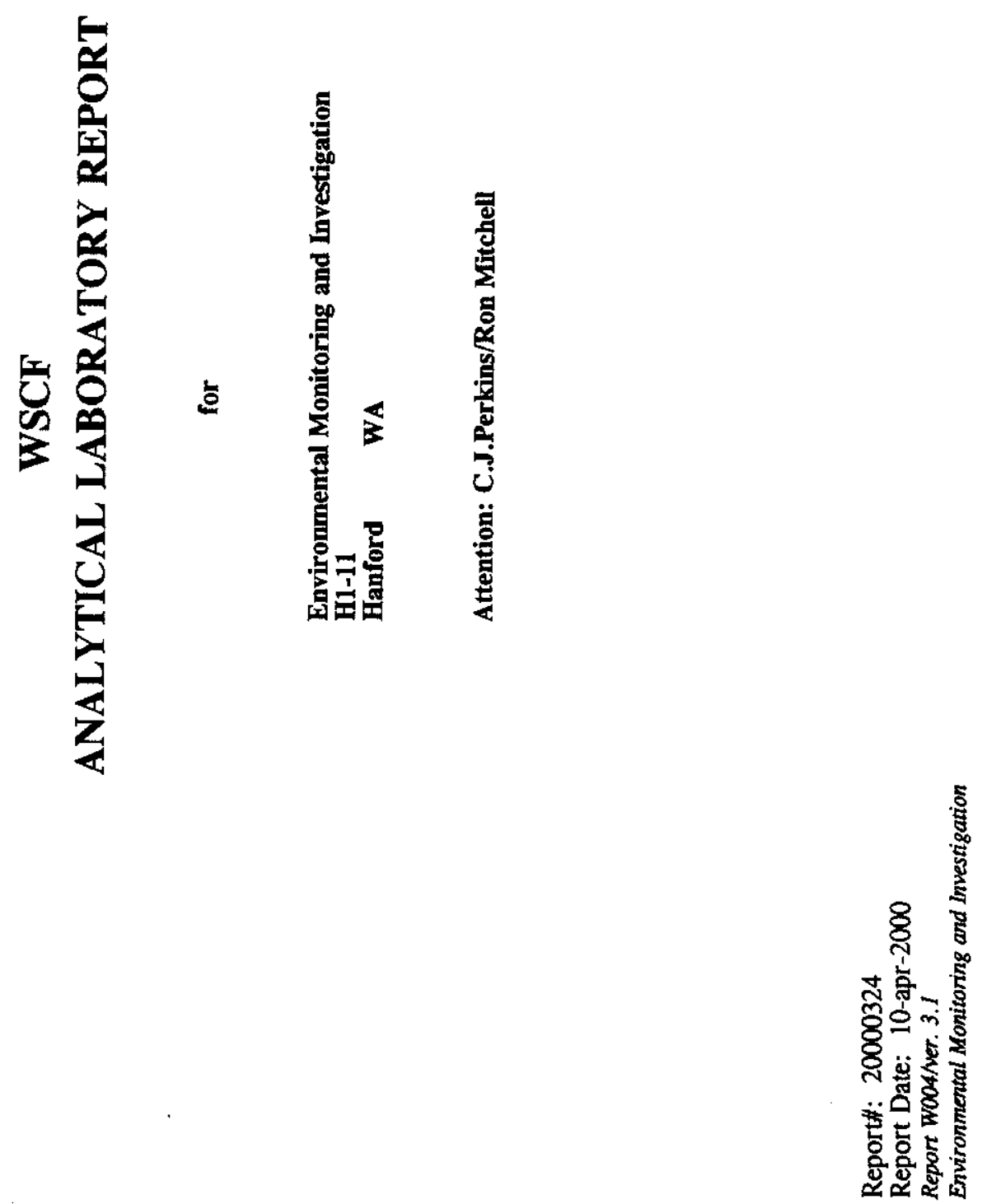
HNF-6150 Rev 0

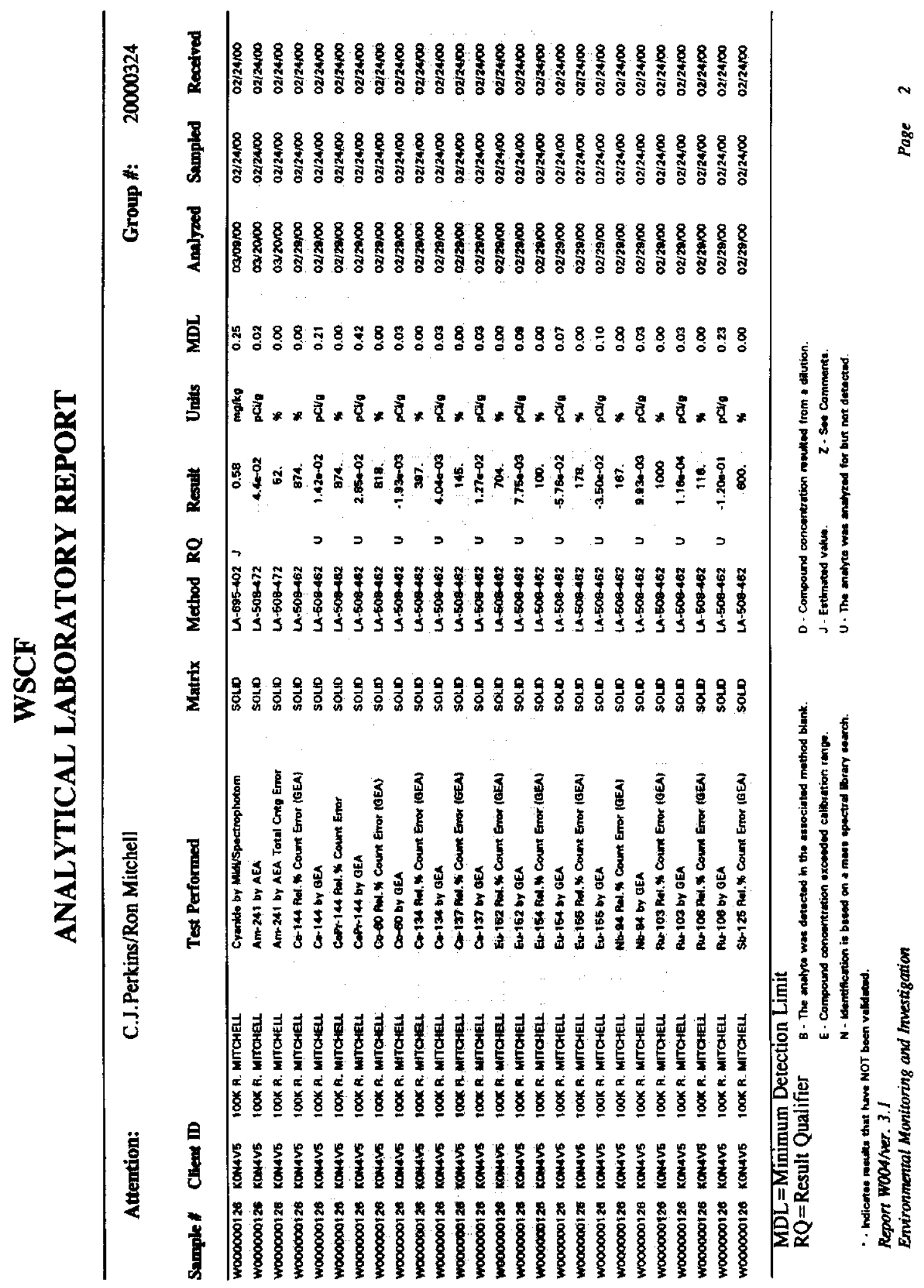


HNF-6150 Rev 0

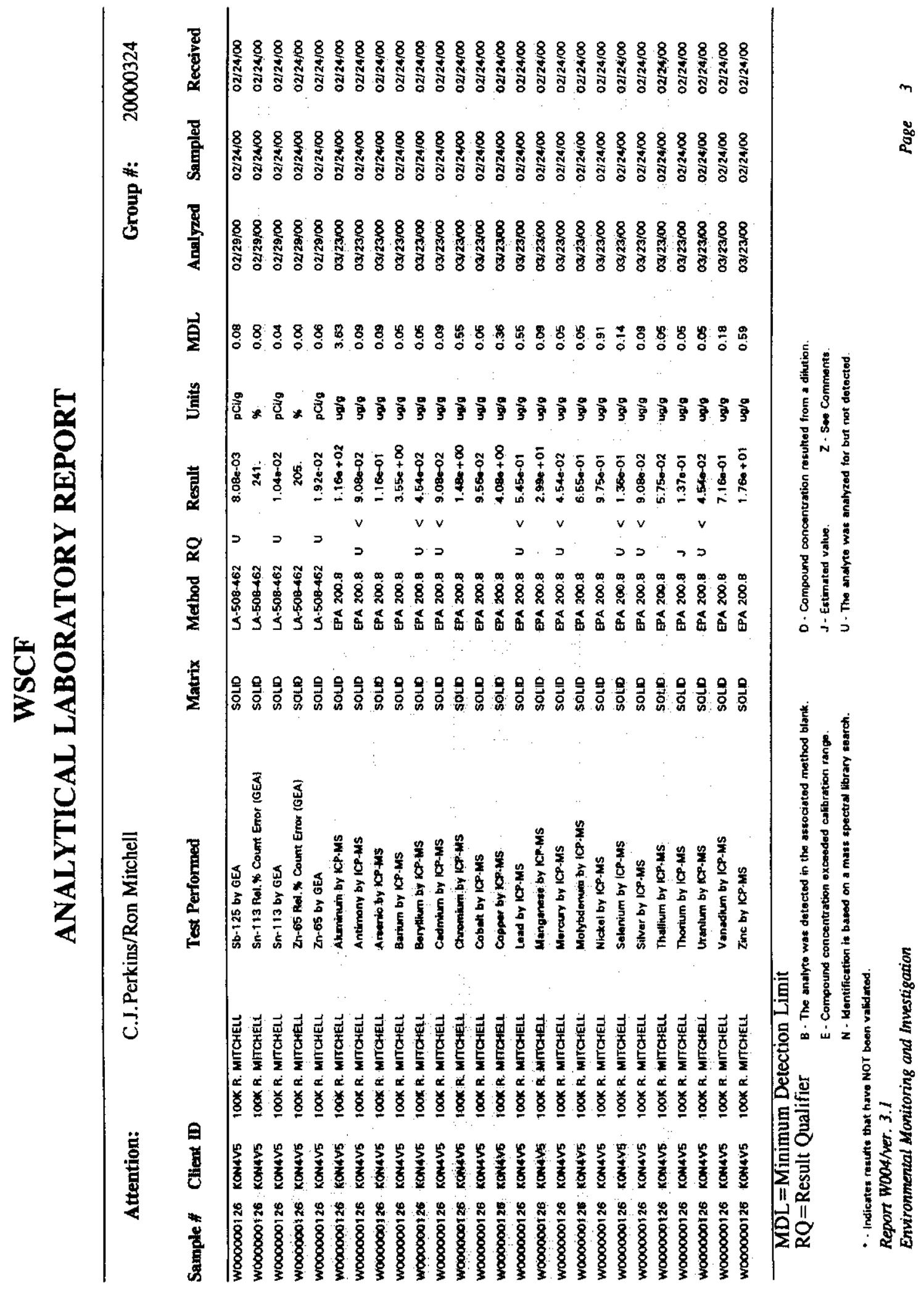


HNF-6150 Rev 0

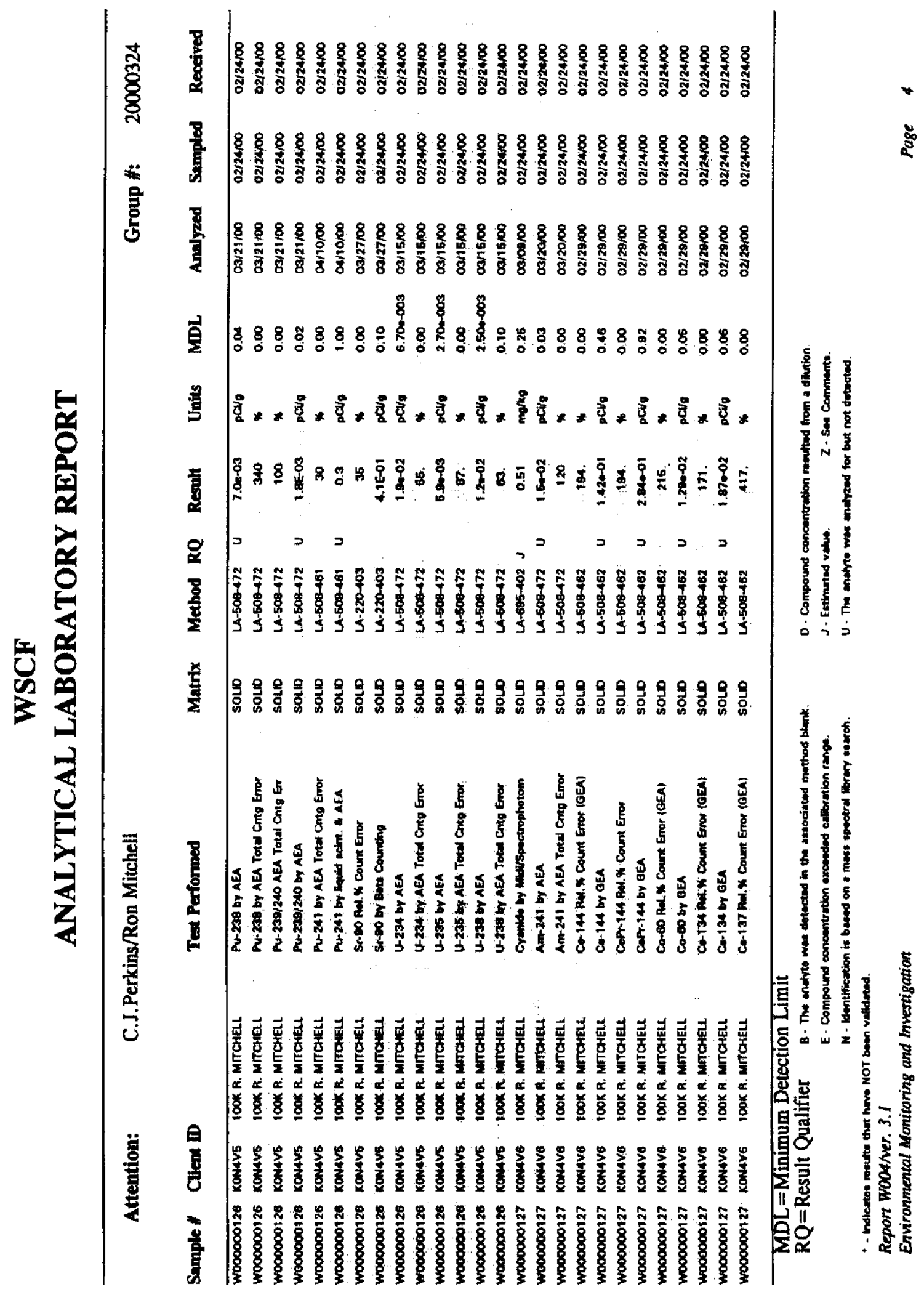


HNF-6150 Rev 0

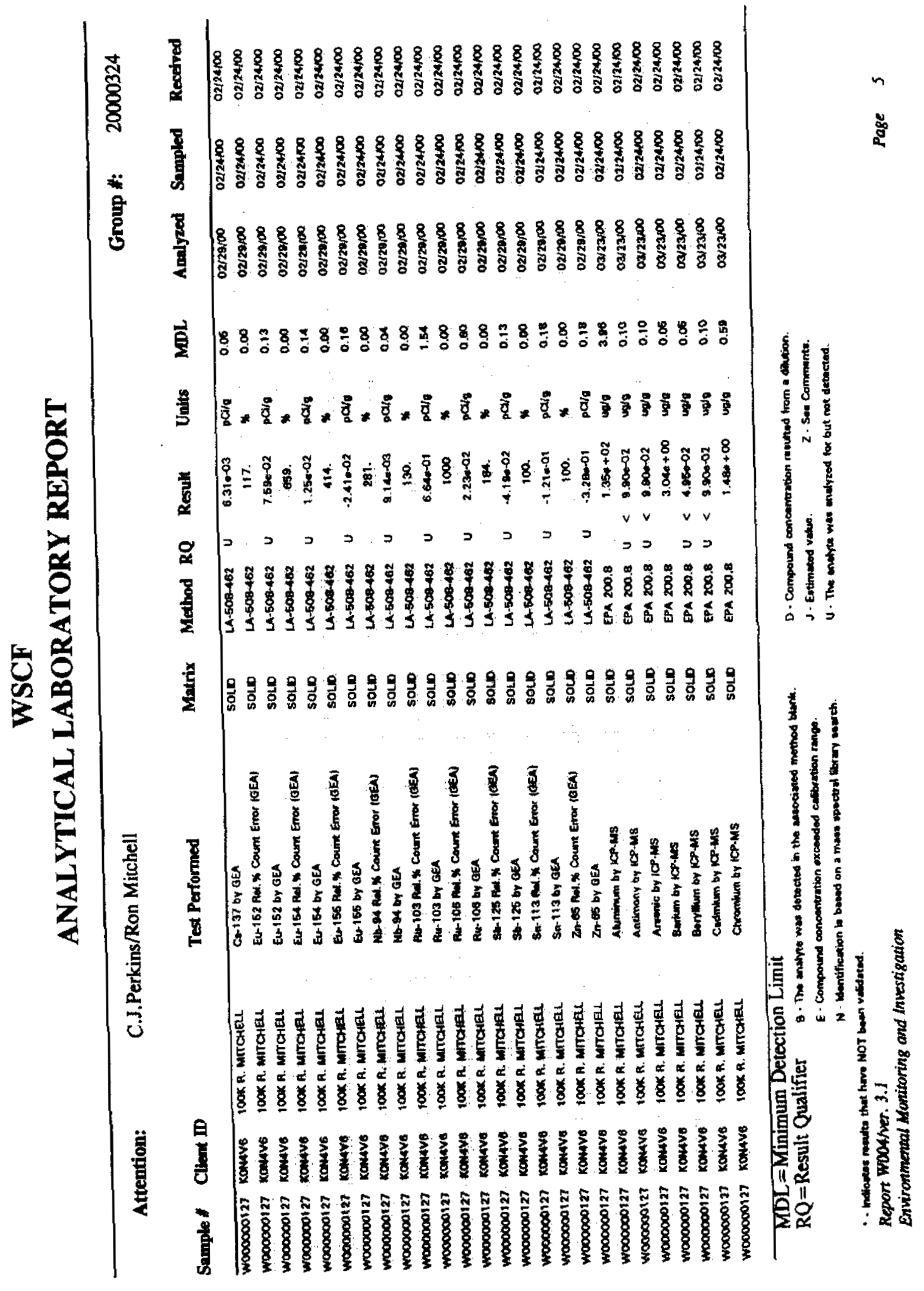


HNF-6150 Rev 0

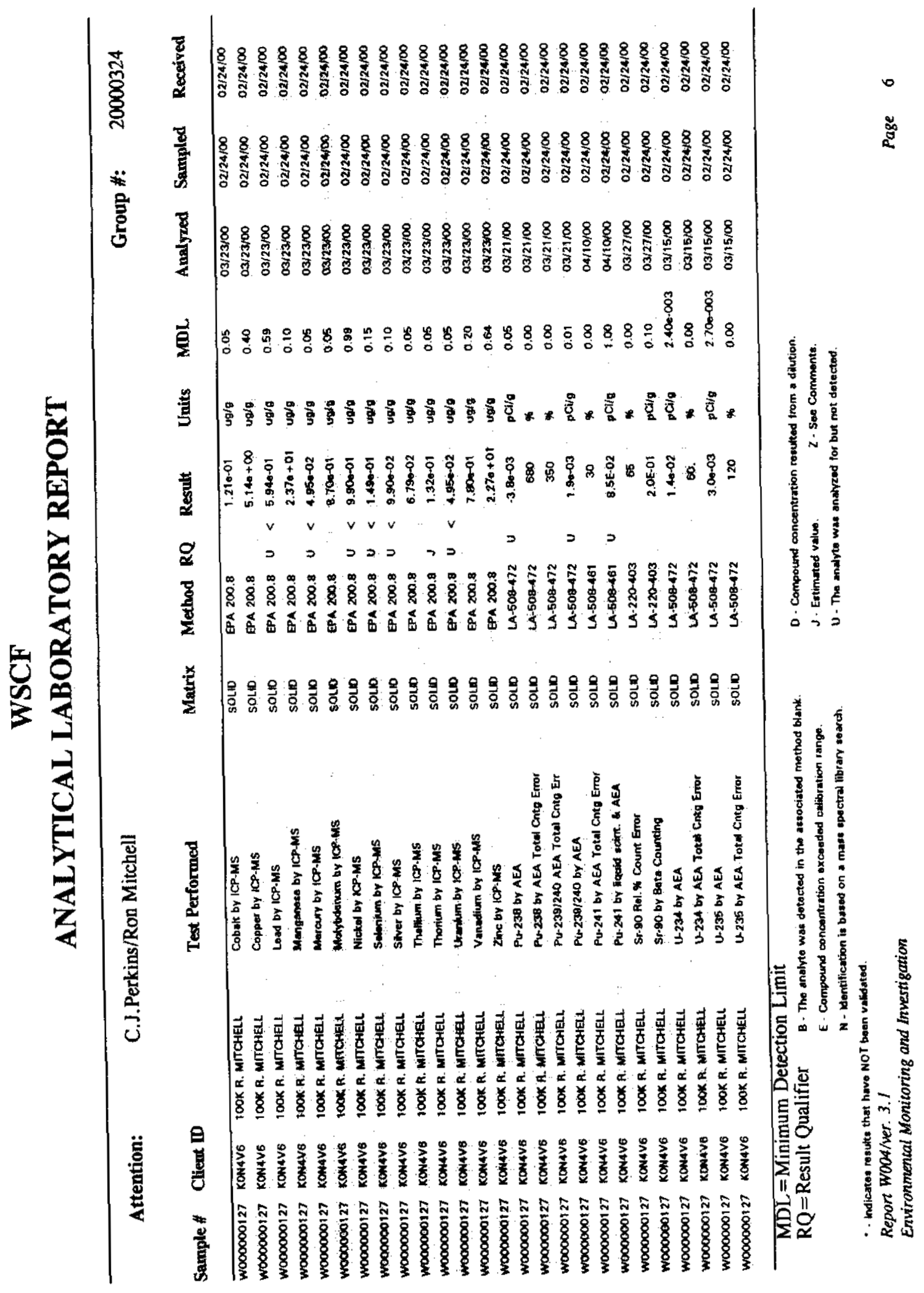


HNF-6150 Rev 0
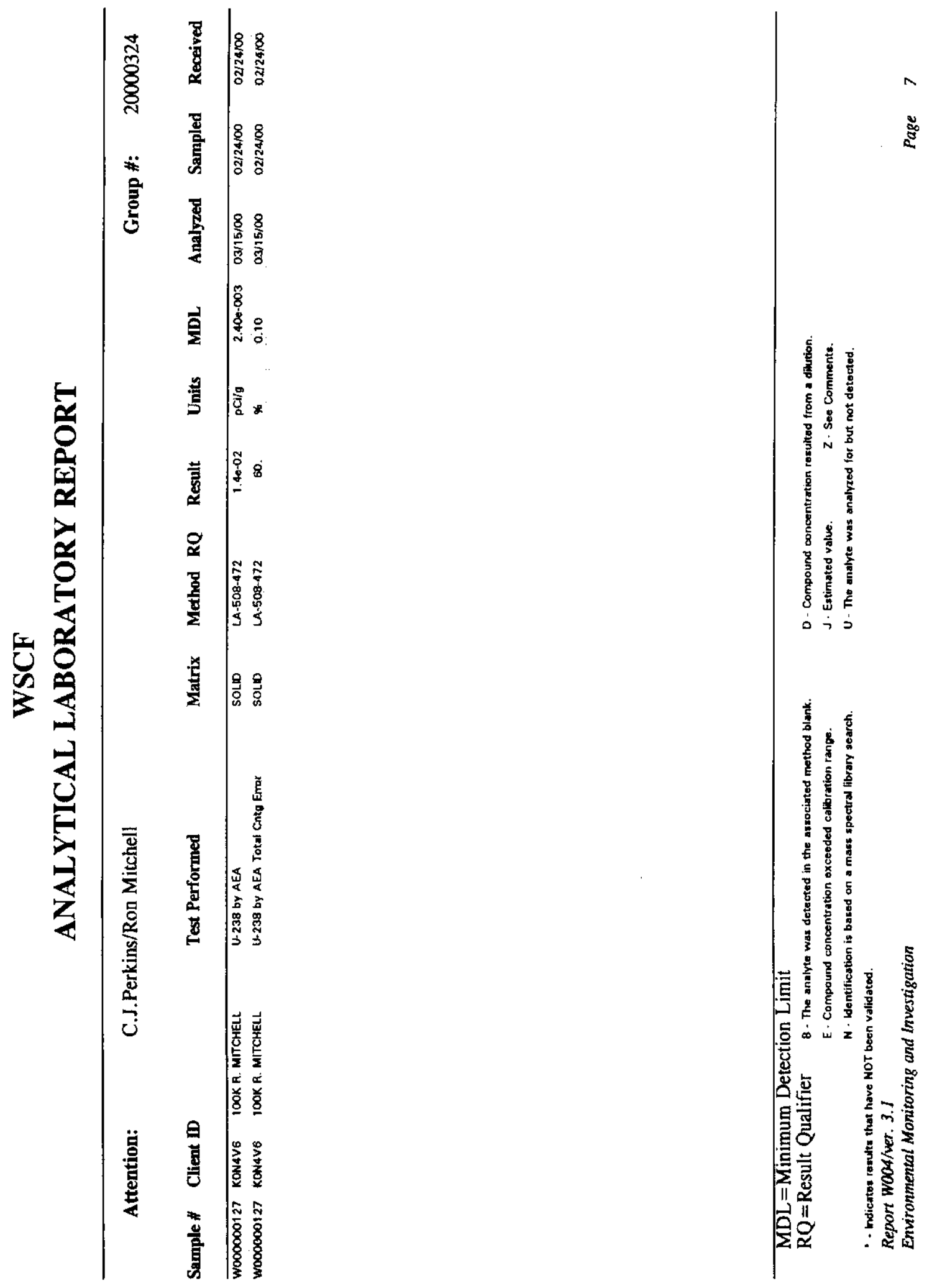
HNF-6150 Rev 0

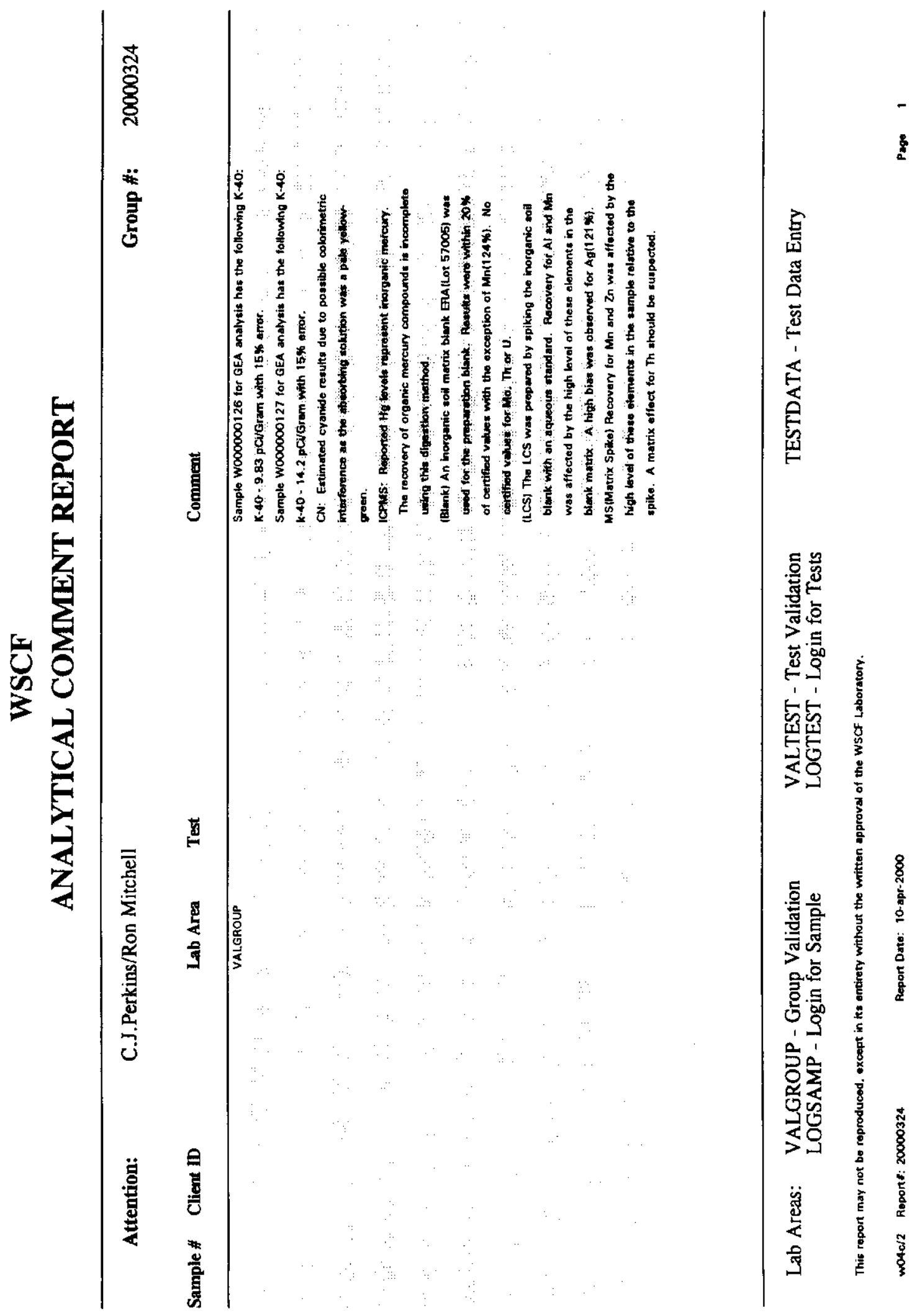


HNF-6150 Rev 0
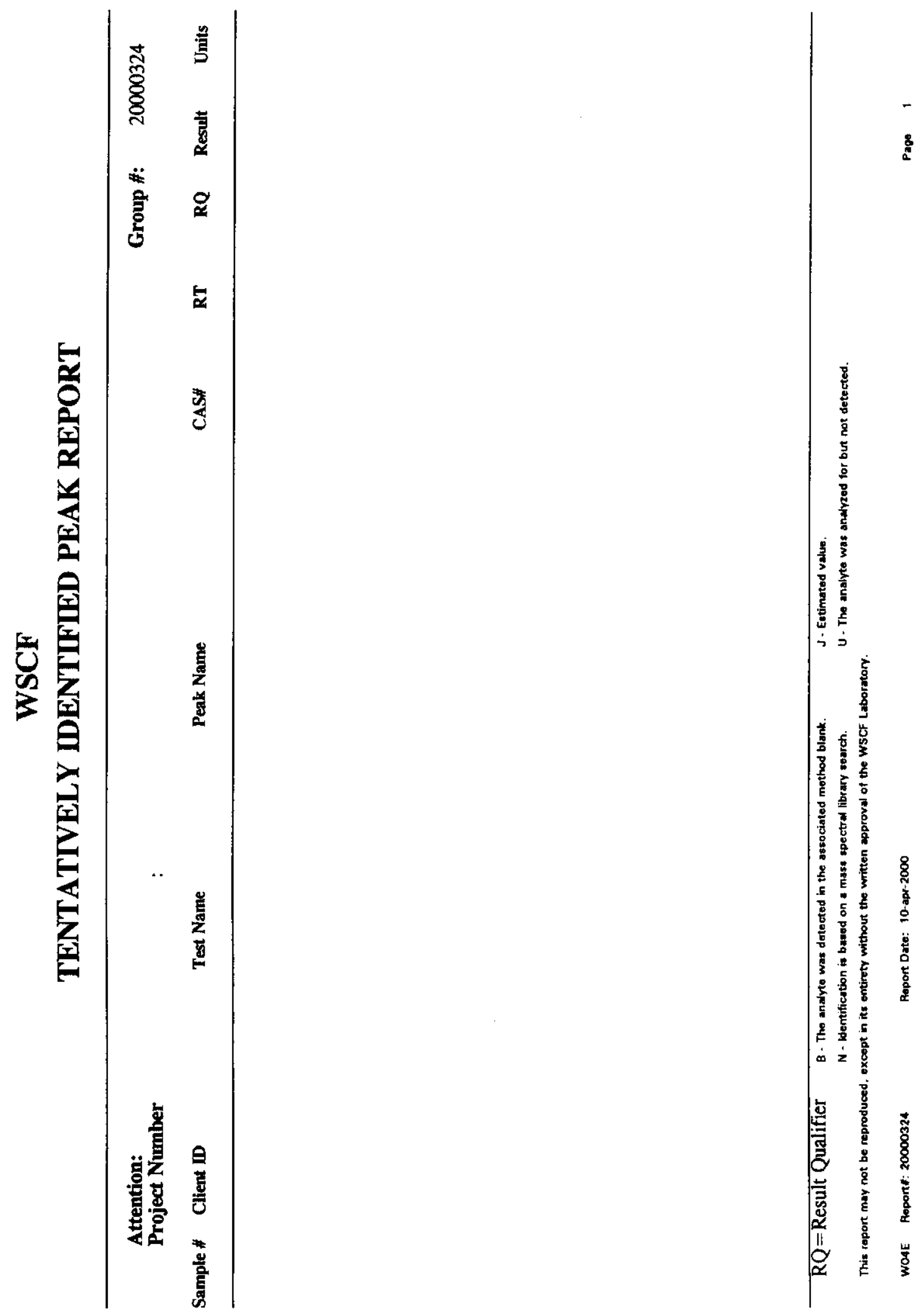
HNF-6150 Rev 0

\section{WSCF ANALYTICAL LABORATORY QC REPORT}

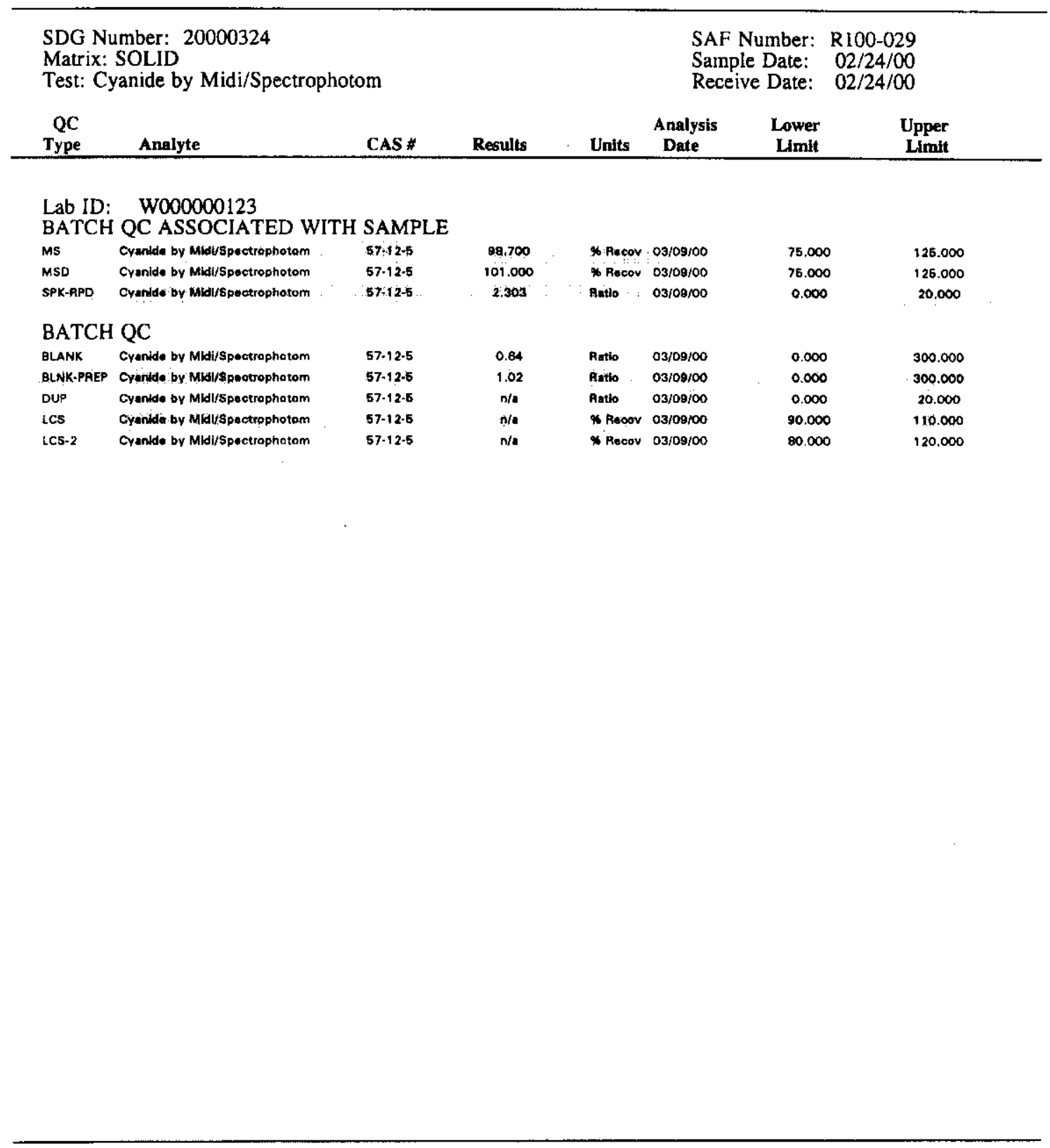

Report wit3q/rov, 4 P 1

10- ppr-2000 13:45:42 


\section{WSCF ANALYTICAL LABORATORY QC REPORT}

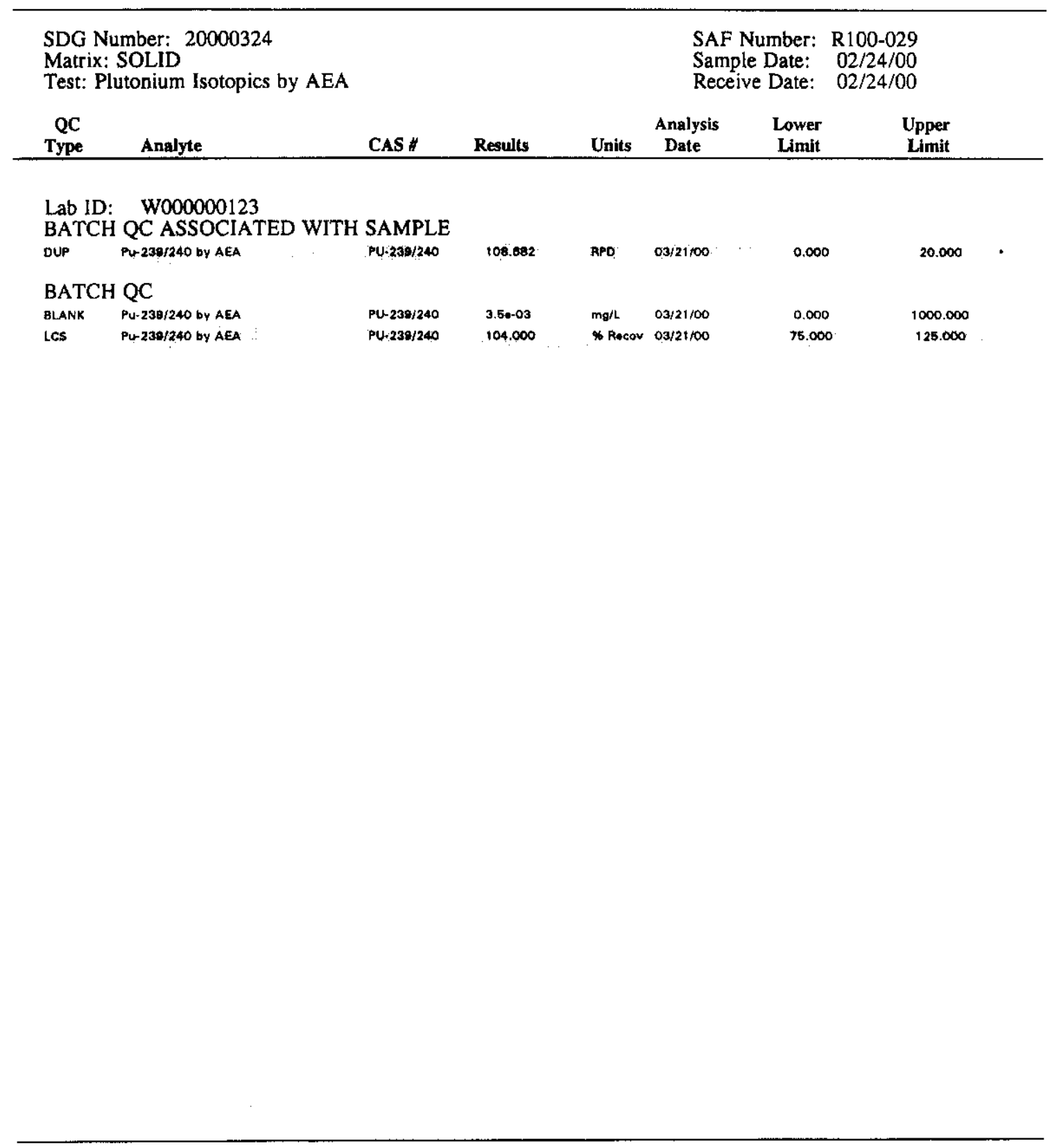

Report w13qirev.4 p 2

10-apr-2000 13:46:42 
HNF $-6150 \quad \operatorname{Rev} 0$

WSCF ANALYTICAL LABORATORY QC REPORT

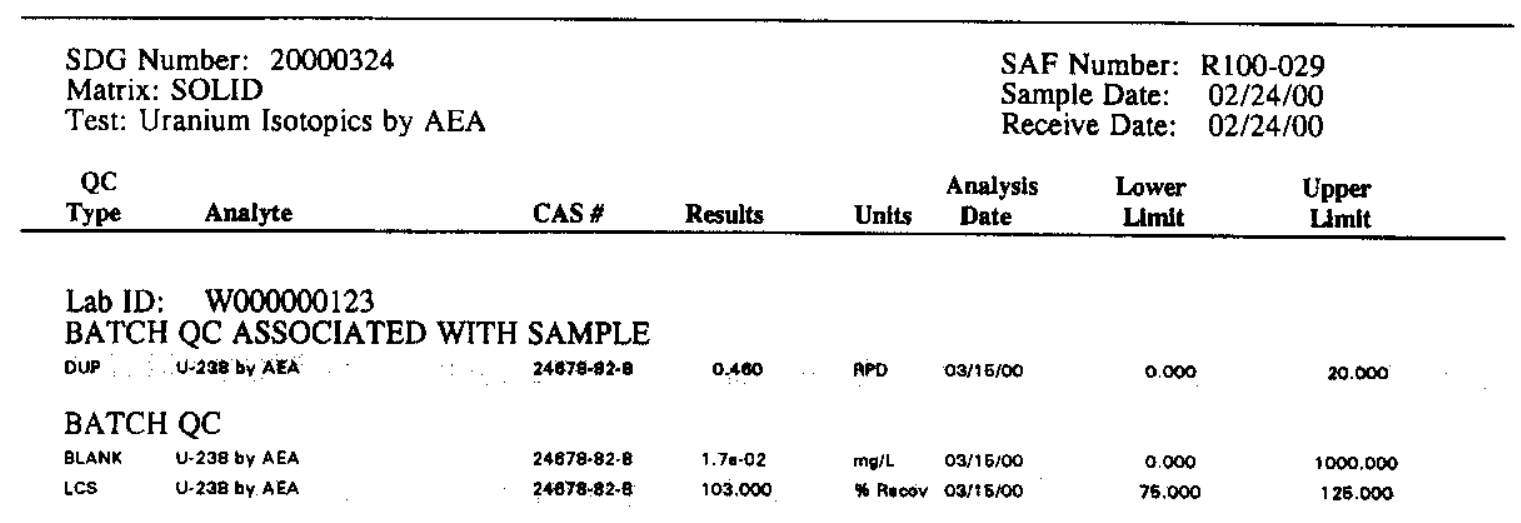

Aeport w13q/rev.4 P 3

10-apr-2000 13:45:42 
HNF-6150 Rev 0

WSCF ANALYTICAL LABORATORY QC REPORT

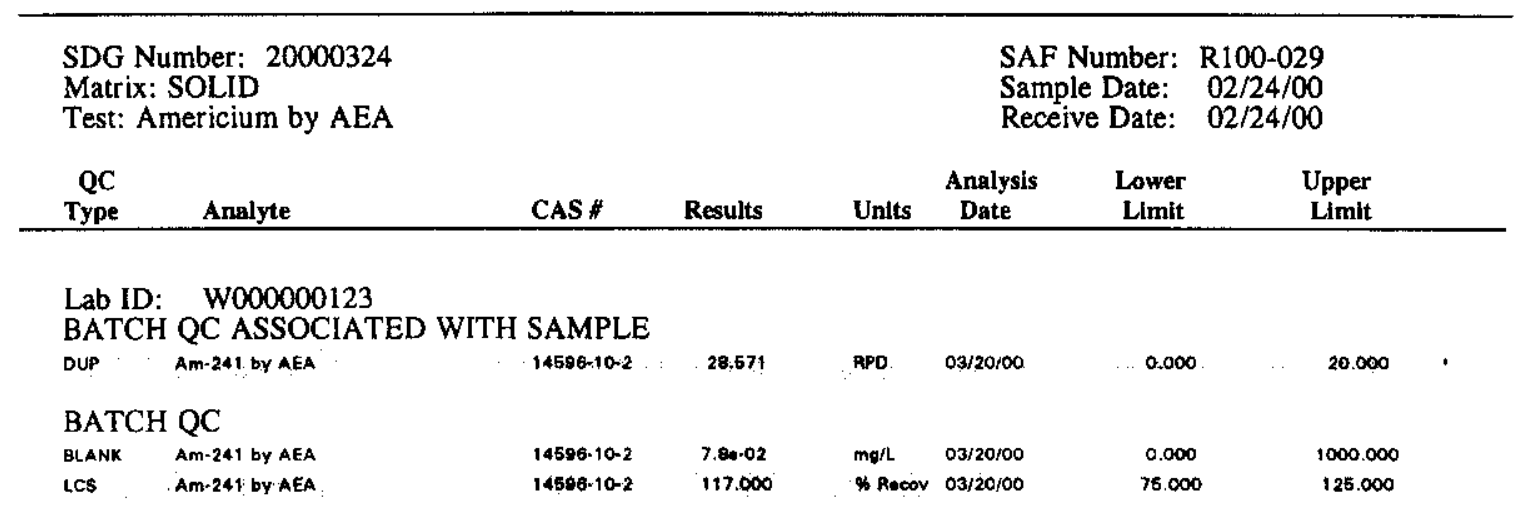

Report w13q/rev.4 p 4

10.2pr-2000 13:45:42 
HNF-6150 Rev 0

WSCF ANALYTICAL LABORATORY QC REPORT

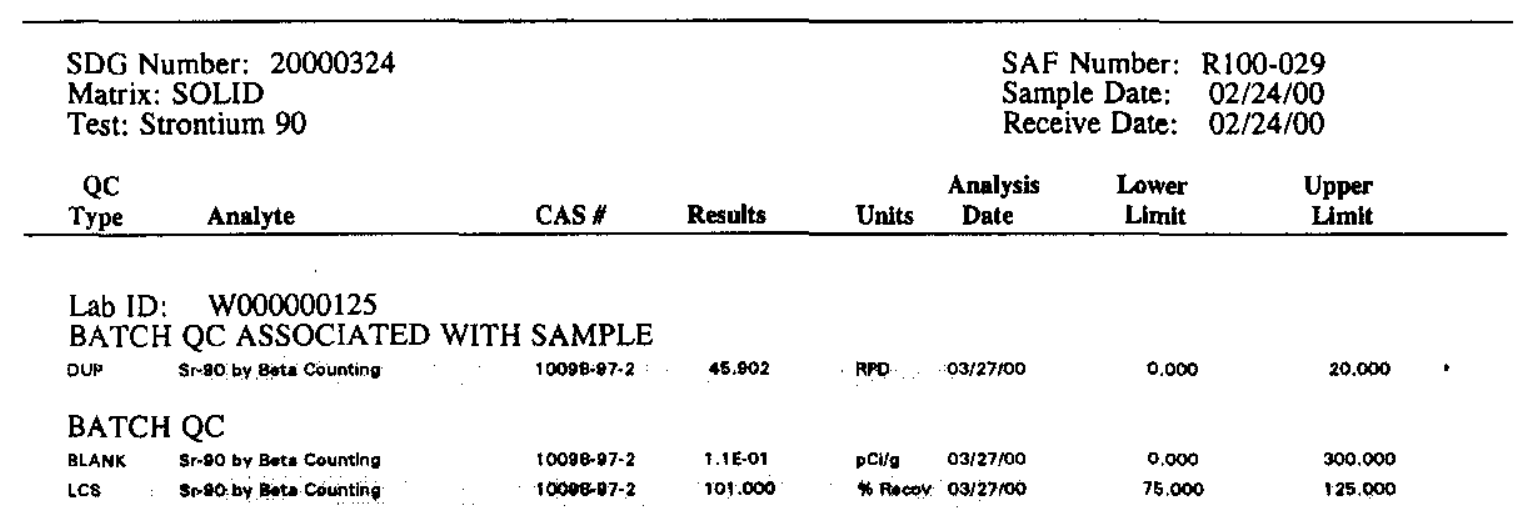

Report w13a/rov.4 5

1G.epr.2000 13:45:42 
WSCF ANALYTICAL LABORATORY QC REPORT

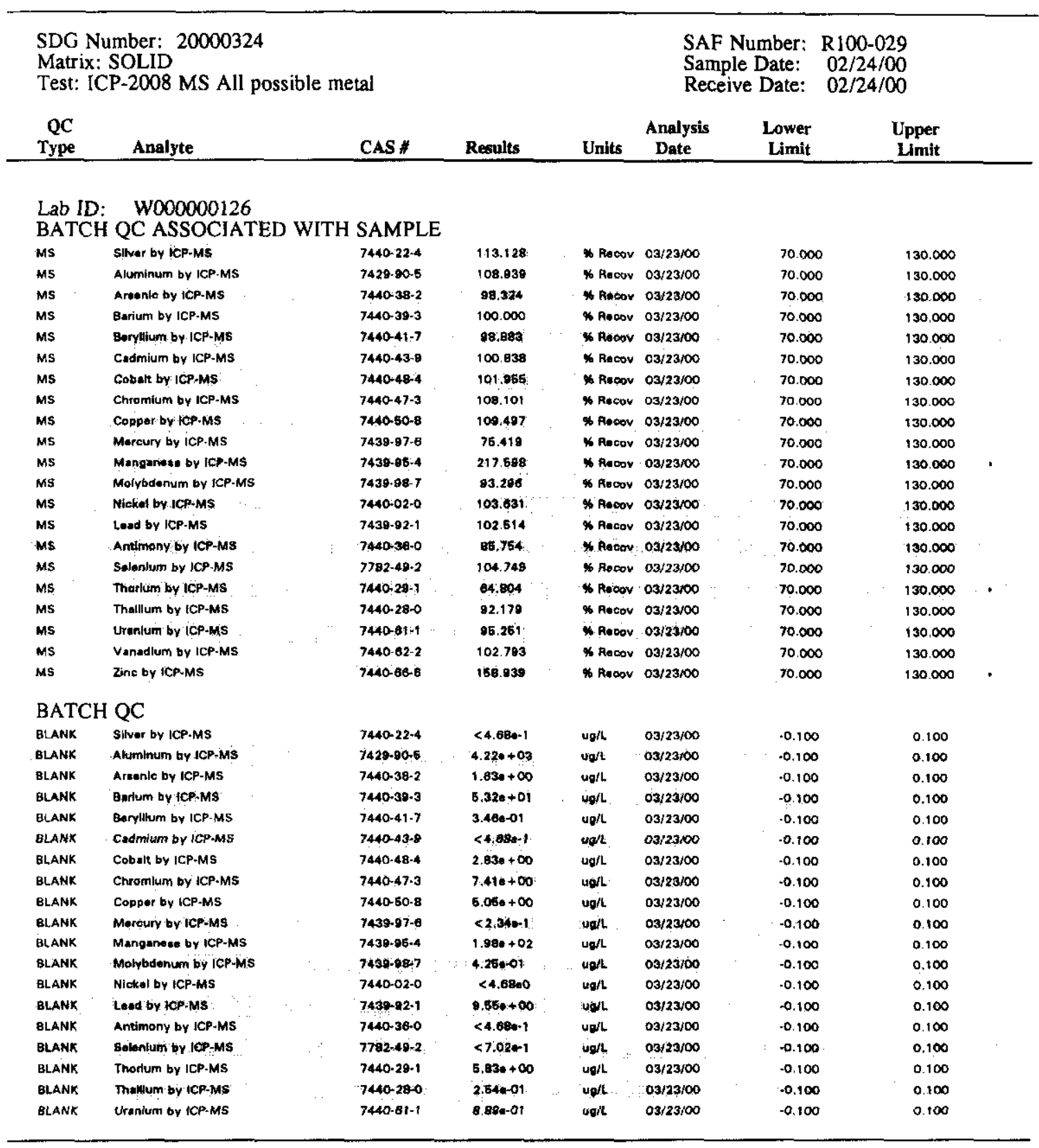

Roport w13q/rov.4 D 6

10.spr.2000 13:45:42 


\section{WSCF ANALYTICAL LABORATORY QC REPORT}

\begin{tabular}{|c|c|c|c|c|c|c|c|c|c|}
\hline \multicolumn{5}{|c|}{$\begin{array}{l}\text { SDG Number: } 20000324 \\
\text { Matrix: SOLID } \\
\text { Test: ICP-2008 MS All possible metal }\end{array}$} & \multicolumn{5}{|c|}{$\begin{array}{l}\text { SAF Number: R100-029 } \\
\text { Sample Date: }\end{array}$} \\
\hline $\begin{array}{r}\text { QC } \\
\text { Type }\end{array}$ & Analyte & & CAS \# & Results & Units & $\begin{array}{c}\text { Analysis } \\
\text { Date }\end{array}$ & $\begin{array}{l}\text { Lower } \\
\text { Limit }\end{array}$ & $\begin{array}{c}\text { Upper } \\
\text { Limit }\end{array}$ & \\
\hline BLANK & Voriditum by fCP Ms & $\because$ & $7440-62-2$ & $1,730+01$ & $49 / 2$ & $03 / 23 / 00$ & .0 .100 & 0.100 & \\
\hline BLANK & Zlne by ICP-MS & & 7440.66 .6 & $2.570+01$ & $\operatorname{ug} / \mathrm{h}$ & $03 / 23 / 00$ & -0.100 & 0.100 & \\
\hline LCS & Slvor by ICP.MS & & $7440-22 \cdot 4$ & 120.009 & W Rucov & $03 / 23 / 00$ & 85.000 & 1.16 .000 & • \\
\hline LCs & Aluminum by ICP-MS & & $7429-80-6$ & 1791.000 & \% Rncor & $03 / 23 / 00$ & 85.000 & 116.000 & + \\
\hline LCS & Areonic by ICP-MS : .. & & $7440-38-2$ & 100.000 & \% Rancov & $03 / 23 / 500$ & 86.000 & 115.000 & \\
\hline LCS & Barlum by ICP-MS & & $7440-39-3$ & 101.166 & \% Rocor & $03 / 23 / 00$ & 85.000 & 116.000 & \\
\hline LCs & Baryllium by ICP-NS: & & $7440-41-7$ & 89,280 & Thooov & $03 / 23 / 00$ & 95.000 & 115.000 & \\
\hline LCS & Cadmium by ICP.MS & & $7440-43-9$ & 104.046 & \% Rocov & $03 / 23 / 00$ & 85.000 & 315.000 & \\
\hline LCS & Cobatt by IC-Ms & & $7440-48.4$ & 00.632 & \% Alocov & $03 / 23 / 00$ & 85.000 & 115.000 & \\
\hline LCS & Chromium by ICP-MS & & 7440.47 .3 & 102.890 & \% Recor & $03 / 23 / 00$ & 85.000 & 115.000 & \\
\hline LCS & Copper by ICP:MS & & $7440-50 \%$ & 101.734 & N Alacor. & $03 / 23 / 00$ & 85.000 & 115.000 & \\
\hline LCS & Mercury by ICP.MS & & $7439 \cdot 97 \cdot 6$ & 106.829 & \% Recov & $03 / 23 / 00$ & $86 . \infty 0$ & 115.000 & \\
\hline LCS & Manganede by LCPP-MS & & $7430: 90-4$ & $n / a$ & \%Recov. & $03 / 23 / 00$ & 85.000 & 115.000 & \\
\hline LCS & Molybdenum by ICP-MS & & $7439-98-7$ & 99.422 & * Racor & $03 / 23 / 00$ & 85.000 & 115.000 & \\
\hline LCS & Nickal by ICP-MS & & $7440-02-0$ & 101,156 & \% Reoov & $03 / 23 / 00$ & $86: 000$ & 115.000 & \\
\hline LCs & Lend by ICP-MS & & $7439-22 \cdot 1$ & 98.266 & * Recor & $03 / 23 / 00$ & 85.000 & 115.000 & \\
\hline LCs & Antimeny by ICP.MS & & $7440-36-0$ & $101: 166$ & \% Recov & $03 / 23 / 00$ & 85.000 & $\$ 15.000$ & \\
\hline Les & Solenium by ICP-MS & & $7782 \cdot 40 \cdot 2$ & 106.780 & * Recov & $03 / 23 / 00$ & 85.000 & 115.000 & \\
\hline Les & Thorlum by ICPins & & $7440-29-1$ & 97.110 & * Pooov & $03 / 23 / 00$ & 65.000 & 115.000 & \\
\hline LCS & Thallium by ICP-MS & & $7440-280$ & 103.468 & \% Plecov & $03 / 23 / 00$ & 85.000 & 115,000 & \\
\hline Les & Uranium by kCp:Ms & & $7440.61-1$ & 98.844 & \% Recov & $03 / 23 / 00$ & 86.000 & 116.000 & \\
\hline LCs & Vonadlum by ICP.MS & & $7440-62.2$ & 95.954 & \% Recov & $03 / 23 / 00$ & 85.000 & 115.000 & \\
\hline LCS & Zlnc by ICP-MS & & $7440-66-6$ & 102312 & \% Rocov & $03 / 23 / 00$ & 98.000 & 115,000 & \\
\hline
\end{tabular}

